UNIVERSIDADE PRESBITERIANA MACKENZIE (BRASIL)

UNIVERSIDADE DE SALAMANCA (ESPANHA)

LARISSA DIAS PUERTA DOS SANTOS

EVOLUÇÃO DAS TÉCNICAS E DOS PROCEDIMENTOS IDEALIZADOS PARA A MELHORIA DOS INDICADORES E DO DESEMPENHO DA EDUCAÇÃO JURÍDICA NO BRASIL

SÃO PAULO/SALAMANCA

2020 


\title{
EVOLUÇÃO DAS TÉCNICAS E DOS PROCEDIMENTOS IDEALIZADOS PARA A MELHORIA DOS INDICADORES E DO DESEMPENHO DA EDUCAÇÃO JURÍDICA NO BRASIL
}

\begin{abstract}
Tese submetida à Banca Examinadora de qualificação do Programa de Pós-graduação stricto sensu em Direito Político e Econômico da Universidade Presbiteriana Mackenzie como requisito parcial à obtenção do título de Doutora em Direito Político e Econômico da Universidade Presbiteriana Mackenzie em regime de cotutela com a Escuela de Doctorado "Studii Salamantini" en Administración, hacienda y justicia en el Estado Social da Universidade de Salamanca.
\end{abstract}

ORIENTADOR NO BRASIL: Prof. Dr. Felipe Chiarello de Souza Pinto ORIENTADORA NA ESPANHA: Prof. a Dra. Pilar Jiménez Tello

SÃO PAULO/SALAMANCA 
S237e Santos, Larissa Dias Puerta dos.

Evolução das técnicas e dos procedimentos idealizados para a melhoria dos indicadores do desempenho da educação jurídica no Brasil / Larissa Dias Puerta dos Santos.

280 f. : il. ; $30 \mathrm{~cm}$

Tese em regime de cotutela (Doutorado em Direito Político e Econômico) Universidade Presbiteriana Mackenzie, (Doctorado en Ciencias Jurídicas y Sociales: Administración, Hacienda y Justicia en el Estado Social) - Universidade Presbiteriana Mackenzie e Universidad de Salamanca, São Paulo/Salamanca, 2020.

Orientadores: Felipe Chiarello de Souza Pinto e Maria Teresa del Pilar Jiménez Tello

Referências bibliográficas: f. 256-279.

1. Direito constitucional. 2. Direito econômico. 3. Direito administrativo. 4. Direito educacional. 5. Ensino Superior. I. Pinto, Felipe Chiarello de Souza, orientador. II. Título.

CDDir 342.5981 


\title{
EVOLUÇÃO DAS TÉCNICAS E DOS PROCEDIMENTOS IDEALIZADOS PARA A MELHORIA DOS INDICADORES E DO DESEMPENHO DA EDUCAÇÃO JURÍDICA NO BRASIL
}

\begin{abstract}
Tese submetida à Banca Examinadora de qualificação do Programa de Pós-graduação stricto sensu em Direito Político e Econômico da Universidade Presbiteriana Mackenzie como requisito parcial à obtenção do título de Doutora em Direito Político e Econômico da Universidade Presbiteriana Mackenzie em regime de cotutela com a Escuela de Doctorado "Studii Salamantini" en Administración, hacienda y justicia en el Estado Social da Universidade de Salamanca.
\end{abstract}

Aprovada em:

BANCA EXAMINADORA

Prof. Dr. Felipe Chiarello de Souza Pinto

Universidade Presbiteriana Mackenzie

Prof. a Dra. Pilar Jiménez Tello

Universidade de Salamanca

Prof. Dr. Ricardo Rivero Ortega

Universidade de Salamanca

Prof. ${ }^{a}$ Dra. Monica Herman Salem Caggiano

Universidade Presbiteriana Mackenzie

Prof. Dr. Carlos Eduardo do Nascimento

Universidade de Uberaba

Prof. Dr. Paulo César Diniz de Araújo

Universidade do Estado do Amazonas 
Para um Brasil melhor. 


\section{AGRADECIMENTOS}

A Deus, por me dar toda a condição necessária para começar, coragem para continuar e força suficiente para finalizar.

Aos meus pais, Élia e Paulo, por acreditarem em meu trabalho e me darem todo o suporte necessário para que eu fosse capaz de sonhar e, mais do que isso, atingir cada um dos sonhos e das conquistas que tive a oportunidade de alcançar.

Aos meus familiares, por estarem presentes em todas as conquistas, de corpo e em espírito. Aos meus amores vó Iracema, vô Moacir, vó Maria, vô Pedro, tia Eliane e tio Paulo. Especialmente ao Gustavo, meu irmão de vida e de caminhada.

Ao Bruno, por ter me dado dias de tranquilidade e confiança durante o período na Espanha. Por ter sido minha família e meu ombro amigo diário nos momentos em que a distância parecia insuportável. Por ter partilhado tanto e por ter me mostrado a fragilidade das relações humanas.

À minha família salamantina, por terem se tornado minha família para todos os dias durante os momentos mais difíceis que já vivi. Por terem feito festa comigo e terem me acolhido em suas casas e vidas durante nosso intercâmbio. À Renata e a seus meninos Marcelo e Adriano, Ana Raquel e Daniel, Marina e Diego, Bruna e Gabriel, Juliana, Gabriela, Beatriz e Brena. Especialmente à minha irmã Renata e ao meu cunhado Daniel - também parceiro de doctorado -, que trouxeram para nossas vidas a linda Luna. Obrigada de verdade por tudo!

Às amigas maravilhosas que permanecem em minha vida e deixam um pouco delas em mim, especialmente à Kátia, Amanda, Natália, Pamella, Kamilla, Jéssica, Gabriela, Isabella, Paula, Fernanda, Mayara, Aline, Karine, Marília e Nathaly, que souberam estar presente mesmo com mais de $8.000 \mathrm{~km}$ de distância e, depois, com a inevitável ausência que a redação de uma tese impõe.

Devo agradecer também àqueles que foram cruciais na elaboração deste trabalho, justamente pelas parcerias firmadas, por terem colaborado diretamente de alguma forma para a sua conclusão.

Ao dr. Benedito Guimarães Aguiar Neto, então reitor da Universidade Presbiteriana Mackenzie quando tive a oportunidade de ir à Salamanca aprofundar os estudos desta pesquisa. Mesmo do alto de seu cargo, fez questão de acompanhar meu trabalho de perto e o incentivou desde que me conheceu. Atualmente no comando da Coordenação de Aperfeiçoamento de Pessoal de Nível Superior (Capes), órgão do governo federal que prima pelas pesquisas em todo 
o país e é a maior incentivadora do desenvolvimento científico e tecnológico da sociedade brasileira.

A todos os funcionários e ao corpo docente da Faculdade de Direito e do Programa de Pós-Graduação da Universidade Presbiteriana Mackenzie. Professores na verdadeira acepção do termo, dos quais tive o prazer de ser aluna durante a graduação e a pós-graduação, além de tornar-me professora dessa renomada instituição ao longo dessa caminhada. Aqui, agradeço ao atual Reitor do Mackenzie Marco Tullio de Castro Vasconcellos e o atual Diretor da Faculdade de Direito Gianpaolo Poggio Smanio, os quais, não mediram esforços para que eu pudesse morar na Espanha e estar vinculada às duas universidades.

Também agradeço especialmente à professora Monica Herman Salem Caggiano, que teve a generosidade de conhecer meu trabalho e, quando soube da temática, fez de tudo para eu ter a oportunidade de encontrar sua amiga e referência na área, que veio a se tornar minha coorientadora na Universidade de Salamanca.

A la Universidad de Salamanca, por haber creído en mi proyecto y aportar inagotables recursos de investigación. Por la maravillosa estructura proporcionada a todos los investigadores. Por ser un verdadero centro de excelencia en investigación con más de ochocientos años de existencia. Por cuidar a todos sus estudiantes extranjeros, que forman su excelente plantilla y promueven debates en profundidad en las más diversas áreas del conocimiento científico.

Agradeço também aos professores que compuseram minha banca de qualificação e defesa e gentilmente atenderam ao convite, cedendo algumas de suas preciosas horas para contribuir ao desenvolvimento e ao aprimoramento deste trabalho. Sem eles, esta pesquisa jamais teria alcançado a profundidade inerente a uma tese. Especialmente ao amigo e incentivador professor Carlos Eduardo do Nascimento, docente na essência, que leu cada vírgula deste trabalho como se fosse dele próprio e fez questão de auxiliar com todo e qualquer pedido de bibliografia e de acesso aos documentos mais sigilosos possíveis.

À Carolina de Gioia Paoli, sócia, parceira, colega de turma, colega de profissão, colega de angústias e frustrações, colega de sonhos e conquistas compartilhadas, irmã de vida e de caminhada. A quem eu agradeço separadamente justamente por seu protagonismo em minha vida e por ter tornado possível a concretização deste sonho enquanto eu precisei deixar todo o "nosso" aqui no Brasil.

Ao Lourenço de Miranda Freire Neto. Por chegar chutando a porta e ficar na janelinha. Por ter transformado todo o meu referencial de relacionamento saudável. Pela parceria diária. Por escrever comigo na cadeira ao lado. Por todo fim de semana de trabalho e dedicação. Por 
ser vocacionado e me ensinar diariamente a amar o que faz. Pela liberdade de me deixar ser quem sou. Por catapultar a minha existência. Por ser bom. Por ser muito mais do que eu poderia imaginar.

Aos amigos de caminhada Bruna Azzari Puga, Pedro Avelino Buck, Diego Monteiro de Arruda Fortes, Mayara Ferrari Longuini, Ruth Carolina Sgrignoli, Michelle Asato Junqueira e Melina Ferracini de Moraes. Justamente porque todos vocês me ajudaram a chegar até aqui, sem os quais este trabalho nunca poderia ser finalizado, seja porque auxiliaram aliviando minha parte no trabalho, seja por terem me encaminhado bibliografias para a pesquisa, por toda a ajuda com a redação do projeto, com os recortes necessários, com todas as preocupações que envolvem essa nossa carreira tão amada e tão bem executada por todos vocês.

A la querida Profesora Pilar Jiménez Tello, directora de mi tesis, que me recibió en su España y con mucho cariño me enseñó a hacerla un poco mía. Con quien aprendí y aprendo cada día sobre la bondad y humildad de los grandes. Con quien cometí errores en Español y sin embargo fui acogida y comprendida. Le di dolores de cabeza cuando perdí la voz y mucha preocupación por ser una niña sola en un país diferente, lejos de mi casa. Quien siempre ha creído en mi potencial y respondió puntualmente a todas las solicitudes de conversaciones sobre el tema que desarrollamos conjuntamente en este trabajo. Ella, que me dio la bienvenida a su grupo de estudio, dándome la oportunidad de reflexionar sobre la Calidad de la Educación Jurídica de una forma crítica. Ella, que fue y es mi fuente de inspiración en Derecho Administrativo. En ella lo que miro y en lo que pienso cuando me pregunto dónde me gustaría estar en el futuro.

E por último, mas não menos importante, ao meu ídolo, prof. Felipe Chiarello de Souza Pinto, que acreditou em mim desde o primeiro dia. O verdadeiro e grande idealizador desta pesquisa, deste projeto e da minha carreira acadêmica. Que realiza todos os meus sonhos. Que foi me buscar na Europa. Que confiou a mim o seu mais ousado projeto. Que batalhou por mim quando todos diziam que eu não seria capaz. Que me autoriza a executar os seus planos mais brilhantes e inovadores. Que acredita em meu potencial e que me incentiva a nunca me conformar com a mediocridade. Que me faz ir além, quando eu acho que já não tenho mais recursos para melhorar. Que consegue extrair o melhor do que existe em mim. Obrigada por ter me coagido ao intercâmbio. Como sempre, o senhor estava certo e tem razão! 
A crise da educação no Brasil não é uma crise;

É um projeto.

(Darcy Ribeiro) 


\section{RESUMO}

Tendo por pressuposto a necessidade de apurar a qualidade da educação superior brasileira, pautada pela existência de uma crise nesse setor, e a busca pelo constante aprimoramento dos serviços prestados em território nacional, a presente tese se propõe a analisar a importância de compreender a estrutura e o procedimento dos mecanismos públicos e privados idealizados para isso. Também objetiva-se conhecer as eventuais influências econômicas que estão por trás das formas dos modelos de gestão pública que foram identificados até hoje. O propósito consistiu em entender os meandros que percorrem a instituição e manutenção de entidades privadas que atuam na prestação positiva de serviços públicos essenciais, para averiguar se os objetivos pretendidos pelo referido Plano Diretor são realmente atingidos por meio da aproximação entre o setor público e o setor privado. Soma-se a isso o intuito de compreender como se dá a aplicação de mecanismos típicos de mercado pelo Estado, a fim de assegurar a satisfação do "cidadão-cliente". A pesquisa busca tecer uma análise crítica de toda a reforma intencionada, apontando as específicas alterações constitucionais adotadas para melhorar a gestão pública, por meio de uma linha temporária da sucessão de acontecimentos que cercaram os ideais executados. Desenvolveu-se a descrição teórica dos modelos de Estado idealizados e implementados no contexto brasileiro, sendo eles: o modelo patrimonialista, o modelo burocrático ou intervencionista e, finalmente, o modelo gerencial. A pesquisa foi elaborada utilizando-se do método de procedimento sistêmico, com auxílio da abordagem histórica e comparativa, tecendo uma análise crítica ao modelo previsto implementado em nossa sociedade desde os anos 1990, sob a argumentação de que a eficiência na prestação dos serviços públicos seria alcançada mais facilmente com o modelo gerencial idealizado. Apresentou-se a evolução do pensamento concebido pelos administrativistas, na tentativa de melhor organizar a administração pública e conseguir gerir com mais efetividade os bens e o patrimônio público e buscar o desenvolvimento da sociedade. Pretendeu-se demonstrar o panorama da gestão pública, justificando o atual cenário por intermédio dos fatos que nos trouxeram ao presente modelo de gestão pública. A importância da pesquisa realizada consubstancia-se na necessidade de sistematizar historicamente a compreensão como um todo dos ideais que permeiam a organização pública, para que seja possível entender o ponto organizacional em que estamos e quais transformações estruturais serão eventualmente observadas adiante.

Palavras-chave: Direito Constitucional. Direito Econômico. Direito Administrativo. Direito Educacional. Ensino Superior. 


\section{RESUMEN}

Asumiendo la necesidad de conocer la calidad de la educación superior brasileña, a partir de la existencia de una crisis en este sector, y la búsqueda de la mejora constante de los servicios prestados en el territorio nacional, esta tesis propone analizar la importancia de comprender la estructura y el procedimiento de los mecanismos públicos y privados idealizados para ello. También pretende conocer las posibles influencias económicas que están detrás de las formas de modelos de gestión pública que se han identificado hasta el día de hoy. El propósito fue comprender los entresijos que atraviesan la institución y mantenimiento de las entidades privadas que actúan en la prestación positiva de los servicios públicos esenciales, a fin de verificar si los objetivos que pretende el referido Plan Maestro se logran realmente a través de la aproximación entre el sector público y el sector. privado. A esto se suma la intención de comprender cómo el Estado aplica los mecanismos típicos de mercado, para asegurar la satisfacción del "ciudadano-cliente". La investigación busca realizar un análisis crítico de toda la reforma pretendida, señalando los cambios constitucionales específicos adoptados para mejorar la gestión pública, a través de una línea temporal de sucesión de hechos que rodearon los ideales ejecutados. Se desarrolló la descripción teórica de los modelos de Estado idealizados e implementados en el contexto brasileño, a saber: el modelo patrimonialista, el modelo burocrático o intervencionista y, finalmente, el modelo gerencial. La investigación se llevó a cabo utilizando el método de procedimiento sistémico, con la ayuda del enfoque histórico y comparativo, realizando un análisis crítico del modelo esperado implementado en nuestra sociedad desde la década de 1990, bajo el argumento de que la eficiencia en la prestación de los servicios públicos sería lograrse más fácilmente con el modelo de gestión idealizado. Se presentó la evolución del pensamiento concebido por los administrativistas, en un intento por organizar mejor la administración pública y gestionar con mayor eficacia los bienes y el patrimonio público y buscar el desarrollo de la sociedad. Se pretendía demostrar el panorama de la gestión pública, justificando el escenario actual a través de los hechos que nos llevaron al modelo actual de gestión pública. La importancia de la investigación realizada se basa en la necesidad de sistematizar históricamente la comprensión como un todo de los ideales que permean la organización pública, de manera que sea posible comprender el punto organizativo en el que nos encontramos y qué cambios estructurales eventualmente se observarán a continuación.

Palabras clave: Derecho Constitucional. Derecho Económico. Derecho Administrativo. Derecho Educacional. Educación Superior. 


\begin{abstract}
Assuming the need to ascertain the quality of Brazilian higher education, based on the existence of a crisis in this sector, and the search for constant improvement of services provided in the national territory, this thesis proposes to analyze the importance of understanding the structure and the procedure of the public and private mechanisms idealized for this. It also aims to know the possible economic influences that are behind the forms of public management models that have been identified until today. The purpose was to understand the intricacies that go through the institution and maintenance of private entities that act in the positive provision of essential public services, in order to verify if the objectives intended by the referred Master Plan are really achieved through the approximation between the public sector and the private. Added to this is the intention to understand how the State applies typical market mechanisms, in order to ensure the satisfaction of the "citizen-client". The research seeks to carry out a critical analysis of the entire intended reform, pointing out the specific constitutional changes adopted to improve public management, through a temporary line of the succession of events that surrounded the executed ideals. The theoretical description of the State models idealized and implemented in the Brazilian context was developed, namely: the patrimonialist model, the bureaucratic or interventionist model and, finally, the managerial model. The research was carried out using the systemic procedure method, with the help of the historical and comparative approach, making a critical analysis of the expected model implemented in our society since the 1990s, under the argument that efficiency in the provision of public services would be achieved more easily with the idealized management model. The evolution of the thinking conceived by the gestor was presented, in an attempt to better organize the public administration and manage to manage public goods and assets more effectively and seek the development of society. It was intended to demonstrate the panorama of public management, justifying the current scenario through the facts that brought us to the present model of public management. The importance of the research carried out is based on the need to historically systematize the understanding as a whole of the ideals that permeate the public organization, so that it is possible to understand the organizational point in which we are and what structural changes will eventually be observed below.
\end{abstract}

Keywords: Constitutional Law. Economic Law. Administrative Law. Educational Law. Higher Education. 


\section{LISTA DE ESQUEMAS}

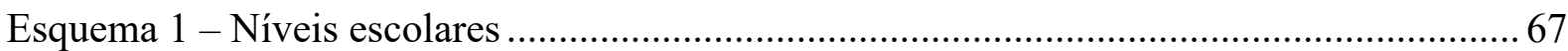

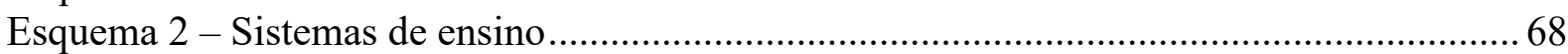

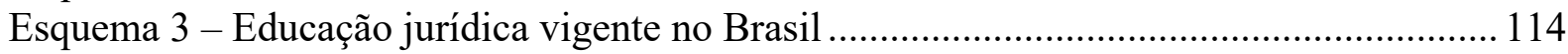

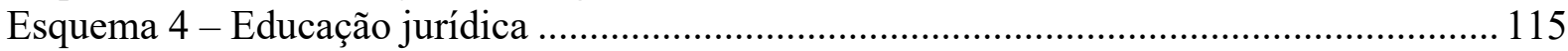

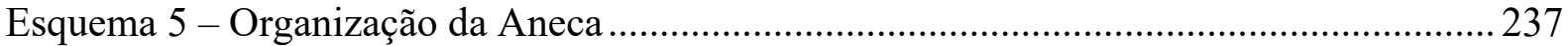

\section{LISTA DE FIGURAS}

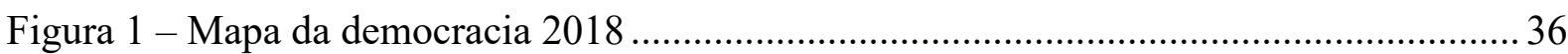

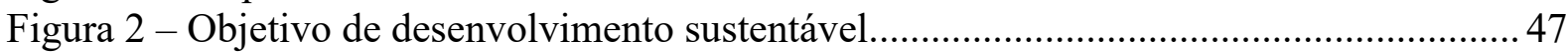

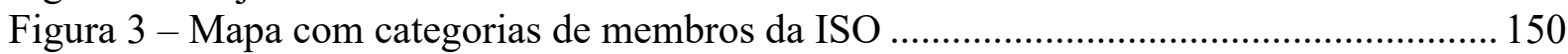

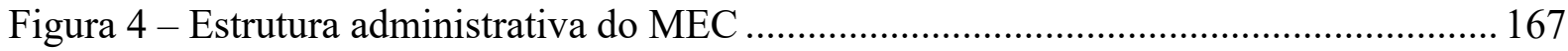

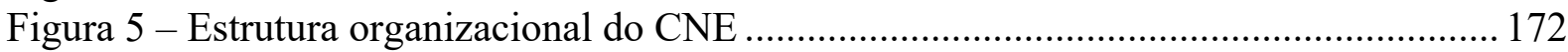

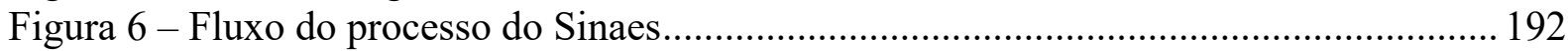

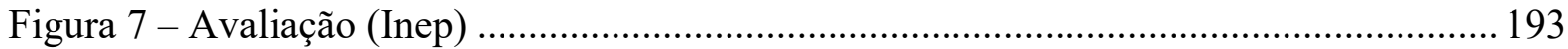

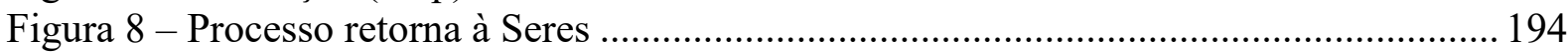

Figura 9 - Regulamentação da avaliação da educação superior no Brasil............................. 200

Figura 10 - Composição da avaliação e componentes do RUF ........................................... 228

\section{LISTA DE GRÁFICOS}

Gráfico 1 - Despesa do Poder Judiciário como (\%) percentual do produto interno .............. 119

Gráfico 2 - Número de magistrados por 100.000 habitantes.............................................. 120

Gráfico 3 - Proporção de cursos de Direito por região ............................................................ 139

Gráfico 4 - Proporção de cursos de Direito por região e número de habitantes..................... 139

Gráfico 5 - Proporção de cursos na região Norte ................................................................ 141

Gráfico 6 - Proporção de cursos na região Nordeste ............................................................ 141

Gráfico 7 - Proporção de cursos na região Sul ................................................................... 141

Gráfico 8 - Proporção de cursos na região Sudeste................................................................ 141

Gráfico 9 - Proporção de cursos na região Centro-Oeste .................................................. 142

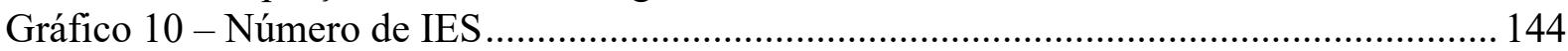

Gráfico 11 - Proporção de IES brasileiras em atividade (públicas e privadas) .................... 145

Gráfico 12 - Número de IES em atividade no Brasil no ano de 2017 ................................. 177

Gráfico 13 - Número de IES que oferecem o curso de Direito no Brasil.............................. 178 


\section{LISTA DE QUADROS}

Quadro 1 - Competências de cada sistema de ensino.

Quadro 2 - Principais ações governamentais na política da educação superior no período de 2003 a 2010 (governo Lula)

Quadro 3 - Principais ações governamentais na política da educação superior no período de 2011 a 2018 (governo Dilma e Temer) ...................................................... 110

Quadro 4 - IES que ofertaram curso de Direito em 2017 ................................................. 179

Quadro 5 - IES estaduais que ofertaram Direito em 2017 .............................................. 181

Quadro 6 - IES municipais que ofertaram Direito em 2017 ............................................ 182

Quadro 7 - IES municipais que ofertaram Direito em 2017, segundo o Inep ...................... 182

Quadro 8 - Rankings acadêmicos e respectivos indicadores condicionantes no processo de avaliação de instituições de ensino superior

\section{LISTA DE TABELAS}

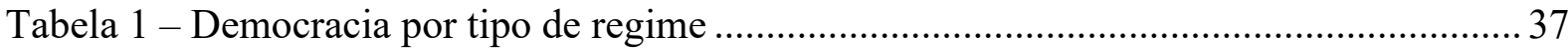

Tabela 2 - Classificação por país da América Latina e Caribe 2018...................................... 40

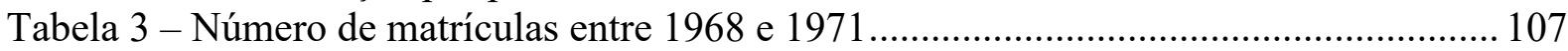

Tabela 4 - Número de instituições que oferecem o curso no Brasil (2017) .......................... 131

Tabela 5 - Número de instituições que oferecem o curso por Estado (2017)........................ 131

Tabela 6 - Comparação entre número de instituições que oferecem o curso e tabela

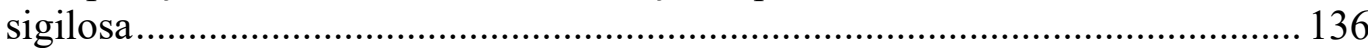

Tabela 8 - Total de cursos de Direito por região e número de habitantes ............................ 138

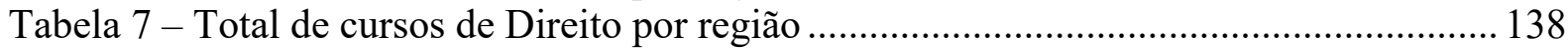

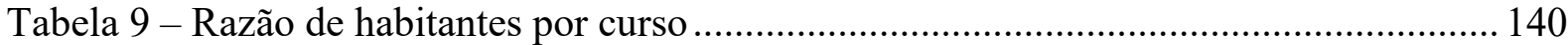

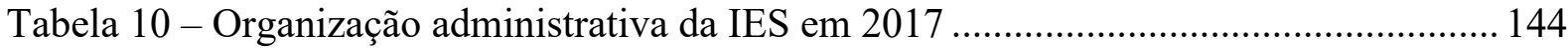

Tabela 11 - IES brasileiras em atividade (públicas e privadas) .......................................... 145

Tabela 12 - Organização administrativa das IES em atividade ......................................... 178

Tabela 13 - Número de instituições que oferecem o curso................................................ 179 


\section{LISTA DE ABREVIATURAS E SIGLAS}

ABNT Associação Brasileira de Normas Técnicas

AMN Associação Mercosul de Normalização

Aneca Agencia Nacional de Evaluación de la Calidad y Acreditación

Bovespa Bolsa de Valores de São Paulo

CAC Coordenação de Apoio ao Colegiado

Capes Coordenação de Aperfeiçoamento de Pessoal de Nível Superior

CEB Câmara de Educação Básica

CES Câmara de Educação Superior

CF Constituição Federal

CNE Conselho Nacional de Educação

CNÉ Comité National d'Évaluation

CNJ Conselho Nacional de Justiça

CNPq Conselho Nacional de Desenvolvimento Científico e Tecnológico

Conae Conferência Nacional da Educação

Conaes Conselho Nacional de Avaliação da Educação Superior

Copant Comissão Pan-Americana de Padrões

CPC Conceito Preliminar de Curso

CTAA Comissão Técnica de Acompanhamento da Avaliação

CWUR Center for World University Rankings

DAA Divisão de Apoio Administrativo

DCN Diretrizes Curriculares Nacionais

DUDH Declaração Universal de Direitos Humanos

EAD Ensino a distância

EFQM European Foundation Quality Management

Enade Exame Nacional de Desempenho de Estudantes

ENC Exame Nacional dos Cursos

Enem Exame Nacional do Ensino Médio

EPB Estudo dos Problemas Brasileiros

EUA Estados Unidos da América

Fies Fundo de Financiamento Estudantil

FMU Centro Universitário das Faculdades Metropolitas Unidas

GEN Global Ecolabelling Network 
IBGE Instituto Brasileiro de Geografia e Estatística

IEC Comissão Eletrotécnica Internacional

IES Instituição de Ensino Superior

Ifes Instituições Federais de Ensino Superior

Ifet Institutos Federais de Educação, Ciência e Tecnologia

IGC Índice Geral de Cursos

Inep Instituto Nacional de Estudos e Pesquisas Educacionais Anísio Teixeira

Inpi Instituto Nacional da Propriedade Industrial

ISO International Organization for Standardization

LDB Lei de Diretrizes e Bases da Educação Nacional

MEC Ministério da Educação

MPOG Ministério do Planejamento, Desenvolvimento e Gestão

OAB Ordem dos Advogados do Brasil

OCDE Organização para a Cooperação e Desenvolvimento Econômico

ONU Organização das Nações Unidas

OS Organizações sociais

OSC Organizações da sociedade civil

Oscip Organizações da sociedade civil de interesse público

PDE Plano de Desenvolvimento da Educação

PDI Projeto de Desenvolvimento Institucional

PIB Produto Interno Bruto

Pnaes Programa Nacional de Assistência Estudantil

PNE Plano Nacional de Educação

PNUD Programa das Nações Unidas para o Desenvolvimento

PPC Projeto Pedagógico de Curso

Prouni Programa Universidade para Todos

PUC/RJ Pontifícia Universidade Católica do Rio de Janeiro

QS Quacquareli Symonds

Reuni Programa de Apoio a Planos de Restruturação e Expansão das Universidades Federais

RUF Ranking Universitário Folha

SciELO Scientific Electronic Library Online

Seres Secretaria de Regulação e Supervisão da Educação Superior

Sesu Secretaria de Ensino Superior 
Sinaes Sistema Nacional de Avaliação da Educação Superior

Sinapes Sistema Nacional de Avaliação e Progresso do Ensino Superior

THE-TR Times Higher Education

UAB Universidade Aberta do Brasil

Unesco Organização das Nações Unidas para a Educação, a Ciência e a Cultura

UNG Universidade de Guarulhos

Uninove Universidade Nove de Julho

Unip Universidade Paulista

Univeritas Centro Universitário Universus Veritas

USP Universidade de São Paulo 


\section{SUMÁRIO}

INTRODUÇÃ

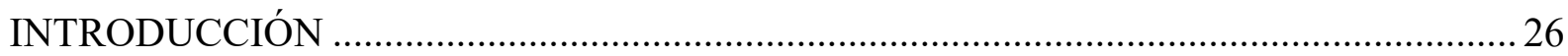

1 DEMOCRACIA E DIREITO À EDUCAÇÃO SUPERIOR DE QUALIDADE: FORMAS DE PRESTAR O SERVIÇO EDUCACIONAL, PROTEÇÃO CONSTITUCIONAL E PECULIARIDADES DA ÁREA DO DIREITO ..................... 34

1.1 A educação superior na Constituição Federal brasileira e as peculiaridades da área

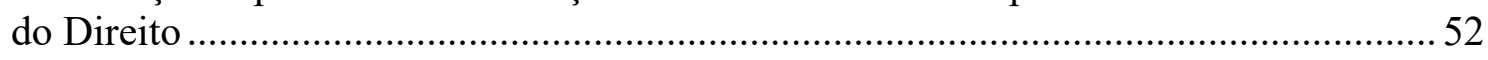

1.2 Serviço público educacional em nível superior e autorização à livre iniciativa: organização acadêmica e administrativa dos cursos de Direito no Brasil ...................... 76

2 A CRISE DA EDUCAÇÃO JURÍDICA BRASILEIRA E OS ATORES NELA ENVOLVIDOS

2.1 Mercantilização da educação superior: a lógica de mercado aplicada ao sistema educacional brasileiro

2.2 Crise da educação jurídica brasileira e a parcela de responsabilidade dos envolvidos....

2.3 Mecanismo público de controle de qualidade da educação jurídica brasileira e suas fragilidades: críticas ao modelo e dados públicos coletados para comprovar a existência da crise

3 PROCESSOS E MECANISMOS EUROPEUS E BRASILEIROS IDEALIZADOS PARA ASSEGURAR A QUALIDADE UNIVERSITÁRIA..

3.1 Iniciativa própria da instituição de ensino superior pelo controle de qualidade dos serviços que presta: uma proposta de compliance educacional.

3.2 Avaliação e credenciamento público: autorizações estatais para funcionamento das instituições de ensino superior

3.3 Uma possível alternativa para apuração de qualidade educacional: mecanismos de controle de qualidade efetuados pelo setor privado com apoio da sociedade civil ...... 202

4 NECESSIDADE DO FOMENTO DE ESTUDOS E IMPLEMENTAÇÃO DE POLÍTICAS PÚBLICAS QUE OBJETIVEM O RECONHECIMENTO MUNDIAL DA QUALIDADE DA EDUCAÇÃO JURÍDICA BRASILEIRA:

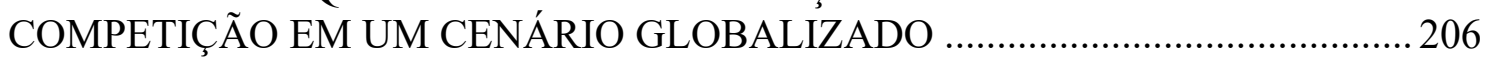

4.1 A lógica da competitividade aplicada ao setor educacional na realidade brasileira..... 210

4.2 Qualidade da educação superior aferida por rankings nacionais e internacionais ....... 221

4.3 Adequações necessárias para apuração da qualidade da educação superior visando a inserção do Brasil no cenário mundial ..................................................................... 234

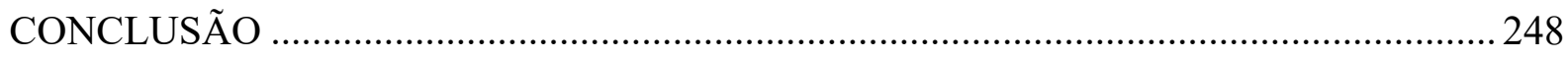

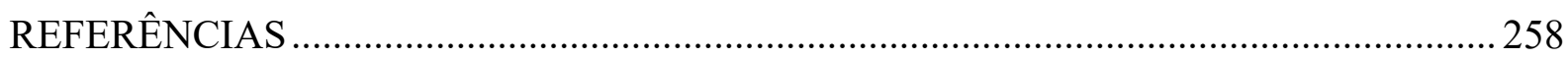




\section{INTRODUÇÃO}

A educação superior é tema de análises, discussões e investigações desde a sua institucionalização como a competente formação técnica capaz de habilitar o sujeito de direitos para o exercício eficaz da atividade profissional. Portanto, para que a educação seja efetiva, é de rigor ser de boa qualidade, sendo esta o elemento principal para a garantia de efetivação do direito à educação.

Nesse sentido, a presente pesquisa foi pautada pelo interesse duradouro em compreender os meandros que envolvem os deveres estatais inerentes à físcalização e ao controle das atividades desenvolvidas pelas instituições de ensino superior (IES). Tal condição visou apreender a qualidade desses serviços prestados em território nacional, assim como o estudo dos processos de autorização, implementação e manutenção das referidas instituições de ensino superior de cursos na área do Direito desenvolvidos no Brasil.

Com a pesquisa, destaca-se a necessidade de aprofundar uma abordagem jurídica que não caminha sozinha, visto que ela se vale de compreensões advindas de diversos campos das ciências sociais que se entrelaçam com o Direito, tais como a Administração Pública, a Política e a Educação. Nesse introito, destaca-se a transdisciplinaridade que o trabalho conseguiu alcançar em razão de versar sobre uma temática que abrange variados campos do saber científico.

Essa investigação foi desenvolvida sob regime de parceria entre os programas de pósgraduação de duas renomadas instituições de ensino superior, uma no Brasil e outra no Reino da Espanha. No Brasil, o Programa de Pós-Graduação em Direito Político e Econômico da Universidade Presbiteriana Mackenzie, na linha de pesquisa "Poder Econômico e seus Limites Jurídicos", concentra a realização de estudos que abordem as relações entre o fenômeno jurídico e o modo de produção capitalista. O objetivo é identificar, fundamentar e justificar os limites jurídicos do poder econômico, relacionando-os com o papel do Estado no domínio econômico.

A presente pesquisa pode ser inserida nessa diretriz, tendo em vista a sua vinculação à uma linha de pesquisa de ampla margem que se propõe a abarcar, de forma aprofundada, temas afetos ao Direito Público, tais como o Direito Constitucional, Administrativo e Educacional, Gestão Pública e Privada e Política Aplicada.

Além disso, para que a análise comparativa pudesse ser efetuada com rigorosidade, foi essencial o período de estágio doutoral na Universidade de Salamanca, localizada no Reino da Espanha, para a análise dos índices de qualidade auferidos no cenário europeu. Nessa instituição de ensino, dentro do programa de Doutorado em Administración, Hacienda y Justicia en el 
Estado Social, a linha de pesquisa adotada foi "Administrações Públicas no Estado Social de Direito", pautando-se por elementos similares à promoção da educação na Espanha como mecanismo de desenvolvimento nacional e levando em consideração origem e preceitos desenvolvimentistas próximos daqueles que pretendem ser implementados no Brasil. Partindo da importância do papel da educação para efetivação do Estado Social de Direito na Espanha, foram adotadas as mesmas premissas lá aplicadas para a tentativa de melhoria do cenário da educação superior brasileira.

Somente com essa análise foi possível compreender os elementos que devem ser aplicados no Brasil para que as instituições de ensino nacionais ganhem força e um dia possam figurar entre as mais renomadas em um cenário globalizado - embora seja imperioso ressaltar que mesmo as mais importantes instituições de ensino de excelência encontram dificuldades para conseguir esse feito caso estejam fora do circuito dos Estados Unidos da América (EUA) e da Inglaterra.

A escolha das referidas linhas de pesquisa parte do pressuposto da existência de um Estado forte, capaz de controlar os interesses privados dos detentores do poder econômico. A preocupação central deste estudo se destinou a consolidar uma perspectiva de raciocínio crítico do Direito, à luz dos impactos provocados pelas mudanças e transformações de paradigmas da sociedade contemporânea na ampla esfera de problemas, perplexidades e interesses públicos e privados que fazem divisa ou até mesmo se confundem com as dimensões mais aglutinadoras, interdependentes e, por essa razão, mais atualizadas de Direito Político, Econômico, Administrativo e Educacional.

A metodologia científica empregada é consubstanciada no método sistêmico, tendo em vista que os diversos elementos investigados foram reunidos de maneira conjuntural, obedecendo a uma lógica de organização. Tal estrutura compreende as influências que os modelos educacionais vigentes se sujeitam para apresentar resultados positivos perante as avaliações oficiais efetuadas pelos responsáveis órgãos públicos brasileiros.

A ideia central consistiu em verificar a possibilidade de se instituir um modelo alternativo ao atualmente desempenhado pelo governo brasileiro para aferição da qualidade da educação em nível superior. Assim, a proposta foi de compreender a metodologia, as métricas e a forma de realização de ranqueamentos internacionais capazes de influenciar a escolha daqueles que irão estudar nas instituições de ensino superior no Brasil. A finalidade era conseguir apresentar uma alternativa viável na apuração da qualidade do serviço prestado, mas que fosse de maneira diversa daquela praticada atualmente no país e que estabelecesse uma nova forma de competitividade institucional. 
Para atingir o mencionado objetivo, foram estudadas as metodologias adotadas no ranqueamento universitário internacional de instituições de ensino, cujas métricas pretendem ser aplicadas no Brasil. Tais parâmetros devem apurar de forma transparente e equânime todas as instituições de ensino que regularmente prestem serviços educacionais em território nacional.

A presente pesquisa discute aspectos intrínsecos à educação superior na área do Direito no Brasil, considerando sua importância como ferramenta de desenvolvimento social e econômico. Posto que a educação consiste em um dos papéis de interesses estratégicos do Estado capazes de abrir caminhos para o desenvolvimento nacional, ela também é instrumento essencial na formação para a cidadania.

Para tanto, objetiva-se compreender quais são as premissas, os indicadores e os procedimentos de avaliação instituídos pelo Ministério da Educação (MEC), os quais foram implementados com a intenção de assegurar a efetiva entrega de cursos de qualidade para a sociedade brasileira.

Além disso, pretende-se analisar se tais requisitos são verdadeiramente apurados pelos vigentes sistemas de avaliação e se de fato essas avaliações atualmente realizadas pelo poder público conseguem verificar a realidade do serviço que as instituições de ensino superior prestam à sociedade brasileira.

Parte-se do pressuposto que a educação, reconhecida como direito humano basilar e direito social consagrado na Constituição Federal (CF), é de responsabilidade do Estado, o qual deve promover o desenvolvimento da sociedade mediante a prestação de serviços educacionais que podem ser oferecidos diretamente por ele, com o auxílio da atuação privada, ou pelo setor privado, mediante sua autorização e constante fiscalização da qualidade do serviço posta à sociedade.

Especificamente com relação à educação, o Estado autoriza que o mercado atue nesse setor, autonomamente ou em parceria. A partir da implementação da vigente Lei de Diretrizes e Bases da Educação Nacional (LDB), o setor privado passou a ter autorização legal para atuar, inclusive com o objetivo de lucrar, ainda que a melhor atuação esperada seja aquela em que o mencionado propósito não prevaleça sobre a necessidade da disseminação do conhecimento e de acesso a melhores condições de vida dos educandos.

Levando-se em consideração a existência desse específico nicho em que o mercado possui permissão para atuar, diversos desdobramentos puderam ser observados no setor, desde a educação de base até os níveis mais altos do conhecimento científico.

Observando esses desdobramentos no setor educacional brasileiro, é possível afirmar que o desenvolvimento nacional está intimamente atrelado às políticas públicas educacionais, 
bem como à forma pela qual o Estado autoriza que o setor privado desempenhe suas atividades nesse campo.

Visando a compreensão do possível impacto que o poder econômico possui nesse setor, a presente pesquisa identificará a forma de atuação do poder econômico e do poder público no cenário brasileiro, desvendando os limites jurídicos que lhes são idealizados e impostos a fim de limitar o objetivo do lucro para que se coadune com a percepção do respeito à qualidade educacional.

Por meio da Constituição Federal de 1988, responsável por definir normas programáticas sobre a educação superior e promulgar a Lei de Diretrizes e Bases da Educação Nacional e as Diretrizes Curriculares, em 20 de dezembro de 1996 (Lei nº 9.394/96), podemos observar o desenho primário do que fora idealizado para implementação da política pública educacional em nível superior.

Qualquer curso de graduação instituído no Brasil deve obedecer ao que está previsto na mencionada Lei de Diretrizes e Bases da Educação Nacional, especialmente no que está apontado a partir do artigo 43.

No que atine à lei, os artigos que compõem tal capítulo versam sobre algumas das mais importantes normas relativas à estrutura e ao funcionamento do grau de ensino superior, mas, claro, de forma extremamente abrangente e aplicável a qualquer área de conhecimento.

No Brasil, a classificação por áreas do conhecimento científico é proposta pelas agências educacionais, que, de maneira hierarquizada por especificidades, aglutina objetos a partir de suas relações com as atividades desenvolvidas nos contextos de conhecimento.

Nesse cenário, a área de conhecimento à qual se vincula o Direito é denominada Ciências Sociais Aplicadas. No plano geral da educação superior, as Ciências Sociais constituem um ramo da ciência que agrega diferentes campos do saber que tem por objetivo primordial estudar os aspectos sociais do "mundo humano", isto é, a vida social de indivíduos e grupos humanos a partir de uma dimensão de inserção e atuação em sociedade.

O Direito vincula-se a essa área uma vez que, objetivamente considerado e abarcado sob qualquer manto teórico, seja qual for o aspecto em que se apresente, revela-se como fenômeno que busca uma forma de estabelecer a ordem social.

A proposta desta pesquisa é desvendar a realidade da educação superior jurídica, apontando as deficiências inerentes ao setor educacional da área do Direito no Brasil. Com isso, a fim de desenvolver e melhorar o setor educacional, serão consolidados novos mecanismos aptos a transformarem o atual cenário definido pelas políticas educacionais implementadas pelo setor público. Inclusive, é justamente esse o aspecto inovador da pesquisa, haja vista a patente 
necessidade de investigar e desenvolver um mecanismo capaz de transformar a realidade dos cursos de bacharelado em Direito.

A pesquisa ganhou robustez com a participação direta dos orientadores. No Brasil, foi acompanhada pelo professor Felipe Chiarello de Souza Pinto, que se dedica institucionalmente à pesquisa e implementação de mecanismos aptos à melhoria dos índices e compreensão dos indicadores apontados pelos órgãos públicos capacitados para a avaliação da educação superior.

Já no Reino da Espanha, foi acompanhada pela professora Maria Teresa del Pilar Jiménez Tello, que se dedica à pesquisa e compreensão da auditoria universitária e sua qualidade, sendo uma referência internacional nessa temática e responsável direta pelo setor de qualidade da Universidade de Salamanca.

Destaque-se o aprofundamento na temática da qualidade e nos modelos internacionais de qualidade aplicados à administração pública, bem como à educação que por ela deve ser desenvolvida. Serão compreendidos os mecanismos de garantia da qualidade aplicados na Espanha, que será o ponto de partida, enquanto referencial, para aplicabilidade no Brasil.

Além disso, com o domínio dessa técnica, será apresentado um novo mecanismo de aferição da qualidade educacional específico para o Brasil, com base nos mecanismos estudados, desempenhados e adotados na Europa e nos Estados Unidos. Dessa maneira, será possível que instituições de ensino superior brasileiras compitam, primeiramente entre si, buscando a melhoria da qualidade educacional nacional como um todo, para, posteriormente, reunirmos condições reais e concretas suficientes para competição direta com renomadas instituições internacionalmente reconhecidas como de excelência.

Diante dos plausíveis indícios constatados pela análise dos resultados dos exames nacionais realizados pela Ordem dos Advogados do Brasil (OAB), é totalmente factível notar nesse contexto a existência da mencionada crise na educação jurídica brasileira. Soma-se a isso os extratos avaliativos do desempenho das instituições de ensino superior e dos milhares de bacharéis em Direito que, mesmo após a completa formação, não valorizam ou, até mesmo, desconhecem mecanismos para o exercício da cidadania, atrelado à má qualidade dos profissionais que, finalmente, ingressam no mercado de trabalho.

Discorre-se também sobre a grave crise pedagógica na área do Direito, levando-se em consideração que os educadores da área raramente buscam compreender mecanismos e técnicas educacionais para praticar a melhor educação jurídica possível.

Para desvendar os problemas apontados nesta pesquisa, a principal proposta é a de examinar a fundo a compreensão de que a educação no nível superior se baseia em três eixos fundamentais constitucionalmente consagrados, quais sejam: ensino, pesquisa e extensão. Com 
esse aprofundamento, objetiva-se criticar o que de fato acontece para oportunamente idealizar mecanismos capazes de melhorar a forma pela qual a vinculação desses fundamentais eixos se perfaz na área do Direito.

Para tanto, visa compreender o cenário da educação jurídica para demonstrar a dinamicidade de sua atuação. Assim, é fundamental descobrir quem são os principais atores envolvidos na qualidade desse setor educacional, quais seus tamanhos e sua relevância para aferir a qualidade da educação jurídica brasileira.

Atualmente, os mecanismos de avaliação da qualidade da educação superior no Direito desenvolvida no Brasil são idealizados e elaborados pelo Ministério da Educação, pautados fundamentalmente em análises de dados estatísticos considerados de maneira objetiva, aliadas às análises subjetivas decorrentes das visitas e avaliações exaradas por avaliadores previamente selecionados pelo poder público.

Averígua-se o destino dado para esse conjunto de avaliações efetuados por todo o país, a fim de conseguir comprovar se esses índices apontados são, de fato, aplicados para a melhoria do setor educacional e desenvolvimentista do Brasil.

Além disso, pretende-se demonstrar que a atuação do mercado no setor educacional, da forma como é atualmente desempenhada no cenário brasileiro, gera uma série de distorções negativas, sendo que o objetivo principal da autorização estatal para que o setor privado pudesse atuar na educação era a melhoria do desenvolvimento nacional diante da adoção da lógica concorrencial no setor, e nunca o mero enriquecimento de um único e específico ator desse complexo cenário.

Investigam-se as mazelas decorrentes do atual formato de permissão da atuação do mercado no setor educacional, para a propositura de uma tentativa de reestruturação do cenário educacional brasileiro, levando-se em consideração que essa pesquisa será restrita à análise dos impactos da qualidade educacional dos cursos jurídicos na educação superior brasileira.

Este estudo foi redigido diante da divisão da temática em quatro capítulos, organizados em um sentido lógico para a compreensão do que será abordado. O primeiro consiste na elucidação dos meandros inerentes à efetivação do direito à educação superior em um regime democrático de direito, abordando também os elementos que asseguram a proteção constitucional da autonomia universitária, o regramento jurídico destinado a esse setor, a relação existente entre os eixos da educação superior e as peculiaridades atinentes à área do Direito. Esses são temas correlatos, que se tocam em muitos aspectos, mas de forma alguma podem ser considerados indissociáveis. 
Após explicar brevemente as diferenças e os pontos de convergência existentes entre a autonomia universitária e a necessidade de sua proteção, abordou-se a crise da educação jurídica brasileira e os atores nela envolvidos. Logo, o segundo capítulo trata do papel do Estado, da sociedade civil, das instituições de ensino superior, públicas, sem fins lucrativos e privadas, dos docentes e discentes, na atual composição brasileira da educação jurídica. Para essa explicação, buscamos compreender a postura de cada um dos atores no período descrito, para que as críticas não pareçam desconexas ao cenário em que elas são praticadas.

No terceiro capítulo são apresentadas questões atinentes aos mecanismos brasileiros públicos e privados idealizados para assegurar a qualidade da educação superior. Será apresentado um estudo comparado entre Brasil, Europa e Estados Unidos para compreensão dos ideais e das práticas relativas à aferição da qualidade educacional efetivamente entregue à sociedade, com o objetivo de compreender como os indicadores devem ser preenchidos para visar a excelência.

A importância de compreender quais são os fatores inerentes à qualidade da educação superior na Europa advém de nosso histórico institucional baseado em premissas fundantes que reproduziram aqui instituições implementadas lá. A análise dos mecanismos efetivados nos Estados Unidos também se mostra essencial para a pesquisa, na medida em que as instituições de ensino superior localizadas nessa região são majoritariamente tidas como de excelência em escala global.

O quarto capítulo tem como objetivo compreender a necessidade de incentivar o fomento de estudos e a implementação de políticas públicas que visem o reconhecimento mundial da qualidade da educação jurídica brasileira. Nesse contexto, buscamos mecanismos para tornar viável a competição em um cenário globalizado para lograr êxito em tornar nossas instituições de ensino superior reconhecidas como de "classe mundial".

A pesquisa serve para, além de criticar as atuais proposições previstas para os mecanismos de aferição da qualidade da educação jurídica no Brasil, apresentar um novo mecanismo, apto a constatar o nível educacional ofertado, com a consequente possibilidade de introjeção no contexto mundial de instituições de ensino reconhecidas como centros de excelência.

Para tanto, é preciso compreender os meandros em que o serviço educacional é desempenhado atualmente, visando sair do senso comum de que qualquer prática advinda do poder público consiste em ingerência e burocratização. Buscou-se compreender a interligação que deve ser feita entre a avaliação oficial exarada pelo poder público e aquela efetuada por sistemas privados de ranqueamento reconhecidos mundialmente, com o objetivo de finalmente 
conseguir figurar instituições de ensino brasileiras como centros educacionais de excelência legitimados internacionalmente.

Como medida de inovação, encerra-se a pesquisa apresentando uma proposta de procedimento avaliativo totalmente renovado, voltado para a execução de uma avaliação da educação superior brasileira que efetivamente consiga apurar a qualidade do setor, como medida de urgência diante da constatação de que o atual sistema é injusto e falho, como será demonstrado a seguir. 


\section{INTRODUCCIÓN}

La educación superior ha sido objeto de discusiones e investigaciones desde su institucionalización como la formación técnica competente capaz de habilitar al sujeto de derechos para el ejercicio efectivo de la actividad profesional. Por lo tanto, para que la educación sea eficaz, es riguroso que sea de buena calidad, siendo la calidad el elemento principal para garantizar la realización del derecho a la educación.

En este sentido, la presente investigación estuvo guiada por el interés duradero en comprender los medios en que se debaten los deberes estatales inherentes a la fiscalización y control de las actividades que desarrollan las Instituciones de Educación Superior con miras a la calidad de estos servicios prestados en el territorio nacional además del estudio de los procesos de autorización, implementación y mantenimiento de las referidas Instituciones de Educación Superior de cursos en el área de Derecho desarrollados en Brasil.

Con la investigación se enfatiza la necesidad de profundizar en un enfoque jurídico que no va solo, ya que se basa en entendimientos de diferentes campos de las ciencias sociales que se entrelazan con el derecho, como la Administración Pública, la Política y Educación. En esta introducción, destacamos la transdisciplinariedad que el trabajo logró por tratar una temática que abarca varios campos del conocimiento científico.

La investigación ocurrió en régimen de colaboración entre los programas de posgrado de dos reconocidas Instituciones de Educación Superior, una en Brasil y otra en el Reino de España. En Brasil, el Programa de Postgrado en Derecho Político y Económico de la Universidade Presbiteriana Mackenzie, dentro de su línea de investigación "El poder económico y sus límites legales", se enfoca en realizar investigaciones que aborden la relación entre el fenómeno jurídico y la producción capitalista, con el fin de identificar, fundamentar y justificar los límites legales del poder económico, relacionándolos con el papel del Estado en el ámbito económico.

La presente investigación puede insertarse en esta línea en vista de su vinculación con una línea de investigación de grande margen que propone tratar de manera integral temas relacionados con el Derecho Público, como el Derecho Constitucional, Administrativo y Educación, la Gestión Pública, privada y Política aplicada.

Además, para que el comparativo sea realizado con rigor, fue imprescindible el periodo de prácticas de doctorado en la Universidad de Salamanca en el Reino de España, para el análisis de los índices de calidad obtenidos en el escenario europeo. En esta Institución, la 
línea de investigación adoptada dentro del programa del Doctorado en Administración, Hacienda y Justicia en el Estado Social, fue "Las Administraciones Públicas en el Estado Social de Derecho", guiada por elementos similares de la promoción de la educación en España como mecanismo de desarrollo nacional, teniendo en cuenta el origen y preceptos evolutivos cercanos a los que pretenden ser implementados en Brasil. Sobre la base de la importancia del papel de la educación para la realización del Estado de Derecho Social en España, se adoptaron las mismas premisas aplicadas allí para el intento de mejorar el escenario de la educación superior brasileña.

Solamente con este análisis fue posible comprender los elementos necesarios que se deben aplicar en Brasil para que las instituciones educativas nacionales se fortalezcan para que algún día puedan estar entre las más reconocidas en un escenario globalizado, aunque es imperativo enfatizar que incluso las instituciones más importantes de excelencia en la enseñanza les resulta difícil estar entre las instituciones más reconocidas si están fuera del circuito de EEUU e Inglaterra.

La elección de estas líneas de investigación se basa en el supuesto de la existencia de un Estado fuerte capaz de controlar los intereses privados de los poseedores del poder económico. La principal preocupación de este estudio fue consolidar una perspectiva de razonamiento crítico del Derecho, a la luz de los impactos provocados por los cambios y transformaciones de paradigmas de la sociedad contemporánea en el amplio ámbito de problemas, perplejidades e intereses públicos y privados que hacen frontera o incluso si confundirse con las dimensiones más aglutinantes, interdependientes y, por ello, más actualizadas del Derecho Político, Económico, Administrativo y Educativo.

La metodología científica que se utilizó está fijada en el método sistémico considerando que los diversos elementos investigados fueron reunidos de manera coyuntural, obedeciendo a una lógica organizacional, es decir, la comprensión de las influencias a las que están sometidos los modelos educativos actuales para presentar resultados positivos. antes de las evaluaciones oficiales realizadas por los organismos públicos brasileños responsables.

La idea central es verificar la posibilidad de establecer un modelo alternativo al que actualmente utiliza el gobierno brasileño para medir la calidad de la educación en un nivel superior. Así, la propuesta es comprender la metodología, las métricas y la forma de realizar rankings internacionales capaces de influir en la elección de quienes estudiarán en las Instituciones de Educación Superior en Brasil, con el fin de presentar una alternativa viable en la determinación de la calidad de manera diferente al que se realiza actualmente en Brasil. 
Para lograr el objetivo antes mencionado, se estudiaron las metodologías adoptadas en el ranking universitario internacional de instituciones educativas cuyas métricas se pretenden aplicar en Brasil, con el fin de institucionalizar una nueva forma de competitividad institucional que se determina de manera transparente y equitativa entre todas las instituciones. Instituciones Educativas que brindan servicios educativos de manera regular en todo el territorio nacional.

Esta investigación discute aspectos intrínsecos a la educación superior en el área del Derecho en Brasil, tomando en cuenta su importancia como herramienta para el desarrollo social y económico, dado que la educación es uno de los intereses estratégicos del Estado capaz de abrir caminos para el desarrollo nacional, además de ser un instrumento fundamental en la formación para la ciudadanía.

Tiene como objetivo comprender cuáles son los supuestos, indicadores y procedimientos de evaluación establecidos por el Ministerio de Educación (MEC) en alianza con el Instituto Nacional de Estudios e Investigaciones Educativas Anísio Teixeira (INEP), implementados con la intención de asegurar la entrega efectiva de los cursos. de calidad para la sociedad brasileña, además de analizar si tales requisitos están realmente determinados por los sistemas de evaluación vigentes y si de hecho las evaluaciones que actualmente realiza el Gobierno permiten conocer la realidad del servicio que las Instituciones de Educación Superior brindan a la sociedad brasileña.

Se parte del supuesto de que la Educación, reconocida como derecho humano fundamental y derecho social consagrado en la Constitución Federal, es responsabilidad del Estado, el cual debe promover el desarrollo de la sociedad a través de la provisión de servicios educativos que pueda ser brindado directamente por éste, con la asistencia de la acción privada, o incluso del sector privado a través de su autorización e inspección constante de la calidad del servicio prestado a la sociedad.

Restrictamente en Educación, el Estado autoriza al mercado a operar en este sector, ya sea de forma autónoma o en sociedad. A partir de la implementación de la actual Ley de Bases y Directrices Educativas Nacionales de Brasil, el sector privado tiene autorización legal para actuar, incluso con el objetivo de obtener ganancias, aunque el mejor desempeño esperado es aquel donde el objetivo mencionado no prevalece sobre la necesidad. difusión de conocimientos y acceso a mejores condiciones de vida para los estudiantes. 
Teniendo en cuenta la existencia de este nicho específico en el que se permite operar al mercado, se pudieron observar varios desarrollos en el sector, desde la educación básica hasta los más altos niveles de conocimiento científico.

Observando estos desarrollos en el sector educativo brasileño, es posible afirmar que el desarrollo nacional está estrechamente vinculado a las políticas públicas de educación, así como a la forma en que el Estado autoriza al sector privado a desarrollar sus actividades en este campo.

Con el objetivo de comprender el posible impacto que el poder económico tiene en este sector del desarrollo nacional, esta investigación identificará la forma en que actúa el poder económico y público en el escenario brasileño, desentrañando los límites legales que se idealizan e imponen para limitar el objetivo de lucro para que sea consistente con la percepción de respeto a la calidad educativa.

La Constitución Federal brasileña de 1988 se encargó de definir las normas programáticas de la educación superior, así como la promulgación de la Ley de Directrices y Bases de la Educación Nacional y los Lineamientos Curriculares el 20 de diciembre de 1996 (Ley $n^{\circ}$ 9.394/96), podemos observar el diseño primario de lo que se había diseñado para implementar la política educativa pública a un nivel superior.

Todo curso de grado instituido en Brasil debe cumplir con las disposiciones de la Ley de Lineamientos y Bases de la Educación Nacional antes mencionada, especialmente lo dispuesto en el artículo 43 y siguientes.

En lo que respecta a la ley, los artículos que componen este capítulo tratan algunas de las normas más importantes en cuanto a la estructura y funcionamiento del título de educación superior, es decir, por supuesto, de forma sumamente comprensiva y aplicable a cualquiera de las áreas del conocimiento.

En Brasil, la clasificación por Áreas de conocimiento científico es propuesta por Agencias Educativas, que de manera jerárquica por especificidades reúne objetos, en función de su relación con las actividades desarrolladas en los contextos de conocimiento.

En este escenario, el área de conocimiento a la que se vincula el Derecho se denomina “Ciencias Sociales Aplicadas". En el nivel general de la educación superior, las Ciencias Sociales constituyen una rama de la ciencia que aglutina diferentes campos del conocimiento, y cuyo objetivo primordial es estudiar los aspectos sociales del "mundo humano", es decir, la 
vida social de los individuos y grupos humanos, desde una dimensión de inserción y actuación en la sociedad.

Está vinculado a este ámbito ya que el Derecho, objetivamente considerado y englobado bajo cualquier manto teórico en cualquier aspecto en el que se presente, se revela como un fenómeno que busca una vía para establecer el orden social.

El propósito de esta investigación es dar a conocer la realidad de la educación superior jurídica tratando de señalar las deficiencias inherentes al sector educativo del área de Derecho en Brasil, con la intención de tratar de consolidar nuevos mecanismos capaces de transformar el escenario actual definido por las políticas educativas implementadas por el sector. público para el desarrollo y mejoramiento del sector educativo. Este es incluso el aspecto innovador de la investigación, dada la patente necesidad de investigar y desarrollar un mecanismo capaz de transformar la realidad actual de las carreras de derecho.

La investigación cobró fuerza con la participación directa de los asesores. En Brasil, estuvo acompañada por el profesor Felipe Chiarello de Souza Pinto, quien se dedica institucionalmente a la investigación e implementación de mecanismos capaces de mejorar los índices y comprensión de los indicadores señalados por los organismos públicos calificados para la evaluación de la educación superior.

En el Reino de España estuvo acompañada de la profesora Maria Teresa del Pilar Jiménez Tello, quien se dedica a la investigación y comprensión de la auditoría universitaria y su calidad, siendo una referencia internacional en esta temática, la cuya ha sido responsable directa del sector de la calidad en la Universidad de Salamanca.

Cabe profundizar en el tema de Calidad y em los parametros de medición Internacionales aplicados a la Educación Superior para su aplicación, en base a este marco de aplicabilidad en Brasil.

Además, con el dominio de esta técnica, se presentará un nuevo mecanismo de medición de la calidad educativa propio de Brasil, basado en los mecanismos estudiados, realizados y adoptados en Europa y EEUU, de modo que sea posible que las Instituciones de Educación Superior brasileñas puedan Competir, primero entre sí, buscando mejorar la calidad educativa nacional en su conjunto, para que, posteriormente, podamos reunir condiciones reales y concretas que sean suficientes para la competencia directa con instituciones de reconocido prestigio internacionalmente reconocidas como de excelencia. 
Es totalmente factible notar en este contexto la existencia de la mencionada crisis en la educación jurídica brasileña, dada la plausible evidencia verificada por el análisis de los resultados de los exámenes nacionales realizados por el Colegio de Abogados de Brasil, así como los extractos evaluativos del desempeño de las Instituciones de Educación Superior y de los miles de licenciados en derecho que, aún después de una formación completa, no valoran ni desconocen los mecanismos para el ejercicio de la ciudadanía, ligados a la mala calidad de los profesionales que finalmente ingresan al mercado laboral.

También se analiza la grave crisis pedagógica en el área del Derecho, teniendo en cuenta que los educadores del área rara vez buscan comprender los mecanismos y técnicas educativas para la mejor aplicación posible de la educación jurídica.

Para desentrañar los problemas señalados en esta investigación, la propuesta principal es profundizar en el entendimiento de que la Educación en el nivel superior se sustenta en tres ejes fundamentales consagrados constitucionalmente, a saber: docencia, investigación y extensión. Con esta profundización, el objetivo es criticar lo que realmente sucede para idealizar oportunamente mecanismos que sean capaces de mejorar la forma en que se realiza la articulación de estos ejes fundamentales en el ámbito del Derecho.

Por tanto, busca comprender el escenario de la educación jurídica para demostrar la dinámica de su desempeño. Por tanto, es fundamental descubrir quiénes son los principales actores involucrados en la calidad de este sector educativo, cuáles son sus dimensiones y su relevancia para evaluar la calidad de la educación jurídica brasileña.

Actualmente, los mecanismos de evaluación de la calidad de la Educación Superior en Derecho desarrollados en Brasil son diseñados y desarrollados por el Ministerio de Educación (MEC), con base principalmente en el análisis de datos estadísticos considerados objetivamente, junto con el análisis subjetivo resultante de las visitas y evaluaciones realizadas por evaluadores previos. seleccionado por el Gobierno. Investigamos el destino dado a este conjunto de evaluaciones realizadas por todo el país, con el fin de comprobar que estos índices señalados son, de hecho, aplicados a la mejora del sector educativo y de desarrollo en Brasil.

Además, se pretende demostrar que el desempeño del mercado en el sector educativo tal como se realiza actualmente en el escenario brasileño implica una serie de distorsiones negativas, con el objetivo principal de la autorización estatal para que el sector privado pueda actuar en Educación. fue la mejora del desarrollo nacional ante la adopción de la lógica competitiva en el sector y nunca el mero enriquecimiento de un actor único y específico en este complejo escenario. 
Investiga las dolencias derivadas del actual formato de permiso para la actividad de mercado en el sector educativo, para proponer un intento de reestructuración del escenario educativo brasileño, teniendo en cuenta que esta investigación se restringirá al análisis de los impactos de la calidad educativa de los cursos de derecho. en Educación Superior Brasileña.

Esta investigación fue redactada en vista de la división del tema en cuatro capítulos, los cuales fueron organizados en un sentido lógico para entender lo que se abordará. El primer capítulo consiste en dilucidar los entresijos inherentes a la realización del derecho a la educación superior en un régimen democrático de derecho, abordando también los elementos que aseguran la protección constitucional de la autonomía universitaria, las normas legales para este sector, la relación entre los ejes la educación superior y las peculiaridades relacionadas con el área del Derecho. Estos son temas relacionados, que tocan muchos aspectos, pero de ninguna manera pueden considerarse inseparables.

Después de explicar brevemente las diferencias y puntos de convergencia entre la autonomía universitaria y la necesidad de su protección, se abordó la crisis de la educación jurídica brasileña y los actores involucrados. Aquí nos ocupamos del rol del Estado, Sociedad Civil, Instituciones de Educación Superior, Públicas, Sin Fines de Lucro y Privadas, Docentes y Estudiantes en la actual composición brasileña de la educación jurídica. Para esta explicación, buscamos entender la posición de cada uno de los actores en el período descrito, para que las críticas no parezcan desconectadas del escenario en el que se practican.

En el tercer capítulo, se presentan preguntas relacionadas con los mecanismos públicos y privados brasileños diseñados para asegurar la calidad de la Educación Superior. Se presentará un estudio comparativo entre Brasil, Europa y Estados Unidos para comprender los ideales y prácticas relacionados con la medición de la calidad educativa efectivamente entregada a la sociedad, todo en el sentido de entender, cómo se deben llenar los indicadores para apuntar a la excelencia.

La importancia de entender cuáles son los factores inherentes a la calidad de la Educación Superior en Europa proviene de nuestra historia institucional basada en premisas fundamentales que reproducen aquí las instituciones implementadas allí. El análisis de los mecanismos implementados en EE.UU. también es fundamental para la investigación, ya que las Instituciones de Educación Superior ubicadas en esta región son consideradas en su mayoría como de excelencia a nivel global. 
El cuarto capítulo tiene como objetivo comprender la necesidad de impulsar la promoción de estudios y la implementación de políticas públicas que tengan como objetivo el reconocimiento mundial de la calidad de la educación jurídica brasileña. En este escenario, buscamos mecanismos que viabilicen la competencia en un escenario globalizado para lograr que nuestras Instituciones de Educación Superior sean reconocidas como de "clase mundial".

La investigación se presta no solo para criticar las propuestas actuales previstas para los mecanismos de medición de la calidad de la educación jurídica en Brasil, para presentar un nuevo mecanismo capaz de verificar la calidad de la educación jurídica, con la consiguiente posibilidad de introyección en el contexto mundial de las instituciones educativas. reconocidos como centros de excelencia.

Por tanto, es necesario comprender las complejidades en las que se desempeña actualmente el servicio educativo, con el objetivo de salir del sentido común de que cualquier práctica que surja del Poder Público consiste en injerencia y burocratización. Se buscó comprender la interconexión que debe hacerse entre la evaluación oficial realizada por las autoridades y la realizada por los sistemas privados de ranking reconocidos a nivel mundial, con el objetivo de finalmente poder figurar a las Instituciones Educativas Brasileñas como centros educativos de excelencia reconocidos mundialmente.

Como medida de innovación, la investigación finaliza con la presentación de una propuesta de procedimiento de evaluación totalmente renovado para realizar una evaluación de la Educación Superior Brasileña que logre efectivamente conocer la calidad del sector, como una medida urgente ante la constatación de que el sistema actual La evaluación es injusta y defectuosa, como se mostrará a continuación. 


\section{DEMOCRACIA E DIREITO À EDUCAÇÃO SUPERIOR DE QUALIDADE: FORMAS DE PRESTAR O SERVIÇO EDUCACIONAL, PROTEÇÃO CONSTITUCIONAL E PECULIARIDADES DA ÁREA DO DIREITO}

A democracia pode ser encarada como uma derivação da tendência humana de associação em geral, que cresce na personalidade daqueles que a compõem. Para entender a democracia por esse aspecto é necessário compreender em que consiste a participação do indivíduo. Tal atuação sempre exigirá comunicação pública e debate, razão pela qual em uma democracia plena há que ser respeitado o diálogo como base do desenvolvimento de mentes livres, bem como a possibilidade da livre manifestação dos pensamentos.

Para falar em democracia também deve ser mencionado o exercício da tolerância e do respeito aos mais diversos posicionamentos advindos dessas mentes livres que desejam viver em conjunto. Deve ser assegurada a comunicação, que precisa ser participativa, no sentido de que todos os posicionamentos devem ser ao menos considerados, para que haja a transformação de uma sociedade, invariavelmente composta por diferentes visões.

Parte-se do pressuposto que a democracia é a pré-condição para deliberações inteligentes destinadas aos mais variados setores do desenvolvimento da humanidade. Por conseguinte, somente em um regime democrático será possível desenvolver discussões sobre problemas políticos ou sociais que considerem os mais variados pontos de vistas existentes em uma sociedade plural. Inclusive, a democracia é necessária para promoção de resoluções autônomas desses problemas por parte dos indivíduos que a compõem.

É justamente para o exercício livre desses posicionamentos diversificados, de forma respeitosa, que se encara a educação como instrumento de efetivação da democracia, pois esta depende da educação, e a educação libertadora, capaz de emancipar o ser humano, só acontece, verdadeiramente, em uma democracia.

A educação, assim, deve ser enxergada como promotora da democracia, visto que ela é justamente a base capaz de tornar uma pessoa apta à comunicação respeitosa em um espaço de convivência plural.

Robert Dahl ${ }^{1}$ esclarece que o processo democrático é capaz de promover o desenvolvimento humano, sobretudo no tocante à capacidade para exercer a autodeterminação, a autonomia moral e a responsabilidade do indivíduo por suas próprias ações e decisões. Ainda, é a forma mais segura de que os seres humanos dispõem para proteger e promover os interesses

1 DAHL, Robert Alan. La democracia y sus criticos. Tradução: Leandro Wolfson. 3. ed. Barcelona: Paidós, 2000. p. 373. 
e bens que compartilham entre si.

A ordem democrática assegura a liberdade pretendida desde que se efetive em um Estado de Direito, fundado sobre a autodeterminação do povo de acordo com a vontade da maioria, sobre a liberdade e a igualdade, excluído todo poder violento e arbitrário.

Em um regime democrático, para assegurar que todos tenham condições de igualdade de participação nos processos democráticos, Robert Dahl ${ }^{2}$ aponta que pelo menos cinco critérios devem ser respeitados: participação efetiva, igualdade de voto, aquisição de entendimento esclarecido, exercício de controle definitivo do programa de planejamento e a inclusão dos adultos.

Respeitados esses cinco critérios, a adoção da democracia como regime de organização de um Estado, ainda que apresente falhas, apresenta mais consequências desejáveis do que qualquer outra alternativa viável a ela.

Apenas o regime democrático é capaz de evitar o governo de autocratas cruéis e perversos e de garantir aos cidadãos uma série de direitos fundamentais que os sistemas não democráticos não concedem nem podem conceder.

Só no regime democrático é que são assegurados aos cidadãos uma liberdade individual mais ampla do que qualquer alternativa viável. Tal sistema ajuda as pessoas a protegerem seus próprios interesses fundamentais, proporcionando uma oportunidade máxima para elas exercitarem a liberdade da autodeterminação e assim viverem sob leis de sua própria escolha.

Além disso, a democracia pode conferir uma oportunidade máxima de exercer a responsabilidade moral, promover o desenvolvimento humano mais plenamente do que qualquer opção e ser capaz de propiciar a igualdade política em um grau relativamente elevado. Ademais, as democracias representativas modernas buscam, constantemente, consensos e acordos múltiplos de paz para não guerrear umas com as outras. E, finalmente, países com governos democráticos tendem a ser mais prósperos do que países com governos não democráticos ${ }^{3}$.

O estudo de países soberanos que se autodeclaram como adotantes de regimes democráticos consiste em uma pauta que intriga pesquisadores no mundo inteiro, destacandose que não existe consenso para a mensuração da democracia. Desde 2006, o periódico inglês

2 DAHL, Robert Alan. Sobre a democracia. Tradução: Beatriz Sidou. Brasília, DF: Editora Universidade de Brasília, 2001. p. 50.

3 Ibid., p. 57-74. 
The Economist ${ }^{4}$ realiza estudo anual analisando globalmente a situação da democracia em países independentes ${ }^{5}$. Mediante a concessão de pontuação, que varia de 0 (zero) a 10 (dez), ele se baseia em uma metodologia que avalia cinco categorias nos países analisados, chegando ao seguinte mapa da democracia (Figura 1), em 2018:

Figura 1 - Mapa da democracia 2018

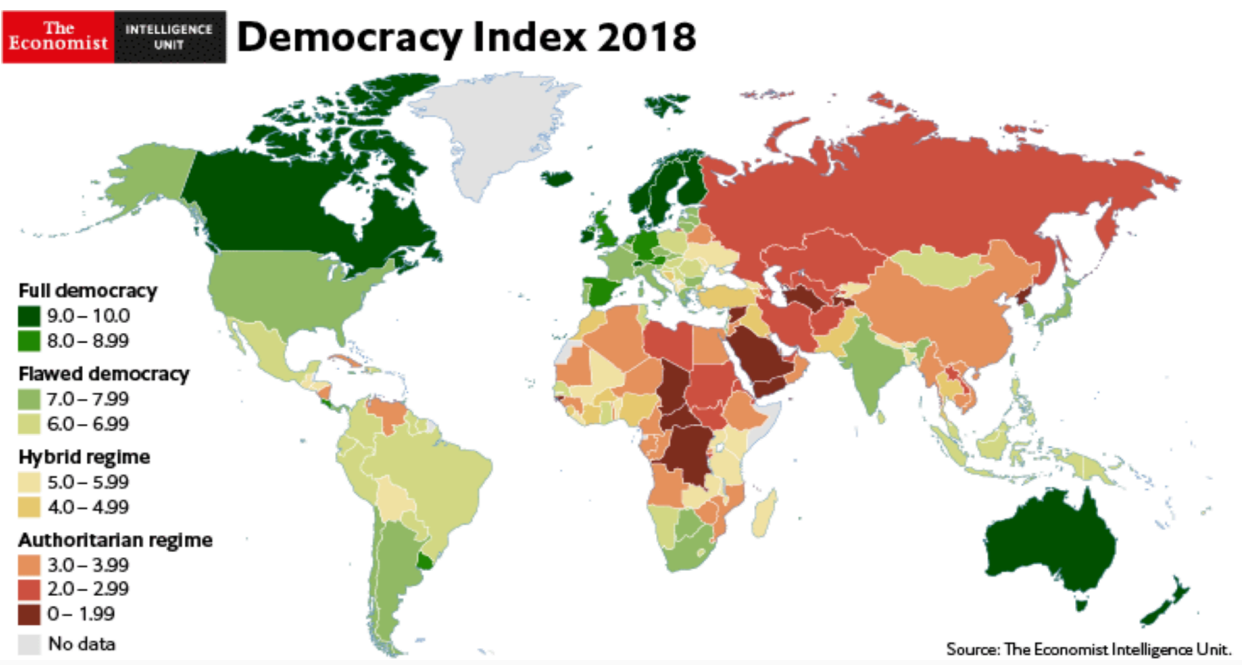

Fonte: The Economist Intelligence Unit, 2019.

Referido índice de democracia calculado por esse estudo é baseado em um cálculo que leva em conta aspectos sobre processo eleitoral e pluralismo, liberdades civis, funcionamento do governo, participação política e cultura política. São analisados e pontuados 60 indicadores dentro dessas categorias, os quais podem ser avaliados com notas que variam de 0 a 1 com base na pontuação que o país recebe diante da efetividade ou não daquele indicador analisado.

Com base no cálculo efetuado, cada país terá uma pontuação específica, a qual estará apta a classificá-lo como incluso em um dos quatro tipos de regime democrático definidos pelo

4 “The Economist Intelligence Unit's Democracy Index provides a snapshot of the state of democracy worldwide for 165 independent states and two territories. This covers almost the entire population of the world and the vast majority of the world's states (microstates are excluded). The Democracy Index is based on five categories: electoral process and pluralism; civil liberties; the functioning of government; political participation; and political culture. Based on its scores on a range of indicators within these categories, each country is then itself classified as one of four types of regime: full democracy, flawed democracy, hybrid regime and authoritarian regime. A full methodology and explanations can be found in the Appendix." Cf. THE ECONOMIST INTELLIGENCE UNIT. Democracy Index 2018: me too?: political participation, protest and democracy: a report by The Economist Intelligence Unit. London: The Economist Intelligence Unit, 2019. p. 2. Disponível em:

https://www.eiu.com/public/topical_report.aspx?campaignid=Democracy2018. Acesso em: 11 jan. 2019.

5 O estudo avalia 165 estados independentes e dois territórios. Segundo a metodologia da pesquisa, isso cobre quase toda a população do mundo e a grande maioria de seus Estados (microestados são excluídos). Destacamos que a Organização das Nações Unidas reconhece a existência de 193 países-membros. Cf. UNITED NATIONS. Member States. Geneva: ONU, [20-?]. 
estudo, quais sejam: democracia plena, democracia falha, regime híbrido e regime autoritário. De acordo com os dados levantados pela pesquisa, encontramos, em linhas gerais, os seguintes percentuais (Tabela 1):

Tabela 1 - Democracia por tipo de regime

\begin{tabular}{|c|c|c|c|}
\hline & No. of countries & $\%$ of countries & $\%$ of world population \\
\hline Full democracies & 20 & 12.0 & 4.5 \\
\hline Flawed democracies & 55 & 32.9 & 43.2 \\
\hline Hybrid regimes & 39 & 23.4 & 16.7 \\
\hline Authoritarian regimes & 53 & 31.7 & 35.6 \\
\hline
\end{tabular}

Fonte: The Economist Intelligence Unit, 2019.

O estudo enquadra como democracia plena (full democracy) ${ }^{6}$ apenas os países que receberam nota acima de 8 . Nesse nível estão os países nos quais não apenas as liberdades políticas básicas e as liberdades civis são respeitadas, mas que também tendem a ser sustentadas por uma cultura política propícia ao florescimento da democracia; o funcionamento do governo é satisfatório; enquadraram a mídia como independente e diversificada, com a existência de um sistema eficaz de verificações e balanços; Poder Judiciário independente e decisões judiciais aplicadas, concluindo que existem apenas limitados problemas no funcionamento do regime democrático.

Foram inseridos no grupo das democracias falhas (flawed democracy) ${ }^{7}$ países que receberam notas maiores do que 6 , porém menores ou iguais a 8 . Nesse grupo foram inseridos os países que também têm eleições livres e justas e, mesmo que haja problemas (como violações à liberdade de imprensa), as liberdades civis básicas são respeitadas. No entanto, existem fragilidades significativas em outros aspectos da democracia, incluindo problemas de

6 "Full democracies: Countries in which not only basic political freedoms and civil liberties are respected, but which also tend to be underpinned by a political culture conducive to the flourishing of democracy. The functioning of government is satisfactory. Media are independent and diverse. There is an effective system of checks and balances. The judiciary is independent and judicial decisions are enforced. There are only limited problems in the functioning of democracies." Cf. THE ECONOMIST INTELLIGENCE UNIT. Democracy Index 2018: me too?: political participation, protest and democracy: a report by The Economist Intelligence Unit. London: The Economist Intelligence Unit, 2019. p. 49. Disponível em:

https://www.eiu.com/public/topical_report.aspx?campaignid=Democracy2018. Acesso em: 11 jan. 2019.

7 Ibid., loc. cit.: "Flawed democracies: These countries also have free and fair elections and, even if there are problems (such as infringements on media freedom), basic civil liberties are respected. However, there are significant weaknesses in other aspects of democracy, including problems in governance, an underdeveloped political culture and low levels of political participation". 
governança, cultura política subdesenvolvida e baixos níveis de participação política.

Países cujas notas atribuídas são menores de 4, porém iguais ou menores a 6 , foram inseridos no grupo dos países com regimes híbridos (hybrid regimes). Nesse grupo consideraram que as eleições têm irregularidades substanciais, que muitas vezes as impedem de serem livres e justas, sendo que a pressão do governo sobre partidos da oposição e candidatos pode ser comum. Consideram a existência de fraquezas graves que são mais prevalentes do que nas democracias falhas - na cultura política, no funcionamento do governo e na participação política. A corrupção tende a ser generalizada, o Estado de Direito é fraco, assim como a sociedade civil. Normalmente, há assédio e pressão sobre os jornalistas, e o Poder Judiciário não é independente ${ }^{8}$.

Por fim, foram inseridos no grupo de países sob regimes autoritários (authoritarian regimes $)^{9}$ aqueles cuja nota tenha sido menor ou equivalente a 4. Para a pesquisa, nessas nações, o pluralismo político estatal está ausente ou fortemente circunscrito, de forma que muitos países dessa categoria são ditaduras definitivas. Algumas instituições formais da democracia podem existir, mas estas têm pouca substância. Por exemplo, caso as eleições ocorram, elas não são compreendidas como livres e justas; ademais, há desrespeito pelos abusos e pelas violações das liberdades civis, a mídia é tipicamente pertencente ao Estado ou controlada por grupos ligados ao regime dominante, há repressão de críticas ao governo e censura generalizada e, finalmente, o Poder Judiciário não é independente.

O mencionado estudo efetuado pelo The Economist consiste em sua $11^{\text {a }}$ edição, e o Brasil já variou muito sua posição. Nessa última, foram analisados 165 estados independentes e dois territórios. Segundo informam, isso cobriria quase toda a população mundial, pois

8 "Hybrid regimes: Elections have substantial irregularities that often prevent them from being both free and fair. Government pressure on opposition parties and candidates may be common. Serious weaknesses are more prevalent than in flawed democracies - in political culture, functioning of government and political participation. Corruption tends to be widespread and the rule of law is weak. Civil society is weak. Typically, there is harassment of and pressure on journalists, and the judiciary is not independent." Cf. THE

ECONOMIST INTELLIGENCE UNIT. Democracy Index 2018: me too?: political participation, protest and democracy: a report by The Economist Intelligence Unit. London: The Economist Intelligence Unit, 2019, p. 49. Disponível em: https://www.eiu.com/public/topical_report.aspx?campaignid=Democracy2018. Acesso em: 11 jan. 2019.

9 Ibid.: "Authoritarian regimes: In these states, state political pluralism is absent or heavily circumscribed. Many countries in this category are outright dictatorships. Some formal institutions of democracy may exist, but these have little substance. Elections, if they do occur, are not free and fair. There is disregard for abuses and infringements of civil liberties. Media are typically state-owned or controlled by groups connected to the ruling regime. There is repression of criticism of the government and pervasive censorship. There is no independent judiciary". 
microestados foram excluídos ${ }^{10}$. Do grupo de países analisados, apenas 20 países $^{11}$ foram classificados como democracia plena, haja vista que somente eles atingiram pontuação excelente acima de 8. Desse grupo de 20 países, tem-se 14 localizados na Europa Ocidental ${ }^{12}$.

Além de permitir analisar os dados em perspectiva mundial, a pesquisa também elaborou fracionamento regional do globo terrestre para tornar possível efetuar uma análise por regiões. No grupo regional do Brasil estão inseridos os demais países da América Latina e do Caribe, do qual apenas o Uruguai e a Costa Rica foram considerados como democracias plenas. Todos os demais países foram considerados como democracias falhas em maior ou menor grau, regimes híbridos ou, pior, tão pouco democráticos que foram incursos no grupo dos regimes autoritários.

O Brasil recebeu nota 6,97 e foi classificado como democracia falha, figurando no ranking global em $50^{\circ}$ lugar, atrás de países como Suriname, Jamaica, Argentina, Índia e África do Sul. No ranking regional da América Latina e Caribe, aparece na $9^{a}$ posição, como apontado na Tabela 2.

10 “The Economist Intelligence Unit's Democracy Index provides a snapshot of the state of democracy worldwide for 165 independent states and two territories. This covers almost the entire population of the world and the vast majority of the world's states (microstates are excluded)." Cf. THE ECONOMIST INTELLIGENCE UNIT. Democracy Index 2018: me too?: political participation, protest and democracy: a report by The Economist Intelligence Unit. London: The Economist Intelligence Unit, 2019. p. 49. Disponível em: https://www.eiu.com/public/topical_report.aspx?campaignid=Democracy2018. Acesso em: 11 jan. 2019.

11 Na ordem de pontuação da maior para menor como democracia plena figuram: Noruega, Islândia, Suécia, Nova Zelândia, Dinamarca, Canadá, Irlanda, Finlândia, Austrália, Suíça, Holanda - Países Baixos, Luxemburgo, Alemanha, Reino Unido da Grã-Bretanha e Irlanda do Norte, Uruguai, Áustria, Ilhas Maurício, Malta, Espanha e Costa Rica.

12 Na ordem de pontuação da maior para menor democracia plena na Europa Ocidental figuram: Noruega, Islândia, Suécia, Dinamarca, Irlanda, Finlândia, Suíça, Holanda - Países Baixos, Luxemburgo, Alemanha, Reino Unido da Grã-Bretanha e Irlanda do Norte, Áustria, Malta e Espanha. 
Tabela 2 - Classificação por país da América Latina e Caribe 2018

\begin{tabular}{|c|c|c|c|c|c|c|c|c|c|}
\hline Uruguay & 8.38 & 15 & 1 & 10.00 & 8.57 & 6.11 & 7.50 & 9.71 & Full democracy \\
\hline Costa Rica & 8.07 & 20 & 2 & 9.58 & 7.50 & 6.67 & 7.50 & 9.12 & Full democracy \\
\hline Trinidad and Tobago & 7.16 & 43 & 4 & 9.58 & 7.14 & 6.11 & 5.63 & 7.35 & Flawed democracy \\
\hline Panama & 7.05 & 45 & 5 & 9.58 & 6.07 & 6.67 & 5.00 & 7.94 & Flawed democracy \\
\hline Argentina & 7.02 & $47=$ & 6 & 9.17 & 5.36 & 6.11 & 6.25 & 8.24 & Flawed democracy \\
\hline Jamaica & 7.02 & $47=$ & 7 & 8.75 & 7.14 & 4.44 & 6.25 & 8.53 & Flawed democracy \\
\hline Guyana & 6.67 & $54=$ & 11 & 9.17 & 5.71 & 6.11 & 5.00 & 7.35 & Flawed democracy \\
\hline Peru & 6.60 & 59 & 12 & 9.17 & 5.00 & 5.56 & 5.63 & 7.65 & Flawed democracy \\
\hline Dominican Republic & 6.54 & 61 & 13 & 9.17 & 5.36 & 6.11 & 5.00 & 7.06 & Flawed democracy \\
\hline Ecuador & 6.27 & 68 & 14 & 8.75 & 5.36 & 6.11 & 4.38 & 6.76 & Flawed democracy \\
\hline Paraguay & 6.24 & 70 & 15 & 8.75 & 5.71 & 5.00 & 4.38 & 7.35 & Flawed democracy \\
\hline Mexico & 6.19 & $71=$ & 16 & 8.33 & 6.07 & 7.22 & 3.13 & 6.18 & Flawed democracy \\
\hline El Salvador & 5.96 & 77 & 17 & 9.17 & 4.29 & 5.56 & 3.75 & 7.06 & Hybrid regime \\
\hline Bolivia & 5.70 & 83 & 18 & 7.50 & 4.64 & 5.56 & 3.75 & 7.06 & Hybrid regime \\
\hline Honduras & 5.63 & 85 & 19 & 8.50 & 4.64 & 4.44 & 4.38 & 6.18 & Hybrid regime \\
\hline
\end{tabular}

Source: The Economist Intelligence Unit.

Fonte: The Economist Intelligence Unit, 2019.

Tais dados refletem o que o senso comum já acreditava: o Brasil precisa do fomento de estudos e consequente implementação de políticas públicas capazes de enrobustecer a democracia nacional com o intuito final de promover os objetivos previstos em nossa Constituição. Só assim será possível observar a melhoria nos índices de desenvolvimento social e econômico no Brasil.

Torna-se evidente que o país precisa se organizar para adotar medidas capazes de melhorar nossa pontuação e, logicamente, nossa democracia. Toma-se por base que para o desenvolvimento da democracia, os indicadores que apuram a participação política dos cidadãos, a cultura política e as liberdades civis devem ser mais bem avaliados em nosso país.

Tal progresso certamente se dará com o avanço de alguns aspectos sociais, destacandose nessa oportunidade a importância da educação, justamente com a promoção da qualidade do ensino jurídico, que se mostra essencial nesse sentido. Se considerarmos que ele é um dos principais responsáveis por implementar, respeitar e conscientizar os valores retro mencionados, tais aspectos sociais são a base do conteúdo formativo dos juristas. 
Ricardo Rivero Ortega ${ }^{13}$ ao tratar da importância da organização administrativa e a necessidade de simplificação de suas estruturas para o desenvolvimento da democracia, aponta que existe uma relação direta entre os princípios constitucionais da organização da Administração Pública e os direitos fundamentais, isso porque a sustentabilidade a objetividade ou da eficácia desses direitos, é imprescindível o acesso em condições de igualdade às funções públicas, ou a proteção da saúde e até mesmo à educação das pessoas, sendo que sem uma organização administrativa adequada não será possível assegurar a satisfação desses direitos.

Monica Herman Salem Caggiano é pontual quando afirma que "em verdade, a ideia da impositiva presença e efetivação do direito à instrução nas sociedades politicamente organizadas vem vinculada, cada vez mais, à própria evolução da sociedade, preordenada a viabilizar um clima de respeito à dignidade humana"14.

A implementação de um Estado Democrático de Direito, como almeja o Brasil, depende diretamente da efetivação dos direitos previstos em Constituição. Como mencionado alhures, somente no regime democrático é que direitos e liberdades civis podem ser discutidos com base na proteção do exercício da livre manifestação do pensamento e da liberdade de crença e escolha consciente de posicionamentos políticos.

Liberdades civis consistem na primeira dimensão ${ }^{15}$ de direitos humanos salvaguardados pelos documentos internacionalmente reconhecidos e devem ser protegidos como piso mínimo de direitos necessários para a proteção e o desenvolvimento do indivíduo; porém, o indivíduo não pode ser considerado como ser isolado.

É da natureza humana essa necessidade de manter a vida em sociedade; logo, para a construção sadia de uma sociedade que seja cada vez mais justa, fraterna e solidária, é preciso investir e refletir sobre quais medidas devem ser adotadas para o pleno desenvolvimento da individualidade, buscando uma saudável convivência entre todos.

É só com o desenvolvimento do indivíduo que se torna possível sua autorrealização, a qual só consegue ser efetivamente desempenhada em uma democracia, reconhecendo-a como

13 ORTEGA, Ricardo Rivero. La necesaria innovación en las instituciones administrativas : organización, procedimientos, función pública, contratos administrativos y regulación. 1a. ed. Madrid: Instituto Nacional de la Administración Pública, 2012, p. 15.

14 CAgGiAnO, Monica Herman Salem. A educação. Direito fundamental. In: RANIERI, Nina Beatriz Stocco; RIGHETTI, Sabine (org.). Direito à educação: aspectos constitucionais. São Paulo: Edusp, 2009. p. 24.

15 A doutrina costuma utilizar os termos 'dimensões' ou 'gerações' dos direitos fundamentais. Para essa pesquisa, utilizou-se a concepção das dimensões porque o termo 'gerações' seria impróprio para descrever uma evolução dos direitos fundamentais. Assim, ele poderia desencadear a falsa ideia de que, conforme fossem evoluindo, ocorreria a substituição de uma geração por outra, o que, como se sabe, jamais poderá acontecer. Por outro lado, a expressão 'dimensão' é capaz de descrever o fenômeno de uma expansão, uma cumulação e um fortalecimento dos direitos humanos consagrados, consoante uma visão necessariamente integrada de todos os direitos humanos. 
a melhor forma de participação de indivíduos em uma ação coletiva.

[...] a democracia não pode ser imaginada sem a atualização histórico-cultural de seus cidadãos, proporcionada pela educação, posto que ela mesma é um valor construído historicamente a ser apropriado pelos indivíduos. Por sua vez, a verdadeira educação deve ser necessariamente democrática visto que, por seu caráter histórico, supõe a relação entre sujeitos autônomos (cidadãos) e um mínimo de cultura produzida historicamente que o indivíduo precisa assimilar para poder viver e desempenhar seu papel social à altura de seu tempo e da sociedade em que está inserido ${ }^{16}$ (grifo nosso).

É essa espécie de educação emancipadora que uma sociedade democrática deve perseguir. É com uma educação tendente ao senso crítico do educando, com liberdade para formação e construção do conhecimento, preparando os sujeitos de direito para o exercício da cidadania de acordo com valores próprios e respeito a posicionamentos contrários, que se consegue vislumbrar o desenvolvimento de indivíduos aptos à propagação das características necessárias para a participação da vida pública e social.

Só existe a possibilidade de se encarar o indivíduo como conceito significante se o inserirmos e considerarmos como parte integrante de uma coletividade, ou seja, da sociedade em que está imerso. A sociedade, por sua vez, também não possuiria nenhum significado ou importância sem a presença do indivíduo que a compõe.

Visando a melhoria do atual regime democrático desempenhado no Brasil que se firma o posicionamento de que o atual sistema educacional nacional vigente deve ser repensado. Isso ocorre porque a educação é, seguramente, o instrumento indispensável para a fundação e o desenvolvimento da democracia. Sob essa perspectiva, compreende-se que a educação não será restrita à mera transmissão de conhecimento como algo finalizado.

Segundo essa concepção, reconhece-se que educação consiste no saber e na técnica manipulados por sujeitos de direito para torná-los aptos ao exercício da cidadania ${ }^{17}$. A educação como princípio aqui adotado é fundamental por traduzir-se como renovação da vida pela

16 ARONI, Allan. O ensino superior como atividade empresarial e o cidadão mínimo no Brasil: o peso da mão liberal e a marca de uma aliança não visível: uma análise do ensino superior brasileiro a partir dos dilemas que envolvem as políticas públicas. 2008. 215 f. Dissertação (Mestrado em Educação) - Faculdade de Educação, Universidade de São Paulo, São Paulo, 2008. Disponível em:

https://www.teses.usp.br/teses/disponiveis/48/48134/tde-09102008-115646/pt-br.php. Acesso em: 18. fev. 2019. p. 67.

17 "Sobre o propósito da Educação e a vertente adotada nesta pesquisa como base da Filosofia da Educação, consulte John Dewey. Filósofo e pedagogo norte-americano, Dewey defende que o sistema educativo de uma democracia assim se caracteriza porque seus centros de educação mantêm um claro compromisso com a promoção de conteúdos culturais e modalidades organizativas que contribuam com a formação de pessoas comprometidas com valores e modelos democráticos de sociedade. Deixa claro que a educação é uma modalidade de ação política na medida em que obriga a reflexão e valorização de dimensões sociais, políticas, econômicas, culturais e morais da sociedade." Cf. DEWEY, John. Democracia y educación: una introducción a la filosofía de la educación. 3. ed. Madrid: Morata, 1998. p. 63. 
comunicação, por sua função no meio ambiente social, por exercer papel diretivo no meio ambiente social, por oferecer condições de crescimento e desenvolvimento do ser humano, entre outros fins necessários a uma sociedade sadia.

Nesse contexto, cabe analisar a concepção da educação na visão de Paulo Freire ${ }^{18}$, o qual salienta o papel e a percepção da escola como um ambiente que deve ser pensado para favorecer a aprendizagem significativa. Nessa aprendizagem, a relação entre professor e aluno acontece com base no diálogo, na ética, no respeito mútuo e na autonomia do educando. Portanto, na escola, deve ser incentivada não só a aquisição de competências e habilidades para exercício no mercado de trabalho, mas também a criatividade, a curiosidade, o estímulo à descoberta e o raciocínio lógico; enfim, deve-se ensinar a pensar.

Com essa breve introdução, parte-se do pressuposto que para o bom desempenho da democracia e do processo democrático como um todo, a educação se apresenta como estrutura fundante e base necessária ao exercício da cidadania, inerente ao regime democrático. Assim, a educação como processo de reconstrução da experiência é um atributo da pessoa e, por isso, deve ser comum a todos. É justamente essa a concepção que a Constituição Federal brasileira prevê nos artigos 205 a 214, ao declarar a educação como direito de todos e dever do Estado.

A devoção da democracia para a educação é um fato consolidado, pois a emersão de governos com base na vontade popular é mais bem implementada quando eleitores e seus representantes são educados a ponto de compreenderem os atos políticos em que estão inevitavelmente envolvidos.

A democracia é mais do que uma forma de governo; ela é a forma mais primária de associação de pessoas vivendo em conjunto e harmonicamente ${ }^{19}$, "demanda cidadãos autônomos, adultos emancipados, capazes de se responsabilizar pelas suas escolhas e se mover pela razão" ${ }^{20}$.

Para seu devido exercício e desenvolvimento, liberdades públicas e privadas devem ser preservadas, partindo da premissa que a liberdade de expressão deve sempre ser assegurada em uma democracia. A associação humana possui inúmeros derivados, sendo um dos fundamentais a necessidade de assegurar a existência de posicionamentos contrários em um mesmo cenário de debate. E isso só é possível com a educação.

18 FREIRE, Paulo. Pedagogia da autonomia: saberes necessários à prática educativa. 25. ed. São Paulo: Paz e Terra, 1996. p. 45.

19 DEWEY, John. The political writings. Indianapolis/Cambridge: Hackett Publishing Company, 1993. p. 110.

20 PUERTA DOS SANTOS, Larissa Dias; JUNQUEIRA, Michelle Asato. O atual protagonismo da interpretação constitucional como norteadora da aplicação do direito. Revista de Argumentação e Hermenêutica Jurídica, Brasília, DF, v. 2, n. 1, p. 230-249, jan./jun. 2016. p. 233. 
Felipe Chiarello e Michele Asato ${ }^{21}$ afirmam que a educação se funde, simultaneamente, em conservar e transformar valores e práticas que uma determinada sociedade opta por transmitir às futuras gerações, apresentando-se de maneira vinculada a uma dimensão política, relacionando-se com a democracia porque está associada à tomada de consciência da cidadania.

Complementando a noção, Pilar Jiménez Tello e Victoria Plaza ${ }^{22}$ destacam que a formação tem como objetivo primordial dotar os estudantes de aptidões, habilidades, competências e formação humana para o mercado de trabalho, com a obviedade de que ética é a base desses propósitos que o estudante deve desenvolver não só durante a sua aprendizagem, mas por toda sua carreira.

Assim, a finalidade da educação é evidentemente o desenvolvimento, o crescimento do homem sob todos os seus aspectos e a emancipação do indivíduo, porque é só com a educação que ele será capaz de aumentar suas próprias capacidades, sejam quais forem.

A educação é essencial para a humanização e socialização do homem. Seguramente se trata de um procedimento que dura a vida inteira e que não se limita à simples continuidade ou mera superação de níveis e etapas, mas sim considera a possibilidade de rupturas pelas quais a cultura se revigora e o homem faz a história.

Um dos principais objetivos da educação é claramente a evolução da própria pessoa e da sociedade em que ela está inserida, com o consequente crescimento do ser humano sob todos os pontos de vista e desenvolvimento econômico e social da humanidade. Tal entendimento é ratificado, inclusive, pela vigente Constituição Federal brasileira, quando preceitua que um dos objetivos básicos da educação é, justamente, o pleno desenvolvimento da pessoa.

O indivíduo, nas relações interpessoais desempenhadas com outros seres humanos, desenvolve suas próprias aptidões, sejam quais forem. Não existe somente uma capacidade, mas a pessoa como um complexo delas que precisa ser desenvolvido. O ser humano, a partir de suas características existentes, vai estabelecendo aos poucos a própria personalidade por meio da atuação efetiva em todos os setores.

21 PINTO, Felipe Chiarello de Souza; JUNQUEIRA, Michelle Asato. Educação para o desenvolvimento: objetivo do estado democrático e social de direito. Direito e Justiça (URI), ano 16, n. 23, p. 77-90, nov. 2014. p. 78.

22 "El programa formativo tiene como objetivo primordial dotar al estudiante de las aptitudes, habilidades, competencias y formación humana para su incorporación al mercado laboral, no podemos obviar que las aptitudes éticas son la base de essas aptitudes, habilidades, competências y formación humana que el estudiante debe desarrollar no solo a lo largo de su carrera, sino también a la hora de incorporarse al mercado laborar y vamos más allá el estudiante uma vez incorporado al mercado laboral debe de transmitir, ya que se lo debe a la sociedade, esos valores que el ha adquirido a lo largo de su carrera." Cf. TELLO, Pilar Jiménez; PLAZA, Victoria Eugenia. La ética en la enseñanza del derecho. Revista Direito UFMS, Campo Grande, v. 3, n. 1, p. 23-31, enero/jul. 2017. p. 27. 
A educação em si envolverá concepções que dependerão de objetivos formulados visando a aquisição de conhecimento para a consequente transformação da sociedade e da realidade daqueles que se submetem aos processos educativos. Por sua vez, tais processos idealizados para uma sociedade, por meio da transmissão e assimilação de conhecimentos e habilidades, devem ser realizados com o objetivo de preparar os educandos para uma compreensão mais ampla da realidade social em que estão inseridos, para que eles possam se tornar agentes ativos da transformação dessa realidade.

É com base nesse objetivo educacional que se pode afirmar que o conceito de educação não se resume a um mero conjunto de atitudes, mas envolve ações, passos e procedimentos relacionados ao método de reflexão, compreensão e transformação da realidade. Sob condições concretas de cada situação, a finalidade da educação assegura o encontro formativo entre o aluno e os conteúdos do ensino.

Diante da importância que a educação alçou como ferramenta de transformação da humanidade, por ser um dos principais mecanismos de desenvolvimento individual e social, são muitos os organismos supranacionais dedicados a analisar qual papel a educação desempenha em cada país soberano. Descobrir os reais investimentos que os países efetuam internamente para a educação de seu povo é uma difícil tarefa, cujo objetivo é dimensionar o verdadeiro interesse de uma nação no desenvolvimento do seu povo.

Um dos maiores exemplos de organismo supranacional destinados ao incentivo da educação em países independentes, em razão da sua importância para o desenvolvimento da humanidade, é a Organização das Nações Unidas (ONU). Nos termos da Declaração Universal de Direitos Humanos (DUDH), de 10 de dezembro de 1948, em seu artigo 26, encontram-se as seguintes diretrizes:

Artigo 26. 1. Toda a pessoa tem direito à educação. A educação deve ser gratuita, pelo menos a correspondente ao ensino elementar fundamental. O ensino elementar é obrigatório. O ensino técnico e profissional dever ser generalizado; o acesso aos estudos superiores deve estar aberto a todos em plena igualdade, em função do seu mérito.

2. A educação deve visar à plena expansão da personalidade humana e ao reforço dos direitos do Homem e das liberdades fundamentais e deve favorecer a compreensão, a tolerância e a amizade entre todas as nações e todos os grupos raciais ou religiosos, bem como o desenvolvimento das actividades das Nações Unidas para a manutenção da paz.

3. Aos pais pertence a prioridade do direito de escolher o gênero de educação a dar aos filhos. $^{23}$

23 ORGANIZAÇÃO DAS NAÇÕES UNIDAS. Declaração Universal dos Direitos Humanos. Geneva: ONU, [1948]. Disponível em: https://www.ohchr.org/EN/UDHR/Documents/UDHR_Translations/por.pdf. Acesso em: 15 mar. 2019. 
Justifica-se, assim, a educação como preocupação central do Programa das Nações Unidas para o Desenvolvimento (PNUD) ${ }^{24}$, visto que o referido órgão internacional apresenta como um dos seus objetivos de desenvolvimento sustentável a busca por "educação de qualidade: assegurar a educação inclusiva, e equitativa e de qualidade, e promover oportunidades de aprendizagem ao longo da vida para todos" ${ }^{25-26}$, conforme Figura 2.

\begin{abstract}
Alcançar a educação de qualidade e inclusiva para todas e todos reafirma a crença de que a educação é a mais poderosa ferramenta para o desenvolvimento sustentável. Esse objetivo garante que meninas e meninos completem, gratuitamente, as escolas primária e secundária até 2030. Também oferece acesso igualitário e a baixo custo para formação profissional para eliminar a disparidade de riquezas, e alcançar 0 acesso universal para uma educação de qualidade ${ }^{27}$ (grifos nossos).
\end{abstract}

24 “O Programa das Nações Unidas para o Desenvolvimento (PNUD) contribui, há mais de 50 anos, para o crescimento inclusivo e sustentável, de forma contínua e em bases democráticas, sempre em parceria com o Estado, a sociedade civil organizada e o setor privado. O PNUD, atualmente em 170 países e territórios, tem a constante missão de alinhar seu trabalho às necessidades do país, colaborando no desenvolvimento de políticas, habilidades de liderança, capacidades institucionais, resiliência e, especialmente, erradicação da pobreza e redução de desigualdades e exclusão social. O QUE FAZEMOS: A visão que orienta a atuação do PNUD em todo o mundo é a de apoiar os países a erradicar a pobreza e reduzir significativamente as desigualdades e a exclusão social. A estratégia de atuação do PNUD no Brasil prevê: apoio à implementação da Agenda 2030; Foco em áreas vulneráveis e populações de baixo Índice de Desenvolvimento Humano (IDH), sobretudo nas áreas de pobreza e extrema pobreza do Norte e do Nordeste; mulheres afrodescendentes; LGBTI; indígenas e agroextrativistas; Expansão das parcerias com estados e municípios; Desenvolvimento de novas parcerias com a administração pública em geral (governo federal, estados, municípios), a sociedade civil, o setor privado e universidades; Participação social e promoção de diálogos para construção de consensos; Ação conjunta com outros organismos da ONU no país e centros de pesquisa globais. NOSSO FOCO: Desde a entrada em vigor da Agenda 2030 e seus Objetivos de Desenvolvimento Sustentável (ODS), em janeiro de 2016, o PNUD Brasil vem desenvolvendo sua cooperação em torno de quatro áreas-chave ou eixos, conforme seu Programa de País para o ciclo 2017-2021. [Na área chave relativa às] Pessoas [a diretriz é a do] Desenvolvimento de capacidades para reduzir as desigualdades, superar crises e melhorar a qualidade dos serviços públicos, com foco nas pessoas em situação vulnerável, por meio de subsídios técnicos para políticas públicas”. Cf. PROGRAMA DAS NAÇÕES UNIDAS PARA O DESENVOLVIMENTO. PNUD no Brasil. Brasília, DF: PNUD, [2018?]. Disponível em: http://www.br.undp.org/content/brazil/pt/home/about-us.html. Acesso em: 4 fev. 2019.

25 “Os Objetivos de Desenvolvimento Sustentável, também conhecidos como Objetivos Globais, são um chamado universal para ação contra a pobreza, proteção do planeta e para garantir que todas as pessoas tenham paz e prosperidade." Cf. Id. Objetivos de desenvolvimento sustentável. Brasília, DF: PNUD, c2020a. Disponível em: http://www.br.undp.org/content/brazil/pt/home/sustainable-development-goals.html. Acesso em: 4 fev. 2019.

26 Ibid., tradução nossa: "Ensure inclusive and equitable quality education and promote lifelong learning opportunities for all".

27 Id. Objetivo 4: educação de qualidade. Brasília, DF: PNUD, c2020b. Disponível em: http://www.br.undp.org/content/brazil/pt/home/sustainable-development-goals/goal-4-qualityeducation.html. Acesso em: 4 fev. 2019. 
Figura 2 - Objetivo de desenvolvimento sustentável

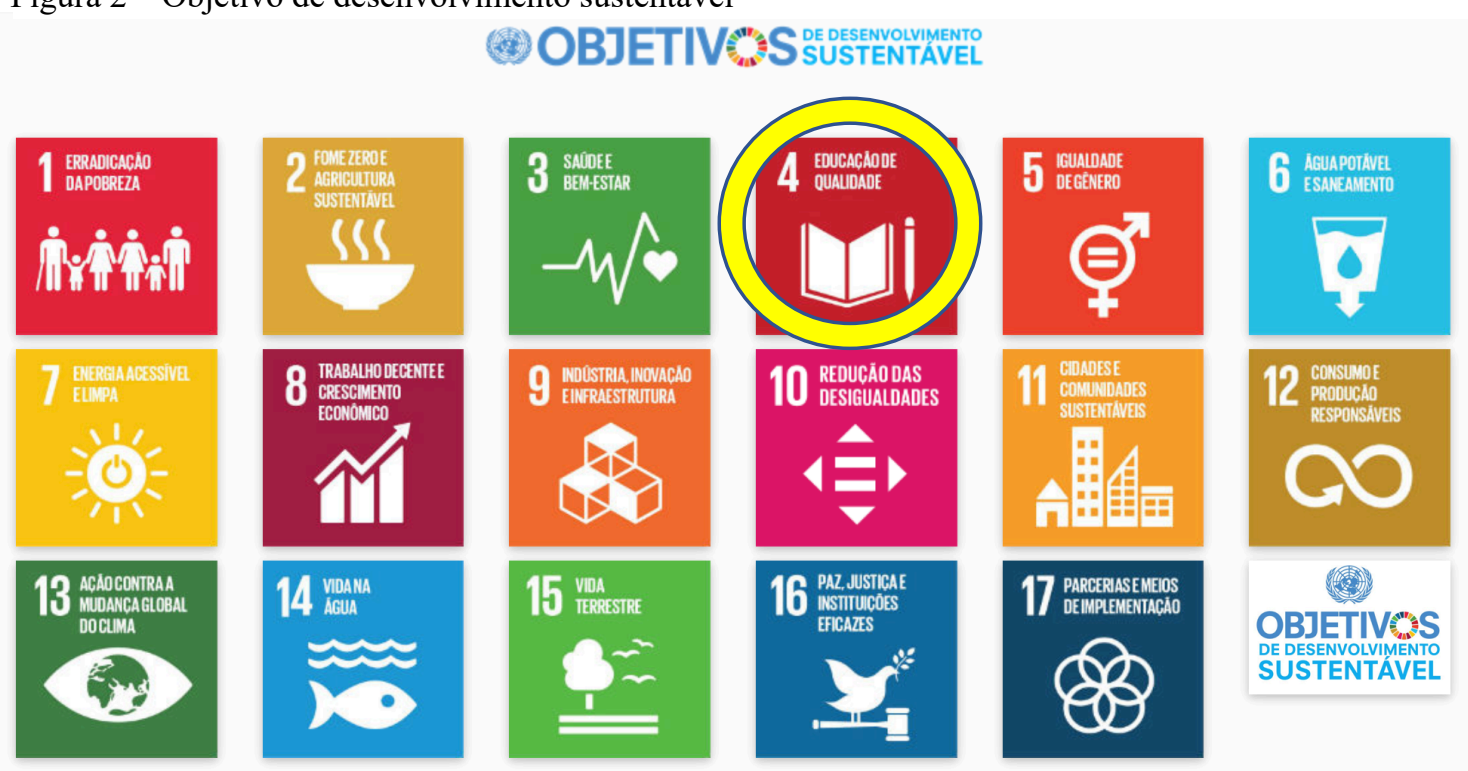

Fonte: PNUD - Brasil, c2020a.

Atentos, inclusive, aos desdobramentos necessários para assegurar acesso a todos à educação superior, a resolução adotada foi específica em definir que até 2030 a meta é a de "assegurar a igualdade de acesso para todos os homens e mulheres à educação técnica, profissional e superior de qualidade, a preços acessíveis, incluindo universidade"28.

Segundo informações oficiais do Ministério das Relações Exteriores, o Brasil desempenhou papel fundamental na implementação dos Objetivos de Desenvolvimento do Milênio, que precederam os estudos dos Objetivos para o Desenvolvimento Sustentável, e também mostrou grande empenho no processo em torno de sua idealização, com representação nos diversos comitês criados para apoiar o processo pós-2015. Sediou a primeira Conferência sobre Meio Ambiente e Desenvolvimento (Rio 92), bem como a Conferência Rio+20, em 2012, demonstrando que o Brasil tomou para si um papel importante a desempenhar na promoção da Agenda Pós-2015².

28 "Assegurar a educação inclusiva e equitativa e de qualidade, e promover oportunidades de aprendizagem ao longo da vida para todas e todos." Cf. NAÇÕES UNIDAS. Objetivo de desenvolvimento sustentável 4: educação de qualidade. Brasília, DF: Nações Unidas, c2020. Disponível em: https://brasil.un.org/ptbr/sdgs/4. Acesso em: 4 fev. 2019.

29 BRASIL. Ministério das Relações Exteriores. Objetivos de desenvolvimento sustentável (ODS). Brasília, DF: Ministério das Relações Exteriores, 2015. Disponível em: https://www.gov.br/mre/ptbr/assuntos/desenvolvimento-sustentavel-e-meio-ambiente/desenvolvimento-sustentavel/objetivos-dedesenvolvimento-sustentavel-ods. Acesso em: 4 fev. 2019. 
A preocupação com a educação no cenário brasileiro, entretanto, não advém apenas de suas participações e seu protagonismo no debate internacional para a reafirmação dos Direitos Humanos. Em verdade, o Estado brasileiro demonstra reconhecer a importância e preocupação com a educação, ao menos juridicamente, desde 1824, com a promulgação de sua primeira Constituição, a do Império ${ }^{30}$.

Outorgada em 25 de março de 1824, a Constituição do Império Brasileiro, influenciada pelos ideais revolucionários franceses, foi a primeira, no mundo, a positivar os direitos do homem. Contudo, paradoxalmente, introduziu institutos incompatíveis com a proteção da liberdade, como a escravidão e a unicidade religiosa. [...] Os dispositivos dedicados à educação refletiam a mentalidade da época, segundo a qual aquela ficava a cargo da família e da Igreja. Ainda assim, foi garantida a instrução primária gratuita a todos os cidadãos, colégios e universidades, onde seriam ensinados elementos de ciências, belas-artes e $\operatorname{artes}^{31}$.

Justamente diante dessa importância e desse protagonismo da educação para o desenvolvimento social e econômico é que o legislador não pode se refutar ao dever de dedicar diretrizes constitucionais e infraconstitucionais para assegurar o papel do Estado como agente promotor da educação no cenário brasileiro.

Nesse sentido, é adequado ressaltar que a educação consiste em direito humano fundamental atribuído ao indivíduo, mas não só, haja vista que ao mesmo tempo é direito essencial para a o desenvolvimento econômico e social, razão pela qual é extremamente importante racionalizar e implementar políticas públicas voltadas para o âmbito educacionais.

A Constituição Federal brasileira, quando define o dever do Estado com a educação (art. 205) e o seu comprometimento com o desenvolvimento nacional e a construção de uma sociedade justa e solidária (art. $3^{\circ}$ ), individualiza a educação - direito de todos - como bem

30 "O peso relativo das consequências mais imediatas, tendo em vista pelo menos o aspecto educacional, presente em regulamentos, estatutos e normas nacionais e, principalmente, na Constituição de 25 de março de 1824, nascida de cima para baixo, por imposição de Dom Pedro I ao "povo", a partir do texto promulgado depois da dissolução da Assembléia Constituinte, corresponderam, na corrente dos acontecimentos, a uma intenção de garantir apenas uma formação escolar mínima da população, ou seja, somente uma "instrução primária e gratuita a todos os cidadãos", excluindo a maior parte da população composta por escravos (não cidadãos) etc., e, mesmo assim, o quadro da realidade não se altera significativamente pois a Constituição de 1824 não apresentou os meios necessários a serem utilizados pelo governo para modificar a situação. Além do mais, o contexto histórico foi marcado por uma grande instabilidade política protagonizada pelos setores conservadores. Podemos acrescentar, na mesma medida, os obstáculos à difusão de qualquer outra ideologia que não fosse a católica e até mesmo do saber científico." Cf. ARONI, Allan. O ensino superior como atividade empresarial e o cidadão mínimo no Brasil: o peso da mão liberal e a marca de uma aliança não visível: uma análise do ensino superior brasileiro a partir dos dilemas que envolvem as políticas públicas. 2008. 215 f. Dissertação (Mestrado em Educação) - Faculdade de Educação, Universidade de São Paulo, São Paulo, 2008. Disponível em: https://www.teses.usp.br/teses/disponiveis/48/48134/tde-09102008-115646/ptbr.php. Acesso em: 18 fev. 2019. p. 34.

31 JUNQUEIRA, Michelle Asato. Universidade, autonomia e atuação estatal: a avaliação como garantia do direito à educação. 2011. 148 f. Dissertação (Mestrado) - Programa de Pós-Graduação em Direito Político e Econômico da Universidade Presbiteriana Mackenzie, São Paulo, 2011. p. 25-26. 
jurídico, dado o seu fundamental papel no desenvolvimento humano e no exercício dos demais direitos civis, políticos, econômicos, sociais e culturais ${ }^{32}$.

$\mathrm{Na}$ atual democracia brasileira, a Constituição Federal de 1988 denota a preocupação estatal com a temática, a começar com a inserção da educação no caput do artigo $6^{033}$, o qual elenca o rol dos direitos sociais que devem ser assegurados para o desenvolvimento sadio da sociedade, atribuindo ao Estado o dever de promoção da educação em território nacional em seus diversos níveis de aprofundamento.

[...] no mundo atual, o direito à educação comparece nas suas duas facetas (da primeira e segunda dimensão ou geração), enquadrado como uma realidade social e individual. Com efeito, insuflado e robustecido pelos caracteres de índole coletiva, extraídos das duas últimas gerações de direitos, vislumbra-se o direito à educação com conteúdo multifacetado, envolvendo não apenas o direito à instrução como um processo de desenvolvimento individual, mas também o direito a uma política educacional, ou seja, a um conjunto de intervenções juridicamente organizadas e executadas em termos de um processo de formação da sociedade, visando oferecer aos integrantes da comunidade social instrumentos a alcançar os seus fins ${ }^{34}$.

Inclusive, em razão de sua importância, a educação é mencionada como o primeiro direito social no rol dos direitos sociais reconhecidos constitucionalmente. Ademais, para comprovar o protagonismo dado pelo legislador, destaca-se que o termo educação aparece no texto constitucional brasileiro, ao menos, em outras 58 ocorrências, para tratar das mais diferenciadas temáticas.

Segundo Monica Herman Salem Caggiano, no atual contexto não nos parece subsistir nenhuma dúvida sobre a inclusão do direito à educação como elencado no rol dos direitos humanos fundamentais, amparado por um quadro jurídico-constitucional apto a assegurar um sistema de garantias. É direito fundamental, portanto, porque por um lado se consubstancia em prerrogativa inerente à condição humana, em razão da exigência de dignidade e, por outro lado, porque é reconhecido e consagrado por instrumentos internacionais e por constituições que o $\operatorname{asseguram}^{35}$.

Além da importância constitucional dada ao tema da educação no cenário mundial e

32 RANIERI, Nina Beatriz Stocco. Os Estados e o direito à educação na Constituição de 1988: comentários acerca da jurisprudência do Supremo Tribunal Federal. In: RANIERI, Nina Beatriz Stocco; RIGHETTI, Sabine (org.). Direito à educação: aspectos constitucionais. São Paulo: Edusp, 2009. p. 42.

33 "São direitos sociais a educação, a saúde, a alimentação, o trabalho, a moradia, o transporte, o lazer, a segurança, a previdência social, a proteção à maternidade e à infância, a assistência aos desamparados, na forma desta Constituição" (grifo nosso). Cf. BRASIL. [Constituição (1988)]. Constituição da República Federativa do Brasil de 1988. Brasília, DF: Presidência da República, 1988. Disponível em: http://www.planalto.gov.br/ccivil_03/constituicao/constituicaocompilado.htm. Acesso em: 18 fev. 2019.

34 CAGGIANO, Monica Herman Sāem. A educação. Direito fundamental. In: RANIERI, Nina Beatriz Stocco; RIGHETTI, Sabine (org.). Direito à educação: aspectos constitucionais. São Paulo: Edusp, 2009. p. 23.

35 Ibid., p. 22. 
brasileiro, há consenso de que o desenvolvimento econômico e nacional de uma sociedade sempre dependerá de uma educação de qualidade prestada, em quaisquer dos níveis de aprendizagem existentes. O problema está justamente no contrassenso que existe entre a teoria e a prática.

Pleitear o acesso à educação é direito de todos, e é dever do Estado que, com ou sem o auxílio do particular, está obrigado a oferecer a todos não somente o acesso, mas também conceder a prestação desses serviços desde que todos os postos sejam de boa qualidade. Muito se fala que o futuro de uma nação depende da educação, porém a preocupação com a efetivação desse importante e consagrado direito social no Brasil deve ser repensado.

O legislador brasileiro se dedicou a idealizar um mecanismo de implementação de política pública educacional voltada à estruturação de um ordenado sistema educacional nacional por meio da Lei de Diretrizes e Bases da Educação Nacional. O referido instrumento normativo entende que "a educação abrange os processos formativos que se desenvolvem na vida familiar, na convivência humana, no trabalho, nas instituições de ensino e pesquisa, nos movimentos sociais e organizações da sociedade civil e nas manifestações culturais" ${ }^{\text {"36 }}$.

Tal instrumento normativo estrutura a educação escolar brasileira de forma generalizada, efetuando sua composição em dois níveis escolares, quais sejam, a educação básica, formada pela educação infantil, ensino fundamental e ensino médio, e a educação superior ${ }^{37}$. Posta como obrigação do Estado e da família, deve ser inspirada nos princípios de liberdade e ideais de solidariedade humana, tendo a lei lhe imputado três importantes finalidades: o pleno desenvolvimento do educando, seu preparo para o exercício da cidadania e sua qualificação para o trabalho ${ }^{38}$.

Com o intuito de apresentar a importância da educação superior para o cumprimento e efetivação das três finalidades incumbidas à educação em um Estado Democrático de Direito, a presente pesquisa se propõe a compreender e criticar os meandros do atual desenho institucional idealizado para a educação superior no Brasil, com vistas à melhoria dos setores econômicos e sociais brasileiros. O objetivo é apresentar possíveis mecanismos passíveis de

36 Art. $1^{\circ}$ da LDB: “A educação abrange os processos formativos que se desenvolvem na vida familiar, na convivência humana, no trabalho, nas instituições de ensino e pesquisa, nos movimentos sociais e organizações da sociedade civil e nas manifestações culturais”. Cf. BRASIL. Lei n ${ }^{\circ}$ 9.394, de 20 de dezembro de 1996. Estabelece as diretrizes e bases da educação nacional. Brasília, DF: Presidência da República, 1996a. Disponível em: http://www.planalto.gov.br/ccivil_03/leis/19394.htm. Acesso em: 5 fev. 2019.

37 Ibid., art. 21: "A educação escolar compõe-se de: I - educação básica, formada pela educação infantil, ensino fundamental e ensino médio; II - educação superior".

38 Ibid., art. $2^{\circ}$ : “A educação, dever da família e do Estado, inspirada nos princípios de liberdade e nos ideais de solidariedade humana, tem por finalidade o pleno desenvolvimento do educando, seu preparo para o exercício da cidadania e sua qualificação para o trabalho". 
adoção pelo setor público e pelo setor privado com o intuito de aprimorar o atual serviço educacional superior entregue à sociedade brasileira na área do Direito.

Para tanto, acredita-se que no atual cenário democrático a educação só será amplamente efetivada quando suas finalidades forem alcançadas e os atores envolvidos no desenvolvimento social e econômico do país se propuserem a pensar em mecanismos que vão além de assegurar igualdade de acesso educacional a todos, dedicando-se à incansável busca pela boa qualidade do setor educacional.

Já que a educação é um dos direitos humanos essenciais ao desenvolvimento sadio da humanidade, o objeto do estudo da presente pesquisa ganha importância quando analisa os mecanismos existentes e os que podem ser implementados para a promoção de uma educação, no nível superior, de boa qualidade à sociedade brasileira. A intenção final é apresentar uma possível saída que vise a melhoria da qualidade desse nível de educação para a formação do indivíduo e do próprio meio em que está imerso.

O sistema educacional voltado à existência em um regime democrático deve ser caracterizado, então, por instituições de ensino que mantenham um claro compromisso com a promoção de conteúdos culturais e modalidades organizativas que contribuam com a formação de pessoas alinhadas com valores e modelos democráticos de sociedade.

Justamente por reconhecer a complexidade de um sistema educacional idealizado para funcionar em um país de escala continental é que se faz extremamente necessário proceder a um recorte científico de análise da educação superior. Assim, o presente estudo será restrito à análise da educação jurídica brasileira, para posterior apresentação de possíveis mecanismos idealizados a serem implementados buscando a melhoria do setor. Talvez, esse mecanismo que será apresentado adiante consista em algo precursor da tão almejada revolução do sistema educacional brasileiro.

O recorte é necessário por duas finalidades: a primeira consiste em conseguir realizar estudo que efetivamente seja aprofundado; a segunda é a de conseguir, com relativa segurança, imprimir uma alternativa para melhorar o cenário de crise que descreveremos adiante.

Ademais, não se olvide que um dos principais objetivos da formação universitária, não apenas a formação jurídica, é o de permitir que o aluno se prepare para o mundo profissional e, acima de tudo, desenvolva as habilidades e competências que o farão não temer as abordagens regulares que lhe serão impostas pela sociedade em permanente evolução durante o exercício de sua carreira ${ }^{39}$.

39 TELLO, Pilar Jiménez; PLAZA, Victoria Eugenia. La ética en la enseñanza del derecho. Revista Direito UFMS, Campo Grande, v. 3, n. 1, p. 23-31, enero/jul. 2017. p. 24. 
[...] o compromisso da Universidade vai além do compromisso de treinar recursos humanos ou de preparar o que William Zinsser certa vez chamou de "bárbaros altamente qualificados". Nosso compromisso é o de contribuir para a formação do homem, do ser humano, em sua totalidade. Tenho dito repetidamente e não me importo em repetir aqui mais uma vez que antes de formar o jornalista, devemos formar o ser humano, que conheça a ética, a estética e a técnica que devem orientar os meios de comunicação de massa; antes do advogado, o ser humano, que entenda de leis $^{40}$ (grifos nossos).

Compreender os meandros adstritos à educação superior envolve também o compromisso de pensar em alguns mecanismos jurídicos, ou, ainda, na idealização de políticas públicas que possam ser adotadas para transformar a atual realidade dessa educação.

Não obstante a universidade, desde sua criação como instituição na Idade Média, ter experimentado inúmeras transformações e sido invariavelmente abalada por inevitáveis circunstâncias sociais, ideológicas e econômicas de diferentes gerações, sempre encontrou um caminho que lhe conduzisse à subsistência ${ }^{41}$.

Não seria diferente com a abordagem que será aqui adotada, já que as universidades e demais instituições de ensino superior são organizações sociais que exercem funções estratégicas para o desenvolvimento cultural, tecnológico, científico e para os projetos de consolidação de uma sociedade cada vez mais plural, justa e fraterna.

Seguiremos, portanto, com as bases para a compreensão do atual sistema educacional, os regramentos específicos atinentes à educação superior e as peculiaridades da área do Direito para, após o diagnóstico, apresentar uma viável alternativa à melhoria não apenas do setor educacional, mas também do Poder Judiciário brasileiro e de todas as funções essenciais à Justiça. Optou-se por essa maneira porque não é presunção afirmar que a base do sistema é amplamente composta por profissionais formados nos mais diversos cursos de Direito espalhados pelo Brasil, os quais precisam, urgentemente, ser repensados.

\subsection{A educação superior na Constituição Federal brasileira e as peculiaridades da área do Direito}

A defesa da necessidade de intervenção estatal no domínio econômico demandou a idealização de um Estado mais atuante na economia e na proteção da sociedade; assim, os direitos sociais são considerados desdobramentos de um Estado Social de Direito. Paulo

40 DIAS SOBRINHO, José; RISTOFF, Dilvo. Avaliação democrática: para uma universidade cidadã.

Florianópolis: Insular, 2002. p. 24.

41 CALVO-SOTELO, Pablo Campos. España: campus de excelencia internacional. Madrid: Ministerio de Educación, Secretaría General de Universidades, Subdirección General de Documentación y Publicaciones, 2010. p. 31. 
Bonavides esclarece que o Estado Social de Direito representa uma transformação superestrutural pela qual o Estado liberal se sujeitou, com a finalidade de conservar sua adesão à ordem capitalista, princípio fundamental que não renuncia ${ }^{42}$.

\begin{abstract}
O modelo de Estado Social consiste em apontar que algumas concessões de direitos precisam ser garantidas para a população no sentido de que certos direitos [...] lhes sejam resguardados para que a exploração alheia não ultrapasse o limite do razoável a ponto de impedir o desenvolvimento de uma sociedade. Importa dizer que é preciso resguardar às pessoas um núcleo mínimo de proteção para que elas consigam trabalhar e gerar lucros, riquezas e desenvolvimento para a sociedade ${ }^{43}$.
\end{abstract}

Sem pretender conceituar e esgotar a temática, parte-se da compreensão de que os direitos sociais consistem em direitos de segunda dimensão e se apresentam como prestações positivas, cujo dever de implementação cabe ao Estado. Tais direitos objetivam a concretização da perspectiva de uma isonomia substancial e social na busca de melhores e adequadas condições de vida ${ }^{44}$, adotando posicionamento consolidado por José Afonso da Silva.

\begin{abstract}
Podemos dizer que os direitos sociais, como dimensão dos direitos fundamentais do homem, são prestações positivas proporcionadas pelo Estado direta ou indiretamente, enunciadas em normas constitucionais, que possibilitam melhores condições de vida aos mais fracos, direitos que tendem a realizar a igualização de situações desiguais. São, portanto, direitos que se ligam ao direito de igualdade. Valem como pressupostos do gozo dos direitos individuais na medida em que criam condições materiais mais propícias ao aferimento da igualdade real, o que, por sua vez, proporciona mais compatível com o exercício efetivo da liberdade ${ }^{45}$.
\end{abstract}

No caput do artigo $6^{\circ}$ da Constituição Federal brasileira, foi inserida a educação como primeiro direito social que deve ser promovido pelo Estado. Tal previsão ganhará contornos específicos mais adiante, quando o constituinte opta por descrever o sistema da ordem social brasileira em seu Título VIII, inserindo no Capítulo III, Seção I, em seus artigos 205 a 214, aspectos específicos atinentes à educação nacional, que serão a seguir abordados com ênfase na promoção do nível superior.

42 BONAVIDES, Paulo. Do Estado liberal ao Estado social. 11. ed. São Paulo: Malheiros, 2014. p. 184.

43 PUERTA DOS SANTOS, Larissa Dias. A instrumentalização jurídica da gestão pública brasileira e os mecanismos para a reforma da organização administrativa. 2016. 162 f. Dissertação (Mestrado) - Programa de Pós-Graduação em Direito Político e Econômico, Universidade Presbiteriana Mackenzie, São Paulo, 2017. p. 25.

44 Sobre a conceituação dos direitos sociais pela doutrina brasileira, Thiago Acca apresenta posicionamento crítico a respeito da forma pela qual tal ato se concretiza: "[...] o que fica claro a partir das leituras dos textos é que conceituar os direitos sociais é uma atividade 'mecânica'. Essa afirmação tem como base o fato de que a doutrina adota determinado conceito, contudo não discute suas consequências. O conceito de direitos sociais é incluído sem conexão direta com as outras partes do texto". Cf. ACCA, Thiago dos Santos. Teoria brasileira dos direitos sociais. São Paulo: Saraiva, 2013. p. 45.

45 SILVA, José Afonso da. Curso de direito constitucional positivo. 41. ed. rev. e atual. São Paulo: Malheiros, 2018. p. 285-286. 
O tratamento do tópico educação é identificado, ao longo de toda a textura constitucional. De forma sucinta e sistematizada, o analista vai se deparar com a seguinte lista de preceitos abordando a questão educacional:

Art. $5^{\circ}$, IV e XIV;

Art. $6^{\circ}$, caput, (D. Sociais) - Cap. II do Tit. II;

Art. $7^{\circ}, \mathrm{XXV}$ - assistência a dependentes e filhos de 0 a 5 anos;

Art. 23, V - competência comum - promoção da educação;

Art. 24, IX e XV - competência concorrente. Normas gerais e específicas;

Art. 30, VI (competência comum envolvendo obrigação do município);

Art. 205 (Sec. I, Cap. III, Tit. VIII - Da ordem social);

Art. 206 - princípios de regência do ensino;

Art. 207 - universidades - a autonomia universitária;

Art. 208 - educação dever do Estado;

Art. 209 - ensino privado - regras de atendimento;

Art. 210 - formação básica comum e respeito aos valores culturais e artísticos, nacionais e regionais; Ensino religioso e língua portuguesa $\left(\S 1^{\circ}\right)$;

Art. 211 - organização do sistema federal de ensino;

Art. 212 - 18\% União e 25\% Estados e municípios;

Art. 213 - direção dos recursos públicos

[Art. 214 - plano nacional de educação e seus objetivos $]^{46}$.

O dispositivo constitucional que define a educação como direito e dever é o artigo 205, ao estipular que "a educação, direito de todos e dever do Estado e da família, será promovida e incentivada com a colaboração da sociedade, visando ao pleno desenvolvimento da pessoa, seu preparo para o exercício da cidadania e sua qualificação para o trabalho" 47 .

Seguindo com diretrizes que buscam a promoção e a proteção da educação nacional, o artigo 206 do texto constitucional prevê oito princípios constitucionais adstritos à regência da educação. São eles: igualdade de condições para o acesso e permanência na escola; liberdade de aprender, ensinar, pesquisar e divulgar o pensamento, a arte e o saber; pluralismo de ideias e de concepções pedagógicas e coexistência de instituições públicas e privadas de ensino; gratuidade do ensino público em estabelecimentos oficiais; valorização dos profissionais da educação escolar, garantidos, na forma da lei, planos de carreira, com ingresso exclusivamente por concurso público de provas e títulos, aos das redes públicas; gestão democrática do ensino público, na forma da lei; garantia de padrão de qualidade; e piso salarial profissional nacional

46 CAGgianO, Monica Herman Salem. A educação. Direito fundamental. In: RANIERI, Nina Beatriz Stocco; RIGHETTI, Sabine (org.). Direito à educação: aspectos constitucionais. São Paulo: Edusp, 2009. p. 30.

47 Art. 205: "Os Estados organizam-se e regem-se pelas Constituições e leis que adotarem, observados os princípios desta Constituição”. Cf. BRASIL. [Constituição (1988)]. Constituição da República Federativa do Brasil de 1988. Brasília, DF: Presidência da República, 1988. Disponível em:

http://www.planalto.gov.br/ccivil_03/constituicao/constituicaocompilado.htm. Acesso em: 18 fev. 2019. 
para os profissionais da educação escolar pública, nos termos de lei federal ${ }^{48}$.

São esses princípios constitucionais que devem ser entendidos como as diretrizes nacionais de orientação na atuação do legislador para editar as regras inerentes à educação. Ainda, devem nortear os representantes dos diversos níveis de governo para escolherem as políticas públicas a serem idealizadas e implementadas na promoção da educação nacional, de instituições de ensino e de educadores em todo o país. Dessa forma, a promoção desse importante direito será capaz de atingir suas finalidades, e então a sociedade civil e os estudantes poderão se orientar, conscientes de quais são os princípios regentes do serviço público que lhes fora constitucionalmente assegurado.

Nesse momento, faz-se essencial chamar a atenção para o princípio que garante padrão de qualidade no dever de prestação do serviço educacional. Tal destaque é feito tendo em vista que esta pesquisa guarda estrita relação com a mencionada previsão. Como será visto adiante, os melhores esforços foram dedicados à efetivação desse princípio. Para tanto, é preciso destacar que o padrão de qualidade aqui assegurado diz respeito a qualquer nível da educação nacional, embora tenha-se restringido o objeto deste estudo para a educação superior, especificamente no que atine à área de conhecimento do Direito.

Além disso, a Constituição Federal se dedica especificamente à educação superior em diversas passagens. Outra importante proteção constitucionalmente conferida para a efetivação dela foi o princípio da autonomia universitária, consagrado em seu artigo $207^{49}$, como forma de preservar a consecução da prestação adequada dos serviços educacionais em nível superior no Brasil, como se pode ver: "as universidades gozam de autonomia didático-científica, administrativa e de gestão financeira e patrimonial, e obedecerão ao princípio de indissociabilidade entre ensino, pesquisa e extensão".

O serviço público educacional superior, seja de natureza pública, seja de natureza privada, só pode ser plenamente efetivado se tal prestação se der de forma autônoma, livre de

48 Art. 206: “O ensino será ministrado com base nos seguintes princípios:

I - igualdade de condições para o acesso e permanência na escola;

II - liberdade de aprender, ensinar, pesquisar e divulgar o pensamento, a arte e o saber;

III - pluralismo de idéias e de concepções pedagógicas, e coexistência de instituições públicas e privadas de ensino;

IV - gratuidade do ensino público em estabelecimentos oficiais;

V - valorização dos profissionais do ensino, garantidos, na forma da lei, planos de carreira para o magistério público, com piso salarial profissional e ingresso exclusivamente por concurso público de provas e títulos;

VI - gestão democrática do ensino público, na forma da lei;

VII - garantia de padrão de qualidade". Cf. BRASIL. [Constituição (1988)]. Constituição da República

Federativa do Brasil de 1988. Brasília, DF: Presidência da República, 1988. Disponível em:

http://www.planalto.gov.br/ccivil_03/constituicao/constituicaocompilado.htm. Acesso em: 18 fev. 2019.

49 Ibid., art. 207. 
amarras e ideologias, sem que deva obedecer aos desígnios, mandos e desmandos dos governantes eleitos, cujas prioridades e compreensões podem ser variáveis de acordo com seus posicionamentos.

Em sentido amplo, a autonomia universitária é o princípio que reconhece as liberdades de cátedra, investigação e estudo. Tal autonomia não é apenas um requisito de direitos históricos das universidades, nem mesmo mera previsão constitucional, mas sim verdadeira proteção constitucional de autonomia da educação superior, conquista extremamente importante para o cenário educacional ${ }^{50}$.

A Constituição Federal de 1988 firmou a autonomia didático-científica, administrativa e de gestão financeira das universidades com a intenção de consagrar a liberdade de aprender, ensinar, pesquisar e divulgar o pensamento, a arte e o saber como princípio basilar da educação. Nesse sentido, há plena coerência com a autonomia das universidades:

\begin{abstract}
Autonomia não é apenas a independência da instituição universitária, mas a do próprio saber humano, pois as universidades não serão o que devem ser se não cultivarem a consciência da independência do saber e se não souberem que a supremacia do saber, graças a essa independência, é levar a um novo saber. E para isto precisam viver em uma atmosfera de autonomia e estímulos vigorosos de experimentação, ensaio e renovação. Não é por simples acidente que as universidades se constituem em comunidades de mestres e discípulos, casando a experiência de uns com o ardor e a mocidade dos outros. Elas não são, com efeito, apenas instituições de ensino e de pesquisas, mas sociedades devotadas ao libre, desinteressado e deliberativo cultivo da inteligência e do espírito fundadas na esperança do progresso humano prelo progresso da razão ${ }^{51}$.
\end{abstract}

Pilar Jiménez Tello ${ }^{52}$ explica que a constitucionalização da autonomia universitária tem como finalidade a existência de um espaço de liberdade para a investigação, o ensino e a aprendizagem, tendo como consequência lógica a auditoria e a avaliação universitária, vez que avaliar o grau de qualidade universitária é também avaliar o grau de liberdade no âmbito universitário autônomo.

Tal previsão só é possível de ser efetivada se a educação superior for protegida pelo

50 "En un sentido amplio se desprende que la autonomía universitaria reconoce las libertades de cátedra, investigación y estudio. Dicha autonomía no es sólo un requerimiento de derechos históricos de las universidades o incluso un requerimiento constitucional, es decir la constitucionalización de la autonomía universitária." Cf. TELLO, Pilar Jiménez. Auditoría universitaria y calidad: la evaluación como conquista social ante la competencia universitaria global. Saarbrücken: VDM Verlag Dr. Müller, 2009. p. 64.

51 TEIXEIRA, Anísio. A educação e a crise brasileira. São Paulo: Nacional, 1956. p. 267 e 271.

52 "La constitucionalización de la autonomía universitaria tiene como finalidad la existencia de un espacio de libertad para la investigación, la enseñanza y el aprendizaje. Evaluar el grado de calidad universitaria, es también, evaluar el grado de libertad en el ámbito universitario autónomo. [...] Una consecuencia lógica de la autonomía universitaria y de su constitucionalización está implícita en la auditoría y evaluación universitaria." Cf. TELLO, op. cit., p. 63. 
manto da autonomia. Só se fala em autonomia universitária quando nos referimos à autonomia econômica. Isso ocorre porque a autonomia só pode ser de fato desempenhada quando as instituições de ensino possuem verba para desenvolver livremente suas atividades.

Em verdade, o verdadeiro fundamento da autonomia universitária seriam os interesses
peculiares da universidade, ou seja, o ensino e a pesquisa. O reconhecimento da
autonomia na Constituição espanhola representa o compromisso do Estado com
ciência livre. Nessa medida, o Estado estaria obrigado a atuar positivamente em favor
da universidade, possibilitando e fomentando o cultivo da ciência livre e buscando,
por meio de medidas organizativas apropriadas, que o direito à liberdade científica
permaneça inatingível ${ }^{53}$.

No mesmo dispositivo constitucional em que está prevista a autonomia universitária, logo em seguida o legislador constitucional determinou que as universidades também “obedecerão ao princípio de indissociabilidade entre ensino, pesquisa e extensão". A justificativa para ambos os princípios estarem regulados no mesmo dispositivo constitucional reside na própria finalidade social das universidades. Assim, somente a autonomia universitária assegurada por sua autonomia financeira será capaz de resguardar a busca pelo cumprimento de suas finalidades, pela promoção do ensino, pela realização da pesquisa e pela efetivação da extensão.

O princípio da indissociabilidade, inclusive, é norte de atuação para as instituições de ensino superior em todo o Brasil, já tendo sido objeto de discussão se a aplicabilidade do referido princípio seria destinada apenas às universidades, como expresso mediante leitura literal do dispositivo, ou deveria ser aplicável a qualquer instituição que preste serviços educacionais em nível superior.

Um claro desdobramento do princípio da indissociabilidade entre ensino, pesquisa e extensão é justamente o estabelecimento de padrão de qualidade acadêmica, dado que é por meio das atividades desempenhadas que as instituições de ensino superior atingem as suas finalidades; dentre elas, diminuir as desigualdades sociais por meio da capacitação dos seus estudantes para o exercício da cidadania e a formação para o mercado de trabalho. Evidentemente, quanto maior o sucesso no cumprimento desse objetivo, melhor a qualidade do serviço prestado pela instituição de ensino, expressando assim o papel social da universidade na construção de uma sociedade democrática e igualitária.

A expressão "indissociabilidade entre ensino, pesquisa e extensão" consagrada pela Constituição de 1988, não deve ser considerada como uma fraseologia de efeito, mas

53 SAMPAIO, Anita Lapa Borges. Autonomia universitária. Brasília, DF: Editora Universidade de Brasília, 1998. p. 47. 
como uma síntese atual da história educacional brasileira que aponta diretamente para a construção de uma universidade de um bom nível acadêmico, pública, autônoma, democrática, que se coloca a serviço da realização de uma sociedade independente e soberana científica, tecnológica e culturalmente, voltada para os interesses concretos da população brasileira ${ }^{54}$.

Filomena Moita e Fernando Andrade $^{55}$ argumentam que para tratar da indissociabilidade na universidade é imprescindível considerar dois vetores de um debate: de um lado, a constitucionalização das relações entre universidade, ensino, pesquisa e extensão, que deve ser cumprida por ser determinação constitucional; e, de outro, confluindo para a formulação de uma tridimensionalidade ideal da educação superior, as relações entre o conhecimento científico e aquele produzido culturalmente pelos diferentes grupos que compõem a sociedade. Cumpre, portanto, considerar brevemente esse debate para melhor entender por que, apesar de ideal, a pretendida indissociabilidade muitas vezes não se verifica na prática.

Maria das Graças Silva ${ }^{56}$ pondera que pouco a pouco a legislação educacional registrou o esforço por transformar o modelo de transmissão de conhecimento em um modelo de produção e transmissão do saber científico, aliando pesquisa e ensino como decorrência das pressões por democratização do acesso às universidades.

Mais recentemente ainda, a extensão surge como terceiro elemento do fazer acadêmico, em resposta às críticas e pressões sofridas pela universidade, oriundas de setores e demandas sociais. Foi nesse contexto que, ao final do século XX, ensino, pesquisa e extensão apareceram unidos pelo princípio constitucional da indissociabilidade.

Levando em conta que os três elementos estruturais que compõem a base da educação superior foram inseridos na Constituição depois de conquistas históricas educacionais, o debate teórico acabou trazendo certos problemas na aplicação prática do dito princípio da indissociabilidade, sendo justamente o desconhecimento do conteúdo desse regramento um dos grandes responsáveis pela crise da educação superior nacional.

Um destaque relativo à crise, que cabe ser apontado aqui e será oportunamente

54 PUCCI, Bruno. A indissociabilidade entre ensino, pesquisa e extensão. Piracicaba: Impulso, 1991. p. 19.

55 MOITA, Filomena Maria Gonçalves da Silva Cordeiro; ANDRADE, Fernando Cézar Bezerra de. Ensinopesquisa-extensão: um exercício de indissociabilidade na pós-graduação. Revista Brasileira de Educação, Rio de Janeiro, v. 14, n. 41, p. 269-280, ago. 2009. p. 270. Disponível em:

http://www.scielo.br/scielo.php?script=sci_arttext\&pid=S1413-24782009000200006\&lng=en\&nrm=iso. Acesso em: 18 mar. 2019.

56 SILVA, Maria das Graças. Universidade e sociedade: cenário da extensão universitária? In: REUNIÃO ANUAL DA ANPED, 23., 2000, Caxambu. Anais [...]. Caxambu: Associação Nacional de Pesquisa e PósGraduação em Educação, 2000. Disponível em: http://www.anped11.uerj.br/23/1101t.htm. Acesso em: 20 mar. 2019. 
explorado no próximo capítulo, está justamente atrelado ao grande número de desconhecedores do dito princípio em órgãos administrativos nas diversas instituições de ensino superior em todo o Brasil, o que por si só gera a incompreensão de como tais eixos estruturantes deveriam ser efetivados e inter-relacionados.

Outro problema está na compreensão da autonomia como impossibilidade de interferência estatal nas atividades das instituições educacionais. É inquestionável que demasiada intervenção estatal consistiria na limitação das ideias, da liberdade de pensamento e da pesquisa. Porém, sob o manto da autonomia, querer afastar uma atuação estatal consiste no distanciamento dos objetivos e das funções da educação superior, ou pior, resumir a autonomia universitária à possibilidade de conduzir o processo educacional de forma totalmente alheia ao Estado.

Questão que também se deve pensar diz respeito à complexidade da correta implementação desses três indissociáveis eixos. A própria pesquisa só pode ser devidamente desenvolvida se a autonomia financeira das instituições de ensino superior for verdadeira. Caso contrário, sem apoio financeiro não há como serem efetivadas pesquisas aptas a melhorar e ampliar o ensino e o conhecimento.

A título de exemplo, no Brasil, caso uma indústria decida regularmente apoiar uma pesquisa desenvolvida em uma universidade, se o processo for considerado uma prestação de serviços, impostos lhe serão devidos. Com isso, parte da verba para a pesquisa deve ser entregue ao Estado em total desrespeito ao incentivo que o próprio poder público deve fazer ao setor.

Também se nota que a ausência de regulamentação das pesquisas, com a mera previsão constitucional, é um fator de desestímulo privado ao desenvolvimento científico. Os órgãos de financiamento à pesquisa costumam ser exclusivamente públicos e geralmente tendem a privilegiar instituições públicas.

A extensão também não faz mais sucesso do que a pesquisa. São inúmeras as instituições de ensino superior que sequer sabem o seu papel na efetivação da educação superior. Como política pública imposta de "cima para baixo", cuja obrigatoriedade foi determinada pela própria Constituição Federal, falta conscientização dos educadores, principalmente nos cursos de natureza iminentemente técnicos como é o caso do Direito.

Darcy Ribeiro ${ }^{57}$ nos apresenta um conjunto de concepções capazes de definir a boa efetivação da extensão, cujo papel pode ser resumido a quatro diretrizes. A primeira delas consiste em defini-la como amplos programas de especialização e de recapacitação profissional

57 RIBEIRO, Darcy. A universidade necessária. 4. ed. Rio de Janeiro: Paz e Terra, 1982. p. 240-241. 
aos egressos, que retornariam periodicamente à universidade para aperfeiçoar e atualizar seus conhecimentos. Desse modo, a educação superior se converteria num processo continuado, como deve ser, de renovação e ampliação do conhecimento.

A segunda consistiria em uma série de programas extracurriculares, de recapacitação e formação de pessoal qualificado em todos os campos do saber e suas aplicações técnicoprofissionais nos setores de atividade em que o mercado de trabalho exigisse novas categorias de pessoal qualificado.

Também a idealização de programas regulares de divulgação cultural nos campos da literatura, das artes e de outras disciplinas orientadas para o combate à colonização cultural e para desmascaramento das diversas formas de alienação, a fim de despertar a consciência crítica.

E, finalmente, amplas ofertas de cursos sequenciais, que permitiriam multiplicar várias vezes as carreiras formalmente instituídas e criar novas linhas extracurriculares de preparação, correspondentes às necessidades da comunidade. Nestas últimas, deverá ser conferido direito à graduação, através da outorga de certificado de estudos. Assim, as amplas instalações da universidade e seus vastos recursos de pessoal docente seriam abertas ao grande público, a todas as horas e durante todo o ano, promovendo efetiva atividade de extensão propiciadora duma intercomunicação do maior alcance com a sociedade como um todo.

O artigo 208 da Constituição Federal, por sua vez, estipula as primeiras diretrizes para orientar a atuação obrigatória do Estado na efetivação da educação nacional. Nesse sentido, e com relação especificamente à educação superior, a Constituição assegura, no inciso V do referido artigo, o acesso aos níveis mais elevados do ensino, da pesquisa e da criação artística, segundo a capacidade de cada um. É em razão dessa obrigação constitucionalmente assegurada que se enxerga uma série de políticas públicas nos diversos níveis da Federação, tendentes a buscar melhorar o acesso dos brasileiros aos mais elevados níveis de ensino.

Ainda sobre o acesso à educação superior, podemos encarar a autorização constitucional prevista no artigo 209 em que o Estado brasileiro permitiu que a iniciativa privada também pudesse prestar o referido serviço, impondo-lhe, inicialmente, duas restrições: cumprimento das normas gerais da educação nacional e a autorização e avaliação de qualidade pelo poder público.

Nesse sentido, está claro que o permissivo constitucional autoriza a prestação do serviço pelo setor privado sem, contudo, retirar-lhe a natureza de serviço público e remanescendo ao Estado o dever de fiscalizar a qualidade do que a iniciativa privada entrega à sociedade. 
Desde a redemocratização e com a autorização constitucional mencionada, atrelada à autorização prevista na LDB, o setor da educação superior brasileira passou por grandes transformações, sobretudo na maneira pela qual a atuação do setor privado na prestação desse serviço se deu, haja vista o seu substancial crescimento.

Verifica-se diante da análise de dados oficialmente coletados que, inclusive e principalmente na área do Direito, o crescimento foi exponencial no número de vagas ofertadas, ampliando consideravelmente a concorrência do setor.

Com esse aumento, foi inevitável observar que o número de novas instituições de educação superior criadas se proliferou por boa parte dos estados, devendo destacar a concentração nos grandes centros urbanos.

\footnotetext{
Concorrência e competição, inevitavelmente, passam a se acirrar no setor, fazendo que com as instituições passassem a enfrentar diversos desafios em um mercado cada vez mais exigente. Para exemplificar, no ano de 1997 o total de vagas existentes era de 505 mil para atender a um contingente de 392 mil alunos que estavam ingressando na educação superior. Seis anos depois, no ano de 2003, o número de vagas geradas era de 1 milhão e 721 mil e os alunos 995 mil. Este cenário começou a trazer prejuízos ao setor em pouco tempo.

A partir do voluptuoso crescimento, em 2005 , o setor já possuía $42 \%$ de vagas ociosas, em um montante de 1762 instituições de ensino particulares. Vale a pena destacar que 998 destas instituições possuíam menos de dez anos de existência, e 935 menos de 500 alunos $^{58}$.
}

Os desdobramentos dessa autorização constitucional serão tratados mais detalhadamente no próximo capítulo, principalmente porque, em razão dessa abertura para a possibilidade de aferir lucro, é identificada uma crise atual da educação jurídica que merece ser aprofundada em tópico próprio.

Com base no pacto federativo que decorre da forma de Estado adotada no Brasil, pressupõe-se que a repartição das competências do setor público fora assim estipulada para a consecução dos interesses públicos por meio da divisão de tarefas administrativas e normativas.

Esta distribuição constitucional de poderes é o ponto nuclear da noção de Estado federal. São notórias as dificuldades quanto a saber que matérias devem ser entregues à competência da União, quais as que competirão aos Estados e quais as que se indicarão aos Municípios ${ }^{59}$.

Para efetivar a educação, respeitando o pacto federativo, a Constituição estabeleceu

58 PAIVA, Ricardo Viana Carvalho de; COSTA, Danilo de Melo; GONÇALVES, Raquel Garcia; BARBOSA, Francisco Vidal. Fatores influenciadores da competitividade na educação superior privada brasileira. Revista Global Manager, Rio Grande do Sul, v. 14, n. 1, p. 19-39, 2014. p. 20.

59 SILVA, José Afonso da. Curso de direito constitucional positivo. 41. ed. rev. e atual. São Paulo: Malheiros, 2018. p. 477. 
uma repartição de competências por meio da instauração de forma de cooperação entre os entes federativos denominada "regime de colaboração". Assim, o dever estatal de promover a educação relaciona a democracia e o pacto federativo para que a efetivação desse direito social ocorra por meio de ações integradas e coordenadas entre todos os entes, caracterizando o federalismo cooperativo.

No que diz respeito ao dever do Estado, Nina Ranieri ${ }^{60}$ aponta que, para assegurar a efetivação da promoção da educação, a Constituição discriminou encargos e competências específicos para os sistemas de ensino atribuídos à União, aos Estados e aos Municípios, bem como os correspondentes percentuais de receita pública orçamentária atribuídos aos entes da Federação para aplicação na manutenção e no desenvolvimento desse direito (art. 22, XXIV, art. 24, IX, art. 30, VI, art. 208 e art. $212^{61}$, todos da Constituição Federal brasileira).

60 RANIERI, Nina Beatriz Stocco. Os Estados e o direito à educação na Constituição de 1988: comentários acerca da jurisprudência do Supremo Tribunal Federal. In: RANIERI, Nina Beatriz Stocco; RIGHETTI, Sabine (org.). Direito à educação: aspectos constitucionais. São Paulo: Edusp, 2009. p. 42.

61 "Art. 22. Compete privativamente à União legislar sobre: XXIV - diretrizes e bases da educação nacional; Art. 24. Compete à União, aos Estados e ao Distrito Federal legislar concorrentemente sobre: IX - educação, cultura, ensino, desporto, ciência, tecnologia, pesquisa, desenvolvimento e inovação;

Art. 30. Compete aos Municípios: VI - manter, com a cooperação técnica e financeira da União e do Estado, programas de educação infantil e de ensino fundamental;

Art. 208. O dever do Estado com a educação será efetivado mediante a garantia de:

I - educação básica obrigatória e gratuita dos 4 (quatro) aos 17 (dezessete) anos de idade, assegurada inclusive sua oferta gratuita para todos os que a ela não tiveram acesso na idade própria;

II - progressiva universalização do ensino médio gratuito;

III - atendimento educacional especializado aos portadores de deficiência, preferencialmente na rede regular de ensino;

IV - educação infantil, em creche e pré-escola, às crianças até 5 (cinco) anos de idade;

$\mathrm{V}$ - acesso aos níveis mais elevados do ensino, da pesquisa e da criação artística, segundo a capacidade de cada um;

VI - oferta de ensino noturno regular, adequado às condições do educando;

VII - atendimento ao educando, em todas as etapas da educação básica, por meio de programas suplementares de material didático-escolar, transporte, alimentação e assistência à saúde.

$\S 1^{\circ} \mathrm{O}$ acesso ao ensino obrigatório e gratuito é direito público subjetivo.

$\S 2^{\circ} \mathrm{O}$ não-oferecimento do ensino obrigatório pelo Poder Público, ou sua oferta irregular, importa responsabilidade da autoridade competente.

$\S 3^{\circ}$ Compete ao Poder Público recensear os educandos no ensino fundamental, fazer-lhes a chamada e zelar, junto aos pais ou responsáveis, pela frequência à escola.

Art. 212. A União aplicará, anualmente, nunca menos de dezoito, e os Estados, o Distrito Federal e os Municípios vinte e cinco por cento, no mínimo, da receita resultante de impostos, compreendida a proveniente de transferências, na manutenção e desenvolvimento do ensino.

$\S 1^{\circ}$ A parcela da arrecadação de impostos transferida pela União aos Estados, ao Distrito Federal e aos Municípios, ou pelos Estados aos respectivos Municípios, não é considerada, para efeito do cálculo previsto neste artigo, receita do governo que a transferir.

$\S 2^{\circ}$ Para efeito do cumprimento do disposto no "caput" deste artigo, serão considerados os sistemas de ensino federal, estadual e municipal e os recursos aplicados na forma do art. 213.

$\S 3^{\circ} \mathrm{A}$ distribuição dos recursos públicos assegurará prioridade ao atendimento das necessidades do ensino obrigatório, no que se refere a universalização, garantia de padrão de qualidade e equidade, nos termos do plano nacional de educação.

$\S 4^{\circ}$ Os programas suplementares de alimentação e assistência à saúde previstos no art. 208, VII, serão

financiados com recursos provenientes de contribuições sociais e outros recursos orçamentários. 
É importante descrever a divisão de competências firmadas pelo poder público para atribuir deveres específicos aos entes estatais na concretização da educação. Destaque-se a finalidade última de compreensão específica do sistema educacional idealizado para a promoção da educação superior. Serão apresentadas as determinações constitucionais para então analisar os desdobramentos infraconstitucionais estabelecidos.

O sistema educacional vigente consiste em uma interpretação sistêmica do que está previsto no artigo $211^{62}$ da Constituição Federal, somado aos desdobramentos infraconstitucionais destinados à regulação da matéria. Referido artigo estipula a organização em regime de colaboração entre todos os entes da Federação.

Para buscar o regramento jurídico aplicável à temática, e não apenas o constitucional, será efetuada análise dos preceitos normativos exarados pelo Poder Legislativo e também pelo Poder Executivo, dois entes federativos autorizados constitucionalmente a regulamentar a educação superior brasileira. Para tanto, é preciso identificar as espécies de competência definidas na Constituição Federal brasileira relativas à educação superior, bem como o papel que cada ente da Federação deverá exercer no cumprimento delas.

Inicia-se, assim, com uma breve distinção sobre as espécies de competências destinadas aos entes da Federação fixadas no regramento constitucional brasileiro. Portanto, adota-se a concepção de Canotilho nos seguintes termos:

Por competência entender-se á [...] o poder de acção e de actuação atribuído aos vários órgãos e agentes constitucionais com o fim de perseguirem as tarefas de que são constitucional ou legalmente atribuídos. A competência envolve, por conseguinte, a atribuição de determinadas tarefas bem como os meios de acção ("poderes") necessários para a sua prossecução. Além disso, a competência delimita o quadro jurídico de actuação de uma unidade organizatória relativamente a outra ${ }^{63}$.

$\S 5^{\circ} \mathrm{A}$ educação básica pública terá como fonte adicional de financiamento a contribuição social do salárioeducação, recolhida pelas empresas na forma da lei.

$\S 6^{\circ}$ As cotas estaduais e municipais da arrecadação da contribuição social do salário-educação serão distribuídas proporcionalmente ao número de alunos matriculados na educação básica nas respectivas redes públicas de ensino.”. Cf. BRASIL. [Constituição (1988)]. Constituição da República Federativa do Brasil de 1988. Brasília, DF: Presidência da República, 1988. Disponível em:

http://www.planalto.gov.br/ccivil_03/constituicao/constituicaocompilado.htm. Acesso em: 10 fev. 2019.

62 Ibid., art. 211: "A União, os Estados, o Distrito Federal e os Municípios organizarão em regime de colaboração seus sistemas de ensino.

$\S 1^{\circ}$ A União organizará o sistema federal de ensino e o dos Territórios, financiará as instituições de ensino públicas federais e exercerá, em matéria educacional, função redistributiva e supletiva, de forma a garantir equalização de oportunidades educacionais e padrão mínimo de qualidade do ensino mediante assistência técnica e financeira aos Estados, ao Distrito Federal e aos Municípios;

$\S 2^{\circ}$ Os Municípios atuarão prioritariamente no ensino fundamental e na educação infantil.

$\S 3^{\circ}$ Os Estados e o Distrito Federal atuarão prioritariamente no ensino fundamental e médio.

$\S 4^{\circ} \mathrm{Na}$ organização de seus sistemas de ensino, a União, os Estados, o Distrito Federal e os Municípios

definirão formas de colaboração, de modo a assegurar a universalização do ensino obrigatório.

$\S 5^{\circ}$ A educação básica pública atenderá prioritariamente ao ensino regular."

63 CANOTILHO, José Joaquim Gomes. Direito constitucional. 5. ed. Coimbra: Almedina, 1992. p. 690. 
É possível falar, então, em espécies de competências tendo em vista que as matérias que compõem o seu conteúdo podem ser reunidas segundo critérios de sua natureza, sua vinculação exclusiva ou cumulativa para efetivação da atribuição que lhe fora conferida, ou seu vínculo à função de governo. Logo, a competência atribuída pela Constituição poderá ser legislativa ou material ${ }^{64}$.

No tocante à competência legislativa sobre educação, a Constituição vigente define que apenas a União detém competência legislativa para estipular as diretrizes e bases da educação nacional ${ }^{65}$ e também para estabelecer o Plano Nacional de Educação (PNE) ${ }^{66}$. Indo além, a Constituição também atribuiu competência legislativa concorrente à própria União, aos Estados e ao Distrito Federal para legislar sobre educação, cultura, ensino, desporto, ciência, tecnologia, pesquisa, desenvolvimento e inovação ${ }^{67}$.

Sendo assim, fica evidente que a União detém a competência para legislar mediante normas gerais que deverão ser aplicáveis a todos os entes da Federação, e cada ente deterá competência para legislar sobre matéria educacional específica à sua região, respeitando sempre a determinação geral definida a todos pela União.

Com essa análise, pode-se afirmar que a competência dos estados nesse cenário é bastante restrita, posto que remanescente, complementar e supletiva, limita-se a baixar normas

64 "Sob esses vários critérios, podemos classificar as competências [...] em dois grandes grupos com suas subclasses: (1) competência material que pode ser: (a) exclusiva (art. 21); e (b) comum, cumulativa ou paralela (art. 23); (2) competência legislativa, que pode ser: (a) exclusiva (art. $25, \S \S 1^{\circ}$ e $2^{\circ}$ ); (b) privativa (art. 22); (c) concorrente (art. 24); (d) suplementar (art. 24, §2 $2^{\circ}$.” Cf. SILVA, José Afonso da. Curso de direito constitucional positivo. 41. ed. rev. e atual. São Paulo: Malheiros, 2018. p. 480.

65 Art. 22, XXIV: "Compete privativamente à União legislar sobre [...] XXIV - diretrizes e bases da educação nacional. Cabe esclarecimento para destacar que o parágrafo único do mesmo regramento constitucional preceitua que a União poderá autorizar, por meio de Lei Complementar, que os Estados legislem sobre questões específicas relativas às matérias previstas nos seus incisos". Cf. BRASIL. [Constituição (1988)]. Constituição da República Federativa do Brasil de 1988. Brasília, DF: Presidência da República, 1988. Disponível em: http://www.planalto.gov.br/ccivil_03/constituicao/constituicaocompilado.htm. Acesso em: 18 fev. 2019.

66 Essa temática será abordada com mais atenção adiante.

67 BRASIL, op. cit., art. 24, IX: “Compete à União, aos Estados e ao Distrito Federal legislar concorrentemente sobre [...] IX - educação, cultura, ensino, desporto, ciência, tecnologia, pesquisa, desenvolvimento e inovação". 
complementares para os respectivos sistemas de ensino que lhes são afetos ${ }^{68}$. A competência dos municípios, então, deve ser encarada de forma mais restrita ainda, visto que a autorização constitucional para atividade legislativa foi clara em definir que os municípios devem estar adstritos a assuntos de interesse local e suplementar à legislação federal e estadual ${ }^{69}$, nunca podendo contrariá-las, sob pena de inconstitucionalidade.

Porém, para a efetivação da educação como direito social é que a Constituição foi além e também definiu competências materiais atribuídas aos entes da Federação, para compelir a atuação estatal na prestação do serviço educacional.

Assim, é da competência comum entre União, estados, Distrito Federal e municípios proporcionar os meios de acesso à cultura, à educação, à ciência, à tecnologia, à pesquisa e à inovação ${ }^{70}$. Ademais, há atribuição de competência expressa aos municípios para o dever de manter, com a cooperação técnica e financeira da União e do Estado, programas de educação infantil e de ensino fundamental ${ }^{71}$.

Segundo se verifica, a União detém competência coordenadora em matéria de política nacional de educação. Implica dizer que ela é o ente federativo responsável por articular os diferentes níveis, básico e superior, bem como os diferentes sistemas de ensino: federal, estadual e municipal.

Tal compreensão, inclusive, pode ser ratificada pela própria Lei de Diretrizes e Bases da Educação Nacional que, em seu artigo $8^{\circ}$, estipula que a União, os Estados, o Distrito Federal e os Municípios organizarão, em regime de colaboração, os respectivos sistemas de ensino, cabendo à União a coordenação da política nacional de educação, articulando os diferentes níveis e sistemas e exercendo função normativa, redistributiva e supletiva em relação às demais

68 “A legislação concorrente da União sobre as matérias indicadas se limitará a estabelecer normas gerais. Nisso a Constituição foi, às vezes, redundante. Por exemplo, no art. 22, XXIV, dá como privativo da União legislar sobre diretrizes e bases da educação nacional, enquanto, no art. 24 , IX, combinado como $\S 1^{\circ}$, declara caber-lhe legislar sobre normas gerais de educação. Nisso não há incoerência, como pode parecer. Legislar sobre as diretrizes e bases da educação nacional e sobre normas gerais de educação somam, no fundo, a mesma coisa. A tradição arrastou os educadores da Constituinte a manter a regra que vem de 1946, que dava competência à União para legislar sobre diretrizes e bases da educação nacional, mas também não poderiam deixar de incluir na competência comum legislar sobre educação, situação em que a União só tem poderes para fixar normas gerais. Tudo somado, dá na mesma, com um dispositivo a mais sem necessidade." Cf. SILVA, José Afonso da. Curso de direito constitucional positivo. 41. ed. rev. e atual. São Paulo: Malheiros, 2018. p. 503.

69 Art. 30: "Compete aos Municípios: I - legislar sobre assuntos de interesse local; II - suplementar a legislação federal e a estadual no que couber [...]”. Cf. BRASIL. [Constituição (1988)]. Constituição da República Federativa do Brasil de 1988. Brasília, DF: Presidência da República, 1988. Disponível em: http://www.planalto.gov.br/ccivil_03/constituicao/constituicaocompilado.htm. Acesso em: 18 fev. 2019.

70 Ibid., art. 23, inciso V: "V - É competência comum da União, dos Estados, do Distrito Federal e dos Municípios: V - proporcionar os meios de acesso à cultura, à educação, à ciência, à tecnologia, à pesquisa e à inovação".

71 Ibid., art. 30, inciso VI: "VI - manter, com a cooperação técnica e financeira da União e do Estado, programas de educação infantil e de ensino fundamental". 
instâncias educacionais ${ }^{72}$.

Essa previsão, inclusive, complementa a norma genérica prevista na Constituição Federal, o que significa que sob a coordenação da União, todos os entes da Federação deverão atuar na educação básica e na educação superior, atendida a seguinte diretriz: municípios atuarão prioritariamente na educação infantil e no ensino fundamental, e estados e Distrito Federal, no ensino fundamental e médio, sendo que o não oferecimento do ensino obrigatório pelo poder público, ou sua oferta irregular, importará em responsabilidade da autoridade competente $^{73}$.

A Constituição Federal não atribuiu nenhum nível de educação escolar como de exclusividade da União, o que reforça sua atuação supletiva e redistributiva em quaisquer dos mencionados níveis. Considerando o amplo escopo da mencionada atribuição, resta claro que compete à União o oferecimento da educação superior diante da ausência de atribuição específica dessa promoção às demais esferas de governo, embora não haja nenhum tipo de vedação à competência dos demais entes da Federação à prestação de serviços educacionais no nível superior. No entanto, como os demais entes devem se ocupar prioritariamente da educação básica, a conclusão primária que podemos efetuar é a de que a competência da União em relação à educação superior é residual.

A União, quando instituiu as Diretrizes e Bases da Educação Nacional mediante a promulgação da Lei ${ }^{\circ}$ 9.394, de 20 de dezembro de 1996, estipulou os níveis e as modalidades de educação, respeitando a determinação constitucional e definindo em seu artigo 21 que a educação escolar é composta por dois níveis, quais sejam, a educação básica, formada pela educação infantil, ensino fundamental e ensino médio, e a educação superior.

Nesse sentido, vale apresentar o Esquema 1:

72 Art. $8^{\circ}$ da LDB: “A União, os Estados, o Distrito Federal e os Municípios organizarão, em regime de colaboração, os respectivos sistemas de ensino. ... $\S 2^{\circ}$ Os sistemas de ensino terão liberdade de organização nos termos desta Lei". Cf. BRASIL. Lei $n^{\circ}$ 9.394, de 20 de dezembro de 1996. Estabelece as diretrizes e bases da educação nacional. Brasília, DF: Presidência da República, 1996a. Disponível em: http://www.planalto.gov.br/ccivil_03/leis/19394.htm. Acesso em: 5 fev. 2019.

73 Art. 208, $\S 2^{\circ}$ : “\$2 $2^{\circ}$ O não-oferecimento do ensino obrigatório pelo Poder Público, ou sua oferta irregular, importa responsabilidade da autoridade competente". Cf. BRASIL. [Constituição (1988)]. Constituição da República Federativa do Brasil de 1988. Brasília, DF: Presidência da República, 1988. Disponível em: http://www.planalto.gov.br/ccivil_03/constituicao/constituicaocompilado.htm. Acesso em: 18 fev. 2019. 
Esquema 1 - Níveis escolares

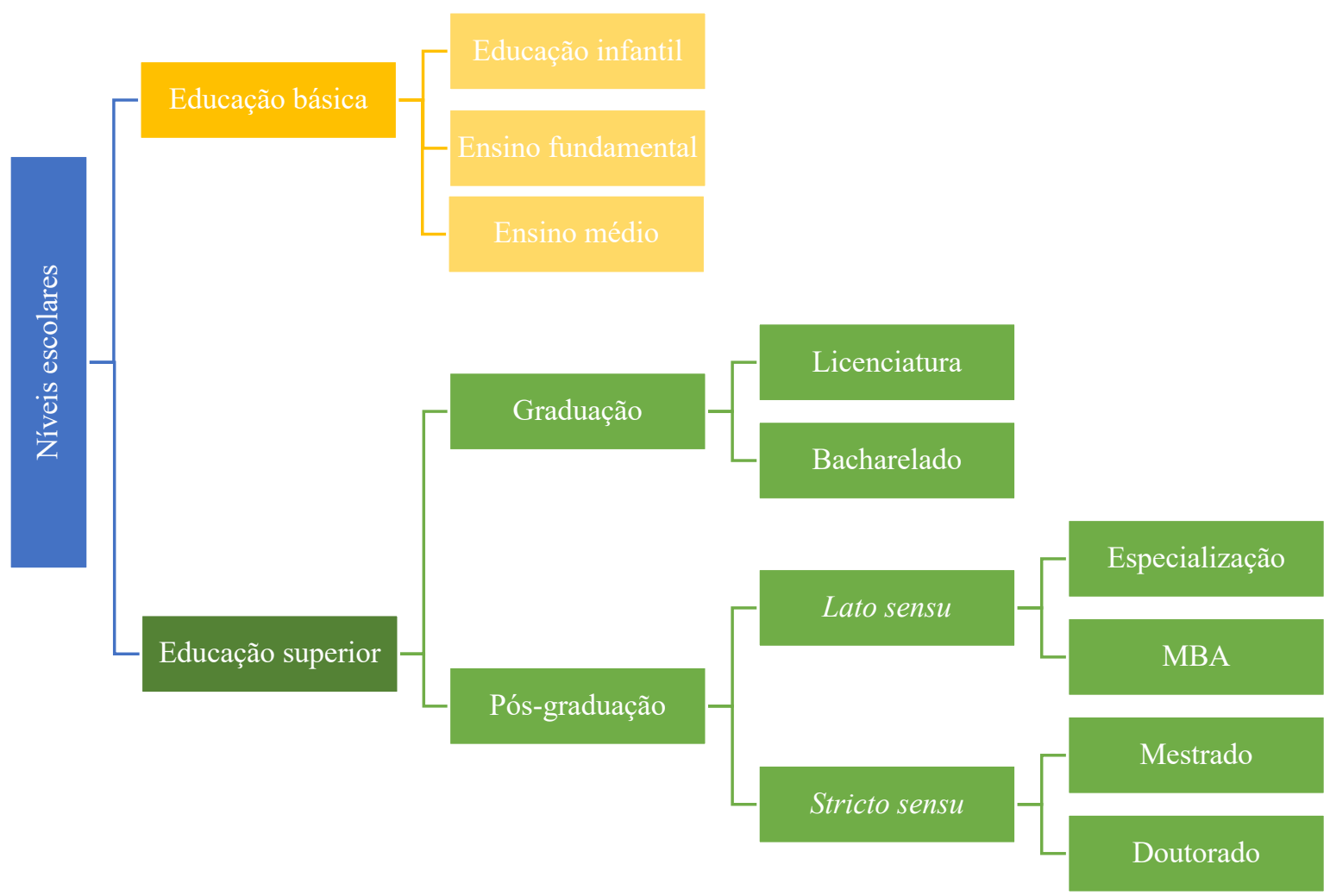

Fonte: Elaboração própria.

Visando sistematizar a educação nacional, foram idealizados sistemas públicos federativos destinados à organização educacional, tendo a Constituição atribuído distintas competências para os níveis. Cada um dos sistemas possui autorização constitucional para prestar serviços educacionais de quaisquer dos níveis educacionais; no entanto, o texto constitucional é expresso em atribuir prioridades de atuação para cada sistema.

Neste modelo, a partir da ênfase à competência genérica comum, dá-se a indicação dos níveis de atuação prioritária, mas não exclusiva, para cada esfera de governo, à exceção do federal, o que reclama e evidencia a necessidade de organização dos respectivos sistemas em regime de colaboração, especialmente enfatizado com referência ao ensino obrigatório. Assim, compete aos municípios atuar prioritariamente no ensino fundamental e na educação infantil, aos estados e Distrito Federal no ensino fundamental e médio, e à União atuar supletivamente para garantir a equalização de oportunidades educacionais e padrão mínimo de qualidade de ensino, mediante assistência técnica e financeira aos estados, Distrito Federal e municípios, em todos os níveis de ensino (art. $\left.211, \S 1^{\circ}, \mathrm{CF} / 88\right)^{74}$.

74 RANIERI, Nina Beatriz Stocco. Os Estados e o direito à educação na Constituição de 1988: comentários acerca da jurisprudência do Supremo Tribunal Federal. In: RANIERI, Nina Beatriz Stocco; RIGHETTI, Sabine (org.). Direito à educação: aspectos constitucionais. São Paulo: Edusp, 2009. p. 42. 
É a legislação infraconstitucional que tecerá esses meandros inerentes aos diferentes sistemas educacionais, de acordo com o que se pode observar pelo preceituado nos artigos 16 e seguintes da $\operatorname{LDB}^{75}$.

Como forma de criar um sistema organizacional das atuações que devem ser desempenhadas pelos entes da Federação, com fulcro no artigo 211 da Constituição Federal, foram atribuídas diferentes competências materiais que devem ser incumbidas aos entes federativos. Assim, o sistema da educação pode ser desmembrado, com dedicação prioritária, embora não exclusiva, de acordo com o que se observa no Esquema 2.

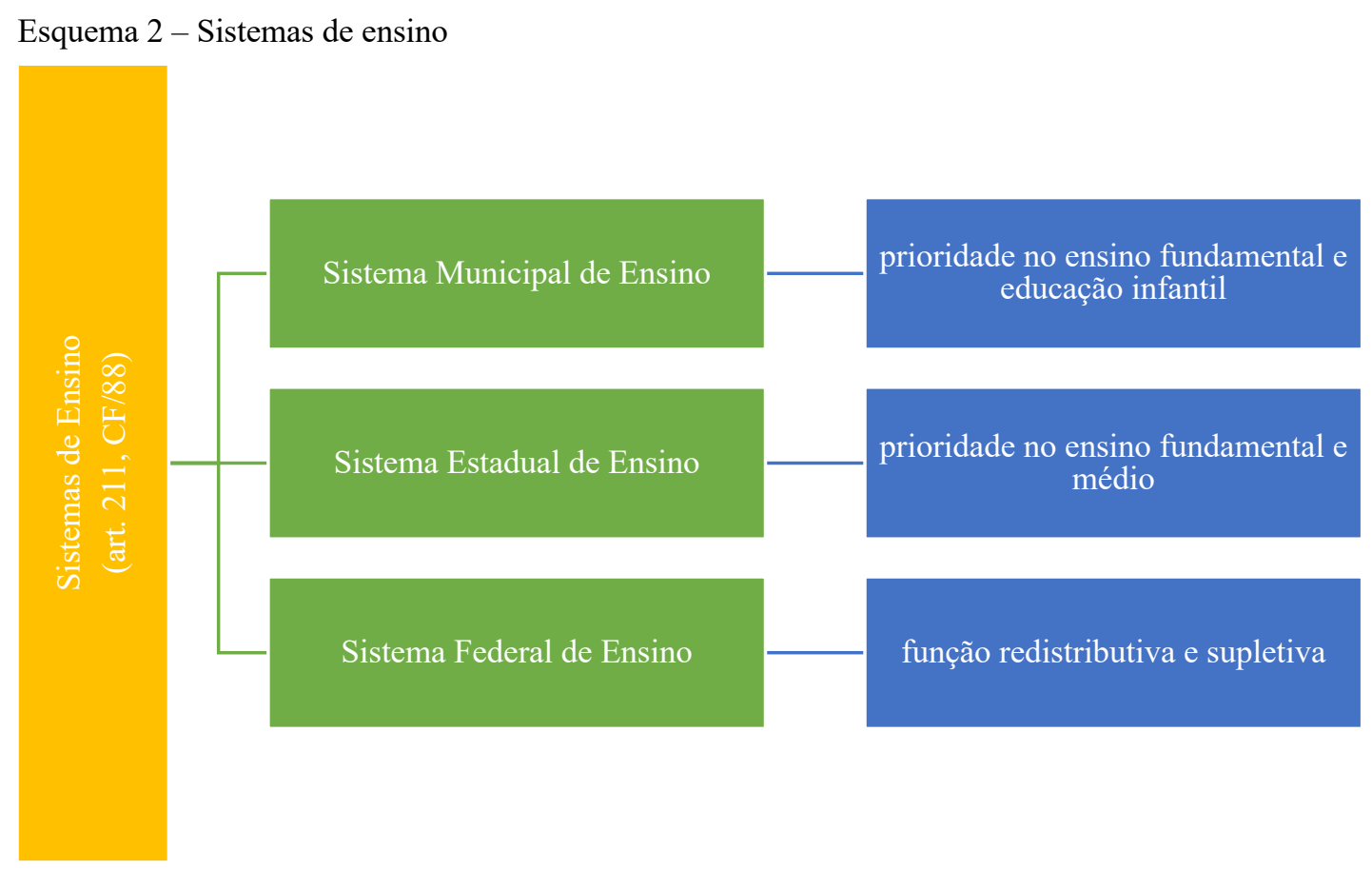

Fonte: Elaboração própria.

Como apontado pelo esquema, nem a Constituição Federal nem a LDB atribuíram expressamente a promoção da educação superior como prioridade de quaisquer dos sistemas de ensino idealizados, o que permite duas conclusões: a primeira, que quaisquer dos sistemas pode se dedicar à promoção da educação superior no Brasil; e, a segunda, que a União terá destaque na promoção da educação superior diante da sua função supletiva definida no $\S 1^{\circ}$, do artigo 211 da Constituição Federal.

Todavia, existem outras peculiaridades que nos permitem apontar o protagonismo da

75 BRASIL. Lei $n^{\circ}$ 9.394, de 20 de dezembro de 1996. Estabelece as diretrizes e bases da educação nacional. Brasília, DF: Presidência da República, 1996a. Disponível em:

http://www.planalto.gov.br/ccivil_03/leis/19394.htm. Acesso em: 5 fev. 2019. 
União nesse nível educacional, especialmente por três questões que chamam a atenção: a primeira, já mencionada anteriormente e ratificada pela LDB em seu artigo $8^{\circ}, \S 1^{\circ}$, ao incumbir à União o dever de coordenar a política nacional de educação; a segunda, ao definir que o sistema federal de ensino compreende as instituições de ensino mantidas pela União e as instituições de educação superior criadas e mantidas pela iniciativa privada, ou seja, a maioria absoluta das instituições de ensino superior em atividade no Brasil; e a terceira, em razão da atual vigência do Decreto $\mathrm{n}^{\circ}$ 9.235, de 15 de dezembro de 2017, editado pelo Poder Executivo Federal, o qual dispõe sobre o exercício das funções de regulação, supervisão e avaliação das instituições de educação superior e dos cursos superiores de graduação e de pós-graduação do sistema federal de ensino.

Como se todas essas atribuições não bastassem para o desenvolvimento da educação superior no Brasil, a LDB, em seu artigo $9^{\circ}$, atribuiu à União os deveres de baixar normas gerais sobre cursos de graduação e pós-graduação, assegurar processo nacional de avaliação das instituições de educação superior, com a cooperação dos sistemas que tiverem responsabilidade sobre este nível de ensino, e autorizar, reconhecer, credenciar, supervisionar e avaliar, respectivamente, os cursos das instituições de educação superior e os estabelecimentos do seu sistema de ensino.

Ainda sobre os deveres dos entes na promoção da educação superior, a LDB define em seu artigo 10 que os estados estarão incumbidos de organizar, manter e desenvolver os órgãos e instituições oficiais dos seus sistemas de ensino. Assim, o estado que detiver sob sua responsabilidade uma instituição de ensino superior também se dedica à promoção de educação nesse nível. Porém, seu compromisso com o ensino superior não acaba aí, haja vista que mais adiante a legislação atribuiu como seu o dever de autorizar, reconhecer, credenciar, supervisionar e avaliar, respectivamente, os cursos das instituições de educação superior e os estabelecimentos do seu sistema de ensino.

Somando-se à previsão do artigo 17, a LDB vai além ao definir que no sistema estadual de ensino também estão compreendidas as instituições de ensino mantidas pelo poder público estadual e pelo Distrito Federal e também as instituições de educação superior mantidas pelo poder público municipal. Importa dizer que não só os estados, mas também as municipalidades, detêm a prerrogativa de gerirem instituições de ensino superior em todo o Brasil, e que ditas instituições de ensino, caso existam, farão parte do sistema estadual de ensino.

Nesse sentido, sobre as competências firmadas pela Constituição e pela lei sobre o dever público para a promoção da educação superior, vale apresentar o seguinte quadro resumo (Quadro 1): 
Quadro 1 - Competências de cada sistema de ensino

Sistema Federal de Ensino
- Organizar a Política
Nacional de Educação
- Organizar, manter e
desenvolver (gestão) das IES
Federais
- IES Particulares
- Normas gerais para
graduação e pós-graduação
(de quaisquer dos sistemas)
- Garantir processo nacional
de avaliação de todas as IES
(de quaisquer dos sistemas)
com a cooperação dos
demais sistemas
- Autorizar, reconhecer,
credenciar, supervisionar os
cursos das IES do seu
sistema
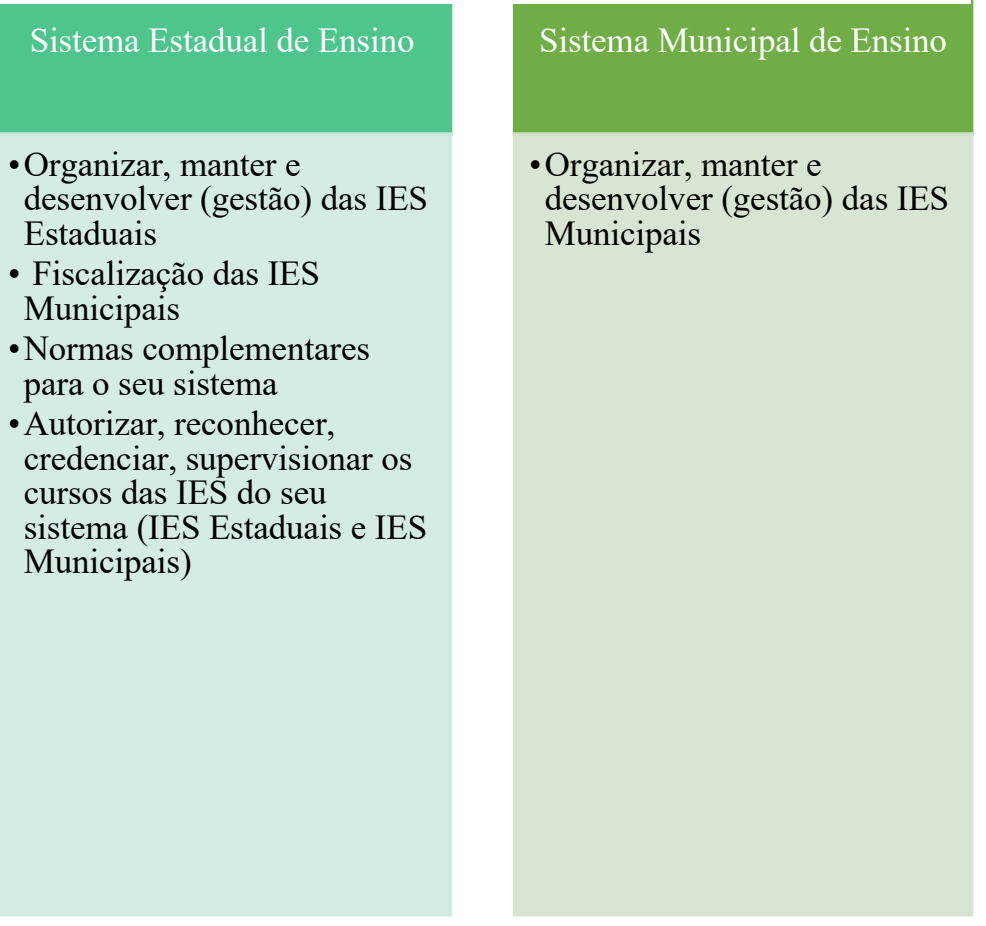

Fonte: Elaboração própria.

É possível observar que, além do sistema federal de ensino, o sistema estadual também se dedica à manutenção da qualidade das IES que thes são afetas. Estamos diante de uma duplicidade de sistemas responsáveis pela apuração da qualidade do nível superior educacional, sem olvidar, entretanto, que à União foi incumbido o dever de assegurar processo nacional de avaliação das instituições de educação superior, com a cooperação dos sistemas que tiverem responsabilidade sobre este nível de ensino, nos termos do artigo $9^{\circ}$, inciso VIII da LDB, razão pela qual todas as instituições de ensino superior brasileiras deveriam, em regra, submeter-se aos processos de avaliação pública, que serão oportunamente analisados.

Efetivamente será comprovado adiante que essa complexidade do sistema abre margem para que significativa parcela das instituições de educação superior em atividade no Brasil justifiquem a desnecessidade de submissão aos procedimentos públicos de avaliação da qualidade do serviço que prestam, o que de per si já caracterizaria uma grande ingerência do sistema educacional, que será demonstrado adiante em tópico próprio.

Ainda na temática das competências públicas para a promoção da educação no Brasil, é possível constatar que a Constituição Federal se preocupa de forma tão veemente com a educação nacional que fora estabelecida previsão constitucional determinando a vinculação de receita tributária para compelir o agente público a se empenhar com a promoção desse 
importante direito social.

Há que se ter atenção com essa temática, visto que todos os direitos possuem custos, e deveria ser papel do Estado, ao menos, definir quem arcaria com tais despesas. Sobre o custo dos direitos, Stephen Holmes e Cass Sunstein ${ }^{76}$ enfatizam que tal temática gera uma série de questionamentos adicionais, não apenas sobre o quanto custam realmente esses direitos, mas também sobre quem decide e como alocar os escassos recursos públicos para a proteção de quais direitos, para quem eles se destinarão, quais princípios são comumente invocados para orientar essas alocações e se esses princípios podem ser defendidos.

A simples percepção de que os direitos têm custos aponta o caminho para uma apreciação da inevitabilidade do governo e das várias atribuições que ele deve se incumbir, muitas das quais o senso comum sequer nota o envolvimento do Estado na promoção desses direitos.

A atenção aos custos públicos dos direitos individuais pode lançar nova luz sobre questões antigas, como as dimensões apropriadas do Estado de Bem-Estar Social e a relação entre o governo moderno e os direitos liberais clássicos. As decisões sobre as políticas públicas que serão efetivadas não devem ser tomadas com base em alguma hostilidade imaginária entre a liberdade e a arrecadação de impostos, pois se essas duas concepções fossem genuinamente contraditórias, todas as nossas liberdades básicas seriam candidatas à abolição.

Assim, direitos não podem ser protegidos nem promovidos sem fomento ou financiamento público, e não poderia ser diferente com a educação. Para assegurar verba pública destinada à promoção da educação nacional brasileira, o artigo 212 da Constituição Federal assegura a destinação mínima em percentuais de verbas públicas que devem ser aplicadas à educação nas seguintes frações: a União deve aplicar anualmente nunca menos de $18 \%$ da receita resultante de impostos, e os estados, o Distrito Federal e os municípios, 25\% no mínimo, incluindo-se nesse patamar receitas provenientes de transferências.

No que atine ao financiamento educacional, também é importante mencionar que o

76 "Attention to the cost of rights raises a flurry of additional questions, not just about how much various rights actually cost, but also about who decides how to allocate our scarce public resources for the protection of which rights, and for whom. What principles are commonly invoked to guide these allocations? and can those principles be defended? The simple insight that rights have costs points the way toward an appreciation of the inevitability of government and of the various good things that government does, many of which are taken so much for granted that, to the casual observer, they do not appear to involve government at all. Attention to the public costs of individual rights can shed new light upon old questions such as the appropriate dimensions of the regulatory welfare state and the relationship between modern government and classical liberal rights. Public policy decisions should not be made on the basis of some imaginary hostility between freedom and the tax collector, for if these two were genuinely at odds, all of our basic liberties would be candidates for abolition." Cf. SUNSTEIN, Cass; HOLMES, Stephen. The cost of rights: why liberty depends on taxes. Nova York: W.W. Norton \& Company, 1999. p. 31. 
artigo $213^{77}$ da Constituição Federal preceitua que os recursos públicos serão destinados preferencialmente às escolas públicas, podendo, todavia, ser dirigidos a escolas comunitárias, confessionais ou filantrópicas, em caráter de fomento, definidas em lei, que comprovem finalidade não lucrativa, apliquem seus excedentes financeiros em educação e assegurem a destinação de seu patrimônio a outra escola comunitária, filantrópica ou confessional, ou ao poder público, no caso de encerramento de suas atividades.

Os recursos mencionados poderão ser destinados a bolsas de estudo para o ensino fundamental e médio, na forma da lei, aos que demonstrarem insuficiência de recursos, quando houver insuficiência de vagas e de cursos regulares da rede pública na localidade da residência do educando, ficando o poder público obrigado a investir prioritariamente na expansão de sua rede na localidade.

Além disso, é oportuno destacar que a Constituição determina que as atividades de pesquisa, de extensão e de estímulo e fomento à inovação realizadas por universidades ou por instituições de educação profisssional e tecnológica também poderão receber apoio financeiro do poder público.

\begin{abstract}
No que se refere à Educação, a CF/1988 criou um fundo de destinação específica que constitui, portanto, uma despesa obrigatória. Em suma prevê:

a. Desde que outorgada, um percentual mínimo calculado sobre a receita auferida com impostos a ser aplicado na "manutenção e desenvolvimento do ensino". Esse percentual - de aplicação mínima - é prefixado em $18 \%$ para a União e $25 \%$ para Estados, o Distrito Federal e os Municípios;

b. A partir da EC 14/1996, a criação de um fundo de destinação específica (Fundo de Desenvolvimento do Ensino Fundamental - FUNDEF) que, com a EC 53/2007, foi substituído pelo FUNDEB (Fundo de Desenvolvimento da Educação Básica). Em ambos os casos, as leis instituidoras identificam, expressamente, as despesas de custeio obrigatório por meio dos recursos neles constantes. É o que alguns denominam financiamento público protegido, como lembra Paulo Sena, tomando como exemplo exatamente o setor educacional ${ }^{78}$.
\end{abstract}

Diante do compromisso constitucionalmente firmado, resta evidente que o Estado pode não ser um agente exclusivo na promoção da educação nacional brasileira; todavia, é

77 Art. 213: “Os recursos públicos serão destinados às escolas públicas, podendo ser dirigidos a escolas comunitárias, confessionais ou filantrópicas, definidas em lei, que:

I - comprovem finalidade não-lucrativa e apliquem seus excedentes financeiros em educação;

II - assegurem a destinação de seu patrimônio a outra escola comunitária, filantrópica ou confessional, ou ao Poder Público, no caso de encerramento de suas atividades". Cf. BRASIL. [Constituição (1988)].

Constituição da República Federativa do Brasil de 1988. Brasília, DF: Presidência da República, 1988.

Disponível em: http://www.planalto.gov.br/ccivil_03/constituicao/constituicaocompilado.htm. Acesso em: 18 fev. 2019.

78 DE GIOIA, Fulvia Helena. Tributação e custeio da educação pública. Curitiba: Juruá Editora, 2018. p. 93. Para aprofundamento da temática do financiamento público da educação brasileira, sugere-se leitura da obra citada. 
preciso reconhecer que a Constituição não se olvidou em assumir que parcela do financiamento inerente à prestação desses serviços deveria ter origem em receita pública.

Seguindo na temática das previsões constitucionais para a promoção da educação superior, o artigo $214^{79}$ da Constituição Federal determinou que o poder público deveria idealizar a implementação de um Plano Nacional de Educação, a ser criado por lei para definir metas que deveriam ter vigência durante 10 (dez) anos e com o objetivo de articular a atuação do Sistema Nacional de Educação. Portanto, trata-se da implementação de uma política de Estado, e não um programa restrito a um governo.

Assim, independentemente de ideologias político-partidárias dos governos que estejam a frente dos mandatos, haverá uma política pública de metas específicas que devem ser cumpridas para o desenvolvimento da nação, respeitando a Constituição e indo além de possíveis interesses políticos ou ideológicos.

O primeiro PNE foi implementado pela Lei $\mathrm{n}^{\mathrm{o}} 10.172$, de 09 de janeiro de 2001, durante o mandato do governo do Fernando Henrique Cardoso. Poucos avanços foram alcançados, o que foi atribuído ao pouco controle social da implementação da lei, da ínfima participação da sociedade civil na sua elaboração e por conta dos vetos do então presidente, mantidos pelo governo que lhe sucedeu. Tal legislação vigeu nos anos de 2001 a 2010.

Diante da baixa adesão social e dos próprios educadores ao anterior PNE, em março de 2010 foi realizada a I Conferência Nacional da Educação (Conae), com o objetivo de efetuar uma avaliação das conquistas do PNE e idealizar um projeto de lei do que viria a ser implementado como novo plano de ação. A Conae aprovou um documento que deveria apoiar a construção do segundo plano.

79 Art. 214: “A lei estabelecerá o plano nacional de educação, de duração decenal, com o objetivo de articular o sistema nacional de educação em regime de colaboração e definir diretrizes, objetivos, metas e estratégias de implementação para assegurar a manutenção e desenvolvimento do ensino em seus diversos níveis, etapas e modalidades por meio de ações integradas dos poderes públicos das diferentes esferas federativas que conduzam a:

I - erradicação do analfabetismo;

II - universalização do atendimento escolar;

III - melhoria da qualidade do ensino;

IV - formação para o trabalho;

V - promoção humanística, científica e tecnológica do País.

VI - estabelecimento de meta de aplicação de recursos públicos em educação como proporção do produto interno bruto". Cf. BRASIL. [Constituição (1988)]. Constituição da República Federativa do Brasil de 1988. Brasília, DF: Presidência da República, 1988. Disponível em:

http://www.planalto.gov.br/ccivil_03/constituicao/constituicaocompilado.htm. Acesso em: 18 fev. 2019. 
No final do mesmo ano, o Poder Executivo apresentou um projeto de $1 \mathrm{ei}^{80}$ ao Congresso do que viria a ser o novo PNE. Esse cenário já era muito diferente do passado, visto que a democracia e a participação social já haviam adquirido uma consciência significativa do seu papel.

$\mathrm{O}$ referido projeto de lei recebeu inúmeras críticas $^{81}$ naquele contexto e os questionamentos ganharam força e relevância a ponto de ser postergada a implementação do novo PNE, levando em conta, principalmente, que o texto não respeitava as deliberações entregues ao Poder Executivo efetuadas por ocasião da Conae.

Ao todo, mais de 2.900 emendas foram efetuadas no projeto inicial do executivo, comprovando o interesse nacional pela implementação de uma política pública que respeitasse os interesses dos mais diversos setores. Após quatro anos e intensos debates sobre seu conteúdo, em 25 de junho de 2014, a então presidente Dilma Rousseff sancionou o vigente PNE pela Lei $\mathrm{n}^{\mathrm{o}} 13.005$, sem efetuar nenhum veto.

Nesse novo texto legislativo sobre as metas idealizadas para o desenvolvimento da educação nacional brasileira, o artigo $13^{82}$ definiu expressamente que, após dois anos da implementação dessa lei, deveria ser instituído por meio de lei o Sistema Nacional da Educação, o qual deveria conter expressa definição das atribuições e competências dos entes da Federação para a sua contribuição ao regime de colaboração na promoção da educação nacional.

Essa lei deveria ter sido implementada em 2016, porém até o momento não foi promulgada. Desde 2014, alguns projetos de lei foram propostos buscando a regulamentação desse artigo e a consequente sistematização da educação brasileira, embora sem sucesso. Tais propostas foram arquivadas nos termos do artigo 105 do Regimento Interno da Câmara dos Deputados, ou seja, ao final da legislatura, foram suspensas todas as proposições submetidas à

80 BRASIL. Congresso. Câmara dos Deputados. Projeto de Lei $n^{\circ}$ 8.035, de 20 de dezembro de 2010. Aprova o Plano Nacional de Educação para o decênio 2011-2020 e dá outras providências. Brasília, DF: Câmara dos Deputados, 2010. Disponível em: https://www.camara.leg.br/proposicoesWeb/fichadetramitacao?idProposicao=490116. Acesso em: 20 fev. 2019.

81 BORGES, Priscilla. Avaliação das 20 metas do Plano N. de Educação. São Paulo: CRE Mario Covas, 2020. Disponível em: http://www.crmariocovas.sp.gov.br/noticia.php?it=14821. Acesso em: 30 maio 2020. CIEGLINSKI, Amanda. Entidades pedem divulgação rápida do novo Plano Nacional de Educação. Uol Notícias, Brasília, DF, 8 dez. 2010. Disponível em: https:/educacao.uol.com.br/noticias/2010/12/08/entidades-pedem-divulgacao-rapida-do-novo-planonacional-de-educacao.htm. Acesso em: 30 maio 2019.

CARRIEL, Paola. Atraso compromete metas do Plano de Educação. Gazeta do Povo, Brasília, DF, 14 dez. 2010. Disponível em: https://www.gazetadopovo.com.br/vida-e-cidadania/atraso-compromete-metas-doplano-de-educacao-1d5om9j8d1x9rku2uol862fym/. Acesso em: 30 maio 2019.

82 Lei no 13.005/2014, art. 13: "O poder público deverá instituir, em lei específica, contados 2 (dois) anos da publicação desta Lei, o Sistema Nacional de Educação, responsável pela articulação entre os sistemas de ensino, em regime de colaboração, para efetivação das diretrizes, metas e estratégias do Plano Nacional de Educação". 
deliberação da Câmara ou que ainda estavam em tramitação, bem como as que abriam crédito suplementar, com pareceres ou sem eles.

A deputada Dorinha Seabra Rezende propôs um projeto de lei complementar ${ }^{83}$, com o objetivo de conseguir finalmente institucionalizar esse Sistema Nacional da Educação, o qual já fora apensado a outro, proposto pelo deputado Pedro Cunha Lima, com mesmo objetivo ${ }^{84}$. Ambos estão na Comissão de Educação para análise e emissão de parecer.

Porém, independentemente da sistematização legislativa da educação nacional, já existe, na prática, um sistema de educação plenamente em atuação no cenário nacional, o que é correto afirmar com a mera análise do regramento constitucional e infraconstitucional que o legislador atribuiu para a organização administrativa da educação brasileira apresentados alhures.

Ainda que existam posicionamentos contrários, a análise das leis e demais espécies normativas que já estão efetivamente vigentes no país sobre a temática nos permite concluir que, independentemente da promulgação de um sistema nacional nos termos do que foi estabelecido pelo PNE, esse sistema já existe. Contudo, reconhece-se que há uma falta de alinhamento entre os atores desses sistemas diante da complexidade estrutural da educação que foi idealizada para um país de dimensões continentais como é o caso do Brasil. Por isso, não é exagero concluir que esse país possui um dos mais complexos sistemas educacionais em atividade no cenário mundial.

Diante do regramento constitucional apresentado, idealizado para atribuir competências na promoção da educação nacional brasileira, temos um patamar mínimo de direitos previstos pelo constituinte visando a efetivação desse importante direito social. Demonstrou-se, portanto, que esse piso mínimo constitucional atribuiu competências para os diferentes entes da Federação na consecução dos objetivos educacionais. Todavia, não se deve esquecer que a legislação infraconstitucional tece outros esclarecimentos e atribui competências

83 BRASIL. Congresso. Câmara dos Deputados. Projeto de Lei Complementar $n^{\circ}$ 25/2019, de 13 de fevereiro de 2019. Institui o Sistema Nacional de Educação (SNE), fixando normas para a cooperação entre a União, os Estados, o Distrito Federal e os Municípios nas políticas, programas e ações educacionais, em regime de colaboração, nos termos do inciso $\mathrm{V}$ do caput e do parágrafo único do art. 23, do art. 211 e do art. 214 da Constituição Federal. Brasília, DF: Câmara dos Deputados, 2019a. Disponível em: https://www.camara.leg.br/proposicoesWeb/prop_mostrarintegra;jsessionid=28D160B67BA956215C07AC9 3A67BD795. proposicoesWebExterno2? codteor $=1712345 \&$ filename=Avulso+-PLP+25/2019. Acesso em: 26 fev. 2019.

84 BRASIL. Congresso. Câmara dos Deputados. Projeto de Lei Complementar $n^{\circ}$ 47/2019, de 26 de fevereiro de 2019. Dispõe sobre instrumento de cooperação federativa para transferência à União de competências educacionais de Estados, Distrito Federal e Municípios. Brasília, DF: Câmara dos Deputados, $2019 \mathrm{~b}$. Disponível em: https://www.camara.leg.br/proposicoesWeb/fichadetramitacao?idProposicao=2193198. Acesso em: 26 fev. 2019. 
legislativas e materiais para a promoção da educação brasileira.

A proteção constitucional prevista visa a concretização do dever do Estado com a promoção da educação, que pode ser efetivada por meio da promulgação de leis dentro do exercício legislativo de cada ente federativo, ou também por meio da prestação do serviço público educacional, praticado pelo ente público ou pelo setor privado. Assim, diante da sua importância para a concretização de interesses públicos, o serviço educacional, mesmo quando prestado pelo setor privado, deve submeter-se às regras inerentes ao regime jurídico de direito público.

Em razão dessa importância para a sociedade e do interesse público na promoção da educação superior é que serão apresentadas as características e os desdobramentos inerentes à implementação do serviço educacional no cenário brasileiro, para melhor compreensão de como ele é efetivamente entregue à sociedade.

\subsection{Serviço público educacional em nível superior e autorização à livre iniciativa: organização acadêmica e administrativa dos cursos de Direito no Brasil}

Definir o serviço público não é uma das tarefas mais simples, pois além de envolver compreensões de toda natureza, a doutrina não é uníssona e alguns partem de pressupostos diferentes sobre essa importante atividade desempenhada pela administração pública para a consecução de seus fins. Assim, a definição aqui apresentada é pautada em uma objetiva compreensão do que deve ser entregue à sociedade pelo Estado ou, ao menos, mediante sua fiscalização.

O serviço público é a atividade material que o Estado reconhece não poder ser simplesmente relegada à livre iniciativa diante de sua importância para a sociedade. Sempre será oferecido à população, passível de ser por ela usufruída individualmente, prestado diretamente pela administração pública, ou com o apoio do particular, ou diante de autorização para que o particular preste esse serviço diretamente, por sua conta e risco, sujeitando-se ao controle público.

Pode o Estado prestar o referido serviço por si mesmo ou por quem lhe faça as vezes, desde que sob as regras do regime de Direito Público, instituído em favor dos interesses definidos como públicos no sistema normativo. Nas palavras de Celso Antônio Bandeira de Mello, 
Serviços Públicos [são as] atividades materiais que o Estado, inadmitindo que possam ficar simplesmente relegadas à livre iniciativa, assume como próprias, por considerar de seu dever de prestá-las ou patrocinar-lhes a prestação, a fim de satisfazer necessidades ou comodidades do todo social, reputadas como fundamentais em dado tempo e lugar. Por esta mesma razão as submete a uma disciplina jurídica específica, preordenada a garantir proteção aos interesses coletivos nelas encarnados, de sorte a facilitar-lhes a viabilização, assim como defende-las não apenas contra terceiros ou contra as pessoas que ele próprio haja habilitado a prestá-los, mas também contra omissões ou desvirtuamentos em que o próprio Estado possa incorrer ao propósito $\operatorname{delas}^{85}$.

Léon Duguit, publicista que capitaneou a chamada Escola do Serviço Público ${ }^{86}$, define a noção de serviço público como toda atividade cujo cumprimento deva ser regulamentado, assegurado e controlado pelos governantes, porque o cumprimento dessa atividade é indispensável para a realização e o desenvolvimento da interdependência social, e porque, ademais, é de tal natureza que não pode ser completamente assegurada sem a intervenção da força governante ${ }^{87}$.

Dinorá Grotti assevera que caberá a cada povo dizer o que é serviço público de acordo com seu sistema jurídico próprio. "A qualificação de uma dada atividade como serviço público remete ao plano da concepção do Estado sobre seu papel. É o plano da escolha política, que pode estar fixada na Constituição do país, na lei, na jurisprudência e nos costumes vigentes em um dado tempo histórico" $" 88$.

O serviço público deve sempre estar adstrito à concepção de responder às finalidades e aos objetivos que o Estado deve perseguir. Para a Constituição Federal brasileira, são objetivos fundamentais da República a construção de uma sociedade livre, justa e solidária, a garantia do desenvolvimento nacional, a erradicação da pobreza e a marginalização e a redução das desigualdades sociais e regionais, bem como a promoção do bem de todos, sem

85 MELLO, Celso Antônio Bandeira de. Curso de direito administrativo. 27. ed. refund. ampl. e atual. São Paulo: Malheiros, 2010. p. 667.

86 Ibid., p. 671: 'Da 'Escola do Serviço Público' advém a noção de que o serviço público apareceu como fórmula revolucionadora do Direito Público em geral e do Direito Administrativo em particular, intentando fazer substituir o eixo metodológico desta disciplina - que antes se constituía sobre a ideia de 'poder' estatal - pela ideia de serviços aos administrados".

87 "Así aparece claramente determinada la noción de servicio publico: toda actividad cuyo cumplimiento debe ser regulado, assegurado y controlado por los governantes, porque el cumplimiento de esta actividad es indispensable para la realización y el desenvolvimiento de la interdependência social, y porque, además, es de tal naturaliza que no puede ser completamente assegurada sino mediante la intervención de la fuerza governante." Cf. DUGUIT, Léon. Manual de derecho constitucional: teoría general del Estado, el derecho y el estado, las libertades públicas y organización política. Madrid: Francisco Beltrán, 1926. p. 73.

88 GROTTI, Dinorá Adelaide Musetti. O serviço público e a Constituição brasileira de 1988. São Paulo: Malheiros, 2003. p. 87. 
preconceitos de origem, raça, sexo, cor, idade e quaisquer outras formas de discriminação ${ }^{89}$. Buscando a consolidação desses valores é que se tem por finalidade estatal a incessante busca pelo bem comum $^{90}$.

[...] o ente estatal deve ser encarado como uma nação politicamente organizada, dotado de personalidade jurídica própria, sendo pessoa jurídica de direito público interno [...]. Para os autores finalistas, o Estado democrático tem como finalidade social a concretização e busca incessante do bem comum ${ }^{91}$.

Duguit aduz que, ao considerar as atuais sociedades civilizadas, fica relativamente fácil enumerar as diversas atividades que servem de fundamento como serviços públicos. Não nos parece inútil observar, desde logo, que o caráter de serviço público não implica no monopólio em proveito dos governantes e seus agentes e de certas atividades; ainda que possam ser livremente exercitadas pelos particulares, são objeto de serviços públicos quando e nos limites em que os governantes e seus agentes as exercitem por sua vez. A educação e a assistência social são dois exemplos bem patentes disso ${ }^{92}$.

Para o referido autor, a noção de serviço público pode ser feita nos seguintes termos:

89 Art. 30: "Constituem objetivos fundamentais da República Federativa do Brasil:

I - construir uma sociedade livre, justa e solidária;

II - garantir o desenvolvimento nacional;

III - erradicar a pobreza e a marginalização e reduzir as desigualdades sociais e regionais;

IV - promover o bem de todos, sem preconceitos de origem, raça, sexo, cor, idade e quaisquer outras formas de discriminação". Cf. BRASIL. [Constituição (1988)]. Constituição da República Federativa do Brasil de 1988. Brasília, DF: Presidência da República, 1988. Disponível em:

http://www.planalto.gov.br/ccivil_03/constituicao/constituicaocompilado.htm. Acesso em: 18 fev. 2019.

90 “...] finalistas, por sustentarem que há uma finalidade social, livremente escolhida pelo homem. [...] O homem tem consciência de que deve viver em sociedade e procura fixar, como objetivo da vida social, uma finalidade condizente com suas necessidades fundamentais e com aquilo que lhe parece ser mais valioso. [...] Essa finalidade deverá ser algo, um valor, um bem, que todos considerem como tal, daí a primeira conclusão de que a finalidade social é o bem comum. [...] Verifica-se que o Estado, como sociedade política, tem um fim geral, constituindo-se em meio para que os indivíduos e as demais sociedades possam atingir seus respectivos fins particulares. Assim, pois, pode-se concluir que o fim do Estado é o bem comum. [...] $\mathrm{Na}$ verdade existe uma diferença fundamental, que qualifica a finalidade do Estado: este busca o bem comum de um certo povo, situado em determinado território. Assim, pois, o desenvolvimento integral da personalidade dos integrantes desse povo é que deve ser o seu objetivo, o que determina uma concepção particular de bem comum para cada Estado, em função das peculiaridades de cada povo." Cf. DALLARI, Dalmo de Abreu. Elementos de teoria geral do Estado. 26. ed. São Paulo: Saraiva, 2007. p. 23 e 108.

91 PUERTA DOS SANTOS, Larissa Dias. A instrumentalização jurídica da gestão pública brasileira e os mecanismos para a reforma da organização administrativa. 2016. 162 f. Dissertação (Mestrado) - Programa de Pós-Graduação em Direito Político e Econômico, Universidade Presbiteriana Mackenzie, São Paulo, 2017. p. 33.

92 "Si se consideran y examinan las actuales sociedades civilizadas, resulta relativamente fácil enumerar las diversas atividades que sirven de fundamento a los servicios públicos. No nos parece inútil hacer observar, desde luego, que el caracter de servicio público no implica su monopólio em provecho de los governantes y de sus agentes, y que ciertas atividades, aunque pueden ser libremente ejercitadas por los particulares, son objeto de servicios públicos en la medida y limites em que los governantes y sus agentes las ejercitan a su vez. La enseñanza y la beneficência son dos ejemplos bien patentes de lo que acabamos de decir." Cf. DUGUIT, Léon. Manual de derecho constitucional: teoría general del Estado, el derecho y el estado, las libertades públicas y organización política. Madrid: Francisco Beltrán, 1926. p. 74. 
toda atividade cujo cumprimento deve ser regulado, assegurado e fiscalizado pelos governantes, por ser indispensável à realização e ao desenvolvimento da interdependência social, e de tal natureza que não pode ser assegurado completamente a sua prestação a todos, exceto se houver a intervenção da força governante ${ }^{93}$.

A respeito do serviço público, é essencial considerar que, a depender do posicionamento ideológico de um governo sobre o papel do Estado na economia, será observado o aumento ou esvaziamento na prestação dos ditos serviços. Quanto mais liberal for o posicionamento de um governo, mais ele tenderá a se posicionar para que o Estado não tenha que se preocupar com outra coisa senão a segurança interna e externa do seu país ${ }^{94}$, devendo desinteressar-se de todo o resto e deixar que a liberdade e a concorrência entre os indivíduos assegurem a satisfação das demais necessidades sociais.

Os feitos observados nas sociedades economicamente desenvolvidas, porém, são muito mais arrojados do que esse reducionismo proposto pelos liberais. E a consciência social deseja outro posicionamento estatal, pois não se admite, por exemplo, que o Estado se omita do dever de prestar e de intervir nos serviços educacionais, sendo este considerado na sua essência como o serviço prestado, seja pelo ente público, seja pelo setor privado, em que há verdadeiro interesse público para a efetivação de sua qualidade.

Entretanto, é preciso retomar que o objetivo aqui não é o de tratar com aprofundamento as classificações e a conceituação do serviço público, o que por si só seria objeto de trabalho específico. A presente pesquisa, no entanto, visa o aprofundamento de questões atinentes ao serviço educacional entregue à sociedade brasileira na educação superior, sendo ela pública ou privada. Parte-se, dessa maneira, da concepção que a promoção da educação é o maior exemplo de serviço de natureza pública.

Diante do relato a respeito da importância da educação para a democracia, assim como a relevância desta para a efetivação da educação em sua mais pura acepção, temos que as normas constitucionais destinadas à promoção da educação nacional detêm o significado jurídico de alçar a educação à categoria de serviço público essencial, que ao poder público deve

93 "[...] la noción de servicio público parece que puede formularse de este modo: es toda actividad cuyo cumplimiento debe ser regulado, asegurado y fiscalizado por los governantes, por ser indispensable a la realización y al desenvolvimiento de la interdependencia social, y de tal naturaleza que no puede ser asegurado completamente más que por la intervención de la fuerza governante." Cf. DUGUIT, Leon. Las transformaciones del derecho público y privado. Buenos Aires: Editorial Heliasta, 1975. p. 37.

94 Ibid., p. 35: "Se ha hecho notar anteriormente que hay tres actividades cuyo cumplimiento se ha pedido a los gobernantes de todos los tiempos: la defensa de la colectividad y del territorio contra el enemigo del exterior, el mantenimiento de la seguridad, del orden y de la tranquilidad en el territorio y en el interior de la colectividad; elementos éstos constitutivos de los tres servicios públicos originarios: la guerra, la policía y la justicia". 
ser atribuído, impendendo-o o dever de assegurá-la a todos.

O dever imposto ao Estado para a prestação de serviços públicos de qualquer natureza se destina ao desenvolvimento econômico e social da sociedade e está previsto no artigo 175 da Constituição Federal, nos seguintes termos: “incumbe ao Poder Público, na forma da lei, diretamente ou sob regime de concessão ou permissão, sempre através de licitação, a prestação de serviços públicos" $"$.

É evidente que a educação exerce papel fundamental para a consecução dos mencionados objetivos da República Federativa do Brasil ${ }^{96}$, razão pela qual o Estado Nacional possuirá dever de efetivar tal direito na sociedade brasileira por meio da prestação direta desses serviços públicos essenciais, ou mediante apoio do setor privado, ou ainda, como previsto pela própria Constituição Federal, autorizar que a iniciativa privada preste esse serviço diretamente mediante intensa e constante fiscalização do poder público.

Nesse ponto, cabe levantar duas importantes classificações que a doutrina administrativista costuma fazer a respeito das espécies de serviços públicos previstos na Constituição Federal de 1988.

Aventada por Celso Antônio Bandeira de $\mathrm{Mello}^{97}$, essa classificação tem relação com o tratamento dado ao serviço público pela Constituição, distinguindo-o da seguinte forma: (i) serviços de prestação obrigatória e exclusiva do Estado; (ii) serviços de prestação obrigatória do Estado e em que é também obrigatório outorgar em concessão a terceiros; (iii) serviços de prestação obrigatória pelo Estado, mas sem exclusividade; (iv) e serviços de prestação não obrigatória pelo Estado, mas não os prestando há obrigação de que ele promova a prestação, tendo, pois, que outorgá-los em concessão ou permissão a terceiros.

Segundo essa classificação, é possível inserir a prestação do serviço público educacional como uma espécie de serviço que o Estado tem a obrigação de prestar ainda que sem exclusividade, pois embora seja um serviço público, ele não é privativo do Estado diante da constitucional autorização de exploração dessa atividade pela livre iniciativa privada. Em outros termos, o Estado, quando presta o serviço educacional, está sob o manto do regime de direito público, porém sem proibir a atividade do particular nesse setor, sendo a eles lícita a prestação independentemente de concessão.

95 Art. 175 (grifos nossos). Cf. BRASIL. [Constituição (1988)]. Constituição da República Federativa do Brasil de 1988. Brasília, DF: Presidência da República, 1988. Disponível em:

http://www.planalto.gov.br/ccivil_03/constituicao/constituicaocompilado.htm. Acesso em: 18 fev. 2019.

96 Ibid., art. $3^{\circ}$.

97 MELLO, Celso Antônio Bandeira de. Curso de direito administrativo. 27. ed. refund. ampl. e atual. São Paulo: Malheiros, 2010. p. 688. 
Outra importante classificação foi apontada por Eros $\mathrm{Grau}^{98}$, que divide os serviços públicos entre os privativos que, se prestados pelo setor privado, só podem ser executados após concessão ou permissão de serviços públicos, e serviços públicos não privativos, que são, para o autor, educação e saúde, uma vez que os artigos 209 e 199 da Constituição os consideram livres à iniciativa privada, mas condicionam a liberdade a uma série de restrições, porque eles estão "submetidos a um tratamento normativo mais estrito do que o aplicável ao conjunto das atividades privadas. Assim, o poder público, dada a grande relevância social que tais serviços possuem, os disciplina com um rigor especial" ${ }^{\prime 99}$.

Para esclarecer a temática, Irene Patrícia Nohara ${ }^{100}$ nos aponta que a noção de serviços públicos acaba sendo variável em função do espaço, do tempo e principalmente do papel que a coletividade confere ao Estado. No seu posicionamento, só o ordenamento jurídico será capaz de atribuir a determinada categoria de atividade a qualificação jurídica de serviço público, submetendo-a total ou parcialmente ao regime jurídico de Direito Administrativo.

Logo, o legislador é quem erige as categorias de serviços públicos, conquanto obedeçam aos preceitos constitucionais. Segundo seu entendimento, as finalidades que fazem com que determinadas atividades sejam consideradas serviços públicos são: proteger setores delicados ou estratégicos da especulação privada; propiciar o benefício do serviço aos menos favorecidos (justiça social); suprir carências da iniciativa privada; favorecer o progresso técnico ou o desenvolvimento nacional; ordenar o aproveitamento de recursos finitos, como os hidroelétricos; e manter a unidade do país.

Destaque-se, novamente, que não há consenso na doutrina administrativista a respeito das classificações em torno do serviço público, e que especialmente o serviço educacional abre margem para uma série de debates acerca de critérios políticos e desdobramentos que ocorrem de acordo com a orientação do governo eleito para a gestão ${ }^{101}$.

De todo modo, existem pisos legais que devem ser respeitados a partir do momento em que estão vigentes, razão pela qual quando o serviço educacional é prestado diretamente pelo setor público, indubitavelmente se tratará de serviço essencialmente público de inegável titularidade pertencente à administração pública e, por esse motivo, sujeito ao regime jurídico

98 GRAU, Eros Roberto. A ordem econômica na Constituição de 1988. São Paulo: Malheiros, 2006. p. 93.

99 MELlO, Celso Antônio Bandeira de. Curso de direito administrativo. São Paulo: Malheiros, 2008. p. 676.

100 NOHARA, Irene Patrícia. Direito administrativo. 8. ed. Rio de Janeiro: Atlas, 2018. p. 473.

101 Ibid., p. 475: “[...] 'cada povo diz o que é serviço público em seu sistema jurídico'. Trata-se, pois, de escolha política de cada nação fixar em seu ordenamento jurídico dada atividade como serviço público, a depender da concepção que se tenha sobre o papel do Estado. Essa concepção é variável não apenas no espaço, mas também no tempo, a depender da maior ou menor propensão de uma economia a resistir ou a incorporar medidas liberalizantes". 
de direito público.

Outrossim, quando prestado pelo setor privado diante da autorização constitucional expressa de que a livre iniciativa possui a prerrogativa de atuação nesse setor social, ainda que a titularidade do serviço seja da pessoa jurídica de direito privado que atua no ramo da prestação da atividade educacional, essa atividade não perde a característica de serviço público diante da sua importância para a consolidação da finalidade estatal.

Portanto, além de sujeitar-se ao regime de direito privado, diante da natureza do titular da prestação, também se sujeita ao regime de direito público e ao poder de polícia da administração pública do sistema educacional ao qual a instituição de ensino deve estar vinculada e, portanto, passível de fiscalização pública e de intervenção em razão de má prestação.

Logo, quando a educação é prestada pelo setor público, estamos de modo indiscutível diante de um serviço essencialmente público, posto que prestado pela própria administração pública. A celeuma reside quando esse serviço é prestado pelo setor privado. Para a abordagem desta pesquisa será adotada a compreensão de que tal atividade jamais perderá a natureza de serviço público diante de sua importância para o desenvolvimento de uma nação, ainda que sua titularidade não pertença ao setor público.

A sujeição das instituições de ensino privadas às específicas regras do setor educacional deve ser infinitamente mais rígida do que qualquer outra atividade econômica desempenhada pela livre iniciativa. Além disso, a inciativa privada, quando atuar nesse ramo, deve sujeitar-se à prerrogativa que a administração pública detém de determinar o encerramento das atividades diante do descumprimento de padrões de qualidade que serão por ela instituídos.

Independentemente da titularidade do prestador, o serviço educacional é um serviço essencialmente público em razão da sua natureza e do interesse público dos seus objetivos. Por isso, a iniciativa privada, quando atua nesse ramo como atividade econômica, deve estar ciente de sua sujeição ao regime que o setor público entender como adequado para a entrega de um serviço de boa qualidade.

Com a autorização constitucional da livre iniciativa na educação, o primeiro patamar de sujeição para a prestação do serviço educacional está previsto no artigo $7^{\circ}$ da Lei de 
Diretrizes e Bases da Educação Nacional ${ }^{102}$, que especificou algumas noções para a autorização da prestação do referido serviço por esse setor.

A iniciativa privada poderá prestar serviços educacionais desde que a prestadora do serviço educacional cumpra as normas gerais da educação nacional e do respectivo sistema de ensino, sujeite-se ao procedimento público para autorização do seu funcionamento, submeta-se à avaliação de qualidade pelo poder público e detenha capacidade de autofinanciamento.

Classifica-se, portanto, a educação como inserta no rol dos serviços públicos próprios, essenciais, por ser atividade destinada a satisfazer a coletividade em geral. Em razão de sua relevante atribuição e da importância para a efetiva concretização do bem comum, o Estado considera pertinente a prestação do referido serviço por ele próprio, ainda que o faça sem exclusividade, e em consequência e exatamente por isso, submete a prestação do serviço público educacional prestado, por quem quer que seja, ao regime jurídico de direito público.

Para adequadamente desempenhar os serviços educacionais no nível superior, justamente em virtude do interesse público que o Estado Nacional possui na prestação do dito serviço, a LDB se dedicou a definir a organização acadêmica e administrativa que essas instituições de ensino devem adotar.

Portanto, é preciso esclarecer a natureza jurídica das instituições de ensino, seja de direito público, seja de direito privado, que prestam serviços educacionais no nível superior à sociedade brasileira, oportunamente detalhando suas respectivas formas societárias com a consequente explicação a respeito da possibilidade ou não de auferir lucro com a referida atividade.

As pessoas jurídicas de direito público que prestam serviços educacionais na educação superior podem ser atreladas a qualquer um dos entes da República Federativa, importa dizer, a pessoa jurídica pode ser vinculada à União, aos estados, ao Distrito Federal e aos municípios. Quando um ente da federação opta por ser responsável por uma instituição de ensino superior, deverá fazê-lo sob a égide do regime de direito público, ou seja, sua criação deve ser previamente autorizada por lei e a forma societária terá natureza jurídica determinada por lei.

O Decreto-Lei $n^{0}$ 200/67 é o texto normativo responsável pela implementação da descentralização dos serviços públicos prestados pela administração pública, por meio da

\footnotetext{
102 Art. $7^{\circ}$ : "O ensino é livre à iniciativa privada, atendidas as seguintes condições:

I - cumprimento das normas gerais da educação nacional e do respectivo sistema de ensino;

II - autorização de funcionamento e avaliação de qualidade pelo Poder Público;

III - capacidade de autofinanciamento, ressalvado o previsto no art. 213 da Constituição Federal". Cf.

BRASIL. Lei $n^{\circ}$ 9.394, de 20 de dezembro de 1996. Estabelece as diretrizes e bases da educação nacional.

Brasília, DF: Presidência da República, 1996a. Disponível em:

http://www.planalto.gov.br/ccivil_03/leis/19394.htm. Acesso em: 5 fev. 2019.
} 
criação de pessoas jurídicas na administração indireta. Para corretamente descentralizar a prestação de serviços públicos, o poder público deve criar ou autorizar, por meio de lei, pessoas jurídicas de direito público ou privado, atribuindo-lhes a execução do serviço público.

Em consonância com a conceituação encontrada na referida legislação, para a adequada prestação de serviços educacionais, apenas autarquias e fundações podem ser criadas para essa finalidade. Quaisquer outras espécies de pessoa jurídica criadas com finalidade de prestação de serviços educacionais e fora dessas duas modalidades consistiriam na inadequada prestação do serviço público.

Complementando o mencionado preceito normativo e especificando a temática da prestação de serviços educacionais, a Lei $n^{\circ} 5.540 / 68$, quando foi editada, determinou que universidades e estabelecimentos de ensino oficiais seriam constituídos como autarquias em regime especial ou fundações de direito público ${ }^{103}$. Porém, é preciso destacar que referida lei foi revogada pela atual LDB e que não existe determinação expressa vigente estabelecendo a obrigatoriedade de aplicabilidade de específica natureza jurídica às instituições de ensino superior públicas, o que permite concluir que essa natureza jurídica deverá obedecer à regra geral da organização da administração pública estabelecida pelo Decreto-Lei no 200/67.

Autarquia é a pessoa jurídica da administração pública indireta capaz de desempenhar “o serviço autônomo, criado por lei, com personalidade jurídica, patrimônio e receita próprios, para executar atividades típicas da administração pública, que requeiram, para seu melhor funcionamento, gestão administrativa e financeira descentralizada" ${ }^{104}$, para prestar serviço público ou exercer outra atividade administrativa que implique poderes próprios do Estado.

São características das autarquias: criação por lei; personalidade e natureza jurídica públicas; capacidade de autoadministração; especialização dos fins ou das atividades; e sujeição ao controle de tutela. [...] Este tipo de descentralização envolve: reconhecimento da personalidade jurídica do ente descentralizado; existência de

${ }^{103}$ O texto dessa lei foi revogado em grande parte pela vigente LDB (Lei $\mathrm{n}^{\circ}$ 9.394/96), inclusive no que diz respeito à natureza jurídica das instituições de ensino superior públicas, porém, é importante trazer o texto do artigo que determinava tal natureza para esses prestadores de serviços: Lei n ${ }^{\circ}$ 5.540/68, art. 4": “As universidades e os estabelecimentos de ensino superior isolados constituir-se-ão, quando oficiais, em autarquias de regime especial ou em fundações de direito público e, quando particulares, sob a forma de fundações ou associações." Cf. BRASIL. Lei $n^{\circ}$ 5.540, de 28 de novembro de 1968. Fixa normas de organização e funcionamento do ensino superior e sua articulação com a escola média, e dá outras providências. Brasília, DF: Presidência da República, 1968. Disponível em: http://www.planalto.gov.br/ccivil_03/leis/15540.htm. Acesso em: 5 fev. 2019.

104 Art. 5’, inciso I, do Decreto-Lei 200/67: “Art. $5^{\circ}$ Para os fins desta lei, considera-se: I - Autarquia - o serviço autônomo, criado por lei, com personalidade jurídica, patrimônio e receita próprios, para executar atividades típicas da Administração Pública, que requeiram, para seu melhor funcionamento, gestão administrativa e financeira descentralizada". Cf. BRASIL. Decreto-Lei $n^{\circ} 200$, de 25 de fevereiro de 1967. Dispõe sôbre a organização da Administração Federal, estabelece diretrizes para a Reforma Administrativa e dá outras providências. Brasília, DF: Presidência da República, 1967. Disponível em: http://www.planalto.gov.br/ccivil_03/decreto-lei/del0200.htm. Acesso em: 5 fev. 2019. 
órgãos próprios, com certa capacidade de autoadministração; patrimônio próprio; capacidade específica em relação ao serviço público que lhe foi transferido, o que o impede de se desviar dos fins que determinaram a sua criação; e sujeição a controle ou tutela exercido pelo ente instituidor, nos limites da lei ${ }^{105}$.

Quanto ao regime jurídico, as autarquias são divididas em autarquias comuns e autarquias especiais, sendo que as universidades consistem na última categoria. Odete Medauar ${ }^{106}$ aduz que os requisitos capazes de demonstrar o caráter especial das universidades públicas são: (i) nomeação do reitor pelo chefe do Poder Executivo com base em lista elaborada pela própria universidade ${ }^{107}$; (ii) mandato do dirigente (reitor), insuscetível de cassação pelo chefe do Poder Executivo ${ }^{108}$; (iii) estatuto e regimento elaborados pela própria universidade ${ }^{109}$; (iv) existência de órgãos colegiados centrais na administração superior, com funções deliberativas e normativas, dos quais participam docentes, representantes do corpo discente e da comunidade ${ }^{110}$; e (v) carreira específica para o pessoal docente, com progressão baseada na obtenção de graus acadêmicos e concursos ${ }^{111}$.

No entanto, as instituições de ensino superior públicas não estão obrigadas a adotar exclusivamente a forma jurídica de autarquia, podendo plenamente constituir-se como fundação pública. Ainda assim, respeitarão integralmente o que está preceituado pelo DecretoLei $n^{\circ} 200 / 67$, porque a forma jurídica da fundação também autoriza a prestação do serviço educacional de maneira adequada. Por definição, fundação pública é

105 NOHARA, Irene Patrícia. Direito administrativo. 8. ed. Rio de Janeiro: Atlas, 2018. p. 596.

106 MEDAUAR, Odete. Direito administrativo moderno. São Paulo: Revista dos Tribunais, 2006. p. 75.

107 Art. 16, inciso I, da Lei ${ }^{\circ}$ 5.440/68: "o Reitor e o Vice-Reitor de universidade federal serão nomeados pelo Presidente da República e escolhidos entre professores dos dois níveis mais elevados da carreira ou que possuam título de doutor, cujos nomes figurem em listas tríplices organizadas pelo respectivo colegiado máximo, ou outro colegiado que o englobe, instituído especificamente para este fim, sendo a votação uninominal; (Redação dada pela Lei no 9.192, de 1995)". Cf. BRASIL. Lei $n^{\circ} 5.540$, de 28 de novembro de 1968. Fixa normas de organização e funcionamento do ensino superior e sua articulação com a escola média, e dá outras providências. Brasília, DF: Presidência da República, 1968. Disponível em: http://www.planalto.gov.br/ccivil_03/leis/15540.htm. Acesso em: 5 fev. 2019.

108 Súmula 47 do STF: Reitor de universidade não é livremente demissível pelo Presidente da República durante o prazo de sua investidura. Cf. BRASIL. Superior Tribunal de Justiça. Súmula $n^{\circ} 47$. Reitor de universidade não é livremente demissível pelo Presidente da República durante o prazo de sua investidura. Brasília, DF: Superior Tribunal Federal, [1964]. Disponível em: http://www.stf.jus.br/portal/cms/verTexto.asp?servico=jurisprudenciaSumula\&pagina=sumula_001_100. Acesso em: 19 ago. 2019.

109 Art. 53, V, LDB: "elaborar e reformar os seus estatutos e regimentos em consonância com as normas gerais atinentes". Cf. BRASIL. Lei $n^{\circ}$ 9.394, de 20 de dezembro de 1996. Estabelece as diretrizes e bases da educação nacional. Brasília, DF: Presidência da República, 1996a. Disponível em: http://www.planalto.gov.br/ccivil_03/leis/19394.htm. Acesso em: 5 fev. 2019.

110 Ibid., art. 56: "As instituições públicas de educação superior obedecerão ao princípio da gestão democrática, assegurada a existência de órgãos colegiados deliberativos, de que participarão os segmentos da comunidade institucional, local e regional".

111 Ibid., art. 54, $\S 1^{\circ}$, inciso I: "propor o seu quadro de pessoal docente, técnico e administrativo, assim como um plano de cargos e salários, atendidas as normas gerais pertinentes e os recursos disponíveis". 
a entidade dotada de personalidade jurídica de direito privado, sem fins lucrativos, criada em virtude de autorização legislativa, para o desenvolvimento de atividades que não exijam execução por órgãos ou entidades de direito público, com autonomia administrativa, patrimônio próprio gerido pelos respectivos órgãos de direção, e funcionamento custeado por recursos da União e de outras fontes ${ }^{112}$.

Conclui-se então que pessoas jurídicas de direito público, ao prestar serviços educacionais, podem adotar a forma de autarquia ou fundação e estarão plenamente respeitando o ordenamento jurídico. Tanto é verdade que o Decreto $\mathrm{n}^{\circ} 10.195 / 19$, que aprova a estrutura regimental do MEC, elenca no artigo $2^{\circ}$, inciso IV, alíneas "a" e "b", de seu anexo I, as pessoas jurídicas de direito público que prestam serviços educacionais em nível superior na forma de autarquias e fundações.

Já no cenário privado, foi a Lei $n^{\circ} 9.131 / 95$, em seu artigo $7^{\circ}$ e seguintes, que determinou que as formas societárias para prestação de serviços educacionais por entidades privadas poderão acontecer por intermédio de pessoas jurídicas de direito privado e por qualquer das formas admitidas em direito, importa dizer, a mantenedora dessas instituições poderá ou não auferir lucro, devendo eleger uma das formas societárias admitidas para atuação no direito privado na forma do artigo 44 do Código Civil ${ }^{113}$.

Sobre a atuação do particular prestando serviços públicos, é preciso fazer duas breves distinções. A primeira tem relação com a concepção do terceiro setor, enquanto a outra é totalmente diferente, visto que o particular presta serviços de relevante interesse social, porém visando objetivos próprios, tais como o lucro.

O terceiro setor é composto por entidades da sociedade civil que exercem atividades de interesse público sem finalidade lucrativa. Como a atividade pública não se esgota no Estado, a iniciativa privada pode, através de recursos próprios ou de recursos de terceiros, públicos ou privados, passar a atender interesses públicos, tais como a promoção da educação. Para tanto, como será adiante elucidado, deve ser pessoa jurídica privada formalmente constituída e sem buscar a finalidade lucrativa.

112 Art. 5 , inciso IV, do Decreto-Lei no 200/67. Cf. BRASIL. Decreto-Lei $n^{\circ}$ 200, de 25 de fevereiro de 1967. Dispõe sôbre a organização da Administração Federal, estabelece diretrizes para a Reforma Administrativa e dá outras providências. Brasília, DF: Presidência da República, 1967. Disponível em: http://www.planalto.gov.br/ccivil_03/decreto-lei/del0200.htm. Acesso em: 5 fev. 2019.

113 Art. 44: "São pessoas jurídicas de direito privado: I - as associações; II - as sociedades; III - as fundações; IV - as organizações religiosas; V - os partidos políticos; VI - as empresas individuais de responsabilidade limitada". Cf. BRASIL. Lei $n^{\circ} 10.406$, de 10 de janeiro de 2002. Institui o Código Civil. Brasília, DF: Presidência da República, 2002. Disponível em: http://www.planalto.gov.br/ccivil_03/leis/2002/L10406compilada.htm. Acesso em: 18 fev. 2019. 
Felipe Chiarello e Larissa Dias Puerta ${ }^{114}$ apontam que o fato de existir a possibilidade de o serviço público de interesse social ser prestado concomitantemente pelo setor público e pelo particular de modo algum exime a necessidade de prestação desse serviço pelo setor público, sendo que ele também não pode se olvidar a controlar o serviço prestado pelo ente privado, já que esses núcleos de interesse social devem ter asseguradas a sua existência e qualidade.

Nessa aproximação do setor privado para atender interesses públicos, observa-se o pioneirismo da sociedade civil, que passa a ser elevada ao primeiro plano na estrutura organizacional estatal. A cidadania ativa um pressuposto básico para a sua concretização, pois o setor privado passa a servir o interesse geral, com base, também, no princípio da solidariedade.

Acredita-se que é justamente em razão da solidariedade que as entidades privadas começam a atuar nos campos do desenvolvimento social, em que se nota a existência de uma força atuante que o setor privado emprega para atingir a conquista da melhora na qualidade de vida das pessoas que integram a sociedade.

Para que exista a possibilidade de formulação dessas mencionadas parcerias entre os setores público e privado, a Constituição Federal autoriza, em seu artigo 175, a elaboração de parcerias por intermédio do regime de concessão ou permissão para a prestação dos serviços públicos. Em respeito a essa previsão, foi idealizado o Plano Nacional de Publicização baseado nas ideias desenvolvidas pelo Plano Diretor da Reforma do Aparelho do Estado, criando, inicialmente, a figura das organizações sociais (OS) por meio da Lei $n^{\circ} 9.637 / 98$, a qual veio a ser complementada pelas organizações da sociedade civil de interesse público (Oscip), com a implementação da Lei $n^{\circ}$ 9.790/99, e, posteriormente, a criação da figura das organizações da sociedade civil (OSC) por intermédio da promulgação da Lei no 13.019/14.

Destaque-se que quaisquer das mencionadas figuras pertencentes ao terceiro setor serão invariavelmente pessoas jurídicas de direto privado, que serão assim qualificadas pela lei desde que cumpram certos requisitos lá previstos.

A Lei $n^{0} 9.637 / 98$ foi a responsável pela criação de uma nova figura jurídica, em âmbito federal, a primeira capaz de transitar entre o setor público e o privado sem ser configurado como um verdadeiro ente pertencente ao setor público, ao mesmo tempo em que

114 PINTO, Felipe Chiarello de Souza; PUERTA DOS SANTOS, Larissa Dias. As transformações na organização da administração pública por ocasião do regramento destinado às Organizações Sociais e os impactos nas instituições do terceiro setor. In: JAEGER JUNIOR, Augusto; REVERBEL, Carlos Eduardo Dieder; MARTINI, Sandra Regina (org.). O movimento do saber: uma homenagem para Claudia Lima Marques. 1. ed. Porto Alegre: Editora RJR, 2017. p. 189-203. 
de modo algum figura como uma pessoa dotada de interesse meramente privado.

Quaisquer das figuras pertencentes ao terceiro setor necessariamente serão associações ou fundações privadas já existentes que recebem, posteriormente, uma qualificação específica mediante solicitação. Tais entidades privadas prestam serviços públicos de interesse social, e por essa finalidade já merecem tratamento diferenciado das instituições que atuam visando o lucro, justamente por desempenharem papel relevante para o conceito de cidadania participativa.

Nos termos do artigo $1^{\circ}$ da Lei $n^{0}$ 9.637/98, um ente do setor privado consegue qualificar-se, adquirindo a natureza de organização social quando se tratar de pessoa jurídica de direito privado, sem fins lucrativos, cujas atividades por ela desenvolvidas destinarem-se ao ensino, à pesquisa científica, ao desenvolvimento tecnológico, à proteção e preservação do meio ambiente, à cultura e à saúde. Assim, instituições de ensino superior são totalmente aderentes aos objetivos previstos por lei e possuem a prerrogativa de solicitar a qualificação como organização social ao setor público.

Essas entidades podem fazer a solicitação de qualificação como organização social ao preencher a determinação prevista no artigo $2^{\circ}$ da Lei $\mathrm{n}^{\circ}$ 9.637/98, atendendo a uma série de requisitos inerentes ao registro de ato constitutivo da pessoa jurídica solicitante. Essa solicitação é efetuada perante o ministro ou titular de órgão supervisor ou regulador da área de atividade correspondente ao seu objeto social e do ministro do planejamento, orçamento e gestão. A aprovação da entidade como organização social dependerá exclusivamente da conveniência e oportunidade, ou seja, de eventual interesse público da qualificação dessa pessoa.

Apenas as entidades qualificadas como organizações sociais estarão aptas a firmarem contrato de gestão com o poder público. Nos termos do que preceitua a Lei $n^{\circ}$ 9.637/98, o contrato de gestão é o instrumento firmado entre o poder público e a entidade qualificada, no intuito de formalizar uma parceria entre as partes para o fomento e a execução de atividades relativas às áreas especificadas na própria lei. Obviamente, a celebração desse contrato deve ser conduzida de forma pública, objetiva e impessoal.

Por sua vez, a organização da sociedade civil de interesse público consiste, na origem, em uma associação privada que, mediante solicitação expressa ao poder público, pleiteia seu reconhecimento como tal para que possa firmar termo de parceria com o poder público no 
âmbito educacional, buscando a promoção gratuita da educação ${ }^{115}$.

Ao contrário do que acontece com o pedido de qualificação como organização social, no caso das Oscip, caso o agente preencha todos os requisitos previstos em lei, sua qualificação como tal deve ser realizada mediante ato vinculado do poder público, não havendo que se falar em análise de conveniência e oportunidade do poder público para tanto ${ }^{116}$.

A última figura do terceiro setor, que para ser assim reconhecida depende de qualificação prévia do poder público, é a organização da sociedade civil, idealizada pela Lei ${ }^{\circ}$ 13.019/14. Por meio dela, o poder público implementou um mecanismo para regularmente formalizar parcerias entre a administração pública e organizações da sociedade civil, em regime de mútua cooperação, para a consecução de finalidades de interesse público e recíproco, mediante a execução de atividades ou de projetos previamente estabelecidos em planos de trabalho inseridos em termos de colaboração, em termos de fomento ou em acordos de cooperação ${ }^{117}$.

Desde que seja constituída na forma de associação ou fundação sem finalidade lucrativa, quaisquer instituições de educação superior poderão pleitear o seu reconhecimento pelo poder público como entidade pertencente ao terceiro setor e, a partir daí, regularmente conseguirem receber verba pública para a promoção da educação.

As instituições de ensino superior podem requerer essa qualificação pública a qualquer momento caso preencham os requisitos específicos de quaisquer uma das mencionadas leis,

115 Art. 3º, inciso III, Lei no 9.790/99: “A qualificação instituída por esta Lei, observado em qualquer caso, o princípio da universalização dos serviços, no respectivo âmbito de atuação das Organizações, somente será conferida às pessoas jurídicas de direito privado, sem fins lucrativos, cujos objetivos sociais tenham pelo menos uma das seguintes finalidades: [...] III - promoção gratuita da educação, observando-se a forma complementar de participação das organizações de que trata esta Lei”. Cf. BRASIL. Lei no 9.790, de 23 de março de 1999. Dispõe sobre a qualificação de pessoas jurídicas de direito privado, sem fins lucrativos, como Organizações da Sociedade Civil de Interesse Público, institui e disciplina o Termo de Parceria, e dá outras providências. Brasília, DF: Presidência da República, 1999. Disponível em: http://www.planalto.gov.br/ccivil_03/LEIS/L9790.htm. Acesso em: 18 fev. 2019.

116 Ibid., art. $1^{\mathrm{o}}, \S 2^{\circ}$ : “A outorga da qualificação prevista neste artigo é ato vinculado ao cumprimento dos requisitos instituídos por esta Lei".

117 Art. 1': "Estabelece o regime jurídico das parcerias entre a administração pública e as organizações da sociedade civil, em regime de mútua cooperação, para a consecução de finalidades de interesse público e recíproco, mediante a execução de atividades ou de projetos previamente estabelecidos em planos de trabalho inseridos em termos de colaboração, em termos de fomento ou em acordos de cooperação; define diretrizes para a política de fomento, de colaboração e de cooperação com organizações da sociedade civil; e altera as Leis n's 8.429, de 2 de junho de 1992, e 9.790, de 23 de março de 1999”. Cf. BRASIL. Lei no 13.019, de 31 de julho de 2014. Estabelece o regime jurídico das parcerias entre a administração pública e as organizações da sociedade civil, em regime de mútua cooperação, para a consecução de finalidades de interesse público e recíproco, mediante a execução de atividades ou de projetos previamente estabelecidos em planos de trabalho inseridos em termos de colaboração, em termos de fomento ou em acordos de cooperação; define diretrizes para a política de fomento, de colaboração e de cooperação com organizações da sociedade civil; e altera as Leis $n^{\circ}$ s 8.429, de 2 de junho de 1992, e 9.790, de 23 de março de 1999. Brasília, DF: Presidência da República, 2014b. Disponível em: http://www.planalto.gov.br/ccivil_03/_ato2011-2014/2014/lei/113019.htm. Acesso em: 26 fev. 2019. 
mas não estão obrigadas a tanto. No entanto, para que formalizem contratos de fomento e recebimento de verbas públicas para a consecução dos seus objetivos, tais qualificações servem como mecanismos de desburocratização dos procedimentos de solicitação e recebimento de verbas.

Existem instituições de ensino superior privadas que não possuem interesse em receber tal qualificação e ainda assim desempenham atividades para a promoção da educação sem finalidade lucrativa. Não são reconhecidas como entidades pertencentes ao terceiro setor, porém prestam serviços de interesse público. Nesse grupo estão inseridas as associações e fundações de direito privado, que devem ser regularmente constituídas sob o manto do direito privado.

Ainda assim, referidas instituições de ensino podem requerer os benefícios da Lei $\mathrm{n}^{\mathrm{o}} 12.101 / 09$ e serem reconhecidas como filantrópicas, momento a partir do qual passam a ser beneficiárias de imunidade tributária prevista na Constituição Federal ${ }^{118}$ para essa espécie de pessoa jurídica, ou seja, dita imunidade não é aplicável indistintamente a qualquer instituição de ensino em atividade no país, mas somente àquelas que cumprem os requisitos previstos na mencionada lei.

A lei que regulamenta a organização administrativa das instituições de ensino superior privadas, Lei $n^{\circ}$ 9.131/95, é expressa em determinar que as entidades mantenedoras de instituições de ensino superior sem finalidade lucrativa deverão, entre outras atribuições, elaborar e publicar em cada exercício social demonstrações financeiras, com o parecer do conselho fiscal, ou órgão similar; manter escrituração completa e regular de todos os livros fiscais, na forma da legislação pertinente, bem como de quaisquer outros atos ou operações que venham a modificar sua situação patrimonial, em livros revestidos de formalidades que assegurem a respectiva exatidão; conservar em boa ordem, pelo prazo de cinco anos, contado da data de emissão, os documentos que comprovem a origem de suas receitas e a efetivação de suas despesas, bem como a realização de quaisquer outros atos ou operações que venham a modificar sua situação patrimonial; submeter-se, a qualquer tempo, à auditoria pelo poder público, e destinar seu patrimônio a outra instituição congênere ou ao poder público, no caso de encerramento de suas atividades, promovendo, se necessário, a alteração estatutária

118 Art. 150, inciso VI, alínea "c": "patrimônio, renda ou serviços dos partidos políticos, inclusive suas fundações, das entidades sindicais dos trabalhadores, das instituições de educação e de assistência social, sem fins lucrativos, atendidos os requisitos da lei”. Cf. BRASIL. [Constituição (1988)]. Constituição da República Federativa do Brasil de 1988. Brasília, DF: Presidência da República, 1988. Disponível em: http://www.planalto.gov.br/ccivil_03/constituicao/constituicaocompilado.htm. Acesso em: 18 fev. 2019. 
correspondente ${ }^{119}$.

Devem ainda comprovar, sempre que solicitada pelo órgão competente, a aplicação dos seus excedentes financeiros para os fins da instituição de ensino, a não remuneração ou concessão de vantagens ou benefícios, por qualquer forma ou título, a seus instituidores, dirigentes, sócios, conselheiros ou equivalentes. Essas comprovações determinadas por lei são tidas como indispensáveis para fins de credenciamento e recredenciamento da instituição de ensino superior, ratificando o posicionamento de que, ainda que sejam instituições privadas, prestam serviços públicos e sujeitam-se às regras de direito público sob pena de determinação de encerramento de suas atividades.

A mencionada lei é expressa em determinar que as entidades mantenedoras de instituições privadas de ensino superior comunitárias, confessionais e filantrópicas ou constituídas como fundações não poderão ter finalidade lucrativa e deverão adotar os preceitos do artigo 14 do Código Tributário Nacional e da Lei $\mathrm{n}^{\circ}$ 12.101/19.

No entanto, existem instituições de ensino superior privadas que podem plenamente, com permissivo legal e constitucional ${ }^{120}$, atuar no ramo de prestação de serviços educacionais e, ainda assim, aferirem lucro; no entanto, não podem ser beneficiárias da imunidade tributária mencionada alhures. Tais instituições podem adotar qualquer uma das formas admitidas em direito de natureza civil ou comercial ${ }^{121}$.

A obrigação mais importante que a lei impôs às instituições de ensino superior que objetivam o lucro foi o dever de elaborarem, em cada exercício social, demonstrações financeiras atestadas por profissionais competentes ${ }^{122}$.

Mesmo para essas instituições são impostas regras de direito público em que o Estado objetiva o controle de qualidade do serviço que prestam. É nesse sentido que é totalmente possível firmar o posicionamento de que o serviço educacional prestado por ente público ou privado em nenhuma hipótese perde a natureza de serviço público, portanto sujeito às regras de direito público. Com base nesse entendimento que o presente estudo se funda e busca primeiro

119 Art. $7^{\circ}$-B e incisos da Lei ${ }^{\circ}$ 9.131/95. Cf. BRASIL. Lei $n^{\circ} 9.131$, de 24 de novembro de 1995. Altera dispositivos da Lei n ${ }^{\circ}$ 4.024, de 20 de dezembro de 1961, e dá outras providências. Brasília, DF: Presidência da República, 1995a. Disponível em: http://www.planalto.gov.br/ccivil_03/leis/19131.htm. Acesso em: 7 fev. 2019.

120 Art. 209 da CF/88 (Cf. BRASIL. [Constituição (1988)]. Constituição da República Federativa do Brasil de 1988. Brasília, DF: Presidência da República, 1988. Disponível em:

http://www.planalto.gov.br/ccivil_03/constituicao/constituicaocompilado.htm. Acesso em: 18 fev. 2019) e art. $7^{\circ}$ da Lei $n^{\circ}$ 9.394/96 (Cf. BRĀSIL. Lei $n^{\circ}$ 9.394, de 20 de dezembro de 1996. Estabelece as diretrizes e bases da educação nacional. Brasília: Presidência da República, 1996a. Disponível em: http://www.planalto.gov.br/ccivil_03/leis/19394.htm. Acesso em: 5 fev. 2019).

${ }^{121}$ Id., 1995, art. $7^{\circ}$-A da Lei ${ }^{\circ}$ 9.131/ 95 .

122 Ibid., art. 7-D. 
compreender, depois criticar, para então propor novos mecanismos que sejam aptos a efetivamente construírem um cenário melhor para a educação superior brasileira, restritos desde o início à específica análise da área do Direito.

Em suma, em razão da natureza de serviço público social destinado à coletividade, a educação superior pode ser prestada diretamente pelo Estado, por meio da criação de pessoas jurídicas de direito público criadas com a finalidade específica de prestação do serviço educacional, vinculadas a quaisquer dos entes da administração pública, tais como a União, Estados e Municípios.

Pode ser prestado por particulares, em regime de parceria com a administração pública, por meio de parcerias firmadas com organizações do terceiro setor com esta finalidade, ou, ainda, prestado por particulares sem finalidade lucrativa, mas que não sejam necessariamente vinculadas ao terceiro setor, ou também prestado diretamente pela livre iniciativa com expressa possibilidade de auferir lucro, sendo que todas as formas respeitam o ordenamento jurídico. No entanto, todas as formas mencionadas estão sujeitas ao poder estatal de físcalização e intervenção na atividade desempenhada diante de sua natureza.

Para conseguir aferir uma dimensão do tamanho do sistema educacional brasileiro em nível superior, especificamente no que diz respeito aos cursos de Direito, serão apresentados no capítulo seguinte os dados oficiais relativos ao número de instituições de ensino superior no Brasil que oferecem cursos jurídicos. Visando a compreensão dos desdobramentos ocasionados nacionalmente em razão da implementação dessas premissas na área do Direito, passaremos à análise do atual cenário jurídico-educacional encontrado no país, elucidado no próximo capítulo, quando serão apresentados os meandros em que educação jurídica brasileira se desenvolveu e seu atual contexto. 


\title{
2 A CRISE DA EDUCAÇÃO JURÍDICA BRASILEIRA E OS ATORES NELA ENVOLVIDOS
}

Diversas causas permitem concluir pela existência de uma crise na educação superior em estabelecimentos de ensino de todo o mundo, haja vista que, pelo menos desde 1969, Darcy Ribeiro fala sobre a crise universitária. Segundo aponta, a crise enfrentada pelas universidades é tangível em vários aspectos, tais como conjuntural, político, estrutural, intelectual e ideológico ${ }^{123}$.

Por serem identificáveis as mais diversas formas de crise na sociedade contemporânea, é relativamente simples concluir que o modelo universitário está em crise, considerando-se que a função mais genérica da instituição de ensino deve ser a de contribuir para a satisfação dos requisitos necessários à perpetuação ou alteração da sociedade global. Segundo o próprio Darcy Ribeiro, não será pelo fato de uma universidade apresentar-se como rudimentar e precária que necessariamente ela estará imersa em uma crise estrutural, haja vista que isso não acontece se ainda assim ela corresponder às aspirações do cultivo do saber e da preparação dos profissionais para uma sociedade atrasada e resignada com o atraso $^{124}$.

\begin{abstract}
A crise estrutural instaura-se quando a sociedade e a universidade divergem e andam em ritmos distintos, generalizando-se atitudes inconformadas que começam a por em causa tudo o que antes parecia aceito, indagando - de cada instituição e de cada forma de conduta - se contribuem para as coisas permanecerem como são, ou se, inversamente, concorrem para que se alterem de acordo com as novas aspirações. Desde então, a universidade passa a ser representada por uma consciência vivaz, que busca descobrir a qual grupo de interesses tradicionais está servindo e para que rumos suas tendências de alteração a encaminham. As opiniões se dividem, gerando duas ordens de descontentamento cada vez mais conflitantes: o dos que querem reformar a universidade para aquietá-la e fazê-la mais conservadora, e o dos que desejam transformá-la numa trincheira de luta revolucionária, embora única, a opor-se à ordem social global ${ }^{125}$.
\end{abstract}

O grande desafio possível para delinear a identificação da referida crise consiste em encontrar mecanismos que consigam idealizar um novo modelo teórico de universidade capaz de transformar o atual papel tradicional que ela tem hoje, qual seja, reflexo do meio social ou mera réplica mecânica das reivindicações e das pressões externas, buscando torná-la um agente de transformações da sociedade. Tal desafio, apesar de antigo, permanece extremamente atual em razão dos dados que serão a seguir compilados, para comprovar que a universidade deve ser

\footnotetext{
${ }^{123}$ RIBEIRO, Darcy. A universidade necessária. 4. ed. Rio de Janeiro: Paz e Terra, 1982. p. 23.

124 Ibid., p. 49.

125 Id., loc. cit.
} 
repensada e que seu objetivo na atuação como agente da promoção do desenvolvimento econômico e social da nação possa ser efetivamente implementado e constatado.

Para essa pesquisa, há que ser destacado o aprofundamento do estudo com ênfase na crise universitária relacionada aos cursos da área do Direito, com enfoque em possíveis perspectivas para o desenvolvimento e aprimoramento dessa específica realidade, razão pela qual a partir daqui será relatada a realidade da educação jurídica.

No Brasil, o ensino superior historicamente esteve restrito a uma pequena parcela da população e se apresentou como fator imprescindível para que o sujeito legitimamente exerça a cidadania e se prepare para o mercado de trabalho, adotando uma compreensão de que apenas a educação superior é capaz de preparar não só o indivíduo, mas também a nação para o alcance de independência cultural, política, científica e de desenvolvimento. Mesmo com toda essa importância, não foi identificado, para o contexto da criação das universidades no Brasil, o fomento de práticas responsáveis pela institucionalização e pelo amplo acesso ao setor.

Em contraste com o resto da América, o Brasil declarou sua independência em 1822 sem contar com a existência de nenhuma universidade. Especificamente no que atine aos cursos jurídicos no Brasil, inicialmente se destaca a influência europeia, tanto na formação quanto na estrutura de organização acadêmica e administrativa adotada por aqui, justamente porque os primeiros cursos de Direito foram implementados apenas após a Proclamação da Independência. Antes disso, toda e qualquer formação universitária na área do Direito concluída por qualquer brasileiro era proveniente de intercâmbio e período de estudos fora do país, especialmente no eixo Portugal e Espanha.

Segundo os dados disponíveis, as universidades da América espanhola prepararam 150.000 graduados durante o período colonial; calcula-se que, no mesmo lapso (15771822), tão somente 2.500 jovens nascidos no Brasil acompanharam cursos em Coimbra. Verifica-se, assim, quão reduzido era o pessoal de nível superior de que dispunha o Brasil para dirigir sua vida independente. Este país apenas implantou suas primeiras escolas de ensino superior na década anterior a da Independência. Quando a República foi proclamada (1889), havia apenas cinco faculdades, duas de Direito (São Paulo e Recife), duas de Medicina (Bahia e Rio) e uma Politécnica nesta última cidade. A matrícula destes estabelecimentos somava 2.300 estudantes $^{126}$.

Com a finalidade de atender os filhos das classes sociais dominantes brasileiras, os quais seriam os futuros responsáveis pela condução jurídica e política nacional, foram instalados cursos superiores no Brasil, prescindindo das viagens à Europa. Os primeiros cursos jurídicos foram implementados no Brasil em 1827, com a promulgação da Lei de 11 de agosto

${ }^{126}$ RIBEIRO, Darcy. A universidade necessária. 4. ed. Rio de Janeiro: Paz e Terra, 1982. p. 90. 
de $1827^{127}$, por meio da qual D. Pedro I criou dois cursos de ciências jurídicas e sociais, um na cidade de São Paulo e outro na cidade de Olinda, precursores na área do Direito no Brasil.

Referida lei apresentava uma proposição do que seria ministrado durante os cinco anos de curso, com a seguinte formatação: no primeiro ano, a cadeira inicial era composta por direito natural, direito público, análise de Constituição do Império, direito das gentes, e diplomacia; no segundo ano, a primeira cadeira era composta pela continuação das matérias do ano antecedente e a segunda cadeira, por direito público eclesiástico; no terceiro ano, a primeira cadeira era composta por direito pátrio civil e a segunda, pelo direito pátrio criminal com a teoria do processo criminal; o quarto ano era composto pela primeira cadeira consistente na continuação do direito pátrio civil e a segunda cadeira, como direito mercantil e marítimo; finalmente, o quinto ano seria composto pela primeira cadeira com economia política e a segunda cadeira, com a teoria e prática do processo adotado pelas leis do Império.

Pode-se considerar que, naquele contexto, a lei de criação dos cursos exerceu o mesmo papel que as Diretrizes Curriculares Nacionais (DCN) exaradas pelo MEC possuem atualmente. No entanto, essa obrigatoriedade só se aplicava aos cursos que foram autorizados pela mencionada lei, ou seja, os de ciências jurídicas e sociais implementados nas cidades de Olinda e São Paulo, os quais foram os únicos durante todo o Império.

Diante da análise do que ficou estabelecido como conteúdo do curso, é possível afirmar que a criação e a formação dos cursos jurídicos no Brasil estão intimamente atreladas às exigências de consolidação do Estado no Império e traduzem as contradições e as expectativas das elites brasileiras comprometidas com o processo de independência. Proveniente das contradições observadas pela elite imperial conservadora e buscando atender os imperativos da igreja, o Estado brasileiro procurou, com a implementação dos cursos jurídicos, uma possível solução para a formação de quadros políticos e administrativos que viabilizassem a completa independência nacional ${ }^{128}$.

Os cursos jurídicos, em sua concepção ainda no Império, não foram organizados para atender às expectativas judiciais da sociedade, mas sim para atender aos interesses do novo Estado brasileiro. Naquele contexto, foi dada prioridade às exigências institucionais, e os cursos jurídicos claramente não objetivavam a formação de advogados e técnicos para a implementação das demandas da sociedade civil, mas sim o atendimento das prioridades

127 BRASIL. Lei do Império, de 11 de agosto de 1827. Crêa dous Cursos de sciencias juridicas e sociaes, um na cidade de S. Paulo e outro na de Olinda. Brasília, DF: Presidência da República, 1827. Disponível em: http://www.planalto.gov.br/ccivil_03/leis/lim/LIM.-11-08-1827.htm. Acesso em: 24 fev. 2020.

128 BASTOS, Aurélio Wander. Ensino jurídico no Brasil. 2. ed. rev. e atual. Rio de Janeiro: Lumen Juris, 2000. p. 1. 
definidas pelo Estado.

No período do Império, inclusive, os cursos de Direito possuíam em seus componentes curriculares conteúdos de cunho claramente tendenciosos a demonstrar a base políticoideológica da instituição a que era vinculado. Apenas com o advento da República, notamos uma inclinação à tendência positivista, que perdurou durante muitos anos nos cursos de Direito em todo o Brasil.

Somente após a proclamação da República é que novos cursos de Direito vieram a ser implementados, quais sejam: na Federal da Bahia ${ }^{129}$ em 1891, na Federal do Rio de Janeiro ${ }^{130}$, também no mesmo ano, na Federal de Minas Gerais ${ }^{131}$ em 1892 e na Federal de Goiás ${ }^{132}$ em 1898. Todos esses cursos vieram a ser incorporados por universidades do Sistema Federal de Ensino e inicialmente criadas por lei ou de forma livre, em sessões legislativas que chancelavam sua existência.

Os cursos de Direito no Brasil que vieram a ser implementados, muitas vezes sob a denominação de Faculdades Livres de Direito, invariavelmente recebiam subsídios públicos, razão pela qual futuramente o Estado passou a ser responsável por essas instituições.

Foi apenas a partir de 1930 que o Estado passou a se debruçar sobre a educação superior com o viés de efetivamente regulamentá-la. Com a instauração do novo regime decorrente da tomada de poder por Getúlio Vargas, Francisco Luís da Silva Campos foi

129 BRASIL. Decreto $n^{\circ}$ 599, de 18 de outubro de 1891. Concede á Faculdade de Direito da Bahia, na fórma do art. 420 do decreto n. $1232 \mathrm{H}$ de 2 de janeiro deste anno, o titulo de Faculdade Livre com todos os privilegios e garantias de que gozam as Faculdades federaes. Brasília, DF: Câmara dos Deputados, 1891. Disponível em: https://www2.camara.leg.br/legin/fed/decret/1824-1899/decreto-599-17-outubro-1891-516940-

publicacaooriginal-1-pe.html. Acesso em: 24 fev. 2020.

130 Em 18 de abril de 1882, por iniciativa do Dr. Fernando Mendes de Almeida foi criada a Faculdade Livre de Ciências Jurídicas e Sociais do Rio de Janeiro, que, no entanto, só funcionaria a partir de 19 de maio de 1891, após a implementação da Reforma Benjamin Constant, que estabeleceu efetivamente a liberdade de ensino no Brasil. Inicialmente instalada no prédio da Escola Senador Correia, na Praça São Salvador teve como primeiro diretor o próprio Dr. Fernando Mendes de Almeida. Em 31 de maio de 1891, foi instituída a Faculdade Livre de Direito da Capital Federal, por iniciativa dos Drs. Carlos Antônio de França Carvalho e José Joaquim do Carmo, sendo este escolhido para exercer a direção do novo estabelecimento de ensino superior, que funcionou, a princípio, nas dependências do mosteiro de São Bento, na Rua Dom Gerardo. No dia 24 de abril de 1920, ocorreu a fusão das duas faculdades, sendo a instituição resultante, a Faculdade de Direito do Rio de Janeiro, logo depois integrada à Universidade do Rio de Janeiro, criada pelo Decreto no 14.343, de 7 de setembro desse mesmo ano. Cf. A CRIAÇÃO dos cursos jurídicos no Brasil. Rio de Janeiro: Museu da Justiça do Estado do Rio de Janeiro, 2011. (Cadernos de Exposições, ago. 2011). Disponível em: http://ccmj.tjrj.jus.br/documents/5989760/6464634/caderno-expo-2.pdf. Acesso em: 22 jan. 2020.

131 A Faculdade Livre de Direito de Minas Gerais, apesar de privada, foi transformada, em instituição de interesse do Estado, na sessão solene de instalação, realizada no prédio da Câmara dos Deputados no dia 10 de dezembro de 1892, em Ouro Preto, presidida pelo diretor-presidente Afonso Pena, cuja sessão viabilizou sua existência. Cf. UNIVERSIDADE FEDERAL DE MINAS GERAIS. Faculdade de Direito da UFMG. Histórico. Belo Horizonte: UFMG, [entre 2018 e 2020]. Disponível em: https://www.direito.ufmg.br/?page_id=4044. Acesso em: 22 jan. 2020.

132 Instituído pela Lei ${ }^{\circ} 186$, de 13 de agosto de 1898. Cf. GOIÁS. Secretaria de Estado da Casa Civil. Lei $n^{\circ}$ 186, de 13 de agosto de 1898. Sobre a Instrucção Publica. Goiânia: Câmara dos Deputados, 1898. Disponível em: https://legisla.casacivil.go.gov.br/public/arquivos/8193. Acesso em: 20 mar. 2019. 
nomeado ministro da educação e saúde, pasta que acabara de ser criada, promovendo, então, a reforma do ensino secundário e universitário no país. Tal reforma educacional proposta por ele compreendia um plano de longo alcance visando a modernização do país.

\begin{abstract}
Para Campos, não bastava o conhecimento da legislação por si só, devendo, o estudante, antes de conhecer o direito, conhecer a realidade social na qual estava integrado, razão pelo qual afirma em várias passagens que os juristas deveriam conhecer a economia antes de conhecer o direito. Jocosamente, Campos colocava que a reforma deveria afastar o jurista do caráter "duelístico", ou seja, no qual dois indivíduos duelam pelo melhor argumento, completamente alheios ao mundo que os circunda. [...] especialmente a educação superior, propunha, já em 1931, a diminuição das disciplinas filosóficas e, a substituição por matérias aplicadas criando cursos técnicos e profissionalizantes, centrados em áreas voltadas diretamente à produção como engenharia, agronomia e contabilidade, servindo como exemplo a proposta de reforma do Curso de Direito da Universidade do Brasil, incluindo disciplinas como economia política e introdução ao estudo do direito ${ }^{133}$.
\end{abstract}

Felipe Chiarello e Daniel Nagao ${ }^{134}$ apontam que a atuação de Francisco Campos, como primeiro ministro da pasta da Educação, logo se fez presente através de uma série de decretos que efetivaram as chamadas Reformas Francisco Campos na educação brasileira. Dentre a gama de textos normativos por ele capitaneadas, destacam-se aqueles destinados à regulamentação da educação superior: Decreto $n^{0}$ 19.850, de 11 de abril de 1931, que criou o Conselho Nacional de Educação (CNE); Decreto $n^{0} 19.851$, da mesma data, que dispôs sobre a organização do ensino superior no Brasil e adotou o regime universitário; e o Decreto ${ }^{\circ}{ }^{19.852}$, também da mesma data, que dispôs sobre a organização da Universidade do Rio de Janeiro.

Dentre os mencionados textos normativos implementados no âmbito educacional, merece destaque o Decreto $\mathrm{n}^{\mathrm{o}} 19.851 / 1931$, o qual teve por objetivo determinar que o ensino superior no Brasil pertenceria a um sistema universitário, com a possibilidade de que fosse ministrado em institutos isolados.

Foi esse decreto que definiu como objetivo para o ensino universitário a missão de elevar o nível da cultura geral, estimular a investigação científica em quaisquer áreas dos conhecimentos humanos, habilitar os sujeitos para o exercício de atividades que requeiram preparo técnico e científico superior, concorrer para a educação do indivíduo e da coletividade, para a harmonia de objetivos entre professores e alunos e para aproveitamento de todas as áreas do conhecimento com foco no desenvolvimento da nação e o aperfeiçoamento da humanidade.

Desde a concepção do que seria nosso sistema universitário, houve uma grande

133 PINTO, Felipe Chiarello de Souza; MENEZES, Daniel Francisco Nagao. Francisco Campos e as reformas do ensino jurídico na década de 30. In: CONGRESSO DO CONPEDI, 25., 2016, Curitiba. Anais [...]. Florianópolis: CONPEDI, 2016. p. 23-24. Tema: História do Direito.

134 Ibid., p. 33. 
preocupação com a área do direito como curso relevante para a estruturação do Estado e seus desígnios. Tanto é verdade que, nesse contexto, o mencionado decreto estipulou que para a constituição de uma universidade deveria ser congregada à unidade pelo menos três dos seguintes institutos do ensino superior: Faculdade de Direito, Faculdade de Medicina, Escola de Engenharia e Faculdade de Educação, Ciências e Letras.

Tal decreto também foi importante para reconhecer a possibilidade, até então não autorizada, de que as universidades fossem geridas por entes particulares sob a forma de fundações ou associações, além das instituições públicas que já haviam sido criadas e mantidas pela União ou pelos estados. Com isso verificamos a concepção de que essas instituições de ensino eram denominadas como universidades federais, estaduais ou livres. Destaque-se que nesse momento há clara vontade do gestor público de que essas instituições de ensino particulares estivessem proibidas de existir com intuito de lucro.

No período do Império e mesmo após a Proclamação da República, todos os cursos jurídicos no Brasil foram implementados com a chancela do Estado e, invariavelmente, mantidos com verba pública. Com a promulgação do Decreto no $19.851 / 1931$, vem a ser autorizada a primeira instituição de ensino superior privada a oferecer o curso de Direito no Brasil, a Pontifícia Universidade Católica do Rio de Janeiro (PUC/RJ), que, segundo dados oficiais extraídos do Inep, iniciou suas atividades em $1^{\circ}$ de março de 1943.

Durante mais de 114 anos de história, no período de 1827 a 1941, foram ofertados apenas 20 cursos de Direito somente em instituições públicas de ensino superior em todo Brasil, o que comprova duas afirmações. A primeira é a de que o posicionamento elitista pretendido pelo Estado é tangível, principalmente, levando-se em consideração a estimativa do Instituto Brasileiro de Geografia e Estatística (IBGE) de que a população brasileira daquela época girava em torno de 41.236 .315 habitantes $^{135}$. Claramente, o acesso à educação superior não consistia em uma política pública de interesse para o Estado.

A segunda explica uma razão histórica pela qual existe uma verdadeira hegemonia das instituições públicas de ensino superior, que buscam firmar posicionamento desarrazoado de serem de melhor qualidade frente às privadas, com base em critérios pouco transparentes e nunca totalmente esclarecidos à sociedade nem à comunidade acadêmica.

Já nesse período, houve a clara determinação de que, mesmo em se tratando de entidades públicas, até mesmo as privadas que passaram a ser autorizadas, as universidades

135 INSTITUTO BRASILEIRO DE GEOGRAFIA E ESTATÍSTICA. Brasil: 500 anos de povoamento. Rio de Janeiro: IBGE, 2000. p. 221. Disponível em: https://brasil500anos.ibge.gov.br/estatisticas-dopovoamento/evolucao-da-populacao-brasileira.html. Acesso em: 21 jan. 2020. 
detinham a prerrogativa de gozarem de personalidade jurídica própria, totalmente independente do ente público que a mantém, além de autonomia administrativa, didática e disciplinar.

Especialmente no Direito, a pretendida modernização da educação superior foi efetivada apenas no final da década de 1960, com a eliminação completa das disciplinas consideradas não técnicas. O objetivo, inspirado em Francisco Campos, era a transformação do Direito no manejo de técnicas positivadas nas leis, afastando a capacidade de abstração e reflexão do jurista, o qual é transformado em mero operador do Direito, isento de raciocínio crítico, totalmente adequado à pretensão estatal.

De todo modo, no período de 1930 a 1970, poucas foram as alterações em nível qualitativo no ensino jurídico, já que, à parte do mencionado, mudanças estruturais não foram observadas. Porém, nesse mesmo período é possível constatar uma grande proliferação de cursos de Direito por todo o Brasil, ampliando o acesso ao ensino superior para a população, buscando acabar com a observada destinação do curso a apenas um setor da sociedade brasileira.

\begin{abstract}
As reformas efetuadas buscaram novamente dar um caráter mais profissionalizante ao curso e mantiveram a rigidez curricular, a exceção da realizada em 1962. A qualidade permaneceu, em geral, de baixo nível e o conteúdo desvinculado da realidade social. Continuou prevalecendo, na prática, a aula-conferência, embora seja nesse período que se inicia a pensar, principalmente com San Tiago Dantas, a crise do ensino do Direito como um aspecto da crise do Direito e da sua cultura, e a criticar o ensino meramente legalista, defendendo, como meta pedagógica, o desenvolvimento do raciocínio jurídico ${ }^{136}$.
\end{abstract}

O crescimento da educação superior no Brasil, segundo dados oficiais, foi muito lento nas décadas seguintes à criação dos primeiros cursos. Ainda em 1940, havia apenas 21.235 estudantes em nível superior. Em 1950, em compensação, o Brasil já contava com a existência de 600 cursos em 15 universidades, embora o número de matriculados somasse apenas 37.548 estudantes ${ }^{137}$.

Na década de 1960, o Brasil continuava sendo a nação latino-americana com menor proporção de população entre 19 e 22 anos matriculada em cursos superiores. Existiam em funcionamento o total de 69 (sessenta e nove) cursos de Direito - realidade extremamente destoante da vivida atualmente.

A realidade retroapresentada foi objeto de profunda transformação na educação

\footnotetext{
${ }^{136}$ RODRIGUES, Horácio Wanderlei. Pensando o ensino do direito no século XXI: diretrizes curriculares, projeto pedagógico e outras questões pertinentes. Florianópolis: Fundação Boiteux, 2005. p. 28.

137 RIBEIRO, Darcy. A universidade necessária. 4. ed. Rio de Janeiro: Paz e Terra, 1982. p. 90.
} 
superior no Brasil ocasionada na década de 1980 e 1990. Nesse período, a formação pedagógica dos docentes foi impregnada pelo positivismo, com uma estrutura que priorizava as cadeiras estritamente dogmáticas, apesar de ser possível verificar nas grades curriculares uma tentativa de conteúdo crítico. Nesse contexto, com relação ao conteúdo programático, ainda eram observados resquícios da ditadura, o começo do processo de abertura política e a transição para o processo democrático. Os discentes eram submetidos à grade curricular obrigatória, que incluía disciplinas do currículo mínimo previsto na Resolução no 3/1972 do Conselho Federal de Educação, tais como o Estudo dos Problemas Brasileiros (EPB) e a obrigatoriedade de atividade física $^{138}$.

De acordo com a análise dos dados oficiais sigilosos e coletados no Inep após autorização própria ${ }^{139}$, podemos concluir que entre 1827 até o final de 1996, data de implementação da Lei de Diretrizes e Bases da Educação Nacional, a qual foi capaz de transformar profundamente o cenário da educação superior brasileira, existiam 258 instituições de ensino superior em atividade que ofertavam cursos jurídicos, sendo 188 instituições de natureza privada e 70 de natureza pública.

Antônio Alberto Machado ${ }^{140}$ aponta que "o número de escolas de Direito no Brasil, em um período de apenas sete anos, entre 1995 e 2002, aumentou 154\%”. No entanto, nesse contexto de abertura à livre iniciativa para atuação no setor, os números não pararam de aumentar. Segundo o mesmo autor, no final de 2002, término do mandato do presidente Fernando Henrique Cardoso, eram 5.995 cursos jurídicos em funcionamento. Fica fácil constatar que o acesso à educação superior como projeto de desenvolvimento da nação mais uma vez aconteceu sem planejamento e, principalmente, sem atender a critérios mínimos de oferta de cursos de qualidade.

A realidade mencionada de abertura desenfreada de cursos começou, aos poucos, a ser alterada com a implementação dos mecanismos públicos de aferição da qualidade. Tanto é verdade que, segundo dados oficiais disponibilizados pelo Inep, em 2017, o número total de cursos de Direito ofertados no Brasil, com a regular autorização pelo MEC, está quase 500\% abaixo do número de cursos apurados no final de 2002, já que naquele ano estiveram em

138 ROCHA, Adriana de Lacerda. O professor reflexivo e o professor de Direito: uma pesquisa de caráter etnográfico. Curitiba: CRV, 2012. p. 56.

139 A informação foi obtida por meio de solicitação ao acesso às bases de dados protegidos do Serviço de Acesso a Dados Protegidos (Sedap) do Inep, subscrita no Processo n ${ }^{\circ} 23036.002755 / 2019-55$, deferida nos termos da Portaria $\mathrm{n}^{\mathrm{o}} 52$, de 28 de janeiro de 2019, estando apta a acessar os seguintes dados solicitados:

DATA_DEED_SUPERIOR (2013 a 2017). Os dados foram coletados na sala segura do Inep, cuja extração ocorreu no período de 20 a 24 de janeiro de 2020, e a disponibilização dos resultados foi enviada por meio do protocolo de transferência FTPs, nos termos no Despacho no 0484837/2020/SEDAP/CIBEC/DIRED.

140 MACHADO, Antônio Alberto. Ensino jurídico e mudança social. Franca: Unesp, 2005. p. 109. 
funcionamento 1.197 cursos de Direito em todo o Brasil.

A abertura irrestrita à livre iniciativa de atuação na educação superior brasileira observada na década de 1990 tornou-se realidade com a Lei de Diretrizes e Bases da Educação Nacional, implementada durante o governo de Fernando Henrique Cardoso, autorizando o processo de oferecimento de cursos superiores no Brasil por grandes grupos educacionais, de onde se observa a grande expansão do setor privado na educação superior.

Infelizmente, a principal consequência de autorizar a partir de uma lógica mercadológica aplicada à área da educação consistiu no afastamento dos seus objetivos primordiais para a cidadania e desenvolvimento ${ }^{141}$, razão pela qual torna-se evidente que a livre adoção dessa premissa desemboca em um sistema educacional cuja qualidade chega a ser temerária.

Para sustentar com embasamento científico essa afirmação, torna-se essencial entender os meandros de adotar princípios mercadológicos à educação, além de descrever a estrutural crise em que a educação superior na área do Direito no Brasil está imersa.

\subsection{Mercantilização da educação superior: a lógica de mercado aplicada ao sistema educacional brasileiro}

A pretendida reforma do Estado, idealizada nos anos 1990, traduz-se em um projeto amplo que teve relação com as várias áreas do governo e da sociedade brasileira. Ela deve ser compreendida no contexto da redefinição do papel do ente estatal, que deixaria de ser o responsável direto pelo desenvolvimento econômico e social pela via da produção de bens e serviços, para se fortalecer como o verdadeiro promotor e regulador do desenvolvimento, numa demonstração de transformação da dimensão econômico-financeira.

No plano econômico e financeiro, o Estado tem a função principal de funcionar como um instrumento de transferência de renda, atuando como o personagem capaz de diminuir as desigualdades. No desempenho dessa atividade, o Estado atua no sentido de promover a

141 PINTO, Felipe Chiarello de Souza; JUNQUEIRA, Michelle Asato. Educação para o desenvolvimento: objetivo do estado democrático e social de direito. Direito e Justiça (URI), ano 16, n. 23, p. 77-90, nov. 2014. p. 88 . 
arrecadação das verbas para cumprir objetivos clássicos ${ }^{142}$, objetivos sociais ${ }^{143}$ e objetivos econômicos ${ }^{144}$.

Para atingir tanto os objetivos sociais quanto os econômicos, o Estado, no modelo intervencionista, passou a assumir funções diretas de execução de serviços. A pretendida reforma do Estado visava a alteração da execução desses serviços, conforme se depreende do que está narrado no Plano Diretor da Reforma do Aparelho do Estado, publicado nos Cadernos MARE em 1995:

[...] reformar o Estado significa transferir para o setor privado as atividades que podem ser controladas pelo mercado. Daí a generalização dos processos de privatização de empresas estatais. Neste plano, entretanto, salientaremos um outro processo tão importante quanto, e que não está tão claro: a descentralização para o setor público não-estatal da execução de serviços que não envolvem o exercício do poder de Estado, mas devem ser subsidiados pelo Estado, como é o caso dos serviços de educação, saúde, cultura e pesquisa científica. Chamaremos a esse processo de "publicização" 145 .

Para a tentativa do ajuste fiscal, os idealizadores do Plano Diretor definiram duas espécies de programas: o de privatizações $^{146}$ e o de publicizações $^{147}$. Por meio da implementação desses programas, sustentavam que assim o Estado conseguiria reduzir o seu papel de executor ou prestador direto dos serviços não exclusivos ou da produção de bens e serviços, para se ater ao de regulador e provedor ou promotor desses serviços, ou seja, passaria do papel ativo de provedor para o papel passivo de capacitador ou facilitador.

Acreditavam que as medidas idealizadas estariam aptas a melhorar a capacidade de governança estatal, visto que, segundo eles, o Brasil também enfrentava um problema nesse setor, afirmando que supostamente existiria uma dificuldade em implementar as políticas públicas por conta da rigidez e ineficiência da máquina administrativa.

142 São os objetivos de garantia da ordem interna e da segurança externa. As atividades aqui desempenhadas são aquelas atinentes ao núcleo estratégico do Estado, bem como as atividades exclusivas do Estado.

143 São os objetivos destinados à promoção de maior justiça e igualdade. Estamos nos referindo, aqui, às atividades não exclusivas do Estado, setor onde ele atua concomitantemente com outras organizações não estatais.

144 São os objetivos que atuam para a estabilização e desenvolvimento. São as atividades de produção de bens e serviços para o mercado, desempenhadas pelo próprio Estado como um player do mercado.

145 BRASIL. Presidência da República. Câmara da Reforma do Estado. Plano Diretor da Reforma do Aparelho do Estado. Brasília, DF: Presidência da República, 1995b. p. 12-13. Disponível em: http://www.bresserpereira.org.br/documents/mare/planodiretor/planodiretor.pdf. Acesso em: 21 mar. 2019.

146 Ibid., p. 13: "O programa de privatizações reflete a conscientização da gravidade da crise fiscal e da correlata limitação da capacidade do Estado de promover poupança forçada através das empresas estatais. Através desse programa transfere-se para o setor privado a tarefa da produção que, em princípio, este realiza de forma mais eficiente".

147 Id., loc. cit.: “[...] programa de publicização, transfere-se para o setor público não-estatal a produção dos serviços competitivos ou não-exclusivos de Estado, estabelecendo-se um sistema de parceria entre Estado e sociedade para seu financiamento e controle". 
No texto do Plano Diretor, foi apresentado um diagnóstico com números relativos à administração pública, por meio do qual afirmou-se a existência de um retrocesso burocrático como resultado da redemocratização de 1988, em razão de um encarecimento significativo com o custeio da máquina administrativa no que se refere a gastos com pessoal e também com bens e serviços, além de um aumento da ineficiência dos serviços públicos.

Foi justamente com esses dados que os governantes na ocasião pretenderam sustentar a flexibilização das rígidas regras para a contratação de pessoal, e até mesmo a possibilidade de criação de metas para os servidores com a possibilidade de motivações positivas ${ }^{148}$ e negativas ${ }^{149}$, bem como a aproximação do setor privado para auxílio na prestação de serviços públicos.

Os objetivos globais do Plano Diretor consistiam em: aumentar a governança do Estado, ou seja, a sua capacidade administrativa de governar com efetividade e eficiência, voltando a ação dos serviços do Estado para o atendimento dos cidadãos; restringir a ação do Estado àquelas funções que lhe são próprias, reservando-se, em princípio, os serviços não exclusivos para a entidade pública não estatal; e produção de bens e serviços para a iniciativa privada.

Já os objetivos específicos, por sua vez, desdobraram-se em quatro frentes de atuação estatal: objetivos específicos para o núcleo estratégico do Estado; objetivos específicos para as atividades estatais exclusivas; objetivos específicos para os serviços estatais não exclusivos; e, finalmente, objetivos específicos para a produção estatal destinada ao mercado.

No tocante aos objetivos destinados aos serviços públicos não exclusivos do Estado, dentre eles a educação, o Plano Diretor previa uma grande transformação, transferindo para o setor público não estatal os serviços que eram prestados diretamente pelo Estado através de um programa de publicização. Tal programa supostamente seria capaz de transformar as atuais fundações públicas em organizações sociais, ou seja, em entidades de direito privado sem fins lucrativos, que teriam autorização específica do Poder Legislativo para celebrar contrato de gestão com o Poder Executivo e, assim, teriam direito a dotação orçamentária, atingindo uma maior autonomia e proporcionando maior responsabilidade para os dirigentes desses serviços.

A base jurídica necessária para a efetivação da reforma do modelo de gestão pública foi idealizada inicialmente por meio do Plano Diretor. Porém, a efetiva transformação do

\footnotetext{
148 Motivações positivas podem ser traduzidas como promoção na carreira por mérito acompanhada de remuneração maior, bonificação para servidores que cumprirem metas de excelência, sorteio de prêmios para os servidores, entre outros mecanismos difundidos e adotados para os empregados do setor privado.

149 Motivações negativas podem ser adotadas, como demissão por insuficiência de desempenho.
} 
cenário público começou a ser notada pela adoção de instrumentos jurídicos específicos, consistentes em alterações constitucionais, mecanismos legais, implementação de políticas públicas, entre outras atitudes tendentes a viabilizar o modelo gerencial, aproximando-se do setor privado para a promoção do desenvolvimento social sob a premissa de que seus produtos e serviços são melhores do que os públicos.

No âmbito da educação superior, a grande transformação foi pautada nas premissas de desburocratização e altamente influenciadas pelo modelo gerencial brevemente descrito. Tal transformação foi observada a partir da promulgação da Lei de Diretrizes e Bases da Educação Nacional em 1996, justamente um ano após a publicação do Plano Diretor da Reforma do Aparelho do Estado, que se propôs a adotar mecanismos tendentes à diminuição do papel do Estado também no setor educacional como prestador de serviços.

Os anos 90 e a Reforma Gerencial, perpetrada por Luiz Carlos Bresser Pereira no
Governo Fernando Henrique Cardoso, representam a lógica neoliberal já iniciada na
Inglaterra e o New Public Manegement, onde o Estado deixa de ser o executor para
ser agente promotor e, portanto, atuar na economia apenas em ramos estratégicos e
em que a iniciativa privada não é capaz de suprir as demandas, quer do ponto de vista
econômico ou social.
Nessa linha, o instrumento da publicização trouxe o serviço público para dentro da
iniciativa privada e não foi diferente em relação à educação. Desta forma, o Brasil se
viu inundado de novos cursos universitários, porém, a lógica do capital e do mercado
tornou-se regra, de forma em que, com pouco investimento, privilegiam-se os cursos
com menor custo operacional e maior procura consumidora. A educação passa a ser
mercantil ${ }^{150}$.

Allan Aroni explica que a prestação do serviço educacional encarada como atividade empresarial, atrelada à ausência direta do Estado nesse e em outros setores sociais, é resultado da adoção da lógica liberal em uma sociedade oligárquica e autoritária. Esse posicionamento foi capaz de repercutir no aumento generalizado de manifestações populares que buscaram a alteração dessa lógica visando uma participação mais ampla da sociedade na formulação das políticas públicas $^{151}$.

${ }^{150}$ PINTO, Felipe Chiarello de Souza; JUNQUEIRA, Michelle Asato. Educação para o desenvolvimento: objetivo do estado democrático e social de direito. Direito e Justiça (URI), ano 16, n. 23, p. 77-90, nov. 2014. p. 88.

151 ARONI, Allan. O ensino superior como atividade empresarial e o cidadão mínimo no Brasil: o peso da mão liberal e a marca de uma aliança não visível: uma análise do ensino superior brasileiro a partir dos dilemas que envolvem as políticas públicas. 2008. 215 f. Dissertação (Mestrado em Educação) - Faculdade de Educação, Universidade de São Paulo, São Paulo, 2008. p. 91. Disponível em: https://www.teses.usp.br/teses/disponiveis/48/48134/tde-09102008-115646/pt-br.php. Acesso em: 18 fev. 2019. 
Segundo o mesmo autor ${ }^{152}$, o fenômeno da mercantilização em âmbito educacional pode ser constatado por diversas formas, tal como a aquisição de IES privadas de menor potencial econômico por grandes grupos educacionais, realizadas por fundos privados, bem como a abertura de capital de organizações educacionais na Bolsa de Valores com a consequente oferta pública de ações.

Assim, ficou estabelecido o comprometimento financeiro com interesse dos acionistas de se obter vantagens nos negócios educacionais, transcendendo, dessa forma, a maximização do lucro, ficando subordinados à maximização do valor acionário no mercado de capitais. Tal estratégia financeira, juntamente com as demais estratégias organizacionais, é incompatível aos princípios que deveriam nortear o processo educativo.

Essa lógica mercadológica autorizada com a previsão do artigo $7^{\circ}$ da LDB de que a educação pode ser prestada pela iniciativa privada implicou, durante os anos 1995 a 2002, em uma degradação contínua da situação educacional, especialmente à educação superior, visto que na ocasião da abertura as condições impostas na lei para a atuação da iniciativa privada no setor educacional sequer eram respeitadas.

No período mencionado foi possível observar uma contínua degradação da situação educacional desde o permissivo legal, diante dessa clara tentativa de transformar a sociedade inteira em um mercado, em que prevaleceria a lei da oferta e da procura a tudo e a todos. No entanto, considerando-se que na verdade o mercado é resultado da própria organização societária, tal permissão legal pretendeu atribuir aos particulares a possibilidade de prestação desse importante serviço público, encarando o ensino como mercadoria ${ }^{153}$.

Do ponto de vista numérico, reconhece-se que o ensino superior no Brasil pode ser equiparado à atividade ou ao serviço empresarial, considerando que é a iniciativa privada a grande responsável por ofertar o maior número de vagas dos cursos postos à disposição da sociedade brasileira, em uma demonstração clara de que a presença do Estado brasileiro na promoção desse serviço não é universal ou uniforme.

Foi a partir dessa história marcada pelo desenvolvimento desigual que a educação assumiu o papel de adequar suas políticas e forças produtivas às exigências econômicas,

152 GOMES, Válter; MACHADO-TAYLOR, Maria de Lourdes; SARAIVA, Ernani Viana. O ensino superior no Brasil: breve histórico e caracterização. Ciência \& Trópico, Recife, v. 42, n. 1, p. 106-129, jan./jul. 2018. p. 126. Disponível em: https://periodicos.fundaj.gov.br/CIC/article/view/1647. Acesso em: 20 fev. 2019.

153 ARONI, Allan. O ensino superior como atividade empresarial e o cidadão mínimo no Brasil: o peso da mão liberal e a marca de uma aliança não visível: uma análise do ensino superior brasileiro a partir dos dilemas que envolvem as políticas públicas. 2008. 215 f. Dissertação (Mestrado em Educação) - Faculdade de Educação, Universidade de São Paulo, São Paulo, 2008. p. 50. Disponível em: https://www.teses.usp.br/teses/disponiveis/48/48134/tde-09102008-115646/pt-br.php. Acesso em: 18 fev. 2019. 
agroexportadoras e industriais. A expansão da educação superior, por consequência, também passou a ser uma exigência do próprio capital, seja em razão da necessidade de capacitação da força de trabalho para a produção, seja pela conveniência de transparecer interna e externamente a imagem do alcance de uma política inclusiva.

Foi assim que o Estado expandiu a rede privada e conseguiu levar adiante esse crescimento, por meio da injeção de verbas públicas em programas de desenvolvimento do ensino superior, ou subsidiariamente quando reduz as exigências legais para a regulamentação dos cursos. Segundo Maria Gracileide Alberto Lopes ${ }^{154}$, "o governo permitiu e até estimulou a expansão do ensino superior privado, que cresceu vertiginosamente sem, contudo, ter impulsionado a melhoria significativa na qualidade do ensino particular, contribuindo dessa forma, para o crescimento das desigualdades sociais".

Essa expansão estimulou principalmente o setor privado, que apesar de ter se desenvolvido numericamente, não impulsionou melhorias na qualidade do ensino superior particular, reforçando diretamente o desenvolvimento desigual da sociedade que identificamos ao longo da história ${ }^{155}$. Isso aconteceu porque a expansão ocorreu predominantemente pela iniciativa privada com o apoio do Estado, a fim de garantir o diploma que permitia a classe média sua ascensão social ${ }^{156}$.

O processo de mercantilização da educação, além de fomentar o desenvolvimento desigual da sociedade, também é responsável pela promoção de políticas econômicas privadas na educação superior. Com a exploração das possibilidades de mercado, a educação se torna um elemento chave para o fortalecimento econômico do país, sofrendo desde a ditadura militar uma crescente onda de privatização e fragmentação de seus conceitos, somando-se à insuficiência das instituições públicas em atender a demanda educacional ${ }^{157}$. Consolida-se, a partir de então, a educação enquanto mercadoria, tornando-a um pilar empresarial do capital financeiro.

Com a massiva abertura de instituições de ensino privadas com finalidade lucrativa e grandes negócios empresariais do ramo começaram a ser identificáveis. Desde março de 2007,

154 ALBERTO LOPES, Maria Gracileide. A mercantilização do ensino superior no contexto atual: considerações para o debate. Interfaces Científicas - Educação, Aracaju, v. 6, n. 2, p. 29-44, fev. 2018. p. 32. Disponível em: https://periodicos.set.edu.br/index.php/educacao/article/view/4249. Acesso em: 25 fev. 2020.

${ }^{155}$ MELLO, Noval Benayon. Desigualdades sociais e políticas públicas na região norte. In: ZIMERMAN, Artur (org). Educação em pauta. Santo André: Universidade Federal do ABC, 2013. p. 12-13.

156 SILVA JR., João dos Reis; SGUISSARDI, Valdemar. Novas faces da educação superior no Brasil: reforma do Estado e mudanças na produção. Bragança Paulista: EDUSF; Cortez, 2001. p. 24.

157 MARTINS, Carlos Benedito. A reforma universitária de 1968 e a abertura para o ensino superior privado no Brasil. Educação e Sociedade, Campinas, v. 30, n. 106, abr. 2009. p. 19. Disponível em: http://www.scielo.br/scielo.php?script=sci_arttext\&pid=S0101-73302009000100002\&lng=pt\&nrm=iso. Acesso em: 26. fev. 2020. 
o mercado financeiro e a Bolsa de Valores de São Paulo (Bovespa) negociam transações, depois que mantenedoras de ensino superior abriram suas ações para venda, sendo o crescimento do mercado financeiro nesse período, consequência da mercantilização educacional ${ }^{158}$.

\begin{abstract}
A mercantilização da educação trouxe muitos entraves para a educação brasileira, uma vez que ela se transformou em organização social, abandonando a pesquisa e a extensão universitária para se dedicar ao ensino em um mercado competitivo, assim como subordinou a formação e a produção acadêmica às condições e exigências do mercado financeiro, ou seja, a educação transformou-se em grande capital ${ }^{159}$.
\end{abstract}

Segundo pesquisa numérica levantada por Maria Gracileide Alberto Lopes ${ }^{160}$, "a expansão do ensino superior é perceptível pela duplicação das matrículas entre os anos de 1968 a 1971, atingindo um número de 561.397, dobrados novamente nos sete anos seguintes", conforme a Tabela 3.

Tabela 3 - Número de matrículas entre 1968 e 1971

\begin{tabular}{c|c}
\hline Ano & Matrículas \\
\hline 1968 & 278.295 \\
\hline 1971 & 561.397 \\
\hline 1977 & 1.159 .046 \\
\hline 1980 & 1.377 .286 \\
\hline
\end{tabular}

Fonte: Alberto Lopes, 2018.

Os anos 1990 foram marcados por disputas entre projetos bem marcados: de um lado, alguns setores defendiam a educação privada no âmbito da gestão e forma de pensar a educação, e, de outro lado, movimentos sociais buscavam a implementação de uma educação em sua concepção materialista, com base em uma escola unitária. Após os anos 1990, a política educacional é tida como fragmentada e de estrutura dualista ${ }^{161}$.

No ano de 1996 é que a promulgação da LDB consolida essa expansão extraordinária da educação superior privada, com a possibilidade de compras, vendas e fusões de estabelecimentos educacionais, movimento esse denominado como mercantilização da

158 MORA, José Ginés. O processo de modernização das universidades europeias: o desafio da sociedade do conhecimento e da globalização. In: AUDY, Jorge Luis Nicolas; MOROSINI, Marília Costa (org.). Inovação e empreendedorismo na universidade. Porto Alegre: EDIUCRS, 2006. p. 140.

159 ALBERTO LOPES, Maria Gracileide. A mercantilização do ensino superior no contexto atual: considerações para o debate. Interfaces Científicas - Educação, Aracaju, v. 6, n. 2, p. 29-44, fev. 2018. p. 35. Disponível em: https://periodicos.set.edu.br/index.php/educacao/article/view/4249. Acesso em: 25 . fev. 2020.

${ }^{160}$ Ibid., p. 32.

161 Id., p. 33. 
educação superior ${ }^{162}$.

[...] uma das novas faces da educação superior no Brasil, com ênfase no que se viu no setor privado, traduz-se na subsunção ao econômico e na aproximação identitária cada vez maior dessas IES ao modelo de empresas prestadoras de serviços, o que é condicionado por novas formas de organização e de gestão, em um contexto de adensamento dos aspectos mercantis desse setor e do acirrado movimento de concorrência entre suas IES, nunca dantes em tal grau presenciado nesse nível de ensino. Diante disso, são previsíveis sérios impactos sobre a organização da educação superior brasileira, assim como, por decorrência, sobre a produção científica e a organização da sociedade no Brasil ${ }^{163}$.

Essa proliferação desenfreada dos cursos na educação superior obviamente colocou em dúvida a qualidade dos serviços prestados por essas instituições. Ademais, ainda que em nome do acesso à educação superior como mecanismo de ascensão social, é evidente que a quantidade não pode ser priorizada em detrimento da qualidade, uma vez que a universidade só logra êxito no alcance de seus objetivos se for reconhecido o sucesso em sua produção científica e na contribuição à sociedade onde está inserida, verificando-se assim a efetividade da implementação do princípio da indissociabilidade entre ensino, pesquisa e extensão.

Nos anos posteriores, identifica-se o processo de crise da universidade brasileira, diante da escassez de recursos financeiros, atrelado ao fim do crescimento da expansão das instituições privadas, interferindo diretamente em sua finalidade lucrativa ${ }^{164}$. No período de 2003 a 2010, como apontado pela pesquisa mencionada, diversas ações foram tomadas visando uma readequação da política educacional. Nesse sentido, vale transcrever o quadro sinótico (Quadros 2 e 3) apresentado por Kátia Lima ${ }^{165}$ :

162 ALBERTO LOPES, Maria Gracileide. A mercantilização do ensino superior no contexto atual: considerações para o debate. Interfaces Científicas - Educação, Aracaju, v. 6, n. 2, p. 29-44, fev. 2018. p. 33. Disponível em: https://periodicos.set.edu.br/index.php/educacao/article/view/4249. Acesso em: 25 . fev. 2020.

${ }^{163}$ SILVA JR., João dos Reis; SGUISSARDI, Valdemar. Novas faces da educação superior no Brasil: reforma do Estado e mudanças na produção. Bragança Paulista: EDUSF; Cortez, 2001. p. 255.

164 ALBERTO LOPES, loc. cit.

${ }^{165}$ LIMA, Kátia. Expansão da educação superior brasileira na primeira década do novo século. In: PEREIRA, Larissa Dahmer; ALMEIDA, Ney Luiz Teixeira (org.). Serviço social e educação. Rio de Janeiro: Lumen Juris, 2013. p. 11-34. 
Quadro 2 - Principais ações governamentais na política da educação superior no período de 2003 a 2010 (governo Lula)

\begin{tabular}{|c|c|}
\hline Ato normativo & Conteúdo \\
\hline $\begin{array}{l}\text { Grupo de trabalho } \\
\text { Interministerial em } 20 \text { de } \\
\text { outubro de } 2003\end{array}$ & $\begin{array}{l}\text { O grupo de trabalho elaborou o documento Bases para o Enfrentamento da Crise } \\
\text { Emergencial das Universidades Federais e Roteiro para a Reforma Universitária } \\
\text { Brasileira }\end{array}$ \\
\hline $\begin{array}{l}\text { Medida Provisória }{ }^{\circ} 147 \text { de } \\
15 \text { de dezembro de } 2003\end{array}$ & $\begin{array}{l}\text { Instituiu o Sistema Nacional de Avaliação e Progresso do Ensino Superior } \\
\text { (Sinapes) }\end{array}$ \\
\hline $\begin{array}{l}\text { Grupo Executivo da Reforma } \\
\text { do Ensino Superior em } 06 \text { de } \\
\text { fevereiro de } 2004\end{array}$ & $\begin{array}{l}\text { Elaborou o documento reafirmando princípios e consolidando diretrizes da } \\
\text { reforma da educação superior }\end{array}$ \\
\hline $\begin{array}{l}\text { Lei }{ }^{\circ} 10.861 \text { de } 14 \text { de abril } \\
\text { de } 2004\end{array}$ & nstitui o Sistema Nacional de Avaliação da Educação Superior (Sinaes) \\
\hline $\begin{array}{l}\text { Decreto Presidencial n. } 5.205 \\
\text { de } 14 \text { de setembro de } 2004\end{array}$ & $\begin{array}{l}\text { Regulamenta as parcerias entre as universidades federais e as fundações de } \\
\text { direito privado }\end{array}$ \\
\hline $\begin{array}{l}\text { Medida Provisória }{ }^{\circ} 213 \text { de } \\
10 \text { de setembro de } 2004\end{array}$ & Institui o Programa Universidade para Todos (Prouni) \\
\hline Projeto de Lei n $3627 / 2004$ & $\begin{array}{l}\text { Trata do sistema especial de reserva de vagas para estudantes egressos de escolas } \\
\text { públicas, em especial negros e indígenas, nas instituições públicas federais de } \\
\text { educação superior }\end{array}$ \\
\hline $\begin{array}{l}\text { Lei de Inovação Tecnológica } \\
\text { n}^{\circ} 10.973 \text { de } 02 \text { de dezembro } \\
\text { de } 2004\end{array}$ & Trata do estabelecimento de parcerias entre universidade públicas e empresas \\
\hline $\begin{array}{l}\text { Lei de Parceria Público- } \\
\text { Privada } n^{\circ} 11.079 \text { de } 30 \text { de } \\
\text { dezembro de } 2004\end{array}$ & $\begin{array}{l}\text { Institui normas gerais para licitação e contratação de parceria público-privada no } \\
\text { âmbito da administração pública }\end{array}$ \\
\hline $\begin{array}{l}\text { Lei } n^{\circ} 11.096 \text { de } 13 \text { de janeiro } \\
\text { de } 2005\end{array}$ & $\begin{array}{l}\text { Institui o Programa Universidade para Todos, que trata de "generosa" ampliação } \\
\text { de isenção fiscal para as instituições privadas de ensino superior }\end{array}$ \\
\hline $\begin{array}{l}\text { Projeto de Lei } \mathrm{n}^{\circ} 7.200 / 2006 \\
\left.\text { (apensado ao PL } \mathrm{n}^{\circ} 4.221 / 04\right)\end{array}$ & $\begin{array}{l}\text { Legislação que trata da regulamentação do ensino a distância (EAD) e da criação } \\
\text { da Universidade Aberta do Brasil (UAB), consórcio para oferta de curso a } \\
\text { distância }\end{array}$ \\
\hline $\begin{array}{l}\text { Decreto } \mathrm{n}^{\circ} 6.095 \text { de } 24 \text { de } \\
\text { abril de } 2007\end{array}$ & $\begin{array}{l}\text { Estabelece diretrizes para o processo de integração de instituições federais de } \\
\text { educação tecnológica para fins de constituição dos Institutos Federais de } \\
\text { Educação, Ciência e Tecnologia (Ifet), no âmbito da Rede Federal de Educação } \\
\text { e Tecnológica }\end{array}$ \\
\hline $\begin{array}{l}\text { Decreto Presidencial } \mathrm{n}^{\mathrm{o}} \\
\text { 6069/07 e a divulgação das } \\
\text { Portarias Interministeriais } \mathrm{n}^{\circ} \\
\text { 22/07 e 224/07 (Ministério do } \\
\text { Planejamento, Orçamento e } \\
\text { Gestão [MPOG] e MEC) }\end{array}$ & $\begin{array}{l}\text { Decreto de criação do Programa de Apoio a Planos de Restruturação e } \\
\text { Expansão das Universidades Federais (Reuni) e portarias que tratam da criação } \\
\text { de um Banco de Professor- Equivalente, inscritos no Plano de } \\
\text { Desenvolvimento da Educação (PDE) em } 2007\end{array}$ \\
\hline $\begin{array}{l}\text { "Pacote de autonomia" em } \\
2010 \text { e composto pela Medida } \\
\text { Provisória } \mathrm{n}^{\circ} 495 / 10 \text { e pelos } \\
\text { Decretos } \mathrm{n}^{\mathrm{o}} 7232,7233 \mathrm{e} \\
7234 / 10 \\
\text { Convertida na Lei } \mathrm{n}^{\circ} 12.349 \\
\text { de } 15 \text { de dezembro de } 2010\end{array}$ & $\begin{array}{l}\text { Esse "pacote" amplia a ação das fundações de direito privado nas universidades } \\
\text { federais; retira das universidades a definição dos projetos acadêmicos a serem } \\
\text { financiados, transferindo essa prerrogativa para as fundações de direito } \\
\text { privado; legaliza a quebra do regime de trabalho de dedicação exclusiva; não } \\
\text { resolve a falta de técnico-administrativos, criando somente um mecanismo de } \\
\text { realocação de vagas entre as instituições federais de ensino superior (Ifes); cria } \\
\text { as condições para a diferenciação dos orçamentos das Ifes, de acordo com } \\
\text { índices de produtividade, intensificando ainda mais o trabalho docente; e, por } \\
\text { fim, cria o Programa Nacional de Assistência Estudantil (Pnaes), sem deixar } \\
\text { claro onde sairão os recursos financeiros para realização do Programa }\end{array}$ \\
\hline $\begin{array}{l}\text { Medida Provisória } \text { n }^{\circ} 520 \text { de } \\
31 \text { de dezembro de } 2010 \text { (não } \\
\text { foi convertida em lei) }\end{array}$ & $\begin{array}{l}\text { Autoriza a criação da Empresa Brasileira de Serviços Hospitalares. Embora } \\
\text { estatal e vinculada ao MEC, a nova entidade terá responsabilidade jurídica de } \\
\text { direito privado, flexibilizando a contratação de trabalhadores dos hospitais } \\
\text { universitários }\end{array}$ \\
\hline
\end{tabular}

Fonte: Lima, 2013. 
Quadro 3 - Principais ações governamentais na política da educação superior no período de 2011 a 2018 (governo Dilma e Temer) ${ }^{166}$

\begin{tabular}{|c|c|}
\hline Ato normativo & Conteúdo \\
\hline $\begin{array}{l}\text { Lei de Cotas }- \text { Lei } n^{\circ} \\
12.711 \text { de } 29 \text { de agosto de } \\
2012\end{array}$ & $\begin{array}{l}\text { Trata do sistema especial de reserva de vagas para estudantes egressos de escolas } \\
\text { públicas, em especial negros e indígenas, nas instituições públicas federais de } \\
\text { educação superior }\end{array}$ \\
\hline $\begin{array}{l}\text { Lei } \mathrm{n}^{\mathrm{o}} 12.858 \text {, de } 09 \text { de } \\
\text { setembro de } 2013\end{array}$ & $\begin{array}{l}\text { Dispõe sobre a destinação para as áreas de educação e saúde de parcela da } \\
\text { participação no resultado ou da compensação financeira pela exploração de } \\
\text { petróleo e gás natural, com a finalidade de cumprimento da meta prevista no } \\
\text { inciso VI do caput do art. } 214 \text { e no art. } 196 \text { da Constituição Federal }\end{array}$ \\
\hline $\begin{array}{l}\text { Lei } \mathrm{n}^{\mathrm{o}} 13.005 \text {, de } 25 \text { de } \\
\text { junho de } 2014\end{array}$ & Nacional de Fducacãoe dá \\
\hline $\begin{array}{l}\text { Lei } \mathrm{n}^{\circ} 13.174 \text {, de } 21 \text { de } \\
\text { outubro de } 2015\end{array}$ & $\begin{array}{l}\text { Insere inciso VIII no art. } 43 \text { da Lei } \mathrm{n}^{\circ} 9.394 \text {, de } 20 \text { de dezembro de } 1996 \text {, que } \\
\text { estabelece as diretrizes e bases da educação nacional, para incluir, entre as } \\
\text { finalidades da educação superior, seu envolvimento com a educação básica }\end{array}$ \\
\hline $\begin{array}{l}\text { Lei } \mathrm{n}^{\mathrm{o}} 13.243 \text {, de } 11 \text { de } \\
\text { janeiro de } 2016\end{array}$ & $\begin{array}{l}\text { Dispõe sobre estímulos ao desenvolvimento científico, à pesquisa, à capacitação } \\
\text { científica e tecnológica e à inovação e altera a Lei no } 10.973 \text {, de } 2 \text { de dezembro } \\
\text { de } 2004 \text {, a Lei } n^{\circ} 6.815 \text {, de } 19 \text { de agosto de } 1980 \text {, a Lei }{ }^{\circ} 8.666 \text {, de } 21 \text { de junho } \\
\text { de } 1993 \text {, a Lei } n^{\circ} 12.462 \text {, de } 4 \text { de agosto de } 2011 \text {, a Lei }{ }^{\circ} 8.745 \text {, de } 9 \text { de dezembro } \\
\text { de } 1993 \text {, a Lei } n^{\circ} 8.958 \text {, de } 20 \text { de dezembro de } 1994 \text {, a Lei } n^{\circ} 8.010 \text {, de } 29 \text { de } \\
\text { março de } 1990 \text {, a Lei } \text { n }^{\circ} 8.032 \text {, de } 12 \text { de abril de } 1990 \text {, e a Lei } \text { n }^{\circ} 12.772 \text {, de } 28 \\
\text { de dezembro de } 2012 \text {, nos termos da Emenda Constitucional } n^{\circ} 85 \text {, de } 26 \text { de } \\
\text { fevereiro de } 2015\end{array}$ \\
\hline $\begin{array}{l}\text { Lei } \mathrm{n}^{\mathrm{o}} 13.490 \text {, de } 10 \text { de } \\
\text { outubro de } 2017\end{array}$ & $\begin{array}{l}\text { Altera o art. } 53 \text { da Lei } \text { n }^{\circ} 9.394 \text {, de } 20 \text { de dezembro de } 1996 \text { (Lei de Diretrizes e } \\
\text { Bases da Educação Nacional), para dispor sobre doações às universidades }\end{array}$ \\
\hline $\begin{array}{lllll}\text { Lei } n^{\circ} & 13.530 & \text { de } & 7 & \text { de } \\
\text { dezembro de } 2017 & & \end{array}$ & $\begin{array}{l}\text { Altera substancialmente o Fundo de Financiamento Estudantil (Fies), reduzindo } \\
\text { o investimento público com essa política em razão da implementação de corte de } \\
\text { gastos públicos em diversos setores }\end{array}$ \\
\hline
\end{tabular}

Fonte: Elaborado pela autora, a partir de dados extraídos de consulta realizada ao site da Associação Brasileira de Mantenedoras de Ensino Superior (c2020).

Para constatar o impacto dessas políticas públicas relatadas no cenário da educação jurídica, foi necessário compilar e efetuar uma análise sobre os números atuais do referido setor.

De acordo com a mais recente sinopse estatística, divulgada pelo Inep ${ }^{167}$, sobre os dados coletados no ano de 2018, fora constatado o total de 1.010 (mil e dez) instituições de ensino superior em regular atividade no Brasil que oferecem cursos de Direito. Dessas instituições, 99 (noventa e nove) são de natureza pública e 911 (novecentas e onze), de natureza privada. São 1.303 (mil trezentos e três) cursos atualmente ofertados, implicando em um total de 272.613 (duzentos e setenta e dois mil, seiscentos e treze) vagas oferecidas em todo o país.

O atual número de alunos matriculados em cursos de Direito em todo o Brasil é de 1.243.855 (um milhão, duzentos e quarenta e três mil, oitocentos e cinquenta e cinco), o que por si só já demonstra o grande impacto de pessoas diretamente envolvidas nesse cenário de

${ }^{166}$ Dados extraídos de consulta realizada ao site da ABMES. Cf. ASSOCIAÇÃO BRASILEIRA DE MANTENEDORAS DE ENSINO SUPERIOR. Legislação. Brasília, DF: ABMES, c2020. Disponível em: https://abmes.org.br/legislacoes. Acesso em: 7 abr. 2020.

167 INSTITUTO NACIONAL DE ESTUDOS E PESQUISAS EDUCACIONAIS ANÍSIO TEIXEIRA. Sinopse Estatística da Educação Superior 2018. Brasília, DF: Inep, 2019a. Disponível em: http://inep.gov.br/sinopses-estatisticas-da-educacao-superior. Acesso em: 05 out. 2019. 
crise que é aqui estudado, já que, como apontado até o momento, os objetivos constitucionais da educação jurídica quiçá conseguirão ser atingidos pelo atual sistema desempenhado.

\begin{abstract}
Não seria exagero dizer que o ensino jurídico no Brasil está praticamente entregue à lógica do lucro e da exploração econômica, levada a efeito pelos empresários da educação que passaram a enxergar nesse "filão" de mercado um negócio extremamente lucrativo. Observe-se que, entre os fatores que contribuíram significantemente para a proliferação dos cursos jurídicos no país está exatamente o baixo custo desse investimento, centrado basicamente na contratação de professores e funcionários - aqueles nem sempre titulados - bem como na construção de salas de aula. O curioso, ou talvez irônico, é que esse investimento privado na expansão das escolas de direito é realizado em nome de uma suposta democratização da universidade e do princípio da liberdade de empresa, cujos argumentos sempre buscaram escamotear o forte impacto negativo dessa proliferação de escolas sobre a cultura jurídica nacional ${ }^{168}$.
\end{abstract}

Como mencionado alhures, para poder apresentar devidamente as distorções do atual sistema de ensino superior brasileiro, as referidas instituições podem ser classificadas, em um primeiro momento, entre públicas e privadas, levando em consideração que as instituições públicas são (ou pelo menos deveriam ser) aquelas geridas, administradas e mantidas integral e somente com patrimônio público, de quaisquer dos entes da federação. Já as privadas são aquelas cuja atividade é desempenhada por uma pessoa jurídica de direito privado, ainda que realize suas atividades sob o manto do regime de direito público em razão do relevante interesse público relativo ao serviço que prestam.

Sucessivos governos, ao invés de contribuírem para enfrentar os desafios a que a população brasileira tem sido submetida - desemprego sazonal (agora também estrutural), alto custo de vida, elevados índices de violência etc. -, têm sido coniventes com inúmeras distorções cometidas desde a cartelização de mantenedoras, a manutenção de mensalidades em patamares elevados, a fusão de estabelecimentos e de turmas, que têm servido para gerar uma retenção e uma evasão surpreendentes ${ }^{169}$.

Allan Aroni é preciso quando sustenta que a verdadeira democratização, com o consequente acesso ao ensino superior de efetiva qualidade, tem se caracterizado como grande desafio para a sociedade, justamente porque na contramão da garantia do acesso e da permanência dos estudantes a um ensino de boa qualidade, o poder público continua delegando a oferta de vagas à iniciativa privada, permitindo que esta aufira lucros através de atividades

168 MACHADO, Antônio Alberto. Ensino jurídico e mudança social. Franca: Unesp, 2005. p. 109.

169 ARONI, Allan. O ensino superior como atividade empresarial e o cidadão mínimo no Brasil: o peso da mão liberal e a marca de uma aliança não visível: uma análise do ensino superior brasileiro a partir dos dilemas que envolvem as políticas públicas. 2008. 215 f. Dissertação (Mestrado em Educação) - Faculdade de Educação, Universidade de São Paulo, São Paulo, 2008. p. 26. Disponível em: https://www.teses.usp.br/teses/disponiveis/48/48134/tde-09102008-115646/pt-br.php. Acesso em: 8 fev. 2015. 
escolares restritas a um exíguo grupo pagante ou beneficiário de alguma medida assistencialista dos indistinguíveis governos ${ }^{170}$.

$\mathrm{O}$ autor ainda enfatiza que, ao mesmo tempo, a expansão das vagas que se vem operando é tratada como se fosse democratizante, ainda que como consequência superlote as salas de aula com: desrespeito à indissociabilidade entre ensino, pesquisa e extensão, precariedade de bibliotecas e laboratórios, quando existentes, e não contratação, em número suficiente, de colaboradores técnico-administrativos e de professores, sobretudo em regime de dedicação integral ${ }^{171}$.

\begin{abstract}
Nesta visão, o professor torna-se mero prestador de serviços, pronto para satisfazer a todos os anseios e necessidades subjetivas do aluno, e sua função pedagógica resumese a "ter o cliente sempre satisfeito". [...] De acordo com a política da "máxima satisfação do cliente', 'que não pode ser aborrecido', senão pede transferência para outra IES, dentro de sua liberdade de opção, num mercado competitivo, qualquer contrariedade por parte do professor quanto a seu aproveitamento escolar, quanto a sua postura acadêmica, é motivo de fortes repreensões, por vezes de iniciativa da própria IES, afeita ao apreço pelo aluno, paternalista na defesa do seu cliente. [...] O professor torna-se um mercantilista que vende satisfação e contentamento aos seus alunos e não um didata de assuntos de sua especialidade ${ }^{172}$.
\end{abstract}

Por certo, existem exceções a essa regra, mas elas constituem iniciativas isoladas, que dependem mais da dedicação de professores, colaboradores técnico-administrativos e estudantes do que propriamente de condições propiciadas por essas instituições particulares que efetivamente lucram para isso.

\title{
2.2 Crise da educação jurídica brasileira e a parcela de responsabilidade dos envolvidos
}

Apesar da reconhecida importância do lugar e do papel que a universidade tem desempenhado no desenvolvimento das sociedades em suas múltiplas dimensões, muitas críticas têm pesado sobre qual a sua missão diante da denominada Revolução 4.0, em um mundo de rápidas transformações no qual a aquisição de conhecimento tem se tornado moeda de alto valor.

170 ARONI, Allan. O ensino superior como atividade empresarial e o cidadão mínimo no Brasil: o peso da mão liberal e a marca de uma aliança não visível: uma análise do ensino superior brasileiro a partir dos dilemas que envolvem as políticas públicas. 2008. 215 f. Dissertação (Mestrado em Educação) - Faculdade de Educação, Universidade de São Paulo, São Paulo, 2008. p. 26. Disponível em: https://www.teses.usp.br/teses/disponiveis/48/48134/tde-09102008-115646/pt-br.php. Acesso em: 18 fev. 2019.

171 Ibid.

172 BITTAR, Eduardo Carlos Bianca. O ensino jurídico na pós-modernidade. In: ANUÁRIO ABEDI. Florianópolis: Fundação Boiteux, ano 3, n. 3, p. 91, 2005. 
Pesquisadores sobre a educação em todas as áreas efetuam considerações relevantes sobre o papel difuso da universidade, apontando que, apesar de o valor reconhecido de sua existência ser inegável, há um sentimento geral de frustração decorrente das expectativas não atingidas quanto a promessas que não se cumprem após a formação do discente ao longo do curso no qual se forma.

A universidade atualmente é duplamente desafiada, pela sociedade e pelo Estado, os quais são seus principais atores e destinatários finais do serviço, pois o serviço por ela prestado, de natureza essencialmente pública, possui o condão de atender à população e melhorar a sociedade. No entanto, atualmente reconhece-se que ela não parece estar preparada para encarar os desafios que são atualmente impostos, porque eles exigem que haja permanente adaptação e profundas transformações para adequação à nova realidade da sociedade. É justamente por isso que é possível inferir a existência de uma crise na educação superior.

Há extensa produção acadêmica que se preocupa com o diagnóstico e a idealização de possíveis mecanismos voltados à superação da crise da educação jurídica. Horácio Wanderlei Rodrigues nos apresenta vasta lista de autores voltados à reflexão sobre essa temática, além de ele próprio mencionar Alberto Venancio Filho, Álvaro Melo Filho, Aurélio Wander Chaves Bastos, Edmundo Lima de Arruda Junior, Eliane Botelho Junqueira, João Baptista Villela, Joaquim Arruda Falcão, José Eduardo Faria, Luis Alberto Warat, Paulo Luiz Netto Lôbo, Roberto Fragale Filho e Roberto Lyra Filho ${ }^{173}$.

Um dos fatores, mas não o único, que Horácio Wanderlei Rodrigues descreve como condicionante para referida crise na educação jurídica foi justamente o desenfreado crescimento do número de vagas e dos cursos de Direito em todo Brasil, principalmente em instituições pertencentes à iniciativa privada. Todavia, tal fator está longe de ser o responsável exclusivo pela crise estrutural que a educação jurídica suporta.

Para esclarecimento dos meandros inerentes à crise, o autor nos apresenta o seguinte esquema representativo (Esquema 3) da realidade da educação superior na área do Direito no Brasil que será a seguir detalhado.

173 RODRIGUES, Horácio Wanderlei. Pensando o ensino do direito no século XXI: diretrizes curriculares, projeto pedagógico e outras questões pertinentes. Florianópolis: Fundação Boiteux, 2005. p. 29. 
Esquema 3 - Educação jurídica vigente no Brasil

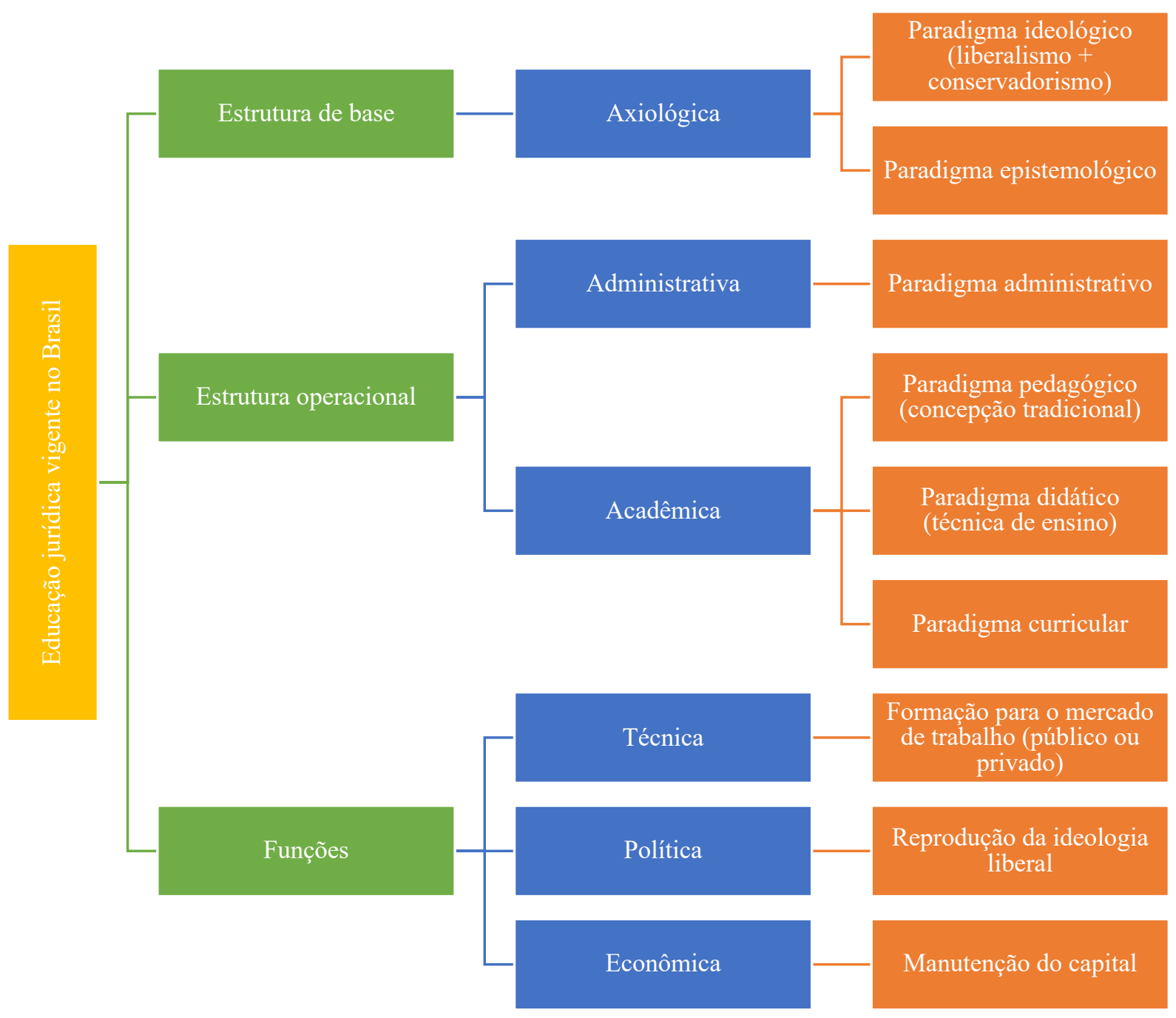

Fonte: Rodrigues, 2005.

Segundo o autor, esse esquema-resumo nos situa de forma didática sobre quais são as principais questões relativas ao ensino superior na área do Direito em seus diferentes níveis. Para tanto, é imprescindível mencionar que a crise educacional não caminha alheia à crise da sociedade, inclusive porque muitas de suas causas são consequência direta do atual cenário social, político e econômico brasileiro. Falaremos, portanto, da crise estrutural, operacional e técnica enfrentada pela atual educação jurídica desempenhada no Brasil.

No quadro social, político e econômico brasileiro, uma série de fenômenos vem contribuindo para a crise do ensino do Direito. Entre eles, as mudanças por que tem passado o país nos últimos anos, as quais tem levado a uma extensa produção 
legislativa [...]. Novos instrumentos de controle social, cada vez mais complexos, têm surgido: a ciência e a tecnologia são hoje as suas formas mais efetivas. Esses fatos fazem com que cada dia se exija dos profissionais do Direito uma visão mais ampla, e não apenas legalista, para que eles possam participar ativamente no processo social global, deixando de ser meros técnicos ligados exclusivamente às atividades forenses. Modificaram-se as exigências com relação à prática profissional do jurista, mas o ensino do Direito não acompanhou essa evolução ${ }^{174}$.

A atual crise da educação jurídica é extremamente complexa, sendo que quaisquer tentativas simplistas efetuadas não serão capazes de retratar seu aspecto multifacetário. A compreensão da atual situação exige análise integral e dialética, que seja capaz de analisar essa realidade como um todo.

Horácio Wanderlei Rodrigues, em uma abordagem precisa desse complexo cenário, apresenta visão esquemática, que tem como ponto de partida o Esquema 3, comprovando o aspecto múltiplo da crise da educação jurídica, a qual acontece nos três níveis que fundamentam a educação jurídica nacional, conforme o Esquema 4:

Esquema 4 - Educação jurídica

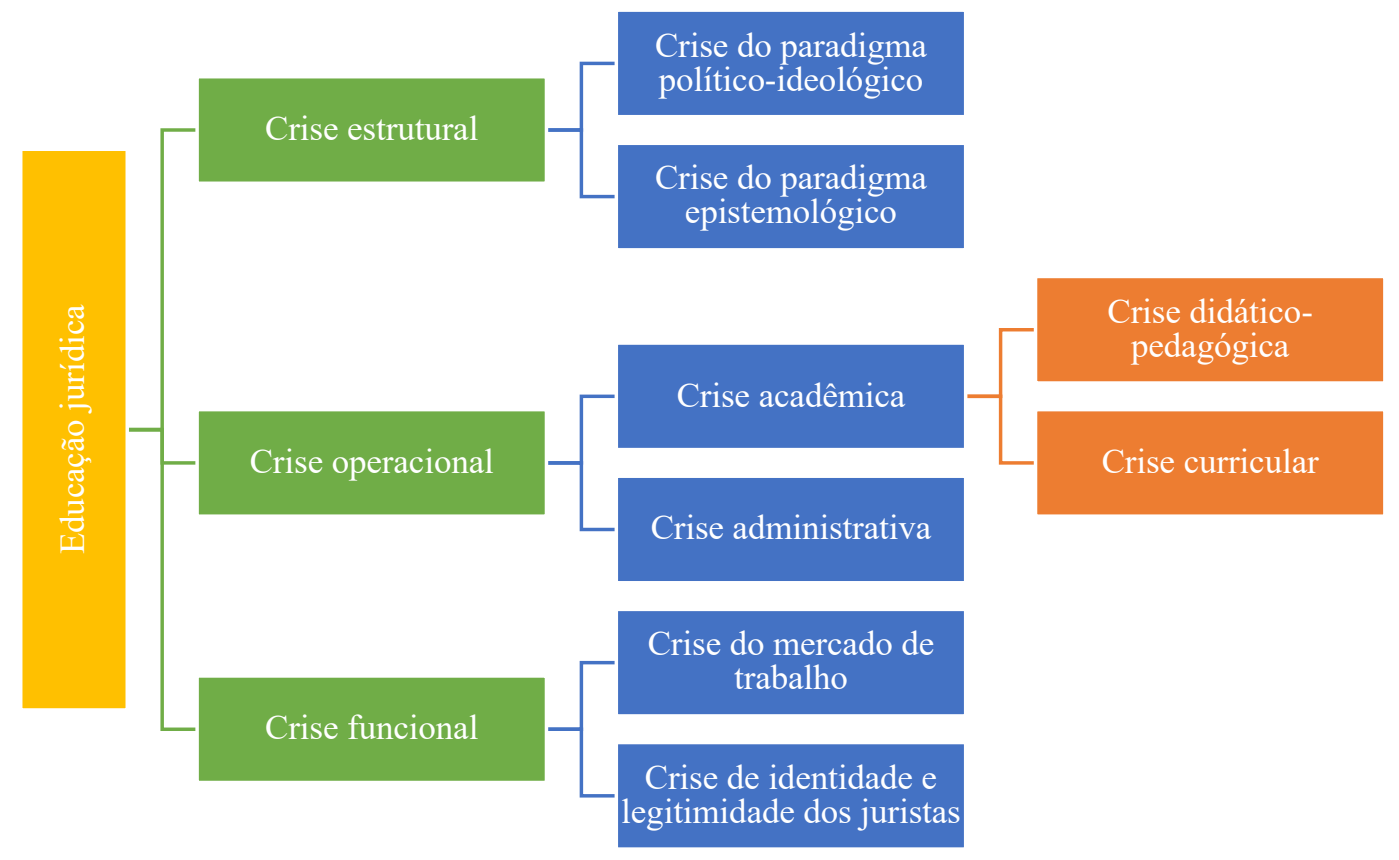

Fonte: Rodrigues, 2005.

A crise estrutural se relaciona com o aspecto axiológico do Direito, ou seja, está intimamente ligado aos valores que essa área do conhecimento se propõe a conservar e

174 RODRIGUES, Horácio Wanderlei. Pensando o ensino do direito no século XXI: diretrizes curriculares, projeto pedagógico e outras questões pertinentes. Florianópolis: Fundação Boiteux, 2005. p. 34. 
perpetuar. Nesse sentido, é correto dizer que a crise estrutural pode ser observada tanto na vertente do paradigma ideológico quanto no paradigma epistemológico.

De acordo com a educação jurídica vigente no Brasil, no que atine ao aspecto axiológico, observamos dois paradigmas que sustentam os valores que a educação jurídica pretende perpetuar: o paradigma ideológico e o paradigma epistemológico.

No paradigma ideológico, a educação do Direito busca a proteção e continuidade do liberalismo com nuances de conservadorismo, enquanto no paradigma epistemológico, ou seja, naquilo que é relativo à forma pela qual os estudantes se apropriarão do conhecimento jurídico, o direito que se conhece e que se ensina atualmente está fundado em uma base positivista, de cunho normativista baseado em uma metodologia lógico-formal de base dedutivista.

A breve menção desses aspectos em que a educação jurídica se funda já é capaz de nos fazer perceber a existência de uma quebra entre esses valores e a atual sociedade em que vivemos. Assim, a crise da educação jurídica no Brasil não é somente interna. Está, em verdade, imersa na crise do próprio modelo político, econômico e social adotado em nosso país, que busca concretizar suas crenças e seus valores através de aspectos jurídicos. Os problemas e as crises do sistema trazem desdobramentos em todos os subsistemas que com ele se relacionam, entre eles, o educacional e o jurídico ${ }^{175}$.

Especificamente no que atine à educação na área do Direito, essa vinculação entre Estado e sua implementação acontece de maneira mais clara, haja vista que desde a sua criação a educação jurídica tem como objetivo manter o aparelho ideológico do Estado como um de seus alicerces $^{176}$.

A falência do Estado é, portanto, a falência do Direito, e vice-versa [...]. O que se ensina é o Direito contextualmente construído a partir dessas crenças e posições político-ideológicas, mas apresentado como neutro e comprometido com a justiça e a democracia. Para que se possa ter um ensino transformador, é necessário que ele deixe de ser um aparelho ideológico do Estado - mera instância reprodutora - e se

175 RODRIGUES, Horácio Wanderlei. Pensando o ensino do direito no século XXI: diretrizes curriculares, projeto pedagógico e outras questões pertinentes. Florianópolis: Fundação Boiteux, 2005. p. 36.

176 No capitalismo, o Estado passa a ser encarado como instituição e regula comportamentos, atos e relações sociais, por meio do Direito. É com base na noção de contrato que conseguimos observar a manutenção do sistema proposto pelo capitalismo, isso porque, essa é a célula menor que dá sustentação à todo sistema. Com o advento do capitalismo, há a necessidade de estabilização da sociedade para que ela possa ser tratada com rigor técnico, para que as relações sociais travadas entre as pessoas não se esmoreçam com facilidade e principalmente para que o dono do capital não precise agir por força bruta na tentativa de concretizar seus objetivos. $\mathbf{O}$ direito é estrutura fundante da sociedade capitalista. Tal afirmação é possível de ser realizada com base apenas no entendimento de que o maior interessado na concretização das relações por ele estabelecidas, sejam devidamente realizadas sem a necessidade de coerção física como acontecia outrora. Neste momento, o detentor do capital necessita da força coercitiva de um terceiro, que aparenta neutralidade para assegurar que seus interesses sejam devidamente garantidos. Sobre o papel estrutural do Direito na manutenção do aparelho ideológico do Estado, cf. MASCARO, Alysson Leandro. Estado e forma política. São Paulo: Boitempo, 2013. 
transforme em uma instancia orgânica de construção de um novo imaginário social criativo e comprometido com os valores da maioria da população. Sua vinculação deve ser com a sociedade e não com os interesses dos grupos que detêm o poder do Estado $^{177}$.

Portanto, a crise do paradigma político-ideológico mistura-se com a crise do papel do Estado na sociedade atual. A educação jurídica está longe de ser a ferramenta exclusiva capaz de transformar e superar essa crise estrutural; todavia, é preciso reconhecer que, como instância privilegiada, possui destaque e protagonismo na formação e reprodução da ideologia do Estado no qual está inserido. Porém, essa modificação é apenas parcial, pois ela não possui abrangência necessária para proporcionar uma revolução.

Assim, para conquistar uma transformação, há que primeiramente reconhecer a importância do papel dos cursos de Direito na formação acadêmica de considerável parcela dos políticos do país e da burocracia estatal, sem mencionar que é exclusiva a sua responsabilidade na formação dos membros do Poder Judiciário, de grande parcela dos seus servidores e dos cargos inerentes às funções essenciais à Justiça, tais como Ministério Público e advocacias públicas e privadas.

Observando em números os gastos que o Estado brasileiro efetivamente despende para a manutenção do sistema jurídico, é preciso reconhecer que a formação desse pessoal tem protagonismo no desenvolvimento nacional e, portanto, deve ser repensada diante de uma constatada ineficiência dos objetivos aos quais se propõe.

Como forma de tentar superar a crise em seu paradigma político-ideológico, a educação jurídica deve se propor a construir um novo imaginário, comprometido com a democracia, a ética, a justiça social e a construção de uma sociedade solidária.

Deve o ensino do Direito formar agentes sociais críticos, competentes e
comprometidos com as mudanças emergentes, com o novo; operadores jurídicos que
possuam uma qualificação técnica de alto nível, acompanhada da consciência de seu
papel social, da importância estratégica que possuem todas as atividades jurídicas no
mundo contemporâneo e, portanto, da responsabilidade que lhes compete nessa
caminhada $^{178}$.

A crise estrutural também acontece no paradigma epistemológico, aquele que se destina à compreensão da teoria do conhecimento do Direito, no paradigma da ciência, e que o faz como forma de imposição de um saber em detrimento de outros. O atual paradigma

\footnotetext{
177 RODRIGUES, Horácio Wanderlei. Pensando o ensino do direito no século XXI: diretrizes curriculares, projeto pedagógico e outras questões pertinentes. Florianópolis: Fundação Boiteux, 2005. p. 38.

178 Ibid., p. 39.
} 
epistemológico se pauta em um positivismo de cunho normativista fundado em uma metodologia de lógica formal de base dedutivista, como já mencionado alhures.

Modificar essas bases consistiria em alterar a ciência do Direito, o que daria ensejo a colocar de lado a atual estrutura de produção de saberes e substituí-la por outra. Assim sendo, o atual modelo baseado no método lógico formal tem servido apenas para aprender o dever-ser, produzindo assim uma visão unidimensional do real e transformando a educação jurídica em mera descrição e interpretação do direito positivo vigente.

O posicionamento crítico tem fundamental importância nesse cenário porque, por buscar a compreensão e superação do atual sistema dominante, é por meio dele que será possibilitado um novo ato de criação. É preciso reconhecer que a produção do Direito e do conhecimento jurídico que dele decorre não será mais de exclusividade dos juristas.

A verdade é que a atual versão da educação jurídica produzida no Brasil não satisfaz. Nesse momento, o que se pode fazer é, como partícipes, auxiliar na busca da construção de uma sociedade democrática e solidária, recuperando no Direito o seu aspecto libertário e o colocando a serviço da justiça social efetiva. Porém, não há possibilidade de mudanças estruturais no ensino do Direito a partir do positivismo vigente.

Outra vertente da denominada crise está ligada às funções idealizadas que deveriam ser observadas com a efetivação da educação jurídica. Assim, o eixo funcional da educação na área do Direito se divide em três aspectos pretendidos de serem concretizados: técnico, político e econômico.

O objetivo do aspecto técnico da educação jurídica vigente consiste em formar operadores do Direito para trabalharem como profissionais liberais ou empregados na iniciativa privada, ou como agentes ou servidores públicos naquelas atividades nas quais se exige o diploma de bacharel em Direito. Assim, é com a concretização desse objetivo que deveria ser observada a efetivação da preparação para o mercado de trabalho prevista na Constituição Federal.

A função política da educação jurídica vigente, por sua vez, tem por objetivo sistematizar e reproduzir a ideologia liberal, enriquecida com elementos conservadores, através da formação e socialização do senso comum teórico dos juristas. Dessa forma, funcionará como instrumento de violência simbólica e exercerá o papel de aparelho ideológico. Já a função econômica se presta à formação de um singular exército acadêmico de reserva, com duas funções específicas: a excelência e a proletarização.

Dadas as premissas que as funções deveriam desempenhar na vigente educação do Direito no Brasil, passemos a tratar dos aspectos de crise identificados nesse setor, a qual está 
relacionada com a qualidade do produto final do processo educacional e sua absorção pelo mercado de trabalho. Assim, fala-se em crise consistente na inadequação da formação dos egressos para o mercado de trabalho e nos problemas de identidade e legitimidade dos operadores jurídicos.

Para dimensionar a crise no mercado de trabalho, é preciso inicialmente compreender a importância do curso de Direito para o Estado brasileiro e o seu mercado de trabalho. Para tanto, são apresentados dados sobre o Poder Judiciário nacional, fruto da pesquisa de Luciano Da Ros ao analisar o custo da justiça no Brasil em uma análise comparativa exploratória ${ }^{179}$.

Com apontamentos específicos sobre o Poder Judiciário, consegue-se começar a compreender a importância que referido poder tem para o Estado Brasileiro. Quando confrontado em números, nota-se que a relação entre o gasto público com a máquina judiciária e o produto interno bruto (PIB) nacional no Brasil é singular no mundo, como podemos verificar pelo Gráfico 1:

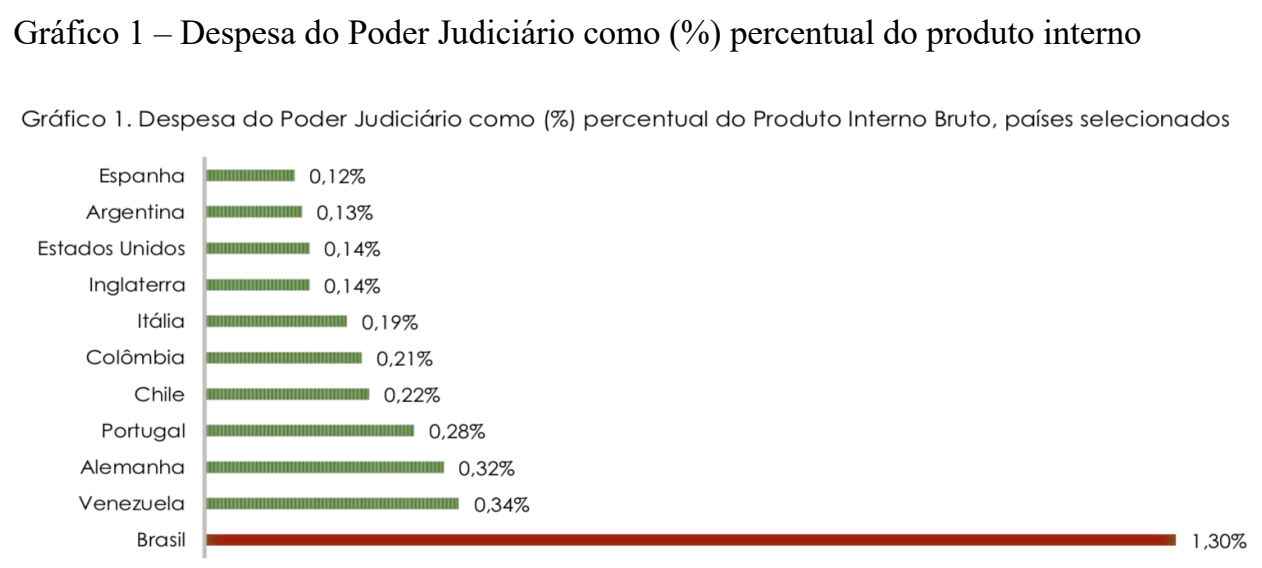

Fontes: CNJ 2014; European Commission for the Efficiency of Justice (CEPEJ) 2014, 32; Centro de Estudios de Justicia de las Américas (CEJA) 2007; National Center for State Courts (NCSC) 2012; Supreme Court of the United States (SCOTUS) 2012.

Fonte: Da Ros, 2015.

O orçamento destinado ao Poder Judiciário brasileiro é provavelmente o mais alto por habitante entre todos os países federais do hemisfério ocidental. Tal despesa é diversas vezes

179 “Quanto custa, portanto, o conjunto das instituições do sistema de justiça para a sociedade brasileira? A resposta curta é: muito caro. Começando pelo Poder Judiciário propriamente dito, ao considerarmos todos os diferentes "ramos" da justiça - i.e., estadual, federal, trabalhista, militar e eleitoral - e todos seus níveis hierárquicos - i.e., da primeira instância ao Supremo Tribunal Federal (STF), incluindo o Conselho Nacional de Justiça $(\mathrm{CNJ})$ - o orçamento global deste Poder do Estado brasileiro totalizou R\$ 62,3 bilhões em 2013, último ano para o qual há dados disponíveis (CNJ 2014, 38). O Gráfico apresenta dados nesse sentido e demonstra que o Poder Judiciário brasileiro é claramente um caso desviante em relação aos demais, sendo sua despesa proporcionalmente muito mais elevada que a de outras nações." (grifos nossos). Cf. DA ROS, Luciano. O custo da Justiça no Brasil: uma análise comparativa exploratória. Observatório de elites políticas e sociais do Brasil, Curitiba, v. 2, n. 9, p. 1-15, jul. 2015. Newsletter. p. 3-4. 
superior a de outros países em diferentes níveis de desenvolvimento, seja em valores proporcionais à renda média, seja em valores absolutos per capita.

De acordo com a mencionada pesquisa, a exemplo do que ocorre em grande parte dos países, a maior fatia das despesas com o Poder Judiciário no Brasil se destina ao pagamento de pessoal. Por aqui, esse percentual chega a aproximadamente $89 \%$ dos gastos, atendo-se a cerca de $70 \%$ em média nos países europeus ${ }^{180}$.

Isso não significa, todavia, que tais gastos se devam necessariamente à remuneração de juízes. O Poder Judiciário brasileiro totaliza cerca de 16.500 magistrados, o equivalente a cerca de 8,2 juízes por 100.000 habitantes, conforme o Gráfico 2. Trata-se de proporção que não destoa da maioria das nações e que, portanto, dificilmente explica a disparidade observada nas despesas.

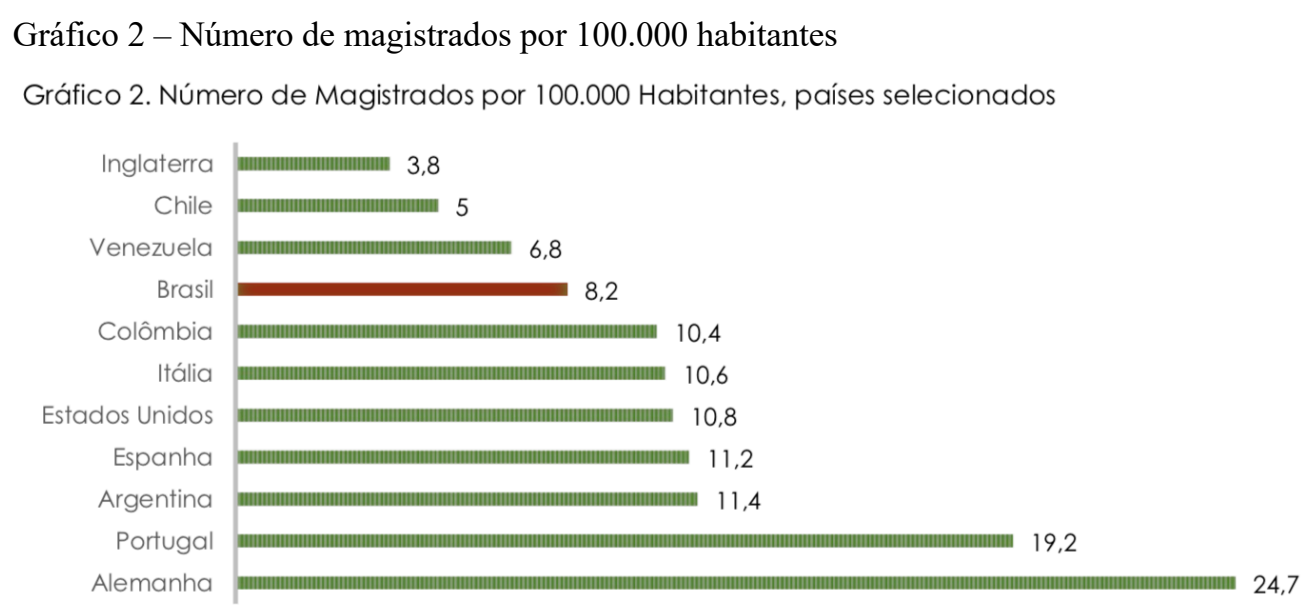

Fontes: CNJ 2014; European Commission for the Efficiency of Justice (CEPEJ) 2014, 158; Centro de Estudios de Justicia de las Américas (CEJA) 2007; Ramseyer e Rasmusen 2010, World Bank 2011.

Fonte: Da Ros, 2015.

Portanto, o que esse gráfico torna claro é que a quantidade de magistrados existente no Brasil não explica por que a despesa com o Poder Judiciário é tão destoante em relação a dos demais países. Mesmo considerando que os salários dos nossos juízes são altos e escalonados de maneira comprimida (com pouca diferença entre topo e base), o fato é que a maior parcela do gasto com pessoal no Judiciário brasileiro se destina ao corpo de servidores, assessores, terceirizados, cedidos e afins, com exceção dos magistrados propriamente ditos, que também trabalham nesse poder do Estado, muitos dos quais com remuneração elevada em relação à renda média do país.

180 CONSELHO NACIONAL DE JUSTIÇA. Justiça em Números 2014: ano-base 2013. Brasília: CNJ, 2014. p. 32. 
Somente com os dados mencionados conseguimos verificar que há uma crise na formação desse pessoal, ao levar em conta o importante papel que o Estado tem como promotor do emprego e do desenvolvimento social. Considerando que a área certamente não prepara o egresso para a iniciativa privada, a grande maioria dos bacharéis formados em Direito acabam trabalhando para o Estado em serviços técnicos-burocráticos, cujos dados alarmantes conseguiram comprovar.

Esse excesso de mão de obra, que mesmo em condições de demanda aquecida, não é capaz de ser totalmente absorvida pelo mercado, razão pela qual o Estado, como agente principal do desenvolvimento social do país, vê-se na obrigação de dar emprego ao gigantesco número de profissionais com qualificação formal, porém muitas vezes sem qualidade material para concretização do exercício de uma carreira técnica.

\footnotetext{
A essa realidade se contrapõe uma situação que seria curiosa, não fosse dramática: as vagas existentes nos concursos para cargos públicos não conseguem, em regra, ser totalmente preenchidas, porque a grande maioria dos candidatos não obtém a aprovação necessária; paralelamente os índices de reprovação nos Exames de Ordem aumentam a cada ano ${ }^{181}$.
}

É evidente que possíveis soluções para esse cenário extrapolam os meandros relativos à educação do Direito. Porém, uma das medidas que podem ser adotadas na instância educacional para a tentativa de melhoria dessa realidade certamente consiste em uma decisão política de ampliar as exigências, no quesito da qualidade, para a criação de novos cursos. Isso permitiria a implantação de apenas projetos de excelência, bem como o fechamento de alguns deles - verdadeiras indústrias culturais, fábricas de diplomas - quando ficar comprovada, mediante processo regular de avaliação, a sua falta de qualidade ${ }^{182}$.

Também não se pode olvidar a importância que o ensino superior, principalmente na área do Direito, por diversas razões, continua sendo opção de expressiva parcela da população brasileira, que o encara, por vezes, como a única forma de transformação da realidade social em que está imerso. A escolha dessas pessoas se firma no curso jurídico como possibilidade de ascensão, depositando ali toda a sua expectativa e todos os seus sonhos de construção de uma vida melhor. Por isso, há necessidade de repensar esse cenário com extremo cuidado, sob pena de retirar a esperança de considerável número de brasileiros(as). O quadro é crítico, portanto as soluções engendradas definitivamente não podem ser simplistas.

\footnotetext{
181 RODRIGUES, Horácio Wanderlei. Pensando o ensino do direito no século XXI: diretrizes curriculares, projeto pedagógico e outras questões pertinentes. Florianópolis: Fundação Boiteux, 2005. p. 46.

182 Ibid., p. 47.
} 
Outra vertente da crise funcional, como já mencionado, está ligada à crise de identidade e legitimidade dos operadores do Direito, pois infelizmente a concretização do curso de Direito não atinge as expectativas daquele que encerra sua formação em grau de bacharelado. Nesse sentido, Horácio Wanderlei Rodrigues nos apresenta as seguintes perspectivas:

a. Autonomia profissional, aos que optarem pela advocacia liberal, o que é um mito, tendo em vista que contemporaneamente a regra é o advogado empregado - ou melhor subempregado ou desempregado;

b. O exercício de uma atividade que busca preponderantemente a realização da justiça, o que efetivamente não ocorre, tendo em vista que a legislação vigente é, em muitas situações, claramente beneficiadora de uma pequena parcela da população, justamente aquela que detém os meios de produção e o poder político;

c. Uma remuneração condizente com a qualificação profissional. Nesse sentido, destaca-se sempre o mercado de trabalho como selecionador, omitindo-se que na prática são a situação de classe, os vínculos sociais, o nome de família e o escritório do pai (para aqueles cujo ascendente exerce a profissão) que definem, na maioria das vezes, o sucesso econômico do exercício da advocacia. No que se refere aos cargos públicos alcançáveis através de concursos a situação salarial atual, não é muito diferente da dos demais funcionários do Estado: em plena decadência.

[...] Nota-se então que a autonomia profissional inexiste, que a igualdade entre advogados, juízes e promotores no processo é uma falácia. Que a busca da justiça esbarra em uma legislação material e processual em parte ultrapassada, em um Judiciário burocratizado, lento e, algumas vezes, corrupto ou comprometido com o poder. Por fim, nota-se que, para sobreviver nesse ambiente é necessário se adequar ao status quo e abandonar os ideais dos tempos de estudante. Está concretizada a crise de identidade $^{183}$ (grifo nosso).

Conclui-se que a educação jurídica, nos moldes em que é praticada, de acordo com a manutenção dos valores arcaicos que visa proteger, fundada em métodos ultrapassados e que não representam mais a dinamicidade atual da sociedade nem seus valores atualmente perseguidos, possui grande responsabilidade nesse ponto da crise. Por isso, pensar um novo modelo de educação na área do Direito, voltado para atender as atuais demandas sociais e dedicado a entregar profissionais que efetivamente respondam às demandas do mercado de trabalho, será capaz de auxiliar, em médio prazo, na superação dessa crise.

No tocante aos aspectos inerentes à crise operacional, volta-se para a compreensão dos paradigmas administrativo e acadêmicos necessários para viabilizar o estudo do Direito. Tratase da crise enfrentada para operacionalizar a educação jurídica e entregar efetivamente o conhecimento inerente a esse campo do saber para o estudante.

A crise operacional da educação no campo do Direito reside nos instrumentos eleitos pelo Estado para serem desenvolvidos pelas instituições de ensino como capazes de formar adequadamente os estudantes. Como exemplo de tais ferramentas, pode-se mencionar

183 RODRIGUES, Horácio Wanderlei. Pensando o ensino do direito no século XXI: diretrizes curriculares, projeto pedagógico e outras questões pertinentes. Florianópolis: Fundação Boiteux, 2005. p. 48. 
administração centralizada, ensino tradicional pautado em uma concepção bancária, aulas expositivas formuladas por códigos comentados, currículos fixos com programas estanques com ênfase legalista.

Tais mecanismos de operacionalização do ensino do Direito não preparam o futuro jurista para o mercado de trabalho, deixando-o abaixo do nível exigido para atuar com o público, para lidar com problemas jurídicos extremamente complexos na prática e impossíveis de serem fracionados nas matérias lecionadas nos cursos. Além disso, os cursos não são suficientes para embasar a aprovação dos estudantes em concursos públicos para ingresso inicial nas carreiras públicas federais, estaduais e municipais e, por vezes, se mostram insuficientes até mesmo para aprovação no Exame Nacional da $\mathrm{OAB}$, requisito essencial para o exercício da advocacia.

Esses instrumentos operacionais, sejam de ordem administrativa, sejam de ordem acadêmica, visam a reprodução dos valores eleitos para a estrutura de base da educação jurídica, razão pela qual eles também precisam ser repensados para atender à expectativa da sociedade na formação dos seus bacharéis em Direito.

Inicialmente são apresentados os elementos que caracterizam a crise acadêmica, em suas vertentes didático-pedagógicas e curriculares, e oportunamente fala-se da crise administrativa, ponto central da presente pesquisa, cujas alternativas para melhoria desse cenário serão aqui idealizadas.

No aspecto didático-pedagógico, a educação jurídica pode ser tomada como um dos grandes exemplos de educação tradicional, modelo pautado pelo protagonismo do professor, encarando o aluno como receptor passivo do conhecimento que ele só recebe mediante a atividade docente na escola.

\footnotetext{
Nessa concepção, a educação é vista como um processo de transmissão de informações, como instrução; e a escola, como o lugar onde ela se realiza. A relação professor-aluno é vertical, sendo o aluno o ouvinte e o professor o mediador entre ele e o conhecimento. O docente é o agente principal da relação ensino-aprendizagem. Há ênfase às situações de sala de aula, e a avaliação tem caráter quantitativo ${ }^{184}$.
}

Também na área didática, como regra geral, o ensino do Direito mantém a mesma metodologia da época de sua criação: aula-conferência, implica dizer, o professor é a peça fundamental do ensino tradicional, e o método de transmissão do conhecimento científico é sempre baseado no modo como ele entende ser o correto, de forma que o docente é encarado

184 RODRIGUES, Horácio Wanderlei. Pensando o ensino do direito no século XXI: diretrizes curriculares, projeto pedagógico e outras questões pertinentes. Florianópolis: Fundação Boiteux, 2005. p. 53. 
como depositário do saber e o aluno detém a condição de não saber, de ignorância.

De acordo com essa técnica obsoleta, há irrelevância das diferenças e dos saberes individuais, pois a relação entre professor e aluno é vertical e o fluxo de informações é unidirecional: só o professor ensina o aluno. A missão clara do docente é transmitir seu conhecimento ao aluno por meio do fluxo de informação unidirecional. Tal processo de transmissão da informação em um contexto educacional de fluxo unidirecional pode ser comparado a um corriqueiro download de arquivos na mente dos alunos.

Há que ser mencionada também a resistência dos professores à capacitação pedagógica, apontada por Thais Luzia Colaço ${ }^{185}$, ocasionada, dentre outros fatores, por falta de tempo e desinteresse sobre questões didático-pedagógicas, em razão de assumirem tal ofício como secundário, inerente a uma atividade alternativa e não como uma profisssão. Tudo isso aponta a existência de um modelo subliminar orientando a atuação dos professores que dizia que para ser docente na área do Direito bastava saber o conteúdo, passá-lo bem e a experiência profissional não acadêmica seria suficiente para qualificá-lo para essa atividade ${ }^{186}$.

Para Antônio Alberto Machado ${ }^{187}$, o "senso comum jurídico foi construído pelas enunciações linguísticas acumuladas e habitualmente tomadas como princípios", que culminam em

\begin{abstract}
Uma espécie de neutralização do componente político do direito, o que estabelece verdades extraídas não da realidade, mas da aparência da realidade, ou das próprias significações mentais que compõem o discurso dos juristas. [...] o senso comum jurídico opera uma espécie de inculcação ideológica que propicia a compreensão da realidade por meio do discurso habitual, sem nenhum componente de crítica ou de consciência política acerca do saber e do fazer jurídicos, favorecendo assim uma atuação repetitiva e burocrática por parte dos juristas, nos moldes daquilo que normalmente se identifica como a 'praxe jurídica' ou 'praxe forense', que nada mais é senão a reprodução passiva, e até mesmo inconsciente de uma legalidade que reflete toda a ideologia positivista ligada ao poder ${ }^{188}$.
\end{abstract}

Grave problema encontrado nessa área consiste nos mais variados tipos de projetos pedagógicos de cursos existentes na área jurídica no Brasil. Isso decorre justamente da falta de profissionais da área do Direito que se dediquem a realmente estruturar um projeto pedagógico factível e que não comporte apenas um amontoado de informações com única finalidade de serem disponibilizadas para as avaliações oficiais do MEC.

\footnotetext{
${ }^{185}$ COLAÇO, Thais Luzia (org.). Aprendendo a ensinar direito o Direito. Florianópolis: OAB/SC, 2006.

${ }^{186}$ ROCHA, Adriana de Lacerda. O professor reflexivo e o professor de Direito: uma pesquisa de caráter etnográfico. Curitiba: CRV, 2012. p. 57.

${ }^{187}$ MACHADO, Antônio Alberto. Ensino jurídico e mudança social. Franca: Unesp, 2005. p. 118.

${ }^{188}$ Ibid., p. 118-119.
} 
A elaboração dos projetos pedagógicos deveria envolver seriamente a coordenação dos cursos de Direito que, engajadas na missão pedagógica dos docentes, traçaria um plano estratégico com metas a serem atingidas em curtos, médios e longos prazos. Deveria envolver toda a comunidade acadêmica, a começar pelo núcleo docente estruturante, o qual, composto por professores com regime de trabalho compatível, deveria debater propostas e mecanismos de aperfeiçoamento da educação na área do Direito, elaborar atas e formalizar as discussões de maneira séria e adequada. E, oportunamente, consultar especialistas da educação que esclareceriam meandros pedagógicos e corrigiriam eventuais impropriedades inerentes ao desconhecimento técnico específico da área.

Em verdade, sabe-se que o planejamento pedagógico dos cursos de Direito em todo Brasil não acontece assim, sendo esse outro importante fator capaz de dar ensejo ao caos pedagógico e à má formação dos egressos.

Outra crise que acomete a educação na área do Direito no Brasil consiste na defasagem histórica dos currículos jurídicos observados nas instituições de ensino em todo Brasil. Essa denominada crise curricular tem como grande responsável o próprio $\mathrm{MEC}$, já que é sua a responsabilidade pela elaboração e implementação das Diretrizes Curriculares Nacionais.

Vige atualmente a Resolução $n^{\circ}$ 5, de 17 de dezembro de 2018, do Ministério da Educação, a qual instituiu as Diretrizes Curriculares Nacionais do curso de graduação em Direito e deu outras providências. Tal instrumento normativo é recente e possui alterações substanciais em sua normativa se comparado à Resolução $\mathrm{CNE} / \mathrm{CES}^{189} \mathrm{n}^{\circ} 9$, de 29 de setembro de 2004.

A presente pesquisa possui o condão de abordar, principalmente, os aspectos inerentes à crise da educação jurídica no setor operacional em sua conjuntura administrativa, justamente com o objetivo de apresentar uma possível alternativa para melhoria desse cenário.

A mencionada crise administrativa está voltada para a administração pública, que é a responsável pelo controle e fiscalização da educação entregue para a sociedade brasileira, importa dizer, tanto o MEC quanto o CNE são responsáveis, ainda que em último grau, pela proliferação exponencial e continuidade de cursos que não atingem a mínima qualidade necessária para continuidade na área do Direito.

Também se fala em crise administrativa quando nos referimos à má gestão da

189 CONSELHO NACIONAL DE EDUCAÇÃO. Câmara de Educação Superior. Resolução CNE/CES $n^{\circ}$ 9, de 29 de setembro de 2004. Institui as Diretrizes Curriculares Nacionais do Curso de Graduação em Direito e dá outras providências. Brasília, DF: CNE, 2004. Disponível em:

http://portal.mec.gov.br/cne/arquivos/pdf/rces09_04.pdf. Acesso em: 20 fev. 2019. 
administração das instituições de ensino, bem como à má gestão da administração interna específica dos cursos de Direito efetuados pelas instituições de natureza pública ou privada.

As administrações das instituições de ensino superior invariavelmente promovem atitudes populistas, raramente preocupadas com a qualidade da educação que ofertam, enquanto as administrações internas dos próprios cursos se valem de apadrinhamentos como substitutos da competência dos docentes e servidores, sendo essa uma característica histórica na contratação de pessoal e no preenchimento dos cargos administrativos.

Pode-se dizer que, de certa forma, o neopatrimonialismo é a base das práticas administrativas muitas vezes disseminadas nesses locais ${ }^{190}$. Esse cenário leva a uma série de distorções desse mercado, dos quais os grandes prejudicados acabam sendo os alunos e, em última instância, a própria sociedade, que suporta o ônus de lidar com profissionais mal preparados postos no mercado de trabalho.

Horácio Wanderlei Rodrigues propõe algumas soluções passíveis de serem adotadas para minimizar a prática dessas ações, tais como a obrigatoriedade de contratação de professores apenas por concurso público de provas e títulos em instituições públicas e privadas, cumprimento da LDB no que atine à exigência mínima do título de especialista para ingresso no magistério, participação da comunidade acadêmica na escolha de todos os participantes de cargos acadêmicos, criação de mecanismos de controle externo das instituições de ensino superior, implantação de um sistema de avaliação do corpo docente que também seja considerada para progressão funcional do professor e avaliação institucional interna e externa das instituições e dos cursos ${ }^{191}$.

Com relação às propostas efetuadas pelo autor, destacamos a introdução de uma efetiva avaliação institucional capaz de abranger considerações sobre a infraestrutura material e humana das instituições e dos cursos, do corpo docente e dos projetos pedagógicos. A abordagem adotada nesse instrumento de pesquisa foca nos aspectos inerentes à avaliação e ao controle de qualidade das instituições de ensino superior no Brasil pelos órgãos oficiais aptos a realizarem tal verificação, além de efetivamente sugerir uma alternativa ao que é realizado atualmente.

Nesse sentido, será importante compreender o vigente Sistema Nacional de Avaliação da Educação Superior, analisando a forma pela qual referido controle de qualidade se

190 RODRIGUES, Horácio Wanderlei. Pensando o ensino do direito no século XXI: diretrizes curriculares, projeto pedagógico e outras questões pertinentes. Florianópolis: Fundação Boiteux, 2005. p. 50.

191 Para aprofundamento dessas questões, sugerimos a leitura da tese: Id. A crise do ensino jurídico de graduação no Brasil contemporâneo: indo além do senso comum. 1992. 397 f. Tese (Doutorado) - Curso de Direito, Universidade Federal de Santa Catarina, Florianópolis, 1992. 
desempenha no Brasil em comparação a outros mecanismos observados na Espanha. Neste, obteve-se êxito na melhoria do desempenho da educação superior com a implementação de políticas públicas, que colocaram o setor em destaque na União Europeia. Serão apontadas qualidades e efetuadas críticas aos problemas do sistema espanhol, propondo-se uma alternativa capaz de verdadeiramente apurar a qualidade da educação superior na área do Direito no Brasil.

\subsection{Mecanismo público de controle de qualidade da educação jurídica brasileira e suas fragilidades: críticas ao modelo e dados públicos coletados para comprovar a existência da crise}

O controle de qualidade de serviços prestados em território nacional não consiste em uma preocupação exclusivamente inerente ao setor público, pois não só o Estado, mas principalmente a sociedade civil e todos os seus membros, possui interesse na prestação de serviços que atendam às demandas individuais e coletivas na formação das pessoas que frequentem esses cursos.

Embora não seja o único, atualmente o mais importante mecanismo de controle da qualidade dos cursos de Direito no Brasil é de natureza pública e responsabilidade federal, conforme prevê o artigo $9^{\circ}$, inciso VIII da LDB (Lei n ${ }^{\circ}$ 9.394/96), ao preceituar que a União está incumbida de assegurar o processo nacional de avaliação das instituições de educação superior, com a cooperação dos sistemas que tiverem responsabilidade sobre tal nível de escolarização - implica dizer que os demais entes da Federação deveriam cooperar com tal dever.

Atualmente, o sistema avaliativo público é efetuado por órgão específico e especializado no auxílio ao MEC com essas questões: o Instituto Nacional de Estudos e Pesquisas Educacionais Anísio Teixeira (Inep).

O Inep é o órgão responsável por conduzir todo o sistema de avaliação dos cursos superiores nacionais, efetuando a coleta de todos os dados relativos aos cursos superiores, produzindo indicadores e um sistema de informações que subsidia o processo de regulamentação dos cursos e a transparência dos dados sobre a qualidade dos cursos.

Os instrumentos que subsidiam a produção de indicadores de qualidade e os processos de avaliação de cursos desenvolvidos pelo Inep são o Exame Nacional de Desempenho de Estudantes (Enade) e as avaliações in loco realizadas pelas comissões de especialistas.

Essas formas de apuração de qualidade de cursos superiores no Brasil compõem o denominado Sistema Nacional de Avaliação da Educação Superior, o qual define que os cursos 
devem ser periodicamente submetidos às avaliações. Nesse sentido, os cursos de graduação passam por três tipos de avaliação: uma para autorizar seu funcionamento, outra para reconhecimento do curso recentemente autorizado e outra para a renovação do reconhecimento.

Além disso, o Inep também é responsável por efetuar uma coleta de dados oficiais sobre as instituições de educação superior nacionais para elaboração do Censo da Educação Superior, que deveria consistir no instrumento de pesquisa mais completo do Brasil sobre as instituições que ofertam cursos de graduação, além de coletar dados sobre seus alunos e docentes. Essa coleta objetiva fornecer à comunidade acadêmica e à sociedade, de um modo geral, informações detalhadas sobre o setor.

Os dados do censo são todos coletados por meio do preenchimento dos questionários disponibilizados às instituições de ensino, bem como pela importação de dados por meio do sistema e-MEC, conforme cronograma anual publicado no Diário Oficial da União e que deve ser respeitado por todas as instituições de ensino.

Segundo a última portaria que atribuiu essa obrigação às IES, Portaria ${ }^{\circ} 911$, de 6 de novembro de 2019, em seu artigo 11, a relação das IES que não preencherem o censo de 2019 e não apresentarem justificativa até a data final do cronograma será encaminhada para as Secretarias de Educação Superior e de Regulação e Supervisão da Educação Superior do Ministério da Educação e para a Coordenação de Aperfeiçoamento de Pessoal de Nível Superior para providências cabíveis.

Segundo apurado, o cumprimento da obrigação retro constitui como pré-requisito para que a IES participe do Sinaes, possa expedir seus atos regulatórios de credenciamento e recredenciamento, autorização e reconhecimento dos seus cursos e suas respectivas modificações, possibilidade de aderir ao Fundo de Financiamento Estudantil, bem como ao Programa Universidade para Todos e participar dos programas de bolsas que são concedidas pela Coordenação de Aperfeiçoamento de Pessoal de Nível Superior.

É preciso esclarecer que esse mecanismo de apuração de qualidade e levantamento dos dados inerentes às instituições de ensino superior existentes no Brasil, apesar de possuir seus pontos fortes que merecem de fato ser exaltados, por outro lado, merece uma série de críticas em razão da forma pela qual é executado. Algumas delas são a falta de compromisso e rigor técnico-científico com a divulgação dos dados e, principalmente, a falta de fiscalização das informações que são efetivamente prestadas pelas instituições de ensino, como será a seguir elucidado.

A primeira crítica que cabe ser mencionada consiste especificamente no procedimento adotado pelas instituições de ensino superior para prestar as informações que são solicitadas 
pelos órgãos oficiais como forma de relatar de maneira fidedigna o que se passa em suas instituições. Tais informações são de responsabilidade do gestor maior da instituição, ou seja, seu representante legal, que costuma ser o reitor.

Ciente da importância de relatar essas informações, a administração pública autoriza que tal função inerente ao cargo possa ser delegada a um pesquisador institucional, o qual receberá essa atribuição exclusiva de sua instituição de ensino para preenchimento do sistema correspondente, coletando todas as informações solicitadas, sob pena de responsabilidade.

O que acontece na realidade das mais diferentes IES brasileiras é que apenas um único sujeito fica responsável pela coleta de todas as informações relativas à organização em que trabalha, de todas as diversas áreas de conhecimento que aquela instituição possui autorização para atuar.

Está evidente que no mínimo deveria existir uma equipe responsável pela prestação dessas informações, composta por pelo menos um membro correspondente a cada curso ministrado pela IES, buscando a coleta fidedigna das informações prestadas ao órgão público responsável. Infelizmente, não é isso o que acontece nas IES consultadas por todo o Brasil.

Essa realidade nos permite concluir que as informações prestadas pelas IES para órgãos de controle e fiscalização da educação superior brasileira são efetuadas de forma fragilizada e sem o necessário rigor técnico esperado. Logo, isso não permite realizar uma análise coerente de que os cursos oferecidos em território nacional são prestados com a qualidade necessária para a consecução dos seus objetivos.

Outra importante crítica que pode ser mencionada relativa ao procedimento de coleta das informações prestadas pelas IES consiste na falta de efetiva fiscalização daquilo que os pesquisadores institucionais e seus representantes legais prestam para o órgão público competente. Isto é, o mecanismo consiste em disponibilizar a ferramenta de coleta de informações para que as IES preencham com os dados relativos aos cursos que prestam, bem como suas informações estruturais; porém, depois, não existe uma checagem daquilo que informaram, nem há em momento alguma atuação de nenhum agente público para consultar se as informações prestadas pelas IES correspondem à realidade, o que evidentemente abre margem para questionar tais dados.

Não foi idealizado nenhum mecanismo que realmente apure a verdade das informações prestadas pelas IES, o que permite concluir que a manipulação das informações não só seja factível como efetivamente acontece. Grande exemplo disso consiste em apontar que nas bases de dados oficiais coletadas pelo Inep e disponibilizadas para consulta mediante solicitação própria, verificou-se que a Universidade Paulista (Unip), Centro Universitário das Faculdades 
Metropolitas Unidas (FMU) - integrante do grupo educacional Laureate International Universities -, Centro Universitário Universus Veritas (Univeritas), Universidade de Guarulhos (UNG), Universidade Nove de Julho (Uninove), entre outras, todas IES privadas com finalidade lucrativa assim reconhecidas pelo mercado e sociedade, autodeclararam-se em 2017 (informações mais recentes disponibilizadas) como instituições de ensino privadas e sem finalidade lucrativa, o que já demonstra fragilidade das informações coletadas.

Assim, a falta de fiscalização das informações que são prestadas pelas IES consiste em verdadeiro problema do sistema de apuração de qualidade, haja vista que essas instituições registram as informações solicitadas segundo critérios próprios, informando aquilo que lhe convém e ao próprio Estado - este que detém a prerrogativa de fiscalizar a veracidade dessas informações não o faz. Além disso, como apontado anteriormente no exemplo, diversas informações prestadas não refletem a realidade intencionalmente e nenhuma adequação é realizada, nem nenhuma sanção é imposta às IES, que continuam fornecendo informações que não refletem a realidade, tornando os dados disponibilizados no censo da educação superior inverídicos.

Não bastasse esse mecanismo frágil de coleta e prestação das informações relativas às IES e aos cursos que elas oferecem, outra crítica plausível de ser efetuada sobre o atual sistema público de controle de qualidade dos cursos ministrados no Brasil consiste na falta de compromisso e rigor técnico-científico com a divulgação dos dados oficiais.

Tal afirmação pode ser feita levando-se em consideração duas grandes falhas encontradas durante a análise dos dados disponibilizados pelo Inep. A primeira delas está justamente na desatualização dos dados que são disponibilizados para consulta, implica dizer, mesmo no ano de 2020, quando essa pesquisa foi realizada, os dados mais atualizados disponibilizados para consulta pelo órgão público responsável eram relativos a 2017, ou seja uma lacuna de mais de três anos para poder efetuar uma análise concreta sobre o atual cenário. É evidente que a dinamicidade da sociedade frente aos dados disponibilizados já não são capazes de verdadeiramente refletir o atual cenário da educação superior nacional brasileira, o que novamente nos coloca no cenário de crise estrutural do setor, e agora com a possibilidade de afirmar que não só no âmbito do Direito, mas no ensino superior como um todo.

A outra falha encontrada durante a pesquisa e que deve ser relatada está justamente na conferência dos dados disponibilizados pelo Inep para consulta pública em seu site oficial ${ }^{192}$.

192 INSTITUTO NACIONAL DE ESTUDOS E PESQUISAS EDUCACIONAIS ANÍSIO TEIXEIRA. Sinopse Estatística da Educação Superior 2017. Brasília, DF: Inep, 2018. Disponível em: http://inep.gov.br/sinopsesestatisticas-da-educacao-superior. Acesso em: 25 mar. 2019. 
Com relação ao curso de Direito, foram apontados para o ano de 2017 que 923 (novecentas e vinte e três) instituições de ensino superior ministrariam cursos de Direito em todo o Brasil.

No entanto, ao fazer a análise separada desse mesmo indicador, consultando estado por estado, o número de IES que ministrariam cursos de Direito no Brasil geram o somatório de 931(novecentas e trinta e uma), ou seja, uma divergência de valores de 8 (oito) IES, como comprova as Tabelas 4 e 5, extraídas do relatório oficial do Inep.

Tabela 4 - Número de instituições que oferecem o curso no Brasil (2017)

\begin{tabular}{|c|c|c|c|}
\hline \multirow{2}{*}{$\begin{array}{c}\text { Áreas gerais, áreas } \\
\text { detalhadas e programas e/ou } \\
\text { cursos }\end{array}$} & \multicolumn{3}{|c|}{$\begin{array}{c}\text { Número de instituições que oferecem o curso } \\
\text { no Brasil }\end{array}$} \\
\hline & Total & Pública & Privada \\
\hline Direito & 923 & 97 & 820 \\
\hline
\end{tabular}

Fonte: Inep, 2018.

Tabela 5 - Número de instituições que oferecem o curso por Estado (2017)

(continua)

\begin{tabular}{l|r|r|r}
\hline \multirow{2}{*}{$\begin{array}{c}\text { Unidade da Federação / curso } \\
\text { (classe Inep) }\end{array}$} & \multicolumn{3}{|c}{$\begin{array}{c}\text { Número de instituições que oferecem o } \\
\text { curso }\end{array}$} \\
\cline { 2 - 4 } & \multicolumn{1}{|c|}{ Total } & \multicolumn{1}{c}{ Pública } & \multicolumn{1}{c}{ Privada } \\
\hline Direito RONDÔNIA & 11 & 1 & 10 \\
\hline Direito ACRE & 4 & 1 & 3 \\
\hline Direito AMAZONAS & 11 & 2 & 9 \\
\hline Direito RORAIMA & 4 & 2 & 2 \\
\hline Direito PARÁ & 23 & 3 & 20 \\
\hline Direito AMAPÁ & 6 & 1 & 5 \\
\hline Direito TOCANTINS & 14 & 3 & 11 \\
\hline Direito MARANHÃO & 18 & 2 & 16 \\
\hline Direito PIAUÍ & 20 & 2 & 18 \\
\hline Direito CEARÁ & 25 & 3 & 22 \\
\hline Direito RIO GRANDE DO & & & 10 \\
\hline NORTE & 13 & 3 & 15 \\
\hline Direito PARAÍBA & 37 & 3 & 27 \\
\hline Direito PERNAMBUCO & 18 & 2 & 16 \\
\hline Direito ALAGOAS & 9 & 1 & 8 \\
\hline Direito SERGIPE & 54 & 6 & 48 \\
\hline Direito BAHIA & 133 & 9 & 124 \\
\hline Direito MINAS GERAIS & 31 & 1 & 30 \\
\hline Direito ESPÍRITO SANTO & & & 10 \\
\hline & & & \\
\hline
\end{tabular}


Tabela 5 - Número de instituições que oferecem o curso por Estado (2017)

\begin{tabular}{|c|c|c|c|}
\hline \multirow{2}{*}{$\begin{array}{l}\text { Unidade da Federação / curso } \\
\text { (classe Inep) }\end{array}$} & \multicolumn{3}{|c|}{$\begin{array}{c}\text { Número de instituições que oferecem o } \\
\text { curso }\end{array}$} \\
\hline & Total & Pública & Privada \\
\hline Direito RIO DE JANEIRO & 43 & 5 & 38 \\
\hline Direito SÃO PAULO & 170 & 11 & 159 \\
\hline Direito PARANÁ & 74 & 8 & 66 \\
\hline Direito SANTA CATARINA & 36 & 2 & 34 \\
\hline Direito RIO GRANDE DO SUL & 54 & 5 & 49 \\
\hline $\begin{array}{l}\text { Direito MATO GROSSO DO } \\
\text { SUL }\end{array}$ & 14 & 3 & 11 \\
\hline Direito MATO GROSSO & 25 & 2 & 23 \\
\hline Direito GOIÁS & 43 & 5 & 38 \\
\hline $\begin{array}{l}\text { Direito DISTRITO FEDERAL } \\
\text { (53) }\end{array}$ & 22 & 1 & 21 \\
\hline EAD Direito & 1 & - & 1 \\
\hline TOTAL & 931 & 97 & 834 \\
\hline
\end{tabular}

Fonte: Inep, 2018.

Somente essa falha já denota a falta de rigorosidade técnico-científica com a conferência e oportuna apresentação das informações relativas ao setor por parte do órgão responsável pelo controle e pela fiscalização da educação jurídica no Brasil.

Além disso, como forma de registrar outra crítica sobre os dados disponibilizados pelo Inep de acesso ao público geral, é oportuno mencionar que a conferência dessas informações não é feita de forma intuitiva e de fácil acesso à população geral, pois são fornecidas informações de forma consolidada sobre todas as áreas do conhecimento.

Segundo informações oficiais prestadas pelo próprio Inep, a sinopse estatística tem um total de 51 tabelas, distribuídas entre as seguintes temáticas: instituições e dados gerais de cursos de graduação presencial e a distância, docentes e funcionários técnico-administrativos, cursos, processo seletivo, matrículas, concluintes, graduação a distância, sequencial de formação específica presencial e a distância e instituições federais.

As informações consolidadas dizem respeito a todo o cenário da educação superior nacional, cujas tabelas devem ser analisadas por especialistas na área de estatística para que a correta análise desses dados seja verdadeiramente realizada. Além disso, fica evidente que esse grande número de informações se traduz em verdadeira desinformação, haja vista que a ausência de interpretação do que esses números significam para cada uma das áreas do conhecimento consiste em informação vazia de significação.

O Inep até apresenta um relato com as notas estatísticas relativas ao setor, o que 
indubitavelmente é muito importante para a análise crítica do atual cenário da educação superior brasileira de forma geral. No entanto, para conquistarmos a melhoria de todos os campos do conhecimento, é preciso reconhecer a essencialidade de uma análise particularizada dos dados relativos a cada área ofertada em território nacional. Sem a devida compreensão da educação desempenhada em cada setor, é impossível imaginar que a melhoria do cenário acontecerá naturalmente.

Assim, a mera disponibilização desses dados sem a efetiva elaboração de um relatório de prestação de contas específico de cada área permite concluir que a fiscalização efetivamente exarada pelo órgão competente é vazia de significação e não consegue se traduzir em um elemento importante para o aprimoramento do setor, o que, se não é, deveria ser o principal objetivo dessa fiscalização.

Apenas a título de exemplo, pode ser mencionado que na Espanha, país selecionado para comparação com o Brasil em razão de seu êxito na implementação de políticas públicas que buscam a melhoria da educação superior, o Ministério da Educação e Formação Profissional é responsável por editar e publicar relatórios anuais com dados e cifras relativos ao Sistema Universitário Espanhol ${ }^{193}$, justamente como a medida adequada de prestar contas à sociedade sobre o avanço do setor.

É o mínimo que se espera de um órgão público responsável pelo controle e pela fiscalização da qualidade da educação que é prestada em território nacional. O referido relatório apresenta, entre outras informações: o compilado geral dos dados estatísticos relativos ao setor, o número de estudantes e de professores; os índices relativos à pós-graduação e à internacionalização dos setor enviando e recebendo alunos; presta contas sobre as bolsas de estudos pagas com financiamento público; os gastos públicos com o setor e todos os elementos mínimos que devem ser constantemente apresentados à sociedade.

Além disso, em 16 de setembro de 2014, por meio da promulgação da Lei nº 15/2014, a Espanha criou a Agencia Nacional de Evaluación de la Calidad y Acreditación ${ }^{194}$ (Aneca), cujo objetivo específico é realizar atividades de avaliação, certificação e acreditação do sistema universitário espanhol, objetivando a sua melhora contínua e adaptação ao espaço europeu de educação superior.

193 DATOS Y CIFRAS DEL SISTEMA UNIVERSITARIO ESPAÑOL. Madrid: Ministerio de Universidades, 2009- . Informe bienal. Disponível em: https://www.educacionyfp.gob.es/servicios-alciudadano/estadisticas/universitaria/datos-cifras.html. Acesso em: 24 abr. 2020.

194 Tradução livre: Agência Nacional de Avaliação e Acreditação da Qualidade. Cf. ESPAÑA. Ley 15/2014, de 16 de septiembre, de racionalización del Sector Público y otras medidas de reforma administrativa. Boletín Oficial del Estado, 17 sept. 2014. Disponível em: http://www.aneca.es/ANECA. Acesso em: 24. abr. 2020. 
A Aneca atua como órgão especializado e possui competência para avaliar: a educação destinada à obtenção de diplomas universitários oficiais e validade em todo o território nacional; os méritos dos candidatos aos órgãos de ensino, professores e funcionários contratados das universidades; as atividades de ensino, pesquisa, transferência de conhecimento; a gestão dos docentes e pesquisadores das universidade e dos pesquisadores vinculados a órgãos públicos de investigação; as instituições de educação superior; os títulos universitários estrangeiros por meio de homologação ou equivalência.

Tal órgão será melhor estudado adiante, mas é importante mencioná-lo neste momento com a finalidade de esclarecer que todas as políticas públicas adotadas pelo referido órgão fazem parte de um plano estratégico, consistente em uma ferramenta de trabalho básica que define as linhas de atuação fundamentais que a Aneca pretende implementar nos próximos $\operatorname{anos}^{195}$.

Como se isso não bastasse, é preciso mencionar que, por se tratar de um órgão público, autônomo e vinculado ao Ministério de Universidades, toda atividade desempenhada sob a responsabilidade da Aneca é reportada à sociedade por meio de relatórios de prestação de contas específicos sobre sua atuação. Importa dizer, qualquer pessoa pode ter acesso a: relatórios públicos relativos às informações econômicas consistentes nas contas anuais de cada exercício financeiro ${ }^{196}$, informes anuais sobre a qualidade universitária com o intuito de mostrar uma visão global do sistema universitário espanhol ${ }^{197}$, planejamento estratégico de ação para concretização dos objetivos da Aneca ${ }^{198}$, estudos acadêmicos derivados dos resultados do observatório de qualidade do sistema espanhol de universidades ${ }^{199}$, estudos estratégicos de interesse para o âmbito universitário ${ }^{200}$, entre outras ações efetivamente adotadas que buscam a melhoria do setor - o que não se vê no Brasil.

${ }^{195}$ AGENCIA NACIONAL DE EVALUACIÓN DE LA CALIDAD Y ACREDITACIÓN (España). Plan Estratégico 2019-2023. Madrid: ANECA, [2019?]. Disponível em: http://www.aneca.es/ANECA/Planestrategico. Acesso em: 14 abr. 2020.

196 Id. Información económica. Madrid: ANECA, [2019]. Disponível em: http://www.aneca.es/ANECA/Informacion-economica. Acesso em: 14 abr. 2020.

${ }^{197}$ Id. Informes sobre calidad universitária. Madrid: ANECA, [2018]. Disponível em: http://www.aneca.es/Documentos-y-publicaciones/Observatorio-de-la-Calidad-del-Sistema-Espanol-deUniversidades/Informes-sobre-calidad-universitaria. Acesso em: 14 abr. 2020.

198 Id. Planificación. Madrid: ANECA, [2020a]. Disponível em: http://www.aneca.es/Documentos-ypublicaciones/Planificacion. Acesso em: 15 abr. 2020.

199 AGENCIA NACIONAL DE EVALUACIÓN DE LA CALIDAD Y ACREDITACIÓN (España). Observatorio de la Calidad del Sistema Español de Universidades. Madrid: ANECA, [2018?]. Disponível em: http://www.aneca.es/Documentos-y-publicaciones/Observatorio-de-la-Calidad-del-Sistema-Espanol-deUniversidades. Acesso em: 15 abr. 2020.

${ }^{200}$ Id. Estudios de interés para el ámbito universitário. Madrid: ANECA, [20-?]. Disponível em: http://www.aneca.es/Documentos-y-publicaciones/Estudios-de-interes-para-el-ambito-universitario. Acesso em: 15 abr. 2020. 
Tais críticas não pretendem a mera desconstrução das políticas públicas que foram efetivadas no Brasil. Ao contrário, o intuito é o de apontar as falhas buscando o aprimoramento das nossas ações e possível adoção de novas estratégias para melhoria do sistema de controle de qualidade da educação superior, especificamente na área de conhecimento do Direito.

Comprovar o contexto de crise em território brasileiro mencionado alhures não é uma tarefa simples; no entanto, um mecanismo que busca apontar a existência de uma crise consiste na análise dos números e dos indicadores fornecidos pelo órgão público competente, qual seja, o Inep. Assim, torna-se essencial apresentar o atual quadro do ensino superior na área do Direito no Brasil.

Com a intenção de impactar o leitor para que possa dimensionar a diferença do tamanho e das responsabilidades públicas dos sistemas apresentados, é oportuno correlacionar alguns importantes dados específicos sobre o atual cenário da educação superior brasileira na área do Direito.

Diante da análise técnica dos dados apresentados, algumas inconsistências foram encontradas. Para a presente pesquisa, todas as informações que serão apresentadas referem-se aos dados publicados pelo Inep correspondentes ao cenário da educação superior jurídica no ano de $2017^{201}$. Assim, trataremos sobre questões inerentes às instituições de ensino superior que efetivamente prestaram o referido serviço público com autorização pública para ofertar cursos de Direito.

Preliminarmente, é preciso justificar a escolha pautada nessa referência exclusiva. Em primeiro lugar, esclareça-se que a base de dados mais recente disponível para consulta de pesquisadores autorizados para acesso à sala protegida do Inep é relativa a 2017, não tendo sido concedido acesso a dados mais recentes do que o mencionado.

A partir de agora será descrito o resultado do procedimento de cruzamento dos dados, ou seja, nesta oportunidade serão apontadas as percepções relativas aos dados divulgados na sinopse estatística em confronto aos dados extraídos do Inep. A finalidade é buscar a confirmação do que foi tornado público, ou, ao revés, comprovar que os dados publicados não refletem a realidade do que fora coletado e oportunamente divulgado pelo próprio instituto.

Com relação à análise dos números absolutos dos cursos de Direito ofertados no Brasil, verifica-se que há equívoco na informação prestada, considerando que na sinopse estatística

${ }^{201}$ INSTITUTO NACIONAL DE ESTUDOS E PESQUISAS EDUCACIONAIS ANÍSIO TEIXEIRA. Sinopse Estatística da Educação Superior 2017. Brasília, DF: Inep, 2018. Disponível em: http://inep.gov.br/sinopsesestatisticas-da-educacao-superior. Acesso em: 25 mar. 2019. 
relativa aos dados de $2017^{202}$ divulgada no site oficial do Inep foi apontada a existência de 1.203(mil duzentos e três) cursos de Direito em atividade no Brasil, enquanto na planilha de dados sigilosos arquivados junto ao Inep ${ }^{203}$, após a devida conferência, chegou-se ao total de 1.202 (mil duzentos e dois). Apresenta-se a Tabela 6, elaborada para conferência, em que é possível vislumbrar quais informações não convergem.

Tabela 6 - Comparação entre número de instituições que oferecem o curso e tabela sigilosa

(continua)

\begin{tabular}{|c|c|c|c|c|c|c|}
\hline \multirow{2}{*}{$\begin{array}{l}\text { Unidade da Federação / curso } \\
\text { (classe Inep) }\end{array}$} & \multicolumn{3}{|c|}{$\begin{array}{l}\text { Número de cursos (sinopse } \\
\text { estatística) }\end{array}$} & \multicolumn{3}{|c|}{$\begin{array}{c}\text { Número de cursos } \\
\text { CONFERÊNCIA TABELA } \\
\text { SIGILOSA }\end{array}$} \\
\hline & Total & Pública & Privada & Total & Pública & Privada \\
\hline Direito RONDÔNIA & 12 & 2 & 10 & 12 & 2 & 10 \\
\hline Direito ACRE & 5 & 2 & 3 & 5 & 2 & 3 \\
\hline Direito AMAZONAS & 14 & 5 & 9 & 14 & 5 & 9 \\
\hline Direito RORAIMA & 4 & 2 & 2 & 4 & 2 & 2 \\
\hline Direito PARÁ & 23 & 3 & 20 & 23 & 3 & 20 \\
\hline Direito AMAPÁ & 7 & 2 & 5 & 7 & 2 & 5 \\
\hline Direito TOCANTINS & 16 & 5 & 11 & 16 & 5 & 11 \\
\hline Direito MARANHÃO & 22 & 4 & 18 & 22 & 4 & 18 \\
\hline Direito PIAUÍ & 27 & 9 & 18 & 27 & 9 & 18 \\
\hline Direito CEARÁ & 27 & 5 & 22 & 27 & 5 & 22 \\
\hline $\begin{array}{l}\text { Direito RIO GRANDE DO } \\
\text { NORTE }\end{array}$ & 17 & 6 & 11 & 17 & 6 & 11 \\
\hline Direito PARAÍBA & 20 & 5 & 15 & 20 & 5 & 15 \\
\hline Direito PERNAMBUCO & 38 & 11 & 27 & 38 & 9 & 29 \\
\hline Direito ALAGOAS & 19 & 3 & 16 & 19 & 3 & 16 \\
\hline Direito SERGIPE & 12 & 1 & 11 & 12 & 1 & 11 \\
\hline Direito BAHIA & 64 & 14 & 50 & 64 & 14 & 50 \\
\hline Direito MINAS GERAIS & 155 & 14 & 141 & 155 & 14 & 141 \\
\hline Direito ESPÍRITO SANTO & 32 & 1 & 31 & 32 & 1 & 31 \\
\hline Direito RIO DE JANEIRO & 92 & 9 & 83 & 92 & 9 & 83 \\
\hline Direito SÃO PAULO & 229 & 12 & 217 & 229 & 11 & 218 \\
\hline Direito PARANÁ & 90 & 11 & 79 & 90 & 11 & 79 \\
\hline Direito SANTA CATARINA & 61 & 2 & 59 & 61 & 2 & 59 \\
\hline $\begin{array}{l}\text { Direito RIO GRANDE DO } \\
\text { SUL }\end{array}$ & 89 & 6 & 83 & 88 & 5 & 83 \\
\hline $\begin{array}{l}\text { Direito MATO GROSSO DO } \\
\text { SUL }\end{array}$ & 19 & 7 & 12 & 19 & 7 & 12 \\
\hline Direito MATO GROSSO & 32 & 8 & 24 & 32 & 8 & 24 \\
\hline Direito GOIÁS & 48 & 9 & 39 & 48 & 9 & 39 \\
\hline $\begin{array}{l}\text { Direito DISTRITO FEDERAL } \\
\text { (53) }\end{array}$ & 28 & 2 & 26 & 28 & 2 & 26 \\
\hline
\end{tabular}

202 INSTITUTO NACIONAL DE ESTUDOS E PESQUISAS EDUCACIONAIS ANÍSIO TEIXEIRA. Sinopse Estatística da Educação Superior 2017. Brasília, DF: Inep, 2018. Disponível em: http://inep.gov.br/sinopsesestatisticas-da-educacao-superior. Acesso em: 25 mar. 2019.

203 A informação foi obtida por meio de solicitação ao acesso às bases de dados protegidos do Serviço de Acesso a Dados Protegidos (Sedap) do Inep subscrita no Processo no 23036.002755/2019-55, deferida, nos termos da Portaria $n^{\circ} 52$, de 28 de janeiro de 2019, estando apta a acessar os seguintes dados solicitados:

DATA_DEED_SUPERIOR (2013 a 2017). Os dados foram coletados na sala segura do Inep, cuja extração ocorreu no período de 20 a 24 de janeiro de 2020, e a disponibilização dos resultados foi enviada por meio do protocolo de transferência FTPs, nos termos no Despacho n ${ }^{\circ}$ 0484837/2020/SEDAP/CIBEC/DIRED. 
Tabela 6 - Comparação entre número de instituições que oferecem o curso e tabela sigilosa

(conclusão)

\begin{tabular}{|c|c|c|c|c|c|c|}
\hline \multirow[t]{2}{*}{$\begin{array}{l}\text { Unidade da Federação / curso } \\
\text { (classe Inep) }\end{array}$} & \multicolumn{3}{|c|}{$\begin{array}{c}\text { Número de cursos (sinopse } \\
\text { estatística) }\end{array}$} & \multicolumn{3}{|c|}{$\begin{array}{c}\text { Número de cursos } \\
\text { CONFERÊNCIA TABELA } \\
\text { SIGILOSA }\end{array}$} \\
\hline & Total & Pública & Privada & Total & Pública & Privada \\
\hline EAD Direito & 1 & - & 1 & 1 & - & 1 \\
\hline TOTAL & 1.203 & 160 & 1.043 & 1.202 & 156 & 1.046 \\
\hline
\end{tabular}

Fonte: Elaboração própria.

Como é possível verificar, na sinopse estatística ${ }^{204}$ foram apontados 160 (cento e sessenta) cursos de Direito ofertados por instituições de ensino superior públicas no Brasil. Ao cruzar os dados com a planilha informativa coletada após pedido no Inep ${ }^{205}$, verificou-se que o número de cursos de Direito ofertados por essas mesmas instituições consistem na verdade em 156 (cento e cinquenta e seis), ou seja, uma divergência de 4 (quatro) cursos informados pelos dados públicos em confronto aos dados sigilosos, cujo equívoco se deu com relação aos dados relativos a Pernambuco, São Paulo e Rio Grande do Sul, como destacado no quadro de conferência (Tabela 6).

Com relação ao número de cursos de Direito ministrados em instituições de ensino superior privadas, verificou-se que a sinopse estatística ${ }^{206}$ apresenta o número de 1.043 (mil e quarenta e três) cursos de Direito ofertados no Brasil em 2017. Ao confrontar essa informação com os dados sigilosos coletados no Inep ${ }^{207}$, verificou-se que o número de cursos ofertados por IES privadas seriam na ordem de 1.046 (mil e quarenta e seis), havendo equívoco com relação aos estados de São Paulo e Pernambuco.

Além das já apontadas inconsistências encontradas diante de mera revisão e conferência dos dados disponibilizados ao público e dos coletados mediante autorização específica, torna-se imprescindível elaborar uma análise interpretativa da informação

204 INSTITUTO NACIONAL DE ESTUDOS E PESQUISAS EDUCACIONAIS ANÍSIO TEIXEIRA. Sinopse Estatística da Educação Superior 2017. Brasília, DF: Inep, 2018. Disponível em: http://inep.gov.br/sinopsesestatisticas-da-educacao-superior. Acesso em: 25 mar. 2019.

205 A informação foi obtida por meio de solicitação ao acesso às bases de dados protegidos do Serviço de Acesso a Dados Protegidos (Sedap) do Inep subscrita no Processo no 23036.002755/2019-55, deferida, nos termos da Portaria $n^{\circ} 52$, de 28 de janeiro de 2019, estando apta a acessar os seguintes dados solicitados:

DATA_DEED_SUPERIOR (2013 a 2017). Os dados foram coletados na sala segura do Inep, cuja extração ocorreu no período de 20 a 24 de janeiro de 2020, e a disponibilização dos resultados foi enviada por meio do protocolo de transferência FTPs, nos termos no Despacho no ${ }^{\circ}$ 0484837/2020/SEDAP/CIBEC/DIRED.

206 INSTITUTO NACIONAL DE ESTUDOS E PESQUISAS EDUCACIONAIS ANÍSIO TEIXEIRA, op. cit.

207 A informação foi obtida por meio de solicitação ao acesso às bases de dados protegidos do Serviço de Acesso a Dados Protegidos (Sedap) do Inep subscrita no Processo no 23036.002755/2019-55, deferida, nos termos da Portaria $n^{\circ} 52$, de 28 de janeiro de 2019, estando apta a acessar os seguintes dados solicitados:

DATA_DEED_SUPERIOR (2013 a 2017). Os dados foram coletados na sala segura do Inep, cuja extração ocorreu no período de 20 a 24 de janeiro de 2020, e a disponibilização dos resultados foi enviada por meio do protocolo de transferência FTPs, nos termos no Despacho nº 0484837/2020/SEDAP/CIBEC/DIRED. 
estatística. Tal estudo pode ser extraído com base nesse conjunto de informações, que vão culminar na crise da educação jurídica que pretendemos comprovar.

A primeira evidência a ser apresentada consiste em desconstruir o senso comum de que a região sudeste seria privilegiada com a existência do maior número de cursos de Direito, desconsiderando a necessidade de tratamento igualitário entre toda população brasileira. Os números revelam, em verdade, uma proporcionalidade de cursos existentes por região considerando a população de cada uma delas, conforme os números a seguir apresentados pelas Tabelas 7 e 8 e pelos Gráficos 3 e 4:

Tabela 8 - Total de cursos de Direito por região

\begin{tabular}{l|c}
\multicolumn{1}{c|}{ REGIÃO } & $\begin{array}{c}\text { Total de cursos de } \\
\text { Direito }\end{array}$ \\
\hline NORTE & 81 \\
\hline NORDESTE & 246 \\
\hline SUDESTE & 508 \\
\hline SUL & 239 \\
\hline CENTRO-OESTE & 127 \\
\hline & $1.201^{208}$ \\
\hline
\end{tabular}

Fonte: Inep, 2018.
Tabela 7 - Total de cursos de Direito por região e número de habitantes

\begin{tabular}{l|l}
\hline \multicolumn{1}{c|}{ REGIÃO } & Habitantes \\
\hline NORTE & 18.430 .980 \\
\hline NORDESTE & 57.071 .654 \\
\hline SUDESTE & 88.371 .433 \\
\hline SUL & 29.975 .984 \\
\hline CENTRO-OESTE & 16.297 .074 \\
\hline TOTAL & 210.147 .125 \\
\hline
\end{tabular}

Fonte: Inep, 2018.

208 O valor de cursos considerados está baseado exclusivamente nos cursos presenciais, levando-se em consideração a informação oficial de que no ano de 2017 existia um curso EAD em Direito, como apresentado na tabela oficial do Inep. Cf. INSTITUTO NACIONAL DE ESTUDOS E PESQUISAS EDUCACIONAIS ANÍSIO TEIXEIRA. Sinopse Estatística da Educação Superior 2017. Brasília, DF: Inep, 2018. Disponível em: http://inep.gov.br/sinopses-estatisticas-da-educacao-superior. Acesso em: 25 mar. 2019. 
Gráfico 3 - Proporção de cursos de Direito por região



Fonte: Elaboração própria.
Gráfico 4 - Proporção de cursos de Direito por região e número de habitantes

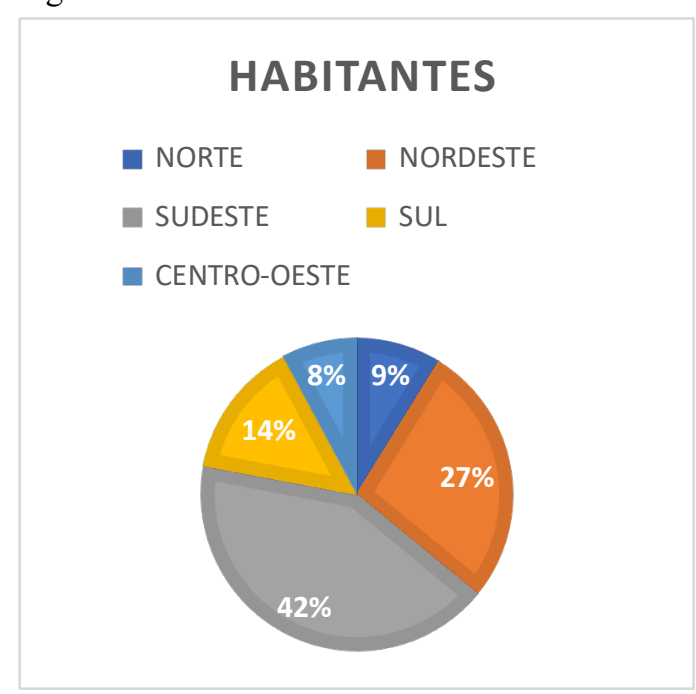

Fonte: Elaboração própria.

Outra evidência apontada está na falsa impressão de que existiria uma grande oferta desproporcional dos cursos de Direito à população brasileira. A impressão é falsa, pois, diante da análise em números absolutos, verifica-se que na média nacional cada curso de direito impacta a vida de cerca de 174.831 habitantes.

Esse valor não destoa das médias encontradas nos estados e nas regiões, o que nos permite concluir que, objetivando a função econômica e social do curso de Direito, de forma absoluta e considerando que os cursos abertos deveriam atender a requisitos mínimos de qualidade para o efetivo desenvolvimento econômico e social da região onde se encontra, não há uma desproporção no oferecimento desses cursos no Brasil. A Tabela 9 apresenta os dados mencionados. 
Tabela 9 - Razão de habitantes por curso

\begin{tabular}{|c|c|c|c|}
\hline $\begin{array}{l}\text { Unidade da Federação / Curso } \\
\text { (Classe Inep) }\end{array}$ & $\begin{array}{c}\text { Total de } \\
\text { cursos de } \\
\text { Direito }\end{array}$ & Habitantes & $\begin{array}{c}\text { Razão } \\
\text { habitantes/curso }\end{array}$ \\
\hline Direito RONDÔNIA & 12 & 1.777 .225 & 148.102 \\
\hline Direito ACRE & 5 & 881.935 & 176.387 \\
\hline Direito AMAZONAS & 14 & 4.144 .597 & 296.043 \\
\hline Direito RORAIMA & 4 & 605.761 & 151.440 \\
\hline Direito PARÁ & 23 & 8.602 .865 & 374.038 \\
\hline Direito AMAPÁ & 7 & 845.731 & 120.819 \\
\hline Direito TOCANTINS & 16 & 1.572 .866 & 98.304 \\
\hline Direito MARANHÃO & 22 & 7.075 .181 & 321.599 \\
\hline Direito PIAUÍ & 27 & 3.273 .227 & 121.231 \\
\hline Direito CEARÁ & 27 & 9.132 .078 & 338.225 \\
\hline $\begin{array}{l}\text { Direito RIO GRANDE DO } \\
\text { NORTE }\end{array}$ & 17 & 3.506 .853 & 206.285 \\
\hline Direito PARAÍBA & 20 & 4.018 .127 & 200.906 \\
\hline Direito PERNAMBUCO & 38 & 9.557 .071 & 251.502 \\
\hline Direito ALAGOAS & 19 & 3.337 .357 & 175.650 \\
\hline Direito SERGIPE & 12 & 2.298 .696 & 191.558 \\
\hline Direito BAHIA & 64 & 14.873 .064 & 232.392 \\
\hline Direito MINAS GERAIS & 155 & 21.168 .791 & 136.573 \\
\hline Direito ESPÍRITO SANTO & 32 & 4.018 .650 & 125.583 \\
\hline Direito RIO DE JANEIRO & 92 & 17.264 .943 & 187.662 \\
\hline Direito SÃO PAULO & 229 & 45.919 .049 & 200.520 \\
\hline Direito PARANÁ & 90 & 11.433 .957 & 127.044 \\
\hline Direito SANTA CATARINA & 61 & 7.164 .788 & 117.456 \\
\hline Direito RIO GRANDE DO SUL & 88 & 11.377 .239 & 129.287 \\
\hline Direito MATO GROSSO DO SUL & 19 & 2.778 .986 & 146.262 \\
\hline Direito MATO GROSSO & 32 & 3.484 .466 & 108.890 \\
\hline Direito GOIÁS & 48 & 7.018 .354 & 146.216 \\
\hline Direito DISTRITO FEDERAL (53) & 28 & 3.015 .268 & 107.688 \\
\hline EAD Direito & 1 & - & - \\
\hline TOTAL & 1.202 & 210.147 .125 & 174.831 \\
\hline
\end{tabular}

Fonte: Elaboração própria.

Dois estados chamam mais a atenção por destoarem da média nacional: Pará e Tocantins. O Tocantins, por demonstrar que, em tese, cada curso de Direito tende a impactar cerca de 98.304 habitantes, atende numericamente um número menor de habitantes, o que seria positivo pensando nas particularidades da população. Enquanto isso, no estado do Pará, cada curso de Direito tende a impactar cerca de 374.038 habitantes, quase o dobro do número encontrado na média nacional, o que justificaria numericamente a necessidade de fomentar a criação de novos cursos de Direito na região.

No entanto, essa análise meramente numérica pode ser tendenciosa por não considerar que a maioria dos cursos estão localizados nas capitais das Unidades Federativas. É evidente que existe uma concentração de habitantes nas capitais, porém, ao pensar o Brasil como projeto de nação em desenvolvimento, é primordial considerar que as regiões interioranas, à parte das 
capitais e suas regiões metropolitanas, devem ser desenvolvidas com estudo, prioridade e assertividade. Assim, é apresentada a proporção dos cursos que são oferecidos nas capitais e no interior, como apontam os Gráficos 5, 6, 7, 8 e 9.

Gráfico 5 - Proporção de cursos na região Norte

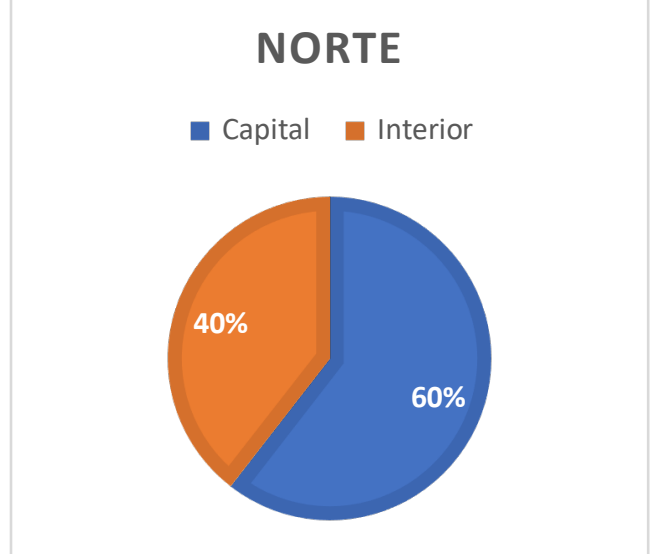

Fonte: Elaboração própria.

Gráfico 8 - Proporção de cursos na região Sudeste

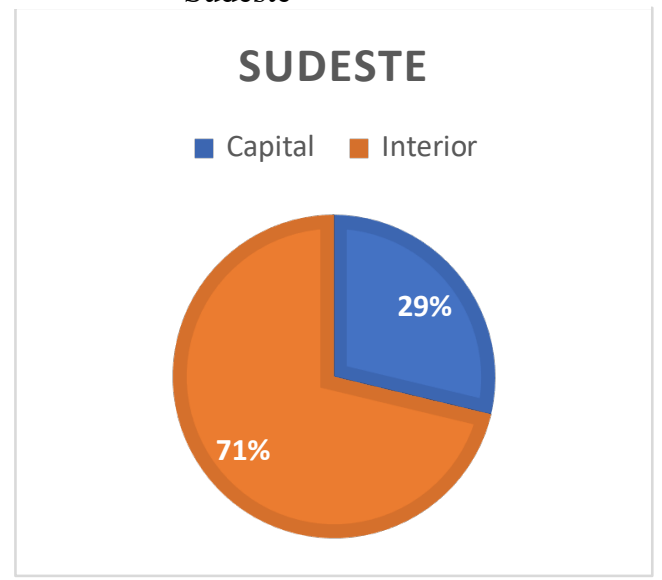

Fonte: Elaboração própria.
Gráfico 6 - Proporção de cursos na região Nordeste

\section{NORDESTE}

- Capital a Interior

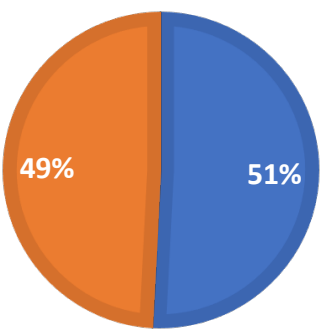

Fonte: Elaboração própria.

Gráfico 7 - Proporção de cursos na região Sul

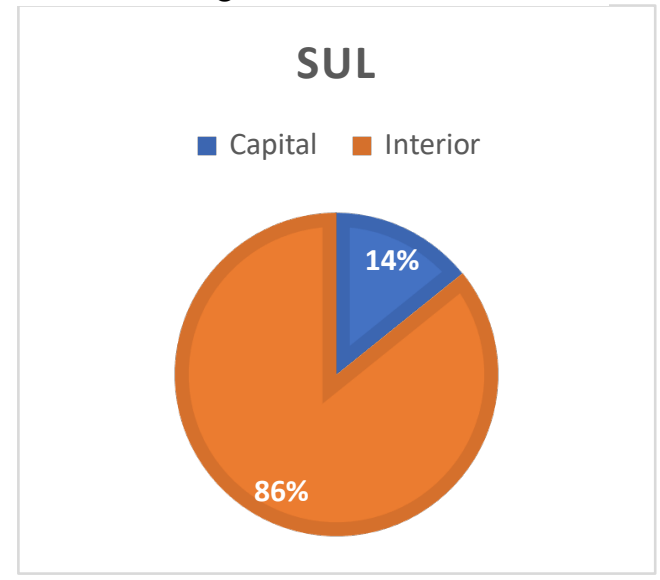

Fonte: Elaboração própria. 
Gráfico 9 - Proporção de cursos na região Centro-Oeste

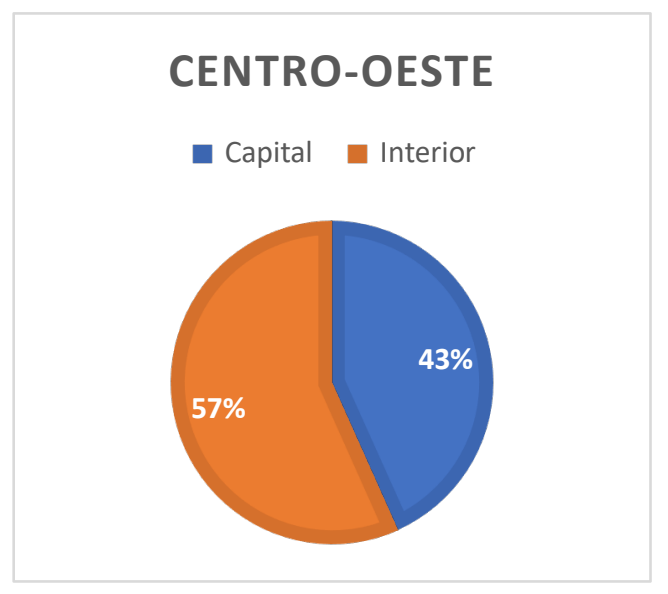

Fonte: Elaboração própria.

Note que, diferentemente do que o senso comum prega, novamente os dados comprovam que nas regiões Sul, Sudeste e Centro-Oeste está em curso um projeto de valorização do interior do Brasil, visto que, principalmente no Sul e no Sudeste, o número de cursos de Direito fora das capitais é proporcionalmente superior, impactando outras regiões além dos grandes centros das capitais federais.

Com os dados apresentados, é possível concluir que existe um projeto de valorização da educação superior jurídica nacional em curso, cujos indicadores denotam que nossa realidade não é tão crítica quanto o senso comum quer nos fazer acreditar. No entanto, ainda resta pendente a compreensão das razões pelas quais os cursos jurídicos não formam sujeitos aptos ao mercado de trabalho se estruturalmente nosso aparato educacional tem total condição de atender a demanda brasileira.

Como forma de comprovar que a realidade brasileira tem total condição de atender a um projeto de nação e considerando que foi mencionada alhures uma comparação entre a Espanha e o Brasil ${ }^{209}$, aproveita-se a relação traçada anteriormente para apresentar uma comparação possível de ser feita com os mesmos indicadores em ambos os países. Será buscado comprovar que, respeitadas as devidas particularidades, não estamos tratando de universos tão distintos quanto o senso comum quer fazer crer.

209 Destacamos que a comparação foi explicada anteriormente e ela é mantida em razão de a Espanha ter logrado êxito em organizar o seu Sistema Educacional Universitário, de forma a conseguir prestar contas com maior transparência à sociedade e figurar nos principais rankings internacionais entre as melhores instituições de ensino para graduandos nacionais e estrangeiros. 
Segundo dados oficiais mais atualizados, estima-se que seria de $47.100 .396^{210} \mathrm{o}$ número total de habitantes na Espanha, e de acordo com informações oficiais prestadas pelo Ministério da Educação ${ }^{211}$, são ofertados 90 cursos de Direito em território espanhol. Assim, na média espanhola, cada curso de Direito consegue impactar a vida de 523.337 habitantes.

No Brasil, como apresentamos anteriormente, verifica-se que na média nacional, cada curso de direito impacta a vida de cerca de 174.831 habitantes, ou seja, é falso imaginar que existe uma oferta em demasia considerando nossa realidade. Além disso, é importante ter em conta que em razão de o Brasil ser um país de dimensões continentais, as regionalidades devem ser respeitadas e os cursos de Direito devem ter prerrogativa discricionária suficiente para definir quais são os melhores conteúdos a serem desenvolvidos dentro de um núcleo mínimo que se espera de um bom operador do Direito.

Os dados relativos à nossa estrutura educacional na área do Direito denotam que não estamos imersos em uma crise educacional com relação ao acesso nem ao impacto e transformação que tais cursos podem causar nos lugares onde são implementados. Na verdade, a crise está justamente na qualidade daquilo é de fato entregue à sociedade, justamente porque não há como se falar em controle de qualidade sem clareza dos padrões nem constante fiscalização.

Vale frisar que quando se fala de fiscalização, trata-se idealmente de um controle que seja justo, rígido e igualitário, que encare todas as instituições de ensino como iguais, independentemente de sua organização administrativa. O que acontece no Brasil é que existe um tratamento diferente para os cursos cuja organização administrativa é pública em detrimento das privadas, e isso se nota de imediato ao verificar que existem diferentes sistemas de ensino, cada qual com suas específicas competências para proceder ao controle de qualidade.

Dentre os sistemas, verifica-se que todas as instituições de ensino superior privadas e as públicas federais fazem parte do sistema federal de ensino, sendo esse o mais relevante pra a educação superior justamente porque é composto por um número muito maior de IES, nos exatos termos dos dados da Tabela 10 e do Gráfico 10:

${ }^{210}$ Dado disponibilizado pelo Instituto Nacional de Estadistica. Cf. INSTITUTO NACIONAL DE ESTADÍSTICA (España). Divulga informações estatísticas sobre a Espanha. Madrid: INE, [20-?]. Disponível em: https://www.ine.es. Acesso em: 24 abr. 2020.

${ }^{211}$ Informação encontrada mediante consulta pública realizada na aplicação do Governo "Qué Estudiar y Dónde en la Universidad - QEDU”. Disponível em:

https://www.educacion.gob.es/notasdecorte/busquedaSimple.action . Acesso em: 24 abr. 2020. 
Tabela 10 - Organização administrativa da IES em 2017

\begin{tabular}{l|r|r}
\hline $\begin{array}{c}\text { Organização Administrativa das IES } \\
\text { em atividade no ano de 2017 }\end{array}$ & \multicolumn{1}{c|}{ Públicas } & \multicolumn{1}{c}{ Privadas } \\
\hline Federal & 109 & 2.162 \\
\hline Estadual e DF & 124 & - \\
\hline Municipal & 53 & - \\
\hline Fonte: Inep, 2018. & &
\end{tabular}

Levando-se em consideração que a LDB define que o sistema federal compreenderá as IES públicas federais e as particulares (art. 16, incisos I e II), e que o sistema estadual compreenderá as IES públicas estatuais e municipais (art. 17, incisos I e II), fica notório perceber a dimensão do sistema federal frente ao sistema estadual, conforme o Gráfico 10:



Fonte: Inep, 2018.

Diante dos dados apresentados, a primeira crítica possível consiste justamente em deixar evidente a desnecessidade dessa divisão sistemática criada na lei, ao menos no que atine às instituições de ensino superior. Não existem motivos plausíveis que justifiquem a manutenção desse fracionamento, que tem por resultado principal tratamento não isonômico entre as IES.

Além disso, outra crítica consiste em explicar por quais razões as IES municipais devem integrar o sistema estadual de ensino, se não existe hierarquia entre os entes da federação, mas tão somente divisão de competências, como definido pela diretriz constitucional do Brasil.

Nesse sentido, as instituições de ensino superior públicas deveriam ser fiscalizadas pelo respectivo sistema estatual ao qual estão vinculadas, mas a verdade é que elas acabam 
entrando em uma espécie de vazio de controle público com a única justificativa de que não pertencem ao sistema federal de ensino. Serão tratadas adiante as especificidades inerentes ao Sinaes, inclusive para apresentar esse cenário da inconsistência apontada.

No entanto, buscando consolidar a desproporcionalidade existente no sistema da educação superior no Brasil, é oportuno apresentar os dados relativos ao montante das instituições de ensino superior em atividade no Brasil, onde verifica-se que o número de instituições de educação superior privadas no território nacional totaliza quase $90 \%$ do número total de IES em atividade, conforme os valores da Tabela 11 e do Gráfico 11 apresentados:

Tabela 11 - IES brasileiras em atividade (públicas e privadas)

\begin{tabular}{l|r|r}
\hline & \multicolumn{1}{|c}{ Públicas } & \multicolumn{1}{c}{ Privadas } \\
\hline IES Brasileiras $^{212}$ & 286 & 2.162 \\
\hline
\end{tabular}

Fonte: Inep, 2018.

Gráfico 11 - Proporção de IES brasileiras em atividade (públicas e privadas)

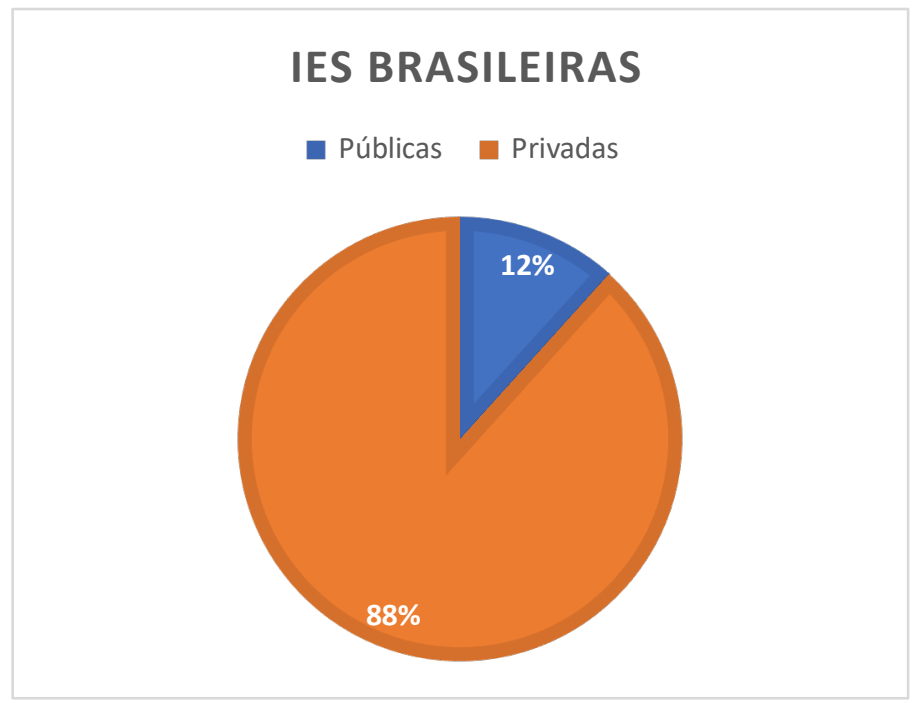

Fonte: Inep, 2018.

212 A informação foi obtida por meio de solicitação ao acesso às bases de dados protegidos do Serviço de Acesso a Dados Protegidos (Sedap) do Inep subscrita no Processo n ${ }^{\circ}$ 23036.002755/2019-55, deferida, nos termos da Portaria $^{\circ} 52$, de 28 de janeiro de 2019, estando apta a acessar os seguintes dados solicitados:

DATA_DEED_SUPERIOR (2013 a 2017). Os dados foram coletados na sala segura do Inep, cuja extração ocorreu no período de 20 a 24 de janeiro de 2020, e a disponibilização dos resultados foi enviada por meio do protocolo de transferência FTPs, nos termos no Despacho nº 0484837/2020/SEDAP/CIBEC/DIRED. 
Diante dessa compilação dos números e da possibilidade de dimensionar o impacto que a educação jurídica tem no Brasil, pode-se sustentar a importância de analisar aquilo que o poder público de fato faz para buscar garantir a prestação desses serviços com boa qualidade, a fim de conseguir, diante das críticas, propor possíveis alternativas que visem a melhoria do setor.

Constatou-se que foi em razão dos estímulos promovidos pelo governo que a expansão do ensino superior no Brasil aconteceu de forma não planejada. Isso tornou-se uma prática mercadológica altamente rentável, e os dados comprovam justamente esse cenário, levando-se em consideração que no Brasil a educação superior é composta por $88 \%$ de instituições privadas.

Há um documento de consultoria para apoio ao setor privado da educação superior ${ }^{213}$ informando que, em 2015, o ensino superior privado no Brasil movimentou aproximadamente cerca de 40 bilhões de reais no ano. Com essa simples informação fica impossível negar que o poder público deve assumir um papel ativo para assegurar, de forma efetiva, a qualidade na prestação do serviço de todo o sistema.

Ernesto Jacob Keim ${ }^{214}$ nos dá um direcionamento sobre o papel que os programas de avaliação devem exercer. Na educação, tais condutas devem ter forma de diagnóstico, motivando a construção de um plano de ação que possibilite a correção do rumo daquilo que foi mal avaliado e promova a emancipação e/ou a conservação do que foi considerado adequado e relevante.

Esse plano deve requerer da escola e de sua equipe docente e administrativa disposição para mudar e assumir novos desafios, das autoridades, lisura e despojamento de compromissos particulares, a fim de que a educação possa estar, de fato, a serviço da emancipação cultural e cognitiva da população, e não de interesses que impeçam a concretização desses ideais.

Diante da descrição do atual cenário crítico sobre os meandros e aspectos inerentes à educação superior na área do Direito no Brasil, é evidente que temos um quadro extremamente complexo que deve ser devidamente compreendido para que políticas públicas específicas sejam adotadas visando a superação desse contexto de crise.

Um dos mecanismos identificados para aprimorar o setor indubitavelmente foi a implementação de procedimento público para a apuração da qualidade da educação superior no Brasil. É justamente por isso que se fala exaustivamente em busca da qualidade como

${ }^{213}$ HOPER. Análise setorial da educação superior privada: Brasil 2015. Foz do Iguaçu: Hoper Educação, 2015.

${ }^{214}$ KEIM, Ernesto Jacob. Complexidade da avaliação, avaliação na complexidade. EccoS Revista Científica, UNINOVE, São Paulo, v. 2, n. 2, p. 45-59, dez. 2000, p. 52. 
instrumento de superação da crise. No entanto, o que pode ser entendido como qualidade e os mecanismos possíveis de adoção para a concretização de um ensino jurídico de boa qualidade também é tema de debates técnicos e científicos, que serão aprofundados nos capítulos seguintes. 


\section{PROCESSOS E MECANISMOS EUROPEUS E BRASILEIROS IDEALIZADOS PARA ASSEGURAR A QUALIDADE UNIVERSITÁRIA}

A busca para assegurar a qualidade na educação superior surge como um grande desafio a ser enfrentado e um mecanismo de superação da crise do referido setor, especialmente pelos países em desenvolvimento. Trata-se de um tema que ganhou grande importância em virtude dos debates travados em todo o mundo. Com a necessidade de se buscar a boa qualidade educacional, os sistemas de acreditação têm-se convertido em fenômenos de grande centralidade em quase todos os países.

Ao fazer referência à qualidade de algum produto ou serviço, necessariamente isso diz respeito às características que aquele produto ou serviço detém quando é entregue à sociedade, visando atribuir-lhe determinado grau de satisfação, maior ou menor, dependendo sempre da efetiva entrega daquilo que o prestador do serviço ou fornecedor do produto se propõe a fazer.

Logo, é correto dizer que a boa qualidade consiste no atributo que designa uma característica boa a algo ou a alguém, sendo uma virtude ou dom quando atrelados ao sujeito e a um objetivo a ser alcançado na prestação de um serviço ou fornecimento de um produto.

Definir o conceito de qualidade é uma tarefa complexa. Quando essa definição se relaciona com a educação superior, a complexidade aumenta, somando-se à complexidade do próprio momento por que passa a educação superior no mundo, em função das mudanças relacionadas à globalização, às tecnologias da informação e comunicação, ao maior interesse pela educação superior e a outros tantos fatores que geram uma grande discussão em torno do papel da universidade e de sua identidade ${ }^{215}$.

Segundo Pilar Jimenéz Tello ${ }^{216}$, a qualidade se trata de um conceito relativamente novo, cuja origem remonta à uma filosofia empresarial idealizada nos anos 1950, no Japão, atrelada à uma concepção de qualidade do produto entregue à sociedade. Diversos são os autores, as formas e os estudos na área, que objetivam definir e compreender os meandros inerentes ao sistema de qualidade, especialmente na área industrial, a fim de entregar produtos de qualidade superior ${ }^{217}$.

215 CARDOSO, Roberta Muriel; DIAS SOBRINHO, José. Os processos de avaliação no Brasil: o que foi proposto e o que ocorre de fato. Revista ComCiência, Campinas, v. 165, p. 1-4, fev. 2015. p. 44.

216 TELLO, Pilar Jiménez. Auditoría universitaria y calidad: la evaluación como conquista social ante la competencia universitaria global. Saarbrücken: VDM Verlag Dr. Müller, 2009. p. 115.

${ }^{217}$ Nesse sentido, destacamos os estudos que se destinam à análise do sistema japonês de qualidade o qual demonstra uma estratégia mais integrada em relação aos vários aspectos da administração da qualidade. A título de exemplo menciona-se o artigo do professor José Carlos de Toledo. Cf. TOLEDO, José Carlos de. O sistema japonês de controle de qualidade. Revista de Administração de Empresas, São Paulo, v. 26, n. 3, p. 77-79, set. 1986. Disponível em: http://www.scielo.br/scielo.php?script=sci_arttext\&pid=S003475901986000300009\&lng=en\&nrm=iso. Acesso em: 23 abr. 2019. 
Assim, é correto afirmar que a qualidade consiste no satisfatório cumprimento de objetivos bem definidos. Por isso, de forma generalizada, Pilar Jiménez Tello ${ }^{218}$ entende a qualidade como a aptidão de um produto ou serviço para satisfazer as necessidades dos clientes ou usuários, depreendendo desse entendimento dois conceitos: que os serviços sejam oferecidos de acordo com as normas, isto é, que cumpram as especificações nelas estabelecidas, e que os serviços estejam adequados às expectativas ou necessidades, aptos a gerar satisfação nos usuários/clientes.

Em todo o mundo, existem entidades que regulamentam o controle de qualidade de acordo com a legislação de cada país. Um dos órgãos pioneiros em padronização de produtos é a International Organization for Standardization (ISO) - em português, Organização Internacional de Estandardização ou padronização. Fundada em 1947, em Genebra, na Suíça, a organização está presente em 164 países e tem a intenção de normatizar diferentes produtos e serviços para que a sua qualidade possa ser assegurada ${ }^{219}$.

Os membros que compõem a ISO são as mais famosas organizações de padrões em seus respectivos países. Há apenas um membro que representa a ISO em cada país. Conforme a figura 3, existem três categorias de membros, sendo que cada uma delas detém um nível diferente de acesso e influência sobre o sistema ISO. Segundo apontam, esse mecanismo ajuda na criação de um padrão mundial de qualidade, ao mesmo tempo em que reconhecem as diferentes necessidades e capacidades de cada órgão nacional de padrões.

\footnotetext{
218 "De manera generalizada, entendemos por calidad la aptitud de un producto o servicio. para satisfacer las necesidades de los clientes o usuarios.

De todas ellas se desprenden dos conceptos:

- Que los servicios se ofrezcan de acuerdo a unas normas, es decir, que se cumplan las especificaciones establecidas en las mismas.

- Que los servicios de adecuen a las expectativas o necesidades, es decir que generen satisfacción en los usuarios/clientes." Cf. TELLO, Pilar Jiménez. Auditoría universitaria y calidad: la evaluación como conquista social ante la competencia universitaria global. Saarbrücken: VDM Verlag Dr. Müller, 2009. p. 116.

219 INTERNATIONAL ORGANIZATION FOR STANDARDIZATION. About us. Geneva: ISO, [2019?]. Disponível em: https://www.iso.org/about-us.html. Acesso em: 13 maio 2019.
} 
Figura 3 - Mapa com categorias de membros da ISO

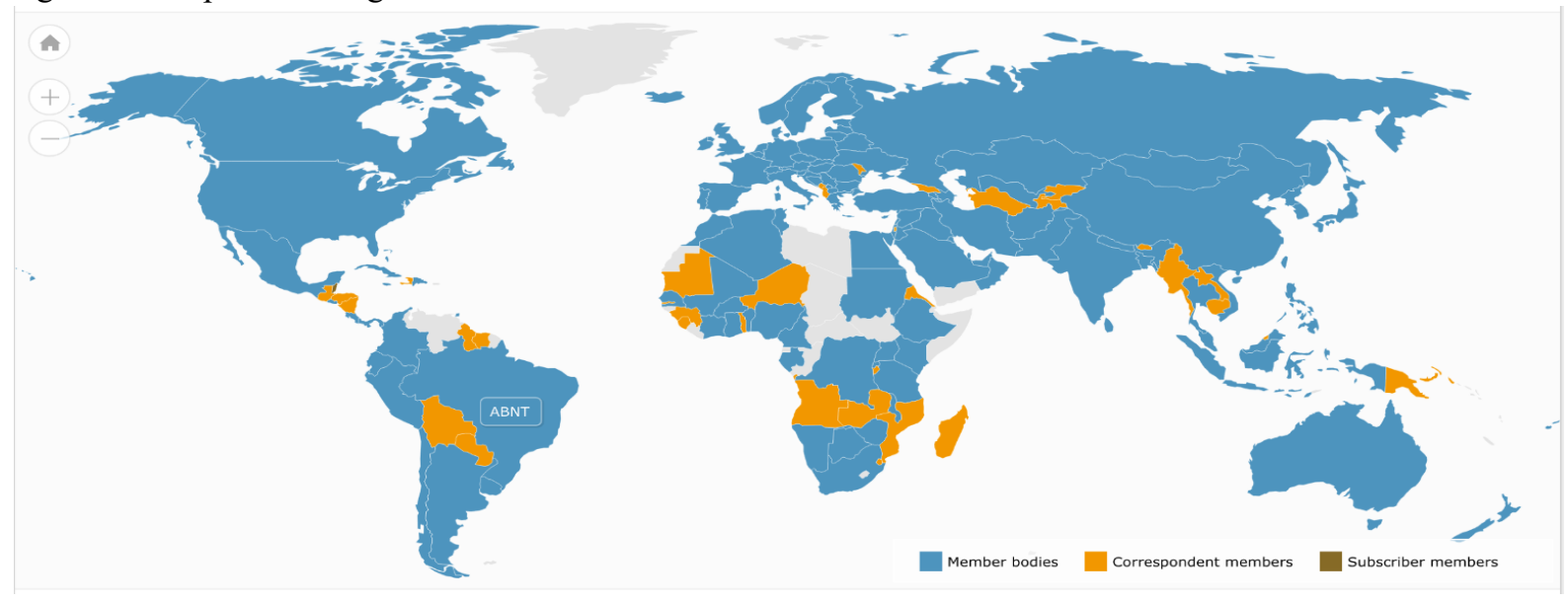

Fonte: Site ISO.

Os full members ou member bodies influenciam o desenvolvimento e a estratégia dos padrões ISO, participando e votando em reuniões técnicas e de políticas da ISO. Essa categoria de membro vende e adota as normas internacionais da ISO em âmbito nacional. Os correspondent members observam o desenvolvimento de padrões e estratégias da organização, participando de reuniões técnicas e de política ISO como observadores. Esses membros também podem vender e adotar as normas internacionais da ISO a nível nacional. Já os subscriber members mantêm-se atualizados sobre o trabalho da organização, mas não podem participar dele; eles não vendem nem adotam as normas internacionais da ISO a nível nacional.

O Brasil participa da mencionada organização internacional na categoria de member body, por intermédio da participação da Associação Brasileira de Normas Técnicas (ABNT), a qual fora criada em 1940 como uma organização sem fins lucrativos engajada na elaboração de normas nacionais.

A Lei Federal $n^{\circ} 4.150$, de 21 de novembro de 1962, além de instituir o regime obrigatório de preparo e observância das normas técnicas nos contratos de obras e compras do serviço público de execução direta ou indireta, através da Associação Brasileira de Normas Técnicas, concedeu à referida associação o status de organização de utilidade pública.

Posteriormente, a Lei Federal n ${ }^{0}$ 5.966, promulgada em 11 de dezembro de 1973, criou o Sistema Nacional de Metrologia, Normalização e Qualidade Industrial, patrocinado pelo Ministério da Indústria e Comércio. Nesse sistema, por uma resolução governamental de 1992, tornou-se responsável pela gestão do processo de padronização brasileiro.

Destaque-se que a ABNT é membro fundador da ISO e, desde 1940, da Comissão Eletrotécnica Internacional (IEC). A ABNT também contribuiu para a fundação da Comissão Pan-Americana de Padrões (Copant) e participou da resolução da Associação Mercosul de 
Normalização (AMN), sendo responsável por sua secretaria executiva. A ABNT também é membro da Global Ecolabelling Network (GEN).

Ainda, a ABNT atua na certificação de produtos desde 1950 e desenvolveu diferentes programas para atender às necessidades das empresas brasileiras. Ela estabelece e gerencia marcas de conformidade com padrões aplicados em esquemas de certificação de produtos voluntários ou compulsórios, sendo um organismo de registro credenciado para certificar sistemas de qualidade, sistemas de gestão ambiental e diversos produtos.

A obtenção de certificação ISO por instituições de ensino superior no Brasil, apesar de ser plenamente possível, não consiste em uma prática comum pelas IES por diversos motivos. Mas, o principal deles consiste em enxergar a certificação ISO como prática inerente à gestão de empresas do setor industrial, as quais não detêm objetivos de transformação social como são esperados de instituições de ensino.

Existem estabelecimentos educacionais que buscam esse tipo de certificação como uma forma de passar para o usuário/cliente do serviço certa confiança daquilo que a instituição se propõe a fazer. Nesse sentido, atualmente existem certificações que as escolas de todos os níveis podem receber por intermédio da certificação ISO, especialmente a ISO 9000.

Wouter Van den Berghe ${ }^{220}$ esclarece que a ISO 9000 é a certificação comumente atribuída para uma série de padrões internacionais de garantia de qualidade das organizações: ISO 9001, ISO 9002, ISO 9003 e ISO 9004 (e seus desdobramentos). A definição oficial da ISO 9001 é atribuída a um sistema de qualidade, que garante um modelo de gestão para projeto, desenvolvimento, produção, produção, instalação e serviços, sendo que os padrões mais relevantes para o contexto educacional são esse e o ISO 9002. Ao contrário de outros textos e normas da série ISO 9000, esses dois regulamentos preveem a certificação de organizações por um terceiro.

Os certificados atestam que o receptor da certificação segue determinados padrões de sistema que a ISO reconhece como necessários para observar uma gestão de boa qualidade dos serviços que são prestados.

220 “'ISO 9000’ es la denominación de uso común para una serie de normas internacionales de garantía de la calidad dentro de organizaciones: ISO 9001, ISO 9002, ISO 9003 e ISO 9004 (y sus subnormas). Las normas más relevantes para el contexto de este artículo son la ISO 9001 y la ISO 9002. El título oficial de la ISO 9001 es 'Sistemas de la calidad'. Un modelo de garantía de calidad para el diseño, el desarrollo, la producción, la instalación y los servicios. La ISO 9002 es semejante a la ISO 9001, exceptuando que no incluye el diseño. A diferencia de otros textos y 'normas'de la serie ISO 9000, estas dos normativas prevén la certificación de organizaciones por una tercera parte." Cf. BERGHE, Wouter Van den. Aplicación de las normas ISO 9000 a la enseñanza y la formación. Revista Europea de Formación Profesional CEDEFOP, [s. l.], n. 15, p. 21-30, sept./dic. 1998. p. 21. Disponível em:

https://dialnet.unirioja.es/servlet/articulo?codigo=131241. Acesso em: 20 maio 2020. 
Ao tratar do tema, Wouter Van den Berghe ${ }^{221}$ explica ainda que a ISO 9001 e a ISO 9002 são padrões do sistema. Certificados a conceder, as organizações apontam que tais instituições possuem uma ação organizada e perfeitamente capaz de cumprir com as necessidades e exigências dos seus clientes de uma forma planejada e controlada. Porém, o rótulo não garante que os produtos ou resultados do trabalho da organização apresentarão o mais elevado nível de qualidade, embora seja assim induzido para fins publicitários.

O mencionado sistema de implementação de qualidade por meio de processos pode às vezes entrar em conflito com um sistema mais absoluto de implementação da qualidade do produto. Por exemplo, um certificado ISO 9000 para uma organização de ensino oferece uma garantia de que é bem estruturado e que os resultados de seus programas e cursos cumprem as metas e necessidades colocadas pelos usuários, mas não garantem necessariamente que o conteúdo desses cursos e programas atendam a um certo nível educacional.

Apesar das críticas e de considerar que as normas ISO com a consequente certificação talvez não sejam a forma mais adequada de se apurar a qualidade no setor educacional, é inegável considerar que atualmente consiste em um mecanismo ou, até mesmo, alternativa viável para enfrentar essa questão, que clama por atenção. Afinal, a qualidade do serviço educacional é tema de interesse do educando, dos educadores, da sociedade civil, do Estado e do mercado, todos com seus peculiares interesses na prestação desse serviço e na apuração da qualidade dele.

Além do que a certificação ISO já foi capaz de transformar para o alcance da prestação de serviços de boa qualidade, parte-se da concepção de que a qualidade que a mencionada certificação afere não se destina a avaliar a qualidade do conteúdo dos cursos, mas sim do setor administrativo das instituições de ensino.

Como referência ao que se pode observar em território europeu, cabe mencionar a existência da Fundação Europeia para a Gestão de Qualidade (European Foundation Quality

221 “Es importante recordar que la ISO 9001 y la ISO 9002 son normas de sistema. Los certificados que pueden concederse mediante ellas señalan que una organización es perfectamente capaz de cumplir las necesidades y requisitos de sus clientes de manera planificada y controlada. Pero el lábel no garantiza que los productos o resultados del trabajo de la organización presenten el máximo nivel posible de calidad (aún cuando ello se sugiere frecuentemente con objetivos publicitarios). Este sistema de implantación de la calidad mediante procesos puede entrar en ocasiones en conflicto con un sistema más "absoluto" de implantación de la calidad por productos. Por ejemplo, un certificado ISO 9000 para una organización docente ofrece una "garantía" de que ésta se halla bien estructurada y de que los resultados de sus programas y cursos responden a los objetivos y necesidades planteados por los usuarios; pero no garantizan necesariamente que los contenidos de dichos cursos y programas cumplan un determinad nivel educativo." Cf. BERGHE, Wouter Van den. Aplicación de las normas ISO 9000 a la enseñanza y la formación. Revista Europea de Formación Profesional CEDEFOP, [s. l.], n. 15, p. 21-30, sept./dic. 1998. Disponível em: https://dialnet.unirioja.es/servlet/articulo?codigo=131241. Acesso em: 20 maio 2020. 
Management - EFQM ${ }^{222}$ ). Trata-se de Fundação não lucrativa sediada em Bruxelas, fundada em 1989 com o objetivo de aumentar a competitividade da economia europeia. Quando se fala em EFQM, refere-se ao modelo de qualidade definido pela fundação que leva esse nome. É justamente a Fundação Europeia para a Gestão da Qualidade, que significa a sigla EFQM, uma fundação sem fins lucrativos sediada em Bruxelas e que tem mais de 500 parceiros espalhados por 55 países.

A Gestão pela Qualidade Total corresponde a um tipo de gestão caracterizado pela procura permanente de introdução de melhorias graduais e contínuas nos processos e procedimentos já existentes, procurando sempre a excelência na qualidade. Essa fundação define o modelo EFQM de Qualidade e Excelência como uma forma de autoavaliação e determinação de processos de melhoria contínua em ambientes de negócios privados e públicos. O modelo EFQM que surgiu na década de 1980 é uma referência na União Europeia, e o Prêmio Europeu da Qualidade tornou-se uma referência para muitas empresas públicas nos diferentes países membros da União. A premiação é baseada nos critérios do modelo Business Excellence.

Os principais conceitos ou características que compõem o modelo EFQM são: a orientação a resultados, orientação ao cliente, liderança e coerência, gerenciamento de processos e fatos, desenvolvimento e envolvimento das pessoas, processo contínuo de aprendizagem, inovação e melhoria, desenvolvimento de alianças e responsabilidade social da organização.

Através da autoavaliação, o modelo EFQM visa uma gestão mais eficaz e eficiente. A identificação dos pontos fortes e fracos aplicados a diferentes áreas da organização é o ponto de partida para o processo de melhoria contínua. O Clube de Excelência em Gestão concede reconhecimentos na forma de selos que avaliam a implementação do EFQM em uma empresa de acordo com a pontuação obtida. Esse modelo de apuração de qualidade é extremamente importante para o contexto europeu e ganhou uma versão ibero-americana denominada CAF.

No sentido de conceber um modelo de excelência que fosse direcionado para a Administração Pública, em 2000, foi criada a CAF - Estrutura Comum de Avaliação (Common Assessment Framework), na tentativa de formar um modelo de autoavaliação através do qual uma organização possa levar a cabo um diagnóstico das suas atividades e resultados com base em evidências.

A CAF foi desenvolvida com base no modelo de excelência da EFQM e no modelo da Universidade Alemã de Ciências Administrativas (Speyer). Além destas duas instituições, contou também com a colaboração do EIPA Instituto Europeu de Administração Pública (European Institute of Public Administration).

À semelhança do Modelo da EFQM, também este é aplicável a qualquer tipo de organização pública, independentemente do seu tamanho, competências e

${ }^{222}$ MODELO EFQM de Calidad y Excelencia. Disponível em: http://www.efqm.es. Acesso em: 16 dez. 2020. 
atribuições. Pode inclusive em organizações de grande dimensão ser apenas utilizado numa delimitada fração da organização. Serve igualmente de referência a outros países e permite o acesso a benchmarking local, regional, nacional e internacional.

A CAF baseia-se na premissa de que as organizações atingem resultados excelentes ao nível do desempenho, bem como na perspetiva dos cidadãos/clientes, colaboradores e sociedade quando têm lideranças que conduzem a estratégia, o planeamento, as pessoas, as parcerias, os recursos e os processos, pelo que este modelo analisa a organização simultaneamente por diferentes ângulos, promovendo uma análise holística do desempenho da organização $0^{223}$.

O modelo CAF apresenta manifestas vantagens para os seus utilizadores, em primeiro lugar, trata-se de um modelo criado com o propósito da aplicação em serviços da Administração Pública. Trata-se de um modelo de fácil entendimento e permite realizar um exercício de autoavaliação com custos reduzidos e por um reduzido número de funcionários diretamente afetos. Serve também como ponte aos diversos modelos de gestão uma vez que é compatível com qualquer um.

Marília Costa Morosini menciona a existência de um espaço de transição entre um modelo ideal weberiano de educação tradicional e um outro de educação superior neoliberal. Refere-se ao modelo de universidade tradicional como aquele voltado ao bem social, com o sentido de promover a cultura e servir à comunidade, e ao modelo neoliberal como aquele voltado a uma formação para o mercado e a prestação de contas à sociedade sobre a qualidade da educação oferecida ${ }^{224}$.

No primeiro modelo, a universidade é um espaço de desenvolvimento do conhecimento voltado para a sociedade, para o coletivo, para a cidadania. No segundo, voltase para o indivíduo, para o mercado, para o desenvolvimento pessoal, uma concepção extremamente individualista, privada. Essa percepção influencia diretamente a noção do que é qualidade para cada indivíduo e para a sociedade.

Com apoio nos fundamentos filosóficos e políticos envolvidos no conceito de qualidade, é fundamental compreender inicialmente que qualidade é algo relativo, tratando-se de um conceito multidimensional, que depende, em grande medida, do contexto em que será

${ }^{223}$ PIMENTEL, Telmo David Marcos. A utilização do modelo de excelência EFQM: um estudo de caso com as organizações portuguesas permeadas pelo pex/spq nos anos de 1994 a 2010. 2013. 205 f. Dissertação (Mestrado) - Curso de Direito, Faculdade de Direito, Universidade de Coimbra, Coimbra, 2013. Disponível em:

https://eg.uc.pt/bitstream/10316/35044/1/A\%20utilizacao\%20do\%20modelo\%20de $\% 20$ excelencia $\% 20 \mathrm{da} \% 2$ 0efqm.pdf. Acesso em: 16 dez. 2020, p. 78.

224 MOROSINI, Marilia Costa. Qualidade da educação superior e contextos emergentes. Avaliação (Campinas), Sorocaba, v. 19, n. 2, p. 385-405, jul. 2014. p. 386. Disponível em:

https://www.scielo.br/scielo.php?pid=S1414-40772014000200007\&script=sci_abstract\&tlng=pt. Acesso em: 10 maio 2020. 
apurada.

Convém destacar que no âmbito da conferência da Organização das Nações Unidas para a Educação, a Ciência e a Cultura (Unesco), em 1998, foi apontada uma definição de qualidade: “[...] é a adequação do Ser e do que Fazer da Educação Superior ao seu Dever ser”. O Ser estaria ligado à pertinência, o Fazer ao funcionamento, e, portanto, à eficiência, enquanto o Dever ser, à eficácia, ou seja, aos resultados ${ }^{225}$.

Mesmo sem conseguir definir a qualidade de maneira precisa, apontar uma instituição de ensino superior como de boa qualidade não se torna uma missão impossível caso seja considerada, para essa apuração, sua responsabilidade social e pertinência à formação dos estudantes para o mercado de trabalho e o exercício da cidadania, de forma crítica e livre, com conhecimentos e valores que devem ser adquiridos para uma justa convivência social. "Em outras palavras, educação de qualidade é aquela que cumpre satisfatoriamente a sua função de contribuir para os projetos e processos de emancipação dos indivíduos e das sociedades"226.

Assim, para apurar a qualidade do conteúdo da prestação do serviço educacional no Brasil, conclui-se que outros mecanismos devem ser idealizados e implementados para a apuração do conteúdo da qualidade desse serviço, os quais serão a seguir apresentados.

Preliminarmente, deve-se reconhecer que existem políticas públicas específicas voltadas para esse intuito, desde muito antes da promulgação da vigente Constituição Federal brasileira. Porém, no contexto educacional, foi por intermédio de sua promulgação que, objetivando o desenvolvimento nacional, observou-se um claro movimento para obrigar os setores público e privado a efetuarem a prestação de serviços e fornecimentos de produtos de boa qualidade no Brasil.

Esse movimento pode ser identificado pela constitucionalização da exigência da qualidade em diversas passagens da atual Constituição Federal, pois ali a qualidade figura como princípio norteador da atuação da administração pública brasileira. Trata-se de um fundamento para o cidadão legitimamente participar dessa gestão, pelo que está previsto em seu no artigo

${ }^{225}$ FERNÁNDEZ LAMARRA, Norberto. Universidad y calidad en América Latina en perspectiva comparada: interrogantes y desafíos. Avaliação (Campinas), Sorocaba, v. 17, n. 3, p. 661-688, nov. 2012. p. 669. Disponível em: http://www.scielo.br/scielo.php?script=sci_arttext\&pid=S141440772012000300006\&lng=en\&nrm=iso. Acesso em: 11 maio 2020.

226 "En otras palabras, educación de calidad es aquella que cumple satisfactoriamente su función de contribución a los proyectos y procesos de emancipación de los individuos y de las sociedades." Cf. DIAS SOBRINHO, José. Políticas y conceptos de calidad: dilemas y retos. Avaliação: Revista de Avaliação da Educação Superior (Campinas), Sorocaba, v. 17, n. 3, p. 601-618, nov. 2012. p. 613. Disponível em: http://www.scielo.br/scielo.php?script=sci_arttext\&pid=S1414-40772012000300003\&lng=en\&nrm=iso. Acesso em: 10 maio 2020. 
$37, \S 3^{\circ}$, inciso $I^{227}$, além de ter sido expressamente atribuída como padrão para a prestação do serviço educacional, seja ele prestado pelo setor público, seja pelo privado, como já mencionado anteriormente ${ }^{228}$.

Esse movimento que constitucionalizou a qualidade como mecanismo de participação social ativa do cidadão na gestão da administração pública trouxe um importante desdobramento para o setor educacional. O conteúdo da lei elaborada para a prestação de serviços públicos, em respeito ao artigo 175 da Constituição Federal, determina que incumbirá ao poder público zelar pela boa qualidade do serviço, receber, apurar e solucionar queixas e reclamações dos usuários, que serão cientificados, em até 30 dias, das providências tomadas ${ }^{229}$.

Como apresentado anteriormente, a educação é um serviço público peculiar, porque é de prestação obrigatória pelo Estado, mas sem exclusividade, ou seja, ele não detém titularidade exclusiva sobre a prestação do serviço educacional. Portanto, o Estado tem o dever, imposto pela Constituição, de prestar o referido serviço, porém autorizou que a livre iniciativa também o faça, desde que se sujeite às suas regras previamente instituídas para o setor e sob constante fiscalização pública inerente ao poder de polícia estatal.

\begin{abstract}
Apesar de a Constituição ter se utilizado da expressão "livre à iniciativa privada", nos arts. 209 e 199, esta expressão ambígua não deve ser interpretada, a nosso ver, no sentido de que se trata de atividade livre ao mercado, como se tivesse sido retirada do campo dos serviços públicos e removida para as atividades econômicas em sentido estrito, porque o regime jurídico de prestação de saúde e educação sofre um controle mais rigoroso, dada sua especial proteção em função da relevância de seu conteúdo para o suprimento de necessidades coletivas (expressão maior da realização de direitos sociais). Reitere-se: apenas se quis ressaltar que são serviços públicos sociais não privativos, ou seja, que convivem com a iniciativa privada, sem a necessidade de sua delegação pela via da concessão ou permissão, daí a pretensa liberdade ${ }^{230}$.
\end{abstract}

227 “Art. 37. A administração pública direta e indireta de qualquer dos Poderes da União, dos Estados, do Distrito Federal e dos Municípios obedecerá aos princípios de legalidade, impessoalidade, moralidade, publicidade e eficiência e, também, ao seguinte:

$\S 3^{\circ}$ A lei disciplinará as formas de participação do usuário na administração pública direta e indireta, regulando especialmente:

I - as reclamações relativas à prestação dos serviços públicos em geral, asseguradas a manutenção de serviços de atendimento ao usuário e a avaliação periódica, externa e interna, da qualidade dos serviços." Cf. BRASIL. [Constituição (1988)]. Constituição da República Federativa do Brasil de 1988. Brasília, DF: Presidência da República, 1988. Disponível em:

http://www.planalto.gov.br/ccivil_03/constituicao/constituicaocompilado.htm. Acesso em: 18 fev. 2019.

228 Ibid., art. 206, inciso VII.

229 Art. 29, inciso VII, Lei no 8.987/95: "VII - zelar pela boa qualidade do serviço, receber, apurar e solucionar queixas e reclamações dos usuários, que serão cientificados, em até trinta dias, das providências tomadas". Cf. BRASIL. Lei $n^{\circ} 8.987$, de 13 de fevereiro de 1995. Dispõe sobre o regime de concessão e permissão da prestação de serviços públicos previsto no art. 175 da Constituição Federal, e dá outras providências. Brasília, DF: Presidência da República, 1995c. Disponível em: http://www.planalto.gov.br/ccivil_03/leis/18987cons.htm. Acesso em: 20 maio 2020.

230 NOHARA, Irene Patrícia. Direito administrativo. 8. ed. Rio de Janeiro: Atlas, 2018. p. 492. 
Então, diante do posicionamento firmado anteriormente e aqui reiterado de que o serviço educacional é um serviço público independentemente do sujeito que o realiza, aquele que se propõe a prestá-lo deve ser submetido a rígido controle de qualidade do conteúdo dos programas, dos planos de ensino e dos efetivos sujeitos postos no mercado de trabalho após a sua formação, que são entregues para a sociedade com a conclusão do curso.

A educação superior como um todo, seja pública, seja privada, é um dos mais importantes institutos sociais do desenvolvimento da humanidade, pois é por meio dela que preparamos nossos cidadãos para a vida em sociedade. Além disso, damos as sólidas bases para exercer efetivamente os instrumentos e as habilidades adquiridos ao logo do processo de conhecimento aplicados ao mercado de trabalho.

O Estado não deve se imiscuir do dever de, em um primeiro momento, estabelecer padrões e critérios para definir no que consistiria um serviço educacional prestado com qualidade para, oportunamente, medir aquilo que está posto para a sociedade.

Além disso, as pessoas que se prestam a entregar esses serviços deveriam ter como preocupação fundamental a qualidade da educação que se propõem a efetivar, independentemente de fiscalização do Estado. Desse modo, a partir do momento em que atuam como atividade econômica prestando um serviço de tamanha importância social, deveriam estar envolvidas com outros objetivos à parte do lucro. Todavia, seria demasiado ingênuo acreditar que o mercado, por si só, adotaria posturas humanistas para a consecução dos seus objetivos.

No campo educacional, as novas diretrizes do século XX e início do século XXI têm
sedimentado um novo perfil de gestão, sobretudo nas organizações universitárias, no
qual está presente um conjunto de características, dentre as quais, a flexibilidade, a
agilidade, a eficiência, a eficácia, a relevância e a produtividade. A universidade é
vista não apenas como um centro de formação de saberes e produção de
conhecimento, mas como aquela que atende aos princípios básicos da modernidade,
seja no que se refere às relações de trabalho, ou à prestação de serviços à sociedade ${ }^{231}$.

No âmbito da educação superior, a avaliação tem sido estimulada através de ações diretas dos governos, com a criação de agências nacionais de avaliação para dar conta da expansão e diversificação desse nível de ensino.

É nesse sentido que o papel do Estado para a promoção de educação de qualidade é fundamental, seja como precursor na promoção e entrega de serviço de qualidade no cenário nacional, atuando diretamente na prestação desse serviço público, seja como constante

231 TENÓRIO, Robinson Moreira; ANDRADE, Maria Antonia Brandão de. A avaliação da educação superior no Brasil: desafios e perspectivas. In: LORDÊLO, José Albertino Carvalho; DAZZANI, Maria Virgínia (org.). Avaliação educacional: desatando e reatando nós. Salvador: EDUFBA, 2009. p. 32. Disponível em: https://repositorio.ufba.br/ri/bitstream/ri/5627/1/Avaliacao_educacional.pdf. Acesso em: 6 set. 2020. 
fiscalizador do serviço que não é por ele prestado, intervindo de maneira indireta para obrigar as instituições de ensino a se voltarem para a constante melhoria na entrega dos seus serviços.

Retomando, é oportuno mencionar que a qualidade deve ser compreendida como o planejamento e a sistematização de ações que devem ser implementadas em um sistema de qualidade. Também devem ser demonstráveis, se necessário, para proporcionar a confiança adequada de que uma entidade cumprirá os requisitos para atingir a boa qualidade.

Pilar Jiménez Tello aponta que é no conceito de qualidade que está a necessidade de incluir todos os aspectos através dos quais as organizações atenderão às expectativas e às necessidades, não apenas de seus clientes/usuários, mas também de seus funcionários e colaboradores, indo além em um compromisso com a própria sociedade. Por sua vez, a qualidade só será alcançável no processo de melhoria contínua em que ela deve ser imersa, se um sistema de aferição estiver disponível por meio de auditorias realizadas por órgãos externos às próprias empresas ${ }^{232}$.

O grande cerne para a adequada prestação do serviço educacional, no entanto, consistirá em racionalizar a melhor forma de empreender ações para que a prestação desse serviço ocorra segundo alguns critérios a fim de que a atividade prestada seja tida como de boa qualidade. Foi nesse contexto que o Estado brasileiro atribuiu para si o dever de fiscalizar o serviço educacional, seja ele prestado por ente público, seja pelo setor privado.

Entretanto, a busca pela prestação de um serviço de qualidade, apesar de ser dever do Estado, também pode ser, por iniciativa própria, atestada pelo setor privado, ou ainda por agentes externos a todo esse sistema, participantes da sociedade civil, levando em conta que a educação é um objetivo comum a todos para o desenvolvimento nacional.

Vale ressaltar que a avaliação não se trata de um procedimento isento e justificável por si só nem é uma simples aplicação de um método de conferência da produtividade ou da eficiência de uma instituição. A avaliação é, pois, a ferramenta principal da organização e implementação de reformas educacionais e mecanismos que devem ser adotados com o objetivo de aprimorar o que efetivamente o alunado recebe para sua formação.

Podemos dizer que estamos vivendo a era das avaliações, que implica conferir, por

232 "En el concepto de calidad ven la necesidad de incluir todos los aspectos a través de los cuales las organizaciones satisfacen las expectativas y necesidades, no sólo de sus clientes, sino también de sus trabajadores y colaboradores, llegando incluso más allá en un compromiso con la propia sociedad. A su vez, la calidad sólo será alcanzable, en el proceso de mejora continua en el que debe estar inmersa, si se dispone de un sistema de medida de la misma a través de auditorías llevadas a cabo por órganos externos a las propias empresas." Cf. TELLO, Pilar Jiménez. Auditoría universitaria y calidad: la evaluación como conquista social ante la competencia universitaria global. Saarbrücken: VDM Verlag Dr. Müller, 2009. p. 115 . 
parte das instituições e do Estado, um grau de adesão plenamente aceito e naturalizado a respeito desta questão. Longe de ser uma tarefa fácil, a avaliação traz consigo, a um só tempo, desafios e reconhecimento quanto a sua importância. Portanto, seja qual for o modelo de avaliação ou os critérios adotados, o reconhecimento da [sua] necessidade é consensual. Dizemos que a avaliação demanda superação de desafios tal como a própria educação - um processo atravessado por contradições e conflitos, os quais tendem a se acirrar em razão da importância que o conhecimento adquiriu na sociedade da informação, como principal motor da economia, do individualismo e da competitividade $^{233}$.

Diante desses apontamentos, é possível concluir que a boa execução da avaliação provavelmente será o principal elemento de consolidação e de articulação simultânea de três concepções necessárias para a configuração da universidade moderna: autonomia, qualidade e responsabilidade.

É importante relembrar que estamos adstritos à análise da educação superior, especialmente na área do Direito, razão pela qual daqui em diante a preocupação será voltada à descrição dos mecanismos existentes para o aprimoramento dos cursos jurídicos no Brasil.

Com essas considerações, conclui-se que os mecanismos aptos a apurar a efetiva qualidade da educação jurídica que podemos apontar são de quatro ordens: (i) auditorias internas, (ii) avaliações públicas, (iii) acreditações públicas e (iv) ranqueamentos nacionais e internacionais efetuados por terceiros imparciais e completamente estranhos a todo esse sistema educacional vigente no Brasil.

Passa-se então à análise minuciosa dos mecanismos de apuração de qualidade identificados no cenário brasileiro. A ideia é centrar-se exaustivamente nas quatro mencionadas ferramentas com o intuito de visualizar de que forma esses procedimentos contribuem para a efetiva melhora do cenário educacional jurídico no Brasil, para então apresentar as críticas observadas no procedimento avaliativo e sugerir uma alternativa viável que busque a apuração da qualidade da forma mais eficiente possível.

\subsection{Iniciativa própria da instituição de ensino superior pelo controle de qualidade dos serviços que presta: uma proposta de compliance educacional}

Constatar a qualidade de um serviço prestado por uma instituição de ensino, em qualquer lugar do mundo, pode consistir em uma tarefa interna ou externa à própria pessoa que presta o serviço. Logo, existem diferentes tipos de mecanismos de verificação de garantia de qualidade, tais como avaliação, acreditação e auditoria dos processos e procedimentos

233 RIBEIRO, Raimunda Maria da Cunha. Avaliação e ranqueamento de universidades sob a lógica de critérios globais. Roteiro, Joaçaba, v. 43, n. 1, p. 259-276, jan./abr. 2018. p. 264. 
efetuados pelas instituições de ensino. Assim, a garantia de qualidade pode ser buscada de forma interna ou externa.

Diante do cenário apresentado, constata-se a necessidade de contextualizar a governança corporativa e o compliance a partir do conceito de diminuição de assimetrias informacionais e conflitos de gestão. Após isso, é preciso analisar as fragilidades existentes na atividade educacional das universidades e a possibilidade de implementar programas de integridade nas instituições de ensino superior.

Uma das formas de apuração externa será apresentada a seguir pelo procedimento público de avaliação e acreditação; contudo, tanto a avaliação interna como a revisão externa são componentes cruciais de qualquer sistema de garantia de qualidade bem desenvolvido.

Internamente, essa apuração pode se dar por um processo de avaliação que assegure o cumprimento dos objetivos e padrões definidos pela própria instituição, pois a autoavaliação é um elemento fundamental para demonstrar que a própria IES compreende que o serviço por ela prestado é de extrema importância social. Esse seria o principal mecanismo próprio para identificar e apurar a qualidade da educação que prestam.

Tal concepção, inclusive, já foi reconhecida pelo próprio Estado brasileiro como fundamental na prestação do serviço público, visto que os instrumentos avaliativos para autorização, reconhecimento e renovação de reconhecimento dos cursos superiores apontam a gestão do curso e os processos de avaliação interna e externa como um dos indicadores mensuráveis para a apuração da qualidade. Tanto é que, para que seja atribuído conceito cinco (o mais alto extrato) ao referido indicador, exige-se o seguinte:

\footnotetext{
a gestão do curso é realizada considerando a autoavaliação institucional e o resultado das avaliações externas como insumo para aprimoramento contínuo do planejamento do curso, com evidência da apropriação dos resultados pela comunidade acadêmica e existência de processo de autoavaliação periódica do curso ${ }^{234}$ (grifo nosso).
}

Para melhor entendimento desses mecanismos de aferição do que de fato acontece nas universidades brasileiras, deve-se compreender que a Constituição Federal determinou o dever do Estado de fiscalizar e constatar que as instituições de ensino no Brasil prestem serviços de qualidade. Por outro lado, à própria universidade, seja ela pública, seja privada, caberá verificar a relevância do ensino que oferece e, assim, garantir a qualidade, que deve nortear a prestação

234 INSTITUTO NACIONAL DE ESTUDOS E PESQUISAS EDUCACIONAIS ANÍSIO TEIXEIRA. Instrumento de avaliação de cursos de graduação presencial e a distância: reconhecimento e renovação de reconhecimento. Brasília, DF: Inep/MEC, 2017. p. 16. Disponível em: http://inep.gov.br/instrumentos. Acesso em: 5 set. 2020. 
do serviço educacional.

Trataremos adiante sobre o papel do Estado na busca por um ensino de qualidade no Brasil e no próximo capítulo, sobre uma relevante forma externa de apuração de qualidade que não é efetuada pelo setor público. No entanto, é preciso reconhecer que a própria instituição de ensino em atividade também deve ter interesse em ofertar uma educação de qualidade à sociedade.

Esse procedimento de autoavaliação possui especial importância em se tratando de uma instituição de natureza pública como forma de comprovar que o investimento público está sendo bem destinado. E, no caso de uma instituição de natureza privada, ainda mais, pois é uma forma de reconhecer que não encara a prestação do serviço educacional como prática pura e simples de uma atividade econômica com objetivo exclusivo de lucro, já que a natureza de serviço público dessa prestação independe do agente que a fornece.

A apuração interna da qualidade pode ser feita pela instituição mediante a adoção de mecanismos próprios que visem a qualidade, traduzindo-se em um verdadeiro sistema de compliance $^{235}$ educacional. A ideia de institucionalização de uma política organizacional veiculada nas IES foi apresentada de forma inovadora por Felipe Chiarello, Bruna Azzari e Amanda Scalisse ${ }^{236}$, de quem as ideias foram extraídas para apresentação.

Essa avaliação institucional interna constituirá em uma ferramenta fundamental para a identificação das possibilidades internas, além de identificar os pontos fortes e fracos das instituições de ensino, com a finalidade de reorientar seus objetivos e suas estratégias ${ }^{237}$.

Para a busca da qualidade dos serviços que são prestados, é possível idealizar um procedimento de apuração por meio de auditoria, a qual consistirá na implementação de um

235 O termo compliance ganhou destaque no Brasil em razão da “Operação Lava-Jato”, razão pela qual acaba sendo atrelado ao Direito Penal em razão de se relacionar com uma política interna criada pela empresa por meio de atividades que identificam as atividades de risco e o estabelecimento de protocolos no sentido de criar-se um órgão interno de vigilância e controle, autônomo e independente capaz de informar e até diminuir os possíveis riscos sob o marco da sociedade de risco e dos medos inerentes à fluidez da pós-modernidade. Com a institucionalização de políticas internas, busca-se a contenção de práticas contrárias à ética e à moral empresariais, assim como o controle de condutas - dentre as quais as criminosas são as mais graves - que infrinjam o ideário da boa governança empresarial. Todavia, apesar de extremamente relacionado à prevenção de condutas criminosas dentro das empresas, o Compliance também pode ser efetuado para controle e fiscalização interno sobre o cumprimento de obrigações de quaisquer naturezas pelas empresas prestadoras de serviços ou fornecimento de produtos.

236 PUGA, Bruna Azzari; PINTO, Felipe Chiarelo de Souza; SILVA, Amanda Scalisse. Ética e integridade nas instituições de ensino superior: a importância da implementação de programas de compliance nas universidades. Revista de Direito Brasileira, v. 26, p. 457-470, 2020.

237 "La evaluación institucional constituye una herramienta fundamental para la identificación de las propias posibilidades y la detección de fortalezas y debilidades en las instituciones de educación superior con la finalidad de reorientar sus objetivos y estratégias." Cf. TELLO, Pilar Jiménez. Auditoría universitaria y calidad: la evaluación como conquista social ante la competencia universitaria global. Saarbrücken: VDM Verlag Dr. Müller, 2009. p. 188. 
exame ou de uma análise efetuada por terceiro, estranho ao quadro de colaboradores de uma empresa. Essa pessoa deve ter com conhecimento especializado, detendo saber técnico e científico capaz de apurar se a qualidade de um sistema, serviço, produto ou processo concorda com as normas que foram previamente adotadas e satisfazem os requisitos estabelecidos.

Andrade e Rossetti ${ }^{238}$ definem que a conceituação de governança corporativa pode ser dividida em quatro grupos principais: (i) guardiã de direitos das partes com interesses em jogo nas empresas; (ii) sistema de relações pelo qual as sociedades são dirigidas e monitoradas; (iii) estrutura de poder que se observa no interior das corporações; (iv) sistema normativo que rege as relações internas e externas das companhias.

O Instituto Brasileiro de Governança Corporativa ${ }^{239}$, ao apresentar o código das melhores práticas de governança corporativa, aponta que os princípios básicos de governança são: a transparência, consistente no desejo de disponibilizar para as partes interessadas as informações que sejam de seu interesse, e não apenas aquelas impostas por disposições de leis ou regulamentos; a equidade, consistente no tratamento justo e isonômico de todos os sócios e das demais partes interessadas, levando em consideração seus direitos, deveres, necessidades, interesses e expectativas; a prestação de contas (accountability), uma vez que os agentes de governança devem apresentar justificativas de sua atuação de modo claro, conciso, compreensível e tempestivo; e, finalmente, a responsabilidade corporativa, já que os agentes de governança devem zelar pela viabilidade econômico-financeira das organizações, reduzir as externalidades negativas de seus negócios e suas operações e aumentar as positivas, considerando, no seu modelo de negócios, os diversos capitais (financeiro, manufaturado, intelectual, humano, social, ambiental, de reputação etc.) em curto, médio e longo prazo.

Florêncio Filho e Zanon ${ }^{240}$ apontam que o termo compliance advém da língua inglesa, cuja significação remete ao cumprir, estar em conformidade, estar de acordo, referindo-se à aderência e ao cumprimento integral das leis e regulações necessárias para o desempenho de suas atividades. Assim, pode-se afirmar que o compliance buscará verificar a relação existente entre o ser e o dever ser institucional que um determinado agente efetivamente entrega para a

238 ANDRADE, Adriana; ROSSETTI, José Paschoal. Governança corporativa: fundamentos, desenvolvimento e tendências. 2. ed. atual. e ampl. São Paulo: Atlas, 2006. p. 138 et. seq.

239 INSTITUTO BRASILEIRO DE GOVERNANÇA CORPORATIVA. Código das melhores práticas de governança corporativa. 5. ed. São Paulo, SP: IBGC, 2018. 108 p. Disponível em: https://edisciplinas.usp.br/pluginfile.php/4382648/mod_resource/content/1/Livro_Codigo_Melhores_Praticas GC.pdf. Acesso em: 5. set. 2020.

240 FLORÊNCIO FILHO, Marco Aurélio Pinto; ZANON, Patricie Barricelli. A efetividade das políticas públicas de criminal compliance para a prevenção da corrupção no Brasil. In: MESSA, Ana Flávia; DOMINGUES, Paulo de Tarso; ESTEVES, João Luiz Martins (org.). Governança, compliance e corrupção. São Paulo: Almedina, 2019. p. 417. 
sociedade.

Por uma questão histórica, relacionada ao fato de que o compliance no Brasil se vincula diretamente com a implementação da Lei Anticorrupção ${ }^{241}$, tem-se que os setores destinados à execução de suas políticas são adstritos às práticas empresariais relacionadas com a possibilidade de as pessoas jurídicas praticarem atos de corrupção contra a administração pública. No entanto, a questão é muito mais abrangente, visto que, quando bem estruturado, o setor pode se destinar à apuração de programas de integridade nas entidades educacionais.

A integridade nas universidades está relacionada a uma série de fatores, como a má conduta nas pesquisas científicas em razão de fraudes e práticas corruptas relacionadas à falta de densidade e profundidade científica, a busca ao exclusivo atendimento de requisitos de avaliações institucionais, muitas vezes quantitativas e não qualitativas, entre outras atitudes condenáveis ética e moralmente.

Contudo, a propositura de um setor de compliance com a abordagem aqui adotada guarda estrita relação com a verificação de que as universidades deveriam se estruturar para conseguir apurar a efetiva adoção dos requisitos pleiteados pelo setor público. Tal feito faria com que as instituições conhecessem de perto os instrumentos regulatórios e seus indicadores, com o viés de conseguir a aplicação dos melhores conceitos por ocasião das avaliações. Além disso, buscariam incessantemente a prestação de serviço educacional de boa qualidade, tudo isso como condição para acreditação dos cursos ofertados.

Seria esse setor o responsável por conhecer de perto todas as formas de apuração de qualidade, públicas e privadas, com organização interna e capacidade de autoavaliação institucional e processo de autoavaliação periódica do curso. Logo, o setor de compliance deveria ser apto a minimizar o risco de não conformidade do curso e da instituição ao que se compreende por uma prestação de serviço educacional de qualidade, reduzindo os danos à imagem da instituição de ensino e dando base administrativa para os procedimentos públicos de avaliação, reconhecimento e acreditação de seus cursos e da própria instituição em si.

Segundo apontado por Silva e $\operatorname{Covac}^{242}$, a matriz institucional de um compliance aplicado aos serviços prestados pelas entidades educacionais de nível superior deveria englobar o tratamento dos conflitos de interesses, a identificação do risco de compliance setorial, o

241 BRASIL. Lei $n^{\circ} 12.846$, de $1^{\circ}$ de agosto de 2013. Dispõe sobre a responsabilização administrativa e civil de pessoas jurídicas pela prática de atos contra a administração pública, nacional ou estrangeira, e dá outras providências. Brasília, DF: Presidência da República, 2013. Disponível em: http://www.planalto.gov.br/ccivil_03/_ato2011-2014/2013/lei/112846.htm. Acesso em: 13 mar. 2020.

${ }^{242}$ SILVA, Daniel Cavalcante; COVAC, José Roberto. Compliance como boa prática de gestão no ensino superior privado. São Paulo: Saraiva. 2015. p. 24. 
planejamento de políticas e procedimentos e a auditoria legal, regulatória e acadêmica.

\begin{abstract}
Destaca-se a realização da auditoria, fundamental para a aplicação de monitoramentos e testes regulares, com o objetivo de averiguar se as atividades da empresa estão de acordo com o planejado. Trata-se de um mecanismo interno de avaliação, ao passo que o compliance faz parte da estrutura de controle institucional, acompanhando os pontos falhos de uma auditoria, por exemplo. A sua divisão em legal, regulatória e acadêmica reflete questões da educação superior em si: a auditoria legal, essencial em todo compliance, implica a revisão da documentação jurídica e administrativa; já a auditoria regulatória, consiste na identificação de deficiências e as respectivas recomendações de ações corretivas dentro de um marco regulatório, neste caso, os atos regulatórios do Ministério da Educação; por fim, a auditoria acadêmica, é a avaliação da situação da organização educacional como um todo, verificando a adequação de atividades e processos acadêmicos à leis, regulamentos e políticas institucionais. As três formam um tripé indissociável no controle do risco de compliance, minimizando custos e perdas, e favorecendo o cumprimento de metas da instituição com a qualidade exigida pelo poder público ${ }^{243}$.
\end{abstract}

A ideia de implementação de um programa de compliance institucional nas instituições de ensino superior não se trata de uma política isolada, já tendo sido encontrada a adoção de matrizes em universidades estrangeiras, como se pode verificar nos casos de Stanford University $^{244}$, Dartmouth College ${ }^{245}$ e Rice University ${ }^{246}$.

Segundo Chiarello, Azzari e Scalisse ${ }^{247}$, além das áreas de compliance normalmente encontradas nas empresas e daquelas de gestão de uma instituição de ensino (como admissões, privacidade dos registros dos alunos, administração de pesquisa, entre outros), verifica-se que uma área foi constante nas matrizes avaliadas: a scientific misconduct, isto é, a má conduta científica.

Importa dizer que a necessidade constante das instituições de ensino em cumprir os deveres inerentes à prestação do serviço público que entregam para a comunidade acadêmica pode ser claramente verificada por ocasião da criação de um setor específico destinado à validação das práticas internas com o viés de fiscalizar e corrigir sua postura. Além disso, seria um setor de referência para a própria instituição e seus colaboradores técnicos e pedagógicos, para orientação interna à incessante busca por altos padrões de qualidade na prestação do

${ }^{243}$ PUGA, Bruna Azzari; PINTO, Felipe Chiarelo de Souza; SILVA, Amanda Scalisse. Ética e integridade nas instituições de ensino superior: a importância da implementação de programas de compliance nas universidades. Revista de Direito Brasileira, 2020. p. 468.

244 STANFORD UNIVERSITY (USA). Compliance Matrix. Redwood City, CA: Stanford University, [2017]. Disponível em: https://ocro.stanford.edu/ethics-compliance/compliance-matrix. Acesso em: 6 set. 2020.

${ }^{245}$ DARTMOUTH COLLEGE (USA). Compliance Matrix. Hanover, NH: Dartmouth College, 2018. Disponível em: https://www.dartmouth.edu/ rmi/compmatrix12315.pdf. Acesso em: 6 set. 2020.

246 RICE UNIVERSITY (USA). Rice University Compliance Matrix. Houstoun, TX: 2020. Disponível em: https://rucompliance.rice.edu/compliance-matrix. Acesso em: 6 set. 2020.

247 PUGA, Bruna Azzari; PINTO, Felipe Chiarelo de Souza; SILVA, Amanda Scalisse. Ética e integridade nas instituições de ensino superior: a importância da implementação de programas de compliance nas universidades. Revista de Direito Brasileira, 2020. p. 469. 
serviço público.

De todo modo, adotando ou não um setor específico da própria instituição que se volte ao cumprimento dos requisitos para a alta valoração do serviço que presta, toda e qualquer instituição de ensino superior no Brasil está sujeita às políticas públicas idealizadas para elevar o padrão de qualidade das universidades, o qual atualmente é controlado tanto pelo setor público quanto pelo setor privado.

Justamente nesse sentido e buscando compreender o que o Estado e a sociedade entendem como cursos jurídicos com padrão elevado de qualidade é que se torna imprescindível efetuar uma análise da política pública atualmente adotada pelo Brasil, para verificar os serviços educacionais prestados em território nacional.

\subsection{Avaliação e credenciamento público: autorizações estatais para funcionamento das instituições de ensino superior}

Para apurar a qualidade da educação que é entregue à sociedade brasileira, a atividade avaliativa efetuada pelo poder público deriva de previsão constitucional vinculativa observada pela conjugação dos artigos 206 inciso VII, 209 inciso II, e 214, inciso III da Constituição Federal de 1988, que determinam o dever estatal de autorização e avaliação das instituições de ensino superior para assegurar padrão de qualidade dos cursos desempenhados pela iniciativa privada e pelo setor público.

Tal atividade é inerente ao poder de polícia estatal e detém a finalidade de prevenir que danos irreparáveis sejam imputados ao alunado ${ }^{248}$. Tanto a avaliação quanto a acreditação consistem em mecanismos de apuração de qualidade tidos como fundamentais para a consecução dessa finalidade.

Há quem defina qualidade, avaliação, garantia de qualidade e acreditação como conceitos inter-relacionados. Embora tais concepções se mesclem porque a avaliação muitas vezes é a base da acreditação, nem sempre isso acontece. José Dias Sobrinho ${ }^{249}$ atribui à avaliação e à acreditação conceitos diferentes, pois a avaliação é apta a fornecer informações e

248 PINTO, Felipe Chiarello de Souza; JUNQUEIRA, Michelle Asato. Aspectos da recente avaliação do ensino jurídico no Brasil: a atuação da OAB e do MEC em busca da qualidade. In: CONGRESSO do Conpedi, 15., 2006, Manaus. Anais [...]. Manaus: CONPEDI, 2006. Tema: Direito, Sociobiodiversidade e Soberania na Amazônia. p. 3. Disponível em:

http://www.publicadireito.com.br/conpedi/manaus/arquivos/anais/manaus/ensino_jur_felipe_c_pinto_e_mich elle junqueira.pdf. Acesso em: 27 jan. 2019.

249 DIAS SOBRINHO, José. Políticas y conceptos de calidad: dilemas y retos. Avaliação (Campinas), Sorocaba, v. 17 , n. 3, p. 601-618, nov. 2012. p. 608. 
comprovações para que a acreditação possa acontecer, enquanto a acreditação por vezes se serve dos resultados da avaliação para atestar a qualidade de uma IES ou de um curso.

A função inerente ao dever de efetivação da avaliação educacional é desempenhada pelo poder público, especificamente por meio das atividades desenvolvidas pelo Ministério da Educação, sendo a Lei n ${ }^{\circ}$ 9.131, de 24 de novembro de 1995, a responsável por definir o âmbito de atuação do referido órgão ministerial, atualmente regulamentada pelo Decreto ${ }^{\circ}{ }^{10.195 / 19}$, que definiu sua estruturação e organização administrativa.

Visando a compreensão específica do procedimento administrativo idealizado para a apuração da qualidade, é oportuno apresentar o atual organograma da estrutura administrativa do referido órgão ministerial (Figura 4), com a posterior explicação das atividades que são efetivadas por cada um dos órgãos da administração direta ou entidades da administração indireta, incumbidas de apurar a qualidade da educação superior brasileira. 
Figura 4 - Estrutura administrativa do MEC

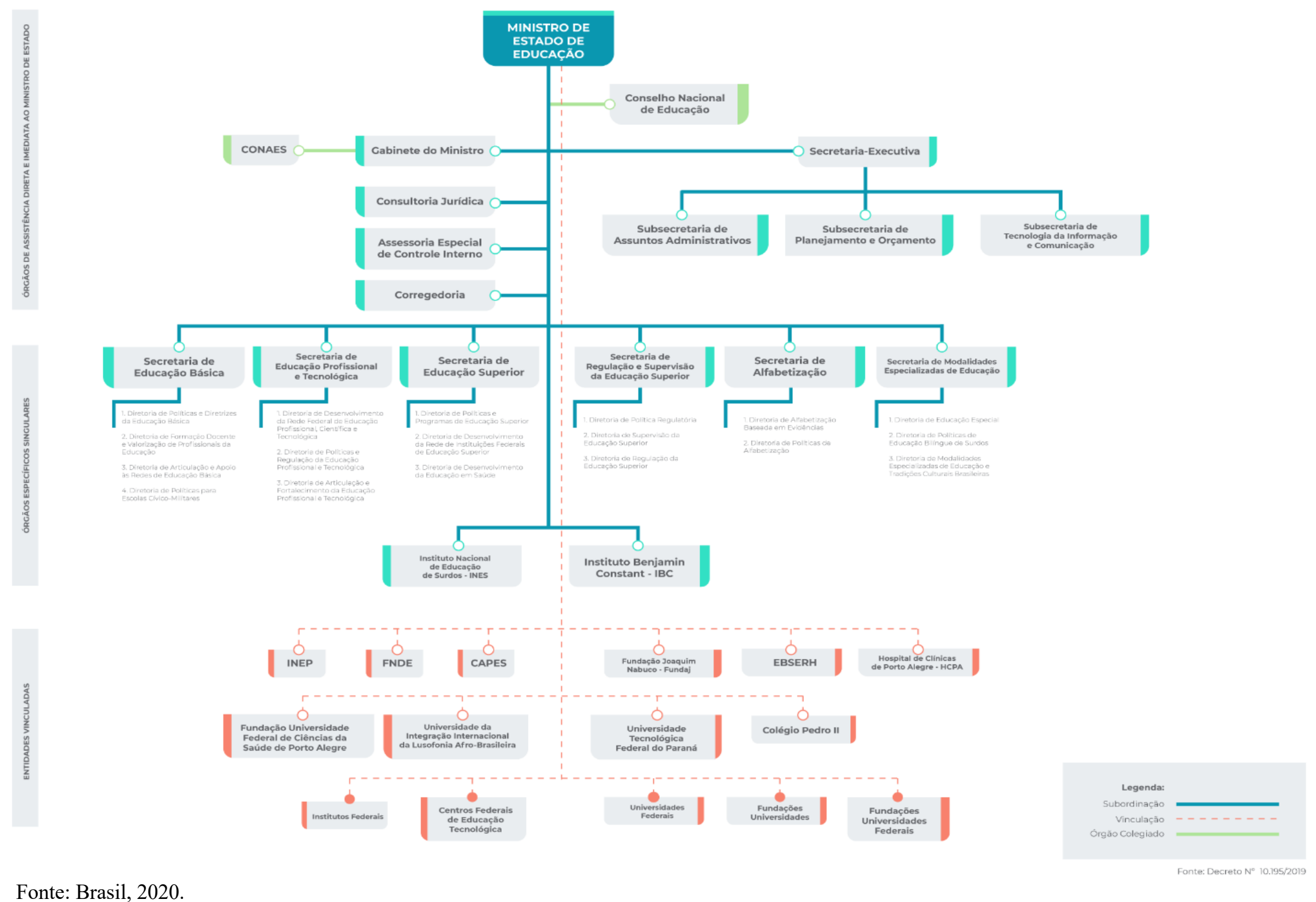

Fonte: Brasil, 2020 
Diante dessa estrutura organizacional, pode-se verificar que o MEC possui determinados institutos que se destinam exclusivamente à estruturação, racionalização e implementação de políticas públicas específicas para a educação superior, tudo no sentido de buscar entregar à sociedade as melhores condições possíveis para a efetivação da educação nesse nível.

No entanto, verifica-se que no Brasil, mesmo diante dos esforços de sistematização da educação nacional, como será a seguir apresentado, não há unidade de plano nem espírito de continuidade, que seria indispensável para dirigir em um mesmo sentido o desenvolvimento da educação. O que vemos é que na realidade toda previsão legal traduz uma alta fragmentação e desarticulação do setor, que passaremos a sistematizar adiante.

A Lei $n^{0}$ 9.131/95 foi responsável por definir a competência material do órgão do Poder Executivo Federal, que seria responsável por dedicar-se à promoção da educação brasileira. Sem dúvida é uma das mais complexas pastas da administração pública, tanto é que seu artigo $1^{\circ}$ define que o Ministério da Educação é o órgão responsável pelas atribuições do poder público federal em matéria de educação, cabendo-lhe formular e avaliar a política nacional de educação, zelar pela qualidade do ensino e velar pelo cumprimento das leis que o regem. Ainda, o mesmo artigo cria as figuras do Conselho Nacional de Educação e das Câmaras de Educação Básica e de Educação Superior, que o compõem para colaborar com essas atribuições ${ }^{250}$.

A educação nacional não deveria ser vista de forma fragmentada, razão pela qual todos os órgãos criados para a promoção da educação e vinculados aos diferentes entes federativos deveriam voltar-se em suas atribuições para efetivar medidas que objetivassem a promoção de quaisquer dos níveis educacionais em total respeito à institucionalização de um Sistema Nacional de Educação, como previsto no Plano Nacional de Educação ${ }^{251}$.

Aliás, é justamente o PNE o documento normativo idealizado para regulamentar o artigo 214 da Constituição Federal, implementando metas para a melhoria do setor, vigentes pelo período de 10 (dez) anos. Logo, tem-se que o presente plano nacional deverá viger até 24 de junho de 2024.

Em quaisquer seguimentos da atuação da administração pública, deve sempre prevalecer a noção da estrita legalidade, razão pela qual, visando a imparcialidade e a incessante

\footnotetext{
250 Art. $1^{\circ}$ da Lei $n^{\circ}$ 9.131/95. Cf. BRASIL. Lei $n^{\circ}$ 9.131, de 24 de novembro de 1995. Altera dispositivos da Lei $\mathrm{n}^{\circ}$ 4.024, de 20 de dezembro de 1961, e dá outras providências. Brasília, DF: Presidência da República, 1995a. Disponível em: http://www.planalto.gov.br/ccivil_03/leis/19131.htm. Acesso em: 7 fev. 2019.

251 Lei ${ }^{\circ} 13.005$, de 25 de junho de 2014.
} 
busca pelo bem comum, pouco importa quem será o agente público responsável pelo comando da máquina pública - ele deverá agir dentro do que a lei previamente autoriza. Todos os seus atos e as suas escolhas políticas devem respeitar o ordenamento jurídico e possuir permissivos legais anteriores que autorizem a atuação do administrador. Não é diferente com os agentes responsáveis pela promoção da educação.

A Constituição Federal determinou que o poder público deveria implementar um PNE a cada decênio. Em âmbito educacional, é esse documento normativo que dá diretriz para que o gestor público eleito possa comandar a execução das atividades da administração pública, a fim de adotar as melhores atitudes possíveis para cumprir o plano de metas regularmente implementado, com objetivos expressamente definidos a serem alcançados no período de 10 (dez) anos.

O atual PNE, em vigor no Brasil desde 2014, estipulou três metas específicas para a educação superior cumprir até 2024 (metas 12 a 14), quais sejam: (i) elevar a taxa bruta de matrícula na educação superior para 50\% (cinquenta por cento) e a taxa líquida para $33 \%$ (trinta e três por cento) da população de 18 (dezoito) a 24 (vinte e quatro) anos, assegurada a qualidade da oferta e expansão para, pelo menos, $40 \%$ (quarenta por cento) das novas matrículas, no segmento público; (ii) elevar a qualidade da educação superior e ampliar a proporção de mestres e doutores do corpo docente em efetivo exercício no conjunto do sistema de educação superior para 75\% (setenta e cinco por cento), sendo, do total, no mínimo, 35\% (trinta e cinco por cento) doutores; (iii) elevar gradualmente o número de matrículas na pósgraduação stricto sensu, de modo a atingir a titulação anual de 60.000 (sessenta mil) mestres e 25.000 (vinte e cinco mil) doutores.

Note que a qualidade do referido setor consiste em uma efetiva preocupação do Estado, o qual engendrou procedimento administrativo particular, que busca apurar a qualidade da educação superior visando o cumprimento das metas que foram efetivamente estipuladas em respeito à Constituição. Diante da especialização dos órgãos do $\mathrm{MEC}$, encontramos na administração pública setores que se destinam especificamente a idealizar e concretizar as políticas públicas institucionalizadas por lei. 
A Lei de Diretrizes e Bases da Educação Nacional, em seu artigo 9 ${ }^{0252}$, instituiu como responsabilidade da União o dever de adotar medidas efetivas que visem coletar, analisar e disseminar informações sobre a educação, assegurar processo nacional de avaliação das instituições de educação superior, com a cooperação dos sistemas que tiverem responsabilidade sobre esse nível de ensino, e autorizar, reconhecer, credenciar, supervisionar e avaliar, respectivamente, os cursos das instituições de educação superior e os estabelecimentos do seu sistema de ensino.

O MEC é o órgão da administração pública federal direta, contando com o apoio das entidades públicas da administração indireta, que tem como área de competência, entre outros assuntos, avaliação, informação e pesquisa educacional ${ }^{253}$ de todos os níveis e áreas do conhecimento.

Para executar tal atribuição, no MEC existem órgãos específicos singulares que se destinam à estruturação, avaliação, organização e fiscalização da educação superior brasileira, quais sejam: a Secretaria de Ensino Superior (Sesu) e a Secretaria de Regulação e Supervisão da Educação Superior (Seres). Além dos referidos órgãos singulares, verifica-se também a existência de dois importantes órgãos colegiados no MEC que tratam de questões relativas à educação superior nacional, quais sejam: o Conselho Nacional de Educação e o Conselho Nacional de Avaliação da Educação Superior (Conaes), este vinculado ao gabinete do ministro.

Outras duas entidades da administração pública federal indireta extremamente relevantes para a apuração da qualidade da educação superior nacional são o Instituto Nacional de Estudos e Pesquisas e a Coordenação de Aperfeiçoamento de Pessoal de Nível Superior. Note que a importância do Inep guarda relação com o fato de que tal entidade é responsável por

${ }^{252}$ Art. 9: "A União incumbir-se-á de:

V - coletar, analisar e disseminar informações sobre a educação;

VIII - assegurar processo nacional de avaliação das instituições de educação superior, com a cooperação dos sistemas que tiverem responsabilidade sobre este nível de ensino;

IX - autorizar, reconhecer, credenciar, supervisionar e avaliar, respectivamente, os cursos das instituições de educação superior e os estabelecimentos do seu sistema de ensino.

$\S 1^{\circ}$. Na estrutura educacional, haverá um Conselho Nacional de Educação, com funções normativas e de supervisão e atividade permanente, criado por lei.

$\S 2^{\circ}$. Para o cumprimento do disposto nos incisos V a IX, a União terá acesso a todos os dados e informações necessários de todos os estabelecimentos e órgãos educacionais.

$\S 3^{\circ}$. As atribuições constantes do inciso IX poderão ser delegadas aos Estados e ao Distrito Federal, desde que mantenham instituições de educação superior". Cf. BRASIL. Lei $n^{\circ}$ 9.394, de 20 de dezembro de 1996. Estabelece as diretrizes e bases da educação nacional. Brasília, DF: Presidência da República, 1996a. Disponível em: http://www.planalto.gov.br/ccivil_03/leis/19394.htm. Acesso em: 5 fev. 2019.

253 Art. $1^{\circ}$, IV do Anexo I: "IV - avaliação, informação e pesquisa educacional". Cf. BRASIL. Decreto $n^{o}$ 10.195, de 30 de dezembro de 2019. Aprova a Estrutura Regimental e o Quadro Demonstrativo dos Cargos em Comissão e das Funções de Confiança do Ministério da Educação e remaneja e transforma cargos em comissão e funções de confiança. Brasília, DF: Presidência da República, 2019c. Disponível em: http://www.planalto.gov.br/ccivil_03/_ato2019-2022/2019/decreto/D10195.htm. Acesso em: 5 fev. 2019. 
todas as pesquisas, os levantamentos e as coletas de dados oficiais que envolvem a educação nacional, independentemente do nível educacional que se apura, diferentemente da Capes, que está intrinsecamente relacionada com a apuração da qualidade do serviço educacional prestado no âmbito da pós-graduação.

Os mencionados órgãos e entidades formam um específico setor da administração pública federal que é, dentro de suas atribuições, responsável por estudos e efetivação de políticas públicas resultantes de trabalho em conjunto, sendo os responsáveis pela aprovação, credenciamento e controle de qualidade dos cursos superiores ofertados à sociedade brasileira.

A vigente Lei $n^{0}$ 9.131, de 24 de novembro de 1995, estruturou a administração do ensino, criando a figura do Conselho Nacional de Educação ${ }^{254}$, também mencionado no parágrafo primeiro do artigo $9^{\circ}$ da LDB. Atuando como órgão colegiado de funções normativas, de supervisão e atividade permanente do ministro de estado, o artigo $1^{\circ}$ da Lei $\mathrm{n}^{\circ}$ 9.131/95 estabelece que o Conselho Nacional de Educação será composto pelas Câmaras de Educação Básica e de Educação Superior e terá atribuições normativas, deliberativas e de assessoramento ao ministro de estado da educação, de forma a assegurar a participação da sociedade no aperfeiçoamento da educação nacional.

Segundo informações oficiais ${ }^{255}$, o atual Conselho Nacional de Educação, órgão colegiado integrante do Ministério da Educação, foi instituído com a finalidade de colaborar com a formulação da Política Nacional de Educação e exercer atribuições normativas, deliberativas e de assessoramento ao ministro da educação, como já mencionado. A estrutura organizacional do CNE pode ser assim apresentada (Figura 5):

254 As atribuições do Conselho são normativas, deliberativas e de assessoramento ao Ministro de Estado da Educação, no desempenho das funções e atribuições do poder público federal em matéria de educação, cabendo-lhe formular e avaliar a política nacional de educação, zelar pela qualidade do ensino, velar pelo cumprimento da legislação educacional e assegurar a participação da sociedade no aprimoramento da educação brasileira. Compete ao Conselho e às Câmaras exercerem as atribuições conferidas pela Lei 9.131/95, emitindo pareceres e decidindo privativa e autonomamente sobre os assuntos que lhe são pertinentes, cabendo, no caso de decisões das Câmaras, recurso ao Conselho Pleno.

255 BRASIL. Ministério da Educação. CNE - Histórico. Brasília, DF: MEC, 2018a. Disponível em: http://portal.mec.gov.br/index.php?option=com_content\&view=article\&id=14306:cnehistorico\&catid=323: orgaos-vinculados. Acesso em: 20 maio 2019. 
Figura 5 - Estrutura organizacional do CNE

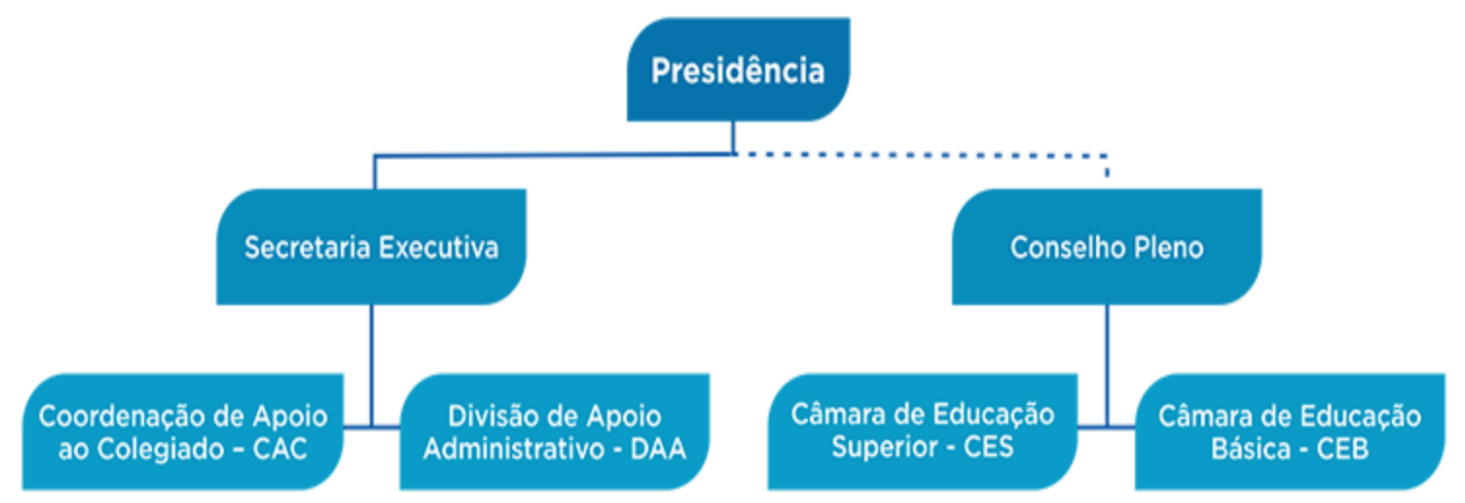

Fonte: Brasil, 2018.

As Câmaras de Educação Básica e de Educação Superior, que compõem o Conselho, são constituídas cada uma por doze conselheiros, sendo membros natos em cada Câmara, respectivamente, o secretário de educação fundamental e o secretário de educação superior do Ministério da Educação, nomeados pelo presidente da república. Compete ao Conselho e às Câmaras exercerem as atribuições conferidas pela Lei no $9.131 / 95$, emitindo pareceres e decidindo privativa e autonomamente sobre os assuntos que lhe são pertinentes, cabendo, no caso de decisões das Câmaras, recurso ao Conselho Pleno.

A Câmara de Educação Superior teve algumas de suas atribuições alteradas na forma dos artigos 20 e 21 da Medida Provisória n 2.216-37, de 31 de agosto de 2001, que alteraram os artigos $9^{\circ}, \S^{\circ}$ da Lei $n^{\circ} 4.024 / 61^{256}$ e o parágrafo único do art. $2^{\circ}$ da Lei $n^{\circ} 9.131 / 95^{257}$.

A lei determina que as atribuições da Câmara de Educação Superior relacionadas aos procedimentos aplicáveis às avaliações públicas consistem em deliberar sobre as normas a serem seguidas pelo Poder Executivo para a autorização, o reconhecimento, a renovação e a suspensão do reconhecimento de cursos e habilitações oferecidos por instituições de ensino superior; deliberar sobre as normas a serem seguidas pelo Poder Executivo para o credenciamento, o recredenciamento periódico e o descredenciamento de instituições de ensino superior integrantes do Sistema Federal de Ensino, bem como a suspensão de prerrogativas de autonomia das instituições que dessas gozem, no caso de desempenho insuficiente de seus cursos no Exame Nacional de Cursos e nas demais avaliações conduzidas

256 BRASIL. Lei n ${ }^{\circ}$ 4.024, de 20 de dezembro de 1961. Fixa as Diretrizes e Bases da Educação Nacional. Brasília, DF: Presidência da República, 1961. Disponível em: http://www.planalto.gov.br/ccivil_03/leis/14024.htm. Acesso em: 6 fev. 2019.

257 BRASIL. Lei $n^{\circ}$ 9.131, de 24 de novembro de 1995. Altera dispositivos da Lei ${ }^{\circ} 4.024$, de 20 de dezembro de 1961, e dá outras providências. Brasília, DF: Presidência da República, 1995a. Disponível em: http://www.planalto.gov.br/ccivil_03/leis/19131.htm. Acesso em: 7 fev. 2019. 
pelo Ministério da Educação; deliberar sobre o credenciamento e o recredenciamento periódico de universidades e centros universitários, com base em relatórios e avaliações apresentados pelo Ministério da Educação, assim como sobre seus respectivos estatutos. Tais atribuições podem ser delegadas, em parte ou no todo, aos Estados e ao Distrito Federal, e o recredenciamento mencionado poderá incluir determinação para a desativação de cursos e habilitações.

Essas deliberações e pronunciamentos do Conselho Pleno e das Câmaras deverão ser homologados pelo ministro de estado da educação, sendo que no sistema federal de ensino a autorização para o funcionamento, o credenciamento e o recredenciamento de universidade ou de instituição não universitária, o reconhecimento de cursos e habilitações oferecidos por essas instituições, assim como a autorização prévia dos cursos oferecidos por instituições de ensino superior não universitárias, serão tornados efetivos mediante ato do Poder Executivo.

Segundo informações oficiais ${ }^{258}$, a partir da edição Medida Provisória $n^{\circ} 2.216^{259}$ e do Decreto 3.860/2001260 que a regulamentou, a Câmara de Educação Superior passou a se manifestar somente nos processos relativos aos cursos de Direito e aos da área de saúde (Medicina, Psicologia e Odontologia) e sobre o credenciamento das instituições que pretendem oferecer cursos na área jurídica e da saúde. Em relação ao credenciamento e o recredenciamento de universidades e centros universitários, fica a cargo do próprio MEC a manifestação sobre os demais cursos de graduação.

O Decreto $\mathrm{n}^{\circ}$ 9.235, de 15 de dezembro de 2017, responsável pela regulamentação dessa política pública, define que a competência do CNE abrangida por esse eixo de atuação consiste em exercer atribuições normativas, deliberativas e de assessoramento ao ministro de estado da educação nos temas afetos à regulação e à supervisão da educação superior, inclusive nos casos omissos e nas dúvidas surgidas na aplicação das disposições desse Decreto; deliberar, por meio da Câmara de Educação Superior, sobre pedidos de credenciamento, recredenciamento e descredenciamento de IES e autorização de oferta de cursos vinculadas a

258 BRASIL. Ministério da Educação. CNE - Histórico. Brasília, DF: MEC, 2018a. Disponível em: http://portal.mec.gov.br/index.php?option=com_content\&view=article\&id=14306:cnehistorico\&catid=323: orgaos-vinculados. Acesso em: 20 maio 2019.

259 Atualmente, a legislação que disciplina a matéria é a Lei $n^{\circ} .13 .844$, de 18 de junho de 2019 Cf. BRASIL. Lei $n^{o}$. 13.844, de 18 de junho de 2019. Estabelece a organização básica dos órgãos da Presidência da República e dos Ministérios. Brasília, DF: Presidência da República, 2019d. Disponível em: http://www.planalto.gov.br/ccivil_03/_ato2019-2022/2019/decreto/D10195.htm. Acesso em: 20 maio 2019.

260 Atualmente, a legislação que disciplina a matéria é o Decreto $\mathrm{n}^{\circ} 9.235$, de 15 de dezembro de 2017. Cf. BRASIL. Decreto $n^{\circ}$ 9.235, de 15 de dezembro de 2017. Dispõe sobre o exercício das funções de regulação, supervisão e avaliação das instituições de educação superior e dos cursos superiores de graduação e de pósgraduação no sistema federal de ensino. Brasília, DF: Presidência da República, 2017. Disponível em: http://www.planalto.gov.br/ccivil_03/_Ato2015-2018/2017/Decreto/D9235.htm. Acesso em: 20 maio 2019. 
credenciamentos; propor diretrizes e deliberar sobre a elaboração dos instrumentos de avaliação para credenciamento e recredenciamento de instituições a serem elaborados pelo Inep; recomendar, por meio da Câmara de Educação Superior, providências da Secretaria de Regulação e Supervisão da Educação Superior do Ministério da Educação, quando não satisfeito o padrão de qualidade para credenciamento e recredenciamento de universidades, centros universitários e faculdades; deliberar, por meio da Câmara de Educação Superior, sobre a inclusão e a exclusão de denominação de curso do catálogo de cursos superiores de tecnologia, nos termos do art. 101; julgar, por meio da Câmara de Educação Superior, recursos a ele dirigidos nas hipóteses previstas nesse Decreto; e analisar e propor ao Ministério da Educação questões relativas à aplicação da legislação da educação superior.

$\mathrm{Na}$ redação desse mesmo texto normativo (Decreto $\mathrm{n}^{\mathrm{o}} 9.235 / 2017$ ), o artigo $3^{\circ}$ combinado com o artigo $5^{\circ}$ do Decreto $n^{\circ} 9.235 / 2017$, as competências para as funções de regulação, supervisão e avaliação no sistema federal de ensino serão exercidas pelo Ministério da Educação, pelo Conselho Nacional de Educação, pelo Instituto Nacional de Estudos e Pesquisas Educacionais Anísio Teixeira e pela Comissão Nacional de Avaliação da Educação Superior. A competência do ministro da educação no exercício das funções de regulação e supervisão da educação superior no âmbito do sistema federal de ensino se concretiza por meio da atuação da Secretaria da Regulação e Supervisão da Educação Superior.

Nos termos do artigo $4^{\circ}$ da mesma legislação sobre o controle de qualidade da educação superior, com apoio da Seres, recai ao ministro de estado a competência para homologar pareceres do CNE em pedidos de credenciamento, recredenciamento e descredenciamento de IES; homologar pareceres e propostas de atos normativos aprovados pelo CNE; aprovar os instrumentos de avaliação elaborados pelo Inep; homologar as deliberações da Conaes; e expedir normas e instruções para a execução de leis, decretos e regulamentos.

As secretarias do MEC que são voltadas à implementação de políticas públicas destinadas à educação superior são: Secretaria de Educação Superior e Secretaria da Regulação e Supervisão da Educação Superior. A finalidade de proceder ao controle de qualidade da educação superior no Brasil é competência da Seres, como será adiante apresentado; no entanto, cabe fazer uma explicação sobre a competência e os objetivos da Sesu como forma de esclarecimento de suas atribuições.

A Secretaria de Educação Superior é um órgão específico singular do Ministério da 
Educação, cuja competência está descrita no artigo 20 do anexo I do Decreto n ${ }^{\circ} 10.195 / 2019^{261}$. Entre as competências que lhe foram atribuídas, objetivando a construção de uma educação superior de qualidade, destacamos sua responsabilidade por planejar, orientar, coordenar e supervisionar o processo de formulação e implementação da Política Nacional de Educação Superior, propor políticas de expansão da educação superior, em consonância com o PNE e promover ações de estímulo e fomento à inovação e melhoria da qualidade da educação superior por meios presenciais e a distância, em diálogo com os setores produtivos e sociais.

$\mathrm{Na} \mathrm{Sesu}$, a diretoria responsável pela consecução desses objetivos é a diretoria de políticas e programas de educação superior, justamente porque o artigo 21 do anexo I do Decreto $\mathrm{n}^{\circ} 10.195 / 2019$ determina que é sua a competência para implantar, acompanhar e avaliar os programas de apoio às instituições de educação superior, em articulação com órgãos afins, além de desenvolver e monitorar projetos especiais de fomento, com vistas à modernização e à qualificação das instituições de educação superior.

Implica dizer, as medidas que o poder público deve tomar para efetivamente buscar a melhoria da qualidade educacional são políticas públicas de responsabilidade do Poder Executivo, que devem ser implementadas pela referida secretaria (Sesu), por intermédio da ação da diretoria de políticas e programas da educação superior.

Após a idealização e efetiva adoção de medidas que busquem essa melhoria do setor, o Estado atribuiu para si o dever de fiscalizar e supervisionar o que de fato é desempenhado na educação superior, determinando, assim, uma atitude posterior, de controle, inerente ao seu poder de polícia.

Para atingir essa finalidade é que a Secretaria de Regulação e Supervisão da Educação Superior foi idealizada. Consistindo em outro específico órgão singular do Ministério da Educação, a Seres é responsável, nos termos do artigo 24 do anexo I do Decreto nº 10.195/2019, entre outras atribuições, por planejar e coordenar o processo de formulação de políticas para a regulação e a supervisão da educação superior, em consonância com as metas do PNE, além de autorizar, reconhecer e renovar o reconhecimento de cursos de graduação e sequenciais, presenciais e a distância.

A importância da Seres para busca da qualidade desse setor é tamanha, haja vista que a lei expressamente atribui como sua competência o dever de supervisionar instituições de

261 BRASIL. Decreto $n^{\circ} 10.195$, de 30 de dezembro de 2019. Aprova a Estrutura Regimental e o Quadro Demonstrativo dos Cargos em Comissão e das Funções de Confiança do Ministério da Educação e remaneja e transforma cargos em comissão e funções de confiança. Brasília, DF: Presidência da República, 2019c. Disponível em: http://www.planalto.gov.br/ccivil_03/_ato2019-2022/2019/decreto/D10195.htm. Acesso em: 5 fev. 2019. 
educação superior e cursos de graduação e sequenciais, presenciais e a distância, com vistas ao cumprimento da legislação educacional e à indução de melhorias dos padrões de qualidade da educação superior, aplicando as penalidades previstas na legislação, estabelecer diretrizes e instrumentos para as ações de regulação e supervisão da educação superior, presencial e a distância, em consonância com o ordenamento legal vigente, além de estabelecer diretrizes para a elaboração dos instrumentos de avaliação de instituições e cursos de educação superior.

Nesse ponto é extremamente importante destacar que o decreto ${ }^{262}$ aqui analisado responsável pela organização e pelo funcionamento da administração federal destinada à prestação e regulação da educação nacional se coaduna totalmente com a Constituição Federal $^{263}$. No entanto, para regulamentar o exercício dessas funções destinadas à regulação, supervisão e avaliação das instituições de educação superior, foi editado o Decreto $n^{\circ} 9.235$, de 15 de dezembro de 2017, o qual atribuiu à Seres a execução das competências do ministro de estado.

Apesar de o Decreto n ${ }^{\circ}$ 10.195/2019 não fazer nenhuma restrição específica ao dever de controle de qualidade das instituições de ensino superior em atividade no país, o Decreto $\mathrm{n}^{\circ}$ 9.235/2017 é expresso em definir que as funções de regulação, supervisão e avaliação das instituições de educação superior exercidas pelo Sinaes são efetivadas apenas no sistema federal de ensino.

Diante de uma interpretação sistêmica, o MEC teria competência constitucional para controlar a qualidade de todas as instituições de ensino superior de quaisquer dos sistemas educacionais vigentes no país, independentemente de sua natureza jurídica ou da categoria administrativa que a IES é classificada. No entanto, ao regulamentar o preceito constitucional, os decretos restringem a atuação pública para o controle de qualidade apenas ao âmbito do sistema federal de ensino.

Essa conclusão é possível de ser efetuada diante da interpretação dos atos autorizativos mencionados e, para ir além, diante da redação expressa do $\S 4^{\circ}$ do artigo $1^{\circ}$ do Decreto $n^{\circ}$ 9.235/2017, o qual estabelece que as funções de supervisão e de avaliação poderão ser exercidas

262 BRASIL. Decreto $n^{\circ} 10.195$, de 30 de dezembro de 2019. Aprova a Estrutura Regimental e o Quadro Demonstrativo dos Cargos em Comissão e das Funções de Confiança do Ministério da Educação e remaneja e transforma cargos em comissão e funções de confiança. Brasília, DF: Presidência da República, 2019c. Disponível em: http://www.planalto.gov.br/ccivil_03/_ato2019-2022/2019/decreto/D10195.htm. Acesso em: 5 fev. 2019.

${ }^{263}$ Art. 84, caput, inciso VI, alínea “a”: “a) organização e funcionamento da administração federal, quando não implicar aumento de despesa nem criação ou extinção de órgãos públicos; (Incluída pela Emenda Constitucional no 32, de 2001)". Cf. BRASIL. [Constituição (1988)]. Constituição da República Federativa do Brasil de 1988. Brasília, DF: Presidência da República, 1988. Disponível em:

http://www.planalto.gov.br/ccivil_03/constituicao/constituicaocompilado.htm. Acesso em: 18 fev. 2019. 
em regime de cooperação com os sistemas de ensino estaduais, distrital e municipais. A previsão autoriza a cooperação, mas não a institui.

Tal informação denuncia um grave problema que acontece no âmbito da política de controle de qualidade educacional em nível superior: nem toda instituição de ensino superior em atividade no Brasil está sujeita à fiscalização do poder público, criando um limbo institucional, muito pouco explorado e criticado, relativo ao serviço prestado pelas instituições públicas de educação superior estaduais e municipais, as quais não se sujeitam às diretrizes da União.

É necessário apurar, então, de que formas essas instituições de ensino superior em funcionamento no Brasil teriam, verdadeiramente, suas atividades fiscalizadas pelo poder público, já que o dever de controlar a qualidade da educação superior remanesce como atividade de interesse público a ser concretizada. Nesse sentido, é apresentado a seguir o Gráfico 13 com a natureza da organização administrativa das IES em atividade no ano de 2017 e a Tabela 13.

Gráfico 12 - Número de IES em atividade no Brasil no ano de 2017

NÚMERO DE IES EM ATIVIDADE NO BRASIL NO ANO DE 2017

- Federal Estadual e DF Municipal a Privadas

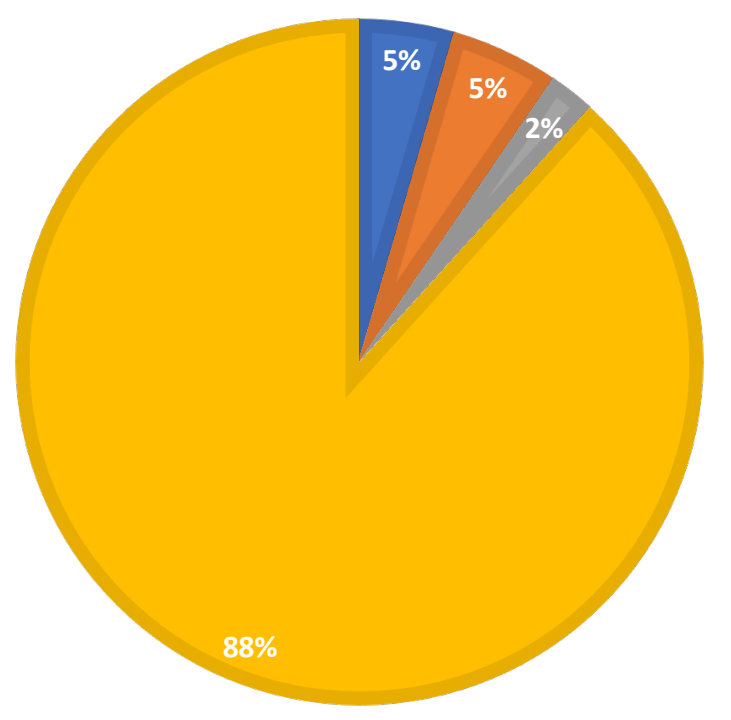

Fonte: Elaboração própria. 
Tabela 12 - Organização administrativa das IES em atividade no ano de 2017

\begin{tabular}{l|r|r}
\hline $\begin{array}{c}\text { Organização Administrativa das } \\
\text { IES em atividade no ano de } \\
2017\end{array}$ & Públicas & \multicolumn{2}{|c}{ Privadas } \\
\hline Federal & 109 & 2.162 \\
\hline Estadual e DF & 124 & - \\
\hline Municipal & 53 & - \\
\hline
\end{tabular}

Fonte: Elaboração própria.

Verifica-se que, não obstante o fato de o sistema federal da educação superior contemplar a fiscalização de $93 \%$ de todas as instituições de ensino superior em atividade no Brasil, nos termos explorados no capítulo anterior, $7 \%$ das instituições seguem sem que nenhum tipo de fiscalização técnica especializada que recaia sobre suas atividades por parte da União.

Restringindo a análise para a área do Direito, tem-se que, segundo as informações oficiais constantes da Sinopse Estatística do Inep relativa ao ano de $2017^{264}$, os números da área do Direito seguem a mesma proporção dos dados relativos ao contexto nacional, já que $11 \%$ da universalidade das IES que ofertam cursos em Direito seriam públicas, enquanto $89 \%$ seriam instituições de ensino superior privadas, na seguinte ordem (Gráfico 14 e Tabela 14):

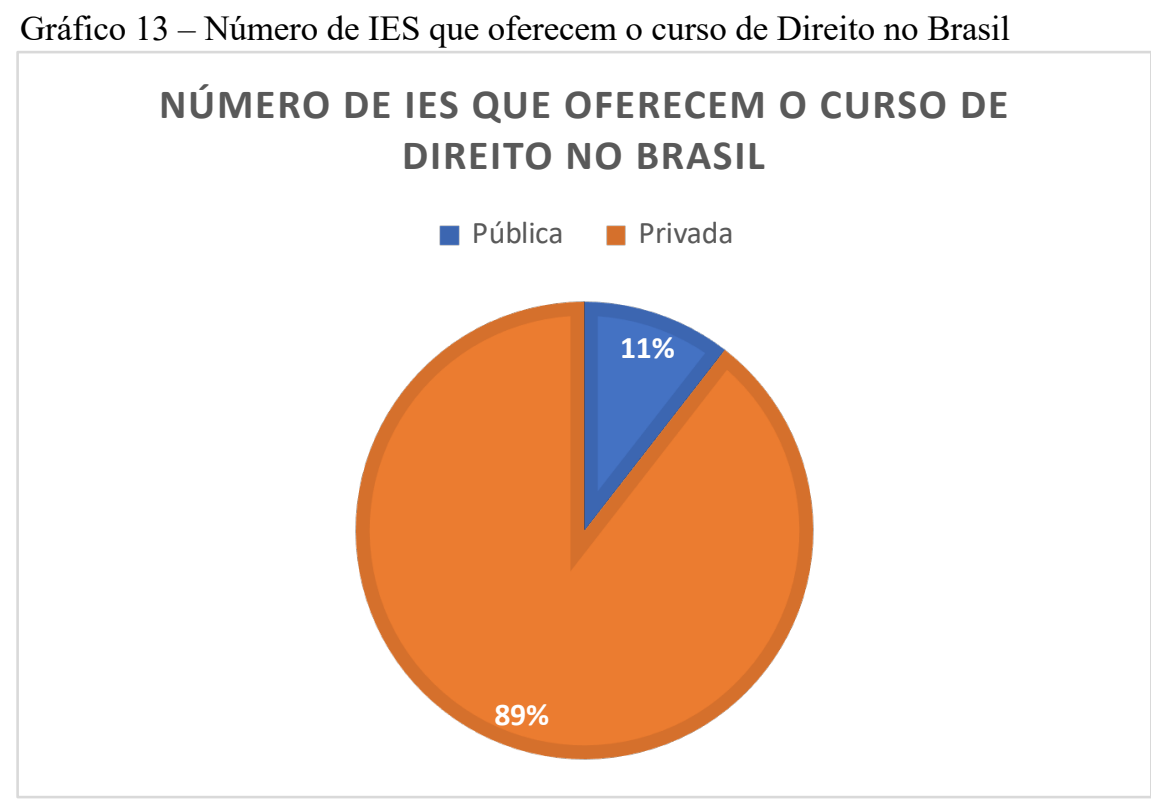

Fonte: Inep, 2018.

${ }^{264}$ INSTITUTO NACIONAL DE ESTUDOS E PESQUISAS EDUCACIONAIS ANÍSIO TEIXEIRA. Sinopse Estatística da Educação Superior 2017. Brasília, DF: Inep, 2018. Disponível em: http://inep.gov.br/sinopsesestatisticas-da-educacao-superior. Acesso em: 25 mar. 2019. 
Tabela 13 - Número de instituições que oferecem o curso

\begin{tabular}{|c|c|c|c|}
\hline \multirow{2}{*}{$\begin{array}{c}\text { Áreas Gerais, } \\
\text { Áreas } \\
\text { Detalhadas e } \\
\text { Programas } \\
\text { e/ou Cursos }\end{array}$} & \multicolumn{3}{|c|}{$\begin{array}{c}\text { Número de Instituições que oferecem o } \\
\text { Curso }\end{array}$} \\
\hline & Total & Pública & Privada \\
\hline Direito & 923 & 97 & 826 \\
\hline
\end{tabular}

Fonte: Inep, 2018.

Após o cruzamento dos dados, consegue-se particularizar as IES públicas que de fato pertencem ao grupo das instituições de natureza pública apontadas pelo Inep e que ofertam cursos de Direito no Brasil, que são 97 (noventa e sete).

No entanto, de acordo com a análise particularizada dos dados coletados no Inep, verificou-se que, entre as instituições de ensino superior públicas, o valor total de instituições que ofertaram cursos de Direito em 2017 não converge com o apresentado na coleta in loco, visto que seriam 44 (quarenta e quatro) federais, 27 (vinte e sete) estaduais e outras 22 (vinte e duas) municipais, totalizando o número de 93 (noventa e três) instituições de ensino superior que ofertaram cursos jurídicos no Brasil, segundo os quadros descritivos apresentados (Quadros $4,5,6$ e 7$)$ :

Quadro 4 - IES que ofertaram curso de Direito em 2017

(continua)

\begin{tabular}{|r|l|l|}
\hline Quant. & IES Federais que ofertaram Direito em $\mathbf{2 0 1 7}^{\mathbf{2 6 5}}$ & Estado \\
\hline $\mathbf{1}$ & Universidade Federal do Acre (Ufac) & AC \\
\hline $\mathbf{2}$ & Universidade Federal de Alagoas (Ufal) & AL \\
\hline $\mathbf{3}$ & Universidade Federal do Amazonas (Ufam) & AM \\
\hline $\mathbf{4}$ & Universidade Federal do Amapá (Unifap) & AP \\
\hline $\mathbf{5}$ & Universidade Federal da Bahia (UFBA) & BA \\
\hline $\mathbf{6}$ & Universidade Federal do Ceará (UFC) & CE \\
\hline $\mathbf{7}$ & Universidade de Brasília (UnB) & DF \\
\hline $\mathbf{8}$ & Universidade Federal do Espírito Santo (Ufes) & ES \\
\hline $\mathbf{9}$ & Universidade Federal de Goiás (UFG) & GO \\
\hline $\mathbf{1 0}$ & Universidade Federal do Maranhão (UFMA) & MA \\
\hline $\mathbf{1 1}$ & Universidade Federal de Minas Gerais (UFMG) & MG \\
\hline $\mathbf{1 2}$ & Universidade Federal de Juiz de Fora (UFJF) & MG \\
\hline
\end{tabular}

265 A informação foi obtida por meio de solicitação ao acesso às bases de dados protegidos (Sedap) do Inep subscrita no Processo $n^{\circ}$ 23036.002755/2019-55, deferida, nos termos da Portaria $n^{\circ} 52$, de 28 de janeiro de 2019, estando apta a acessar os seguintes dados solicitados: DATA_DEED_SUPERIOR (2013 a 2017). Os dados foram coletados na sala segura do Inep, cuja extração ocorreu no período de 20 a 24 de janeiro de 2020, e a disponibilização dos resultados foi enviada por meio do protocolo de transferência FTPs, nos termos no Despacho n ${ }^{\circ}$ 0484837/2020/SEDAP/CIBEC/DIRED. 
Quadro 4 - IES Federais que ofertaram curso de Direito em 2017

(conclusão)

\begin{tabular}{|c|c|c|}
\hline Quant. & IES Federais que ofertaram Direito em $2017^{266}$ & Estado \\
\hline 13 & Universidade Federal de Uberlândia (UFU) & MG \\
\hline 14 & Universidade Federal de Viçosa (UFV) & MG \\
\hline 15 & Universidade Federal de Ouro Preto (Ufop) & MG \\
\hline 16 & Universidade Federal de Lavras (Ufla) & MG \\
\hline 17 & Fundação Universidade Federal da Grande Dourados (UFGD) & MS \\
\hline 18 & Universidade Federal de Mato Grosso do Sul (UFMS) & MS \\
\hline 19 & Universidade Federal de Mato Grosso (UFMT) & MT \\
\hline 20 & Universidade Federal do Pará (UFPA) & $\mathrm{PA}$ \\
\hline 21 & Universidade Federal do Sul e Sudeste do Pará (Unifesspa) & $\mathrm{PA}$ \\
\hline 22 & Universidade Federal do Oeste do Pará (Ufopa) & $\mathrm{PA}$ \\
\hline 23 & Universidade Federal da Paraíba (UFPB) & PB \\
\hline 24 & Universidade Federal de Campina Grande (UFCG) & $\mathrm{PB}$ \\
\hline 25 & Universidade Federal de Pernambuco (UFPE) & $\mathrm{PE}$ \\
\hline 26 & Universidade Federal do Piauí (UFPI) & PI \\
\hline 27 & Universidade Federal do Paraná (UFPR) & PR \\
\hline 28 & Instituto Federal de Educação, Ciência e Tecnologia do Paraná (IFPR) & PR \\
\hline 29 & Universidade Federal do Rio de Janeiro (UFRJ) & RJ \\
\hline 30 & Universidade Federal Fluminense (UFF) & RJ \\
\hline 31 & Universidade Federal do Estado do Rio de Janeiro (Unirio) & RJ \\
\hline 32 & Universidade Federal Rural do Rio de Janeiro (UFRRJ) & RJ \\
\hline 33 & Universidade Federal do Rio Grande do Norte (UFRN) & $\mathrm{RN}$ \\
\hline 34 & Universidade Federal Rural do Semi-Árido (Ufersa) & $\mathrm{RN}$ \\
\hline 35 & Fundação Universidade Federal de Rondônia (Unir) & RO \\
\hline 36 & Universidade Federal de Roraima (UFRR) & $\mathrm{RR}$ \\
\hline 37 & Universidade Federal do Rio Grande do Sul (UFRGS) & $\mathrm{RS}$ \\
\hline 38 & Universidade Federal de Pelotas (Uepel) & $\mathrm{RS}$ \\
\hline 39 & Universidade Federal de Santa Maria (UFSM) & RS \\
\hline 40 & Universidade Federal do Rio Grande (Furg) & RS \\
\hline 41 & Fundação Universidade Federal do Pampa (Unipampa) & RS \\
\hline 42 & Universidade Federal de Santa Catarina (UFSC) & $\mathrm{SC}$ \\
\hline 43 & Universidade Federal de Sergipe (UFS) & SE \\
\hline 44 & Fundação Universidade Federal do Tocantins (UFT) & TO \\
\hline
\end{tabular}

Fonte: Inep, 2018.

${ }^{266}$ A informação foi obtida por meio de solicitação ao acesso às bases de dados protegidos (Sedap) do Inep subscrita no Processo $n^{\circ}$ 23036.002755/2019-55, deferida, nos termos da Portaria $\mathrm{n}^{\circ} 52$, de 28 de janeiro de 2019, estando apta a acessar os seguintes dados solicitados: DATA_DEED_SUPERIOR (2013 a 2017). Os dados foram coletados na sala segura do Inep, cuja extração ocorreu no período de 20 a 24 de janeiro de 2020, e a disponibilização dos resultados foi enviada por meio do protocolo de transferência FTPs, nos termos no Despacho n ${ }^{\circ}$ 0484837/2020/SEDAP/CIBEC/DIRED. 
Quadro 5 - IES estaduais que ofertaram Direito em 2017

\begin{tabular}{|c|c|c|}
\hline Quant. & IES estaduais que ofertaram Direito em $2017^{267}$ & Estado \\
\hline 1 & Universidade Estadual de Alagoas (Uneal) & AL \\
\hline 2 & Universidade do Estado do Amazonas (UEA) & $\mathrm{AM}$ \\
\hline 3 & Universidade Estadual do Sudoeste da Bahia (Uesb) & $\mathrm{BA}$ \\
\hline 4 & Universidade Estadual de Santa Cruz (Uesc) & BA \\
\hline 5 & Universidade do Estado da Bahia (Uneb) & $\mathrm{BA}$ \\
\hline 6 & Universidade Estadual de Feira de Santana (UEFS) & $\mathrm{BA}$ \\
\hline 7 & Universidade Regional do Cariri (Urca) & $\mathrm{CE}$ \\
\hline 8 & Universidade Estadual do Vale do Acaraú (UVA) & $\mathrm{CE}$ \\
\hline 9 & Universidade Estadual do Maranhão (Uema) & MA \\
\hline 10 & Universidade Estadual de Montes Claros (Unimontes) & MG \\
\hline 11 & Universidade do Estado de Minas Gerais (UEMG) & MG \\
\hline 12 & Universidade Estadual de Mato Grosso do Sul (UEMS) & MS \\
\hline 13 & Universidade do Estado de Mato Grosso (Unemat) & MT \\
\hline 14 & Universidade Estadual da Paraíba (UEPB) & $\mathrm{PB}$ \\
\hline 15 & Universidade de Pernambuco (UPE) & $\mathrm{PE}$ \\
\hline 16 & Universidade Estadual do Piauí (Uespi) & PI \\
\hline 17 & Universidade Estadual de Londrina (UEL) & PR \\
\hline 18 & Universidade Estadual de Maringá (UEM) & PR \\
\hline 19 & Universidade Estadual do Norte do Paraná (Uenp) & PR \\
\hline 20 & Universidade Estadual do Oeste do Paraná (Unioeste) & PR \\
\hline 21 & Universidade Estadual de Ponta Grossa (UEPG) & PR \\
\hline 22 & Universidade do Estado do Rio de Janeiro (Uerj) & RJ \\
\hline 23 & Universidade do Estado do Rio Grande do Norte (UERN) & $\mathrm{RN}$ \\
\hline 24 & Universidade Estadual de Roraima (UERR) & RR \\
\hline 25 & Universidade de São Paulo (USP) & SP \\
\hline 26 & Universidade Estadual Paulista Júlio de Mesquita Filho (Unesp) & SP \\
\hline 27 & Universidade do Tocantins (Unitins) & TO \\
\hline
\end{tabular}

Fonte: Inep, 2018.

267 A informação foi obtida por meio de solicitação ao acesso às bases de dados protegidos (Sedap) do Inep subscrita no Processo $n^{\circ} 23036.002755 / 2019-55$, deferida, nos termos da Portaria $n^{\circ} 52$, de 28 de janeiro de 2019, estando apta a acessar os seguintes dados solicitados: DATA_DEED_SUPERIOR (2013 a 2017). Os dados foram coletados na sala segura do Inep, cuja extração ocorreu no período de 20 a 24 de janeiro de 2020, e a disponibilização dos resultados foi enviada por meio do protocolo de transferência FTPs, nos termos no Despacho n ${ }^{\circ}$ 0484837/2020/SEDAP/CIBEC/DIRED. 
Quadro 6 - IES municipais que ofertaram Direito em 2017

\begin{tabular}{|c|c|c|}
\hline Quant. & IES municipais que ofertaram Direito em $2017^{268}$ & Estado \\
\hline 1 & Centro Universitário de Mineiros (Unifimes) & GO \\
\hline 2 & Faculdade de Filosofia e Ciências Humanas de Goiatuba (Fafich) & GO \\
\hline 3 & Faculdade de Anicuns (FA) & GO \\
\hline 4 & Universidade de Rio Verde (Fesurv) & GO \\
\hline 5 & Faculdade de ciências Gerenciais Alves Fortes & MG \\
\hline 6 & Faculdade de Ciências Aplicadas e Sociais de Petrolina (Facape) & $\mathrm{PE}$ \\
\hline 7 & $\begin{array}{l}\text { Faculdade de Ciências e Tecnologia Professor Dirson Maciel de Barros } \\
\text { (Fadimab) }\end{array}$ & $\mathrm{PE}$ \\
\hline 8 & Faculdade de Ciências Humanas e Sociais de Araripina (Facisa) & $\mathrm{PE}$ \\
\hline 9 & Faculdade de Ciências Humanas do Sertão Central (Fachusc) & $\mathrm{PE}$ \\
\hline 10 & $\begin{array}{l}\text { Faculdade de Ciências Humanas e Sociais Aplicadas do Cabo de Santo } \\
\text { Agostinho (Fachuca) }\end{array}$ & $\mathrm{PE}$ \\
\hline 11 & Faculdade de Ciências Aplicadas de Limoeiro (Facal) & $\mathrm{PE}$ \\
\hline 12 & Centro Universitário de Mandaguari (Fafiman) & PR \\
\hline 13 & Universidade Regional de Blumenau (Furb) & $\mathrm{SC}$ \\
\hline 14 & Faculdade de Direito de São Bernardo do Campo (FDSBC) & SP \\
\hline 15 & Faculdade de Direito de Franca (FDF) & SP \\
\hline 19 & Instituto Municipal de Ensino Superior de Assis (Imesa) & SP \\
\hline 17 & Instituto Municipal de Ensino Superior de Catanduva (Imes Catanduva) & SP \\
\hline 18 & Faculdades Integradas de Santa Fé do Sul (Funec) & SP \\
\hline 19 & Universidade de Taubaté (Unitau) & SP \\
\hline 20 & $\begin{array}{l}\text { Instituto Municipal de Ensino Superior de Bebedouro Victório Cardassi } \\
\text { (Imesb) }\end{array}$ & SP \\
\hline 21 & Universidade Municipal de São Caetano do Sul (USCS) & SP \\
\hline 22 & Centro Universitário Unirg (Unirg) & TO \\
\hline
\end{tabular}

Fonte: Inep, 2018.

Quadro 7 - IES municipais que ofertaram Direito em 2017, segundo o Inep

\begin{tabular}{|l|l|l|}
\hline Quant. & IES municipais que ofertaram Direito em 2017, segundo o Inep & Estado \\
\hline $\mathbf{1}$ & Faculdade de Direito de Garanhuns (FDG) & PE \\
\hline $\mathbf{2}$ & Universidade do Contestado (UNC) & SC \\
\hline $\mathbf{3}$ & Universidade Alto Vale do Rio do Peixe (Uniarp) & SC \\
\hline $\mathbf{4}$ & $\begin{array}{l}\text { Centro Universitário Para o Desenvolvimento do Alto Vale do Itajaí } \\
\text { (Unidavi) }\end{array}$ & SC \\
\hline $\mathbf{5}$ & Centro Universitário de Adamantina (FAI) & SP \\
\hline $\mathbf{6}$ & Faculdade Integrada de Ensino Superior de Colinas (Fiesc) & TO \\
\hline
\end{tabular}

Fonte: Inep, 2018.

268 A informação foi obtida por meio de solicitação ao acesso às bases de dados protegidos (Sedap) do Inep subscrita no Processo $n^{\circ} 23036.002755 / 2019-55$, deferida, nos termos da Portaria $n^{\circ} 52$, de 28 de janeiro de 2019, estando apta a acessar os seguintes dados solicitados: DATA_DEED_SUPERIOR (2013 a 2017). Os dados foram coletados na sala segura do Inep, cuja extração ocorreu no período de 20 a 24 de janeiro de 2020, e a disponibilização dos resultados foi enviada por meio do protocolo de transferência FTPs, nos termos no Despacho n ${ }^{\circ}$ 0484837/2020/SEDAP/CIBEC/DIRED. 
Diante do somatório apresentado, verifica-se que, na verdade, seriam 98 (noventa e oito) as instituições de ensino públicas que ofertaram cursos de Direito no Brasil no ano de 2017. Assim, mais uma vez, demonstra-se que é necessário tomar cuidado com as informações oficiais apresentadas, pois o cruzamento dos dados denunciaria, no mínimo, uma ausência de rigor metodológico com o fornecimento das informações oficiais prestadas à população.

Se o órgão responsável pela coleta e divulgação das informações públicas relativas ao setor educacional não o faz com rigor científico e procedimental conforme demonstrado, tornase essencial compreender como o Estado brasileiro efetivamente atua para controlar a qualidade das instituições de ensino superior, a fim atender ao comando legal e constitucional, buscando empreender uma análise crítica do procedimento atualmente adotado. Para tanto, adiante serão apresentados os procedimentos públicos para a instituição do Sistema de Avaliação da Educação Superior.

Na prática, as IES pertencentes ao sistema federal estão plenamente sujeitas às regras implementadas pela Lei $n^{\circ} 10.861 / 2004$, que instituiu o Sistema Nacional de Avaliação da Educação Superior, justamente porque é dever da União assegurar processo nacional de avaliação do rendimento escolar no ensino superior, contando com a cooperação dos sistemas de ensino dos Estados e do Distrito Federal.

Porém, não obstante essa realidade, o que se verifica é que as IES pertencentes ao sistema estadual não se sujeitam a todas as diretrizes estabelecidas no Sinaes, vide o emblemático caso da Universidade de São Paulo (USP), que não participa institucionalmente do Enade, como afirmam em seu jornal oficial que: “O exame é obrigatório apenas às instituições de ensino superior particulares e federais ${ }^{269}$ ".

De acordo com os dados apresentados, na área do Direito, identifica-se a existência de 55 instituições de ensino (IES estaduais e municipais) prestando serviço público de relevante interesse social, sem uma atuação pública específica do executivo correspondente para controlar a adequação dessas atividades. Foram consultados os sites oficiais dos 28 entes da federação $0^{270}$ (estados e DF), e nenhum deles apontou quais seriam as políticas públicas específicas realizadas no sistema estadual de ensino para fiscalização das atividades prestadas pelas IES de sua responsabilidade, o que, de per si, comprovaria a desnecessidade dessa fragmentação em sistemas de ensino federal, estadual e municipal.

\footnotetext{
269 VASSALO, Roberta. A difícil tarefa de avaliar a qualidade do ensino superior: iniciativas nacionais e internacionais buscam formas de examinar a formação dos estudantes e o ensino das universidades. Jornal da USP, São Paulo, 30 set. 2016. Disponível em: https://jornal.usp.br/universidade/a-dificil-tarefa-de-avaliar-aqualidade-do-ensino-superior/. Acesso em: 30 abr. 2020.

${ }^{270}$ Consulta finalizada em 25 de fevereiro de 2020.
} 
No entanto, visando apresentar dados fidedignos à realidade do setor, valendo-se dos mecanismos de transparência e dever de informação impostos à administração pública, os 19 (dezenove) governos estaduais mencionados anteriormente ${ }^{271}$, que deveriam fiscalizar as IES que ofertam cursos jurídicos, foram questionados particularmente sobre os mecanismos adotados para controle de qualidade.

À parte das secretarias dos governos estaduais da Bahia e do Tocantins, todas as respostas foram extremamente evasivas, quando não impeditivas, de prestar os necessários esclarecimentos solicitados. Novamente, mais um claro indicador da premente necessidade de instituir um sistema nacional de educação que tenha vocação para tratar todos de forma igual: comunidade acadêmica e as IES em atividade.

No entanto, há que ser respeitado o fato de que $97 \%$ das IES em atividade no Brasil sejam efetivamente fiscalizadas. Em termos numéricos, considerando-se os dados mais atualizados monitorados nesta pesquisa, as políticas públicas idealizadas para o controle da qualidade educacional conseguiram atingir 2.271 (duas mil, duzentas e setenta e uma) IES em atividade no Brasil, o que merece ser respeitado.

Para efetivar as competências avaliativas na esfera pública, foi idealizado todo um aparato dentro e fora do Ministério da Educação, por meio dos órgãos da administração direta (Seres), entidades da administração indireta (Inep e Capes) e órgãos colegiados (Conaes e CNE) compostos por servidores e membros da sociedade civil, com o objetivo maior de dar especificidade e transparência ao procedimento de apuração da qualidade da educação superior no Brasil.

No MEC, no braço da administração direta, está a Secretaria de Regulação e Supervisão da Educação Superior, a qual se desmembra em três diferentes diretorias, cujas competências tendem à maior especialização para a melhor forma possível de se concretizar a busca pela apuração de qualidade da educação superior. São elas: (i) Diretoria de Política Regulatória; (ii) Diretoria de Supervisão da Educação Superior; e (iii) Diretoria de Regulação da Educação Superior;

São essas três diretorias que, em conjunto, idealizam, implementam e adotam ações efetivas para a apuração da qualidade. A Diretoria de Política Regulatória é responsável por, entre outras competências previstas no artigo 25 do anexo I do Decreto $\mathrm{n}^{\circ} 10.195 / 19$, subsidiar o processo de formulação e implementação de políticas para a regulação e supervisão da educação superior, em consonância com as metas do PNE; propor critérios, planejar, promover,

${ }^{271}$ Segundo a tabela descritiva, tais governos são: AL, AM, BA, CE, MA, MG, MS, MT, PB, PE, PI, PR, RJ, RN, RR, SP, TO, GO e SC. 
executar e acompanhar as ações relacionadas ao cadastro de instituições e cursos de educação superior; propor critérios, planejar, promover e executar, em articulação com a Diretoria de Tecnologia da Informação e Comunicação, sistema eletrônico de acompanhamento de processos relacionados à regulação e supervisão de instituições e cursos de educação superior, entre outras.

Destaque pontual deve ser feito à sua competência para se articular com o Conselho Nacional de Educação, o Inep, a Comissão Nacional de Avaliação da Educação Superior e as Diretorias de Regulação da Educação Superior e de Supervisão da Educação Superior, com vistas ao aprimoramento da legislação e das normas relativas à regulação, supervisão e avaliação da educação superior. Nota-se, assim, que a Diretoria de Política Regulatória é a grande interlocutora de todo aparato público voltado para a construção de uma educação superior nacional de qualidade.

Por sua vez, nos termos do artigo 26 do anexo I do Decreto $\mathrm{n}^{\circ} 10.195 / 2019$, para a construção da educação superior de qualidade em cumprimento ao PNE, a Diretoria de Supervisão da Educação Superior ficou incumbida de planejar e coordenar ações de supervisão de instituições de educação superior e cursos de graduação e sequenciais, presenciais e a distância, relacionadas ao cumprimento da legislação educacional e à indução de melhorias dos padrões de qualidade da educação superior; planejar, coordenar e acompanhar as atividades de comissões de especialistas e de colaboradores, relativas aos procedimentos de supervisão da educação superior; instruir e exarar parecer em processos de supervisão, promover as diligências necessárias à completa instrução dos processos e sugerir a aplicação de medidas administrativas cautelares e sancionatórias nos termos do ordenamento legal vigente; apoiar estudos sobre metodologias, instrumentos e indicadores para a supervisão dos cursos e instituições de educação superior; e planejar e coordenar ações referentes ao monitoramento da implantação de instituições de educação superior privadas e da oferta dos cursos de graduação em áreas estratégicas e verificar as condições estabelecidas nos editais de chamamento público.

Novamente o destaque sobre a competência de sua atuação deve ser reforçado. Em nenhum momento há restrição dos sistemas aos quais as IES estão vinculadas para a competência de fiscalização por parte da Seres, mais uma vez comprovando que a intenção da administração pública é o de efetivamente autorizar que o referido órgão tenha competência para apurar a qualidade de qualquer IES em atividade no Brasil.

A última diretoria integrante da Seres é a Diretoria de Regulação da Educação Superior, a qual destacamos algumas de suas competências, nos termos do artigo 27 do anexo I do Decreto $\mathrm{n}^{\circ} 10.195 / 19$, para estabelecer normas técnicas e fluxos processuais, com vistas a 
promover a sistematização e uniformização de procedimentos regulatórios, de acordo com padrões de qualidade e com a legislação vigente; propor, em articulação com a Diretoria de Política Regulatória, diretrizes para elaboração dos instrumentos de avaliação para o credenciamento e recredenciamento de instituições de ensino superior e para autorização, reconhecimento e renovação de reconhecimento de cursos superiores, nas modalidades presencial e a distância; instruir e exarar pareceres no processo de autorização, reconhecimento e renovação de reconhecimento dos cursos superiores, presenciais e a distância, em consonância com as políticas e normas vigentes, e promover as diligências necessárias à completa instrução do processo; instruir e exarar pareceres referentes ao processo de credenciamento e recredenciamento de instituições de ensino superior no país, para as modalidades presencial e a distância, em consonância com as políticas e normas vigentes, e promover as diligências necessárias à completa instrução do processo; apoiar estudos sobre metodologias, instrumentos e indicadores para a avaliação e regulação dos cursos e instituições de educação superior; e planejar e coordenar processos de chamamento público para credenciamento de instituições de educação superior privadas e para autorização de funcionamento de cursos de graduação em áreas estratégicas.

Como visto, as atribuições da Seres determinam a sua responsabilidade por garantir o cumprimento da legislação educacional, com vistas à busca pela qualidade dos cursos superiores do país, mas ela seria incapaz de fazê-lo sozinha. Como forma de compor o sistema avaliativo das IES no Brasil, a Lei do Sinaes instituiu a criação da Comissão Nacional de Avaliação da Educação Superior, fixada no âmbito do Ministério da Educação e vinculada ao gabinete do ministro de estado.

Mencionada no inciso IV do artigo 25 do anexo I do Decreto $\mathrm{n}^{\circ} 10.195 / 2019$, a Comissão Nacional de Avaliação da Educação Superior é um órgão colegiado de coordenação e supervisão do Sistema da Avaliação da Educação Superior vinculado ao gabinete do ministro 
da educação, criado por ocasião da implementação do $\operatorname{Sinaes}^{272}$, com as atribuições ${ }^{273}$ de propor e avaliar as dinâmicas, procedimentos e mecanismos da avaliação institucional, de cursos e de desempenho dos estudantes; estabelecer diretrizes para organização e designação de comissões de avaliação, analisar relatórios, elaborar pareceres e encaminhar recomendações às instâncias competentes; formular propostas para o desenvolvimento das instituições de educação superior, com base nas análises e recomendações produzidas nos processos de avaliação; articular-se com os sistemas estaduais de ensino, visando a estabelecer ações e critérios comuns de avaliação e supervisão da educação superior; submeter anualmente à aprovação do ministro de estado da educação a relação dos cursos a cujos estudantes será aplicado o Exame Nacional de Desempenho dos Estudantes; elaborar o seu regimento, a ser aprovado em ato do ministro de estado da educação; e, realizar reuniões ordinárias mensais e extraordinárias, sempre que convocadas pelo ministro de estado da educação.

A ideia é justamente a de que haja uma equipe de técnicos e membros da sociedade civil acompanhando de perto todos os procedimentos públicos adotados para a consecução das atividades públicas desempenhadas para o controle da qualidade dos cursos superiores prestados em território nacional. A própria Conaes possui papel fundamental na operacionalização da nossa principal política de apuração de qualidade, que será a seguir descrita.

Ainda, o vigente Decreto $n^{\circ}$ 9.235, de 15 de dezembro de 2017 estabelece competência à Conaes para propor e avaliar as dinâmicas, os procedimentos e os mecanismos de avaliação institucional, de cursos e de desempenho dos estudantes; estabelecer diretrizes para organização das comissões de avaliação, analisar relatórios, elaborar pareceres e encaminhar recomendações

272 O Sinaes é o Sistema Nacional de Avaliação da Educação Superior e foi criado pela Lei no 10.861/2004. Cf. BRASIL. Lei $n^{\circ} 10.861$, de 14 de abril de 2004a. Institui o Sistema Nacional de Avaliação da Educação Superior - SINAES e dá outras providências. DF: Presidência da República, 2004. Disponível em: http://www.planalto.gov.br/ccivil_03/_ato2004-2006/2004/lei/110.861.htm. Acesso em: 15 maio 2020.

273 Ibid., art. $6^{\circ}$ : “Art. $6^{\circ}$ Fica instituída, no âmbito do Ministério da Educação e vinculada ao Gabinete do Ministro de Estado, a Comissão Nacional de Avaliação da Educação Superior - CONAES, órgão colegiado de coordenação e supervisão do SINAES, com as atribuições de:

I - propor e avaliar as dinâmicas, procedimentos e mecanismos da avaliação institucional, de cursos e de desempenho dos estudantes;

II - estabelecer diretrizes para organização e designação de comissões de avaliação, analisar relatórios, elaborar pareceres e encaminhar recomendações às instâncias competentes;

III - formular propostas para o desenvolvimento das instituições de educação superior, com base nas análises e recomendações produzidas nos processos de avaliação;

IV - articular-se com os sistemas estaduais de ensino, visando a estabelecer ações e critérios comuns de avaliação e supervisão da educação superior;

$\mathrm{V}$ - submeter anualmente à aprovação do Ministro de Estado da Educação a relação dos cursos a cujos estudantes será aplicado o Exame Nacional de Desempenho dos Estudantes - ENADE;

VI - elaborar o seu regimento, a ser aprovado em ato do Ministro de Estado da Educação;

VII - realizar reuniões ordinárias mensais e extraordinárias, sempre que convocadas pelo Ministro de Estado da Educação". 
às instâncias competentes; formular propostas para o desenvolvimento das IES, com base nas análises e recomendações produzidas nos processos de avaliação; articular-se com os sistemas estaduais de ensino, com vistas ao estabelecimento de ações e critérios comuns de avaliação e supervisão da educação superior; e submeter anualmente à aprovação do ministro de estado da educação a relação dos cursos cujos estudantes realizarão o Enade.

A Conaes é composta por um representante do Inep; um representante da fundação Coordenação de Aperfeiçoamento de Pessoal de Nível Superior; 3 (três) representantes do Ministério da Educação, sendo 1 (um) obrigatoriamente do órgão responsável pela regulação e supervisão da educação superior; 1 (um) representante do corpo discente das instituições de educação superior; 1 (um) representante do corpo docente das instituições de educação superior; 1 (um) representante do corpo técnico-administrativo das instituições de educação superior; 5 (cinco) membros, indicados pelo ministro de estado da educação, escolhidos entre cidadãos com notório saber científico, filosófico e artístico, e reconhecida competência em avaliação ou gestão da educação superior. As funções exercidas por seus membros são de relevante interesse público e a composição colegiada visa o assessoramento do ministro para o controle da qualidade da educação superior no Brasil.

Diante da breve apresentação do número de setores e pessoas envolvidas nas atividades efetivamente desempenhadas para a apuração da qualidade, observa-se a descentralização de algumas das atividades públicas, com a necessária especificação de setores aptos ao auxílio da coleta de informações adstritas ao setor. Foi justamente nesse sentido que o Estado brasileiro criou a figura de pessoas jurídicas de direito público pertencentes à administração pública indireta, atribuindo-lhes funções específicas para auxiliá-la na apuração da qualidade do ensino superior brasileiro, quais sejam o Inep e a Capes.

A Coordenação de Aperfeiçoamento de Pessoal de Nível Superior, fundação do Ministério da Educação, desempenha papel fundamental na expansão e consolidação da pósgraduação stricto sensu (mestrado e doutorado) em todos os estados da Federação. O papel central da Capes está diretamente relacionado ao controle de qualidade dos Programas de PósGraduação em território nacional. As atividades desempenhadas pela Capes são extremamente relevantes para o aprofundamento da ciência e o desenvolvimento tecnológico nacional. No entanto, tais atividades guardam relação tangencial com a qualidade dos cursos de graduação.

Outro importante órgão público responsável pela manutenção da qualidade da educação no Brasil é o Instituto Nacional de Estudos e Pesquisas Educacionais Anísio Teixeira, uma autarquia federal vinculada ao Ministério da Educação, criada por lei no dia 13 de janeiro de 1937, sendo chamada inicialmente de Instituto Nacional de Pedagogia. Sua missão, segundo 
apontado pelo site oficial da instituição ${ }^{274}$, é a de subsidiar a formulação de políticas educacionais dos diferentes níveis de governo com intuito de contribuir para o desenvolvimento econômico e social do país.

\begin{abstract}
A partir de 1995, aconteceu o processo de reestruturação do órgão. Com a reorganização do setor responsável pelos levantamentos estatísticos, pretendia-se que as informações educacionais pudessem, de fato, orientar a formulação de políticas do Ministério da Educação.

O primeiro passo se deu com a incorporação do Serviço de Estatística da Educação e Cultura (Seec), em 1996, à Secretaria de Avaliação e Informação Educacional (Sediae), do Ministério da Educação. O Seec, criado em 1937, era um órgão do Poder Executivo com longa tradição na realização de levantamentos estatísticos na educação brasileira. Em 1997, a Sediae foi integrada à estrutura do Inep, passando a existir, a partir desta data, um único órgão encarregado das avaliações, pesquisas e levantamentos estatísticos educacionais no âmbito do governo federal.

Também em 1997, o Inep foi transformado em autarquia federal. Desde então, o instituto reorganizou o sistema de levantamentos estatísticos e teve como eixo central de atividades as avaliações em praticamente todos os níveis educacionais ${ }^{275}$ (grifo nosso).
\end{abstract}

Ainda segundo informações oficiais ${ }^{276}$, após a transformação do Inep em autarquia federal vinculada ao Ministério da Educação, foram estabelecidas as seguintes finalidades para a entidade: organizar e manter o sistema de informações e estatísticas educacionais; planejar, orientar e coordenar o desenvolvimento de sistemas e projetos de avaliação educacional para o estabelecimento de indicadores de desempenho das atividades de ensino; apoiar o Distrito Federal, os estados e os municípios no desenvolvimento de sistemas e projetos de avaliação educacional; desenvolver e implementar sistemas de informação e documentação com estatísticas, avaliações educacionais, práticas pedagógicas e gestão das políticas educacionais; subsidiar a formulação de políticas por meio da elaboração de diagnósticos e recomendações decorrentes da avaliação da educação básica e superior; coordenar o processo de avaliação dos cursos de graduação; definir e propor parâmetros, critérios e mecanismos para a realização de exames de acesso ao ensino superior; promover a disseminação de informações sobre a qualidade da educação básica e superior; articular-se com instituições nacionais e internacionais, por meio de ações de cooperação institucional, técnica e financeira bilateral e

274 INSTITUTO NACIONAL DE ESTUDOS E PESQUISAS EDUCACIONAIS ANÍSIO TEIXEIRA. Conheça o Inep. Brasília, DF: Inep, 2015. Disponível em: http://portal.inep.gov.br/conheca-oinep\#: : text $=\mathrm{O} \% 20$ Instituto $\% 20$ Nacional $\% 20 \mathrm{de} \% 20$ Estudos,econ $\% \mathrm{C} 3 \% \mathrm{~B} 4$ mico $\% 20 \mathrm{e} \% 20$ social $\% 20 \mathrm{do} \% 20$ pa\%C3\%ADs. Acesso em: 7 set. 2020.

275 BRASIL. Ministério da Educação. Inep completa 82 anos de serviços prestados à educação. Brasília, DF: MEC, 2019e. Disponível em:

http://portal.mec.gov.br/component/content/article?id=72621\#: :text=Em\%201972\%2C\%20o\%20Inep\%20f oi,da\%20situa\%C3\%A7\%C3\%A3o\%20educacional\%20do\%20pa \%C3\%ADs.\&text=O\%20ano\%20de\%2019 76\%20marca,Rio\%20de\%20Janeiro\%20para\%20Bras\%C3\%ADlia. Acesso em: 7 set. 2020.

${ }^{276}$ Ibid. 
multilateral; publicar estudos para aferir a evolução no cumprimento das metas estabelecidas pelo Plano Nacional de Educação (2014-2024).

As competências do Inep na política de regulação, supervisão e avaliação das IES, definidas pelo artigo $7^{\circ}$ do Decreto $n^{0} 9.235 / 2017$, são as de conceber, planejar, coordenar e operacionalizar as ações destinadas à avaliação de IES, de cursos de graduação e de escolas de governo e o Exame Nacional de Desempenho dos Estudantes, os exames e as avaliações de estudantes de cursos de graduação; conceber, planejar, coordenar, operacionalizar e avaliar os indicadores referentes à educação superior decorrentes de exames e insumos provenientes de bases de dados oficiais, em consonância com a legislação vigente; e a constituição e a manutenção de bancos de avaliadores e colaboradores especializados, incluída a designação das comissões de avaliação; elaborar e submeter à aprovação do ministro de estado da educação os instrumentos de avaliação externa in loco, em consonância com as diretrizes propostas pela Secretaria de Regulação e Supervisão da Educação Superior e pelos outros órgãos competentes do Ministério da Educação; conceber, planejar, avaliar e atualizar os indicadores dos instrumentos de avaliação externa in loco, em consonância com as diretrizes propostas pela Secretaria de Regulação e Supervisão da Educação Superior do Ministério da Educação; presidir a Comissão Técnica de Acompanhamento da Avaliação (CTAA), nos termos do art. $85^{277}$ do mesmo texto normativo; e planejar, coordenar, operacionalizar e avaliar as ações necessárias à consecução de suas finalidades.

O Inep possui estrutura organizacional fracionada com diretorias de avaliação específicas para cada um dos níveis educacionais avaliados. Para mensurar a qualidade dos cursos de graduação no Brasil, o Instituto Nacional de Estudos e Pesquisas Educacionais Anísio Teixeira, com apoio das mencionadas estruturas organizacionais do Ministério da Educação, concebeu o conceito do Índice Geral de Cursos (IGC) - indicador de desempenho institucional, divulgado uma vez por ano, logo após a publicação dos resultados do Exame Nacional de Desempenho dos Estudantes. O IGC é obtido por meio da média dos conceitos dos cursos de graduação da instituição e pela média ponderada a partir do número de matrículas de cada IES.

A Secretaria de Regulação e Supervisão da Educação Superior é a responsável pelo

277 Art. 5: “A CTAA é um órgão colegiado de acompanhamento dos processos periódicos de avaliação externa in loco realizadas no âmbito do Sinaes e do sistema de escolas de governo.

Parágrafo único. A CTAA é a instância recursal dos processos avaliativos relacionados a relatórios de avaliação externa in loco e de denúncias contra avaliadores”. Cf. BRASIL. Decreto $n^{\circ} 9.235$, de 15 de dezembro de 2017. Dispõe sobre o exercício das funções de regulação, supervisão e avaliação das instituições de educação superior e dos cursos superiores de graduação e de pós-graduação no sistema federal de ensino. Brasília, DF: Presidência da República, 2017. Disponível em: http://www.planalto.gov.br/ccivil_03/_Ato2015-2018/2017/Decreto/D9235.htm. Acesso em: 20 maio 2019. 
início da análise dos pedidos de abertura de novos cursos, por meio do procedimento de autorização, pelo reconhecimento de cursos autorizados, bem como pelo credenciamento e recredenciamento das instituições de ensino superior no Brasil. É a Seres, em conjunto com o Inep, que estabelece os padrões de qualidade para os cursos, analisando o corpo docente, a estrutura física, as bibliotecas e o projeto pedagógico, exarando parecer conclusivo positivo ou não para a abertura e manutenção de novos cursos e instituições de ensino.

O processo de avaliação foi instituído pela Portaria Normativa $\mathrm{n}^{\circ} 40$, de 12 de dezembro de 2007, o qual instituiu o e-MEC, sistema eletrônico de fluxo de trabalho e gerenciamento de informações relativas aos processos de regulação da educação superior no sistema federal de educação.

O protocolo do pedido é feito em sistema eletrônico e, na sequência, os documentos são submetidos à análise documental (Figura 6). Concluída a análise, o processo é encaminhado à diretoria competente para apreciar a instrução. Encerrada a fase de instrução documental, o processo segue para o Inep a fim de realizar a avaliação in loco. No Inep, a tramitação do processo inicia com o sorteio da comissão de avaliação e definição da data de visita. A comissão procederá à avaliação utilizando o instrumento de avaliação formulado pelo Inep ${ }^{278}$.

278 Art. 7: “Compete ao Inep: [...] III - elaborar e submeter à aprovação do Ministro de Estado da Educação os instrumentos de avaliação externa in loco, em consonância com as diretrizes propostas pela Secretaria de Regulação e Supervisão da Educação Superior e pelos outros órgãos competentes do Ministério da Educação". Cf. BRASIL. Decreto $n^{\circ}$ 9.235, de 15 de dezembro de 2017. Dispõe sobre o exercício das funções de regulação, supervisão e avaliação das instituições de educação superior e dos cursos superiores de graduação e de pós-graduação no sistema federal de ensino. Brasília, DF: Presidência da República, 2017. Disponível em: http://www.planalto.gov.br/ccivil_03/_Ato2015-2018/2017/Decreto/D9235.htm. Acesso em: 20 maio 2019. 
Figura 6 - Fluxo do processo do Sinaes

Processo se inicia na SERES

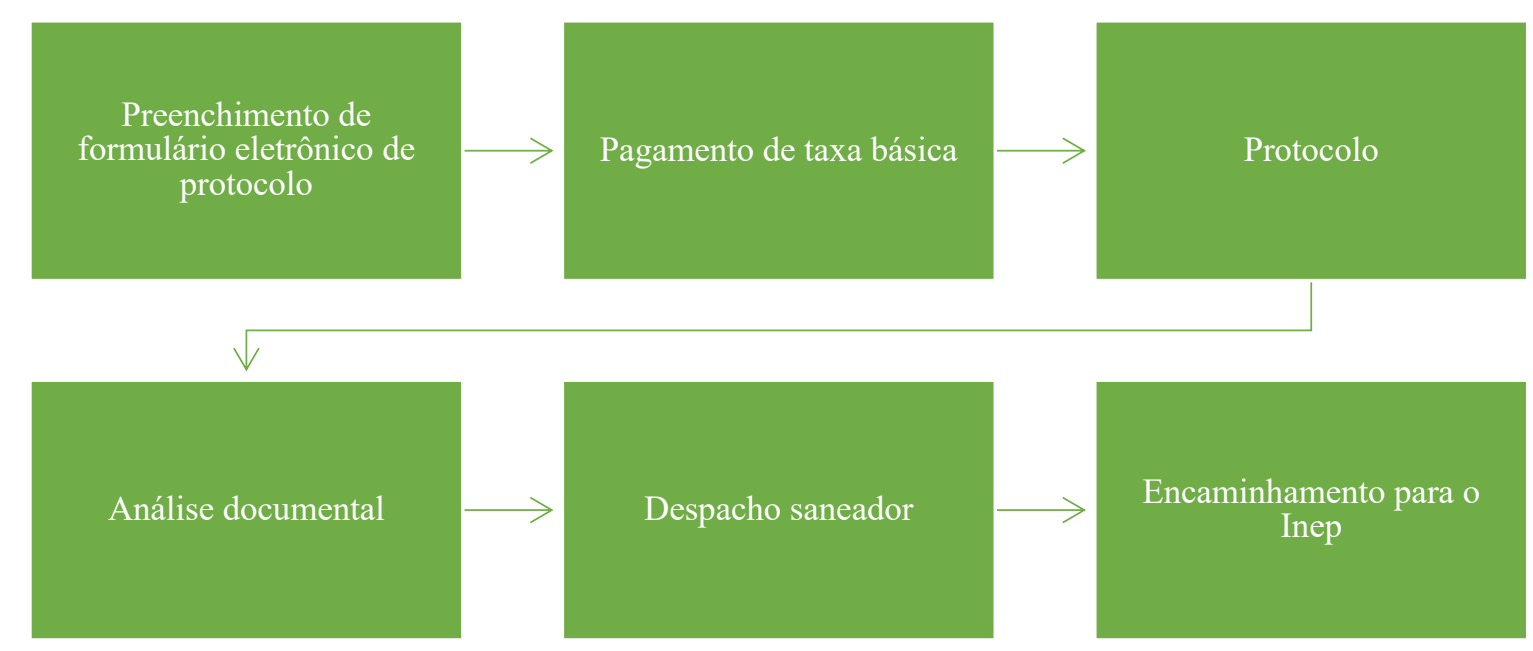

Fonte: Inep, 2017.

O trabalho da comissão de avaliação deverá ser pautado pelo registro fiel e circunstanciado em relatório das condições concretas de funcionamento da instituição ou do curso, incluídas as eventuais deficiências, que servirá como referencial básico à decisão das secretarias ou do CNE, conforme o caso.

A comissão de avaliação, na realização da visita in loco, aferirá a exatidão dos dados informados pela instituição, com especial atenção ao Projeto de Desenvolvimento Institucional (PDI), quando se tratar de avaliação institucional, ou Projeto Pedagógico de Curso (PPC), quando se tratar de avaliação de curso. A comissão de avaliação está impedida de fazer recomendações ou sugestões às instituições avaliadas, ou oferecer qualquer tipo de aconselhamento que influa no resultado da avaliação, sob pena de nulidade do relatório, além de medidas específicas de exclusão dos avaliadores do banco, a juízo do Inep, tudo para evitar a ingerência nos processos avaliativos. Realizada a visita à instituição, a comissão de avaliadores elaborará relatório e parecer, atribuindo conceito de avaliação (Figura 7). 
Figura 7 - Avaliação (Inep)

AVALIAÇÃO (INEP)
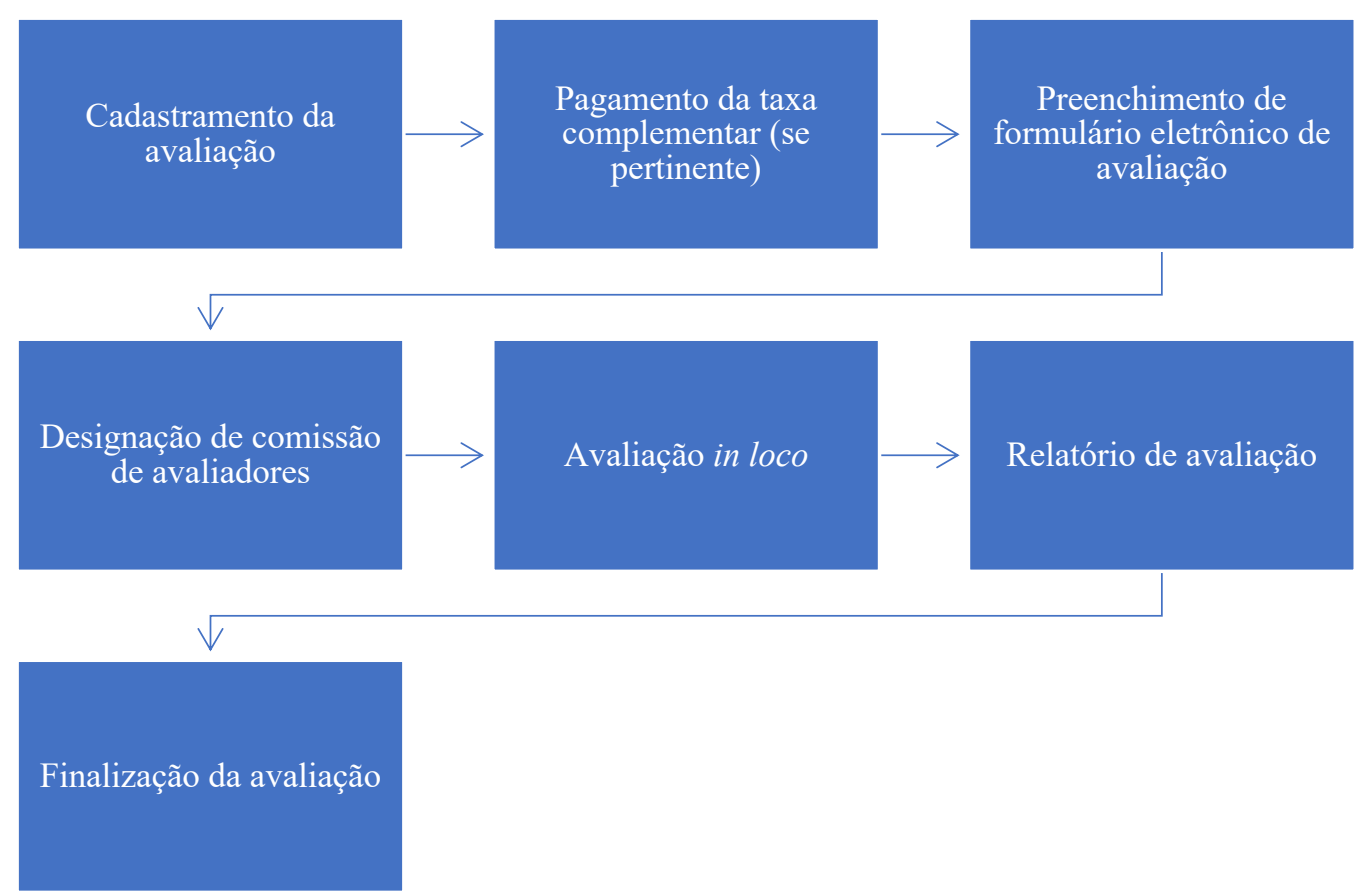

Fonte: Inep, 2017.

O processo seguirá à apreciação da Seres, conforme a situação, que analisará os elementos da instrução documental, a avaliação do Inep e o mérito do pedido e preparará o parecer do secretário, pelo deferimento ou indeferimento do pedido, bem como a minuta do ato autorizativo, se for o caso. Exarado o parecer do secretário, o processo seguirá ao CNE na hipótese de pedido de credenciamento (Figura 8). 
Figura 8 - Processo retorna à Seres

Processo retorna à Seres

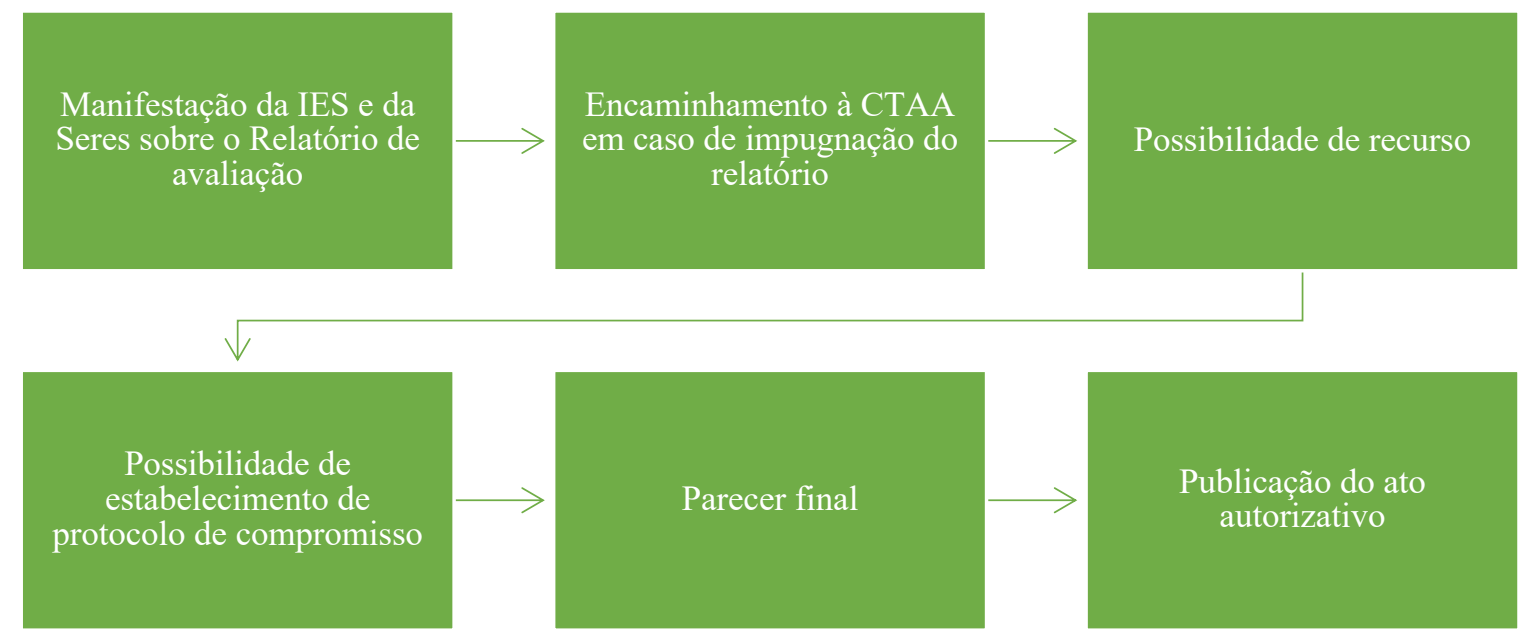

Fonte: Inep, 2017.

O processo seguirá seu fluxo, no CNE, com o sorteio eletrônico de conselheiro relator, necessariamente integrante da Câmara de Educação Superior (CES/CNE), observada a equanimidade de distribuição entre os conselheiros sobre os processos que tramitam pelo e$\mathrm{MEC}$, nos termos do Regimento Interno do CNE. O relator inserirá minuta de parecer no sistema, com acesso restrito aos membros da Câmara e às pessoas autorizadas, podendo solicitar revisão técnica, e submeterá o processo à apreciação da CES/CNE. A deliberação deles ou do Conselho Pleno será encaminhada ao gabinete do ministro para homologação.

Destaque-se que o curso de Direito possui elemento peculiar no processo de avaliação dos cursos devido à sujeição da tramitação prevista no artigo 29 da Portaria Normativa $n^{\circ} 40$, de 12 de dezembro de 2007, a qual faz remissão ao Decreto $n^{0} 5.733 / 2006$, o qual fora revogado pelo vigente Decreto $n^{\circ} 9.235 / 2017$. No artigo 41 deste último, determina-se que a oferta de cursos de graduação em Direito, inclusive em universidades e centros universitários, depende de autorização do Ministério da Educação, após prévia manifestação do Conselho Federal da Ordem dos Advogados do Brasil. Além disso, segundo o mesmo decreto, nos processos de autorização de cursos de graduação em Direito serão observadas as disposições da Lei ${ }^{\circ}{ }^{8} .906$, de 4 de julho de 1994, Estatuto da Advocacia e a Ordem dos Advogados do Brasil.

Essa manifestação do órgão de classe é importante para apresentar sua opinião sobre a criação no novo curso solicitado. No entanto, é oportuno destacar que essa opinião não é 
vinculadora, visto que o processo no MEC tramitará de forma independente e simultânea à análise pelo ente referido, cuja manifestação subsidiará a apreciação de mérito da secretaria, por ocasião da impugnação ao parecer da comissão de avaliação do Inep. Além disso, nos pedidos de autorização de curso de Direito sem parecer favorável da OAB, quando o conceito da avaliação do Inep for satisfatório, a Seres impugnará, de ofício, à Comissão Técnica de Acompanhamento da Avaliação.

Como apontado no fluxograma, atualmente o Inep é responsável pelos dados coletados para a efetivação da apuração da qualidade por meio do mencionado Sistema Nacional de Avaliação da Educação Superior, implementado pela Lei ${ }^{0} 10.861 / 2004^{279}$ e formado por três componentes: avaliação das instituições, avaliação dos cursos e avaliação do desempenho dos estudantes.

Foi a LDB, Lei $n^{\circ}$ 9.394/96, que determinou preliminarmente quais seriam as diretrizes gerais apontadas para os procedimentos administrativos que deveriam ser implementados para efetivar a avaliação pública. Determina inicialmente no artigo $46^{280}$ que a autorização e o reconhecimento de cursos, bem como o credenciamento de instituições de educação superior, terão prazos limitados, sendo renovados, periodicamente, após processo regular de avaliação.

Em sentido complementar à disposição geral prevista na LDB, a União Federal implementou a avaliação da educação superior nos termos do artigo 79 e seguintes do Decreto $n^{\circ}$ 9.235/2017, bem como da Lei no 10.861/2004 e das Portarias MEC n 23/2017 e no 315/2018 no âmbito do Sistema Nacional de Avaliação da Educação Superior.

Tal sistema compreende a avaliação interna e externa das instituições de educação superior, a avaliação dos cursos de graduação e a avaliação do desempenho acadêmico dos

279 BRASIL. Lei $n^{\circ} 10.861$, de 14 de abril de 2004. Institui o Sistema Nacional de Avaliação da Educação Superior - SINAES e dá outras providências. DF: Presidência da República, 2004a.

280 Art. 46: "§ $1^{\circ}$ Após um prazo para saneamento de deficiências eventualmente identificadas pela avaliação a que se refere este artigo, haverá reavaliação, que poderá resultar, conforme o caso, em desativação de cursos e habilitações, em intervenção na instituição, em suspensão temporária de prerrogativas da autonomia, ou em descredenciamento (Vide Lei $n^{\circ} 10.870$, de 2004).

$\S 2^{\circ}$ No caso de instituição pública, o Poder Executivo responsável por sua manutenção acompanhará o processo de saneamento e fornecerá recursos adicionais, se necessários, para a superação das deficiências. $\S 3^{\circ}$ No caso de instituição privada, além das sanções previstas no $\S 1$ lo deste artigo, o processo de reavaliação poderá resultar em redução de vagas autorizadas e em suspensão temporária de novos ingressos e de oferta de cursos.

$\S 4^{\circ}$ É facultado ao Ministério da Educação, mediante procedimento específico e com aquiescência da instituição de ensino, com vistas a resguardar os interesses dos estudantes, comutar as penalidades previstas nos $\S \S 10$ e 3 o deste artigo por outras medidas, desde que adequadas para superação das deficiências e irregularidades constatadas.

$\S 5^{\circ}$ Para fins de regulação, os Estados e o Distrito Federal deverão adotar os critérios definidos pela União para autorização de funcionamento de curso de graduação em Medicina". Cf. BRASIL. Lei $n^{\circ}$ 9.394, de 20 de dezembro de 1996. Estabelece as diretrizes e bases da educação nacional. Brasília, DF: Presidência da República, 1996a. Disponível em: http://www.planalto.gov.br/ccivil_03/leis/19394.htm. Acesso em: 5 fev. 2019. 
discentes. A renovação de qualquer ato autorizativo, seja de instituição (recredenciamento), seja de curso (renovação de reconhecimento), é obrigatoriamente condicionada à respectiva avaliação positiva.

O Sinaes busca a composição do Conceito Preliminar de Curso (CPC), que consiste em um indicador preliminar da situação dos cursos de graduação, capaz de consubstanciar diferentes variáveis que traduzem resultados da avaliação de desempenho de estudantes, infraestrutura e instalações, recursos didático-pedagógicos e corpo docente.

\begin{abstract}
Para agregar ao processo de avaliação da educação superior critérios objetivos de qualidade e excelência dos cursos, o Inep criou um novo indicador. O Conceito Preliminar de Curso (CPC) vai de 1 a 5 e, como o próprio nome diz, é um indicador prévio da situação dos cursos de graduação no país. Para que os valores se consolidem, e representem efetivamente o que se espera de um curso em termos de qualidade e excelência, comissões de avaliadores farão visitas in loco para corroborar ou alterar o conceito obtido preliminarmente.

O CPC será divulgado anualmente, junto com os resultados do Exame Nacional de Desempenho dos Estudantes, o Enade. Operacionalmente, cursos que obtiverem CPC 1 e 2 serão automaticamente inclú́dos no cronograma de visitas dos avaliadores do Inep. Os demais casos, ou seja, cursos com conceito igual ou maior que 3, podem optar por não receber a visita dos avaliadores e, assim, transformar o CPC em conceito permanente.

Consolidado o processo de avaliação conduzido pelo Inep, cursos com conceito 3 serão aqueles que atendem plenamente aos critérios de qualidade para funcionarem. Da mesma forma, cursos com conceito 5 serão cursos de excelência, devendo ser vistos como referência pelos demais. $\mathrm{O}$ conceito permanente servirá como referência para subsidiar o processo de regulação dos cursos de graduação no país.

O referido conceito é composto por diferentes variáveis, que traduzem resultados da avaliação de desempenho de estudantes, infraestrutura e instalações, recursos didático-pedagógicos e corpo docente. As variáveis utilizadas em sua composição foram retiradas do Enade, incluindo o Indicador de Diferença entre os Desempenhos Observado e Esperado (IDD) e o questionário socioeconômico - e do Cadastro de Docentes $2007^{281}$.
\end{abstract}

Segundo a própria orientação definida pela Lei $n^{0} 10.861 / 2004$, o Sinaes tem por finalidade a melhoria da qualidade da educação superior, a orientação da expansão da sua oferta, o aumento permanente da sua eficácia institucional e efetividade acadêmica e social e, especialmente, a promoção do aprofundamento dos compromissos e responsabilidades sociais das instituições de educação superior, por meio da valorização de sua missão pública, da promoção dos valores democráticos, do respeito à diferença e à diversidade, da afirmação da autonomia e da identidade institucional.

A ideia é justamente que o controle de qualidade da educação superior no Brasil acontecesse em cooperação com os sistemas de ensino dos Estados e do Distrito Federal, o que

281 BRASIL. Ministério da Educação. O que é o conceito preliminar de curso? Brasília, DF: MEC, [20-?]. Disponível em: http://portal.mec.gov.br/pet/127-perguntas-frequentes-911936531/educacao-superior399764090/13074-o-que-e-o-conceito-preliminar-de-curso . Acesso em: 18 out. 2020. 
já fora apontado anteriormente como situação não cumprida no contexto da avaliação da educação superior no Brasil.

Ainda nos termos do conteúdo previsto na legislação específica, a avaliação dos cursos em território nacional teria o objetivo de objetivo identificar as condições de ensino oferecidas aos estudantes, em especial as relativas ao perfil do corpo docente, às instalações físicas e à organização didático-pedagógica, com a atribuição de conceitos, ordenados em uma escala com cinco níveis, a cada uma das dimensões e no conjunto das dimensões avaliadas.

Para conseguir medir o desempenho dos estudantes dos cursos de graduação, o Sistema Nacional de Avaliação estipulou a aplicação do Exame Nacional de Desempenho dos Estudantes, o qual busca efetivar a avaliação universitária sobre o tripé universidade, professores e alunos. Estes seriam considerados os ingressantes e os egressos, buscando encontrar referências concretas sobre o que a universidade conseguiu acrescentar aos alunos.

A consolidação de disposições sobre indicadores de qualidade criou dois indicadores de qualidade, à margem da Lei do Sinaes ditos provisórios, mas que se tornaram efetivos: Conceito Preliminar de Curso e Índice Geral de Cursos.

Nos termos da lei, a execução do controle de qualidade se dá pela realização da avaliação das instituições, dos cursos e do desempenho dos estudantes, que é de responsabilidade conjunta da Seres, Inep e Conaes. Ao Ministério da Educação, após o regular trâmite da apuração administrativa da qualidade do serviço prestado e verificação da sua regularidade, cabe o dever de tornar público e disponível o resultado da avaliação das instituições de ensino superior e de seus cursos.

Caso o procedimento avaliativo resulte em algum resultado insatisfatório, a IES estará sujeita à celebração de protocolo de compromisso, a ser firmado entre a instituição de educação superior e o Ministério da Educação.

O mencionado protocolo de compromisso visa a manutenção das atividades da IES identificada como má prestadora do serviço público, buscando prestar auxílio para que os principais interessados não sejam prejudicados com a determinação de encerramento compulsório de suas atividades. Tal protocolo de compromisso, nos termos da lei, deverá conter: o diagnóstico objetivo das condições da instituição; os encaminhamentos, processos e ações a serem adotados pela instituição de educação superior com vistas à superação das dificuldades detectadas; a indicação de prazos e metas para o cumprimento de ações, expressamente definidas e a caracterização das respectivas responsabilidades dos dirigentes; e a criação, por parte da instituição de educação superior, de comissão de acompanhamento do protocolo de compromisso. 
Em uma hipotética situação de descumprimento do protocolo de compromisso, no todo ou em parte, a IES envolvida poderá sofrer a aplicação das seguintes penalidades: suspensão temporária da abertura de processo seletivo de cursos de graduação; cassação da autorização de funcionamento da instituição de educação superior ou do reconhecimento de cursos por ela oferecidos; e advertência, suspensão ou perda de mandato do dirigente responsável pela ação não executada, no caso de instituições públicas de ensino superior. Tais penalidades previstas serão aplicadas pelo órgão do Ministério da Educação responsável pela regulação e supervisão da educação superior, ouvida a Câmara de Educação Superior, do Conselho Nacional de Educação, em processo administrativo próprio, ficando assegurado o direito de ampla defesa e do contraditório.

Toda essa estruturação retroapresentada guarda estrita relação com o sistema federal de ensino, ou seja, apesar de ser relacionado com o controle de qualidade da maioria das instituições de ensino superior, existe uma falha no sistema avaliativo por não serem todas as instituições brasileiras que se sujeitam à referida análise aqui descrita.

Segundo informações oficiais prestadas no site do Inep ${ }^{282}$, O Ministério da Educação contratou a Organização para a Cooperação e Desenvolvimento Econômico (OCDE) em 2017, via Instituto Nacional de Estudos e Pesquisas Educacionais Anísio Teixeira, com o objetivo de realizar avaliação externa do Sistema Nacional de Avaliação da Educação Superior.

Segundo apurado, em março de 2018 a OCDE enviou uma missão ao Brasil, em que entrevistou alguns representantes do governo e de universidades públicas e privadas. O relatório preliminar do estudo produzido por essa organização teve por propósito avaliar a eficiência e a eficácia dos procedimentos de garantia de qualidade da educação superior no Brasil, considerando os níveis de graduação e pós-graduação. Exatamente como relatado, o estudo inicia seu sumário executivo apontando, de forma objetiva, justamente a falha avaliativa consistente no descompromisso de análise de todo o universo que presta o serviço educacional em nível superior no Brasil.

O Brasil possui sistemas bem estabelecidos para avaliar, monitorar e assegurar a qualidade da aprendizagem e do ensino em instituições públicas e privadas de ensino superior no sistema federal de educação superior. O Ministério da Educação (MEC) toma decisões regulatórias sobre credenciamento de instituições e autorização e reconhecimento de cursos de graduação com base nos resultados de avaliações coordenadas pelo Instituto Nacional de Estudos e Pesquisas Educacionais Anísio Teixeira (INEP). A Fundação para a Coordenação de Aperfeiçoamento de Pessoal de

282 INSTITUTO NACIONAL DE ESTUDOS E PESQUISAS EDUCACIONAIS ANÍSIO TEIXEIRA. Considerações sobre o relatório da OCDE Repensando a garantia de qualidade para o Ensino Superior no Brasil. Brasília, DF: Inep, 2019c. Disponível em: http://inep.gov.br/sinaes/relatorio-ocde. Acesso em: 29 jul. 2020. 


\begin{abstract}
Nível Superior (CAPES) implementa um sistema separado de garantia de qualidade para programas de pós-graduação acadêmica.

Os processos externos de qualidade para instituições de ensino superior (IES) e programas de graduação são obrigatórios e se aplicam a instituições públicas privadas e federais. Estes são responsáveis por $90 \%$ das mais de 2.400 IES do Brasil e inscrevem 91\% dos estudantes de graduação no país. Três quartos da matrícula na graduação no Brasil é do setor privado. Os restantes $9 \%$ das matrículas são em instituições públicas estaduais e municipais, que estão sujeitas a regulamentação e garantia de qualidade por parte dos governos estaduais $^{283}$ (grifos nossos).
\end{abstract}

Demonstramos, assim, que, visando efetivar a determinação constitucional, o Estado se organizou para adotar condutas capazes de apurar da qualidade da educação superior nacional. Isso aconteceu em um primeiro momento com a definição constitucional do dever do Estado de promoção de educação de qualidade ${ }^{284}$, após a promulgação da $\operatorname{LDB}^{285}$, que visou implementar diretrizes gerais para a avaliação da educação superior no Brasil. Posteriormente, o sistema avaliativo (Sinaes) foi instituído com a criação específica por lei ${ }^{286}$ e regulamentação por decreto ${ }^{287}$, para descrever a execução do procedimento administrativo instituído. Foi baixada a competente portaria normativa ${ }^{288}$ do MEC, a qual apresenta as diretrizes executivas do procedimento administrativo destinado à apuração da qualidade dos cursos superiores, em especial do curso de Direito no Brasil. Finalmente, a promulgação do Plano Nacional da Educação $^{289}$, que determinou metas objetivas para a apuração da qualidade, no sentido de dar

${ }^{283}$ ORGANISATION FOR ECONOMIC CO-OPERATION AND DEVELOPMENT. Rethinking quality assurance for higher education in Brazil. Paris: OECD, 2018. p. 13. Disponível em: http://www.oecd.org/brazil/rethinking-quality-assurance-for-higher-education-in-brazil-9789264309050en.htm. Acesso em: 29 jul. 2020.

${ }^{284}$ Art. 206, inciso VII: "Art. 206. O ensino será ministrado com base nos seguintes princípios: [...] VII garantia de padrão de qualidade". Cf. BRASIL. [Constituição (1988)]. Constituição da República Federativa do Brasil de 1988. Brasília, DF: Presidência da República, 1988. Disponível em: http://www.planalto.gov.br/ccivil_03/constituicao/constituicaocompilado.htm. Acesso em: 18 fev. 2019.

285 BRASIL. Lei $n^{\circ}$ 9.394, de 20 de dezembro de 1996. Estabelece as diretrizes e bases da educação nacional. Brasília, DF: Presidência da República, 1996a. Disponível em: http://www.planalto.gov.br/ccivil_03/leis/19394.htm. Acesso em: 5 fev. 2019..

286 BRASIL. Lei $n^{\circ} 10.861$, de 14 de abril de 2004. Institui o Sistema Nacional de Avaliação da Educação Superior - SINAES e dá outras providências. DF: Presidência da República, 2004a. Disponível em: http://www.planalto.gov.br/ccivil_03/_ato2004-2006/2004/lei/110.861.htm. Acesso em: 15 maio 2020.

${ }^{287}$ BRASIL. Decreto $n^{\circ} 9.235$, de 15 de dezembro de 2017. Dispõe sobre o exercício das funções de regulação, supervisão e avaliação das instituições de educação superior e dos cursos superiores de graduação e de pósgraduação no sistema federal de ensino. Brasília, DF: Presidência da República, 2017. Disponível em: http://www.planalto.gov.br/ccivil_03/_Ato2015-2018/2017/Decreto/D9235.htm. Acesso em: 20 maio 2019.

288 BRASIL. Ministério da Educação. Portaria Normativa no 40, de 12 de dezembro de 2007. Institui o e-MEC, sistema eletrônico de fluxo de trabalho e gerenciamento de informações relativas aos processos de regulação, avaliação e supervisão da educação superior no sistema federal de educação, e o Cadastro e-MEC de Instituições e Cursos Superiores e consolida disposições sobre indicadores de qualidade, banco de avaliadores (Basis) e o Exame Nacional de Desempenho de Estudantes (ENADE) e outras disposições. Brasília, DF: MEC, 2007. Disponível em:

http://download.inep.gov.br/educacao_superior/censo_superior/legislacao/2007/portaria_40_12122007.pdf. Acesso em: 5 maio 2020.

${ }^{289}$ Lei no 13.005 , de 25 de junho de 2014. 
um norte para a execução dessa política (Figura 9).

Figura 9 - Regulamentação da avaliação da educação superior no Brasil

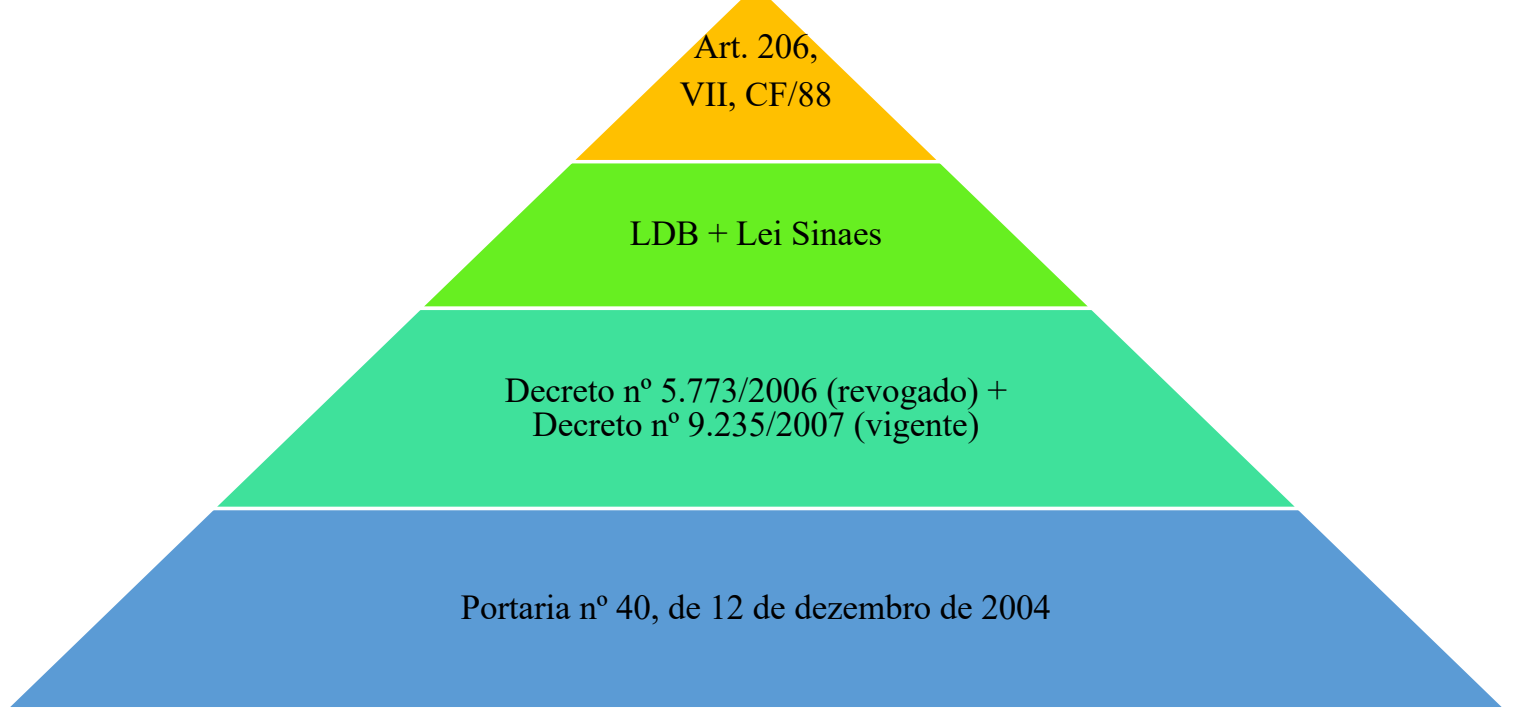

Fonte: Elaboração própria.

Em consonância às diretrizes gerais, quando se menciona que é dever do Estado estabelecer regras para um padrão mínimo de qualidade, referimo-nos, evidentemente, ao regramento geral aplicável à educação superior previsto na LDB.

Porém, para que a apuração da qualidade possa ser desempenhada respeitando as peculiaridades inerentes ao procedimento administrativo, é necessário compreender que a estrutura anteriormente apresentada tem setores específicos para atuação no complexo procedimento avaliativo das instituições de ensino superior.

Como mencionado, cada órgão possui sua importância no procedimento avaliativo; por isso, foi importante apresentar a estrutura complexa para depois descrever o procedimento.

Foi a previsão legal específica à educação que atribuiu à União o dever de baixar normas gerais sobre cursos de graduação e pós-graduação que serão aplicáveis a quaisquer instituições de ensino e seus respectivos cursos em andamento no país ${ }^{290}$.

Adstrito à área jurídica, atualmente as Diretrizes Curriculares Nacionais específicas para o curso de graduação em Direito, bacharelado, que devem ser observadas pelas instituições de educação superior, estão previstas pela Resolução no 5, de 17 de dezembro de 2018, da

290 Art. 9, inciso VII: “Art. 9 A União incumbir-se-á de: [...] VII - baixar normas gerais sobre cursos de graduação e pós-graduação". Cf. BRASIL. Lei $n^{\circ}$ 9.394, de 20 de dezembro de 1996. Estabelece as diretrizes e bases da educação nacional. Brasília, DF: Presidência da República, 1996a. Disponível em: http://www.planalto.gov.br/ccivil_03/leis/19394.htm. Acesso em: 5 fev. 2019. 
Câmara de Educação Superior do Conselho Nacional de Educação.

Pilar Jiménez Tello ${ }^{291}$, ao tratar da constitucionalização da autonomia universitária, enfatiza que tal princípio requer e tem implícito a introdução e o reforço dos sistemas de auditoria e avaliação como complemento essencial dessa maior autodecisão e autorregulação dos planos de estudo por cada universidade. Justamente por isso que se reconhece que as Diretrizes Curriculares Nacionais instituídas pela Câmara de Educação Superior do Conselho Nacional de Educação podem ser tidas como esse padrão mínimo exigível e apurável pelos procedimentos avaliativos idealizados.

Trata-se de um modelo anterior de harmonização dos planos de estudo para um sistema posterior de diversidade, que precisam ser contrastados e avaliados para que os cidadãos tenham direito de eleger entre as diversas instituições de ensino superior existentes. Isso leva consigo a obrigação de avaliá-las em atividades de todas as naturezas e os diferentes projetos educacionais que propõem.

A apuração da qualidade, por ocasião das autorizações para funcionamento de instituições de ensino superior, refere-se a momento anterior à regular existência e funcionamento daquele curso na sociedade, importa dizer, o Estado exerce o dever de autorizar ou não o funcionamento de um novo curso no Brasil.

Já que a autorização será exercida pelo setor público, por meio dos órgãos governamentais dotados de tal competência, inicia-se a descrição de como esse procedimento autorizativo efetivamente ocorre no Brasil.

Retomando o procedimento avaliativo para autorização de cursos, temos que a LDB permite que as atribuições estipuladas para a União de autorizar, reconhecer, credenciar, supervisionar e avaliar, respectivamente, os cursos das instituições de educação superior e os estabelecimentos do seu sistema de ensino, poderão ser delegadas aos estados e ao Distrito Federal, desde que esses entes da federação mantenham instituições de educação superior. Importa dizer, as instituições de ensino superior que fazem parte do sistema federal serão necessariamente avaliadas pela União, enquanto as instituições de ensino superior que façam

291 “Una consecuencia lógica de la autonomía universitaria y de su constitucionalización está implícita en la auditoría y evaluación universitaria. Dicha constitucionalización requiere y lleva implícito, (como se comprueba en todos los sistemas de autorregulación) la introducción y reforzamiento de los sistemas de auditoría y evaluación como complemento esencial de esa mayor autodecisión y autorregulación de los planes de estudio por cada universidad. Es decir que se pasa de un sistema de armonización ex ante de los planes de estudio a un sistema ex post de diversidad de planes de estudio que requieren ser contrastados y evaluados para que los ciudadanos tengan derecho a elegir entre los diferentes centros. Esto lleva consigo la obligación de evaluar las universidades y los diferentes planes de estudio." Cf. TELLO, Pilar Jiménez. Auditoría universitaria y calidad: la evaluación como conquista social ante la competencia universitaria global. Saarbrücken: VDM Verlag Dr. Müller, 2009. p. 63. 
parte dos sistemas estaduais estão sujeitas à avaliação desempenhada pelos Estados caso eles mantenham instituições de educação superior.

\subsection{Uma possível alternativa para apuração de qualidade educacional: mecanismos de controle de qualidade efetuados pelo setor privado com apoio da sociedade civil}

Os sistemas de garantia de qualidade apresentados até o momento devem constituir a imprescindível ferramenta que o Estado deve idealizar, implementar e ser responsável, a fim de deter informações relevantes para utilizar entre distintas finalidades, principalmente no momento de escolha de aporte e distribuição de recursos públicos. Desse modo, diante de dados oficiais que certificam a qualidade de uma determinada instituição de ensino, sua escolha para envio de aporte financeiro público possuirá convencimento motivado para a destinação da verba, além de verdadeiro reconhecimento dos esforços empreendidos pelas instituições de ensino para a melhoria do setor.

No entanto, apostar todo um sistema de apuração de qualidade como exclusivo papel do Estado coloca os demais agentes desse cenário como sujeitos passivos diante da constatação dos serviços de interesse de todos que são entregues. Assim, a sociedade civil não deve se furtar ao dever de se organizar para idealizar e adotar procedimentos próprios e totalmente livres da atuação do poder público, como forma legitima de firmar posicionamento na apuração da qualidade educacional, sob pena de se ver refém do sistema público de apuração de qualidade educacional.

Após a compreensão do que o setor público efetivamente emprega para apurar a qualidade da educação superior no Brasil, a primeira consideração importante que deve ser feita está diretamente relacionada com a ausência de recorte temático na elaboração do processo avaliativo, sob uma perspectiva específica às diversas áreas do conhecimento científico.

Obviamente, há que ser sopesado que, por ocasião da avaliação in loco, os avaliadores que são encaminhados para apuração da qualidade por meio da elaboração de relatório de avaliação consistem em técnicos previamente selecionados com base em inscrição e processo seletivo comandado pelo Inep. No entanto, como relatado anteriormente, a avaliação in loco consiste apenas em uma parte do procedimento avaliativo, que não é acompanhado em sua integralidade por profissionais da área de conhecimento.

Assim, cada uma das áreas do conhecimento científico, incluindo os cursos de Direito, deveria ter maior protagonismo na condução de procedimentos específicos, sendo conduzidos por comissões de especialistas com o necessário apoio técnico que a entidade da administração 
pública indireta deveria fornecer, de maneira adstrita exclusivamente à coleta do material fornecido pelas IES.

Atualmente, o Inep assume um papel de protagonismo no processo avaliativo, que não deveria lhe ser concedido por desvio de finalidade, visto que a entidade da administração indireta tem por finalidade específica, nos termos da lei que o criou, auxiliar o procedimento avaliativo com a coleta das informações, mas não efetuar uma análise crítica ou juízo de valor sobre o processo avaliativo em si, ou sobre os elementos derivativos desses processos, tais como os resultados.

Não obstante essas considerações, é essencial mencionar que a iniciativa privada é responsável atualmente por executar algumas políticas específicas de tentativa de apuração da qualidade educacional. Registre-se que, independentemente da existência do processo avaliativo público, tem-se que a apuração da qualidade é tema de interesse social relevante, já que a formação técnica em grau superior possui o condão de colocar as pessoas no mercado de trabalho e preparar para o exercício da cidadania.

É justamente nesse sentido que cada vez mais se torna relevante a participação de outros atores sociais na constante construção de um ensino jurídico aprimorado para o contexto nacional. Voltado para essa concepção, a presente pesquisa passa à apuração das políticas privadas que a sociedade civil organiza visando o controle de qualidade das IES em atividade no Brasil.

Necessário constatar que tais mecanismos, diferentemente do que ocorre com o mecanismo público, consistem necessariamente em políticas competitivas para o contexto da educação. Segundo apontado por Pilar Jiménez Tello e Victoria Eugenia Plaza,

La competición es un principio político constitucional y democrático, no un principio de la economía de mercado, un ejemplo claro lo tenemos en las elecciones democráticas, no se puede decir que la competición entre partidos sea un mercado, es el principio por excelencia de la democracia, dónde el ciudadano se convierte en el evaluador [...] Todo lo expuesto podemos extrapolarlo al ámbito de la competición entre las instituciones de Educación Superior. En el la competición, entendida como valor, sin duda contribuye a mejorar los procesos de innovación y a una mejora en la docencia, investigación y gestión. No olvidemos la influencia de las universidades en sus respectivos estados, si las universidades tienen prestigio, también lo tendrán 
sus estados ${ }^{292}$.

Segundo apontado por Solange Maria dos Santos ${ }^{293}$, o ranking universitário possui um elemento fundamental para o seu sucesso e sua aceitação do ponto de vista da interlocução com a sociedade. Tal classificação é consistente por facilitar a conversão de aspectos complexos e contextualmente variáveis em medidas claras e impessoais, que são apresentadas de forma atraente e direta, justamente porque o ensino superior se pautou na avaliação dos pares e procedimentos internalizados de garantia ou aprimoramento da qualidade.

[...] a popularidade dos rankings como fonte independente de informação sobre um setor é cada vez mais importante. A aparente simplicidade e clareza dessas classificações fazem com que muitas vezes se acredite que a posição das instituições em um determinado ranking reflita, de maneira precisa, a qualidade das universidades, o que pode facilmente levar a interpretações equivocadas, tanto por parte do público em geral e dos meios de comunicação quanto por parte de gestores públicos.

É surpreendente a rapidez com que os resultados publicados por diferentes rankings são recebidos, interpretados e divulgados, não apenas por assessorias de imprensa e jornais, mas por parte de gestores, especialistas e equipes das próprias universidades. Todos os anos, para atender às necessidades de informação dos distintos públicos interessados nos rankings de universidades, vários desses sistemas de classificação são desenvolvidos, atualizados e publicados por diversos tipos de instituições (revistas e jornais eminentes, institutos de pesquisas, sociedades profissionais, organizações governamentais, e consultorias independentes) e seus resultados geram uma pressão significativa, tanto sobre as universidades ao redor do mundo quanto sobre ministérios e instituições responsáveis por elaborar de políticas nacionais, e, por acompanhar o desempenho das universidades nos rankings globais. [...] essa pressão exercida pelos rankings se deve muito à capacidade que tem de expor, culpar e até envergonhar os países e as instituições que não alcançam boas posições ${ }^{294}$.

Conclui-se que faz parte da natureza humana essa necessidade de competir, o que deve ser encarado não como uma forma agressiva de crescimento, mas sim como uma experiência educacional firmada com base na imersão dos atores nos aspectos concretos do cenário educacional.

A competição é inerente à natureza humana e deve ser aplicada ao setor educacional

292 “A competição é um princípio político constitucional e democrático, não um princípio da economia de mercado, um exemplo claro que temos nas eleições democráticas, não se pode dizer que a competição entre os partidos é um mercado, é o princípio por excelência da democracia, onde o cidadão passa a ser avaliador [...] Todas as anteriores podem ser extrapoladas para o campo da competição entre instituições de ensino superior. Na competição, entendida como um valor, sem dúvida contribui para a melhoria dos processos de inovação e aprimoramento do ensino, da pesquisa e da gestão. Não esqueçamos a influência das universidades em seus respectivos estados, se as universidades têm prestígio, seus estados também terão." [tradução nossa] Cf. TELLO, Pilar Jiménez; PLAZA, Victoria Eugenia. Educación superior y competitividad. Cadernos de Pós-Graduação em Direito, Comissão de Pós-Graduação da Faculdade de Direito da USP, São Paulo, n. 31, p. 4-26, 2014. p. 8.

${ }^{293}$ SANTOS, Solange Maria dos. Rankings internacionais e universidades: comparação e desempenho por áreas. In: MARCOVITCH, Jacques (org.). Repensar a universidade: desempenho acadêmico e comparações internacionais. São Paulo: Com-Arte; Fapesp, 2018. p. 63.

${ }^{294}$ Ibid., p. 64. 
como uma mola propulsora do desenvolvimento de alunos, professores e instituições de ensino. O lado positivo da competição consiste nessa sensação de que o competidor busca evoluir constantemente.

E assim como os seres humanos, as instituições de ensino, quando competem entre si pelos melhores posicionamentos nos rankings universitários, conseguem perceber de forma clara quais são os seus limites e quais são os critérios objetivos diante de um parâmetro de comparação pelos quais precisarão se dedicar para alcançar um crescimento e uma evolução, num cenário que necessariamente é fluido.

Considerando a grande dificuldade de estipular indicadores comuns para toda a região da América Latina, deve ser idealizado um mínimo de indicadores gerais que correspondam às áreas estratégicas da educação superior. Isso terá como finalidade conseguir medir a qualidade de nossas instituições com a capacidade de comparar a qualidade delas através de um ranking.

Justamente por isso inicia-se a abordagem do próximo capítulo, que apresentará os elementos inerentes a alguns dos mais importantes rankings universitários nacionais e internacionais, as diferenças e peculiaridades para apuração da qualidade dos cursos de Direito no Brasil, como forma alternativa de medir a prestação dos serviços educacionais. 


\section{NECESSIDADE DO FOMENTO DE ESTUDOS E IMPLEMENTAÇÃO DE POLÍTICAS PÚBLICAS QUE OBJETIVEM O RECONHECIMENTO MUNDIAL DA QUALIDADE DA EDUCAÇÃO JURÍDICA BRASILEIRA: COMPETIÇÃO EM UM CENÁRIO GLOBALIZADO}

Após a análise crítica das formas de apuração de qualidade apresentadas no capítulo anterior, ainda que efetivamente sejam essas as adotadas pelo estado brasileiro na busca pela qualidade da educação superior, verifica-se que tais ações se apresentaram como insuficientes para atestar os reais níveis de qualidade educacional. Tal constatação se deve a uma série de fatores que foram pormenorizados anteriormente, dos quais destacam-se as injustiças na coleta dos dados, a divergência de procedimentos realizados a depender da natureza jurídica da instituição de ensino a ser avaliada, entre outras subjetividades apontadas e criticadas no presente estudo.

Além disso, foi exaustivamente apontado que o atual procedimento público de avaliação da qualidade das instituições de ensino superior se mostra incapaz de inseri-las em um cenário globalizado de trânsito mundial de estudantes. Isso acontece porque o atual desempenho das IES no Brasil não está fundado nas premissas básicas do monitoramento, impacto e registro, atuando apenas como um grande coletor de dados que deixam de ser devidamente trabalhados para melhorar o setor.

O ambiente do ensino superior, por ser complexo, dinâmico, global e caracterizado pela diversidade, indica a riqueza e a dimensão das possibilidades de inovação e ruptura. Reconhecendo que as instituições de ensino superior brasileiras são capazes de ganhar notoriedade em um cenário globalizado desde que apresentem certos elementos comuns, é possível concluir que o interesse de estudantes para realizar intercâmbio nas IES do Brasil consistirá em uma clara percepção de que a qualidade da educação superior nacional alçou novos padrões - estes que se traduzem em desdobramentos decorrentes de um cenário globalizado e se tal constatação for apontada por agentes estranhos ao governo brasileiro ou à própria instituição de ensino.

O mundo globalizado tem provocado diversos impactos nas relações humanas. Assim, no contexto universitário não é diferente, porque há necessidade de adequação das instituições de ensino em todo o mundo aos novos paradigmas impostos por essas mudanças.

Por isso, cada vez mais são valorizados os intercâmbios culturais, educacionais e jurídicos que a imersão em outros países permite aos sujeitos com a oportunidade de vivenciar um contexto absolutamente diverso do seu. Alguém com chance de transitar e conhecer as 
múltiplas realidades diferentes da sua e retorna ao seu país, além de crescer pessoalmente com a experiência, acaba sendo muito mais valorizado pela sociedade e pelo mercado.

Não há como ser diferente com as instituições de ensino. A universidade encara atualmente seu principal desafio, consistente no objetivo de conseguir desempenhar com qualidade o papel social e educacional, diante da produção de conhecimento com finalidade de desenvolvimento social, cultural e de sustentabilidade, atrelada à produção de ciência, tecnologia e inovação para atender os anseios mercadológicos.

Como já apresentado, o sistema educacional do Brasil, de um modo geral, é extremamente complexo, inclusive no ensino superior. Isso se torna ainda mais evidente quando nos deparamos com o fato de que existem instituições de ensino superior de distintas naturezas jurídicas em atividade; porém, em princípio, as regras e o procedimento de apuração de qualidade exaradas pelo setor público deveriam ser as mesmas, independentemente da natureza jurídica dessas instituições, e não o são.

O capítulo anterior foi destinado a comprovar que os mecanismos de apuração de qualidade dessas instituições, embora tenham sido idealizados para serem os mesmos, nota-se que na prática as IES são avaliadas de maneira subjetiva e extremamente diversa a depender da natureza jurídica da instituição avaliada.

Partindo da comprovação de que o procedimento público de avaliação não é capaz de apurar de maneira equânime instituições que prestam o mesmo serviço, é necessário idealizar nesse cenário uma possível alternativa, mais justa e igualitária, para apurar a qualidade da educação superior e do serviço que é prestado por qualquer instituição de ensino no território nacional, independentemente de sua natureza jurídica. É nesse contexto que os rankings universitários começam a ganhar destaque e relevância.

O ranqueamento é uma realidade mundial há muitos anos, e existem diversas instituições diferentes trabalhando atualmente para concretizar a avaliação por esse mecanismo nos mais diferentes setores de atividade relevante para a sociedade. Funda-se em uma lógica de competição instaurada entre atores de um mesmo grupo que pretendem o fornecimento de um determinado serviço.

Já faz algum tempo que algumas instituições do setor privado se dedicam ao estudo da qualidade da educação superior por meio de análise de ranqueamento institucional. A realidade é que por intermédio do ranking se institucionaliza uma concorrência entre toda e qualquer instituição de ensino superior em atividade, perdendo força a concepção de que a competitividade consistiria em um fator influenciador exclusivo das instituições privadas por ser um mecanismo inerente ao setor privado, decorrente da lógica do consumismo. 
A competitividade é uma concepção que está diretamente relacionada com as práticas de mercado. John Stuart Mill ${ }^{295}$ sustenta que a competitividade da firma está associada à rentabilidade do setor em primeira instância, mas também com a habilidade do empreendedor para investir em determinadas atividades cuja rentabilidade é maior do que de outras.

\begin{abstract}
Ela também pode ser relacionada ao conceito de dependência da trajetória (path dependence), que é apontado como uma característica do programa de pesquisa evolucionário. A firma inovadora pode se beneficiar do lucro extraordinário, podendo estar apta a outras inovações. Essa inovação, devido à sua cumulatividade, pode garantir hegemonia de mercado e até mesmo o monopólio. Entretanto o processo de imitação também pode estar presente, possibilitando que outras firmas não inovadoras alcancem as firmas líderes. Dessa forma, a imitação torna-se uma força estabilizadora, enquanto a inovação uma força desestabilizadora. Diferentes trajetórias fazem com que, em muitas situações, não se possa identificar uma relação de causa e efeito no processo competitivo. Em outras palavras, as trajetórias fazem com que o processo não seja determinado apenas por forças sistemáticas, mas também por eventos aleatórios. Nesse sentido, a competitividade da firma pode ser vista como um processo condicionado pela sua trajetória e por um caráter aleatório onde a inovação atua como força desestabilizadora e a imitação como força estabilizadora entre os concorrentes $^{296}$.
\end{abstract}

Como um valor inerente à condição existencial, a competição pode ser encontrada em relações observadas por atores sociais e econômicos, inclusive entre outras espécies da natureza à parte dos seres humanos. A competitividade entre instituições pode ser observada em diversas dimensões, tais como em práticas concorrenciais de preço e valor de mercado, políticas de marketing, em investimentos, financiamentos, compensações, dividendos, seguros, políticas de contabilidade, entre outras.

De maneira geral, a competição assegura a sobrevivência dos competidores para uma utilização eficiente dos recursos disponíveis. Assim, competição é sinônimo de rentabilidade no longo prazo, atrelada à habilidade de prover retornos superiores aos investimentos aportados.

Michael Porter ${ }^{297}$ trata da competição mencionando que a evolução nas tecnologias de informação, telecomunicação e transportes, principalmente na década de noventa, trouxeram uma nova realidade para as organizações. Segundo aponta, o macroambiente conviveu com um fenômeno mundial que alterou a perspectiva das arenas competitivas de todo o mundo. $\mathrm{O}$ mercado, que antes era formado por ilhas de negócios praticamente isoladas, transformou-se

${ }^{295}$ MILL, John Stuart. Princípios de economia politica: com algumas de suas aplicações à filosofia social. São Paulo: Nova Cultural, 1996. p. 34.

296 PAIVA, Ricardo Viana Carvalho de; COSTA, Danilo de Melo; GONÇALVES, Raquel Garcia; BARBOSA, Francisco Vidal. Fatores influenciadores da competitividade na educação superior privada brasileira. Revista Global Manager, Rio Grande do Sul, v. 14, n. 1, p. 19-39, 2014. p. 21-22.

${ }^{297}$ PORTER, Michael Eugene. Competição on competition: estratégias competitivas essenciais. 10. ed. Rio de Janeiro: Campus Jurídico, 2003. p. 45. 
em um único e complexo ambiente de negócio global. A globalização da economia possibilitou uma abertura de mercado, uma nova realidade a ser enfrentada pelas organizações, destacando a facilidade de transacionar entre os mercados do mundo inteiro e a commoditização dos produtos. Tudo isso criou um ambiente caracterizado por uma acirrada concorrência empresarial cada vez mais competitiva.

Esta nova realidade exige das organizações competências cada vez mais diferentes e
diversificadas para ter sucesso nesta imprevisivel dinâmica competitiva. Neste
contexto, a Inteligência Competitiva (IC) pode exercer um papel importantíssimo
como estratégia no âmbito empresarial. As pressões externas tais como queda de
barreiras, volatilidade econômica, mudanças tecnológicas, mudanças sociais e tantas
outras variáveis que giram o ciclo do processo de mudança cada vez mais rápido,
obrigam as organizações a se adaptarem, a reagir e a incrementar sua capacidade de
operar numa busca constante pela qualidade e produtividade. Na atualidade as
empresas têm um grande desafio: tornarem-se mais competitivas, mantendo ou
aumentando a sua participação no mercado. Por isso existe a necessidade permanente
em monitorar as tendências e a lógica do mercado global, interpretando informações
e sinais do ambiente competitivo, sugerindo a direção, e transformando-as em ações
efetivas de planejamento e estratégia ${ }^{298}$.

Importar a lógica da competitividade para o setor educacional não consiste em uma novel prática, pois o dever de apurar a qualidade ao setor foi instituído pela Constituição Federal, e nesse sentido o Estado não pode se imiscuir de um dever que lhe foi imposto da forma adequada.

A grande questão está adstrita ao que os interesses sociais considerarão como suficientes para medir a qualidade do setor, que carrega um grau de subjetivismo inerente ao tipo de serviço prestado. Tal consideração está alinhada ao que foi mencionado no início deste trabalho, quando se afirmou que o serviço prestado sempre estará relacionado à pretensão da sociedade e do Estado ao perfil de egressos colocados no mercado de trabalho.

Diante dos dados apresentados no capítulo anterior, constatou-se que a apuração da qualidade do serviço prestado pelo setor público com os mecanismos institucionalizados pelo sistema federal de ensino, os quais também deveriam ter sido efetivados pelos sistemas estaduais, não apuram de maneira uniforme a educação superior em atividade em todo o território nacional.

Os rankings universitários surgem como uma alternativa apta a efetuar a apuração da qualidade educacional das IES, mediante a divulgação de classificação das instituições

298 MELO, Diogo Veloso de; MACHADO, André Gustavo Carvalho; MORAES FILHO, Rodolfo Araújo de. Inteligência competitiva: o caso C.E.S.A.R. In: ENCONTRO DA ANPAD, 32., 2008, Rio de Janeiro. Anais [...]. Rio de Janeiro: Anpad, 2008. p. 2. Disponível em: http://www.anpad.org.br/admin/pdf/ESO-A2660.pdf. Acesso em: 21 out. 2020. 
analisadas em escala numérica. Essa medida deve valer-se de metodologia previamente publicada, cuja coleta de informações aconteceria com lisura e de maneira imparcial, idealizando uma tentativa de internacionalização da educação superior entre as universidades de classe mundial e visando uma fiel adequação à concepção de globalização.

Se os rankings surgem como uma alternativa ao que realmente é feito pelo Estado brasileiro e, mais do que isso, se atualmente a sociedade começa a caminhar para o reconhecimento da importância da atuação dessas entidades, a proposta deste capítulo se baseia na necessidade de analisar de que maneira esses atores conseguem apurar e até mesmo influir no desempenho acadêmico das universidades brasileiras.

\subsection{A lógica da competitividade aplicada ao setor educacional na realidade brasileira}

$\mathrm{Na}$ atual sociedade, que possui o conhecimento como alto valor, as instituições de ensino possuem inegável importância por se traduzirem como as detentoras desse intangível ativo disponível, que é essencial para a reprodução da lógica da competitividade. Por consequência, uma instituição de ensino de qualidade é aquela que consegue formar sujeitos de direito em sua integralidade e capazes de obter êxitos em suas carreiras técnicas e científicas.

A competição é um valor enraizado em nossa sociedade, fruto do nosso modelo

econômico baseado na acumulação de riquezas. É exitoso o sujeito que conseguir, ao longo de sua vida, acumular maior número de capital possível em sua trajetória.

As instituições de ensino superior são consideradas peças fundamentais na formação do capital intelectual dessas pessoas. Inclusive, é justamente por isso que a sociedade e o Estado responsabilizam as IES por colocar mão de obra qualificada no mercado de trabalho. Este, por sua vez, é essencialmente regido pela lógica da competitividade, na qual se acredita que os mais bem qualificados tendem a alcançar o sucesso em suas carreiras profissionais.

Essa lógica da competitividade é tão inerente ao nosso modelo de organização societária de forma globalizada que a competição se traduz em um valor importante entre os membros que compõem a sociedade de um modo geral. Mas não só, todos os personagens existentes na atualidade estão em contínua e constante competição como modo de vida. Isso não acontece só no Brasil e, menos ainda, não se trata de um valor inerente ao indivíduo, mas sim de um valor estrutural e enraizado na humanidade.

Nesse sentido, é possível constatar que a competição é uma realidade e propulsionou grandes transformações em nossa história recente. Porém, mais do que ser um valor inerente ao indivíduo, por estar enraizada nos mais diversos setores que estruturam a sociedade 
contemporânea, pode-se concluir que a competitividade existe também entre as empresas e os prestadores de serviços de quaisquer natureza, cada um no seu contexto, ambicionando o reconhecimento de que são os de melhor qualidade e prestam os melhores serviços à sociedade.

No setor educacional não é diferente. Não só no próprio ambiente institucional, entre alunos, professores, gestores e colaboradores, mas, também, entre as próprias IES existe uma competição, ainda que não claramente institucionalizada, pela definição de qual delas prestaria o melhor serviço educacional em âmbito nacional.

A avaliação pública efetuada pelo governo federal brasileiro não se presta a esse desígnio, já que a ideia do Sinaes é justamente a de atribuir uma nota específica para os cursos e para as instituições de ensino que os ofertam, podendo atingir nota máxima desde que cumpram os requisitos previstos nos instrumentos avaliativos específicos dos níveis de excelência. Tal cenário, previamente desenhado, não daria base para uma possível competição entre as próprias instituições de ensino. É diferente do que acontece com os rankings universitários.

O ranking consiste em uma noção de avaliação das instituições de ensino por critérios de comparação e ganhou força na medida em que elas se tornaram determinantes para o desenvolvimento econômico e social, tanto para países desenvolvidos quanto para países em desenvolvimento, justamente em razão de reconhecermos a existência de economias pautadas no conhecimento.

O posicionamento nos rankings exerce um impacto marcante na reputação de uma IES: pode gerar apoio doméstico para investimento em ensino superior, ou, pelo contrário, contribuir (ou até criar) profundas crises e ansiedades no âmbito de suas instituições de mais renome. Internacionalmente, pode tornar a universidade uma colaboradora, destino de estudo ou de trabalho mais atraente, permitindo à universidade parceira captar e reter talentos em pesquisa e recursos financeiros. Ademais, pode oferecer comparações valiosas com pares internacionais em uma variedade de aspectos, estimulando a troca de práticas de boa governança ${ }^{299}$.

Essa política de escalonamento entre instituições de ensino no Brasil, apesar de transparecer uma tentativa de consistir em algo totalmente inovador e capaz de realmente apurar a qualidade da educação superior no cenário nacional, em verdade se trata de uma política de Estado rechaçada por setores que não enxergam com bons olhos a adoção de práticas concorrenciais atrelados à área da educação.

\footnotetext{
299 AXEL-BERG, Justin. Indicadores para efeito de comparação internacional no ensino superior brasileiro. In: MARCOVITCH, Jacques (org.). Repensar a universidade: desempenho acadêmico e comparações internacionais. São Paulo: Com-Arte; Fapesp, 2018. p. 32.
} 
Desde a redemocratização, com a Constituição Federal em 1988, e a posterior institucionalização de uma Lei de Diretrizes e Bases da Educação Brasileira implementada em 1996, já passaram pelo governo sete presidentes diferentes, representantes de projetos políticos extremamente diversos em suas concepções. Mesmo assim, os rankings, enquanto estratégias de estímulo da concorrência para a melhoria da qualidade da educação superior, ganharam consenso e legitimidade técnica no âmbito governamental, deixando de se tratar de políticas de governos específicos para se tornarem política de longo prazo do Estado brasileiro - em tese, acima dos interesses dos grupos políticos que se alternaram no poder.

Como mencionado no capítulo anterior, a implementação de sistemas de avaliação da educação superior em larga escala no Brasil começou a ser observada nos anos 1990, com a criação e efetivação do Exame Nacional dos Cursos (ENC), conhecido também como Provão, criado pela Lei $\mathrm{n}^{\circ}$ 9.131, de 24 de novembro de 1995, e o ainda vigente Exame Nacional do Ensino Médio (Enem), instituído pela Portaria MEC nº 438, de 28 de maio de 1998.

O Provão consistia em um exame escrito, de amplitude nacional, destinado aos estudantes dos cursos superiores brasileiros de áreas pré-determinadas anualmente pelo MEC. As IES recebiam os documentos dos estudos efetuados com os relatórios agregados, e os estudantes recebiam informações sobre seu desempenho, incluindo também a sua posição na escala de notas da área de conhecimento ao qual era pertencente ${ }^{300}$.

Esses resultados eram agregados aos relatórios produzidos por especialistas após as visitas in loco a respeito das condições de ensino, dentre as quais eram analisados os currículos dos cursos, a qualificação dos docentes e a infraestrutura da IES. Esses dados passaram a ser geridos pelo Inep a partir de 1997, quando a entidade foi qualificada como autarquia e assumiu atribuições mais amplas do que as anteriores.

\footnotetext{
Os resultados desse conjunto de instrumentos, especialmente do Provão, serviam de base para os atos regulatórios de credenciamento e recredenciamento de instituições e reconhecimento de cursos. Porém, os efeitos punitivos, apesar de algumas ações do MEC relativamente a poucas instituições privadas que reiteradamente acumularam resultados bastante negativos, jamais se concretizaram, em razão de determinações superiores do judiciário ou por força de pressões políticas ${ }^{301}$.
}

\footnotetext{
300 DIAS SOBRINHO, José. Avaliação e transformações da educação superior brasileira (1995-2009): do provão ao Sinaes. Avaliação (Campinas), Sorocaba, v. 15, n. 1, p. 195-224, 2010a. p. 203. Disponível em: http://www.scielo.br/scielo.php?script=sci_arttext\&pid=S1414-40772010000100011\&lng=en\&nrm=iso. Acesso em: 25 jul. 2020.

301 Ibid., p. 204.
} 
O modelo fora implementado sem consulta nem discussão pública, o que fez com que a comunidade acadêmica efetuasse uma série de críticas sobre o mecanismo avaliativo, além de uma série de boicotes diante da obrigatoriedade de realização do exame, determinado pelo impedimento de expedição do diploma dos ausentes.

De todo modo, o exame se efetivou no período de 1996 a 2003, data de sua última aplicação. Em meio a uma série de críticas, a principal consistia em afirmar que a metodologia se prestava apenas a atestar a qualidade dos concluintes, mas não a efetiva apuração da qualidade do curso. Ainda, alegava-se que a política implementada não buscava a correção dos serviços prestados pela IES, já que a apuração da qualidade dos graduandos inviabilizaria correções de rumo e melhoria no percurso formativo dos estudantes. "O Provão confirmou um efeito bastante conhecido na literatura da área: cursos cujos concluintes apresentam os melhores desempenhos em exames são aqueles que receberam ingressantes com altos níveis econômicos, culturais e intelectuais" ${ }^{\prime 302}$.

O Provão teve o mérito de colocar a avaliação na agenda da educação superior e da
própria sociedade brasileira. Mas podem-se identificar importantes equívocos
conceituais, técnicos e políticos e deficiências de vários tipos: restringir o fenômeno
da avaliação a alguns instrumentos de medição; reduzir a aprendizagem a desempenho
e educação a ensino; restringir os fins de formação integral, crítica e reflexiva à
capacitação técnico-profissional; confundir desempenho de estudante com
qualidade de curso; não construir um sistema integrado nem estabelecer os critérios
de qualidade; não respeitar a autonomia didático-pedagógica; desconsiderar
elementos importantes de valor e de mérito das instituições, para além do desempenho
estudantil em uma prova; não oferecer elementos seguros para os atos decisórios das
instâncias administrativas centrais e tampouco oferecer informações confiáveis à
sociedade; abafar a auto-avaliação nas instituições; favorecer a expansão privada e o
enfraquecimento dos sentidos públicos e sociais da educação; ser um instrumento
autoritário, imposto de cima para baixo sem discussão na sociedade e participação da
comunidade acadêmico-científica

Com o início do governo de Luiz Inácio Lula da Silva, em 2003, as críticas ao Provão tornaram-se maiores. Apresentando as condições necessárias para a mudança e a defesa de uma espécie de avaliação emancipatória por parte dos intelectuais da área, foram levados em conta duas aspirações centrais da comunidade da educação superior: participação democrática na formulação da política pública e a construção de um sistema avaliativo.

302 DIAS SOBRINHO, José. Avaliação e transformações da educação superior brasileira (1995-2009): do provão ao Sinaes. Avaliação (Campinas), Sorocaba, v. 15, n. 1, p. 195-224, 2010a. p. 206. Disponível em: http://www.scielo.br/scielo.php?script=sci_arttext\&pid=S1414-40772010000100011\&lng=en\&nrm=iso. Acesso em: 25 jul. 2020.

${ }^{303}$ Ibid., p. 206-207. 
Os debates sobre a proposta sistemática de uma avaliação da educação superior aconteceram ao longo de 2003, com a implementação da Comissão Especial de Avaliação, criada pela Secretaria da Educação Superior. Fruto desses debates, o Sinaes foi criado pela Lei $\mathrm{n}^{\mathrm{o}} 10.861$, de 14 de abril de 2004.

O Sinaes foi idealizado buscando fulminar a vertente dos princípios neoliberais do governo anterior com a hipervalorização da concorrência entre as instituições educacionais e dos rankings públicos e privados.

Dias Sobrinho esclarece que, desde sua raiz e seu cerne, o sistema idealizado e implementado em 2004 buscou valorizar alguns princípios e compromissos amplamente afirmados pela comunidade acadêmica nas audiências públicas promovidas pela Comissão Especial de Avaliação, autora da proposta, dentre eles:

[...] sistema (não fragmentação de instrumentos e procedimentos), globalidade (todas as dimensões institucionais e educativas vistas integradamente), respeito à identidade e à diversidade institucional, centralidade da avaliação institucional interna e externa, participação (responsabilidade compartilhada), interatuação da avaliação institucional interna e externa, articulação entre auto- regulação e regulação, comunicação (entre comunidade acadêmico-científica e órgãos de regulação do Estado) ${ }^{304}$.

Dias Sobrinho também aponta que o Sinaes estava consolidando um paradigma de avaliação que vai muito além de mera conformação às normas burocrático-legais e aos rankings, os quais não se consolidaram diante da retomada de posturas, axiomas e enfoques próprios do paradigma técnico-burocrático.

\begin{abstract}
A primeira iniciativa consistiu no desmonte da equipe que, com a experiência já demonstrada em mais de 15 anos de estudos e práticas no campo da avaliação da educação superior e com permanente apoio da comunidade universitária, vinha implantando o sistema de avaliação. Desmontada essa equipe, o SINAES, ainda em processo de consolidar-se como cultura, pouco a pouco foi perdendo sua riqueza teórica e sua potencialidade ético-política e foi se reduzindo a ÍNDICES (não se trata de sigla para Î́ndices Nacionais do Desempenho de Instituições e Cursos de Educação Superior).

A avaliação da educação superior brasileira, em razão das recentes medidas do INEP, está deixando de ser uma produção de significados, questionamento sobre a pertinência e a relevância científica e social da formação e dos conhecimentos, e passando a reduzir-se à medida e ao controle. Assim sendo, a educação (em sentido pleno) se reduz a ensino, os processos formativos se anulam ante os resultados quantificáveis, a valoração dá lugar a exames que medem desempenhos estudantis, estes servem de informação básica aos índices, que se transformam em classificações e rankings e representam numericamente a "qualidade" dos cursos e das instituições ${ }^{305}$.
\end{abstract}

304 DIAS SOBRINHO, José. Qualidade, avaliação: do Sinaes a índices. Avaliação (Campinas), Sorocaba, v. 13, n. 3, p. 817-825, nov. 2008. p. 820. Disponível em: http://www.scielo.br/pdf/aval/v13n3/11.pdf. Acesso em: 28 maio 2020.

305 Ibid., p. 821. 
Diante das críticas apontadas, verifica-se que a adoção de um paradigma emancipatório da avaliação educacional, como pretendido por ocasião da criação do Sinaes, com o afastamento da perspectiva classificatória e concorrencial, não é capaz de se sustentar. Tal afirmação se pauta pela ideia de que a competição não é exclusivamente por uma classificação legitimadora dos valores neoliberais, mas sim por um valor inerente à condição humana, que se vale da disputa para galgar novos espaços e reconhecimento de seu aprofundamento e trabalho científico.

\begin{abstract}
Nesta perspectiva, os rankings ganharam primazia e legitimidade técnica enquanto instrumentos de avaliação, incorporando as orientações da Nova Gestão Pública na área da educação: a concorrência como elemento indutor da qualidade, a avaliação por resultados como referência para auferir a qualidade, a transparência das informações como elemento chave para o controle e atuação dos consumidores e a responsabilização das Instituições Educacionais pela melhoria da qualidade e pelo desempenho dos alunos ${ }^{306}$.
\end{abstract}

Com essas ponderações, pode-se concluir que os rankings universitários ganharam consenso no aspecto educacional a ponto de se legitimar como política de longo prazo do Estado brasileiro, independentemente do grupo político que está no poder. Essa é a razão pela qual, em vez de insistir na crítica destrutiva dessa política, torna-se primordial compreender os elementos de institucionalização e a adoção concreta de seus valores para que as instituições brasileiras adquiram condições necessárias para começar a figurar nos rankings internacionais e galgar postos de destaque e reconhecimento da promoção de cursos de qualidade em território nacional.

A retomada do ranking institucional como forma de apurar a qualidade dos serviços prestados pelas instituições de educação superior estimulam a concorrência e também a transparência de informações para o cidadão que pretende sujeitar-se à formação educacional. Essas condições demonstram fortalecimento do setor educacional, independentemente da natureza jurídica da instituição de ensino, seja pública, seja privada. Assim, o sujeito que irá escolher estudar em uma determinada instituição de ensino poderá coletar elementos e referências sobres os cursos ofertados, auxiliando-o no momento de sua escolha.

Assim, o Brasil se adequa às tendências do mundo globalizado, como é o caso da

306 CALDERÓN, Adolfo Ignacio; POLTRONIERI, Heloisa; BORGES, Regilson Maciel. Os rankings na educação superior brasileira: políticas de governo ou de estado? Ensaio: Avaliação e Políticas Públicas em Educação, Rio de Janeiro, v. 19, n. 73, p. 813-826, dez. 2011. p. 816. Disponível em: http://www.scielo.br/scielo.php?script=sci_arttext\&pid=S0104-40362011000500005\&lng=en\&nrm=iso. Acesso em: 11 maio 2019. 
União Européia, por meio da implantação da Declaração de Bolonha, cenário no qual, como afirmam Lima, Azevedo e Catani (2008), está em curso a implantação de um mercado competitivo de Educação Superior, por meio da criação de regras de competição e de critérios de avaliação da sua qualidade, visando a prestar informações aos "consumidores" 307.

É por meio da competição que se observa o desenvolvimento de uma inteligência específica como valor capaz de assegurar a manutenção de uma organização em um mercado cada vez mais agressivo, colocando as instituições de ensino superior focadas em resultados, visando uma gestão mais ativa e com metas orientadas para a promoção da educação.

Em primeira instância, associa-se a competitividade com a rentabilidade, mas em outro grau é possível relacioná-la com a habilidade do gestor para melhor escolher as atividades cuja rentabilidade é maior. Em uma análise mais acurada, a competitividade pode ser relacionada a um processo de imitação do qual uma empresa altamente inovadora é copiada por outras, permitindo que estas alcancem a líder. Dessa forma, a imitação pode ser vista como força estabilizadora, enquanto a inovação, como desestabilizadora.

A competição é inerente à natureza humana e, por isso mesmo, conseguimos presenciá-la tanto entre agentes sociais quanto entre agentes econômicos. Ela pode ser identificada nas organizações em diferentes dimensões, não somente nos preços e políticas de marketing, mas também nos investimentos, financiamentos, políticas de contabilidade, políticas de contratação e desempenho interno dos funcionários. Em termos gerais, é a competição que dá a tônica de uma eficiente utilização de recursos.

É evidente que essa lógica competitiva é inerente ao mercado e consiste em um valor econômico aplicável ao setor, inclusive como mecanismo de subsistência de empresas. No entanto, seria ingenuidade não admitir que esse valor já está presente na lógica educacional, como se negá-lo fosse suficiente para extirpar sua aplicabilidade.

Não são poucos os defensores de que a lógica da competição jamais deveria ser aplicável ao setor educacional, sob pena de massacrar a efetivação de seus objetivos de preparação do sujeito para o mercado de trabalho e de formação de valores para o exercício da cidadania.

Seria como se falar de competitividade no âmbito educacional consistisse em algo espúrio, desprovido de valor, quando na verdade buscar a boa e correta aplicação dessa

307 CALDERÓN, Adolfo Ignacio; POLTRONIERI, Heloisa; BORGES, Regilson Maciel. Os rankings na educação superior brasileira: políticas de governo ou de estado? Ensaio: Avaliação e Políticas Públicas em Educação, Rio de Janeiro, v. 19, n. 73, p. 813-826, dez. 2011. p. 824. Disponível em: http://www.scielo.br/scielo.php?script=sci_arttext\&pid=S0104-40362011000500005\&lng=en\&nrm=iso. Acesso em: 11 maio 2019. 
concepção à educação tende-se a melhorar o setor. Para tanto, adentra-se à necessidade de estudar o capital humano e sua constante busca por reconhecimento com base na concepção adotada por Pilar Jiménez Tello ${ }^{308}$.

Por mais demonizada que seja a aplicação da lógica da competitividade ao setor educacional, ela é constatada diariamente. No nível superior, observam-se alunos que se dedicam a obter reconhecimento dos seus professores para se sobressaírem aos demais colegas, firmando competição explícita, quando todos aspiram a ser os mais bem avaliados e aptos a conseguirem a renovação de suas matrículas, já que elas pressupõem o reconhecimento de seus esforços e os colocam em um plano superior aos colegas. A avaliação efetuada pelos docentes é tida como o reconhecimento de seus esforços, e isso é fundamental porque, por vezes, consiste em um incentivo para que os alunos também se dediquem às carreiras acadêmicas.

Entretanto, a competitividade não se encerra no plano discente. Os professores também aspiram ao reconhecimento de seus esforços pelos alunos e por seus pares. Há constante empenho para que sejam avaliados positivamente pelos alunos, pela comunidade acadêmica e eventualmente por setores públicos que se destinam à essa avaliação. Para os docentes, inclusive, é extremamente importante serem reconhecidos por seus próprios colegas. Todos nos recordamos, seja na condição de aluno, seja na de professor, de algum docente que era valorizado por seus pares e pelos alunos. No fundo, ainda que não se assuma, é da natureza humana buscar o reconhecimento.

No campo da pesquisa, a mesma situação se repete. Todos aspiram ao reconhecimento por seu trabalho investigativo e querem também que colegas valorizem o seu empenho e resultado de suas pesquisas.

$\mathrm{Na}$ atualidade existe uma grande competitividade para que projetos de pesquisa sejam tidos como os melhores, inclusive porque tal feito é capaz de gerar contraprestação de ordem econômica e financeira, como incentivo público e privado para financiamento e fomento de pesquisas tidas como relevantes, além, é claro, do reconhecimento da atividade investigativa desempenhada pelo proponente.

Provas de contratação de professores nas instituições de ensino públicas são regra. No entanto, é crescente o número de instituições de ensino privadas que estão adotando procedimentos cada vez mais transparentes para essas contratações. A título de exemplo, nas provas de contratação os sujeitos que costumam ser selecionados para a composição do comitê de seleção costumam ser aqueles cuja produção científica é relevante, partindo do pressuposto

308 TELLO, Pilar Jiménez. Auditoría universitaria y calidad: la evaluación como conquista social ante la competencia universitaria global. Saarbrücken: VDM Verlag Dr. Müller, 2009. p. 281-305. 
que assim ele possuirá condições suficientes para julgar a contratação de seus pares - afinal, julgará a produção alheia justamente pela sua ter sido reconhecidamente relevante.

Estar apto a participar de comitê de seleção de novos professores não só lhe confere prestígio, mas também respeito dos colegas por terem obtido valoração positiva da produção científica realizada e reconhecimento como bom investigador. Evidentemente, essa conduta possuirá suas vantagens e desvantagens, porém negar essa realidade não impede a constatação de que a prática da competitividade já é uma realidade no setor.

No campo da gestão administrativa das instituições de ensino também é inegável que os profissionais igualmente buscam reconhecimento de sua atuação pelos alunos, pelos professores e pelos próprios colegas de trabalho. Os questionários internos que algumas universidades aplicam consistem em algumas das ferramentas aptas a valorar a gestão administrativa para o melhor funcionamento de um estabelecimento.

Esses profissionais não só buscam o reconhecimento de colegas da mesma instituição em que desempenham suas funções, como também de demais sujeitos que ocupam postos similares em outros estabelecimentos de ensino equiparados de sua região, de seu país e, por que não, do mundo. Adotam a mesma lógica do corpo docente.

Como exaustivamente demonstrado, não só no Brasil, essa é uma lógica adotada em escala global: todo sistema é competitivo e pode ser avaliado por alguns itens pré-fixados. É possível efetivar avaliações individuais, mas não somos sujeitos unidimensionais, ou seja, as comparações sempre existirão.

Para aprimorar essa comparação, o ideal é adotar uma técnica que seja capaz de comparar todos os agentes de um contexto, isto é, identificar aqueles que são tidos como os melhores do campo em que se está sendo medido. Só assim a régua comparativa será capaz de subir. Essa é a denominada técnica de benchmarking que o mercado já utiliza há tempos.

O benchmarking nasceu como um processo de comparação de produtos, serviços e práticas das empresas ao longo do tempo, sendo utilizado para confrontar processos e resultados não só da mesma empresa, mas também com empresas do mesmo setor ou, eventualmente, de outros setores. Essa prática atualmente é adotada em todos os âmbitos, e, inclusive, em nossas universidades consiste em uma prática extremamente comum que resulta grandes benefícios.

A título de exemplo, observa-se que quando uma universidade pretende se destacar em um campo ou avançar para a consecução de um objetivo, ela estuda a instituição que foi classificada como a melhor e busca compreender seus procedimentos com a finalidade não só de se igualar, mas sim de superá-la. 
Tanto é verdade que esta pesquisa conseguiu descobrir por meio de entrevistas com coordenadores de cursos e membros selecionados para composição do conselho técnico científico da Capes que, para a classificação e atribuição das notas dos Programas de PósGraduação na área do Direito no Brasil, a comissão de avaliadores adotou postura comparativa para elaborar os relatórios de avaliação e a respectiva publicação de suas notas, ou seja, escolheu-se um curso compreendido como o melhor para preenchimento dos requisitos apurados e todos foram sendo a ele comparados.

Fica evidente, então, que demonizar uma prática que é realidade na apuração da qualidade da educação consiste em esforço inútil, pois esse ato, além de não ser possível revertê-lo, faz parte da condição humana. O ideal seria reconhecer a prática e permitir o seu aprimoramento por parte das instituições de ensino, que passarão a compreender e adotar as bases de uma economia do reconhecimento.

A economia do reconhecimento não está isolada da economia material ou do regime de poder, sendo que ambas são incapazes de consistir em um sistema homogêneo e singular. Existem subsistemas que coincidem dentro da economia de reconhecimento em quase qualquer sociedade contemporânea. Quase todo indivíduo pertencerá a vários desses subsistemas, possuindo interesse na compreensão de como ele será valorizado em cada um deles. Os subsistemas competirão entre si pela energia e pelo tempo dos participantes ou membros dessa economia. $\mathrm{Na}$ economia do reconhecimento, todos estão frequentemente em conflito, pois o desempenho muito positivo de alguém será contra a possibilidade de outro desempenho favorável ${ }^{309}$.

Esse tipo de competição tem caráter positivo e não deve ser encarada de forma negativa. Ele motiva não só a pessoa que é reconhecida, como também todas as outras que buscam adquirir competências para serem valorizadas por seus trabalhos docentes, de pesquisa ou de gestão que outros já obtiveram êxito no reconhecimento.

\footnotetext{
309 " Just as the economy of esteem is not isolated from the material economy or the power regime, it is not a homogeneous and unique system in itself. There will be subsystems that coincide within the recognition economy in almost any contemporary society. And almost every individual will belong to a number of those subsystems, having interest in how it is valued in each. The subsystems will compete with each other for the energy and time of the participants / members. And they will often be in conflict, in the sense that a very positive performance in one will be against the possibilities of other favorable performance." Cf.

BRENNAN, Geoffrey; PETTIT, Philip. The economy of esteem: an essay on civil and political society. Oxford: Oxford University Press, 2004. p. 72.
} 
Pilar Jiménez Tello ${ }^{310}$ encerra suas considerações sobre os benefícios da competitividade e do reconhecimento no âmbito universitário levantando uma consideração que deve ser destacada, na qual o reconhecimento é o plano transversal dos sistemas de garantia de qualidade do sistema universitário, geralmente implicando a concretização de objetivos econômicos. No entanto, é algo mais profundo que permeia todo o corpo universitário, criando um ambiente de competitividade saudável e de confiança em um trabalho bem feito. Logicamente, esse reconhecimento deve ser objetivo e mensurável para não se tornar uma ferramenta pervertida do sistema que queremos melhorar.

Boas posições em rankings bem acreditados ajudam a universidade na retenção de bons talentos e de recursos. Essa conquista pode ser facilitada pela análise contínua das metodologias dos rankings educacionais, de modo que a instituição avaliada receba o reconhecimento externo, exatamente como acontece com as universidades dos países desenvolvidos.

A experiência internacional comprova que as universidades europeias, bem como as do eixo anglo-saxão, conseguem manter equipes dedicadas à promoção da formação do alunado com qualidade, em tempo integral, questão vital para a governança acadêmica. Cerca de $80 \%$ dos integrantes dos núcleos adstritos à qualidade educacional respondem diretamente às reitorias das instituições a que estão vinculados ${ }^{311}$.

O estudo de Rankings in Institutional Strategies and Processes (Risp) (hazelkorn et
al., 2014) relatou que $93 \%$ dos gestores em universidades europeias consultados
monitoram o desempenho nos rankings; $60 \%$ dedicam recursos humanos para tal fim,
geralmente vinculados a unidades de planejamento estratégico ou coleta de dados;
$85 \%$ desses respondentes reportam diretamente para o gabinete do reitor, ou
equivalente; $39 \%$ já tomou alguma de- cisão administrativa, institucional ou
acadêmica em respostas aos aprendizados dos rankings; e apenas $29 \%$ dizem que
essas comparações não têm nenhum efeito no processo de tomada de decisão. Isso
reflete o reconhecimento elevado dado ao posicionamento nos rankings e reforça
também que tais pesquisas são fatores motivadores fortes para melhorias
institucionais. [...] Essas tendências se manifestam no estabelecimento e na
proliferação de unidades de inteligência institucional capazes de responder às
demandas dos rankings, do progresso científico e da própria comunidade de agentes
interessados, todas em mutação permanente. Isso garante que a universidade esteja
sempre bem preparada e orientada para comparação internacional. Elas também são
capacitadas para identificar polos de excelência dentro da IES, o que facilita o

310 "Para concluir diremos que el reconocimiento es el plano transversal de los sistemas de garantía de calidad del sistema universitario, implica generalmente, consecución de objetivos económicos. Pero según nuestro punto de vista, es algo más profundo que empapa todo el cuerpo universitario, creando un ambiente de sana competitividad y de confianza en el trabajo bien hecho. Lógicamente, este reconocimiento ha de ser objetivable y medible para no convertirse en una herramienta pervertidora del sistema que queremos mejorar." Cf. TELLO, Pilar Jiménez. Auditoría universitaria y calidad: la evaluación como conquista social ante la competencia universitaria global. Saarbrücken: VDM Verlag Dr. Müller, 2009. p. 305.

311 MARCOVITCH, Jacques (org.). Repensar a universidade: desempenho acadêmico e comparações internacionais. São Paulo: Com-Arte; Fapesp, 2018. p. 15. 
planejamento estratégico ${ }^{312}$.

Saliente-se que esses valores são notados em nossa atual sociedade, a qual depende de outra importante diretriz para a manutenção dessa lógica. É justamente a motivação o início do caminho correto para atingir uma boa qualidade universitária, razão pela qual é preciso encontrar mecanismos que a promovam. Existem diversas estratégias para motivar os profissionais e, sem dúvida, o reconhecimento do trabalho consiste em uma delas. Uma via óbvia para gerar motivação desde o início é a competição, sendo ela um poderoso incentivo para ganhar, seja um prêmio em dinheiro, seja um reconhecimento, seja a simples satisfação de se sobrepor aos demais concorrentes ${ }^{313}$.

A competição sempre deve respeitar a ética, tal como um conjunto mínimo de regras e preceitos que não podem ser invadidos sob pena de deslealdade no processo e resultados que não refletem a realidade.

Justamente por isso, como forma de objetivar compreender os meandros que envolvem a competição entre instituições de ensino superior brasileiras, passa-se à análise e compreensão do atual sistema de comparação universitária vigente no Brasil. O intuito é descobrir se esse seria um sistema viável de efetiva apuração de qualidade do setor, buscando, com a compreensão, melhorar o sistema, se isso for possível, ou até mesmo se valer dele para idealizar um procedimento totalmente inovador.

\subsection{Qualidade da educação superior aferida por rankings nacionais e internacionais}

Até o momento, foram apresentados os elementos derivados das políticas públicas institucionalizadas em âmbito nacional para compor o cenário implementado pelo Estado brasileiro e apurar a qualidade dos serviços prestados nos cursos superiores.

Admitindo que os mecanismos de apuração de qualidade da educação superior desenvolvidos no Brasil e estudados até aqui verificam a qualidade sob uma perspectiva não competitiva, que devem ser complementados com o objetivo de criar uma lógica de competição institucional para a constante melhoria dos serviços prestados, passa-se à análise de um importante mecanismo já desempenhado no mundo, cuja respeitabilidade vem ganhando destaque, além de efetivamente ser encarado como alternativa viável para avaliar o setor com

\footnotetext{
312 AXEL-BERG, Justin. Indicadores para efeito de comparação internacional no ensino superior brasileiro. In: MARCOVITCH, Jacques (org.). Repensar a universidade: desempenho acadêmico e comparações internacionais. São Paulo: Com-Arte; Fapesp, 2018. p. 32.

313 BOK, Derek. The cost of talent: how executives and professionals are paid and how it affects America. New Tork: The Free Press, 1993. p. 389.
} 
fidelidade à apuração da qualidade.

Os rankings globais, em sua maioria, são gerenciados por instituições privadas com finalidade lucrativa. A legitimidade para efetuar a avaliação das universidades deriva do interesse público do serviço prestado pelas IES, não obstante a existência de posicionamento contrário no sentido de que as instituições privadas não teriam legitimidade para executar essa avaliação. De todo modo, as universidades deveriam avaliar os rankings e utilizá-los de modo a fortalecer sua reputação.

Reconhece-se que alguns rankings, notadamente aqueles de reconhecimento internacional, conseguem alavancar a reputação de uma instituição de ensino para além da região em que presta seus serviços, atravessando fronteiras e, eventualmente, países e continentes. É justamente por isso que não se pode negar a importância e a necessidade que há em compreender tais medidas de apuração de qualidade.

Rankings bem referenciados também são capazes de atrair para as instituições de ensino novos talentos e mais recursos financeiros. Essas conquistas são facilitadas a partir do momento em que as próprias universidades buscam uma análise contínua das metodologias dos rankings, com o intuito de compreender os meandros específicos dessas classificações em âmbito nacional e internacional. Desse modo, a instituição avaliada ganha reconhecimento externo, como acontece com as congêneres dos países desenvolvidos.

Inclusive, foi possível apurar que a maioria das universidades europeias em atividade possui equipes próprias e específicas para se dedicar em tempo integral ao acompanhamento dos resultados derivados dessas análises de escalonamento, o que acaba por se tornar uma questão vital para a governança acadêmica.

Essas equipes também costumam ser responsáveis pelo acompanhamento interno do desempenho de sua equipe com a constante apuração da produção científica dos docentes, justamente para que seja possível definir de maneira estratégica a adequada alocação de recursos e estímulo de áreas aptas a conseguir maiores impactos na competição institucional. Essas composições, como pretende-se comprovar nesta pesquisa, serão decisivas para o desempenho da instituição ranqueada e também para a revalorização do ranking no âmbito educacional. Assim, é imprescindível a adequada avaliação interna para o consequente reconhecimento externo.

A fim de que possamos averiguar se o serviço prestado pelas universidades brasileiras é realmente de boa qualidade, há que se considerar os novos modelos de apuração desse fator, levando-se em consideração os dados, resultados e elementos apurados no capítulo anterior, mas sem deixar exclusivamente como responsabilidade do Estado o dever de mensurar a 
qualidade da educação superior.

A elaboração de uma estratégia de planejamento constitui a ferramenta decisiva para a reinvenção da universidade. A concepção de um conjunto institucional que aspire à excelência há de ser precedida de um processo de planejamento que abarque duas esferas de intervenção interrelacionadas. São elas: a estruturação de uma filosofia global de intervenção nas instituições de ensino nacionais, vinculadas ao território brasileiro, e a atuação do poder público para cumprimento de uma agenda que implemente as métricas idealizadas nos estudos que definem os indicadores de excelência internacional.

Para tanto, os indicadores internacionais que determinam a excelência na educação superior devem ser compreendidos e aplicados nas IES existentes no Brasil, sob pena de indeferimento da continuidade dos serviços educacionais prestados em território nacional. No sentido de estabelecer um posicionamento para buscar a presença da educação nacional em um cenário globalizado, Felipe Chiarello e Michelle Asato ${ }^{314}$ afirmam que:

\footnotetext{
Do ponto de vista científico, a análise da educação para o desenvolvimento se justifica por ser ainda campo fértil a análise sob o foco jurídico. Outrossim, no momento em que o Brasil se apresenta como economia emergente é relevante a construção de um modelo educacional capaz de se adequar às novas demandas criadas pelo mundo globalizado.
}

A atual mobilidade dos estudantes, da capital das empresas e mesmo do intercâmbio de culturas e conhecimento faz com que as universidades estejam imersas em um inevitável sistema competitivo europeu e global, ainda que tentem resistir a alguns sistemas de consanguinidade e isolacionismo com princípios medievais e canônicos. O grupo reacionário das universidades compreende um coletivo, que reluta em deixar o porto para não perder seus privilégios, tendo que competir com outras universidades. Essa mobilidade torna necessária uma ferramenta para fornecer informações a famílias e estudantes sobre a situação das diferentes universidades na esfera global, e uma das maneiras importantes pelas quais tais

\footnotetext{
314 PINTO, Felipe Chiarello de Souza; JUNQUEIRA, Michelle Asato. educação para o desenvolvimento: objetivo do estado democrático e social de direito. Direito e Justiça (URI), ano 16, n. 23, p. 77-90, nov. 2014. p. 79 .
} 
elementos são expressos é através dos rankings ${ }^{315}$.

Os rankings são o resultado de um processo de avaliação apoiado em indicadores previamente definidos, possíveis de serem realizados por qualquer instituto de pesquisa, não importa de qual país, isto é, tal classificação pode ser desempenhada por organismo público ou privado, desde que a metodologia de avaliação e comparação entre universidades seja previamente divulgada com a análise de dados públicos disponibilizados pelos órgãos oficiais e pelas próprias instituições de ensino.

Devemos reconhecer que a metodologia utilizada para realizá-los e os indicadores são objeto de várias discussões no meio acadêmico; mas também é verdade que esses rankings têm um grande atrativo no momento da escolha da universidade pelas famílias e estudantes para realizar seus estudos, receber financiamento e definir as políticas educacionais de seu ambiente cultural pelos responsáveis. do ensino superior. Portanto, é necessário que nossas universidades estabeleçam as ferramentas necessárias para que possam ser encontradas nos primeiros lugares do ranking reconhecidos mundialmente ${ }^{316}$.

Diante disso, pode-se constatar que os rankings consistem em parâmetros comparativos, especialmente quando a análise envolve critérios de excelência internacional. Como exemplo de tais critérios, é possível mencionar a capacidade da universidade de: produzir conhecimento científico e tecnológico em prol da sociedade; empreender, independentemente do fomento estatal; inovar; proporcionar mobilidade nacional e internacional dos seus alunos e dos seus serviços; entre outras.

Os rankings universitários são capazes, dentre outras atribuições, de comparar instituições considerando critérios e indicadores das mais diversas naturezas, o que permite a consideração de que os resultados são capazes de gerar um retrato das instituições de ensino,

315 "La movilidad actual de los estudiantes, del capital de las empresas y del mismo conocimiento, hace que las universidades estén inmersas en un sistema competitivo europeo y global que no pueden eludir, a pesar de que algunos sistemas endogámicos y aislacionistas con principios medievales y canónicos, intentan resistirse. Los involucionistas forman parte de un colectivo, que se resisten a salir del puerto para no perder sus privilegios, al tener que competir con otras universidades. Esta movilidad, hace imprescindible una herramienta para dar información a las familias y a los estudiantes sobre la situación de las diferentes universidades en el ámbito global, y una de las maneras importantes en que se manifiesta esa información es a través de los ranking." Cf. TELLO, Pilar Jiménez; PLAZA, Victoria Eugenia. Educación superior y competitividad. Cadernos de Pós-Graduação em Direito, Comissão de Pós-Graduação da Faculdade de Direito da USP, São Paulo, n. 31, p. 4-26, 2014. p. 10.

316 "Debemos reconocer que la metodología utilizada para la realización de los mismos así como los indicadores son motivo de diversas discusiones en los ámbitos académicos; pero no es menos cierto que estos rankings tienen un gran atractivo a la hora de la elección de universidad por parte de las familias y estudiantes para realizar sus estudios, para recibir financiación y para definir las políticas educativas de su ámbito cultural por parte de los responsables de la educación Superior. Por tanto, es necesario que nuestras universidades establezcan las necesarias herramientas para que puedan encontrarse en esos primeros lugares de los rankings reconocidos mundialmente." Cf. TELLO, Pilar Jiménez; PLAZA, Victoria Eugenia. Educación superior y competitividad. Cadernos de Pós-Graduação em Direito, Comissão de Pós-Graduação da Faculdade de Direito da USP, São Paulo, n. 31, p. 4-26, 2014. p. 15. 
mas não da sua verdadeira realidade em sua integralidade.

\begin{abstract}
Durante os últimos quinze anos, rankings globais de universidade se tornaram um fato social inerente ao ensino superior. Como a maioria dos fatos sociais, não são completamente positivos, nem negativos. Apesar de uma variedade de inquietações metodológicas, conceituais e epistemológicas, percebe-se uma forma mais pública com que o mundo analisa a qualidade das suas instituições de ensino superior. Argumentos acadêmicos que buscam descartar o seu valor têm pouco efeito no apetite público para tais comparações, e universidades são avaliadas, mesmo que elas prefiram não aparecer nos rankings. A abordagem mais comum para muitas instituições e gestores de fora do eixo anglo-americano, cujas universidades são favorecidas na composição dos rankings, é rejeitar a importância da comparação internacional. A maior crítica aos rankings como relevância contextual na América Latina é a falta de sensibilidade às atividades-fim das universidades, missões locais e liderança regional, afirmando que eles incentivam uma uniformidade de prioridades de pesquisa e modelos de governança com a escolha de uma gama de métricas altamente restritivas ${ }^{317}$.
\end{abstract}

Uma vez que cada ranking se vale de critérios próprios e específicos, é preciso compreender a importância e o peso desses critérios. Logo, para entender o processo de avaliação de cursos jurídicos, a partir dos indicadores colhidos e apurados por instituições responsáveis pela execução de ranqueamentos nacionais e internacionais, foram escolhidos cinco rankings para análise, sendo quatro internacionais e um brasileiro. O objetivo é, ainda, compreender se os indicadores adotados como critérios de fato estariam aptos a apurar a qualidade dos cursos autorizados no Brasil.

Foram eleitos os seguintes rankings para análise: Ranking Universitário Folha $(\text { RUF })^{318}$, do Brasil, U.S. News ${ }^{319}$, dos Estados Unidos, Times Higher Education (THE-TR) ${ }^{320}$, do Reino Unido, Quacquareli Symonds Ranking (QS) ${ }^{321}$, do Reino Unido, Shanghai Ranking

${ }^{317}$ AXEL-BERG, Justin. Indicadores para efeito de comparação internacional no ensino superior brasileiro. In: MARCOVITCH, Jacques (org.). Repensar a universidade: desempenho acadêmico e comparações internacionais. São Paulo: Com-Arte; Fapesp, 2018. p. 31.

318 O Ranking Universitário Folha (RUF) é uma avaliação anual do ensino superior do Brasil feita pela Folha desde 2012. Cf. RUF 2019: Ranking Universitário Folha. São Paulo: Folha de São Paulo, [2019]. Disponível em: https://ruf.folha.uol.com.br/2019/. Acesso em: 8 nov. 2020.

319 US News é um periódico americano de importância nacional, que mantém em atividade o ranqueamento de diversos setores do país, dentre eles o setor educacional. Cf. U.S. NEWS \& WORLD REPORT. New York: US News \& World Report LP, 1948- . Disponível em: https://www.usnews.com/education/best-globaluniversities. Acesso em: 8 nov. 2020.

320 THE-TR, fundado em 2004, fornece lista das melhores universidades do mundo, avaliadas por meio de ensino, pesquisa, perspectivas internacionais e reputação. Cf. THE WORLD UNIVERSITY RANKINGS. London: Times Higher Education, 2004 -. Disponível em: https://www.timeshighereducation.com/worlduniversity-rankings/2020/world-ranking\#!/page/0/length/25/sort_by/rank/sort_order/asc/cols/stats. Acesso em: 8 nov. 2020.

${ }^{321}$ A Quacquareli Symonds (QS), ranking universitário mundial, foi fundada em 1999 e se estabeleceu como principal fornecedor global de informações sobre educação superior. Cf. TOP UNIVERSITIES. London: QS Quacquarelli Symonds Limited, 1999- . Disponível em: https://www.topuniversities.com. Acesso em: 8 nov. 2020. 
Consultancy $^{322}$, da China, e Center for World University Rankings (CWUR) ${ }^{323}$, dos Emirados Árabes Unidos. A escolha dos referidos rankings se deu com base em critério de reconhecimento sobre a atividade desempenhada por eles, amparada pela confiabilidade existente em nível nacional e internacional.

Em uma análise comparativa, é possível verificar que os indicadores mais recorrentes no mundo dos rankings, os quais aparecem com diferentes pesos de ponderação, são a reputação acadêmica, pesquisadores mais citados em bases de dados indexados e reconhecidos como relevantes na área de conhecimento analisada, razão professor aluno, alunos internacionais, professores internacionais e aporte de recursos financeiros.

Visando apresentar os critérios utilizados nas avaliações das universidades, apresentase a seguir o quadro elaborado nesta pesquisa. Destaque-se que não foram considerados os resultados das apurações levantadas nos rankings, mas sim os indicadores e a frequência com que apareceram como forma de metodologia da avaliação (Quadro 8).

Quadro 8-Rankings acadêmicos e respectivos indicadores condicionantes no processo de avaliação de instituições de ensino superior

\begin{tabular}{|c|c|c|c|c|c|}
\hline Rankings & & & ritérios/indicadore & & \\
\hline RUF & Pesquisa & Ensino & Mercado & Inovação & Internacionalização \\
\hline U.S. News & Reputação Acadêmica & $\begin{array}{l}\text { Capacidade de reter } \\
\text { o alunado; } \\
\text { Seleção dos alunos; } \\
\text { Taxa de conclusão } \\
\text { da graduação }\end{array}$ & $\begin{array}{l}\text { Recursos dos } \\
\text { docentes }\end{array}$ & Recursos Financeiros & $\begin{array}{l}\text { Doações dos } \\
\text { alunos egressos }\end{array}$ \\
\hline $\begin{array}{l}\text { Quacquarelli } \\
\text { Symonds }\end{array}$ & $\begin{array}{l}\text { Reputação acadêmica e } \\
\text { entre empregadores }\end{array}$ & $\begin{array}{l}\text { Razão professor } \mathrm{x} \\
\text { aluno }\end{array}$ & Publicações & Número de doutores & Impacto na internet \\
\hline THE-TR & $\begin{array}{l}\text { Opinião de } \\
\text { especialistas }\end{array}$ & $\begin{array}{l}\text { Investigadores mais } \\
\text { citados: número de } \\
\text { citações dos } \\
\text { docentes da IES } \\
\end{array}$ & $\begin{array}{l}\text { Razão professor X } \\
\text { aluno }\end{array}$ & Alunos internacionais & $\begin{array}{l}\text { Professores } \\
\text { internacionais }\end{array}$ \\
\hline $\begin{array}{l}\text { Shanghai } \\
\text { Ranking - } \\
\text { Academic } \\
\text { Ranking of } \\
\text { World } \\
\text { Universities }\end{array}$ & $\begin{array}{l}\text { Alunos da instituição } \\
\text { que obtiveram o } \\
\text { Prêmio Nobel e as } \\
\text { medalhas acadêmicas }\end{array}$ & $\begin{array}{l}\text { Docentes da } \\
\text { instituição que } \\
\text { obtiveram o Prêmio } \\
\text { Nobel e as medalhas } \\
\text { acadêmicas }\end{array}$ & $\begin{array}{l}\text { Número dos } \\
\text { pesquisadores mais } \\
\text { citados em suas } \\
\text { áreas de pesquisa; } \\
\text { Número de artigos } \\
\text { publicados em } \\
\text { periódicos Science } \\
\text { and Nature }\end{array}$ & $\begin{array}{l}\text { Qualidade dos } \\
\text { artigos; } \\
\text { Número do artigo no } \\
\text { ISI }\end{array}$ & $\begin{array}{l}\text { Tamanho da } \\
\text { instituição }\end{array}$ \\
\hline
\end{tabular}

322 A Shanghai Ranking Consultancy é uma organização totalmente independente que se dedica à pesquisa em inteligência e consultoria em ensino superior. É a editora oficial do Academic Ranking of World Universities desde 2003. Cf. ACADEMIC RANKING OF WORLD UNIVERSITIES. Shanghai: ShanghaiRanking Consultancy, 2003- . Disponível em: http://www.shanghairanking.com/arwu2019.html. Acesso em: 8 nov. 2020.

323 Center for World University Rankings (Centro de Classificações Universitárias Mundiais (CWUR): publica ranking universitário global que mede a qualidade da educação e da formação dos estudantes, bem como o prestígio dos membros do corpo docente e a qualidade da sua investigação. Cf. CENTER FOR WORLD UNIVERSITY RANKINGS. United Arab Emirates: CWUR, 2012- . Disponível em: https://cwur.org/about.php. Acesso em: 8 nov. 2020. 


\begin{tabular}{|c|c|c|c|c|}
\hline $\begin{array}{l}\text { Center } \\
\text { for World } \\
\text { University } \\
\text { Rankings }\end{array}$ & \begin{tabular}{|l} 
Qualidade da \\
educação, medida pelo \\
número de ex-alunos \\
de uma universidade \\
que conquistaram \\
importantes distinções \\
acadêmicas em relação \\
ao tamanho da \\
universidade
\end{tabular} & $\begin{array}{l}\text { Empregabilidade } \\
\text { dos egressos }\end{array}$ & $\begin{array}{l}\text { Qualidade dos } \\
\text { professores, medida } \\
\text { pelo número de } \\
\text { membros do corpo } \\
\text { docente que } \\
\text { conquistaram } \\
\text { importantes } \\
\text { distinções } \\
\text { acadêmicas }\end{array}$ & \begin{tabular}{|l|} 
Desempenho da \\
pesquisa: \\
i) Resultado da \\
pesquisa, medido \\
pelo número total de \\
artigos de pesquisa \\
ii) Publicações de alta \\
qualidade, medidas \\
pelo número de \\
artigos de pesquisa \\
que aparecem em \\
periódicos de \\
primeira linha \\
iii) Influência, \\
medida pelo número \\
de artigos de pesquisa \\
que aparecem em \\
periódicos altamente \\
influentes \\
iv) Citações, medidas \\
pelo número de \\
artigos de pesquisa \\
altamente citados
\end{tabular} \\
\hline
\end{tabular}

Fonte: Elaboração própria.

Os rankings de universidades são compostos por dois componentes hierárquicos: os elementos ordinais e os cardinais. O componente ordinal é o posicionamento da universidade no ranking, da primeira colocada seguida pelas demais instituições. Inevitavelmente, esse é o aspecto que ganha mais destaque na mídia e atrai mais atenção. O componente cardinal é o conjunto de escores de indicadores que compôs o escore da universidade. O desempenho nos escores cardinais descreve as caraterísticas que determinam o seu posicionamento ordinal ${ }^{324}$.

A apresentação de dados internos de uma universidade, isoladamente, é capaz de mostrar relativamente pouco sobre o seu desempenho. O número total de artigos publicados, ou o número de citações recebidas é de difícil entendimento sem alguma contextualização e normatização. Tais dados, sem referência às médias globais ou medidas de universidades e departamentos comparáveis, tornam extremamente difícil a formação de avaliações qualitativas. Diferentes áreas de conhecimento publicam quantidades distintas de pesquisa, em formatos diversos, e essa pesquisa recebe citações em velocidades variadas (o immediacy index) e para períodos de tempo diferentes (o half-life). Os outputs variam como um resultado de culturas acadêmicas diferentes e necessidades locais. Nesse sentido, a comparação interna é insuficiente ${ }^{325}$.

Cabe um destaque para os indicadores utilizados pelo Ranking Universitário Folha, justamente por ser o maior ranking nacional do setor, merecendo especial atenção sobre as

\footnotetext{
324 AXEL-BERG, Justin. Indicadores para efeito de comparação internacional no ensino superior brasileiro. In: MARCOVITCH, Jacques (org.). Repensar a universidade: desempenho acadêmico e comparações internacionais. São Paulo: Com-Arte; Fapesp, 2018. p. 35. 325 Ibid.
} 
atividades que desempenham. Verifica-se que cada um dos indicadores possui um peso diferente na composição da avaliação exarada. Conforme as explicações sobre a metodologia lançadas pela própria Folha de S. Paulo ${ }^{326}$, constatou-se que os indicadores apontados no Quadro 8 compõem a avaliação na seguinte proporção (Figura 10):

Figura 10 - Composição da avaliação e componentes do RUF

\section{Composiçăo da avaliaçăo e componentes do RUF}

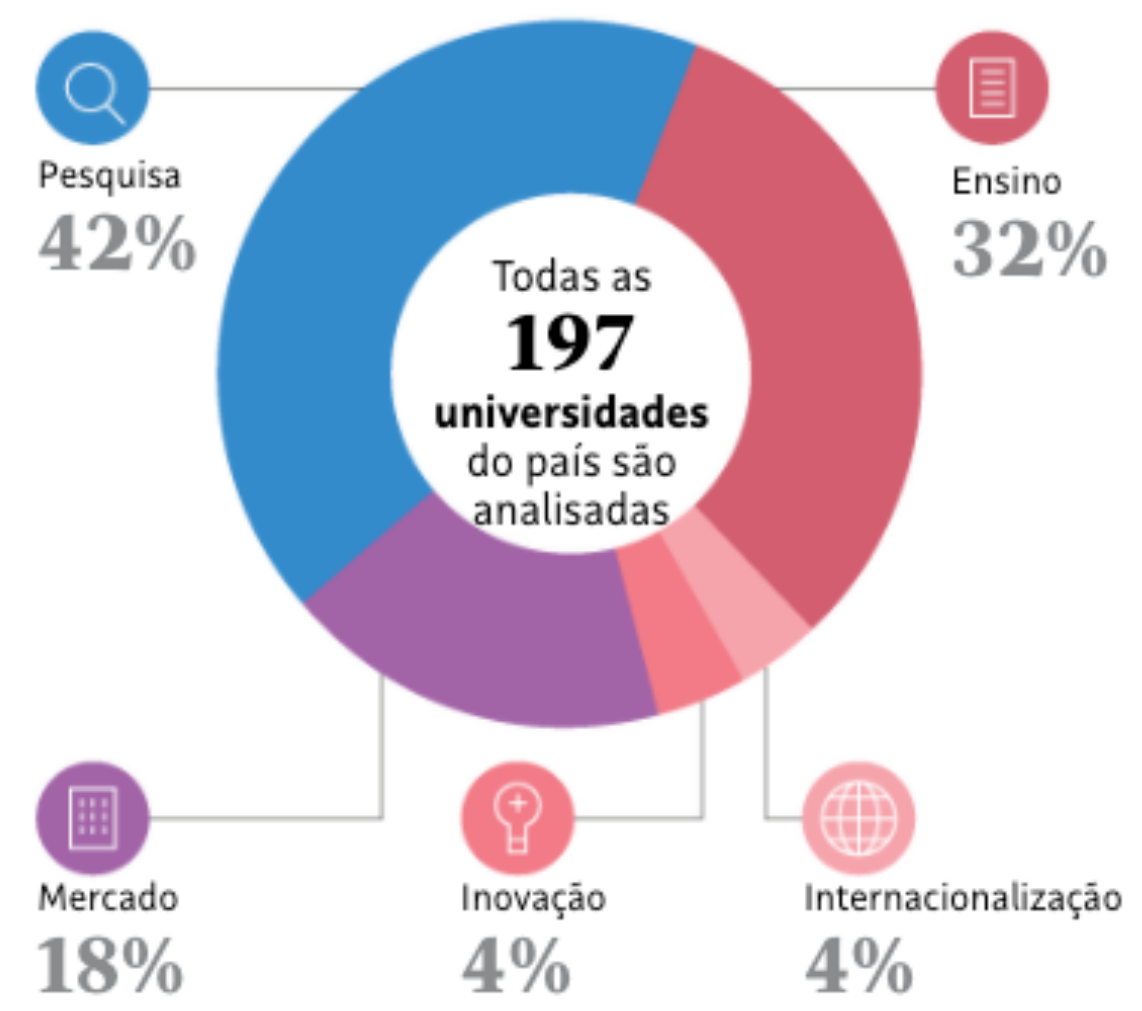

Fonte: Como..., [2019].

Cada componente averigua os mencionados aspectos das universidades. Para composição do indicador da pesquisa, responsável por $42 \%$ do total da nota, o ranking procura averiguar: total de publicações (7\%), consistente nos artigos científicos publicados pela universidade; total de citações (7\%), consistente na relevância dos trabalhos científicos a partir do total de citações recebidas; citações por publicação (4\%), consistente na média de citações para cada artigo científico da universidade; publicações por docente (7\%), consistente na média de artigos científicos por professor; citações por docente (7\%), consistente na média de citações

\footnotetext{
${ }^{326}$ COMO é feito o Ranking Universitário Folha. São Paulo: Folha de São Paulo, [2019]. Disponível em: https://ruf.folha.uol.com.br/2019/noticias/como-e-feito-o-ranking-universitario-folha.shtml. Acesso em: 10 nov. 2020.
} 
por professor; publicações em revistas nacionais (3\%), consistente nos artigos científicos em revistas brasileiras; recursos recebidos por instituição (3\%), buscando o valor médio de recursos obtidos por docente; bolsistas do Conselho Nacional de Desenvolvimento Científico e Tecnológico ( $\mathrm{CNPq}$ ) (2\%), avaliando o percentual de professores da universidade considerados produtivos pela referida agência governamental; teses (2\%), com o número de teses defendidas por docente. Todos os dados, segundo apontado, são coletados das bases Web of Science (de 2012 a 2016 para publicações e 2017 para citações), Capes, CNPq, agências federais de fomento (2017) e Scientific Electronic Library Online (SciELO) (de 2012 a 2016).

Para o indicador do ensino, responsável pela composição de $32 \%$ da nota da universidade, o RUF apura quatro componentes, quais sejam: opinião de docentes do ensino superior $(20 \%)$, por meio de pesquisa feita pelo Datafolha com professores distribuídos pelo país; professores com doutorado e mestrado (4\%), coletando a informação do percentual de professores com doutorado ou mestrado vinculados à IES apurada; professores em dedicação integral e parcial (4\%), mediante informação prestada pela IES relativa ao percentual de docentes em regime de dedicação integral ou parcial; nota no Enade (4\%), levando em conta a nota média da universidade nesse exame. Para apuração desse indicador, a equipe do RUF se vale das bases de dados consistentes na pesquisa Datafolha (2017, 2018 e 2019), Enade (2015, 2016 e 2017) e Censos da Educação Superior (2017, 2016 e 2015).

No indicador relativo ao mercado de trabalho, responsável pela composição de $18 \%$ do total da nota da instituição, o RUF considera a opinião de empregadores sobre preferências de contratação, baseado em pesquisa Datafolha (2017, 2018 e 2019) efetuada pelo mesmo grupo.

A nota da IES também é medida pela inovação (4\%), da qual se apuram as patentes ( $2 \%)$, ou seja, o número de patentes pedidas pela universidade, bem como as parcerias com empresas $(2 \%)$, conferindo a quantidade de estudos da universidade em colaboração com o setor produtivo. As bases de dados para levantamento dessas informações, segundo apontam, são a Web of Science (2012 a 2016) e o Instituto Nacional da Propriedade Industrial (Inpi) (2008-2017).

O último, mas não menos importante, indicador é a verificação da internacionalização (4\%) da instituição. Tal parâmetro é verificado pela quantidade de citações internacionais por docente $(2 \%)$, buscando a média de citações internacionais pelos trabalhos deles, e pelas publicações em coautoria internacional ( $2 \%$ ), apurando o percentual de publicações em parceria com pesquisadores estrangeiros. As bases de dados utilizada para medir esses valores são a $W e b$ of Science (de 2012 a 2016 para publicações e 2017 para citações). 
É importante destacar que no RUF o ranking dos cursos nessa mesma apuração é feito com base em apenas dois dos indicadores mencionados, quais sejam: ensino e mercado. No entanto, apenas para os cursos de Direito existe uma metodologia específica que leva em conta o número de aprovados no exame da Ordem dos Advogados do Brasil. Assim, os critérios para mensurar a qualidade desses cursos no Brasil pelo RUF são feitos conforme a descrição a seguir.

Para o indicador do ensino, responsável pela composição de $44 \%$ da nota do curso, o RUF apura quatro componentes, quais sejam: opinião de docentes do ensino superior (20\%), por meio de pesquisa feita pelo Datafolha com professores distribuídos pelo país; professores com doutorado e mestrado ( $8 \%$ ), coletando a informação do percentual de professores com essas titulações vinculados à IES apurada; professores em dedicação integral e parcial (8\%), mediante informação prestada pela IES relativa ao percentual de docentes nesses regimes de trabalho; nota no Enade (8\%), levando em conta a nota média da universidade no referido exame. Para apuração desse indicador, a equipe do RUF se vale das bases de dados consistentes na pesquisa Datafolha (2017, 2018 e 2019), Enade (2015, 2016 e 2017) e Censo da Educação Superior (2017).

O indicador da Ordem dos Advogados do Brasil corresponde a 38\% da composição da nota do curso. Nesse item, busca-se a apuração do percentual de aprovados nos exames da OAB em 2015, 2016 e 2017, considerando o total de presentes na prova. Finalmente, tem-se o indicador do mercado, responsável por $18 \%$ do total da nota, com um componente consistente na opinião de empregadores sobre preferências de contratação, baseada na pesquisa Datafolha (2017, 2018 e 2019).

Com a apresentação dos dados coletados para apuração da qualidade, verifica-se que a base estrutural que define a medida da qualidade educacional não é a mesma no procedimento público (Lei do Sinaes) e no procedimento privado em âmbito nacional. Além disso, é importante registrar que as métricas dos diversos rankings são diferentes, assim como a maneira de coletar essas informações.

Os dados apresentados no quadro comparativo dos indicadores utilizados pelos diferentes rankings possibilitam verificar que alguns dos critérios para medir a qualidade se repetem, embora o peso para composição da nota não seja o mesmo para todos. Serão esses os critérios medidos pelos responsáveis dos rankings, que buscam classificar as universidades de acordo com a reputação atingida após a investigação das universidades.

O sucesso desses procedimentos de apuração de qualidade dos rankings, tanto no Brasil como no exterior, deve-se à popularização dessas conferências e desse critério de 
competitividade, que é inato à uma espécie de escalonamento das instituições. Alguns consideram que um dos fatores para a significativa influência dos rankings seriam suas metodologias, as quais buscam constantemente uma base científica isonômica, solida, estável e transparente para avaliar as instituições de ensino.

No entanto, é preciso ponderar que as informações coletadas para apuração costumam ser prestadas pelas próprias instituições de ensino, sem que necessariamente seja efetuado um controle de veracidade dos dados fornecidos. Isso pode ser temerário para considerar que haja fidedignidade da informação prestada com aquilo que de fato acontece nas universidades.

A atuação dessas entidades que pretendem medir a qualidade dos serviços prestados por IES em todo o mundo têm se mostrado cada vez mais presente, influentes e importantes para a sociedade, e justamente por isso devem ser executadas de forma responsável e realista.

As universidades estão aderindo à corrida da reputação como uma forma de integração ao contexto mundial, principalmente diante dos benefícios derivados de uma posição de destaque em sistemas de ranqueamentos. O motivo é que, invariavelmente, como já demonstrado, os rankings costumam adotar critérios muito mais globais do que locais. É evidente que uma exagerada competitividade entre instituições e países pode gerar um desvirtuamento da proposta, o que deve ser evitado por todos os atores envolvidos.

De todo modo, é inegável notar que os resultados dos rankings universitários impactam em certas dimensões, tais como: notoriedade para a instituição, prestígio institucional, expansão e captação de recursos para financiamento de pesquisas; uma boa posição no ranking produz uma imagem favorável no mercado e aumenta a atratividades e os benefícios econômicos; os rankings como indutores da qualidade, por meio do estímulo da concorrência, criam as condições para o fortalecimento do mercado educacional, pois o consumidor poderá ter elementos referenciais sobre os diversos cursos ofertados pelas universidades, fato que influenciará no momento da escolha ${ }^{327}$. Nesse sentido, é correto sustentar que o prestígio das instituições de ensino superior é influenciado, cada vez mais, em razão da publicação desses rankings nacionais e internacionais.

Os rankings podem consistir na comprovação de boa reputação das instituições avaliadas, principalmente daquelas que alcançarem os altos estratos de posicionamento. No entanto, podem traduzir-se como medida de desqualificação de instituições de ensino no cenário da alta competitividade.

Geralmente, os rankings refletem anseios mercadológicos, justamente porque existe

327 RIBEIRO, Raimunda Maria da Cunha. Avaliação e ranqueamento de universidades sob a lógica de critérios globais. Roteiro, Joaçaba, v. 43, n. 1, p. 259-276, jan./abr. 2018. p. 263. 
um mercado consumidor que pretende ser atendido com a realização desse escalonamento institucional. Eles costumam utilizar pesos, medidas e indicadores numéricos que guardam relação direta com o que se espera na formação superior, além de conseguir, com isso, monitorar o desempenho das universidades.

A partir de quais indicadores são avaliadas e sob quais critérios são classificadas as
universidades? Sabendo que não há uma resposta totalizadora, vimos diante de nossos
olhos critérios dos mais diversos. Parece a universidade não se incomodar com as
exigências dos rankings, levando-nos a considerar que o que mais importa são os
resultados e a sua reputação diante dos olhos da sociedade, do Estado e do mercado

Outro problema dessas classificações consiste na enorme variação de posicionamento de uma universidade nos diferentes rankings, o que tem gerado ansiedade sobre a validade desse formato de avaliação. De um ano para o outro, as universidades passam por subidas ou quedas drásticas em suas colocações, muitas vezes por um fator de cinquenta ou sessenta posições, e frequentemente em direções contraditórias por rankings diferentes.

A conclusão natural dessa variação é de que não há objetividade nos ranqueamentos: nenhum tem uma autoridade absoluta sobre a qualidade de uma universidade. Não se pode dizer que um resultado pode representar uma instituição em sua totalidade.

Uma explicação para essa variabilidade é que cada ranking tem o seu próprio conjunto de indicadores, que formam a visão dos criadores de uma universidade. Em parte, isso é verdade, mas a maioria dos rankings utiliza uma variedade relativamente restrita de indicadores: de número de artigos indexados, de citações recebidas, entre outros como apontados no quadro retro. Uma variação maior pode ser encontrada na forma com que os rankings são normatizados e escalados.

Um outro problema que tanto as agências que elaboram os rankings quanto as universidades enfrentam é a hipervalorização de indicadores de impacto. Os dados produzidos como resultado de processos internos e os elementos apresentados em rankings pressupõem um determinismo absoluto: os dados correspondem exatamente a alguma realidade que é replicável e estável. Na realidade, no nível micro, dados sobre impacto são medidas de relacionamento de um nódulo (artigo) em uma rede de comunicação em mutação constante, uma vez que novos artigos aparecem diariamente com citações inéditas. A configuração correta desses dados

328 RIBEIRO, Raimunda Maria da Cunha. Avaliação e ranqueamento de universidades sob a lógica de critérios globais. Roteiro, Joaçaba, v. 43, n. 1, p. 259-276, jan./abr. 2018. p. 264. 
ocorre em intervalos de confiança e não representa valores absolutos ${ }^{329}$.

Quando transferido ao nível macro, de instituição, dados de impacto de citação criam a impressão de uma ordem hierárquica estável para um ranking e como um valor absoluto de produção em um anuário estatístico. Rankings não consideram essa variação estatística e, portanto, tornam-se problemáticos como fontes únicas de desempenho institucional.

Rankings são muitas vezes interpretados como se fossem estudos transversais. $\mathrm{Na}$ maioria dos casos, isso não é verdadeiro. As agências que os elaboram mudam a cada ano a metodologia, a normatização, a amostra, os processos de coleta de dados e, no caso de rankings normatizados por score, a média amostral e o desvio padrão. Isso significa que o desempenho de um ano não é diretamente comparável com o do ano anterior. Assim, cada pesquisa, e cada versão anual, deve ser considerada como uma análise única, e não como parte de uma série contínua.

Entre as agências analisadas, verifica-se que os dados apresentados revelaram que a pesquisa e o ensino consistem nos indicadores mais relevantes para o processo de avaliação por políticas de ranqueamento. Além de serem mensuráveis em análise, independentemente das informações prestadas pelas próprias avaliadas, esses indicadores revelam aquilo que a universidade consegue realmente transformar em nossa realidade.

Vale ressaltar que a avaliação não deve ser um empreendimento isento e justificado por si mesma, pois não consiste em uma simples aplicação de método de conferência da produtividade ou da eficiência de uma instituição. Assim, a avaliação consiste na ferramenta principal da organização para implementação das reformas educacionais.

Vivemos a era das avaliações, o que depende, necessariamente, por parte das instituições e do Estado, de um grau de adesão plenamente aceito e natural dessa questão, como algo inerente à vida em sociedade. Isso está longe de ser uma tarefa fácil, justamente porque a avaliação traz consigo desafios e o reconhecimento de sua importância, e é nesse sentido que, independentemente do modo de averiguação, ou dos critérios adotados para ela, o reconhecimento de sua necessidade é consensual.

A avaliação, seja pública, seja privada, demanda a superação de desafios inerentes à própria educação. Trata-se de um processo que atravessa contradições e conflitos objetivos e subjetivos, os quais tendem a se acirrar em consequência da importância que o conhecimento possui, como valor central em uma sociedade da informação, visto que é tido como principal

\footnotetext{
${ }^{329}$ AXEL-BERG, Justin. Indicadores para efeito de comparação internacional no ensino superior brasileiro. In: MARCOVITCH, Jacques (org.). Repensar a universidade: desempenho acadêmico e comparações internacionais. São Paulo: Com-Arte; Fapesp, 2018. p. 35.
} 
motor da economia, do individualismo e da competitividade.

\subsection{Adequações necessárias para apuração da qualidade da educação superior visando a inserção do Brasil no cenário mundial}

Partindo do pressuposto que nossa realidade precisa ser alterada, a presente pesquisa busca trazer alguns dos elementos principais de apuração de qualidade efetuado em todo o mundo para conseguir, da extração desses elementos, idealizar algum novo procedimento capaz de medir a qualidade educacional à parte do que já é realizado no Brasil.

Como apresentado, o ranqueamento universitário, por mais imparcialidade que vise, pode eventualmente atender aos interesses de um determinado setor sem, contudo, apurar efetivamente a qualidade dos cursos jurídicos no Brasil. Além disso, quando se leva em consideração que os rankings internacionais tendem a prestigiar instituições de ensino superior norte-americanas e inglesas, estamos diante de uma barreira intransponível inerente ao próprio sistema jurídico - as referidas IES formam juristas para trabalhar no Common Law, enquanto o Brasil e as demais instituições europeias têm toda a formação jurídica baseada no Civil Law.

Fora isso, não há dever que obrigue as instituições responsáveis pelos rankings a proceder com lisura nem com o objetivo de apurar exclusivamente o aspecto formativo do jurista posto no mercado de trabalho. E, menos ainda, as próprias instituições de ensino não estão obrigadas a colaborar com o fornecimento de dados nem com o procedimento avaliativo que adotam. O ranking pode ter finalidade exclusiva de atender uma específica demanda mercadológica, e isso não consiste em nenhum grau como algo inaceitável. Voltamos então à estaca zero: substituir o procedimento público de apuração de qualidade pelo ranqueamento desempenhado por instituições privadas seria temerário para a educação jurídica.

Novamente reitera-se que o atual sistema público de apuração de qualidade no Brasil é incapaz, por si só, de medir com fidedignidade os cursos jurídicos entregues à sociedade. Por sua vez, os rankings nacionais e internacionais possuem metodologias e indicadores das mais diversas ordens que são impossíveis de serem atendidos todos ao mesmo tempo.

A solução viável seria idealizar um sistema híbrido, pautado na experiência de outros países, alguns dos quais, após adotar novos critérios, começaram a obter êxito em inserir suas instituições em algumas das melhores colocações nos mais famosos e já apresentados rankings internacionais. 
Pilar Jimenéz Tello ${ }^{330}$ aduz que tanto na Grã-Bretanha quanto na França a avaliação tem sido encarada como estratégia nacional para promover a internacionalização da educação superior. Existe por lá a percepção geral entre os políticos e reguladores de que um processo mais transparente e visível de avaliação dá ao sistema universitário uma vantagem comparativa no mercado internacional da educação superior. Outros países, percebendo as vantagens desse pensamento, tal como a Austrália, tentaram copiar o modelo francês e britânico.

Na França existe o Comité National d'Évaluation (CNÉ), que é um Comitê Nacional de Avaliação de instituições públicas de educação científica, cultural e profissional, criado pela Lei de 26 de janeiro de 1984 do ensino superior, pela qual as universidades gozam de autonomia ao mesmo tempo administrativa, pedagógica, científica e financeira. A Lei de 10 de julho de 1989 torna o CNÉ uma autoridade administrativa independente, que se reporta diretamente ao presidente da república e, portanto, não está sob a supervisão do ministério responsável pelo ensino superior ${ }^{331}$.

Tal comitê consiste em uma autoridade administrativa independente que tem como missão avaliar estabelecimentos públicos de cunho científico, cultural e profissional, na perspectiva correspondente à sua missão de serviço público de ensino superior: formação inicial e contínua, investigação, inserção regional, nacional e internacional de cada instituição. No entanto, não tem como objetivo avaliar indivíduos, autorizar programas ou distribuir subsídios estatais, nem tem poder regulamentar ou gerencial. A avaliação do CNÉ chega a conclusões e recomendações que não são obrigatórias para a instituição avaliada.

Já na Espanha, foi na década de 1990 que iniciaram os movimentos favoráveis aos procedimentos avaliativos que culminaram na promulgação da Ley Orgánica de Universidades $n^{\circ}$ 6/2001, de 21 de dezembro. Em seu artigo 32, criou a figura da Agencia Nacional de Evaluación de la Calidad y Acreditación, atribuindo a ela as funções de avaliação e concessão de certificações e autorizações às instituições de ensino superior.

Tal artigo fora modificado por ocasião da reforma administrativa implementada pela Lei $\mathrm{n}^{\circ} 15 / 2014$, de 16 de setembro, no qual seus artigos $7^{\circ}$ e $8^{\circ}$ dedicam-se a estabelecer diretrizes gerais para atuação do referido órgão. Confere-se, dessa forma, status definitivo como

330 “Tanto en Gran Bretaña como en Francia, la evaluación ha sido vista como un elemento central de la estrategia nacional para la internacionalización de la Educación Superior; existe la percepción general entre los políticos y reguladores de que un proceso más transparente y visible de evaluación da al Sistema Universitario una ventaja comparativa en el mercado internacional de la Educación Superior. Otros países como Australia han intentado copiar el modelo francés y británico." Cf. TELLO, Pilar Jiménez. Auditoría universitaria y calidad: la evaluación como conquista social ante la competencia universitaria global. Saarbrücken: VDM Verlag Dr. Müller, 2009. p. 186.

331 EL COMITÉ Nacional de Evaluación: El CNE. [S. l.]: CNE, [20-?]. Disponível em: https://www.cneevaluation.fr/versions/espagnol.htm. Acesso em: 25 jun. 2019. 
o corpo autônomo da Administração Central do Estado, ligado ao Ministério da Educação, Cultura e Esporte (atualmente, o Ministério da Ciência, Inovação e Universidades) através da Secretaria Geral de Universidades.

O procedimento de aferição de qualidade da educação superior efetuado na Espanha é essencialmente diferente daquele desempenhado no Brasil. Atualmente, a Aneca efetua suas atividades por meio de ações especializadas, executadas pelo órgão de gestão e pelo órgão de assessoramento e avaliação, como podemos observar pelo organograma apresentado no Esquema 5 : 
Esquema 5 - Organização da Aneca


Fonte: Elaborado a partir de dados extraídos da Agencia Nacional de Evaluación de la Calidad y Acreditación, [2020b $]^{332}$.

332 Tradução livre. Cf. AGENCIA NACIONAL DE EVALUACIÓN DE LA CALIDAD Y ACREDITACIÓN (España). Estructura. Madrid: ANECA, [2020b]. Disponível em: http://www.aneca.es/ANECA/Estructura. Acesso em: 3 jun. 2019. 
As atividades da Aneca são orientadas por um plano estratégico de atuação específica para desenvolvimento durante o período de 2019-2023. O referido plano consiste em uma ferramenta básica de trabalho que define as linhas fundamentais de ação que essa agência irá desenvolver nos próximos anos, estabelecendo quatro metas básicas que se desdobram, visando a melhoria desse setor.

Inseridos no sistema de apuração de qualidade da educação superior da União Europeia, a Aneca está constantemente voltada a uma preocupação de internacionalizar as instituições de ensino superior, logrando êxito em apontar universidades espanholas nos rankings universitários anteriormente mencionados e mundialmente reconhecidos.

Para atingir a finalidade de constante busca pela melhoria da qualidade da educação superior, a Aneca desenvolve programas de avaliação em três eixos, quais sejam: avaliação dos títulos emitidos, avaliação dos docentes e avaliação das instituições de ensino. Para a avaliação institucional, foram idealizados quatro programas: Programa Docentia, que busca ajudar as universidade a criarem sistemas internos de avaliação de seus docentes; Programa Audit, o qual orienta os centros universitários a criarem sistemas de garantia interna de qualidade; Programa Acreditación Institucional, que avalia os pedidos de credenciamento institucional para funcionamento regular dos centros universitários; e o Programa Audit Internacional, que objetiva certificar os sistema de garantia de qualidade de instituições de ensino superior de outros países ${ }^{333}$.

Destaque-se que programas de avaliação e credenciamento são essencialmente diferentes entre si, tendo a Espanha firmado que os objetivos do credenciamento são: medir e manter os níveis de qualidade da educação que visa obter graus universitários de natureza oficial; estimular o interesse pela qualidade nas instituições universitárias; e fornecer informações aos cidadãos e às administrações públicas sobre os níveis de qualidade e características dos programas, bem como sobre o uso adequado de eventuais recursos públicos recebidos.

Com base nesses dados, pode-se inferir que os processos administrativos idealizados pelo Estado para apurar a qualidade da educação superior na Espanha consiste em um procedimento administrativo relativamente novo, cujos resultados e importância começam a se destacar a partir de agora.

É oportuno registrar que esses procedimentos de apuração de qualidade são efetuados

333 AGENCIA NACIONAL DE EVALUACIÓN DE LA CALIDAD Y ACREDITACIÓN (España). Programas de evaluación. Madrid: ANECA, [2020?]. Disponível em: http://www.aneca.es/Programas-de-evaluacion. Acesso em: 3 jun. 2019. 
pelos Estados Unidos há muito tempo, de forma precursora. Pautados por uma lógica de competitividade inerentes à sua essência, há notícia de que as universidades norte-americanas já debatiam mecanismos de apuração de qualidade desde o início do século XX, quando em Boston realizaram encontro com essa pauta. Mas, só nos anos 1950 e 1960 que se institucionalizou um procedimento de apuração de qualidade nos moldes do que temos atualmente 334 .

O procedimento avaliativo desempenhado nos Estados Unidos consiste em uma autoavaliação da própria instituição, seguido de um credenciamento realizado por uma avaliação externa. O objetivo é justamente o de comprovar a qualidade das titulações para seus estudantes e para a sociedade, com a finalidade de obter financiamento para auxiliar a mobilidade dos seus alunos e para melhorar a empregabilidade dos seus formados ${ }^{335}$.

Diferentemente do que vimos até agora, nos Estados Unidos a certificação da qualidade da educação superior já possui mais de 100 anos de atividade. O procedimento consiste em tarefas inerentes a organizações privadas sem finalidades lucrativas, idealizadas com esse objetivo específico. Assim, a revisão externa da qualidade desse setor não é uma tarefa governamental efetuada pelo setor público ${ }^{336}$.

A estrutura para o credenciamento por lá é descentralizada e complexa, reflexo da descentralização e complexidade do sistema educacional norte-americano. Operam cerca de 80 organismos acreditadores de instituições e programas acadêmicos, sendo que a legitimidade desses órgãos advém das próprias instituições acreditadas, mais que do próprio governo ${ }^{337}$.

A acreditação americana possui a função de assegurar a qualidade das universidades, permitir o acesso a recursos públicos, sejam federais, sejam estatais, pois só uma instituição acreditada pode receber fomento público. Além disso, tal acreditação possui o condão de gerar confiança ao setor privado, além de também servir como fator de facilitação para a transferência dos estudantes entre programas e instituições de ensino ${ }^{338}$.

\footnotetext{
334 "Del modelo acreditación se habló por primera vez en una reunión de las Universidades norteamericanas, de la costa este, celebrada en Boston en 1906 pero es en los años 50 y 60 cuando se generaliza el establecimiento de este proceso, tal y como lo entendemos hoy, y es el que persiste en la actualidad. Acredita instituciones universitarias y programas de estudios." Cf. TELLO, Pilar Jiménez. Auditoría universitaria y calidad: la evaluación como conquista social ante la competencia universitaria global. Saarbrücken: VDM Verlag Dr. Müller, 2009. p. 228.

335 Ibid.

${ }^{336}$ EATON, Judith Sheila. Consejo de acreditación de la educación superior, la acreditación y el reconocimiento en Estados Unidos. In: GLOBAL UNIVERSITY NETWORK FOR INNOVATION. La educación superior en el mundo 2007: acreditación para la garantía de la calidad: ¿qué está en juego? Madrid-Barcelona-México: Mundi-Prensa, 2006. Informe anual. p. 278.

337 Ibid., p. 279.

${ }^{338}$ Id., loc. cit.
} 
Segundo Pilar Jiménez Tello e Victoria Eugenia Plaza ${ }^{339}$, na atualidade, a Europa e Ibero-América, para poderem competir, precisam conhecer as ferramentas anglo-americanas, que são as que efetivamente predominam no mercado. Assim, o importante é conhecer os sistemas e as técnicas de avaliação que utilizam, já que eles estão há muito mais tempo trabalhando nesse terreno. É certo que a Europa e a Ibero-América também possuem alto nível de qualidade em suas universidades, mesmo sem figurar nos primeiros postos dos rankings universitários mais prestigiados.

Se o objetivo, neste momento, for o de competir em nível mundial, deverão primeiro compreender e se valer dos parâmetros estabelecidos no contexto anglo-saxão para se apropriar desses valores e então conseguirem idealizar um sistema de apuração de qualidade própria. Isso para considerar a grande população que efetivamente estuda nessa região, a fim de ter capacidade de criar novo mecanismo de apuração de qualidade, com novos indicadores que respeitem a tradição mais social e menos mercadológica que a educação tem para esses países.

O conflito é inerente à sociedade, razão pela qual se deve reconhecer a existência do conflito também em âmbito universitário, no qual é possível encontrar posicionamentos dos mais diversos para apurar a qualidade, seja na docência, seja na pesquisa, seja nos serviços que são prestados pelas instituições de ensino superior. É preciso, então, que esse conflito se transforme em uma confrontação cívica através do reconhecimento e da aceitação de institucionalização da competição, como realidade que já se efetiva, ainda que sem parametrização dos indicadores e das regras de apuração dessa qualidade por todos os envolvidos.

Deve-se partir do pressuposto que, para instituir um mecanismo de competição capaz de medir a qualidade das universidades, tal procedimento não pode ser baseado exclusivamente em números exatos. A razão é justamente tentar preservar os aspectos sociais que a educação visa promover; assim, em alguma medida, devem ser considerados os diferentes contextos econômicos, sociais e culturais de cada universidade avaliada, já que são muito diferentes.

Os rankings universitários acabam dando cada vez mais relevância à internacionalização das instituições de ensino. Isso ocorre porque em um contexto de

\footnotetext{
339 “En la actualidad, para poder competir, Europa e Iberoamérica necesitan conocer las herramientas angloamericanas, que son las que predominan en el mercado, lo importante es conocer los sistemas y técnicas de evaluación utilizadas en ese contexto. Ellos llevan muchos más años que nosotros trabajando en este terreno. Europa e Iberoamérica tienen un alto nivel de calidad en sus universidades, a pesar de que las universidades europeas no anglosajonas e Iberoamérica se encuentren fuera de los primeros puestos en los rankings universitarios más prestigiosos." Cf. TELLO, Pilar Jiménez; PLAZA, Victoria Eugenia. Educación superior y competitividad. Cadernos de Pós-Graduação em Direito, Comissão de Pós-Graduação da Faculdade de Direito da USP, São Paulo, n. 31, p. 4-26, 2014. p. 12.
} 
globalização é extremamente relevante que a apuração da qualidade leve em conta uma necessidade de intercâmbio entre as diversas realidades mundiais, justamente como medida para melhoria da humanidade. Essa concepção de competitividade entre universidades se trata de algo muito consistente na realidade dos Estados Unidos e dos países anglo-saxões. Fora desse cenário, com exceção da Ásia e do Japão, existe pouquíssima tradição nesse campo.

Os rankings universitários tiveram como missão servir de instrumento de aconselhamento às famílias e aos estudantes no momento de escolher a mais adequada instituição de ensino para a sua formação; aos profissionais, para continuar o desenvolvimento profissional de suas carreiras e aos empregadores, como referência de seleção de empregados, de onde deveriam escolher os profissionais mais qualificado para desempenho de seus negócios. É nesse sentido que se enxerga a institucionalização dos rankings universitários com mais relevância no âmbito universitário globalizado.

Cada ranking se baseia em um conjunto específico de critérios para apuração da qualidade acadêmica, os quais, sob pena de injustiça para a apuração deles, devem ser totalmente conhecidos antes mesmo da coleta das informações. Evidentemente que a escolha dos critérios acontece de forma discricionária pelos responsáveis do ranking, assim cada um escolhe os indicadores e os critérios que acreditam ser os mais relevantes para apuração da qualidade acadêmica.

Os resultados desses processos avaliativos serão atrelados à uma comparação na coleta dos dados previamente escolhidos, traduzindo-se em uma classificação das universidades em torno das pontuações recebidas em cada um dos critérios apurados. Como consequência, a busca pelos primeiros postos acaba por se tornar uma forma de melhorar o desempenho das instituições de ensino.

Os responsáveis pela elaboração dos rankings devem compreender que essa classificação que se propõem a efetuar se trata de ponto de partida para a escolha final do estudante por uma determinada instituição de ensino ou outra. Todavia, essa decisão final levará em conta outros fatores intangíveis, que não podem ser reduzidos apenas a números, como aspectos pessoais, localização no campus, ajuda financeira, entre outros. Mas, tais fatores não podem ser refletidos nos rankings.

No contexto ibero-americano, temos que ser conscientes de que a efetivação de uma proposta comum para medir a qualidade das universidades dessa região também não é uma tarefa fácil, visto que os contextos culturais, econômicos, políticos e sociais em que elas se desempenham são muito diferentes, e que, portanto, o conceito de qualidade variará em função dessas circunstâncias. 
Como os seres humanos não agem apenas racionalmente, mas também movidos por seus ideais, o comportamento no final pode ser modulado pela regulação e pela percepção. Se criarmos um sistema de avaliação objetiva o mais justo possível, mudaremos o comportamento dos professores. Ao serem avaliados com relação a alguns parâmetros estabelecidos com antecedência, os professores tentarão assegurar que seus ensinamentos e suas pesquisas sejam consistentes com os parâmetros de medição. Portanto, é muito importante definir os indicadores que são estabelecidos para medir. Tais parâmetros não podem ser deixados ao acaso, mas precisam ser definidos por especialistas e necessitam de um período de teste e julgamento antes de serem oficialmente implementados.

Uma clara referência aos comentários do parágrafo anterior é feita aos Estados Unidos, onde os acórdãos da Corte Americana citam autores atuais, com os quais os autores norteamericanos são altamente valorizados - isso os ajuda a se destacar para competir com os demais. Em nosso país, a Suprema Corte frequentemente recolhe textos que correspondem aos autores atuais, mas, ao contrário do Tribunal norte-americano, não os cita.

A Alemanha, do mesmo modo que nos Estados Unidos, as sentenças do seu mais alto órgão judicial citam os autores atuais. Nesse sentido, podemos dizer que os tribunais americano e alemão se tornaram avaliadores do sistema intelectual de seus respectivos países, sendo, portanto, um estímulo para que os autores desses países possam medir até o nível intelectual.

A necessidade de inovar a educação superior fica evidente diante de todo o cenário descrito com a presente pesquisa, justamente porque buscou comprovar que a necessidade de adequação do setor com a nova realidade da sociedade globalizada é latente. A universidade é uma instituição centenária que precisa se readaptar para se sustentar na atual dinâmica social.

Uma das vertentes possíveis consiste em reconhecer que no ambiente do ensino superior a melhoria da competitividade da IES requererá essencialmente uma gestão profissionalizada. Buscando algumas das mudanças necessárias na educação superior, alguns consideram que uma alternativa seria a gestão profissionalizada, a qual exige um perfil executivo das pessoas responsáveis pelo comando da reitoria. Entendem que, preferencialmente, é preciso contratar pessoas que possuam trajetórias de sucesso no mundo corporativo das empresas.

Na visão de algumas mantenedoras, a gestão executiva seria positiva, pois esse modelo de gestor conheceria as ferramentas da boa gestão, sendo capaz de proporcionar resultados financeiros positivos para os investidores e proprietários de instituições de ensino privadas. Outra opinião acredita que o perfil ideal para gestão de IES deve ser o acadêmico, pois somente alguém que vive e conhece a universidade sabe que ela se trata de uma prestadora de serviço 
específica, cujas demandas exigem um conhecimento técnico da área. Essa discussão, no entanto, não agrega para a melhoria da competitividade da IES.

O melhor perfil não está atrelado necessariamente à origem acadêmica ou executiva do gestor que comanda a instituição. O gestor educacional deve ter capacidade de engajamento das equipes e propor inovações para as IES em um ambiente dinâmico e complexo. O sucesso da IES depende do líder que a comanda, sendo que as melhores instituições do mundo possuem dirigentes com sólida formação acadêmica.

A verdade é que, independentemente de sua origem e natureza jurídica, a IES é uma instituição complexa, a qual exige capacidade de gestão e entrega de resultados concretos. Logo, o bom gestor será aquele que valoriza a meritocracia e os valores acadêmicos. Assim, os investimentos institucionais adequados seriam aqueles que priorizam projetos sintonizados com a missão e a identidade da instituição.

Apresenta-se então um essencial eixo para colocar uma IES como competitiva em seu contexto: o perfil do líder, a solidez de sua formação acadêmica, a capacidade de engajar pessoas e inovar e o foco nos resultados. A capacidade de inovar, inclusive, pode ser considerada como uma das mais valiosas características do líder de IES.

Ao deparar-se com o dilema da inovação no ambiente corporativo, alguns gestores podem falhar em razão da incapacidade de instigar a reflexão e a propositura de alternativas para a inovação disruptiva. Existem empresas que não possuem a cultura de instigar seus colaboradores e tornar real inovações capazes de viabilizar as rupturas, por isso muitas empresas perdem o tempo da mudança. Essas mesmas falhas podem ser encontradas na governança e gestão de IES.

Em ambiente competitivo, as IES podem sucumbir se forem administradas por gestores mal preparados e sem motivação, burocráticos, arrogantes e incapazes de analisar e enxergar os horizontes. Podem até ser as melhores referências do ensino superior, mas frágeis na gestão dos recursos, realizando investimentos de forma inadequada, sem considerar as áreas promissoras e as atividades essenciais.

De outro lado, a IES pode ser competitiva se os gestores forem capazes de sair do lugar comum e exercerem uma gestão pautada nos princípios da inovação e da sustentabilidade, o que efetivamente já sinalizaria como forte indício de prestação de serviço com boa qualidade. A IES que não busca a gestão para a inovação tende a não sobreviver em ambiente competitivo, o que pode significar a perda da qualidade esperada pela sociedade, dificuldade de agregar valor aos estudantes, aos professores e seus colaboradores, dificuldade de estabelecer boas parcerias, redução na procura das matrículas e, finalmente, resultados inexpressivos nos processos 
avaliativos exarados pelo poder público.

Melhorar as condições para competitividade necessariamente passa pelo estilo de liderar e pela capacidade de inovar. A formação técnica substancial não será suficiente se o gestor não conhecer a dinâmica da IES, o ambiente e as tendências da educação superior, sem ter o perfil empreendedor e a capacidade de transformar boas ideias em projetos e ações executáveis, concretas e sustentáveis.

A ruptura do setor pode ter origem na capacidade das instituições para propor novas tecnologias entendidas como os processos pelo qual a IES transformará o trabalho, o capital e a infraestrutura disponíveis em informação, produtos e serviços que agreguem valor aos seus alunos e à comunidade que absorverá essa mão de obra.

$\mathrm{O}$ ambiente do mercado educacional tende a ser uma das forças predominantes nos sistemas da educação superior, o que exigirá capacidade de agregar valor percebido pela sociedade. Interesses corporativos da academia, de associações de classe e das políticas de Estado são outras forças atuantes nos sistemas de educação.

A tendência é a de que o Estado consiga, cada vez mais, consolidar regras para a dinâmica de mercado desse setor, trazendo uma situação de 'quase mercado', em que o corporativismo acadêmico irá perder força e as associações estarão em constante conflito com o Estado e o mercado para defender os interesses de classe. Os líderes de nossas IES enfrentarão o desafio de inovar em um contexto caracterizado pelo avanço do mercado competitivo e dos grupos educacionais. Os líderes devem se preocupar com o futuro para conseguir entregar novos cursos que se adequem às demandas da sociedade em constante transformação.

Deve ser idealizada também uma nova forma de valorar os cursos superiores em atividade no Brasil, de forma diversa da que vem sendo desempenhada, justamente porque está evidente que a atual forma de apuração de qualidade da educação superior nacional não se mostra justa e igualitária para as diversas IES brasileiras.

Uma tentativa de conseguir satisfatoriamente reformar esse setor educacional pode ser iniciada pela alteração da apuração da qualidade dos cursos de Direito no Brasil. Adotar alguns dos critérios que são aplicados em outros lugares do mundo e criar um sistema de verificação de qualidade pode não ser uma das tarefas mais fáceis, mas certamente é uma medida necessária caso haja real interesse em superar a crise da educação jurídica constatada.

Adotando a concepção norte-americana, passemos à descrição de uma proposta para a inovação da avaliação buscando a melhoria da qualidade da educação jurídica no Brasil. Inicialmente será necessário contar com apoio dos representantes discentes e docentes vinculados aos diversos cursos de Direito em atividade no Brasil. Juntos, eles liderariam um 
movimento para implementar esse projeto em pelo menos seis organizações sem finalidades lucrativas, cujo único objetivo seria o de efetivamente exarar pareceres completos e detalhados sobre os cursos jurídicos existentes em todo o Brasil.

As cinco primeiras organizações buscariam uma instituição regional, cada uma responsável por medir a qualidade da região de sua base territorial. Então, teríamos uma organização para cada uma das cinco regiões do país: Norte, Nordeste, Centro-Oeste, Sudeste e Sul. Todas essas organizações estariam inter-relacionadas e responderiam para um órgão central, capaz de concentrar e difundir todas as informações coletadas e avaliadas.

Toda e qualquer instituição de ensino estaria sujeita à essa avaliação, que apresentaria as regras e consequente acreditação antes do início do procedimento. Tais determinações seriam inalteráveis durante o período de elaboração das avaliações, e quaisquer modificações somente seriam aprovadas com o regular mecanismo de alteração das regras e comunicação prévia às instituições de ensino.

Essa organização seria financiada com cotas anuais precedentes das instituições de ensino em atividade em território nacional, cujo valor seja exatamente o mesmo para todos os envolvidos, independentemente do número de alunos que a compõem e do local onde estiver sediada. Eventualmente, essa organização poderia receber verba advinda de iniciativa especial do governo ou de fundação privada, desde que ela nunca seja repassada para os avaliadores com finalidade lucrativa. Ao final de todo ano, seria divulgado o balanço patrimonial da organização com a clara apresentação das verbas utilizadas durante o exercício. Esse dinheiro não seria considerado verba pública em nenhuma hipótese.

Essa organização seria responsável pela elaboração de um ranking nacional público, a ser divulgado exaustivamente com apoio da mídia impressa e online. Em cada organização regional haveria um conselho responsável pela elaboração e outro, pela fiscalização das avaliações.

O conselho responsável pela elaboração seria composto por um nome indicado por cada uma das 10 melhores IES do ranking, partindo-se do Ranking Universitário da Folha para desenvolvimento das primeiras atividades. $\mathrm{O}$ critério para mensurar a qualidade seria definido previamente, iniciando por uma reformulação do instrumento avaliativo utilizado para apuração de qualidade da Lei do Sinaes, com o aprimoramento inerente às métricas apresentadas no RUF.

Esse instrumento avaliativo seria transformado em um barema, preenchido com as informações apuradas diante do cruzamento de informações prestadas pela própria instituição, confrontado com análise in loco e fornecido ao conselho de elaboração da lista de classificação dos cursos em atividade no Brasil. Essa seria uma atividade desenvolvida em parceria público- 
privada, justamente em razão da necessidade de existir representantes de todas as instituições nesses procedimentos.

Uma vez que a lista de classificação estivesse preparada, seria validada em conjunto pelo conselho de elaboração e esse documento seria submetido à apreciação do conselho de fiscalização do resultado final. A fiscalização seria efetuada por meio do sistema double blind review pelo conselho de fiscalização, composto pela indicação de 20 (vinte) nomes provenientes das últimas colocadas na lista total do ranking das IES da última verificação, partindo-se do Ranking Universitário da Folha para desenvolvimento das primeiras atividades.

Cada nome indicado pela IES receberia os pareceres exarados pelo conselho de elaboração, os quais poderão ser confirmados ou não pelos membros do conselho de fiscalização, sem possibilidade de alterar o conteúdo do documento. Em caso de divergência no resultado do procedimento, seria convocado um terceiro fiscalizador, de uma equipe previamente idealizada para tanto, com o único objetivo de exarar o voto de divergência para solução do impasse.

Em caso de não aprovação do relatório de elaboração da nota, o curso seria reavaliado por outro membro do conselho de elaboração. Com a validação de todos os pareceres e suas respectivas notas, os cursos seriam colocados em escalonamento, na mesma lógica do ranking, com o intuito de travar uma competição entre as IES. Em nenhuma hipótese existiria o caso de empate, pois sempre se estabeleceriam critérios de desempate e organização das instituições em ordem de classificação: da melhor para a mais mal avaliada pela equipe de especialistas.

Esse procedimento seria realizado a cada quatro anos, nos mesmos prazos atualmente idealizados para os procedimentos de avaliação dos Programas de Pós-Graduação no Brasil pela Capes. Tais listas de escalonamento seriam publicadas após o procedimento de apuração de qualidade, com a valoração das atividades desempenhadas e o apontamento específico de todos os pontos positivos e negativos encontrados por ocasião da apuração de qualidade. Isso ocorreria para que as IES pudessem traçar comparações entre si mesmas com as demais, tudo no sentido de constante aprimoramento dos serviços prestados.

Entre outras inovações, as universidades deveriam pensar na estruturação e implantação de unidades de inteligência, capazes de monitorar, analisar e difundir, em tempo real, a performance da instituição a que pertencerem, mantendo contínua interface com entidades que promovem comparações internacionais. Tais avanços permitirão acurado monitoramento das metodologias dos rankings mais acreditados no mundo - como fazem há vários anos as grandes instituições congêneres dos países desenvolvidos.

Aspectos diversos do mesmo tema, como avaliação interna, conformidade jurídica e 
ampla interação com a sociedade, convergem para caracterizar as vantagens comparativas do desempenho acadêmico - certamente o mais relevante patrimônio de qualquer grande universidade - em sua marcha sem fim para garantir um lugar no futuro.

Cinco diretrizes são imprescindíveis para levar as universidades a um patamar efetivamente competitivo na cena global, quais sejam: tornar mais acessível o conhecimento público sobre metodologia e métricas relacionadas a comparações internacionais; elencar processos de monitoramento e internalização dos indicadores adotados em comparações universitárias internacionais; identificar os componentes de uma política pública sobre indicadores de desempenho nas universidades para efeito de comparações internacionais; delinear as atribuições da unidade de inteligência responsável pelos indicadores para efeito de monitoramento e de comparações internacionais; aprimorar a governança das instituições, de modo a projetar a ciência brasileira no cenário nacional e internacional em benefício da sociedade como um todo.

É importante realçar os traços distintivos entre um setor meramente estatístico, nos moldes atuais, e a unidade de inteligência proposta no conjunto de objetivos acima expostos. Essa unidade não se restringiria à coleta de informações acadêmicas e ao cálculo de indicadores - iria muito além disso. Monitoramento, análise e difusão seriam atributos que tornariam disponíveis os dados sobre a produção científica e outros resultados institucionais. Essa sintonia permanente com a sociedade brasileira e com observatórios internacionais para fins de classificação incluiria, como já foi dito, a verificação das metodologias nos rankings globais, de modo a tornar impactantes, quando cabível, as nossas métricas de avaliação. 


\section{CONCLUSÃO}

A pesquisa realizada permitiu o aprofundamento de questões inerentes ao Direito, à sua operacionalização na vida em sociedade, à materialização da transmissão do conhecimento nessa área e à reflexão sobre as práticas educacionais desempenhadas na atualidade pelos cursos jurídicos no Brasil. Além disso, teve-se a oportunidade de efetivamente verificar de que modo o Estado brasileiro se comporta para conseguir implementar o seu dever constitucional de promover o acesso à educação em nível superior e se esse serviço prestado é feito com boa qualidade.

A relevância desta pesquisa está justamente na interdisciplinaridade abordada na temática proposta, visto que, idealizada sob a perspectiva do Direito Constitucional, Administrativo e Educacional, temas correlatos puderam ser abordados e aprofundados sem que deixássemos de lado o viés jurídico envolvido na temática. Tal possibilidade pôde ser concretizada justamente em razão da pesquisa ter sido desenvolvida em regime de cooperação entre duas renomadas instituições de ensino superior, uma no Brasil e outra na Espanha, cujas linhas de pesquisa dialogam diretamente para a construção do desenvolvimento do Estado Social.

Para ir além do conteúdo jurídico, pôde ser registrado com a pesquisa o aprofundamento de questões afetas à gestão pública e à promoção da educação superior, especificamente aos dados relativos à área do Direito em perspectivas históricas, políticas, econômicas e sociais relevantes.

O método de pesquisa histórico-evolutivo desempenhado ao longo de um trabalho realizado pelo método sistêmico verificou as transformações do cenário público administrativo identificadas até o momento. Retornamos à concepção das diretrizes para a implementação dos cursos jurídicos no país, valendo-se dos ideais desenvolvidos por historiadores, juristas e gestores públicos para a compreensão do que está atualmente solidificado em nosso país.

Ao longo de todo trabalho, diversas questões foram desenvolvidas para possibilitar descrever de fato o atual contexto de efetivação da educação jurídica no cenário nacional. Para tornar possível uma apurada análise sobre os elementos que compõem a qualidade dos cursos de graduação em Direito no Brasil, foi necessário percorrer um delicado caminho sobre a concretização dos cursos jurídicos e os mecanismos pelo qual atualmente a sociedade e o Estado se pautam para aferir a qualidade dos serviços realmente prestados.

A pesquisa foi iniciada com a apresentação da relação direta e intrínseca existente entre a democracia e o direito constitucionalmente consagrado de acesso à educação superior de 
qualidade. Nesse contexto, foram apresentados os elementos para a compreensão da prestação do serviço educacional como serviço público, essencial ao desenvolvimento da nação, à proteção constitucional e às demais previsões legais para assegurar seu acesso, bem como algumas das peculiaridades da área do Direito na prestação de serviços públicos educacionais.

Para elucidar os desdobramentos desse ramo específico do serviço público prestado, seja por entidade pública, seja por entidade privada, foi necessário comprovar que a titularidade do serviço público educacional pouco importa frente à importância da sua natureza jurídica, consistindo no que foi denominado como serviço público em sua essencialidade.

Também foram coletados e apresentados dados específicos sobre a importância do serviço educacional para a manutenção da democracia no Estado Social. A razão disso é porque, conforme comprovado, o exercício democrático da livre manifestação do pensamento e o exercício da liberdade de escolha para manutenção da própria vida são as matrizes necessárias para uma sólida base da democracia.

Com a coleta das informações mencionadas, primando pela liberdade dos atores sociais que compõem a educação nacional, ficou evidente a importância do papel da educação como base da sociedade. No entanto, é possível verificar que o atual modelo desempenhado para a aquisição do conhecimento é pautado por uma matriz antiga. Nesse contexto, falar em crise não consiste em uma pauta nova para a educação superior. Como mencionado, são diversos os elementos que constituem a conjuntura de crise desse setor.

No segundo capítulo foram apresentados os elementos que compõem a crise da educação superior na área do Direito, assim como o papel que cada ator exerce para a construção desse cenário crítico, que deve ser repensado dentro de uma proposta de inovação disruptiva para a universidade.

Foram levantados os elementos específicos do contexto da educação superior no Brasil, principalmente no que atine à lógica de mercado aplicada ao sistema educacional brasileiro, culminando na mercantilização da educação superior. É oportuno destacar que, para a presente pesquisa, a promoção da educação superior no Brasil há que ser pensada de forma crítica, visto que a oferta gratuita por parte do Estado brasileiro culmina no reforço da desigualdade social que, cada vez mais, distancia-se do seu principal objetivo - o de promover o desenvolvimento social.

Nesse ponto, é importante mencionar a abordagem referente ao custo dos Direitos Sociais, inspirado pelas ideias de Cass Sunstein e Stephen Holmes. Os autores mostraram que a liberdade de ação dos indivíduos em uma sociedade custa caro, razão pela qual gera injustiça 
social o rateio comum de todos com a promoção restrita do acesso a poucos, uma vez que esse custo facilita a manutenção das garantias constitucionais mais básicas.

Assim, foi apresentado de forma clara a necessidade de ser discutida essa forma de promoção gratuita da educação superior irrestrita a todos que acessam a educação superior pública no Brasil. Se toda a sociedade está arcando com o custo para a promoção de um serviço em que alguns dos beneficiários diretos, poderiam contribuir de forma direta com a manutenção das instituições de ensino a que estão vinculados, enquanto outros, comprovando sua condição de hipossuficiência, deveriam ser beneficiários do acesso gratuito da educação superior pública no modelo que é praticado atualmente no Brasil.

Trata-se de uma questão pragmática de gestão de recursos finitos, já que os direitos custam dinheiro e não podem ser protegidos nem garantidos sem financiamento e apoio públicos. Porém, imputar exclusivamente ao Estado uma obrigação que deve ser assumida na medida das possibilidades dos beneficiários diretos da prestação desse serviço apenas assola a desigualdade social tão criticada em nosso país. Se pensarmos naqueles que tiveram pouco ou nenhum acesso à educação básica de qualidade, continuarão tendo grande dificuldade de ingressar nas instituições de ensino superior públicas, as quais seguirão com altas taxas de concorrência para o acesso, prestigiando o grupo social que já possui demasiado privilégio em detrimento daqueles que verdadeiramente precisariam dos benefícios de acesso ao ensino público gratuito e de qualidade.

É importante destacar que, embora o custo dos direitos seja algo tão óbvio, soa antes como uma espécie de ataque ou ofensa àqueles que usufruem diretamente do seu acesso, talvez como uma ameaça à preservação dos seus direitos - mas não se trata disso. A reflexão aqui proposta guardou relação com a necessidade de ser reavaliada a atribuição do custo da educação superior prestada pelo agente público de forma exclusiva ao Estado.

Ademais, é importante registrar que a presente pesquisa constatou que existe um grupo de instituições de ensino superior, gerenciadas pelo setor público no nível da municipalidade, que efetivamente afrontam o sistema constitucional por ofertar cursos e solicitar o subsídio direto do beneficiário da prestação desse serviço, por meio do pagamento de mensalidades, nos exatos moldes do que a iniciativa privada o faz. Aponta-se, dessa forma, que existe afronta constitucional ao princípio da gratuidade do ensino público em estabelecimentos oficiais e que situações análogas estão sendo tratadas de forma diversa, promovendo a desigualdade no tratamento de instituições de ensino públicas.

Não bastassem esses pontos críticos apontados nesta pesquisa, consigne-se que as críticas aqui exaradas possuem o condão de apontar as inconsistências e de promover o debate 
público para a construção de um cenário que seja, no mínimo, mais harmônico e igualitário a todos: instituições de ensino públicas e privadas e usuários do serviço público prestado por qualquer instituição de ensino em atividade no Brasil.

Nesse ponto, duas questões foram de suma importância para o aprofundamento do estudo: a primeira foi pontuar de forma clara e específica os atributos da crise da educação jurídica brasileira e a parcela da responsabilidade de cada um dos envolvidos nesse cenário; e a segunda, com o objetivo de traduzir em números o contexto de crise vivido pelo Brasil, foi necessário apresentar os dados públicos coletados para comprovar a existência dessas circunstâncias na educação jurídica e o impacto na população direta e indiretamente envolvida.

Com esses apontamentos, ficou evidente que o dever constitucional de assegurar o acesso à educação superior, bem como o importante papel que o Estado possui de controlar a qualidade do serviço que efetivamente é entregue à sociedade, consiste em dois dos mais importantes deveres públicos no âmbito da promoção da educação. A crítica à desigualdade do acesso foi feita à luz do custo dos direitos, apresentando um desdobramento necessário para o estudo e uma sistematização daquilo que atualmente o Estado brasileiro consegue realizar para apurar a qualidade dos cursos jurídicos ofertados em território nacional.

Identificou-se que a vontade do gestor público em melhorar o cenário público brasileiro não é um fator específico da atualidade, sendo que tal desejo é aperfeiçoado em razão dos diversos mecanismos de modernização e racionalização da educação superior que nos são colocados à disposição em razão dos avançados estudos desenvolvidos na área.

Essa constante necessidade de melhorar o setor público é consequência da compreensão do dever de desenvolver e melhorar a realidade coletiva, segundo a qual as pessoas que se submetem a uma mesma ordem estatal reconhecem que a vida em sociedade exige uma série de diretrizes para o bom convívio entre todos.

Dada essa premissa, a presente pesquisa levantou de forma empírica os processos e mecanismos internacionais e nacionais idealizados para assegurar a qualidade universitária, com o objetivo de concentrar as práticas adotadas no Brasil e no mundo para a apuração dos serviços entregues à sociedade.

Destaque-se que, neste momento, tal abordagem aconteceu de forma generalizada para a prática da apuração da qualidade em todo o setor educacional em nível superior e, quando necessário, recortes específicos para a compreensão da apuração da qualidade adstritos à área do Direito foram realizados.

A premissa que abre essa perspectiva consiste no dever de que toda e qualquer instituição de ensino superior em atividade deve ter iniciativa própria para efetuar o controle de 
qualidade dos serviços que presta. A partir dessa concepção, foi apresentada uma proposta de compliance educacional baseada em alguns dos elementos estruturantes para a política de controle interno das empresas em atividade. O objetivo é certificar-se que sua conduta atende a todos os ditames legais pleiteados pelo Estado para que uma empresa possa praticar sua atividade fim.

Nesse contexto, aponta-se que as instituições de ensino poderiam adotar práticas específicas para apurar a qualidade do serviço público prestado por elas. No entanto, esse dever de autofiscalização constante, apesar de ser possivelmente executado pelas instituições de ensino que buscam o constante aprimoramento de suas atividades, em nenhuma hipótese pode gerar a desobrigação do poder público de apurar a qualidade do serviço posto à disposição da sociedade.

Dessa forma, sendo o poder público responsável pela fiscalização constante de todo serviço de relevante interesse público, prestado por um agente público ou privado, foi necessário apresentar as políticas públicas implementadas e atualmente executadas para a efetivação da avaliação e do credenciamento público de cursos em nível superior, consistentes nas autorizações estatais para funcionamento das instituições de ensino superior.

Ressalte-se que essas políticas públicas estudadas foram aquelas implementadas pelo sistema federal de ensino, nos termos da Lei $\mathrm{n}^{\mathrm{o}} 10.861$, de 14 de abril de 2004, a qual instituiu o Sistema Nacional de Avaliação da Educação Superior, em que uma série de procedimentos são adotados para a apuração da qualidade educacional pelo setor público.

Os procedimentos específicos adotados foram todos destrinchados, com a necessária explicação para verificação daquilo que atualmente o poder público efetivamente faz para averiguar a qualidade da educação, nesse ponto não somente adstritos à área do Direito.

Diversas foram as críticas apontadas ao longo da pesquisa no sentido de que o próprio procedimento possui uma série de subjetividades inerentes ao processo de fiscalização. Mas, para ir além, as constantes alterações dos instrumentos de avaliação conferem uma ausência de estabilidade ao mecanismo.

Além disso, a grande constatação apurada por essa pesquisa cinge-se ao fato de que infelizmente não são todas as instituições de ensino que estão sujeitas ao procedimento público de apuração da qualidade educacional, em razão de uma injustificada divisão de competências que, nesse aspecto, é incapaz de agregar melhorias ao sistema educacional.

Com essa pesquisa, ficou claro que as IES em atividade no Brasil não possuem um mesmo tratamento por parte do poder público, o que por si só já denota uma grave injustiça perpetrada pelo setor. Justifica-se essa informação pelo fato de as instituições de ensino superior 
de responsabilidade dos estados e dos municípios não estarem sujeitas às fiscalizações exaradas pelo Sinaes, e os respectivos sistemas estaduais de educação, que são responsáveis pela apuração da qualidade, não o fazem nem solicitam apoio ao sistema federal para a execução dessa importante fiscalização.

Em verdade, o quantitativo de instituições de ensino superior que não se sujeitam ao sistema público de apuração de qualidade não consiste em um valor expressivo, na área do Direito restritas a 7\% (sete por cento) das IES em atividade. No entanto, nenhuma justificativa pode ser plausível frente à tal ausência de fiscalização dos serviços prestados por essas instituições, as quais não se sujeitam ao Sinaes por uma mera divisão de competências, que na prática é geradora de uma omissão do poder público estadual.

Outra importante crítica oportuna de ser mencionada e relativa ao procedimento de coleta de informações para apresentação nesta pesquisa está relacionada com a dificuldade de acesso às informações de relevante interesse público, consistentes nos procedimentos efetivamente adotados pelos governos estaduais para apuração da qualidade das IES pertencentes ao seu sistema de ensino.

Nesse sentido, vale mencionar que a Lei de Acesso à Informação (Lei n ${ }^{\circ} 12.527$, de 18 de novembro de 2011) traduz-se em verdadeiro instrumento de transparência pública e auxílio à coleta de dados e informações relevantes para apuração dos deveres públicos estatais. No entanto, não obstante essa novel ferramenta que efetivamente colabora com a cientificidade da promoção e difusão do conhecimento, diversos governos dificultam o procedimento de solicitação dos dados e, com raras exceções, não prestam a informação que de fato foi solicitada.

Emblemático foi o caso do governo do estado de São Paulo, responsável pelo controle da qualidade dos serviços prestados pela Universidade de São Paulo, uma das instituições de ensino superior mais importantes do país que não se sujeita aos procedimentos inerentes ao Sinaes.

Verifica-se que, por ocasião da solicitação dos procedimentos adotados pelo governo paulista, a resposta informada solicitou que o pedido deveria ser direcionado para o Conselho Estadual de Educação, em consulta formal, com a necessidade de apresentar uma carta assinada pelo orientador informando o objetivo da pesquisa e os dados necessários. Trata-se de uma solicitação arbitrária, já que todo e qualquer cidadão tem direito de saber de que forma a administração pública arca com seus deveres constitucionais.

Outra importante crítica cabível consiste na necessidade de estruturação e apoio jurídico às secretarias educacionais dos estados e da União. Tal ponderação ocorre porque as informações colacionadas por ocasião desta pesquisa não foram localizadas de forma rápida e 
acessível. É necessário ser um conhecedor do tema e verdadeiro atuante no setor para conseguir reunir essas informações, de modo que mesmo o procedimento para apuração da qualidade só é compreendido por gestores que atuam no setor educacional.

Assim, é preciso que seja efetivada uma espécie de organização dos textos normativos já vigentes, para ser correta e devidamente apurado aquilo que ainda está vigente a respeito da estruturação do Ministério da Educação e das respectivas Secretarias de Educação dos governos estaduais. É oportuno mencionar que existem algumas medidas provisórias, da época do governo do Fernando Henrique Cardoso, que nunca foram convertidas em lei e que, em tese, ainda regulamentam temáticas afetas à educação, o que consiste em um grave equívoco jurídico que deve ser corrigido com urgência.

Outra importante constatação foi a de descontinuidade das políticas públicas idealizadas para a área da educação. Justamente por tratar-se de uma das mais importantes e estratégicas pastas de qualquer governo que pretenda o desenvolvimento econômico e social de um país, há evidente interesse político e econômico na condução das atividades desempenhadas no órgão ministerial, o que prejudica muito a busca pela concretização e efetivação do aspecto essencialmente social desse setor.

A sistematização decorrente da ramificação desse importante órgão ministerial facilita o trabalho do intérprete diante de ambiente ainda tão marcado pelo caos legislativo, o que só o estudo do Direito Educacional, e não simplesmente da legislação educacional, pode proporcionar ao oferecer suportes teórico e científico necessários ao enfrentamento dos mais variados problemas do cotidiano educacional.

A rigorosidade solicitada para acessar os dados públicos relativos ao setor, coletados e disponibilizados pelo Inep, mais confundem do que ajudam a apuração da qualidade por quem se interessa por essa temática. Para conseguir efetivamente o acesso a informações públicas de relevante interesse social foi necessário passar por um trâmite burocrático desnecessário, haja vista que as informações prestadas pelas sinopses estatísticas da educação superior não apresentam dados particularizados sobre quais instituições de ensino estão em atividade no Brasil.

Ademais, foi possível constatar que as informações coletadas pelo setor responsável carecem de dupla checagem, visto que são solicitadas que as IES prestem informações relativas ao setor, que são arquivadas sem que haja uma mínima fiscalização sobre a veracidade dos dados apontados. Outrossim, verificou-se que existe uma falta de rigor técnico por ocasião do preenchimento dessas informações, fazendo com que exista a possibilidade de inadequação das informações oficialmente coletadas. 
O Inep, enquanto autarquia, consiste em uma entidade da administração pública indireta, criada por lei para apenas levantar as informações adstritas do setor educacional, não para o tratamento desses dados ou formulação de políticas públicas do setor educacional. Qualquer desvirtuamento dessas funções consistiria em um desvirtuamento do serviço prestado pela entidade, a qual está sujeita à supervisão ministerial do MEC, já que não há que se falar em autonomia da referida entidade.

Buscando apresentar um elemento positivo dentre as hipóteses aventadas no início da presente pesquisa, é preciso mencionar que, após a coleta e tratamento dos dados inerentes ao setor educacional, tem-se, ao contrário do que o senso comum quer fazer acreditar, números que demonstram que a educação superior no Brasil não está imersa em um cenário caótico de crise institucional. Ao contrário, a educação superior atualmente consegue atender a demanda de grande parcela da população brasileira, com percentuais e extratos próximos aos números europeus.

O grande problema está relacionado com a qualidade desses serviços prestados, já que a relevante maioria é realizado por instituições de ensino de natureza privada. Isso faz com que o acesso seja assegurado, mas não necessariamente aos cursos mais bem avaliados, ou, ainda, que exista um efetivo controle da atuação de todas as instituições de ensino superior no Brasil.

A presente pesquisa caminha para o seu encerramento quando propõe a compreensão dos elementos inerentes à apuração de qualidade educacional pelo setor privado, diante da análise do que a própria sociedade civil se presta a efetivar na adoção de metodologias próprias e específicas, a fim de concluir quais são os melhores cursos jurídicos em território nacional e internacional.

Trata-se da concepção do ranqueamento universitário proposto por entidades privadas que se prestam a pesquisar as instituições de ensino superior, por meios próprios e com a adoção de metodologia específica, para atribuir pontuação capaz de colocar as instituições em uma escala de classificação.

Diante da constatação de que cada vez mais a sociedade civil passa a adotar esses índices como critério de auxílio para seleção dos cursos que pretendem cursar, é inegável concluir que os rankings universitários causam um relevante impacto com sua atuação.

Foi justamente diante da constatação dessa influência na sociedade atual que a presente pesquisa se encerrou com uma abordagem sobre a necessidade de fomentar estudos e apoiar a implementação de políticas públicas. O objetivo é o reconhecimento mundial da qualidade da educação jurídica brasileira, com a compreensão e aceitação de que a competição se tornou um valor em um cenário globalizado. 
Para tanto, foi preciso compreender de que forma a lógica da competitividade foi aplicada ao setor educacional na realidade brasileira, pois, apesar de constar que efetivamente tal lógica se aplica ao setor, isso não aconteceu sem crítica e, menos ainda, sem que diversos posicionamentos fossem sopesados.

Após a constatação da importância que essas atividades passaram a ter no atual contexto, foram estudados de forma particularizada os procedimentos adotados por alguns dos mais relevantes rankings nacionais e internacionais em atividade no Brasil e no mundo, justamente com o intuito de comparar as atividades que todos esses indicadores executam.

Finalmente, como forma de apresentar a originalidade da presente investigação, constituindo em uma real contribuição para a área do Direito, foi apresentada a proposta de idealização de um mecanismo inovador de apuração da qualidade da educação superior. Iniciou-se pelo critério de análise específica aos cursos jurídicos, visando a possibilidade de inserção dos cursos nacionais no cenário mundial. Trata-se de uma proposta inovadora e arrojada, a ser executada em uma parceria público-privada, em que representantes do governo, da sociedade civil e das instituições de ensino superior em atividade no Brasil teriam a oportunidade de participar coletivamente da apuração da qualidade dos serviços de relevante interesse público prestados em território nacional.

É importante destacar que essa proposta foi devidamente detalhada no momento oportuno e consiste na originalidade desta pesquisa como mecanismo alternativo e consensual de definir um escalonamento objetivo dos cursos jurídicos no Brasil.

Para concluir, destacamos que a temática abordada não se esgota aqui. É necessário instituir uma agenda de pesquisa para poder proceder na difícil empreitada de analisar as propostas que são racionalizadas para melhorar a prestação dos serviços educacionais jurídicos brasileiros.

É preciso ficar atento às eventuais repercussões de possíveis alterações nos mecanismos de apuração de qualidade propostos pelo Ministério da Educação, principalmente agora que existem justificativas plausíveis derivadas do atual contexto de contingenciamento derivado das suspensões das atividades em razão do isolamento social.

Também é fundamental continuar investigando os desdobramentos da suspensão das atividades públicas de apuração de qualidade para averiguar se as novas condutas adotadas pelos agentes públicos responsáveis efetivamente respeitarão os critérios de isonomia e transparência na apuração da qualidade educacional, com o objeto de academicamente colaborar com a denúncia das distorções identificadas. 
Apesar de conseguir estabelecer, com a revisão dos ideais que permeiam o aparato público estatal, a possibilidade de instituir um mecanismo apto a apurar a qualidade educacional da maneira mais eficiente possível, é vital constatar que essa temática nunca será esgotada. Contudo, a partir daqui, será mais plausível investigar melhorias e distorções, que poderão ser identificadas por meio da continuidade das pesquisas que, com toda sorte, não se encerram aqui. 


\section{REFERÊNCIAS}

ACADEMIC RANKING OF WORLD UNIVERSITIES. Shanghai: ShanghaiRanking Consultancy, 2003- . Disponível em: http://www.shanghairanking.com/arwu2019.html. Acesso em: 8 nov. 2020.

ACCA, Thiago dos Santos. Teoria brasileira dos direitos sociais. São Paulo: Saraiva, 2013.

AFONSO, Almerindo Janela. A educação superior na economia do conhecimento, a subalternização das ciências sociais e humanas e a formação de professores. Avaliação (Campinas), Sorocaba, v. 20, n. 2, p. 269-291, jul. 2015. Disponível em:

http://www.scielo.br/scielo.php?script=sci_arttext\&pid=S1414-

$40772015000200269 \& \operatorname{lng}=$ en\&nrm=iso. Acesso em: 7 fev. 2019.

AFONSO, A. J. Nem tudo o que conta em educação é mensurável ou comparável: crítica à accountability baseada em testes estandardizados e rankings escolares. Revista Lusófona de Educação, Lisboa, v. 13, n. 13, p. 13- 29, jun. 2009. Disponível em:

https://revistas.ulusofona.pt/index.php/rleducacao/article/view/545. Acesso em: 10 mar. 2019.

AGENCIA NACIONAL DE EVALUACIÓN DE LA CALIDAD Y ACREDITACIÓN (España). Evaluación de la calidad y acreditación: Espacio Común de Educación Superior Unión Europea, América Latina y Caribe (UEALC). Madrid: ANECA, 2003.

AGENCIA NACIONAL DE EVALUACIÓN DE LA CALIDAD Y ACREDITACIÓN (España). Estructura. Madrid: ANECA, [2020b]. Disponível em:

http://www.aneca.es/ANECA/Estructura. Acesso em: 3 jun. 2019.

AGENCIA NACIONAL DE EVALUACIÓN DE LA CALIDAD Y ACREDITACIÓN (España). Estudios de interés para el ámbito universitário. Madrid: ANECA, [20-?].

Disponível em: http://www.aneca.es/Documentos-y-publicaciones/Estudios-de-interes-parael-ambito-universitario. Acesso em: 15 abr. 2020.

AGENCIA NACIONAL DE EVALUACIÓN DE LA CALIDAD Y ACREDITACIÓN (España). Información económica. Madrid: ANECA, [2019]. Disponível em:

http://www.aneca.es/ANECA/Informacion-economica. Acesso em: 14 abr. 2020.

AGENCIA NACIONAL DE EVALUACIÓN DE LA CALIDAD Y ACREDITACIÓN (España). Informes sobre calidad universitária. Madrid: ANECA, [2018]. Disponível em: http://www.aneca.es/Documentos-y-publicaciones/Observatorio-de-la-Calidad-del-SistemaEspanol-de-Universidades/Informes-sobre-calidad-universitaria. Acesso em: 14 abr. 2020.

AGENCIA NACIONAL DE EVALUACIÓN DE LA CALIDAD Y ACREDITACIÓN (España). Observatorio de la Calidad del Sistema Español de Universidades. Madrid: ANECA, [2018?]. Disponível em: http://www.aneca.es/Documentos-ypublicaciones/Observatorio-de-la-Calidad-del-Sistema-Espanol-de-Universidades. Acesso em: 15 abr. 2020. 
AGENCIA NACIONAL DE EVALUACIÓN DE LA CALIDAD Y ACREDITACIÓN (España). Planificación. Madrid: ANECA, [2020a]. Disponível em:

http://www.aneca.es/Documentos-y-publicaciones/Planificacion. Acesso em: 15 abr. 2020.

AGENCIA NACIONAL DE EVALUACIÓN DE LA CALIDAD Y ACREDITACIÓN (España). Programas de evaluación. Madrid: ANECA, [2020?]. Disponível em: http://www.aneca.es/Programas-de-evaluacion. Acesso em: 3 jun. 2019.

ALBERTO LOPES, Maria Gracileide. A mercantilização do ensino superior no contexto atual: considerações para o debate. Interfaces Científicas - Educação, Aracaju, v. 6, n. 2, p. 29-44, fev. 2018. Disponível em:

https://periodicos.set.edu.br/index.php/educacao/article/view/4249. Acesso em: 25 fev. 2020.

ALMEIDA, José Ricardo Pires de. Instrução pública no Brasil (1500-1889): história e legislação. Tradução: Antonio Chizotti. 2. ed. São Paulo: Educ, 2000.

ALTBACH, G. Philip. The costs and benefits of world-class universities. International Higher Education, [s. l.], n. 33, p. 5-8, 2003. Disponível em:

https://ejournals.bc.edu/index.php/ihe/article/view/7381. Acesso em: 27 maio 2019.

ALTBACH, G. Philip. O que conta para a produtividade nas universidades de pesquisa? Ensino Superior Unicamp, 27 maio 2015. Disponível em:

https://www.revistaensinosuperior.gr.unicamp.br. Acesso em: 27 maio 2019.

ALTBACH, G. Philip; REISBERG, Liz; RUMBLEY, Laura E. Trends in global higher education: tracking an academic revolution. Boston: Sense Publishers, 2010.

AMORIM, Wellington Lima; SILVA, Everaldo da. Reflexões sobre a educação superior: entrevista com o doutor Adelcio Machado dos Santos. Revista Húmus, São Luís, v. 6, p. 1-6, 2016.

ANDRADE, Adriana; ROSSETTI, José Paschoal. Governança corporativa: fundamentos, desenvolvimento e tendências. 2. ed. atual. e ampl. São Paulo: Atlas, 2006.

APODACA, Pedro; LOBATO, Clemente. Calidad en la universidad: orientación y evaluación. Barcelona: Laertes, 1997.

ARONI, Allan. $O$ ensino superior como atividade empresarial e o cidadão mínimo no Brasil: o peso da mão liberal e a marca de uma aliança não visível: uma análise do ensino superior brasileiro a partir dos dilemas que envolvem as políticas públicas. 2008. 215 f. Dissertação (Mestrado em Educação) - Faculdade de Educação, Universidade de São Paulo, São Paulo, 2008. Disponível em: https://www.teses.usp.br/teses/disponiveis/48/48134/tde-09102008115646/pt-br.php. Acesso em: 18 fev. 2019.

ASSOCIAÇÃO BRASILEIRA DE MANTENEDORAS DE ENSINO SUPERIOR. Legislação. Brasília, DF: ABMES, c2020. Disponível em: https://abmes.org.br/legislacoes. Acesso em: 7 abr. 2020. 
ATIQUE, Andraci Lucas Veltroni. A educação superior e os princípios constitucionais. Revista do Instituto dos Advogados de São Paulo, São Paulo, ano 9, n. 18, jul./dez. 2006.

AXEL-BERG, Justin. Indicadores para efeito de comparação internacional no ensino superior brasileiro. In: MARCOVITCH, Jacques (org.). Repensar a universidade: desempenho acadêmico e comparações internacionais. São Paulo: Com-Arte; Fapesp, 2018.

BABONES, Salvatore; ABERG, John H. S. Globalization and the rise of integrated world society: deterritorialization, structural power, and the endogenization of international society. International Theory, [s. l.], v. 11, n. 32, p. 93-317, 2019. Disponível em:

https://www.cambridge.org/core/journals/international-theory/article/globalization-and-therise-of-integrated-world-society-deterritorialization-structural-power-and-the-endogenizationof-international-society/929956DD5745138E431C55412AE2ED5C. Acesso em: 13 maio 2020.

BARRETO, Lima. A universidade. [S. l.]: Biblio Biblioteca Virtual de Literatura. Disponível em:

http://www.biblio.com.br/defaultz.asp?link=http://www.biblio.com.br/conteudo/LimaBarreto/ cronicas/auniversidade.htm. Acesso em: 10 out. 2018.

BARREYRO, Gladys Beatriz; ROTHEN, José Carlos. "SINAES” contraditórios: considerações sobre a elaboração e implantação do Sistema Nacional de Avaliação da Educação Superior. Educação e Sociedade, Campinas, v. 27, n. 96, p. 955-977, out. 2006. Disponível em: http://www.scielo.br/scielo.php?script=sci_arttext\&pid=S010173302006000300015\&lng=en\&nrm=iso. Acesso em: 31 jan. 2019.

BASTOS, Aurélio Wander. Ensino jurídico no Brasil. 2. ed. rev. e atual. Rio de Janeiro: Lumen Juris, 2000.

BAUMAN, Zygmunt. Modernidade líquida. Tradução: Plínio Dentzien. Rio de Janeiro: Zahar, 2001. $255 \mathrm{p}$.

BERCOVICI, Gilberto. Soberania e Constituição: para uma crítica do constitucionalismo. 2. ed. São Paulo: Quartier Latin, 2013.

BERGHE, Wouter Van den. Aplicación de las normas ISO 9000 a la enseñanza y la formación. Revista Europea de Formación Profesional CEDEFOP, [s. l.], n. 15, p. 21-30, sept./dic. 1998. p. 21. Disponível em:

https://dialnet.unirioja.es/servlet/articulo?codigo=131241. Acesso em: 20 maio 2020.

BERNARDI, Bruno Boti. O conceito de dependência da trajetória (path dependence): definições e controvérsias teóricas. Perspectivas: Revista de Ciências Sociais, São Paulo, v. 41, p. 137-167, jan./jun. 2012. Disponível em:

https://periodicos.fclar.unesp.br/perspectivas/article/view/4978. Acesso em: 25 maio 2020.

BERTOLIN. Juulio Cesar G. Os quase-mercados da educação superior: dos improváveis mercados perfeitamente competitivos à imprescindível regulação do Estado. Educação e Pesquisa, São Paulo, v. 37, n. 2, p. 237-248, maio/ago. 2011. Disponível em: https://www.scielo.br/scielo.php?pid=S151797022011000200002\&script=sci_abstract\&tlng=pt. Acesso em: 10 mar. 2020. 
BITTAR, Eduardo Carlos Bianca. O ensino jurídico na pós-modernidade. In: ANUÁRIO ABEDI. Florianópolis: Fundação Boiteux, ano 3, n. 3, p. 91, 2005.

BLACK, Paul J.; Wiliam, Dylan. Developing the theory of formative assessment. Educational Assessment, Evaluation and Accountability, [s. l.], v. 21, n. 1, p. 5-31, 2009.

BOK, Derek. The cost of talent: how executives and professionals are paid and how it affects America. New Tork: The Free Press, 1993.

BOK, Derek. Universities in the marketplace: the commercialization of higher education. New Jersey: Princeton University Press, 2003.

BONAVIDES, Paulo. Do Estado liberal ao Estado social. 11. ed. São Paulo: Malheiros, 2014.

BORGES, Priscilla. Avaliação das 20 metas do Plano N. de Educação. São Paulo: CRE Mario Covas, 2020. Disponível em:

http://www.crmariocovas.sp.gov.br/noticia.php?it=14821. Acesso em: 30 maio 2020.

BOURDIEU, Pierre. O campo científico. In: ORTIZ, R (org.). Bourdieu. São Paulo: Ática, 1983. p. 82-121.

BOURDIEU, Pierre. Os usos sociais da ciência: por uma sociologia clínica do campo científico. São Paulo: UNESP, 2004.

BRANDÃO, Carlos Rodrigues. O que é educação. São Paulo: Brasiliense, 2007.

BRASIL. Congresso. Câmara dos Deputados. Projeto de Lei $n^{\circ} 8.035$, de 20 de dezembro de 2010. Aprova o Plano Nacional de Educação para o decênio 2011-2020 e dá outras providências. Brasília, DF: Câmara dos Deputados, 2010. Disponível em:

https://www.camara.leg.br/proposicoesWeb/fichadetramitacao?idProposicao=490116. Acesso em: 20 fev. 2019.

BRASIL. Congresso. Câmara dos Deputados. Projeto de Lei Complementar $n^{\circ} 25 / 2019$, de 13 de fevereiro de 2019. Institui o Sistema Nacional de Educação (SNE), fixando normas para a cooperação entre a União, os Estados, o Distrito Federal e os Municípios nas políticas, programas e ações educacionais, em regime de colaboração, nos termos do inciso V do caput e do parágrafo único do art. 23, do art. 211 e do art. 214 da Constituição Federal. Brasília, DF: Câmara dos Deputados, 2019a. Disponível em:

https://www.camara.leg.br/proposicoesWeb/prop_mostrarintegra;jsessionid=28D160B67BA9 56215C07AC93A67BD795.proposicoesWebExterno2? codteor $=1712345 \&$ filename $=$ Avulso + -PLP+25/2019. Acesso em: 26 fev. 2019.

BRASIL. Congresso. Câmara dos Deputados. Projeto de Lei Complementar $n^{\circ}$ 47/2019, de 26 de fevereiro de 2019. Dispõe sobre instrumento de cooperação federativa para transferência à União de competências educacionais de Estados, Distrito Federal e Municípios. Brasília, DF: Câmara dos Deputados, 2019b. Disponível em: https://www.camara.leg.br/proposicoesWeb/fichadetramitacao?idProposicao=2193198. Acesso em: 26 fev. 2019. 
BRASIL. [Constituição (1988)]. Constituição da República Federativa do Brasil de 1988. Brasília, DF: Presidência da República, 1988. Disponível em:

http://www.planalto.gov.br/ccivil_03/constituicao/constituicaocompilado.htm. Acesso em: 18 fev. 2019.

BRASIL. Decreto $n^{\circ}$ 599, de 18 de outubro de 1891. Concede á Faculdade de Direito da Bahia, na fórma do art. 420 do decreto n. $1232 \mathrm{H}$ de 2 de janeiro deste anno, o titulo de Faculdade Livre com todos os privilegios e garantias de que gozam as Faculdades federaes. Brasília, DF: Câmara dos Deputados, 1891. Disponível em: https://www2.camara.leg.br/legin/fed/decret/1824-1899/decreto-599-17-outubro-1891516940-publicacaooriginal-1-pe.html. Acesso em: 24 fev. 2020.

BRASIL. Decreto $n^{\circ}$ 9.235, de 15 de dezembro de 2017. Dispõe sobre o exercício das funções de regulação, supervisão e avaliação das instituições de educação superior e dos cursos superiores de graduação e de pós-graduação no sistema federal de ensino. Brasília, DF: Presidência da República, 2017. Disponível em:

http://www.planalto.gov.br/ccivil_03/_Ato2015-2018/2017/Decreto/D9235.htm. Acesso em: 20 maio 2019.

BRASIL. Decreto $n^{\circ} 10.195$, de 30 de dezembro de 2019. Aprova a Estrutura Regimental e o Quadro Demonstrativo dos Cargos em Comissão e das Funções de Confiança do Ministério da Educação e remaneja e transforma cargos em comissão e funções de confiança. Brasília, DF: Presidência da República, 2019c. Disponível em:

http://www.planalto.gov.br/ccivil_03/_ato2019-2022/2019/decreto/D10195.htm. Acesso em: 5 fev. 2019.

BRASIL. Decreto-Lei $n^{\circ}$ 200, de 25 de fevereiro de 1967. Dispõe sôbre a organização da Administração Federal, estabelece diretrizes para a Reforma Administrativa e dá outras providências. Brasília, DF: Presidência da República, 1967. Disponível em: http://www.planalto.gov.br/ccivil_03/decreto-lei/del0200.htm. Acesso em: 5 fev. 2019.

BRASIL. Lei $n^{\circ} 4.024$, de 20 de dezembro de 1961. Fixa as Diretrizes e Bases da Educação Nacional. Brasília, DF: Presidência da República, 1961. Disponível em: http://www.planalto.gov.br/ccivil_03/leis/14024.htm. Acesso em: 6 fev. 2019.

BRASIL. Lei $\mathrm{n}^{\circ}$ 5.172, de 25 de outubro de 1966. Dispõe sobre o Sistema Tributário Nacional e institui normas gerais de direito tributário aplicáveis à União, Estados e Municípios. DF: Presidência da República, 1996. Brasília, DF: Presidência da República, 1996b. Disponível em: http://www.planalto.gov.br/ccivil_03/leis/15172compilado.htm. Acesso em: 5 fev. 2019.

BRASIL. Lei $n^{\circ} 5.540$, de 28 de novembro de 1968. Fixa normas de organização e funcionamento do ensino superior e sua articulação com a escola média, e dá outras providências. Brasília, DF: Presidência da República, 1968. Disponível em: http://www.planalto.gov.br/ccivil_03/leis/15540.htm. Acesso em: 5 fev. 2019.

BRASIL. Lei $n^{o} 8.987$, de 13 de fevereiro de 1995. Dispõe sobre o regime de concessão e permissão da prestação de serviços públicos previsto no art. 175 da Constituição Federal, e dá outras providências. Brasília, DF: Presidência da República, 1995c. Disponível em: http://www.planalto.gov.br/ccivil_03/leis/18987cons.htm. Acesso em: 20 maio 2020. 
BRASIL. Lei $n^{\circ}$ 9.131, de 24 de novembro de 1995. Altera dispositivos da Lei $\mathrm{n}^{\circ} 4.024$, de 20 de dezembro de 1961, e dá outras providências. Brasília, DF: Presidência da República, 1995a. Disponível em: http://www.planalto.gov.br/ccivil_03/leis/19131.htm. Acesso em: 7 fev. 2019.

BRASIL. Lei $n^{\circ}$ 9.394, de 20 de dezembro de 1996. Estabelece as diretrizes e bases da educação nacional. Brasília, DF: Presidência da República, 1996a. Disponível em: http://www.planalto.gov.br/ccivil_03/leis/19394.htm. Acesso em: 5 fev. 2019.

BRASIL. Lei $n^{\circ}$ 9.637, de 15 de maio de 1998. Dispõe sobre a qualificação de entidades como organizações sociais, a criação do Programa Nacional de Publicização, a extinção dos órgãos e entidades que menciona e a absorção de suas atividades por organizações sociais, e dá outras providências. Brasília, DF: Presidência da República, 1998. Disponível em: http://www.planalto.gov.br/ccivil_03/leis/19637.htm. Acesso em: 5 fev. 2019.

BRASIL. Lei $n^{\circ}$ 9.790, de 23 de março de 1999. Dispõe sobre a qualificação de pessoas jurídicas de direito privado, sem fins lucrativos, como Organizações da Sociedade Civil de Interesse Público, institui e disciplina o Termo de Parceria, e dá outras providências. Brasília, DF: Presidência da República, 1999. Disponível em:

http://www.planalto.gov.br/ccivil_03/LEIS/L9790.htm. Acesso em: 18 fev. 2019.

BRASIL. Lei $n^{\circ}$ 10.172, de 9 de janeiro de 2001. Aprova o Plano Nacional de Educação e dá outras providências. Brasília, DF: Presidência da República, 2001. Disponível em: http://www.planalto.gov.br/ccivil_03/leis/leis_2001/110172.htm. Acesso em: 10 fev. 2019.

BRASIL. Lei $n^{\circ}$ 10.406, de 10 de janeiro de 2002. Institui o Código Civil. Brasília, DF: Presidência da República, 2002. Disponível em: http://www.planalto.gov.br/ccivil_03/leis/2002/L10406compilada.htm. Acesso em: 18 fev. 2019.

BRASIL. Lei $n^{\circ} 10.861$, de 14 de abril de 2004. Institui o Sistema Nacional de Avaliação da Educação Superior - SINAES e dá outras providências. DF: Presidência da República, 2004a. Disponível em: http://www.planalto.gov.br/ccivil_03/_ato2004-2006/2004/lei/110.861.htm. Acesso em: 15 maio 2020.

BRASIL. Lei $n^{\circ} 10.870$, de 19 de maio de 2004. Institui a Taxa de Avaliação in loco das instituições de educação superior e dos cursos de graduação e dá outras providências. DF: Presidência da República, 2004b. Disponível em: http://www.planalto.gov.br/ccivil_03/_ato2004-2006/2004/lei/110.870.htm. Acesso em: 15 maio 2020.

BRASIL. Lei $n^{o} 12.101$, de 27 de novembro de 2009. Dispõe sobre a certificação das entidades beneficentes de assistência social; regula os procedimentos de isenção de contribuições para a seguridade social; altera a Lei no 8.742, de 7 de dezembro de 1993; revoga dispositivos das Leis nos 8.212, de 24 de julho de 1991, 9.429, de 26 de dezembro de 1996, 9.732, de 11 de dezembro de 1998, 10.684, de 30 de maio de 2003, e da Medida Provisória no 2.187-13, de 24 de agosto de 2001; e dá outras providências. Brasília, DF: Presidência da República, 2009. Disponível em: http://www.planalto.gov.br/ccivil_03/_ato2007-2010/2009/lei/112101.htm. Acesso em: 5 maio 2020. 
BRASIL. Lei $n^{\circ} 12.846$, de $1^{\circ}$ de agosto de 2013. Dispõe sobre a responsabilização administrativa e civil de pessoas jurídicas pela prática de atos contra a administração pública, nacional ou estrangeira, e dá outras providências. Brasília, DF: Presidência da República, 2013. Disponível em: http://www.planalto.gov.br/ccivil_03/_ato20112014/2013/lei/112846.htm. Acesso em: 13 mar. 2020.

BRASIL. Lei $n^{\circ} 13.005$, de 25 de junho de 2014. Aprova o Plano Nacional de Educação PNE e dá outras providências. Brasília, DF: Presidência da República, 2014a. Disponível em: http://www.planalto.gov.br/ccivil_03/_ato2011-2014/2014/lei/113005.htm. Acesso em: 25 fev. 2019.

BRASIL. Lei $n^{\circ} 13.019$, de 31 de julho de 2014. Estabelece o regime jurídico das parcerias entre a administração pública e as organizações da sociedade civil, em regime de mútua cooperação, para a consecução de finalidades de interesse público e recíproco, mediante a execução de atividades ou de projetos previamente estabelecidos em planos de trabalho inseridos em termos de colaboração, em termos de fomento ou em acordos de cooperação; define diretrizes para a política de fomento, de colaboração e de cooperação com organizações da sociedade civil; e altera as Leis $n^{\circ}$ s 8.429, de 2 de junho de 1992, e 9.790, de 23 de março de 1999. Brasília, DF: Presidência da República, 2014b. Disponível em: http://www.planalto.gov.br/ccivil_03/_ato2011-2014/2014/lei/113019.htm. Acesso em: 26 fev. 2019.

BRASIL. Lei do Império, de 11 de agosto de 1827. Crêa dous Cursos de sciencias juridicas e sociaes, um na cidade de S. Paulo e outro na de Olinda. Brasília, DF: Presidência da República, 1827. Disponível em: http://www.planalto.gov.br/ccivil_03/leis/lim/LIM.-11-081827.htm. Acesso em: 24 fev. 2020.

BRASIL. Medida Provisória $n^{\circ} 870$, de $1^{\circ}$ de janeiro de 2019. Estabelece a organização básica dos órgãos da Presidência da República e dos Ministérios. Brasília, DF: Presidência da República, 2019d. Disponível em: http://www.planalto.gov.br/ccivil_03/_ato20192022/2019/decreto/D10195.htm. Acesso em: 20 maio 2019.

BRASIL. Ministério da Educação. CNE - Histórico. Brasília, DF: MEC, 2018a. Disponível em: http://portal.mec.gov.br/index.php?option=com_content\&view=article\&id=14306:cnehistorico\&catid=323:orgaos-vinculados. Acesso em: 20 maio 2019.

BRASIL. Ministério da Educação. Coordenação de Aperfeiçoamento de Pessoal de Nível Superior Diretoria de Avaliação. Documento de área: Direito. Brasília, DF: MEC, 2016. Disponível em:

http://www.capes.gov.br/images/documentos/Documentos_de_area_2017/26_DIRE_docarea 2016.pdf. Acesso em: 16 mar. 2017.

BRASIL. Ministério da Educação. Estrutura organizacional. Brasília, DF: MEC, 2020. Disponível em: http://portal.mec.gov.br/institucional/estrutura-organizacional. Acesso em: 5 set. 2020.

BRASIL. Ministério da Educação. Inep completa 82 anos de serviços prestados à educação. Brasília, DF: MEC, 2019e. Disponível em: http://portal.mec.gov.br/component/content/article?id=72621\#: :text=Em\%201972\%2C\%20o 
\%20Inep\%20foi,da\%20situa\%C3\%A7\%C3\%A3o\%20educacional\%20do\%20pa \%C3\%ADs. \&text $=\mathrm{O} \% 20$ ano $\% 20 \mathrm{de} \% 201976 \% 20$ marca,Rio\%20de $\% 20 J a n e i r o \% 20$ para $\% 20 \mathrm{Bras} \% \mathrm{C} 3 \% \mathrm{~A}$ Dlia. Acesso em: 7 set. 2020.

BRASIL. Ministério da Educação. O que é o conceito preliminar de curso? Brasília, DF: MEC, [20-?]. Disponível em: http://portal.mec.gov.br/pet/127-perguntas-frequentes911936531/educacao-superior-399764090/13074-o-que-e-o-conceito-preliminar-de-curso. Acesso em: 18 out. 2020.

BRASIL. Ministério da Educação. Portaria Normativa $n^{\circ}$ 40, de 12 de dezembro de 2007. Institui o e-MEC, sistema eletrônico de fluxo de trabalho e gerenciamento de informações relativas aos processos de regulação, avaliação e supervisão da educação superior no sistema federal de educação, e o Cadastro e-MEC de Instituições e Cursos Superiores e consolida disposições sobre indicadores de qualidade, banco de avaliadores (Basis) e o Exame Nacional de Desempenho de Estudantes (ENADE) e outras disposições. Brasília, DF: MEC, 2007. Disponível em:

http://download.inep.gov.br/educacao_superior/censo_superior/legislacao/2007/portaria_40_1 2122007.pdf. Acesso em: 5 maio 2020.

BRASIL. Ministério da Educação. Resolução $n^{\circ} 5$, de 17 de dezembro de 2018. Institui as Diretrizes Curriculares Nacionais do Curso de Graduação em Direito e dá outras providências. Brasília, DF: MEC, 2018b. Disponível em:

http://portal.mec.gov.br/docman/dezembro-2018-pdf/104111-rces005-18/file. Acesso em: 20 maio 2019.

BRASIL. Ministério das Relações Exteriores. Objetivos de desenvolvimento sustentável $(O D S)$. Brasília, DF: Ministério das Relações Exteriores, 2015. Disponível em:

https://www.gov.br/mre/pt-br/assuntos/desenvolvimento-sustentavel-e-meioambiente/desenvolvimento-sustentavel/objetivos-de-desenvolvimento-sustentavel-ods. Acesso em: 4 fev. 2019.

BRASIL. Presidência da República. Câmara da Reforma do Estado. Plano Diretor da Reforma do Aparelho do Estado. Brasília, DF: Presidência da República, 1995b. Disponível em: http://www.bresserpereira.org.br/documents/mare/planodiretor/planodiretor.pdf. Acesso em: 21 mar. 2019.

BRASIL. Superior Tribunal de Justiça. Súmula $n^{\circ} 47$. Reitor de universidade não é livremente demissível pelo Presidente da República durante o prazo de sua investidura. Brasília, DF: Superior Tribunal Federal, [1964]. Disponível em:

http://www.stf.jus.br/portal/cms/verTexto.asp?servico=jurisprudenciaSumula\&pagina=sumul a_001_100. Acesso em: 19 ago. 2019.

BRENNAN, Geoffrey; PETTIT, Philip. The economy of esteem: an essay on civil and political society. Oxford: Oxford University Press, 2004.

BUCCI, Maria Paula Dallari. O art. 209 da Constituição 20 anos depois: estratégias do poder executivo para a efetivação da diretriz da qualidade da educação superior. Fórum Administrativo: Direito Público, Belo Horizonte, v. 9, n. 105, nov. 2009. Disponível em: http://bdjur.stj.jus.br/dspace/handle/2011/27995. Acesso em: 13 mar. 2019. 
CABRAL NETO, Antônio. Gestão e qualidade de ensino: um labirinto a ser percorrido. In: SOUZA JUNIOR, Luiz de; FRANÇA, Magna; FARIAS, Maria da Salete Barboza de (org.). Políticas de gestão e práticas educativas: a qualidade do ensino. Brasília, DF: Liber Livros/ANPAE, 2011.p. 263-277.

CAGGIANO, Monica Herman Salem. A educação. Direito fundamental. In: RANIERI, Nina Beatriz Stocco; RIGHETTI, Sabine (org.). Direito à educação: aspectos constitucionais. São Paulo: Edusp, 2009.

CALDERÓN, Adolfo Ignacio; POLTRONIERI, Heloisa; BORGES, Regilson Maciel. Os rankings na educação superior brasileira: políticas de governo ou de estado? Ensaio: Avaliação e Políticas Públicas em Educação, Rio de Janeiro, v. 19, n. 73, p. 813-826, dez. 2011. Disponível em: http://www.scielo.br/scielo.php?script=sci_arttext\&pid=S0104$40362011000500005 \& \operatorname{lng}=\mathrm{en} \& \mathrm{nrm}=$ iso. Acesso em: 11 maio 2019.

CALVO-SOTELO, Pablo Campos. España: campus de excelencia internacional. Madrid: Ministerio de Educación, Secretaría General de Universidades, Subdirección General de Documentación y Publicaciones, 2010.

CAMPOS, Douglas Aparecido de. A avaliação da educação superior diante de uma colonialidade do saber e do poder: a participação política discente. Avaliação (Campinas), Sorocaba, v. 22, n. 1, p. 179-199, 2017. Disponível em: https://www.scielo.br/scielo.php?pid=S141440772017000100179\&script=sci_abstract\&tlng=pt. Acesso em: 5 set. 2019.

CANDELA, Javier Eugenio López. Sobre la necessidade de um concepto de servicio público. Madrid: Consejo General del Poder Judicial: Fundación Wellington, D. L., 2004.

CANOTILHO, José Joaquim Gomes. Direito constitucional. 5. ed. Coimbra: Almedina, 1992.

CARDOSO, Roberta Muriel; DIAS SOBRINHO, José. Avaliação e educação no Brasil: avanços e retrocessos. Série-Estudos (UCDB), Campo Grande, v. 1, n. 37, p. 263-273, jan./jun. 2014. Disponível em: https://serie-estudos.ucdb.br/serie-estudos/article/view/766. Acesso em: 2 out. 2020.

CARDOSO, Roberta Muriel; DIAS SOBRINHO, José. Os processos de avaliação no Brasil: o que foi proposto e o que ocorre de fato. Revista ComCiência, Campinas, v. 165, p. 1-4, fev. 2015.

CARRIEL, Paola. Atraso compromete metas do Plano de Educação. Gazeta do Povo, Brasília, DF, 14 dez. 2010. Disponível em: https://www.gazetadopovo.com.br/vida-ecidadania/atraso-compromete-metas-do-plano-de-educacao-1d5om9j8d1x9rku2uol862fym/. Acesso em: 30 maio 2019.

CARVALHO, José Murilo de. Cidadania no Brasil: o longo caminho. 6. ed. Rio de Janeiro: Civilização Brasileira, 2006.

CENTER FOR WORLD UNIVERSITY RANKINGS. United Arab Emirates: CWUR, 2012. Disponível em: https://cwur.org/about.php. Acesso em: 8 nov. 2020. 
CHAUÍ, Marilena de Souza. Ideologia e educação. Educação e Pesquisa, São Paulo, v. 42, n. 1, p. 245-258, jan./mar. 2016. Disponível em:

http://www.scielo.br/scielo.php?script=sci_arttext\&pid=S1517-

97022016000100245\&lng=pt\&nrm=iso. Acesso em: 24 abr. 2017.

CHAUÍ, Marilena de Souza. A universidade hoje. Praga - Revista de Estudos Marxistas, São Paulo: n. 6, p. 23-32, set. 1998.

CHRISTENSEN, Clayton M.; EYRING, Henry J. A universidade inovadora: mudando o DNA do ensino superior de fora para dentro. Tradução: Ayresnede Casarin da Rocha. Porto Alegre: Bookman, 2014.

CIEGLINSKI, Amanda. Entidades pedem divulgação rápida do novo Plano Nacional de Educação. Uol Notícias, Brasília, DF, 8 dez. 2010. Disponível em:

https:/educacao.uol.com.br/noticias/2010/12/08/entidades-pedem-divulgacao-rapida-donovo-plano-nacional-de-educacao.htm. Acesso em: 30 maio 2019.

COLAÇO, Thais Luzia (org.). Aprendendo a ensinar direito o Direito. Florianópolis: $\mathrm{OAB} / \mathrm{SC}, 2006$.

COLADO, Eduardo Ibarra. Capitalismo académico e globalización: la universidad reinventada. Educação e Sociedade, Campinas, v. 24, n. 84, p. 1059-1067, set. 2003. Disponível em: http://www.scielo.br/scielo.php?script=sci_arttext\&pid=S010173302003000300017\&lng=en\&nrm=iso. Acesso em: 1 abr. 2017.

EL COMITÉ Nacional de Evaluación: El CNE. [S. l.]: CNE, [20-?]. Disponível em: https://www.cne-evaluation.fr/versions/espagnol.htm. Acesso em: 25 jun. 2019.

COMO é feito o Ranking Universitário Folha. São Paulo: Folha de São Paulo, [2019].

Disponível em: https://ruf.folha.uol.com.br/2019/noticias/como-e-feito-o-rankinguniversitario-folha.shtml. Acesso em: 10 nov. 2020.

CONSELHO NACIONAL DE EDUCAÇÃO. Câmara de Educação Superior. Resolução $C N E / C E S n^{\circ}$ 9, de 29 de setembro de 2004. Institui as Diretrizes Curriculares Nacionais do Curso de Graduação em Direito e dá outras providências. Brasília, DF: CNE, 2004.

Disponível em: http://portal.mec.gov.br/cne/arquivos/pdf/rces09_04.pdf. Acesso em: 20 fev. 2019.

CONSELHO NACIONAL DE JUSTIÇA. Justiça em Números 2013: ano-base 2012. Brasília: CNJ, 2013.

CONSELHO NACIONAL DE JUSTIÇA. Justiça em Números 2014: ano-base 2013. Brasília: CNJ, 2014.

A CRIAÇÃO dos cursos jurídicos no Brasil. Rio de Janeiro: Museu da Justiça do Estado do Rio de Janeiro, 2011. (Cadernos de Exposições, ago. 2011). Disponível em: http://ccmj.tjrj.jus.br/documents/5989760/6464634/caderno-expo-2.pdf. Acesso em: 22 jan. 2020. 
CUNHA, Luiz Antonio. Educação e desenvolvimento social no Brasil. Rio de Janeiro: Franciso Alves, 1980.

DA ROS, Luciano. O custo da Justiça no Brasil: uma análise comparativa exploratória. Observatório de elites políticas e sociais do Brasil, Curitiba, v. 2, n. 9, p. 1-15, jul. 2015. Newsletter. p. 3-4.

DAHL, Robert Alan. La democracia y sus criticos. Tradução: Leandro Wolfson. 3. ed. Barcelona: Paidós, 2000.

DAHL, Robert Alan. On democracy. New Haven: Yale University Press, 1998.

DAHL, Robert Alan. Sobre a democracia. Tradução: Beatriz Sidou. Brasília, DF: Editora Universidade de Brasília, 2001.

DALLARI, Dalmo de Abreu. Elementos de teoria geral do Estado. 26. ed. São Paulo: Saraiva, 2007.

DANTAS, Francisco Clementino de San Tiago. A educação jurídica e a crise brasileira. In: DANTAS, Francisco Clementino de San Tiago. Palavras de um professor. 2. ed. Rio de Janeiro: Forense, 2001.

DARTMOUTH COLLEGE (USA). Compliance Matrix. Hanover, NH: Dartmouth College, 2018. Disponível em: https://www.dartmouth.edu/ rmi/compmatrix12315.pdf. Acesso em: 6 set. 2020.

DATOS Y CIFRAS DEL SISTEMA UNIVERSITARIO ESPAÑOL. Madrid: Ministerio de Universidades, 2009-. Informe bienal. Disponível em:

https://www.educacionyfp.gob.es/servicios-al-ciudadano/estadisticas/universitaria/datoscifras.html. Acesso em: 24 abr. 2020.

DEWEY, John. Democracia y educación: una introducción a la filosofía de la educación. 3. ed. Madrid: Morata, 1998.

DEWEY, John. Ensayos de educación. Madrid: Ediciones de la lectura, 1976.

DEWEY, John. La opinión publica y sus problemas. Madrid: Morata, 2004.

DEWEY, John. Pedagogia y filosofia. Madrid: Francisco Beltrán Librería Española y Extranjera, 1930.

DEWEY, John. The political writings. Indianapolis/Cambridge: Hackett Publishing Company, 1993.

DIAS SOBRINHO, José. Avaliação e transformações da educação superior brasileira (19952009): do provão ao Sinaes. Avaliação (Campinas), Sorocaba, v. 15, n. 1, p. 195-224, 2010a. p. 203. Disponível em: http://www.scielo.br/scielo.php?script=sci_arttext\&pid=S141440772010000100011\&lng=en\&nrm=iso. Acesso em: 25 jul. 2020. 
DIAS SOBRINHO, José. Democratização, qualidade e crise da educação superior: faces da exclusão e limites da inclusão. Educação e Sociedade, Campinas, v. 31, n. 113, p. 1223-1245, dez. 2010. Disponível em: http://www.scielo.br/scielo.php?script=sci_arttext\&pid=S010173302010000400010\&lng=en\&nrm=iso. Acesso em: 10 abr. 2020.

DIAS SOBRINHO, José. Políticas y conceptos de calidad: dilemas y retos. Avaliação: Avaliação (Campinas), Sorocaba, v. 17, n. 3, p. 601-618, nov. 2012. Disponível em: http://www.scielo.br/scielo.php?script=sci_arttext\&pid=S1414$40772012000300003 \& \operatorname{lng}=\mathrm{en} \& n r m=$ iso. Acesso em: 10 maio 2020.

DIAS SOBRINHO, José. Qualidade, avaliação: do Sinaes a índices. Avaliação (Campinas), Sorocaba, v. 13, n. 3, p. 817-825, nov. 2008. Disponível em: http://www.scielo.br/pdf/aval/v13n3/11.pdf. Acesso em: 28 maio 2020.

DIAS SOBRINHO, José; RISTOFF, Dilvo. Avaliação democrática: para uma universidade cidadã. Florianópolis: Insular, 2002.

DILNOT, Catherine. The relationship between A-level subject choice and league table score of university attended: the 'facilitating', the 'less suitable', and the counter-intuitive. Oxford Review of Education, London, v. 44, n. 1, p. 118-137, Feb. 2018. Disponível em:

https://www.tandfonline.com/doi/full/10.1080/03054985.2018.1409976. Acesso em: 13 maio 2020.

DRUCKER, P. Sociedade pós-capitalista. Lisboa: Actual, 2007.

DUARTE, Roberto Gonzalez; LIMA JÚNIOR, Antônio Ferreira de; BATISTA, Raquel Viana Lessa. O processo de internacionalização das instituições de ensino superior: o caso das Pontifícias Uni- versidades Católicas de Minas Gerais e do Paraná. Revista Economia e Gestão, Belo Horizonte, v. 7, n. 14, p. 1-178, 1, 2007. Disponível em:

http://seer.pucminas.br/index.php/economiaegestao/article/view/20. Acesso em: 11 jun. 2020.

DUGUIT, Léon. Manual de derecho constitucional: teoría general del Estado, el derecho y el estado, las libertades públicas y organización política. Madrid: Francisco Beltrán, 1926.

DUGUIT, Léon. Las transformaciones del derecho público y privado. Buenos Aires: Editorial Heliasta, 1975.

EATON, Judith Sheila. Consejo de acreditación de la educación superior, la acreditación y el reconocimiento en Estados Unidos. In: GLOBAL UNIVERSITY NETWORK FOR INNOVATION. La educación superior en el mundo 2007: acreditación para la garantía de la calidad: ¿qué está en juego? Madrid-Barcelona-México: Mundi-Prensa, 2006. Informe anual.

THE ECONOMIST INTELLIGENCE UNIT. Democracy Index 2018: me too?: political participation, protest and democracy: a report by The Economist Intelligence Unit. London: The Economist Intelligence Unit, 2019. Disponível em: https://www.eiu.com/public/topical_report.aspx? campaignid=Democracy2018. Acesso em: 11 jan. 2019. 
ESPAÑA. Ley 15/2014, de 16 de septiembre, de racionalización del Sector Público y otras medidas de reforma administrativa. Boletín Oficial del Estado, 17 sept. 2014. Disponível em: https://www.boe.es/boe/dias/2014/09/17/pdfs/BOE-A-2014-9467.pdf. Acesso em: 24. abr. 2020.

ESPAÑA. Ministerio de Educación. Programa Campus de Excelencia Internacional. Madrid: Ministerio de Educación, [2019?].

ESPAÑA. Ministerio de Educación. Mapa de universidades. [2019]. 1 infográfico, color. Disponível em: https://www.educacionyfp.gob.es/dam/jcr:a3f70f97-f944-458d-8fb3aa5a5e67d0c8/mapa-universidades2-2019.pdf. Acesso em: 23 fev. 2020.

ESPAÑA. Secretaría de Estado de Universidades. Guía de buenas prácticas para la participación de las universidades españolas en los rankings internacionales. Madrid: Ministerio de Educación, Cultura y Deporte, 2015. Disponível em:

https://sede.educacion.gob.es/publiventa/d/20227/19/0. Acesso em: 11 maio 2020.

ETZKOWITZ, H. MIT and the rise of entrepreneurial science. New York: Rout- ledge, 2002.

FARIA, José Eduardo. A realidade política e o ensino jurídico. Revista da Faculdade de Direito, Universidade de São Paulo, São Paulo, n. 82, p. 198-212, jan. 1987. Disponível em: https://www.revistas.usp.br/rfdusp/article/view/67101. Acesso em: 7 ago. 2019.

FARIA, José Eduardo. A reforma do ensino jurídico. Porto Alegre: Sergio Antonio Fabris, 1987.

FÁVERO, Maria de Lourdes de Albuquerque. Da Universidade "modernizada” à Universidade disciplinada: Atcon e Meira Mattos. São Paulo: Cortez, 1991.

FERNANDES, Florestan. Universidade brasileira: reforma ou revolução? São Paulo: AlfaÔmega, 1975.

FERNÁNDEZ LAMARRA, Norberto. Universidad y calidad en América Latina en perspectiva comparada: interrogantes y desafíos. Avaliação: Revista de Avaliação da Educação Superior (Campinas), Sorocaba, v. 17, n. 3, p. 661-688, nov. 2012. p. 669. Disponível em: http://www.scielo.br/scielo.php?script=sci_arttext\&pid=S141440772012000300006\&lng=en\&nrm=iso. Acesso em: 11 maio 2020.

FESTENSTEIN, Matthew. Pragmatism and political theory: from Dewey to Rorty. Chicago: University Of Chicago Press, 1997.

FLORÊNCIO FILHO, Marco Aurélio Pinto; ZANON, Patricie Barricelli. A efetividade das políticas públicas de criminal compliance para a prevenção da corrupção no Brasil. In: MESSA, Ana Flávia; DOMINGUES, Paulo de Tarso; ESTEVES, João Luiz Martins (org.). Governança, compliance e corrupção. São Paulo: Almedina, 2019.

FONSECA, Marília. Políticas públicas para a qualidade da educação brasileira: entre o utilitarismo econômico e a responsabilidade social. Caderno CEDES, Campinas, v. 29, n. 78, p. 153-177, ago. 2009. Disponível em:

http://www.scielo.br/scielo.php?script=sci_arttext\&pid=S0101- 
32622009000200002\&lng=en\&nrm=iso. Acesso em: 9 ago. 2020.

FRAGALE FILHO, Roberto; VERONESE, Alexandre. A pesquisa em Direito: diagnósticos e perspectivas. RBPG. Revista Brasileira de Pós-Graduação, Brasília, DF, v. 1, n. 2, p. 53-70, 2004.

FREIRE, Paulo. Pedagogia da autonomia: saberes necessários à prática educativa. 25. ed. São Paulo: Paz e Terra, 1996.

FREIRE, Paulo. Pedagogia do oprimido. 63. ed. Rio de Janeiro/São Paulo: Paz e Terra, 2017.

FRIEDMAN, Milton. Capitalismo y libertad. Madrid: Ediciones Rialp, 1966.

FURTADO, Celso. Desenvolvimento e subdesenvolvimento. 5. ed. Rio de Janeiro:

Contraponto; Centro Internacional Celso Furtado de Políticas para o Desenvolvimento, 2009.

FURTADO, Celso. Formação econômica do Brasil. São Paulo: Companhia das Letras, 2007.

GADAMER, Hans-Georg. Verdade e método: traços fundamentais de uma hermenêutica filosófica. Petrópolis: Vozes, 2004.

GATTI, Bernardete Angelina. Os problemas da formação. Revista da Academia Paulista de Educação, São Paulo, v. 4, p. 12-14, 2014.

GHIRARDI, José Garcez; OLIVEIRA, Juliana Ferrari. Caminhos da superação da aula jurídica tradicional: o papel das instituições de ensino. Revista Brasileira de Estudos Políticos, Belo Horizonte, n. 113, p. 379-404, jul./dez. 2016. Disponível em: https://pos.direito.ufmg.br/rbep/index.php/rbep/article/view/388/359. Acesso em: 2 mar. 2020.

GHIRARDI, José Garcez (org.). Métodos de ensino em direito: conceitos para um debate. São Paulo: Saraiva, 2009.

GIL, Antonio Carlos. Didática do ensino superior. São Paulo: Atlas, 2015.

GIOIA, Fulvia Helena de. Tributação e custeio da educação pública. Curitiba: Juruá, 2018.

GOIÁS. Secretaria de Estado da Casa Civil. Lei $n^{\circ} 186$, de 13 de agosto de 1898. Sobre a Instrucção Publica. Goiânia: Câmara dos Deputados, 1898. Disponível em: https://legisla.casacivil.go.gov.br/public/arquivos/8193. Acesso em: 20 mar. 2019.

GOMES, Válter; MACHADO-TAYLOR, Maria de Lourdes; SARAIVA, Ernani Viana. O ensino superior no Brasil: breve histórico e caracterização. Ciência \& Trópico, Recife, v.42, n. 1, p. 106-129, jan/jul, 2018. Disponível em:

https://periodicos.fundaj.gov.br/CIC/article/view/1647 Acesso em 20 fev. 2019.

GRAU, Eros Roberto. A ordem econômica na Constituição de 1988. São Paulo: Malheiros, 2006.

GROTTI, Dinorá Adelaide Musetti. O serviço público e a Constituição brasileira de 1988. São Paulo: Malheiros, 2003. 
DE WIT, Hans. Repensando o conceito da internacionalização. Ensino Superior Unicamp, 20 fev. 2013. Disponível em: https://www.revistaensinosuperior.gr.unicamp.br/internationalhigher-education/repensando-o-conceito-da-internacionalizacao. Acesso em: 31 mar. 2017.

HOPER. Análise setorial da educação superior privada: Brasil 2015. Foz do Iguaçu: Hoper Educação, 2015.

INSTITUTO BRASILEIRO DE GEOGRAFIA E ESTATÍSTICA. Brasil: 500 anos de povoamento. Rio de Janeiro: IBGE, 2000. p. 221. Disponível em:

https://brasil500anos.ibge.gov.br/estatisticas-do-povoamento/evolucao-da-populacaobrasileira.html. Acesso em: 21 jan. 2020.

INSTITUTO BRASILEIRO DE GOVERNANÇA CORPORATIVA. Código das melhores práticas de governança corporativa. 5. ed. São Paulo, SP: IBGC, 2018. 108 p. Disponível em:

https://edisciplinas.usp.br/pluginfile.php/4382648/mod_resource/content/1/Livro_Codigo_Me lhores_Praticas_GC.pdf. Acesso em: 5. set. 2020.

INSTITUTO NACIONAL DE ESTADÍSTICA (España). Divulga informações estatísticas sobre a Espanha. Madrid: INE, [20-?]. Disponível em: https://www.ine.es. Acesso em: 24 abr. 2020 .

INSTITUTO NACIONAL DE ESTUDOS E PESQUISAS EDUCACIONAIS ANÍSIO TEIXEIRA. Conheça o Inep. Brasília, DF: Inep, 2015. Disponível em:

http://portal.inep.gov.br/conheca-oinep\#: :text=O\%20Instituto $\% 20 \mathrm{Nacional} \% 20 \mathrm{de} \% 20$ Estudos,econ $\% \mathrm{C} 3 \% \mathrm{~B} 4 \mathrm{mico} \% 20 \mathrm{e} \% 20$ so cial $\% 20 \mathrm{do} \% 20 \mathrm{pa} \% \mathrm{C} 3 \%$ ADs. Acesso em: 7 set. 2020.

INSTITUTO NACIONAL DE ESTUDOS E PESQUISAS EDUCACIONAIS ANÍSIO TEIXEIRA. Considerações sobre o relatório da OCDE Repensando a garantia de qualidade para o Ensino Superior no Brasil. Brasília, DF: Inep, 2019c. Disponível em:

http://inep.gov.br/sinaes/relatorio-ocde. Acesso em: 29 jul. 2020.

INSTITUTO NACIONAL DE ESTUDOS E PESQUISAS EDUCACIONAIS ANÍSIO TEIXEIRA. Instrumento de avaliação de cursos de graduação presencial e a distância: reconhecimento e renovação de reconhecimento. Brasília, DF: Inep/MEC, 2017. p. 16. Disponível em: http://inep.gov.br/instrumentos. Acesso em: 5 set. 2020.

INSTITUTO NACIONAL DE ESTUDOS E PESQUISAS EDUCACIONAIS ANÍSIO TEIXEIRA. Portaria $n^{\circ}$ 911, de 6 de novembro de 2019. Cronograma do Censo da Educação Superior 2019. Brasília, DF: Inep/MEC, 2019b. Disponível em:

https://www.in.gov.br/en/web/dou/-/portaria-n-911-de-6-de-novembro-de-2019-226837269. Acesso em: 5 set. 2020.

INSTITUTO NACIONAL DE ESTUDOS E PESQUISAS EDUCACIONAIS ANÍSIO TEIXEIRA. Sinopse Estatística da Educação Superior 2017. Brasília, DF: Inep, 2018. Disponível em: http://inep.gov.br/sinopses-estatisticas-da-educacao-superior. Acesso em: 25 mar. 2019. 
INSTITUTO NACIONAL DE ESTUDOS E PESQUISAS EDUCACIONAIS ANÍSIO TEIXEIRA. Sinopse Estatística da Educação Superior 2018. Brasília, DF: Inep, 2019a. Disponível em: http://inep.gov.br/sinopses-estatisticas-da-educacao-superior. Acesso em: 21 jan. 2020.

INTERNATIONAL ORGANIZATION FOR STANDARDIZATION. About us. Geneva: ISO, [2019?]. Disponível em: https://www.iso.org/about-us.html. Acesso em: 13 maio 2019.

JANOTTI, Aldo. Origens da universidade. São Paulo: Edusp, 1992.

JOHNSON, Valen E. Grade inflation: a crisis in college education. New York: Springer, 2003.

JORNADAS DE EVALUACIÓN DE LA CALIDAD EN LA UNIVERSIDAD, 1., 1994, Buenos Aires. Evaluación de la calidad en la Universidad: Jornadas de Evaluación de la Calidad en la Universidad 7, 8 y 9 de septiembre de 1994. Buenos Aires: Gafica Senda Sa, $1995.233 \mathrm{p}$.

JUNQUEIRA, Michelle Asato. Educação para o desenvolvimento: o desafio do ensino técnico e tecnológico. 2016. 172 f. Tese (Doutorado em Direito Político e Econômico) Programa de Pós-Graduação em Direito Político e Econômico da Universidade Presbiteriana Mackenzie, São Paulo, 2016.

JUNQUEIRA, Michelle Asato. Universidade, autonomia e atuação estatal: a avaliação como garantia do direito à educação. 2011. 148 f. Dissertação (Mestrado) - Programa de PósGraduação em Direito Político e Econômico da Universidade Presbiteriana Mackenzie, São Paulo, 2011.

KEIM, Ernesto Jacob. Complexidade da avaliação, avaliação na complexidade. EccoS Revista Científica, UNINOVE, São Paulo, v. 2, n. 2, p. 45-59, dez. 2000, p. 52.

KENNEDY, Duncan. The political significance of the structure of the law school curriculum. Seton Hall Law Review, [s. l.], v. 14, n. 1, p. 1-16, 1983. Disponível em: http://www.duncankennedy.net/documents/The\%20Political\%20Significance $\% 20$ of $\% 20$ the $\%$ 20Structure\%20of\%20the\%20Law\%20School\%20Curriculum.pdf. Acesso em: 17 jul. 2019.

KREPSKY, Giselle Marie; ROCHA, Leonel Severo. O Direito, a Ciência e a Educação: relações intersistêmicas. Quaestio Iuris, Rio de Janeiro, v. 11, n. 1, p. 129-153, 2018. Disponível em: https://www.e-publicacoes.uerj.br/index.php/quaestioiuris/article/view/25609. Acesso em: 5 ago. 2020.

LAMONT, Michèle. Como piensan los profesores: el curioso mundo de la evaluación académica por dentro. Tradução: Maria Teresa Casado Rodíguez. Madrid: Centro de Investigaciones Sociológicas, 2015.

LESSARD, C. A universidade e a formação profissional de docentes: novos questionamentos. Educação e Sociedade, Campinas, v. 27, n. 94, p. 201-227, jan./abr. 2006. Disponível em: https://www.scielo.br/pdf/es/v27n94/a11v27n94.pdf. Acesso em: 31 mar. 2017. 
LIMA, Kátia. Expansão da educação superior brasileira na primeira década do novo século. In: PEREIRA, Larissa; ALMEIDA, Ney Luiz Teixeira (org.). Serviço social e educação. Rio de Janeiro: Lumen Juris, 2013.

LÓPEZ-COLMENAR, José María de Mesa; BARRENA, Rafael Castañeda; ANGULO, Luis Miguel Villar. Asegurar la calidad en las universidades: actas de las III Jornadas Andaluzas de Calidad en la Enseñanza Universitaria. Sevilha: Universidad de Sevilla, 2002. v. 1.

MACHADO, Antônio Alberto. Ensino jurídico e mudança social. Franca: Unesp, 2005.

MAGALHÃES, António. Cenários, dilemas e caminhos da educação superior europeia. Perspectiva, Florianópolis, v. 29, n. 2, p. 623-647, jul./dez. 2011. Disponível em: https://periodicos.ufsc.br/index.php/perspectiva/article/download/2175795X.2011v29n2p623/22225. Acesso em: 5 ago. 2020.

MAGALHÃES, António. A identidade do ensino superior: política, conhecimento e educação numa época de transição. Porto: Fundação Calouste Gulbenkian; Fundação para a Ciência e Tecnologia, 2004.

MALISKA, Marcos Augusto. Direito à educação e a Constituição. Porto Alegre: S. A. Fabris, 2001.

MARCOVITCH, Jacques (org.). Repensar a universidade: desempenho acadêmico e comparações internacionais. São Paulo: Com-Arte; Fapesp, 2018.

MARTINS, Carlos Benedito. A reforma universitária de 1968 e a abertura para o ensino superior privado no Brasil. Educação e Sociedade, Campinas, v. 30, n. 106, abr. 2009. p. 19. Disponível em: http://www.scielo.br/scielo.php?script=sci_arttext\&pid=S010173302009000100002\&lng=pt\&nrm=iso. Acesso em: 26. fev. 2020.

MASCARO, Alysson Leandro. Estado e forma política. São Paulo: Boitempo, 2013.

MEDAUAR, Odete. Direito administrativo moderno. São Paulo: Revista dos Tribunais, 2006.

MELO, Diogo Veloso de; MACHADO, André Gustavo Carvalho; MORAES FILHO, Rodolfo Araújo de. Inteligência competitiva: o caso C.E.S.A.R. In: ENCONTRO DA ANPAD, 32., 2008, Rio de Janeiro. Anais [...]. Rio de Janeiro: Anpad, 2008. p. 2. Disponível em: http://www.anpad.org.br/admin/pdf/ESO-A2660.pdf. Acesso em: 21 out. 2020.

MELLO, Celso Antônio Bandeira de. Curso de direito administrativo. São Paulo: Malheiros, 2008.

MELLO, Celso Antônio Bandeira de. Curso de direito administrativo. 27. ed. refund. ampl. e atual. São Paulo: Malheiros, 2010.

MELLO, Celso Antônio Bandeira de. Natureza e regime jurídico das autarquias. São Paulo: Revista dos Tribunais, 1968.

MELLO, Noval Benayon. Desigualdades sociais e políticas públicas na região norte. In: 
ZIMERMAN, Artur (org). Educação em pauta. Santo André: Universidade Federal do ABC, 2013.

MEZZAROBA, Orides; MONTEIRO, Cláudia Servilha. Manual de metodologia da pesquisa no Direito. 6. ed. São Paulo: Saraiva, 2014.

MILL, John Stuart. Princípios de economia política: com algumas de suas aplicações à filosofia social. São Paulo: Nova Cultural, 1996.

MOITA, Filomena Maria Gonçalves da Silva Cordeiro; ANDRADE, Fernando Cézar Bezerra de. Ensino-pesquisa-extensão: um exercício de indissociabilidade na pós-graduação. Revista Brasileira de Educação, Rio de Janeiro, v. 14, n. 41, p. 269-280, ago. 2009. Disponível em: http://www.scielo.br/scielo.php?script=sci_arttext\&pid=S1413-

$24782009000200006 \& \operatorname{lng}=$ en\&nrm=iso. Acesso em: 18 mar. 2019.

MONTERROSO, Graciela. Perspectivas y desafios de la universidad: el compromiso social y ético y sus dimensiones internacional y regional: 27, 28 y 29 de septiembre de 2010. Buenos Aires: Universidad del Salvador, 2012.

MORA, José Ginés. O processo de modernização das universidades europeias: o desafio da sociedade do conhecimento e da globalização. In: AUDY, Jorge Luis Nicolas; MOROSINI, Marília Costa (org.). Inovação e empreendedorismo na universidade. Porto Alegre: EDIUCRS, 2006. p. 140.

MOROSINI, Marilia Costa. Qualidade da educação superior e contextos emergentes. Avaliação: Revista de Avaliação da Educação Superior (Campinas), Sorocaba, v. 19, n. 2, p. 385-405, jul. 2014. Disponível em: https://www.scielo.br/scielo.php?pid=S1414$40772014000200007 \&$ script=sci_abstract\&tlng=pt. Acesso em: 10 maio 2020.

MOURA, Bruno Azevedo; MOURA, Leides Barroso Azevedo. Ranqueamento de universidades: reflexões acerca da construção de reconhecimento institucional. Acta Scientiarum Education, Maringá, v. 35, n. 2, p. 213-222, jul./dez. 2013. Disponível em: http://periodicos.uem.br/ojs/index.php/ActaSciEduc/article/view/20400. Acesso em: 8 mar. 2020.

MUNIZ, Regina Maria Fonseca. O direito à educação. Rio de Janeiro: Renovar, 2002.

NAÇÕES UNIDAS. Objetivo de desenvolvimento sustentável 4: educação de qualidade. Brasília, DF: Nações Unidas, c2020. Disponível em: https://brasil.un.org/pt-br/sdgs/4. Acesso em: 4 fev. 2019.

NOHARA, Irene Patrícia. Direito administrativo. 8. ed. Rio de Janeiro: Atlas, 2018.

NOHARA, Irene Patrícia. Reforma administrativa e burocracia: impacto da eficiência na configuração do direito administrativo brasileiro. São Paulo: Atlas, 2012.

OLIVEIRA, Romualdo Portela de; ARAUJO, Gilda Cardoso de. Qualidade do ensino: uma nova dimensão da luta pelo direito à educação. Revista Brasileira de Educação, Rio de Janeiro, n. 28, p. 5-23, abr. 2005. Disponível em:

http://www.scielo.br/scielo.php?script=sci_arttext\&pid=S1413- 
$24782005000100002 \& \operatorname{lng}=$ en\&nrm=iso. Acesso em: 17 mar. 2019.

ORGANISATION FOR ECONOMIC CO-OPERATION AND DEVELOPMENT.

Rethinking quality assurance for higher education in Brazil. Paris: OECD, 2018. p. 13.

Disponível em: http:/www.oecd.org/brazil/rethinking-quality-assurance-for-highereducation-in-brazil-9789264309050-en.htm. Acesso em: 29 jul. 2020.

ORGANIZAÇÃO DAS NAÇÕES UNIDAS. Declaração Universal dos Direitos Humanos. Geneva: ONU, [1948]. Disponível em:

https://www.ohchr.org/EN/UDHR/Documents/UDHR_Translations/por.pdf. Acesso em: 15 mar. 2019.

ORTEGA, Ricardo Rivero. Derecho administrativo económico. 5a. ed. Madrid: Marcial Pons, 2009.

ORTEGA, Ricardo Rivero. La necesaria innovación en las instituciones administrativas : organización, procedimientos, función pública, contratos administrativos y regulación . 1a. ed. Madrid: Instituto Nacional de la Administración Pública, 2012.

PAIVA, Ricardo Viana Carvalho de; COSTA, Danilo de Melo; GONÇALVES, Raquel Garcia; BARBOSA, Francisco Vidal. Fatores influenciadores da competitividade na educação superior privada brasileira. Revista Global Manager, Rio Grande do Sul, v. 14, n. 1, p. 19-39, 2014.

PFISTER, Mariana; CALDERÓN, Adolfo Ignacio. Os rankings na educação superior brasileira: um estudo sobre o estado da questão. In: ENCONTRO REGIONAL DA ANPAE, 9., 2014, São Paulo. Anais [...]. São Paulo: ANPAE, 2014. Tema: Gestão de sistemas e instituições de ensino: políticas e práticas profissionais.

PIMENTEL, Telmo David Marcos. A utilização do modelo de excelência EFQM: um estudo de caso com as organizações portuguesas permeadas pelo pex/spq nos anos de 1994 a 2010. 2013. 205 f. Dissertação (Mestrado) - Curso de Direito, Faculdade de Direito, Universidade de Coimbra, Coimbra, 2013. Disponível em:

https://eg.uc.pt/bitstream/10316/35044/1/A\%20utilizacao\%20do\%20modelo\%20de\%20excel encia $\% 20$ da $\% 20$ efqm.pdf. Acesso em: 16 dez. 2020

PINTO, Felipe Chiarello de Souza. Responsabilidade do Estado e ensino superior. In: GUERRA, Alexandre Dartanhan de Mello; PIRES, Luis Manuel Fonseca; BENACCHIO, Marcello. Responsabilidade civil do Estado: desafios contemporâneos. São Paulo: Quartier Latin, 2010.

PINTO, Felipe Chiarello de Souza. O verdadeiro ensino fundamental. Disponível em: http://www.programapainel.com.br/coluna/materia_mostra.php?id=3. Acesso em: 20.jan.2019.

PINTO, Felipe Chiarello de Souza; JUNQUEIRA, Michelle Asato. Aspectos da recente avaliação do ensino jurídico no Brasil: a atuação da OAB e do MEC em busca da qualidade. In: CONGRESSO DO CONPEDI, 15., 2006, Manaus. Anais [...]. Manaus: CONPEDI, 2006. Tema: Direito, Sociobiodiversidade e Soberania na Amazônia. Disponível em: http://www.publicadireito.com.br/conpedi/manaus/arquivos/anais/manaus/ensino_jur_felipe_ 
c_pinto_e_michelle_junqueira.pdf. Acesso em: 27 jan. 2019.

PINTO, Felipe Chiarello de Souza; JUNQUEIRA, Michelle Asato. Educação para o desenvolvimento: objetivo do estado democrático e social de direito. Direito e Justiça (URI), ano 16, n. 23, p. 77-90, nov. 2014.

PINTO, Felipe Chiarello de Souza; MENEZES, Daniel Francisco Nagao. Francisco Campos e as reformas do ensino jurídico na década de 30. In: CONGRESSO DO CONPEDI CURITIBA, 25., 2016, Curitiba. Anais [...]. Florianópolis: CONPEDI, 2016. p. 23-24. Tema: História do Direito.

PINTO, Felipe Chiarello de Souza; PUERTA DOS SANTOS, Larissa Dias. As transformações na organização da administração pública por ocasião do regramento destinado às Organizações Sociais e os impactos nas instituições do terceiro setor. In: JAEGER JUNIOR, Augusto; REVERBEL, Carlos Eduardo Dieder; MARTINI, Sandra Regina (org.). $O$ movimento do saber: uma homenagem para Claudia Lima Marques. 1. ed. Porto Alegre: Editora RJR, 2017.

POLIDORI, Marlis Morosini; MARINHO-ARAUJO, Claisy M.; BARREYRO, Gladys Beatriz. SINAES: perspectivas e desafios na avaliação da educação superior brasileira. Ensaio: Avaliação e Políticas Públicas em Educação, Rio de Janeiro: v. 14, n. 53, p. 425-436, dez. 2006. Disponível em: http://www.scielo.br/scielo.php?script=sci_arttext\&pid=S0104$40362006000400002 \& \operatorname{lng}=$ en\&nrm=iso. Acesso em: 19 jun. 2019.

PORTER, Michael Eugene. Competição on competition: estratégias competitivas essenciais. 10. ed. Rio de Janeiro: Campus Jurídico, 2003.

PROGRAMA DAS NAÇÕES UNIDAS PARA O DESENVOLVIMENTO. Objetivo 4: educação de qualidade. Brasília, DF: PNUD, c2020b. Disponível em:

http://www.br.undp.org/content/brazil/pt/home/sustainable-development-goals/goal-4-qualityeducation.html. Acesso em: 4 fev. 2019.

PROGRAMA DAS NAÇÕES UNIDAS PARA O DESENVOLVIMENTO. Objetivos de desenvolvimento sustentável. Brasília, DF: PNUD, c2020a. Disponível em: http://www.br.undp.org/content/brazil/pt/home/sustainable-development-goals.html. Acesso em: 4 fev. 2019.

PROGRAMA DAS NAÇÕES UNIDAS PARA O DESENVOLVIMENTO. PNUD no Brasil. Brasília, DF: PNUD, [2018?]. Disponível em:

http://www.br.undp.org/content/brazil/pt/home/about-us.html. Acesso em: 4 fev. 2019.

PUCCI, Bruno. A indissociabilidade entre ensino, pesquisa e extensão. Piracicaba: Impulso, 1991.

PUERTA DOS SANTOS, Larissa Dias. A instrumentalização jurídica da gestão pública brasileira e os mecanismos para a reforma da organização administrativa. 2016. $162 \mathrm{f}$. Dissertação (Mestrado) - Programa de Pós-Graduação em Direito Político e Econômico, Universidade Presbiteriana Mackenzie, São Paulo, 2017.

PUERTA DOS SANTOS, Larissa Dias; JUNQUEIRA, Michelle Asato. O atual protagonismo 
da interpretação constitucional como norteadora da aplicação do direito. Revista de Argumentação e Hermenêutica Jurídica, Brasília, DF, v. 2, n. 1, p. 230-249, jan./jun. 2016.

PUGA, Bruna Azzari; PINTO, Felipe Chiarelo de Souza; SILVA, Amanda Scalisse. Ética e integridade nas instituições de ensino superior: a importância da implementação de programas de compliance nas universidades. Revista de Direito Brasileira, v. 26, p. 457-470, 2020.

QUINTÁS, Guillermo (ed.). Reforma y evaluación de la universidad. València: Universitat de València, 1996.

RANIERI, Nina Beatriz Stocco. Autonomia universitária. São Paulo: EDUSP, 1994.

RANIERI, Nina Beatriz Stocco. Os Estados e o direito à educação na Constituição de 1988: comentários acerca da jurisprudência do Supremo Tribunal Federal. In: RANIERI, Nina Beatriz Stocco; RIGHETTI, Sabine (org.). Direito à educação: aspectos constitucionais. São Paulo: Edusp, 2009.

RIBEIRO, Darcy. A universidade necessária. 4. ed. Rio de Janeiro: Paz e Terra, 1982.

RIBEIRO, Jorge Luiz Lordêlo de Sales. Avaliação das universidades brasileiras: as possibilidades de avaliar e as dificuldades de ser avaliado. Avaliação (Campinas), Sorocaba, v. 16, n. 1, p. 57-71, mar. 2011. Disponível em:

http://www.scielo.br/scielo.php?script=sci_arttext\&pid=S1414-

$40772011000100004 \& \operatorname{lng}=$ en\&nrm=iso. Acesso em: 8 nov. 2019.

RIBEIRO, Raimunda Maria da Cunha. Avaliação e ranqueamento de universidades sob a lógica de critérios globais. Roteiro, Joaçaba, v. 43, n. 1, p. 259-276, jan./abr. 2018.

RICE UNIVERSITY (USA). Rice University Compliance Matrix. Houstoun, TX: 2020. Disponível em: https://rucompliance.rice.edu/compliance-matrix. Acesso em: 6 set. 2020.

RINDOVA, Violina P.; MARTINS, Luis L.; SRINIVAS, Santosh B.; CHANDLER, David. The good, the bad, and the ugly of organizational rankings: a multidisciplinary review of the literature and directions for future research. Journal of Management, [s. l.], v. 44, n. 6, p. 2175-2208, Nov. 2017. Disponível em:

https://journals.sagepub.com/doi/10.1177/0149206317741962. Acesso em: 13 maio 2020.

ROCHA, Adriana de Lacerda. O professor reflexivo e o professor de Direito: uma pesquisa de caráter etnográfico. Curitiba: CRV, 2012.

ROCHA, Leonel Severo; SCHERBAUM, Júlia Francieli Neves. O Direito como pressuposto do horizonte literário: uma nova compreensão da realidade jurídica. Quaestio Iuris, Rio de Janeiro, v. 11, p. 1653-1669, 2018.

RODRIGUES, Horácio Wanderlei. A crise do ensino jurídico de graduação no Brasil contemporâneo: indo além do senso comum. 1992. 397 f. Tese (Doutorado) - Curso de Direito, Universidade Federal de Santa Catarina, Florianópolis, 1992.

RODRIGUES, Horácio Wanderlei. O ensino jurídico de graduação no Brasil contemporâneo: análise e perspectivas a partir da proposta alternativa de Roberto Lyra Filho. 
1987. 193 f. Dissertação (Mestrado) - Curso de Direito, Universidade Federal de Santa Catarina, Florianópolis, 1987.

RODRIGUES, Horácio Wanderlei. O exercício do magistério superior e o direito educacional brasileiro. Sequência: Estudos Jurídicos e Políticos, v. 30, n. 58, p. 35-46, 2009. Disponível em: https://periodicos.ufsc.br/index.php/sequencia/article/view/2177-7055.2009v30n58p35. Acesso em: 9 out. 2019.

RODRIGUES, Horácio Wanderlei. Pensando o ensino do direito no século XXI: diretrizes curriculares, projeto pedagógico e outras questões pertinentes. Florianópolis: Fundação Boiteux, 2005.

RODRIGUES, Horácio Wanderlei; GRUBBA, Leilane Serratine. Bachelard e os obstáculos epistemológicos à pesquisa científica do Direito. Sequência: Estudos Jurídicos e Políticos, n. 64, p. 307-334, 2012a. Disponível em:

http://www.scielo.br/scielo.php?script=sci_arttext\&pid=S2177-

$70552012000100013 \& \operatorname{lng}=$ en\&nrm=iso. Acesso em: 29 out. 2019.

RODRIGUES, Horácio Wanderlei; GRUBBA, Leilane Serratine. A epistemologia da complexidade: para uma pesquisa científica do Direito. RIDB - Revista do Instituto do Direito Brasileiro, ano 1, n. 6, p. 3641-3666, 2012b. Disponível em:

http://www.cidp.pt/revistas/ridb/2012/06/2012_06_3641_3666.pdf. Acesso em: 29 out. 2019.

ROMANELLI, Otaíza de Oliveira. História da educação no Brasil. Petrópolis: 1996, p. 209228.

RUF 2019: Ranking Universitário Folha. São Paulo: Folha de São Paulo, [2019]. Disponível em: https://ruf.folha.uol.com.br/2019/. Acesso em: 8 nov. 2020.

SALMI, Jamil. The challenge of establishing world-class universities. Washington: The World Bank, 2009.

SAMPAIO, Anita Lapa Borges. Autonomia universitária. Brasília, DF: Editora Universidade de Brasília, 1998.

SANTOS, Boaventura de Sousa. Um discurso sobre as ciências. São Paulo: Cortez, 1987.

SANTOS, Boaventura de Sousa. Introdução a uma ciência pós-moderna. Rio de Janeiro: Graal, 1989.

SANTOS, Boaventura de Souza. Pela mão de Alice: o social e o político na pós-modernidade. São Paulo: Cortez, 1997.

SANTOS, Solange Maria dos. Rankings internacionais e universidades: comparação e desempenho por áreas. In: MARCOVITCH, Jacques (org.). Repensar a universidade: desempenho acadêmico e comparações internacionais. São Paulo: Com-Arte; Fapesp, 2018. p. 63.

SCHUMPETER, Joseph Alois. Capitalismo, socialismo e democracia. Rio de Janeiro: Zahar, 1984. 
SCHWARTZMAN, Simon; CASTRO, Claudio de Moura. Ensino, formação profissional e a questão da mão de obra. Ensaio: Avaliação e Políticas Públicas em Educação, Rio de Janeiro, v. 21, n. 80, p. 563-624, jul./set. 2013. Disponível em:

https://www.scielo.br/scielo.php?pid=S0104-

40362013000300010\&script=sci_abstract\&tlng=pt. Acesso em: 21 set. 2020.

SÉCCA, Rodrigo Ximenez; SOUZA, Rodrigo Mendes Leal de. Análise do setor de ensino superior privado no Brasil. BNDES Setorial, Rio de Janeiro, n. 30, p. 103-156, set. 2009. Disponível em: https://web.bndes.gov.br/bib/jspui/handle/1408/1943. Acesso em: 15 maio 2019.

SEVERINO, Antônio Joaquim. Educação e universidade: conhecimento e construção da cidadania. Interface - Comunicação, Saúde, Educação, Botucatu, v. 6, n. 10, p. 117-124, fev. 2002. Disponível em: http://www.scielo.br/scielo.php?script=sci_arttext\&pid=S1414$32832002000100015 \& \operatorname{lng}=\mathrm{en} \& \mathrm{nrm}=$ iso. Acesso em: 2 ago. 2020.

SILVA, Daniel Cavalcante; COVAC, José Roberto. Compliance como boa prática de gestão no ensino superior privado. São Paulo: Saraiva. 2015. p. 24.

SILVA, Everaldo da. Entrevista com Paulo Renato Souza: reflexões sobre a Revolução Gerenciada. Educação, Porto Alegre, v. 39, n. 1, p. 3-10, jan./abr. 2016. Disponível em: https://revistaseletronicas.pucrs.br/ojs/index.php/faced/article/view/21412. Acesso em: 23 fev. 2020.

SILVA, José Afonso da. Curso de direito constitucional positivo. 41. ed. rev. e atual. São Paulo: Malheiros, 2018.

SILVA, Maria das Graças. Universidade e sociedade: cenário da extensão universitária? In: REUNIÃO ANUAL DA ANPED, 23., 2000, Caxambu. Anais [...]. Caxambu: Associação Nacional de Pesquisa e Pós-Graduação em Educação, 2000. p. 18. Disponível em: http://www.anped11.uerj.br/23/1101t.htm. Acesso em: 20 mar. 2019.

SILVA JR., João dos Reis; SGUISSARDI, Valdemar. Novas faces da educação superior no Brasil: reforma do Estado e mudanças na produção. Bragança Paulista: EDUSF; Cortez, 2001.

SOUZA, Paulo Renato. A revolução gerenciada: educação no Brasil, 1995-2002. São Paulo: Prentice-Hall, 2005.

STANFORD UNIVERSITY (USA). Compliance Matrix. Redwood City, CA: Stanford University, [2017]. Disponível em: https://ocro.stanford.edu/ethics-compliance/compliancematrix. Acesso em: 6 set. 2020.

SUNSTEIN, Cass; HOLMES, Stephen. The cost of rights: why liberty depends on taxes. Nova York: W.W. Norton \& Company, 1999.

TEIXEIRA, Anísio. A educação e a crise brasileira. São Paulo: Nacional, 1956.

TEIXEIRA, Anísio. Educação não é privilégio. Rio de Janeiro: José Olympio, 1977a. 
TEIXEIRA, Anísio. Educação no mundo moderno. São Paulo: Cia. Editora Nacional, 1977b.

TELLO, Pilar Jiménez. Auditoría universitaria y calidad: la evaluación como conquista social ante la competencia universitaria global. Saarbrücken: VDM Verlag Dr. Müller, 2009.

TELLO, Pilar Jiménez; PLAZA, Victoria Eugenia. Educación superior y competitividad. Cadernos de Pós-Graduação em Direito, Comissão de Pós-Graduação da Faculdade de Direito da USP, São Paulo, n. 31, p. 4-26, 2014.

TELLO, Pilar Jiménez; PLAZA, Victoria Eugenia. La ética en la enseñanza del derecho. Revista Direito UFMS, Campo Grande, v. 3, n. 1, p. 23-31, enero/jul. 2017.

TENÓRIO, Robinson Moreira; ANDRADE, Maria Antonia Brandão de. A avaliação da educação superior no Brasil: desafios e perspectivas. In: LORDÊLO, José Albertino Carvalho; DAZZANI, Maria Virgínia (org.). Avaliação educacional: desatando e reatando nós. Salvador: EDUFBA, 2009. Disponível em:

https://repositorio.ufba.br/ri/bitstream/ri/5627/1/Avaliacao_educacional.pdf. Acesso em: 6 set. 2020.

TOLEDO, José Carlos de. O sistema japonês de controle de qualidade. Revista de Administração de Empresas, São Paulo, v. 26, n. 3, p. 77-79, set. 1986. Disponível em: http://www.scielo.br/scielo.php?script=sci_arttext\&pid=S003475901986000300009\&lng=en\&nrm=iso. Acesso em: 23 abr. 2019.

TOP UNIVERSITIES. London: QS Quacquarelli Symonds Limited, 1999- . Disponível em: https://www.topuniversities.com. Acesso em: 8 nov. 2020.

UNITED NATIONS. Member States. Geneva: ONU, [20-?].

UNIVERSIDADE FEDERAL DE MINAS GERAIS. Faculdade de Direito da UFMG. Histórico. Belo Horizonte: UFMG, [entre 2018 e 2020]. Disponível em: https://www.direito.ufmg.br/?page_id=4044. Acesso em: 22 jan. 2020. U.S. NEWS \& WORLD REPORT. New York: US News \& World Report LP, 1948- . Disponível em: https://www.usnews.com/education/best-global-universities. Acesso em: 8 nov. 2020.

VASSALO, Roberta. A difícil tarefa de avaliar a qualidade do ensino superior: iniciativas nacionais e internacionais buscam formas de examinar a formação dos estudantes e o ensino das universidades. Jornal da USP, São Paulo, 30 set. 2016. Disponível em:

https://jornal.usp.br/universidade/a-dificil-tarefa-de-avaliar-a-qualidade-do-ensino-superior/. Acesso em: 30 abr. 2020.

VILELA, Sueli. USP: uma universidade de classe mundial. In: VILELA, Suely; FRANCO, Maria Lajolo (org.). USP 2034: planejando o futuro. São Paulo: EDUSP, 2009.

WANDERLEY, Luiz Eduardo. O que é universidade. São Paulo: Brasiliense, 1999.

THE WORLD UNIVERSITY RANKINGS. London: Times Higher Education, 2004 -. Disponível em: https://www.timeshighereducation.com/world-university- 
rankings/2020/world-ranking\#!/page/0/length/25/sort_by/rank/sort_order/asc/cols/stats. Acesso em: 8 nov. 2020. 